\title{
$\alpha$-Tertiary Dialkyl Ether Synthesis via Reductive Photocatalytic $\alpha$-Functionalization of Alkyl Enol Ethers
}

Jamie A. Leitch, Thomas Rossolini, Tatiana Rogova, and Darren J. Dixon*

University of Oxford, Chemistry Research Laboratory, 12 Mansfield Road, Oxford, OX1 3TA, United Kingdom

*darren.dixon@chem.ox.ac.uk 


\section{Contents}

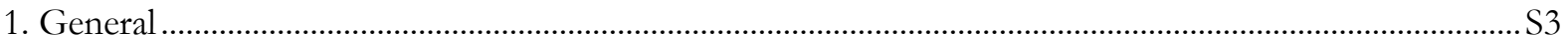

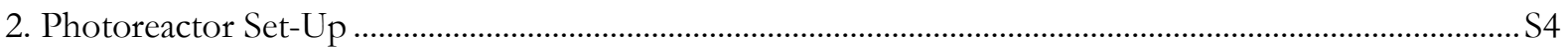

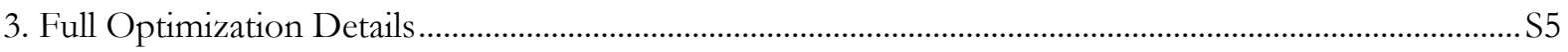

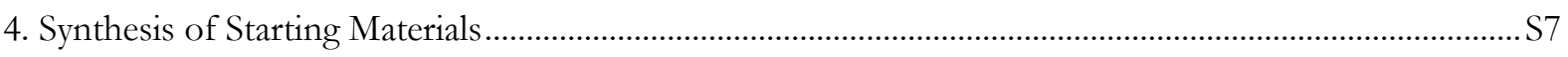

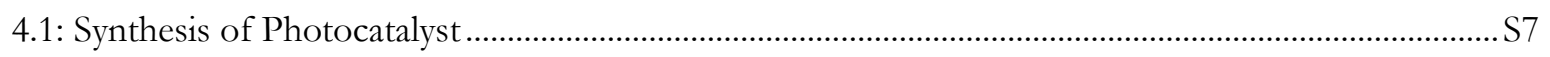

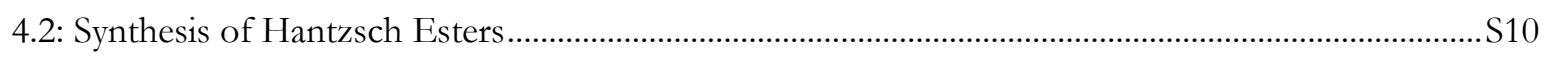

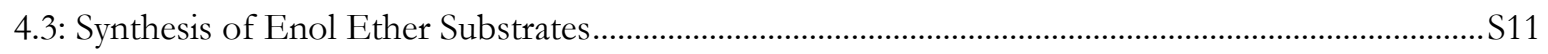

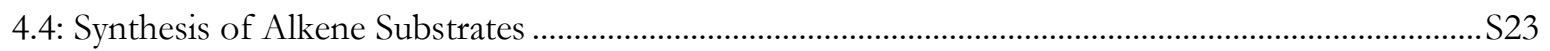

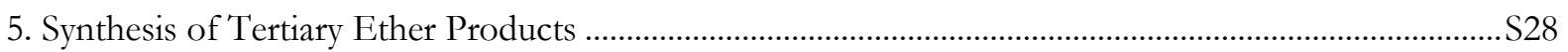

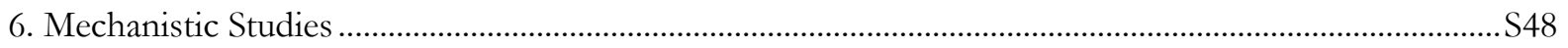

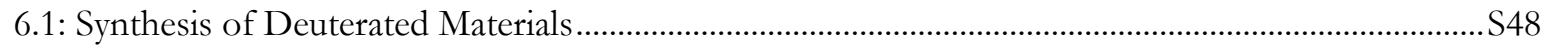

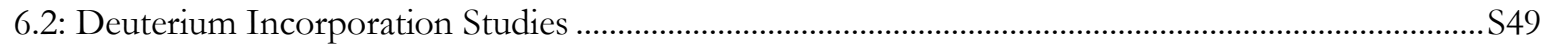

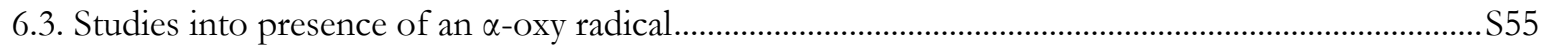

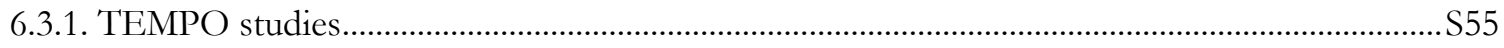

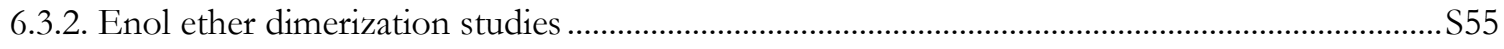

6.3.3. Data for compounds synthesized in this section ...................................................................... S56

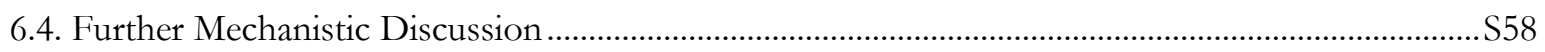

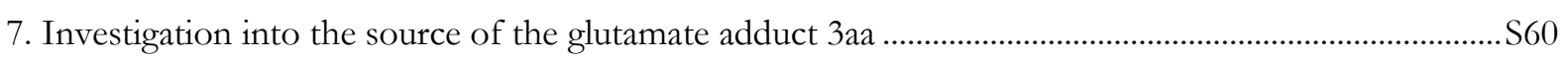

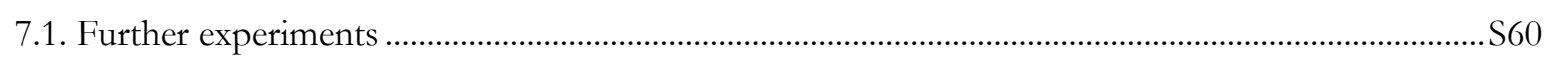

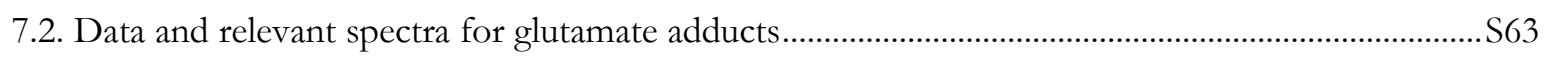

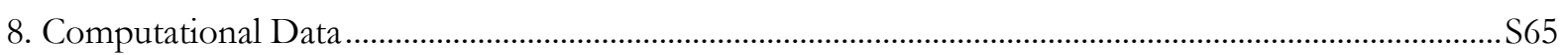

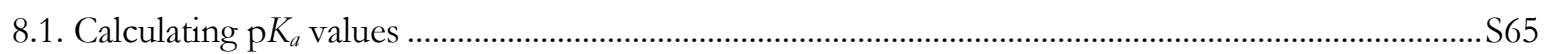

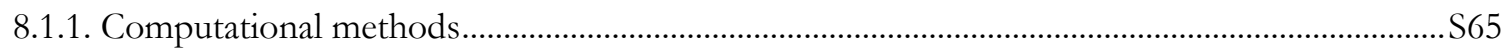

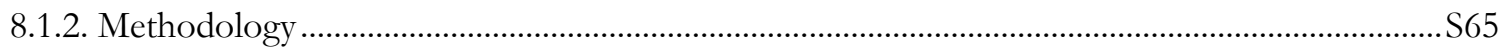

8.1.3. Benchmarking $\mathrm{p} K_{a}$ values: Pyridinium and Hantzsch Ester .......................................................S66

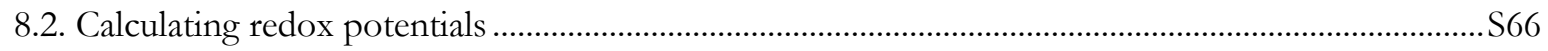

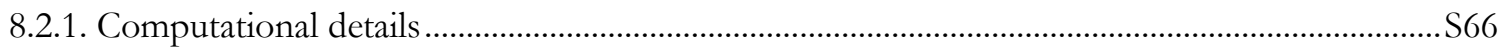

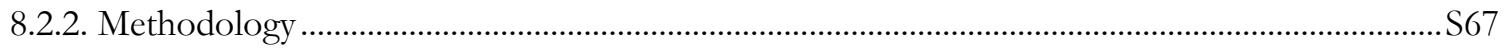

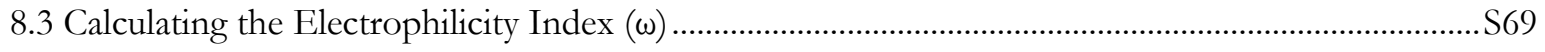

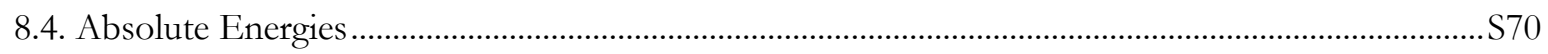

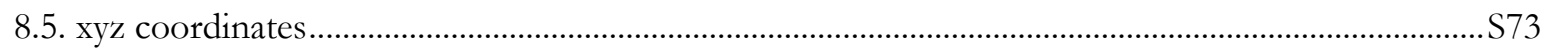

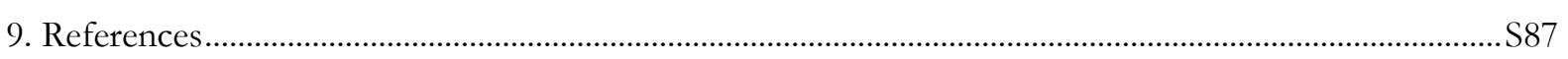

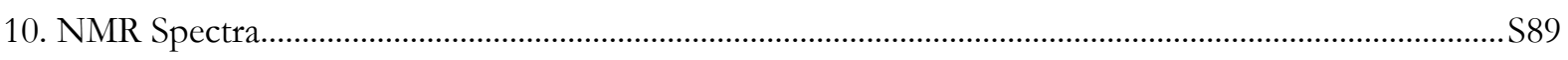




\section{General}

Proton, carbon and fluorine NMR spectra were recorded on Bruker $400 \mathrm{MHz}\left({ }^{1} \mathrm{H}\right.$ NMR at $400 \mathrm{MHz},{ }^{13} \mathrm{C}$ NMR at $101 \mathrm{MHz}$, and ${ }^{19} \mathrm{~F}$ NMR at $\left.377 \mathrm{MHz}\right)$ or Bruker $500 \mathrm{MHz}\left({ }^{1} \mathrm{H} \mathrm{NMR}\right.$ at $500 \mathrm{MHz},{ }^{13} \mathrm{C}$ NMR at $126 \mathrm{MHz}$ ). Chemical shifts for protons are reported in parts per million downfield from $\mathrm{Si}\left(\mathrm{CH}_{3}\right)_{4}$ and are referenced to residual protium in the deuterated solvent $\left(\mathrm{CHCl}_{3}\right.$ at $7.26 \mathrm{ppm}, \mathrm{DMSO}$ at $3.31\left(\mathrm{H}_{2} \mathrm{O}\right), 2.50$ depending on solvent used). Chemical shifts for fluorines are reported in parts per million downfield from $\mathrm{CFCl}_{3}$. NMR data are presented in the following format: chemical shift (multiplicity [app = apparent, br = broad, $\mathrm{d}=$ doublet, $\mathrm{t}=$ triplet, $\mathrm{q}=$ quartet, $\mathrm{dd}=$ doublet of doublets), $\mathrm{dt}=$ doublet of triplets), $\mathrm{dq}=$ doublet of quartets), ddd = doublet of doublet of doublets), $\mathrm{m}=$ multiplet], coupling constant [in $\mathrm{Hz}$ ], number of equivalent nuclei by integration).

High-resolution mass spectra (ESI) were recorded on Bruker $\mu \mathrm{TOF}$ mass spectrometer. Infrared spectra were recorded on a Bruker Tensor 27 FT-IR spectrometer as a thin film. Only selected maximum absorbances are reported (in $\nu_{\max }\left(\mathrm{cm}^{-1}\right)$ ). Melting points were obtained on a Leica Galen III Hot-stage melting point apparatus and microscope and on a Kofler hot block and are reported uncorrected. Analytical thin-layer chromatography (TLC) was performed on Merck silica gel 60 F254 plates and visualised with UV light (254 or $365 \mathrm{~nm}$ ), and/or $\mathrm{KMnO}_{4}$ and/or Vanillin. Silica gel column chromatography was performed using $60 \AA$ silica gel 40-63 $\mu \mathrm{m}$ purchased from Sigma-Aldrich. Samples were dried onto silica gel prior to addition to column.

All reactions were performed using reagents obtained from Sigma-Aldrich, Acros Organics, Alfa Aesar, STREM or Fluorochem without further purification unless stated. Iridium photocatalysts were synthesized in house (see procedures). All water used was purified through a Merck Millipore reverse osmosis purification system prior to use. Dimethyl sulfoxide (anhydrous), tetrahydrofuran (anhydrous), toluene (anhydrous), acetonitrile (anhydrous) and dimethylformamide (anhydrous) were used as supplied. Deuterated solvents were used as supplied. Reactions were performed in under an atmosphere of $\mathrm{N}_{2}$ if not stated. Temperatures quoted are external. Solvents were removed under reduced pressure using Büchi Rotavapor apparatus. 


\section{Photoreactor Set-Up}

Hepatochem PhotoRedOx Box, equipped with an EvoluChem LED 18 W light source supplied by Hepatochem. A cardboard cover was also placed over the reactor during reactions.

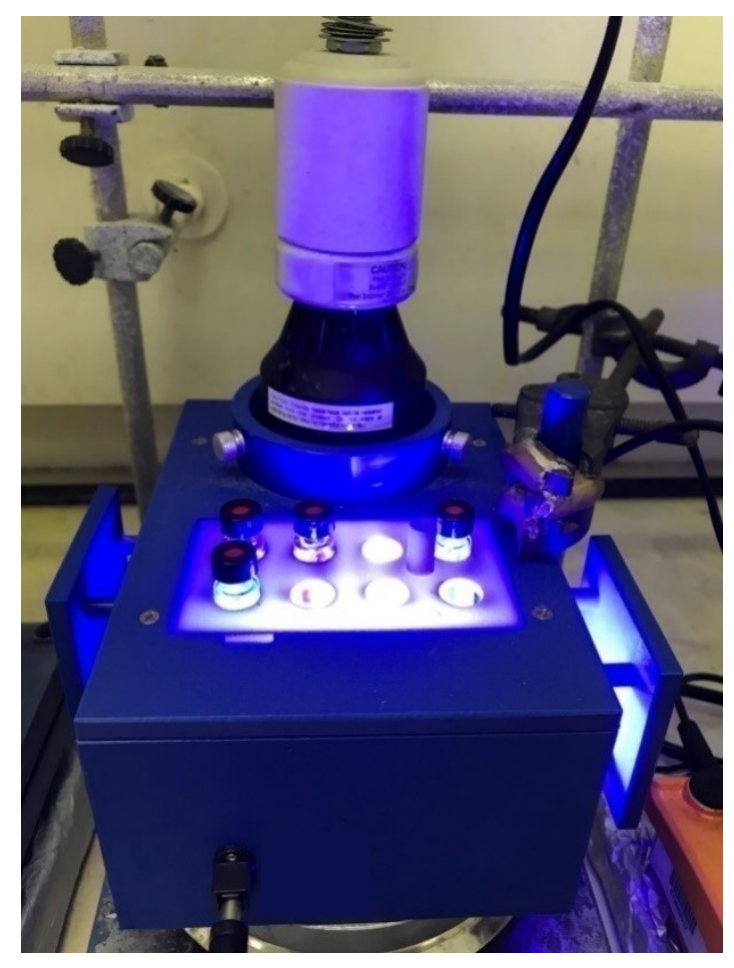




\section{Full Optimization Details}

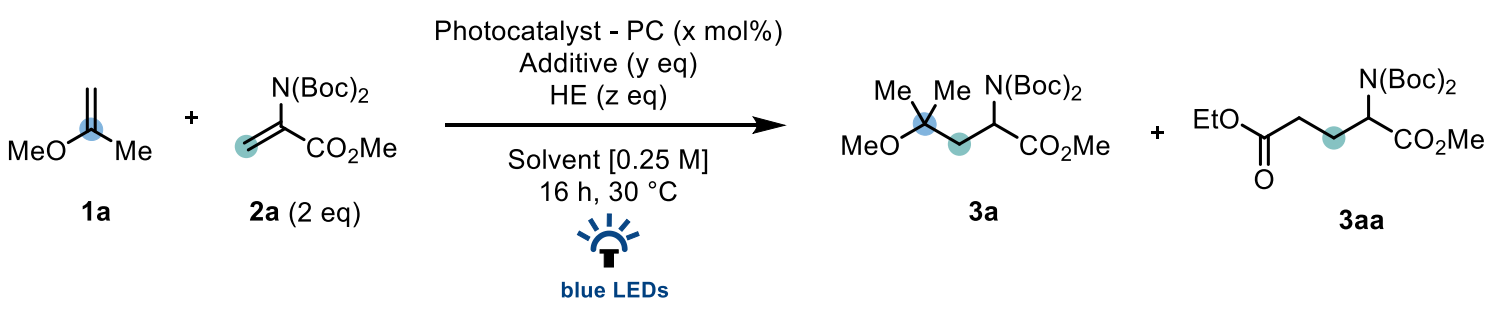

\begin{tabular}{|c|c|c|c|c|c|c|}
\hline Entry & PC (x mol\%) & Additive (y eq) & HE (z eq) & Solvent & $3 a$ & $3 a a$ \\
\hline 1 & {$[\operatorname{Ir} 1](1)$} & - & HE1 (1.5) & DMF & - & - \\
\hline 3 & [Ir1] (1) & PPTS (1) & HE1 (1.5) & DMF & - & - \\
\hline 5 & [Ir1] (1) & $\mathrm{TfOH}(1)$ & HE1 (1.5) & DMF & 23 & 27 \\
\hline 6 & [Ir1] (1) & CSA (1) & HE1 (1.5) & DMF & - & 62 \\
\hline 7 & [Ir1] (1) & TMSOTf (1) & HE1 (1.5) & DMF & 24 & 29 \\
\hline 8 & [Ir1] (1) & TMSCl (1) & HE1 (1.5) & DMF & 63 & 20 \\
\hline 9 & [Ir1] (1) & TMSCl (2) & HE1 (1.5) & DMF & 78 & 20 \\
\hline 10 & [Ir1] (1) & TMSCl (0.3) & HE1 (1.5) & DMF & 48 & 25 \\
\hline 11 & [Ir1] (1) & TMSCl (2) & HE1 (1.0) & DMF & 58 & 14 \\
\hline 12 & [Ir1] (1) & TMSCl (2) & HE1 (1.1) & DMF & 59 & 17 \\
\hline 13 & [Ir1] (1) & TMSCl (2) & HE1 (1.2) & DMF & 62 & 16 \\
\hline 14 & [Ir1] (1) & TMSCl (2) & HE2 (1.5) & DMF & c.m. & - \\
\hline 15 & [Ir1] (1) & TMSCl (2) & HE3 (1.5) & DMF & 13 & 12 \\
\hline 16 & [Ir1] (1) & TMSCl (2) & HE4 (1.5) & DMF & 36 & 10 \\
\hline 17 & [Ir1] (1) & TMSCl (2) & HE5 (1.5) & DMF & 44 & 22 \\
\hline 18 & [Ir1] (1) & TMSCl (2) & HE6 (1.5) & DMF & 41 & 18 \\
\hline 19 & [Ir1] (1) & TMSCl (2) & HE7 (1.5) & DMF & 9 & - \\
\hline 20 & [Ir1] (1) & TMSCl (2) & HE8 (1.5) & DMF & - & - \\
\hline 21 & [Ir1] (1) & TMSCl (2) & HE1 (1.5) & DMSO & - & 6 \\
\hline 22 & [Ir1] (1) & TMSCl (2) & HE1 (1.5) & DCM & 24 & c.m . \\
\hline 23 & [Ir1] (1) & TMSCl (2) & HE1 (1.5) & DCE & 24 & c.m. \\
\hline 24 & [Ir1] (1) & TMSCl (2) & HE1 (1.5) & $\mathrm{DMF} / \mathrm{MeOH}(1: 1)$ & Trace & 6 \\
\hline 25 & [Ir1] (1) & TMSCl (2) & HE1 (1.5) & $\mathrm{DMF} / \mathrm{MeOH}(4: 1)$ & Trace & 43 \\
\hline 26 & [Ir1] (1) & TMSCl (2) & HE1 (1.5) & $\mathrm{DMF} / \mathrm{H}_{2} \mathrm{O}(4: 1)$ & Trace & 61 \\
\hline 27 & [Ir1] (1) & TMSCl (2) & HE1 (1.5) & 1,4-dioxane & 17 & c.m. \\
\hline 28 & [Ir1] (1) & TMSCl (2) & HE1 (1.5) & $\mathrm{MeCN}$ & 19 & c.m. \\
\hline 29 & [Ir2] (1) & TMSCl (2) & HE1 (1.5) & DMF & 62 & 11 \\
\hline 30 & [Ir3] (1) & TMSCl (2) & HE1 (1.5) & DMF & 58 & 12 \\
\hline 31 & [Ir4] (1) & TMSCl (2) & HE1 (1.5) & DMF & 66 & 22 \\
\hline 32 & [Ir5] (1) & TMSCl (2) & HE1 (1.5) & DMF & 51 & 24 \\
\hline 33 & {$[\operatorname{Ir} 6](1)$} & $\operatorname{TMSCl}(2)$ & HE1 (1.5) & DMF & 32 & 4 \\
\hline 34 & {$\left[\mathrm{Ru}(\mathrm{bpy})_{3}\right]\left(\mathrm{PF}_{6}\right)_{2}(1)$} & TMSCl (2) & HE1 (1.5) & DMF & - & - \\
\hline 35 & 4-CzIPN (1) & $\operatorname{TMSCl}(2)$ & HE1 (1.5) & DMF & 64 & 21 \\
\hline 36 & {$[$ [r1] $(0.5)$} & TMSCl (2) & HE1 (1.5) & DMF & 60 & 20 \\
\hline \multicolumn{7}{|c|}{ Changes from entry 9} \\
\hline 37 & \multicolumn{4}{|c|}{ TMSBr (2 eq) instead of TMSCl } & 20 & 16 \\
\hline 38 & \multicolumn{4}{|c|}{ TBSCl (2 eq) instead of TMSCl } & 52 & 22 \\
\hline 39 & \multicolumn{4}{|c|}{$2 \mathbf{a}(1.5 \mathrm{eq})$} & 67 & 16 \\
\hline 40 & \multicolumn{4}{|c|}{$\mathbf{2 a}(1.1 \mathrm{eq})$} & 62 & 11 \\
\hline 41 & \multicolumn{4}{|c|}{$\mathrm{K}_{2} \mathrm{HPO}_{4}(30 \mathrm{~mol} \%)$ added } & 68 & 20 \\
\hline 42 & \multicolumn{4}{|c|}{$\mathrm{NEt}_{3}(2 \mathrm{eq})$ added } & - & - \\
\hline 43 & \multicolumn{4}{|c|}{$\mathbf{1} \mathbf{a}(1.5 \mathrm{eq}), \mathbf{2 a}(1 \mathrm{eq})$} & 79 & 5 \\
\hline 44 & \multicolumn{4}{|c|}{$\mathbf{1 a}(2 \mathrm{eq}), \mathbf{2} \mathbf{a}(1 \mathrm{eq})$} & 70 & 3 \\
\hline 45 & \multicolumn{4}{|c|}{ 1a (3 eq), $2 \mathrm{a}(1 \mathrm{eq})$} & $95(95)$ & 1 \\
\hline & \multicolumn{4}{|c|}{ Control experiments } & & \\
\hline 46 & \multicolumn{4}{|c|}{ no iridium photocatalyst } & - & - \\
\hline 47 & \multicolumn{4}{|c|}{ no light } & - & - \\
\hline 48 & \multicolumn{4}{|c|}{ no Hantzsch Ester } & - & - \\
\hline 49 & \multicolumn{4}{|c|}{ no TMSCl } & - & - \\
\hline
\end{tabular}


KEY
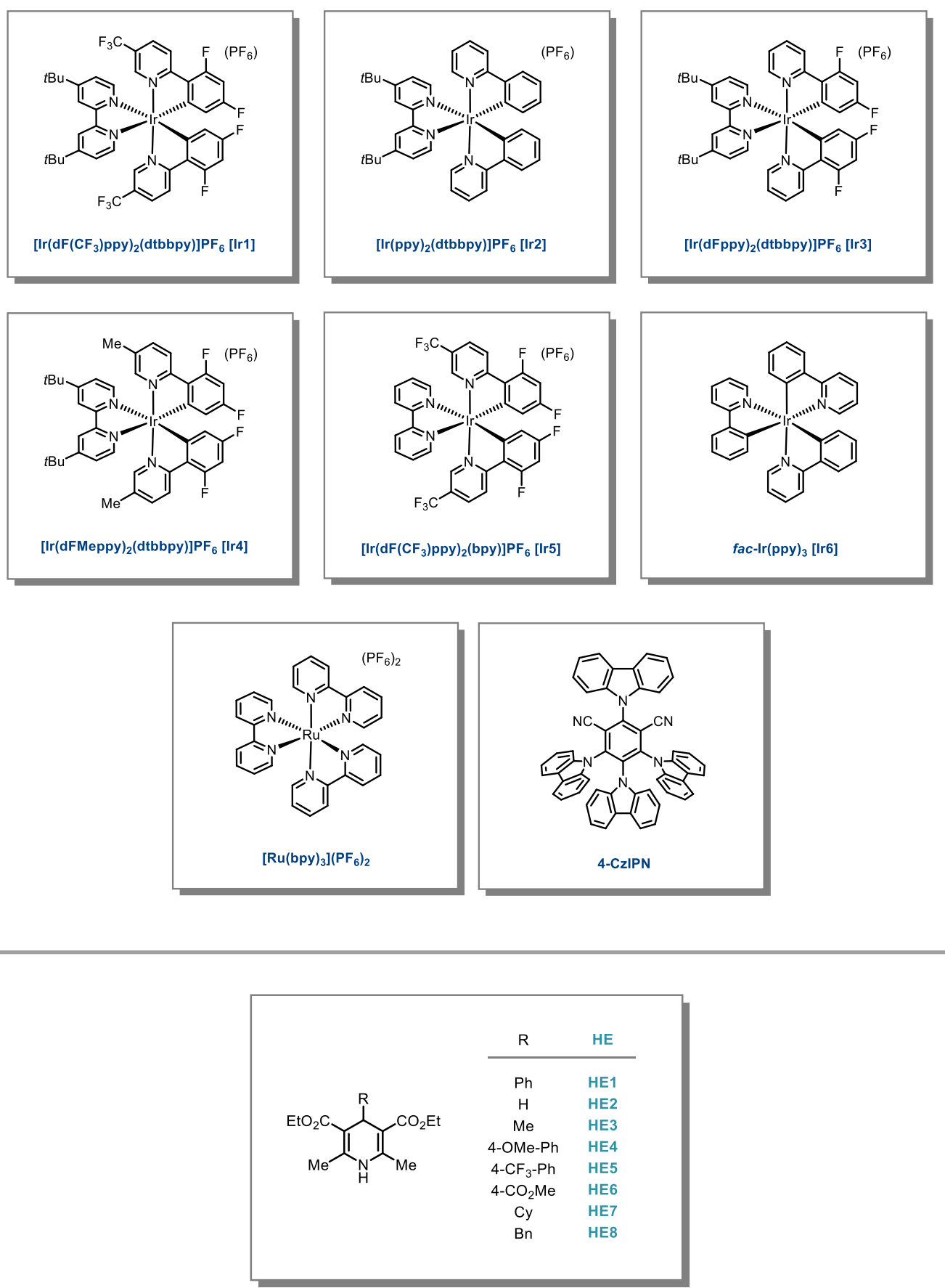


\section{Synthesis of Starting Materials}

\section{1: Synthesis of Photocatalyst}

Synthesis of 2-(2,4-difluorophenyl)-5-(trifluoromethyl)pyridine<smiles>Fc1ccc(-c2ccc(C(F)(F)F)cn2)c(F)c1</smiles>

To a three-necked $250 \mathrm{~mL}$ round bottomed flask was charged with 2,4-difluorophenylboronic acid (5.68 g, $36.0 \mathrm{mmol})$, 2-bromo-5-trifluoromethylpyridine $(6.78 \mathrm{~g}, 30.0 \mathrm{mmol})$, potassium carbonate $(12.4 \mathrm{~g}, 90.0$ $\mathrm{mmol}$ ), palladium acetate (202 $\mathrm{mg}, 0.90 \mathrm{mmol})$ and triphenylphosphine (472 $\mathrm{mg}, 1.80 \mathrm{mmol})$. The flask was equipped with a condenser then evacuated and refilled with $\mathrm{N}_{2}$ three times. Following this, toluene $(40 \mathrm{~mL})$, water $(40 \mathrm{~mL})$ and ethanol $(8 \mathrm{~mL})$ were added via septum. The flask was heated to reflux for $16 \mathrm{~h}$. After this time, the flask was cooled to room temperature and quenched with water $(100 \mathrm{~mL})$. The organic phase was separated and then the aqueous phase re-extracted with $\mathrm{Et}_{2} \mathrm{O}(3 \times 200 \mathrm{~mL})$. The combined organics were washed with brine $(3 \times 200 \mathrm{~mL})$ and then dried over $\mathrm{MgSO}_{4}$ and concentrated in vacuo. The crude residue was the then purified via silica gel column chromatography (EtOAc:Pentane 1:99 - 4:96 v:v) to give the title compound as a white solid $(6.62 \mathrm{~g}, 25.5 \mathrm{mmol}, 85 \%) .{ }^{1} \mathbf{H}$ NMR $\left(400 \mathrm{MHz}, \mathrm{CDCl}_{3}\right): \delta 8.85$ (dd, $J$ $=2.4,1.2 \mathrm{~Hz}, 1 \mathrm{H}), 7.99(\mathrm{td}, J=8.9,6.6 \mathrm{~Hz}, 1 \mathrm{H}), 7.87(\mathrm{dd}, J=8.3,2.4 \mathrm{~Hz}, 1 \mathrm{H}), 7.82-7.76(\mathrm{~m}, 1 \mathrm{H}), 6.98$ $-6.88(\mathrm{~m}, 1 \mathrm{H}), 6.82(\mathrm{ddd}, J=11.3,8.7,2.5 \mathrm{~Hz}, 1 \mathrm{H}) .{ }^{19} \mathbf{F} \mathbf{N M R}\left(377 \mathrm{MHz}, \mathrm{CDCl}_{3}\right): \delta-62.49,-107.28(\mathrm{t}, J$ $=8.0 \mathrm{~Hz}),-112.04(\mathrm{~d}, J=10.0 \mathrm{~Hz}) .{ }^{13} \mathbf{C} \mathbf{N M R}\left(101 \mathrm{MHz}, \mathrm{CDCl}_{3}\right): \delta 164.0(\mathrm{dd}, J=252.8,12.5 \mathrm{~Hz}), 161.1$ (dd, $J=253.6,12.0 \mathrm{~Hz}), 155.9,146.7$ (q, $J=4.2 \mathrm{~Hz}), 133.8$ (q, $J=3.5 \mathrm{~Hz}), 132.6(\mathrm{dd}, J=10.0,4.2 \mathrm{~Hz})$, $125.3(\mathrm{q}, J=33.2 \mathrm{~Hz}), 123.7(\mathrm{q}, J=272.3 \mathrm{~Hz}), 123.7(\mathrm{~d}, J=11.1 \mathrm{~Hz}), 122.5(\mathrm{dd}, J=11.3,3.8 \mathrm{~Hz}), 112.4$ (dd, $J=21.1,3.6 \mathrm{~Hz}$ ), $106.5-101.0$ (app t). Data was consistent with literature precedent. ${ }^{1}$ 
Synthesis of $\left[\operatorname{Ir}\left(\mathrm{dF}\left(\mathrm{CF}_{3}\right) \mathrm{ppy}\right)_{2} \mathrm{Cl}\right]_{2}$<smiles></smiles>

To a three-necked $100 \mathrm{~mL}$ round bottomed flask was charged iridium(III) chloride hydrate (448 $\mathrm{mg}, 1.50$ $\mathrm{mmol}$ ) and 2-(2,4-difluorophenyl)-5-(trifluoromethyl)pyridine $(856 \mathrm{mg}, 3.30 \mathrm{mmol})$. The flask was equipped with a condenser, then evacuated and refilled with nitrogen three times. Rigorously degassed 2ethoxyehtanol $(18 \mathrm{~mL})$ and water $(6 \mathrm{~mL})$ were added via syringe. The reaction mixture was heated $150{ }^{\circ} \mathrm{C}$ for $16 \mathrm{~h}$. After this time the reaction mixture was allowed to return to room temperature and the bright yellow precipitate formed was filtered under a blanket of $\mathrm{N}_{2}$, washing with water $(150 \mathrm{~mL})$ and then hexane $(60 \mathrm{~mL})$, to give title compound after further removal of water via high vacuum $(960 \mathrm{mg}, 0.65 \mathrm{mmol}, 86 \%)$. ${ }^{1} \mathbf{H}$ NMR $\left(400 \mathrm{MHz}, \mathrm{CDCl}_{3}\right): \delta 9.51(\mathrm{~d}, J=2.1 \mathrm{~Hz}, 1 \mathrm{H}), 8.46(\mathrm{dd}, J=8.7,3.0 \mathrm{~Hz}, 1 \mathrm{H}), 8.05(\mathrm{dd}, J=8.7$, $2.3 \mathrm{~Hz}, 1 \mathrm{H}), 6.43(\mathrm{ddd}, J=12.5,8.8,2.3 \mathrm{~Hz}, 1 \mathrm{H}), 5.07$ (dd, $J=8.8,2.3 \mathrm{~Hz}, 1 \mathrm{H}) .{ }^{19} \mathbf{F}$ NMR $(377 \mathrm{MHz}$, $\left.\mathrm{CDCl}_{3}\right): \delta-62.36(12 \mathrm{~F}),-103.41--103.72(\mathrm{~m}, 4 \mathrm{~F}),-106.97--107.91(\mathrm{~m}, 4 \mathrm{~F})$. Data was consistent with literature precedent. ${ }^{1}$ 


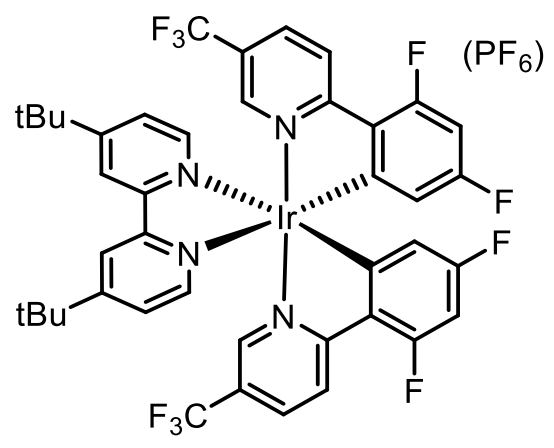

To a three-necked $250 \mathrm{~mL}$ round bottomed flask was charged $\left[\operatorname{Ir}\left(\mathrm{dF}_{(}\left(\mathrm{CF}_{3}\right) \mathrm{ppy}\right)_{2} \mathrm{Cl}\right]_{2}(960 \mathrm{mg}, 0.65 \mathrm{mmol})$ and 4,4'-di-tert-butyl-2,2'-dipyridyl (429 mg, $1.60 \mathrm{mmol})$. The flask was equipped with a reflux condenser, then evacuated and refilled three times with nitrogen. Rigorously degassed ethylene glycol (44 mL) was then added via syringe. The reaction mixture was then heated to $150{ }^{\circ} \mathrm{C}$ for $16 \mathrm{~h}$. After this time the flask was allowed to return to room temperature. The mixture was diluted in water $(300 \mathrm{~mL})$ and hexane $(300 \mathrm{~mL})$. The aqueous phase was then separated and then re-extracted with hexane $(2 \times 300 \mathrm{~mL})$. The aqueous phase was then decanted into a $500 \mathrm{~mL}$ conical flask and equipped with a stirrer bar. The flask was heated at 80 ${ }^{\circ} \mathrm{C}$ for 1 hour to remove residual hexane. The flask was allowed to return to room temperature, and an aqueous solution of potassium hexafluorophosphate $(7 \mathrm{~g}$ in $70 \mathrm{~mL}$ water) was added with stirring, and a vibrant yellow precipitate was formed. The mixture was then allowed to stand at $5{ }^{\circ} \mathrm{C}$ for 1 hour, before the precipitate was collected via vacuum filtration washing with water $(150 \mathrm{~mL})$ and hexane $(100 \mathrm{~mL})$, The collected powdery solid was then subjected to further water removal via high vacuum, to give the title compound, (915 mg, $0.82 \mathrm{mmol}, 63 \%) .{ }^{1} \mathbf{H}$ NMR (400 MHz, CDCl $): \delta 8.88(\mathrm{~d}, J=2.1 \mathrm{~Hz}, 2 \mathrm{H}), 8.47$ (dd, $J=8.7,3.1 \mathrm{~Hz}, 2 \mathrm{H}), 8.04(\mathrm{dd}, J=8.8,2.1 \mathrm{~Hz}, 2 \mathrm{H}), 7.86(\mathrm{~d}, J=5.9 \mathrm{~Hz}, 2 \mathrm{H}), 7.59$ (dd, $J=5.9,1.9 \mathrm{~Hz}, 2$ H), 7.41 (s, $2 \mathrm{H}), 6.64$ (ddd, $J=11.6,8.9,2.3 \mathrm{~Hz}, 2 \mathrm{H}), 5.63$ (dd, $J=8.0,2.4 \mathrm{~Hz}, 2 \mathrm{H}), 1.50(\mathrm{~s}, 18 \mathrm{H}) .{ }^{19} \mathbf{F}$ NMR $\left(377 \mathrm{MHz}, \mathrm{CDCl}_{3}\right): \delta-62.99(6 \mathrm{~F}),-72.24(3 \mathrm{~F}),-74.13(3 \mathrm{~F}),-101.81$ (dt, $\left.J=12.4,8.4 \mathrm{~Hz}, 2 \mathrm{~F}\right)$, $105.92(\mathrm{td}, J=12.4,3.4 \mathrm{~Hz}, 2 \mathrm{~F})$. NMR Spectra matched those from commercial sources. 


\section{2: Synthesis of Hantzsch Esters}

Synthesis of HE-Ph-Et

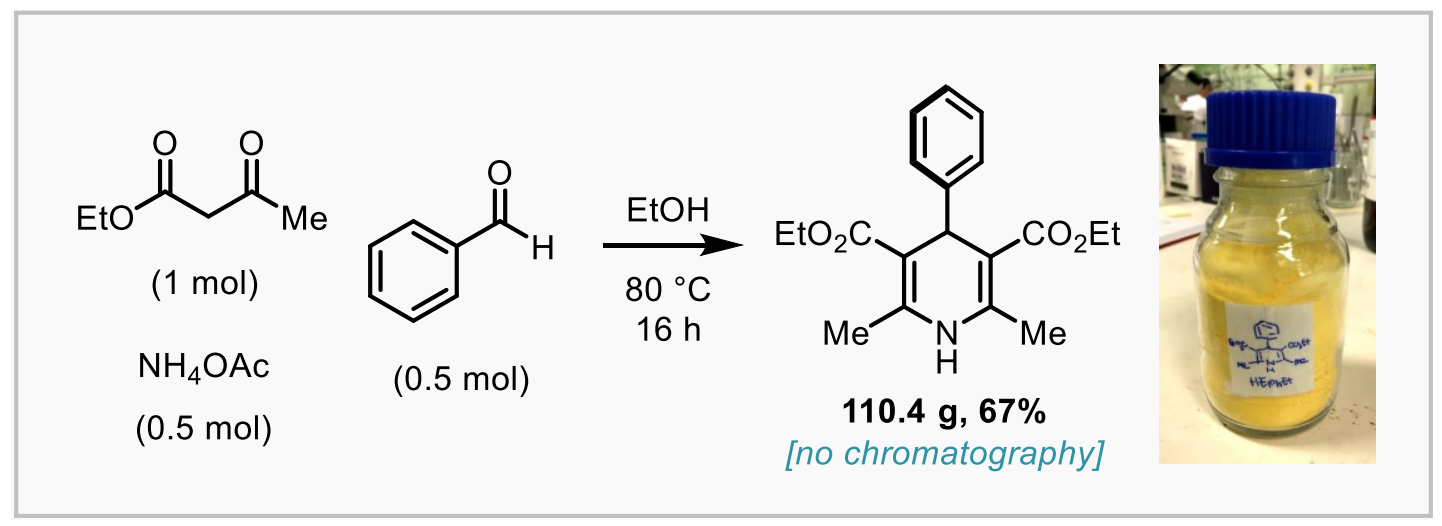

To a $1 \mathrm{~L}$ rbf was added benzaldehyde $(51 \mathrm{~mL}, 500 \mathrm{mmol})$, ethyl acetoacetate $(126.5 \mathrm{~mL}, 1.0 \mathrm{~mol})$, ammonium acetate $(38.54 \mathrm{~g}, 500 \mathrm{mmol})$, and $\mathrm{EtOH}(600 \mathrm{~mL})$. The reaction mixture was heated to $80{ }^{\circ} \mathrm{C}$ for $16 \mathrm{~h}$. After this time the reaction mixture was cooled to $\mathrm{rt}$ and concentrated in vacuo. The crude residue was dispersed in $\mathrm{CH}_{2} \mathrm{Cl}_{2}(700 \mathrm{~mL})$ and brine $(700 \mathrm{~mL})$. The organic phase was extracted and the aqueous phase re-extracted with $\mathrm{CH}_{2} \mathrm{Cl}_{2}(2 \times 700 \mathrm{~mL})$. The combined organic layers were dried over $\mathrm{MgSO}_{4}$ and concentrated in vacuo. The crude powder was purified via recrystallization from $\mathrm{CH}_{2} \mathrm{Cl}_{2} /$ Pentane to give a bright yellow solid (on smaller scales, sometimes a further recrystallization from hot EtOH may be required) HE-Ph (HE1), 67\% (110.44 g). ${ }^{1} \mathbf{H}$ NMR (400 MHz, CDCl $) \delta 7.38-7.26(\mathrm{~m}, 2 \mathrm{H}), 7.25-7.18$ (m, $\left.2 \mathrm{H}\right)$, $7.17-7.08(\mathrm{~m}, 1 \mathrm{H}), 5.85(\mathrm{~s}, 1 \mathrm{H}), 4.21-4.01(\mathrm{~m}, 4 \mathrm{H}), 2.33(\mathrm{~s}, 6 \mathrm{H}), 1.24(\mathrm{t}, J=7.1 \mathrm{~Hz}, 6 \mathrm{H}) .{ }^{13} \mathbf{C}$ NMR (101 $\left.\mathrm{MHz}_{2} \mathrm{CDCl}_{3}\right) \delta 167.8,147.9,144.1,128.1,127.9,126.2,104.2,59.8,39.8,19.6,14.4$. Data was consistent with literature precedent. ${ }^{2}$

Synthesis of HE-Ph-Bn<smiles>CC1=C(C(=O)OCc2ccccc2)C(c2ccccc2)C(C(=O)OCc2ccccc2)=C(C)N1</smiles>

To a $250 \mathrm{~mL}$ rbf was added benzaldehyde $(2.03 \mathrm{~mL}, 20 \mathrm{mmol})$, benzyl acetoacetate $(6.91 \mathrm{~mL}, 40 \mathrm{mmol})$, ammonium acetate $(1.56 \mathrm{~g}, 20 \mathrm{mmol})$, and $\mathrm{EtOH}(80 \mathrm{~mL})$. The reaction mixture was heated to $80{ }^{\circ} \mathrm{C}$ for $16 \mathrm{~h}$. After this time the reaction mixture was cooled to $\mathrm{rt}$ and concentrated in vacuo. The crude residue was dispersed in $\mathrm{CH}_{2} \mathrm{Cl}_{2}(100 \mathrm{~mL})$ and brine $(100 \mathrm{~mL})$. The organic phase was extracted and the aqueous phase re-extracted with $\mathrm{CH}_{2} \mathrm{Cl}_{2}(2 \times 100 \mathrm{~mL})$. The combined organic layers were dried over $\mathrm{MgSO}_{4}$ and concentrated in vacuo. The crude powder was purified silica gel column chromatography (EtOAc:Pentane 5:95 - 10:90 v:v) to give $\mathbf{H E}-\mathbf{P h}-\mathbf{B n}$ as a bright yellow solid, 55\% (4.98 g). ${ }^{1} \mathbf{H} \mathbf{~ N M R}\left(400 \mathrm{MHz}, \mathrm{CDCl}_{3}\right) \delta$ $7.31(\mathrm{dt}, J=4.1,1.5 \mathrm{~Hz}, 6 \mathrm{H}), 7.27-7.20(\mathrm{~m}, 6 \mathrm{H}), 7.20-7.11(\mathrm{~m}, 3 \mathrm{H}), 5.77(\mathrm{~s}, 1 \mathrm{H}), 5.13(\mathrm{~d}, J=12.6 \mathrm{~Hz}$, $2 \mathrm{H}), 5.08(\mathrm{~d}, J=12.6 \mathrm{~Hz}, 2 \mathrm{H}), 2.35$ (s, 6H). ${ }^{13} \mathbf{C} \mathbf{N M R}\left(101 \mathrm{MHz}, \mathrm{CDCl}_{3}\right) \delta$ 167.4, 147.6, 144.5, 136.7, 128.5, 128.2, 128.1, 128.0, 127.9, 126.3, 104.1, 65.8, 39.6, 19.8. Data was consistent with literature precedent. $^{3}$ 


\section{3: Synthesis of Enol Ether Substrates}

General Procedure $\mathbf{A}$ for the synthesis of enol ethers from alcohols.

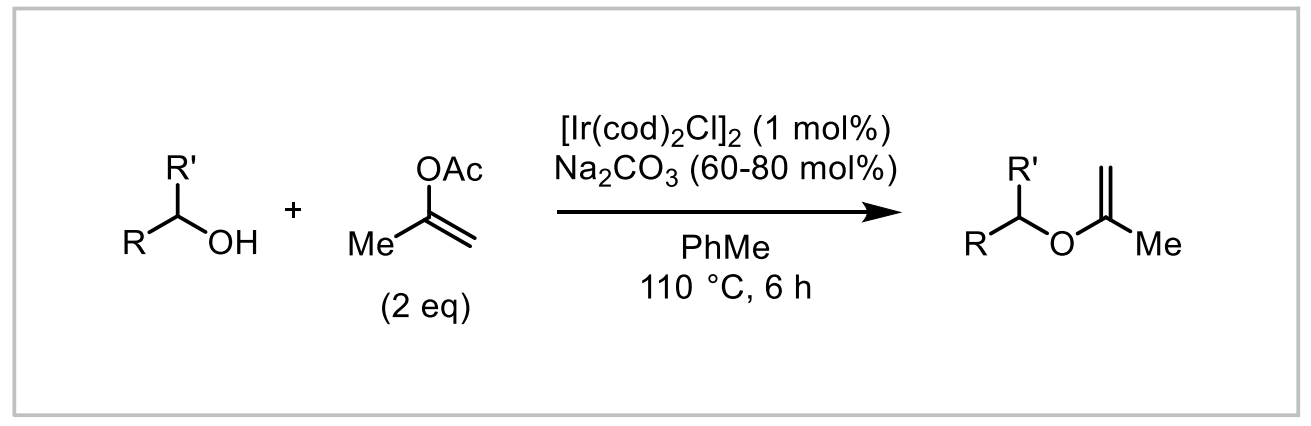

(From a modified literature procedure) ${ }^{4}$. To an oven-dried carousel tube was charged bis(1,5cyclooctadiene)diiridium(I) dichloride (20.1 $\mathrm{mg}, 0.03 \mathrm{mmol}, 1 \mathrm{~mol} \%$ ), oven-dried sodium carbonate (191 $\mathrm{mg}$ or $254 \mathrm{mg}, 1.8 \mathrm{mmol}$ or $2.4 \mathrm{mmol}$ ) and alcohol (if solid, $3 \mathrm{mmol}$ ). The tube was sealed with a Teflon cap then evacuated and refilled three times with argon. To the tube was charged anhydrous toluene $(3 \mathrm{~mL})$, isopropenyl acetate $(0.66 \mathrm{~mL}, 6 \mathrm{mmol})$ and alcohol (if liquid, $3 \mathrm{mmol})$. The flask was then sealed and heated to $110^{\circ} \mathrm{C}$ for 4 hours. After this time, the reaction mixture was allowed to cool, and diluted with $\mathrm{CH}_{2} \mathrm{Cl}_{2}$ $(10 \mathrm{~mL})$. The mixture was filtered, eluting with $\mathrm{CH}_{2} \mathrm{Cl}_{2}$, and the filtrate concentrated in vacuo. The crude residue was purified via column chromatography on basic alumina (EtOAc:Pentane, 0.1:99.9 - 1:99 v:v, unless otherwise stated) to give pure enol ether. 
General Procedure $\mathbf{B}$ for the synthesis of enol ethers from esters using Petasis reagent.

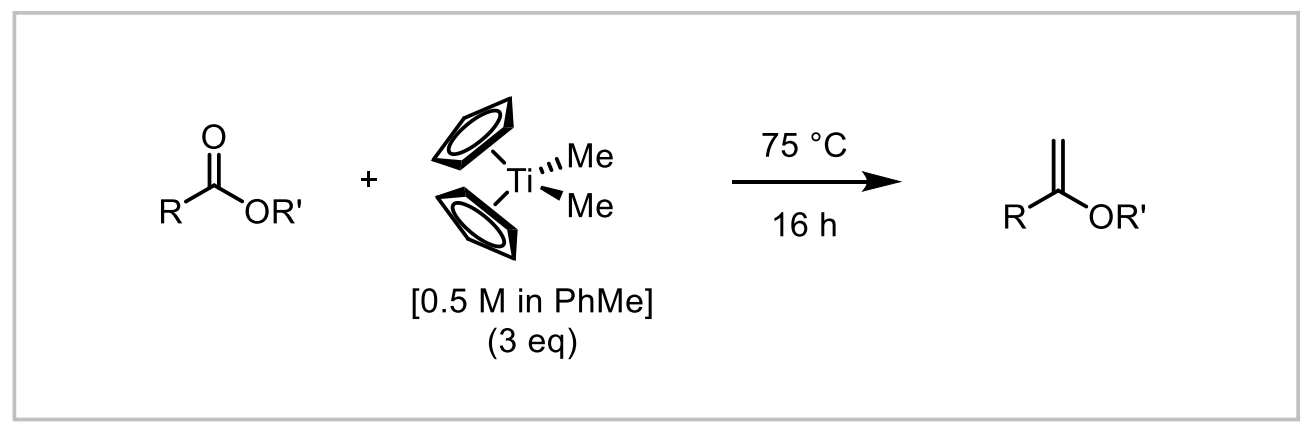

Preparation of Petasis Regaent (from a modified literature procedure) 5 : to an oven dried $500 \mathrm{~mL}$ round bottomed flask was charged bis(cyclopentadienyl)titanium(IV) dichloride ( $9.96 \mathrm{~g}, 40 \mathrm{mmol}$ ). The reaction flask was sealed and then evacuated and refilled three times with argon. Following this, anhydrous $\mathrm{Et}_{2} \mathrm{O}$ $(200 \mathrm{~mL})$ was added the reaction vessel via cannular, and the reaction mixture was allowed to stir for 1 hour at $\sim 10^{\circ} \mathrm{C}$ (cold water bath). After this time the vessel was covered in foil and $\mathrm{MeLi}\left(1.6 \mathrm{M}\right.$ in $\mathrm{Et}_{2} \mathrm{O}, 50 \mathrm{~mL}$, $80 \mathrm{mmol}$ ) was added dropwise to the solution, and then left to stir at $\sim 10{ }^{\circ} \mathrm{C}$ for 30 minutes in the dark. The reaction mixture was then quenched via addition of cold water $(100 \mathrm{~mL})$ via syringe maintaining a stream of argon. The resulting biphasic mixture was then poured into a separating funnel (covered in foil). The phases were separated (organics were kept in a conical flask covered in foil) dried over $\mathrm{MgSO}_{4}$ and then filtered. The flask was then concentrated in vacuo (covering rotavap with foil, bath temperature no more than $25^{\circ} \mathrm{C}$ ). The crude bright orange residue was then dissolved in the minimum amount of anhydrous pentane $\left(\sim 180 \mathrm{~mL}\right.$ ) and slowly cooled to $-78^{\circ} \mathrm{C}$ (all apparatus covered in foil). The bright orange crystals were then filtered washing with pentane $\left(-78^{\circ} \mathrm{C}\right)$, and allowed to dry on the funnel (covered in foil). Following this anhydrous toluene $(80 \mathrm{~mL})$ was added to the crystals slowly, creating a solution in the filtrate, at approximately $0.5 \mathrm{M}$ concentration. The solution was kept in a round bottom flask under argon, covered in foil, at $5{ }^{\circ} \mathrm{C}$, and was used directly.

To an oven-dried $50 \mathrm{~mL}$ round bottomed flask was charged relevant ester substrate $(2.5 \mathrm{mmol})$. The flask was equipped with a condenser and subsequently evacuated and refilled three times with argon. Under a strong flux of argon and covering the flask in foil, Petasis reagent $(15 \mathrm{~mL}, 7.5 \mathrm{mmol})$ was added to the flask. The subsequent bright orange mixture was stirred at $75{ }^{\circ} \mathrm{C}$ for $18 \mathrm{~h}$ in the dark. After this time, to the reaction mixture was poured into pentane $(100 \mathrm{~mL})$, affording a bright yellow precipitate. The precipitate was filtered and the filtrate concentrated in vacuo. The crude residue was then further treated with pentane $(100 \mathrm{~mL})$ to afford further precipitate which was removed via filtration, and the filtrate again concentrated in vacuo. The crude residue was then purified via column chromatography on basic alumina (EtOAc:Pentane, 0.1:99.9 - 1:99 v:v) to give pure enol ether. 
Synthesis of 1aa<smiles>C=C(C)OCc1ccccc1</smiles>

The above compound was synthesized according to General Procedure A using benzylalcohol $(1.03 \mathrm{~mL}$, $10 \mathrm{mmol})$, isopropenyl acetate $(2.20 \mathrm{~mL}, 20 \mathrm{mmol}),\left[\operatorname{Ir}(\operatorname{cod})_{2} \mathrm{Cl}\right]_{2}(67.2 \mathrm{mg}, 0.1 \mathrm{mmol}, 1 \mathrm{~mol} \%)$, sodium carbonate $(636 \mathrm{mg}, 6 \mathrm{mmol})$, and anhydrous toluene $(10 \mathrm{~mL})$. Chromatography on basic alumina gave the title compound as a colourless oil, $41 \%(603 \mathrm{mg})$. FT-IR (neat): $\nu_{\max }\left(\mathrm{cm}^{-1}\right)=3033,1656,1604,1498 . \quad{ }^{1} \mathbf{H}$ NMR (400 MHz, DMSO-d $) \delta 7.37$ (d, $J=4.4 \mathrm{~Hz}, 4 \mathrm{H}), 7.35-7.28(\mathrm{~m}, 1 \mathrm{H}), 4.73(\mathrm{~s}, 2 \mathrm{H}), 4.01(\mathrm{~d}, J=1.7$ $\mathrm{Hz}, 1 \mathrm{H}), 3.99-3.93(\mathrm{~m}, 1 \mathrm{H}), 1.81(\mathrm{~d}, J=0.9 \mathrm{~Hz}, 3 \mathrm{H}) .{ }^{13} \mathbf{C}$ NMR $\left(101 \mathrm{MHz}, \mathrm{DMSO}-d_{6}\right) \delta$ 158.7, 137.1, 128.3, 127.6, 127.5, 82.8, 68.7, 20.8. HRMS (ESI): $\mathrm{m} / \mathrm{z}$ calculated for $\mathrm{C}_{10} \mathrm{H}_{12} \mathrm{O}_{1}$ requires 149.0961 for $[\mathrm{M}+\mathrm{H}]^{+}$, found 149.0961 .

Synthesis of $\mathbf{1 b}$<smiles>C=C(C)OCc1ccccc1C</smiles>

The above compound was synthesized according to General Procedure A using 2-methylbenzylalcohol (244 mg, $2 \mathrm{mmol})$, isopropenyl acetate $(0.44 \mathrm{~mL}, 4 \mathrm{mmol}),\left[\operatorname{Ir}(\operatorname{cod})_{2} \mathrm{Cl}\right]_{2}(13.4 \mathrm{mg}, 0.02 \mathrm{mmol}, 1 \mathrm{~mol} \%)$, sodium carbonate $(108 \mathrm{mg}, 1.2 \mathrm{mmol})$, and anhydrous toluene $(2 \mathrm{~mL})$. Chromatography on basic alumina gave the title compound as a colourless oil, $42 \%(137 \mathrm{mg})$. FT-IR (neat): $\nu_{\max }\left(\mathrm{cm}^{-1}\right)=2981,2923,1655$, 1606, 1494. ${ }^{1} \mathbf{H}$ NMR $\left(400 \mathrm{MHz}, \mathrm{CD}_{2} \mathrm{Cl}_{2}\right) \delta 7.33(\mathrm{dd}, J=7.2,1.9 \mathrm{~Hz}, 1 \mathrm{H}), 7.29-7.14(\mathrm{~m}, 3 \mathrm{H}), 4.72(\mathrm{~s}$, 2H), $4.00(\mathrm{~d}, J=1.9 \mathrm{~Hz}, 1 \mathrm{H}), 3.96(\mathrm{dd}, J=1.9,0.9 \mathrm{~Hz}, 1 \mathrm{H}), 2.32(\mathrm{~s}, 3 \mathrm{H}), 1.87(\mathrm{~d}, J=0.8 \mathrm{~Hz}, 3 \mathrm{H}) .{ }^{13} \mathrm{C}$ NMR $\left(101 \mathrm{MHz}\right.$, DMSO- $\left.d_{6}\right) \delta 158.8,136.5,135.0,130.0,128.5,127.9,125.7,82.7,67.4,20.7,18.3$. HRMS (ESI): $\mathrm{m} / \mathrm{z}$ calculated for $\mathrm{C}_{11} \mathrm{H}_{14} \mathrm{O}_{1}$ requires 185.0937 for $[\mathrm{M}+\mathrm{Na}]^{+}$, found 185.1326 . 
Synthesis of $1 \mathbf{c}$<smiles>C=C(C)OCc1cccc(OC)c1</smiles>

The above compound was synthesized according to General Procedure A using 3-methoxybenzylalcohol $(0.25 \mathrm{~mL}, 2 \mathrm{mmol})$, isopropenyl acetate $(0.44 \mathrm{~mL}, 4 \mathrm{mmol}),\left[\mathrm{Ir}(\operatorname{cod})_{2} \mathrm{Cl}\right]_{2}(13.4 \mathrm{mg}, 0.02 \mathrm{mmol}, 1 \mathrm{~mol} \%)$, sodium carbonate $(108 \mathrm{mg}, 1.2 \mathrm{mmol})$, and anhydrous toluene $(2 \mathrm{~mL})$. Chromatography on basic alumina gave the title compound as a colourless oil, $60 \%(212 \mathrm{mg})$. FT-IR (neat): $\nu_{\max }\left(\mathrm{cm}^{-1}\right)=2980,2971,2887$, 1656, 1604. ${ }^{1} \mathbf{H}$ NMR $\left(400 \mathrm{MHz}, \mathrm{CD}_{2} \mathrm{Cl}_{2}\right) \delta 7.28(\mathrm{t}, J=7.9 \mathrm{~Hz}, 1 \mathrm{H}), 7.05-6.91(\mathrm{~m}, 2 \mathrm{H}), 6.85(\mathrm{ddd}, J=$ 8.3, 2.7, $1.0 \mathrm{~Hz}, 1 \mathrm{H}), 4.72(\mathrm{~s}, 2 \mathrm{H}), 4.00-3.92(\mathrm{~m}, 2 \mathrm{H}), 3.81(\mathrm{~s}, 3 \mathrm{H}), 1.88(\mathrm{~d}, J=0.9 \mathrm{~Hz}, 3 \mathrm{H}) .{ }^{13} \mathbf{C}$ NMR $\left(101 \mathrm{MHz}, \mathrm{CD}_{2} \mathrm{Cl}_{2}\right) \delta 160.3,160.2,139.4,129.8,120.1,113.5,113.4,82.2,69.7,55.6,21.2$. HRMS (ESI): $\mathrm{m} / \mathrm{z}$ calculated for $\mathrm{C}_{11} \mathrm{H}_{14} \mathrm{O}_{2}$ requires 201.0886 for $[\mathrm{M}+\mathrm{Na}]^{+}$, found 201.0887.

Synthesis of $\mathbf{1 d}$<smiles>C=C(C)OCc1cccc(OC(F)(F)F)c1</smiles>

The above compound was synthesized according to General Procedure A using 3(trifluoromethoxy)benzylalcohol (573 mg, $3 \mathrm{mmol}$ ), isopropenyl acetate ( $0.66 \mathrm{~mL}, 6 \mathrm{mmol}),\left[\mathrm{Ir}(\mathrm{cod})_{2} \mathrm{Cl}\right]_{2}$ (20.1 mg, $0.03 \mathrm{mmol}, 1 \mathrm{~mol} \%)$, sodium carbonate $(254 \mathrm{mg}, 2.4 \mathrm{mmol})$, and anhydrous toluene $(3 \mathrm{~mL})$. Chromatography on basic alumina gave the title compound as a colourless oil, $62 \%(430 \mathrm{mg})$. FT-IR (neat): $\nu_{\max }\left(\mathrm{cm}^{-1}\right)=2981,2361,1660,1593,1499 .{ }^{1} \mathbf{H}$ NMR $\left(400 \mathrm{MHz}, \mathrm{DMSO}-d_{6}\right) \delta 7.51(\mathrm{t}, J=7.9 \mathrm{~Hz}, 1 \mathrm{H}), 7.41$ $(\mathrm{ddd}, J=7.7,1.6,0.8 \mathrm{~Hz}, 1 \mathrm{H}), 7.38-7.34(\mathrm{~m}, 1 \mathrm{H}), 7.30(\mathrm{ddt}, J=8.2,2.5,1.1 \mathrm{~Hz}, 1 \mathrm{H}), 4.80(\mathrm{~s}, 2 \mathrm{H}), 4.00$ $(\mathrm{d}, J=1.8 \mathrm{~Hz}, 1 \mathrm{H}), 3.99-3.92(\mathrm{~m}, 1 \mathrm{H}), 1.82(\mathrm{~d}, J=0.9 \mathrm{~Hz}, 3 \mathrm{H}) .{ }^{19} \mathbf{F}$ NMR $\left(377 \mathrm{MHz}\right.$, DMSO- $\left.d_{6}\right) \delta-$ 56.71. ${ }^{13}$ C NMR (101 MHz, DMSO- $\left.d_{6}\right) \delta$ 158.6, 148.5, 140.1, 130.3, 126.2, 120.2 (q, $\left.J=256.2 \mathrm{~Hz}\right), 112.0$, 119.5, 83.1, 67.7, 20.5. HRMS (ESI): $\mathrm{m} / \mathrm{z}$ calculated for $\mathrm{C}_{11} \mathrm{H}_{11} \mathrm{O}_{2} \mathrm{~F}_{3}$ requires 233.0784 for $[\mathrm{M}+\mathrm{H}]^{+}$, found 233.0784 . 
Synthesis of $1 \mathbf{e}$<smiles>C=C(C)OCc1ccc(F)cc1</smiles>

The above compound was synthesized according to General Procedure A using 4-fluorobenzylalcohol (0.33 $\mathrm{mL}, 3 \mathrm{mmol})$, isopropenyl acetate $(0.66 \mathrm{~mL}, 6 \mathrm{mmol}),\left[\mathrm{Ir}(\operatorname{cod})_{2} \mathrm{Cl}_{2}(20.1 \mathrm{mg}, 0.03 \mathrm{mmol}, 1 \mathrm{~mol} \%)\right.$, sodium carbonate $(254 \mathrm{mg}, 2.4 \mathrm{mmol})$, and anhydrous toluene $(3 \mathrm{~mL})$. Chromatography on basic alumina gave the title compound as a colourless oil, 49\% (243 mg). FT-IR (neat): $\nu_{\max }\left(\mathrm{cm}^{-1}\right)=2981,2886,1657,1605,1512$. ${ }^{1} \mathbf{H}$ NMR $\left(400 \mathrm{MHz}, \mathrm{DMSO}-d_{6}\right) \delta 7.58-7.30(\mathrm{~m}, 2 \mathrm{H}), 7.18(\mathrm{t}, J=8.9 \mathrm{~Hz}, 2 \mathrm{H}), 4.71(\mathrm{~s}, 2 \mathrm{H}), 4.00(\mathrm{~d}, J=$ $1.7 \mathrm{~Hz}, 1 \mathrm{H}), 3.94(\mathrm{dt}, J=1.7,0.9 \mathrm{~Hz}, 1 \mathrm{H}), 1.80(\mathrm{~d}, J=0.8 \mathrm{~Hz}, 3 \mathrm{H}) .{ }^{19} \mathbf{F}$ NMR $\left(376 \mathrm{MHz}\right.$, DMSO- $\left.d_{6}\right) \delta-$ $114.87(\mathrm{td}, J=9.3,4.7 \mathrm{~Hz}) .{ }^{13} \mathbf{C}$ NMR $\left(101 \mathrm{MHz}, \mathrm{DMSO}-d_{6}\right) \delta 161.6(\mathrm{~d}, J=243.2 \mathrm{~Hz}), 158.6,133.3(\mathrm{~d}, J$ $=3.7 \mathrm{~Hz}), 129.7(\mathrm{~d}, J=8.1 \mathrm{~Hz}), 115.1(\mathrm{~d}, J=20.9 \mathrm{~Hz}), 82.9,68.0,20.7 . \mathbf{H R M S}(\mathrm{ESI}): \mathrm{m} / \mathrm{z}$ calculated for $\mathrm{C}_{10} \mathrm{H}_{11} \mathrm{O}_{1} \mathrm{~F}_{1}$ requires 167.0867 for $[\mathrm{M}+\mathrm{H}]^{+}$, found 167.0866 .

Synthesis of $\mathbf{1 f}$<smiles>C=C(C)OCc1ccc(Br)cc1</smiles>

The above compound was synthesized according to General Procedure A using 4-bromobenzylalcohol (561 mg, $3 \mathrm{mmol})$, isopropenyl acetate $(0.66 \mathrm{~mL}, 6 \mathrm{mmol}),\left[\operatorname{Ir}(\operatorname{cod})_{2} \mathrm{Cl}\right]_{2}(20.1 \mathrm{mg}, 0.03 \mathrm{mmol}, 1 \mathrm{~mol} \%)$, sodium carbonate $(254 \mathrm{mg}, 2.4 \mathrm{mmol})$, and anhydrous toluene $(3 \mathrm{~mL})$. Chromatography on basic alumina gave the title compound as a colourless oil, $31 \%(210 \mathrm{mg})$. FT-IR (neat): $\nu_{\max }\left(\mathrm{cm}^{-1}\right)=2981,2886,1657$, 1598, 1489. ${ }^{1} \mathbf{H}$ NMR $\left(400 \mathrm{MHz}, \mathrm{DMSO}-d_{6}\right) \delta 7.55(\mathrm{~d}, J=8.4 \mathrm{~Hz}, 2 \mathrm{H}), 7.33(\mathrm{~d}, J=8.3 \mathrm{~Hz}, 2 \mathrm{H}), 4.72(\mathrm{~s}$, $2 \mathrm{H}), 3.99(\mathrm{~d}, J=1.7 \mathrm{~Hz}, 1 \mathrm{H}), 3.95(\mathrm{dd}, J=1.9,0.9 \mathrm{~Hz}, 1 \mathrm{H}), 1.81(\mathrm{~d}, J=0.9 \mathrm{~Hz}, 3 \mathrm{H}) .{ }^{13} \mathbf{C} \mathbf{N M R}(101 \mathrm{MHz}$, DMSO- $\left.d_{6}\right) \delta 158.5,136.6,131.2,129.5,129.5,120.6,83.0,67.8$, 20.6. HRMS (ESI): $\mathrm{m} / \mathrm{z}$ calculated for $\mathrm{C}_{10} \mathrm{H}_{11} \mathrm{O}_{1}{ }^{79} \mathrm{Br}_{1}$ requires 227.0066 for $[\mathrm{M}+\mathrm{H}]^{+}$, found 227.0066 . 
Synthesis of $1 \mathrm{~g}$<smiles>C=C(C)OCc1ccc2ccccc2c1</smiles>

The above compound was synthesized according to General Procedure A using 2-naphthalenemethanol (476 mg, $3 \mathrm{mmol})$, isopropenyl acetate $(0.66 \mathrm{~mL}, 6 \mathrm{mmol}),\left[\mathrm{Ir}(\mathrm{cod})_{2} \mathrm{Cl}\right]_{2}(20.1 \mathrm{mg}, 0.03 \mathrm{mmol}, 1 \mathrm{~mol} \%$ ), sodium carbonate $(254 \mathrm{mg}, 2.4 \mathrm{mmol})$, and anhydrous toluene $(3 \mathrm{~mL})$. Chromatography on basic alumina gave the title compound as white solid, $62 \%(370 \mathrm{mg})$. FT-IR (neat): $\nu_{\max }\left(\mathrm{cm}^{-1}\right)=3131,3061,2981,2888$, 1656, 1598, 1508. ${ }^{1} \mathbf{H}$ NMR $\left(400 \mathrm{MHz}, \mathrm{DMSO}-d_{6}\right) \delta 7.96-7.85(\mathrm{~m}, 4 \mathrm{H}), 7.50(\mathrm{ddd}, J=8.2,5.3,1.5 \mathrm{~Hz}$, $3 \mathrm{H}), 4.90(\mathrm{~s}, 2 \mathrm{H}), 4.07(\mathrm{~d}, J=1.7 \mathrm{~Hz}, 1 \mathrm{H}), 3.98(\mathrm{dd}, J=1.9,1.0 \mathrm{~Hz}, 1 \mathrm{H}), 1.85(\mathrm{~d}, J=0.8 \mathrm{~Hz}, 3 \mathrm{H}) .{ }^{13} \mathrm{C}$ NMR $\left(101 \mathrm{MHz}\right.$, DMSO- $\left.d_{6}\right) \delta$ 158.8, 134.8, 132.8, 132.5, 127.9, 127.8, 127.7, 127.6, 126.3, 126.1, 126.0, 125.7, 83.0, 68.9, 20.8. HRMS (ESI): $\mathrm{m} / \mathrm{z}$ calculated for $\mathrm{C}_{14} \mathrm{H}_{14} \mathrm{O}_{1}$ requires 199.1117 for $[\mathrm{M}+\mathrm{H}]^{+}$, found 199.1118.

Synthesis of $\mathbf{1 h}$<smiles>C=C(OCc1ccccc1)C1CCC1</smiles>

The above compound was synthesized according to General Procedure B using ethyl benzyl cyclobutanecarboxylate ( $380 \mathrm{mg}, 2 \mathrm{mmol}$ ), and Petasis reagent (C $\mathrm{C}_{2}$ TiMe, $0.5 \mathrm{M}$ in PhMe, $12 \mathrm{~mL}, 6 \mathrm{mmol}$ ). Chromatography on basic alumina gave the above compound as a colourless oil, 57\% (216 mg) ${ }^{1} \mathbf{H}$ NMR $\left(400 \mathrm{MHz}, \mathrm{DMSO}-d_{6}\right) \delta 7.37(\mathrm{~d}, J=4.7 \mathrm{~Hz}, 4 \mathrm{H}), 7.35-7.24(\mathrm{~m}, 1 \mathrm{H}), 4.75(\mathrm{~s}, 2 \mathrm{H}), 4.00(\mathrm{~d}, J=2.0 \mathrm{~Hz}, 1 \mathrm{H})$, $3.95(\mathrm{dd}, J=2.1,0.7 \mathrm{~Hz}, 1 \mathrm{H}), 3.17-2.86(\mathrm{~m}, 1 \mathrm{H}), 2.10-1.99(\mathrm{~m}, 4 \mathrm{H}), 1.92-1.79(\mathrm{~m}, 1 \mathrm{H}), 1.79-1.61$ (m, 1H). ${ }^{13} \mathbf{C}$ NMR (101 MHz, DMSO- $\left.d_{6}\right) \delta 164.4,137.4,128.3,127.5,127.2$, 80.8, 68.5, 26.2, 23.7, 17.6 . HRMS (ESI): $\mathrm{m} / \mathrm{z}$ calculated for $\mathrm{C}_{13} \mathrm{H}_{16} \mathrm{O}_{1}$ requires 211.1117 for $[\mathrm{M}+\mathrm{Na}]^{+}$, found 211.1121. 
Synthesis of $1 \mathbf{i}$<smiles>C=C(C)OCC(C)C(C)C</smiles>

The above compound was synthesized according to General Procedure A using dodecanol $(0.32 \mathrm{~mL}, 3$ $\mathrm{mmol})$, isopropenyl acetate $(0.66 \mathrm{~mL}, 6 \mathrm{mmol}),\left[\operatorname{Ir}(\operatorname{cod})_{2} \mathrm{Cl}\right]_{2}(20.1 \mathrm{mg}, 0.03 \mathrm{mmol}, 1 \mathrm{~mol} \%)$, sodium carbonate $(254 \mathrm{mg}, 2.4 \mathrm{mmol})$, and anhydrous toluene $(3 \mathrm{~mL})$. Chromatography on basic alumina gave the title compound as a colourless oil, 54\% (557 mg). FT-IR (neat): $\nu_{\max }\left(\mathrm{cm}^{-1}\right)=2981,2923,2854,1655,1589$. ${ }_{1}^{1}$ H NMR (400 MHz, DMSO-d 6$) \delta 3.84(\mathrm{~d}, J=1.4 \mathrm{~Hz}, 1 \mathrm{H}), 3.82(\mathrm{t}, J=1.2 \mathrm{~Hz}, 1 \mathrm{H}), 3.59(\mathrm{t}, J=6.5 \mathrm{~Hz}$, $2 \mathrm{H}), 1.73(\mathrm{~d}, J=0.9 \mathrm{~Hz}, 3 \mathrm{H}), 1.64-1.54(\mathrm{~m}, 2 \mathrm{H}), 1.24(\mathrm{app} \mathrm{s}, 18 \mathrm{H}), 0.97-0.80(\mathrm{~m}, 3 \mathrm{H}) .{ }^{13} \mathbf{C}$ NMR $(101$ $\left.\mathrm{MHz}, \mathrm{DMSO}-d_{6}\right) \delta$ 158.9, 81.7, 66.7, 31.3, 29.0 (2C), 28.9 (2C), 28.73, 28.66, 28.4, 25.6, 22.1, 20.8, 13.9. HRMS (ESI): $\mathrm{m} / \mathrm{z}$ calculated for $\mathrm{C}_{15} \mathrm{H}_{30} \mathrm{O}_{1}$ requires 227.2369 for $[\mathrm{M}+\mathrm{H}]^{+}$, found 227.2371

Synthesis of $\mathbf{1 j}$

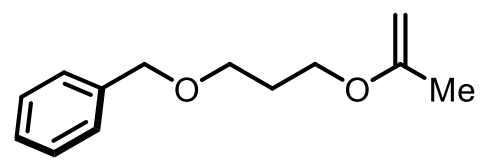

The above compound was synthesized according to General Procedure A using 3-(benzyloxy)propan-1-ol (0.48 mL, $3 \mathrm{mmol})$, isopropenyl acetate $(0.66 \mathrm{~mL}, 6 \mathrm{mmol}),\left[\operatorname{Ir}(\operatorname{cod})_{2} \mathrm{Cl}_{2}(20.1 \mathrm{mg}, 0.03 \mathrm{mmol}, 1 \mathrm{~mol} \%)\right.$, sodium carbonate $(254 \mathrm{mg}, 2.4 \mathrm{mmol})$, and anhydrous toluene $(3 \mathrm{~mL})$. Chromatography on basic alumina gave the title compound as a colourless oil, $61 \%(379 \mathrm{mg})$. FT-IR (neat): $\nu_{\max }\left(\mathrm{cm}^{-1}\right)=2981,2884,1721$, 1655, 1603, 1496. ${ }^{1} \mathbf{H}$ NMR (400 MHz, DMSO- $\left.d_{6}\right) \delta 7.48-7.20(\mathrm{~m}, 5 \mathrm{H}), 4.46(\mathrm{~s}, 2 \mathrm{H}), 3.85(\mathrm{dd}, J=9.8$, $1.4 \mathrm{~Hz}, 2 \mathrm{H}), 3.70(\mathrm{t}, J=6.4 \mathrm{~Hz}, 2 \mathrm{H}), 3.51(\mathrm{t}, J=6.3 \mathrm{~Hz}, 2 \mathrm{H}), 1.88(\mathrm{p}, J=6.3 \mathrm{~Hz}, 2 \mathrm{H}), 1.73(\mathrm{~d}, J=0.8 \mathrm{~Hz}$, 3H). ${ }^{13}$ C NMR (101 MHz, DMSO-d N $_{\text {) }} \delta$ 158.9, 138.6, 128.2, 127.3, 127.3, 81.8, 71.8, 66.3, 63.8, 28.8, 20.7. HRMS (ESI): $\mathrm{m} / \mathrm{z}$ calculated for $\mathrm{C}_{13} \mathrm{H}_{18} \mathrm{O}_{1}$ requires 207.1380 for $[\mathrm{M}+\mathrm{H}]^{+}$, found 207.1381. 
Synthesis of $1 \mathbf{k}$<smiles>C=C(C)OCC1CCCN1C(=O)OCc1ccccc1</smiles>

The above compound was synthesized according to General Procedure A using (S)-prolinol (604 mg, 3 $\mathrm{mmol})$, isopropenyl acetate $(0.66 \mathrm{~mL}, 6 \mathrm{mmol}),\left[\operatorname{rr}(\operatorname{cod})_{2} \mathrm{Cl}\right]_{2}(20.1 \mathrm{mg}, 0.03 \mathrm{mmol}, 1 \mathrm{~mol} \%)$, sodium carbonate $(254 \mathrm{mg}, 2.4 \mathrm{mmol})$, and anhydrous toluene $(3 \mathrm{~mL})$. Chromatography on basic alumina (EtOAc:Pentane, 1:99 - 5:95 - v:v) gave the title compound as a colourless oil, 74\% (538 mg). FT-IR (neat): $\nu_{\max }\left(\mathrm{cm}^{-1}\right)=2980,2884,1693,1656 .{ }^{1} \mathbf{H}$ NMR $\left(400 \mathrm{MHz}, \mathrm{DMSO}-d_{6}\right) \delta 3.92(\mathrm{t}, J=3.3 \mathrm{~Hz}, 2 \mathrm{H}), 3.85(\mathrm{~s}$, $1 \mathrm{H}), 3.71(\mathrm{dd}, J=9.5,3.4 \mathrm{~Hz}, 1 \mathrm{H}), 3.53(\mathrm{~d}, J=9.0 \mathrm{~Hz}, 1 \mathrm{H}), 3.27-3.17(\mathrm{~m}, 2 \mathrm{H}), 1.96-1.76(\mathrm{~m}, 4 \mathrm{H}), 1.75$ (s, 3H), 1.39 (s, 9H). ${ }^{13} \mathbf{C}$ NMR (101 MHz, DMSO- $d_{6}$ ) Rotameric - $\delta 158.8$ (2C), 153.7, 153.4, 82.0, 81.9, 78.4 (2C), 67.5, 66.9, 55.3, 46.4, 46.3, 28.4, 28.1, 27.7, 23.2, 22.3, 20.6 (2C). HRMS (ESI): m/z calculated for $\mathrm{C}_{13} \mathrm{H}_{23} \mathrm{O}_{3} \mathrm{~N}_{1}$ requires 264.1570 for $[\mathrm{M}+\mathrm{Na}]^{+}$, found 264.1574 .

Synthesis of $\mathbf{1 1}$<smiles>C=C(C)OCC1CCCO1</smiles>

The above compound was synthesized according to General Procedure A using (tetrahydrofuran-2yl)methanol ( $0.29 \mathrm{~mL}, 3 \mathrm{mmol})$, isopropenyl acetate ( $0.66 \mathrm{~mL}, 6 \mathrm{mmol}),\left[\operatorname{Ir}(\operatorname{cod})_{2} \mathrm{Cl}\right]_{2}(20.1 \mathrm{mg}, 0.03 \mathrm{mmol}$, $1 \mathrm{~mol} \%)$, sodium carbonate (191 mg, $1.8 \mathrm{mmol})$, and anhydrous toluene $(3 \mathrm{~mL})$. Chromatography on basic alumina gave the title compound as a colourless oil, $26 \%(110 \mathrm{mg})$. FT-IR (neat): $\nu_{\max }\left(\mathrm{cm}^{-1}\right)=2981,2883$, 1656. ${ }^{1} \mathbf{H}$ NMR (400 MHz, DMSO-d $\left.d_{1}\right) \delta 4.03$ (tdd, $\left.J=7.1,6.0,4.4 \mathrm{~Hz}, 1 \mathrm{H}\right), 3.86(\mathrm{~d}, J=1.7 \mathrm{~Hz}, 1 \mathrm{H}), 3.84$ (s, $1 \mathrm{H}), 3.74(\mathrm{dt}, J=8.2,6.7 \mathrm{~Hz}, 1 \mathrm{H}), 3.64(\mathrm{td}, J=7.2,5.8 \mathrm{~Hz}, 1 \mathrm{H}), 3.60-3.51(\mathrm{~m}, 2 \mathrm{H}), 2.01-1.87(\mathrm{~m}$, $1 \mathrm{H}), 1.86-1.77(\mathrm{~m}, 2 \mathrm{H}), 1.75$ (d, $J=0.8 \mathrm{~Hz}, 3 \mathrm{H}), 1.57$ (ddt, $J=11.7,8.4,6.8 \mathrm{~Hz}, 1 \mathrm{H}) .{ }^{13} \mathrm{C}$ NMR $(101$ MHz, DMSO- $\left.d_{6}\right) \delta 158.9,82.0,76.2,69.5,67.3,27.7,25.1,20.6$. HRMS (ESI): $\mathrm{m} / \mathrm{z}$ calculated for $\mathrm{C}_{8} \mathrm{H}_{14} \mathrm{O}_{2}$ requires 143.1067 for $[\mathrm{M}+\mathrm{H}]^{+}$, found 143.1067 . 
Synthesis of $1 \mathrm{~m}$<smiles>C=C(CCc1ccco1)OCC</smiles>

The above compound was synthesized according to General Procedure B using ethyl 3-(furan-2yl)propanoate $(0.40 \mathrm{~mL}, 2.5 \mathrm{mmol})$, and Petasis reagent (Cp. $\mathrm{p}_{2}$ TiMe, $0.5 \mathrm{M}$ in PhMe, $15 \mathrm{~mL}, 7.5 \mathrm{mmol}$ ). Chromatography on basic alumina gave the above compound as a viscous yellow oil, 39\% (160 mg) FTIR (neat): $\nu_{\max }\left(\mathrm{cm}^{-1}\right)=2981,2885,1655,1598,1508 .{ }^{1} \mathbf{H}$ NMR $\left(400 \mathrm{MHz}, \mathrm{DMSO}-d_{6}\right) \delta 7.48(\mathrm{dd}, J=1.9$, $0.9 \mathrm{~Hz}, 1 \mathrm{H}), 6.32(\mathrm{dd}, J=3.2,1.9 \mathrm{~Hz}, 1 \mathrm{H}), 6.09(\mathrm{dd}, J=3.1,1.0 \mathrm{~Hz}, 1 \mathrm{H}), 3.89(\mathrm{~s}, 2 \mathrm{H}), 3.67$ (q, $J=7.0 \mathrm{~Hz}$, 2H), $2.86-2.67(\mathrm{~m}, 2 \mathrm{H}), 2.37-2.29(\mathrm{~m}, 2 \mathrm{H}), 1.22(\mathrm{t}, J=7.0 \mathrm{~Hz}, 3 \mathrm{H}) .{ }^{13} \mathbf{C}$ NMR $\left(101 \mathrm{MHz}, \mathrm{DMSO}-d_{6}\right) \delta$ 161.1, 154.7, 141.2, 110.2, 105.1, 81.8, 62.3, 33.1, 25.5, 14.2. HRMS (ESI): $\mathrm{m} / \mathrm{z}$ calculated for $\mathrm{C}_{10} \mathrm{H}_{14} \mathrm{O}_{2}$ requires 167.1067 for $[\mathrm{M}+\mathrm{H}]^{+}$, found 167.1068 .

Synthesis of $1 \mathrm{n}$<smiles>CCOC1=CCCC1</smiles>

To a stirred solution of cyclopentanone $(8.85 \mathrm{~mL}, 100 \mathrm{mmol})$, triethylorthoformate $(18.3 \mathrm{~mL}, 110 \mathrm{mmol})$, in $\mathrm{EtOH}(25 \mathrm{~mL})$, was added para-toluenesulfonic acid $(100 \mathrm{mg})$. The reaction mixture was then heated to reflux overnight. After this time, the reaction mixture was concentrated in vacuo to remove EtOH. Following this a second amount of para-toluenesulfonic acid $(200 \mathrm{mg})$ was added and the reaction mixture was heated to $160{ }^{\circ} \mathrm{C}$, open to the atmosphere for 6 hours. The reaction mixture was then purified via distillation $(70$ ${ }^{\circ} \mathrm{C}, 100 \mathrm{mbar}$ ) to afford the above compound as a colourless oil, $20 \%(2.21 \mathrm{~g})$.). Further crops are available from redistillation if required. FT-IR (neat): $\nu_{\max }\left(\mathrm{cm}^{-1}\right)=2980,2891,2853,1740,1645,1474 .{ }^{1} \mathbf{H}$ NMR $\left(400 \mathrm{MHz}, \mathrm{CDCl}_{3}\right) \delta 4.42$ (p, J=1.9 Hz, 1H), 3.78 (q, J = 7.0 Hz, 2H), $2.46-2.20$ (m, 4H), $1.97-1.75$ (m, 2H), $1.30(\mathrm{t}, J=7.1 \mathrm{~Hz}, 3 \mathrm{H}) .{ }^{13} \mathbf{C} \mathbf{N M R}\left(101 \mathrm{MHz}, \mathrm{CDCl}_{3}\right) \delta 159.9,93.5,64.7,32.0,29.0,21.2,14.7$. HRMS (ESI): $\mathrm{m} / \mathrm{z}$ calculated for $\mathrm{C}_{7} \mathrm{H}_{12} \mathrm{O}_{1}$ requires 113.0961 for $[\mathrm{M}+\mathrm{H}]^{+}$, found 113.0962 . 
Synthesis of $1 p$<smiles>CCOC1=CCCCCC1</smiles>

To a stirred solution of cycloheptanone $(11.8 \mathrm{~mL}, 100 \mathrm{mmol})$, triethylorthoformate $(18.3 \mathrm{~mL}, 110 \mathrm{mmol})$, in EtOH $(50 \mathrm{~mL})$, was added para-toluenesulfonic acid $(100 \mathrm{mg})$. The reaction mixture was then heated to reflux overnight. After this time, the reaction mixture was concentrated in vacuo to remove EtOH. Following this a second amount of para-toluenesulfonic acid $(200 \mathrm{mg})$ was added and the reaction mixture was heated to $140{ }^{\circ} \mathrm{C}$, open to the atmosphere for 6 hours. The reaction mixture was then purified via distillation (bp $\left.177^{\circ} \mathrm{C}\right)$ to afford the above compound as a colourless oil, $20 \%(2.77 \mathrm{~g})$. Further crops are available from redistillation if required. FT-IR (neat): $\nu_{\max }\left(\mathrm{cm}^{-1}\right)=2980,2920,2850,1704,1658 .{ }^{1} \mathbf{H}$ NMR $(400 \mathrm{MHz}$, DMSO- $\left.d_{6}\right) \delta 4.68(\mathrm{t}, J=6.7 \mathrm{~Hz}, 1 \mathrm{H}), 2.46-2.35(\mathrm{~m}, 1 \mathrm{H}), 2.24-2.08(\mathrm{~m}, 2 \mathrm{H}), 2.06-1.94(\mathrm{~m}, 2 \mathrm{H}), 1.78-$ $1.56(\mathrm{~m}, 4 \mathrm{H}), 1.50-1.37(\mathrm{~m}, 3 \mathrm{H}), 1.17(\mathrm{t}, J=7.0 \mathrm{~Hz}, 3 \mathrm{H}) .{ }^{13} \mathbf{C} \mathbf{N M R}\left(101 \mathrm{MHz}, \mathrm{DMSO}-d_{6}\right) \delta 160.7,96.6$, 61.6, 43.5, 33.6, 31.7, 30.0, 28.0, 25.3, 25.1, 23.8, 14.7. HRMS (ESI): $\mathrm{m} / \mathrm{z}$ calculated for $\mathrm{C}_{9} \mathrm{H}_{16} \mathrm{O}_{1}$ requires 141.1274 for $[\mathrm{M}+\mathrm{H}]^{+}$, found 141.1274 .

Synthesis of 1q<smiles>C=C1CCCCO1</smiles>

To an oven-dried rbf was added 2-(chloromethyl)tetrahydro-2H-pyran $(3.75 \mathrm{~mL}, 30 \mathrm{mmol})$ and potassium hydroxide $(5 \mathrm{~g}, 90 \mathrm{mmol})$. The flask was then equipped with a water condenser and the reaction mixture heated to $100{ }^{\circ} \mathrm{C}$ for $4 \mathrm{~h}$. After this time the condenser was replaced with a distillation head, and the enol ether product was distilled at $100{ }^{\circ} \mathrm{C}$ collecting into a vial at $0{ }^{\circ} \mathrm{C}$ containing $\mathrm{KOH}$ pellets. Distillation afforded the above compound as a colourless oil, $66 \%(1.9 \mathrm{~g})$. Internal alkene isomer observed in NMR analysis ( 9:1). FT-IR (neat): $\nu_{\max }\left(\mathrm{cm}^{-1}\right)=2980,2886,2867,1654 .{ }^{1} \mathbf{H}$ NMR $\left(400 \mathrm{MHz}\right.$, DMSO- $\left.d_{6}\right) \delta 4.15$ $(\mathrm{s}, 1 \mathrm{H}), 3.99(\mathrm{~d}, J=1.0 \mathrm{~Hz}, 1 \mathrm{H}), 3.78(\mathrm{ddd}, J=6.1,3.4,1.6 \mathrm{~Hz}, 2 \mathrm{H}), 2.25-2.09(\mathrm{~m}, 2 \mathrm{H}), 1.75-1.51(\mathrm{~m}$, 4H). ${ }^{13} \mathrm{C}$ NMR (101 MHz, DMSO- $\left.d_{6}\right) \delta$ 159.9, 90.4, 68.4, 28.6, 28.6, 24.4, 22.2. HRMS (ESI): $\mathrm{m} / \mathrm{z}$ calculated for $\mathrm{C}_{6} \mathrm{H}_{10} \mathrm{O}_{1}$ requires 99.0804 for $[\mathrm{M}+\mathrm{H}]^{+}$, found 99.0806 . 
Synthesis of $\mathbf{1 r}$<smiles>C=C(C)OCC1COC(C)(C)O1</smiles>

The above compound was synthesized according to General Procedure A using 2,2-dimethyl-1,3dioxolane-4-methanol $(0.37 \mathrm{~mL}, 3 \mathrm{mmol})$, isopropenyl acetate $(0.66 \mathrm{~mL}, 6 \mathrm{mmol}),\left[\operatorname{Ir}(\operatorname{cod})_{2} \mathrm{Cl}\right]_{2}(20.1 \mathrm{mg}$, $0.03 \mathrm{mmol}, 1 \mathrm{~mol} \%)$, sodium carbonate $(254 \mathrm{mg}, 2.4 \mathrm{mmol})$, and anhydrous toluene $(3 \mathrm{~mL})$. Chromatography on basic alumina gave the above compound as a colourless oil, 41\% (209 mg). FT-IR (neat): $\nu_{\max }\left(\mathrm{cm}^{-1}\right)=2988,2933,2880,1658,1607 .{ }^{1} \mathbf{H}$ NMR $\left(400 \mathrm{MHz}, \mathrm{DMSO}-d_{6}\right) \delta 4.44-4.19(\mathrm{~m}, 1 \mathrm{H})$, $4.03(\mathrm{dd}, J=8.3,6.6 \mathrm{~Hz}, 1 \mathrm{H}), 3.90(\mathrm{~d}, J=1.7 \mathrm{~Hz}, 1 \mathrm{H}), 3.87(\mathrm{dd}, J=1.7,1.0 \mathrm{~Hz}, 1 \mathrm{H}), 3.75-3.57(\mathrm{~m}, 4 \mathrm{H})$, $1.76(\mathrm{~s}, 2 \mathrm{H}), 1.33(\mathrm{~s}, 4 \mathrm{H}), 1.28(\mathrm{~s}, 3 \mathrm{H}) .{ }^{13} \mathrm{C}$ NMR $\left(101 \mathrm{MHz}, \mathrm{DMSO}-d_{6}\right) \delta$ 158.7, 108.7, 82.4, 73.5, 68.1, 65.8, 26.6, 25.4, 20.6. HRMS (ESI): $\mathrm{m} / \mathrm{z}$ calculated for $\mathrm{C}_{9} \mathrm{H}_{16} \mathrm{O}_{3}$ requires 173.1172 for $[\mathrm{M}+\mathrm{H}]^{+}$, found 173.1173.

Synthesis of $1 \mathrm{~s}$<smiles>C=C(C)OC1CCC2(CC1)OCCO2</smiles>

The above compound was synthesized according to General Procedure A using 1,4-dioxaspiro[4.5]decan8 -ol (470 mg, $3 \mathrm{mmol})$, isopropenyl acetate ( $0.66 \mathrm{~mL}, 6 \mathrm{mmol}),\left[\mathrm{Ir}(\operatorname{cod})_{2} \mathrm{Cl}_{2}(20.1 \mathrm{mg}, 0.03 \mathrm{mmol}, 1 \mathrm{~mol} \%)\right.$, sodium carbonate $(254 \mathrm{mg}, 2.4 \mathrm{mmol})$, and anhydrous toluene $(3 \mathrm{~mL})$. Chromatography on basic alumina gave the above compound as a colourless oil, $64 \%(379 \mathrm{mg})$. FT-IR (neat): $\nu_{\max }\left(\mathrm{cm}^{-1}\right)=2952,2879,1652$. ${ }^{1} \mathbf{H}$ NMR $\left(400 \mathrm{MHz}, \mathrm{DMSO}-d_{6}\right) \delta 4.10(\mathrm{dq}, J=7.2,3.6 \mathrm{~Hz}, 1 \mathrm{H}), 3.98-3.88(\mathrm{~m}, 2 \mathrm{H}), 3.85(\mathrm{~d}, J=1.2 \mathrm{~Hz}$, $4 \mathrm{H}), 1.87-1.75(\mathrm{~m}, 2 \mathrm{H}), 1.71(\mathrm{~s}, 2 \mathrm{H}), 1.70-1.58(\mathrm{~m}, 4 \mathrm{H}), 1.58-1.47(\mathrm{~m}, 2 \mathrm{H}) .{ }^{13} \mathbf{C}$ NMR $(101 \mathrm{MHz}$, DMSO- $\left.d_{6}\right) \delta$ 156.9, 107.4, 82.5, 71.0, 63.7, 63.7, 31.0, 27.6, 21.2. HRMS (ESI): $\mathrm{m} / \mathrm{z}$ calculated for $\mathrm{C}_{11} \mathrm{H}_{18} \mathrm{O}_{3}$ requires 199.1329 for $[\mathrm{M}+\mathrm{H}]^{+}$, found 199.1331 . 
<smiles>C=CCCCC(=C)OCC</smiles>

To a stirred solution of ethyl vinyl ether $(1.91 \mathrm{~mL}, 20 \mathrm{mmol})$ in anhydrous THF $(17 \mathrm{~mL})$, was added tertbutyllithium $(1.7 \mathrm{M}$ in pentane, $9.4 \mathrm{~mL})$ dropwise at $-78^{\circ} \mathrm{C}$. After this time the reaction was slowly warmed to $0{ }^{\circ} \mathrm{C}$, and stirred for 30 minutes at this temperature. The solution was re-cooled to $-78{ }^{\circ} \mathrm{C}$ and a solution of 5-iodopent-1-ene $(1.96 \mathrm{~g}, 10 \mathrm{mmol})$ in anhydrous THF $(5 \mathrm{~mL})$ was added slowly. The reaction mixture was allowed to warm to $0{ }^{\circ} \mathrm{C}$, and was stirred at this temperature for 2 hours. To the reaction mixture was added saturated $\mathrm{NH}_{4} \mathrm{Cl}$ solution $(20 \mathrm{~mL})$. The resulting suspension was poured into a separating funnel and extracted withy $\mathrm{Et}_{2} \mathrm{O}(3 \times 30 \mathrm{~mL})$. The combined organics were washed with brine $(50 \mathrm{~mL})$, dried over $\mathrm{Na}_{2} \mathrm{SO}_{4}$, and concentrated in vacuo (Note: water bath was kept at room temperature to avoid evaporation of product). The resulting yellow oil was used without purification, $94 \%(1.32 \mathrm{~g}) .{ }^{1} \mathbf{H}$ NMR $(400 \mathrm{MHz}$, DMSO- $\left.d_{6}\right) \delta 5.79(\mathrm{ddtd}, J=17.0,10.1,6.7,5.0 \mathrm{~Hz}, 1 \mathrm{H}), 5.12-4.90(\mathrm{~m}, 2 \mathrm{H}), 3.86(\mathrm{~d}, J=1.6 \mathrm{~Hz}, 1 \mathrm{H}), 3.83$ $(\mathrm{d}, J=1.5 \mathrm{~Hz}, 1 \mathrm{H}), 3.66(\mathrm{q}, J=7.0 \mathrm{~Hz}, 2 \mathrm{H}), 3.31(\mathrm{~s}, 1 \mathrm{H}), 2.11(\mathrm{dtt}, J=7.7,6.2,1.4 \mathrm{~Hz}, 1 \mathrm{H}), 2.06-1.97$ $(\mathrm{m}, 3 \mathrm{H}), 1.58-1.45(\mathrm{~m}, 2 \mathrm{H}), 1.21(\mathrm{t}, J=7.0 \mathrm{~Hz}, 3 \mathrm{H})$. Hydrolysis to corresponding methyl ketone takes place rapidly in solution, so compound was used without further analysis. ${ }^{1} \mathrm{H}$ NMR data is consistent with literature precedent. ${ }^{6}$ 


\section{4: Synthesis of Alkene Substrates}

Synthesis of 2a-DHA (methyl 2-(bis(tert-butoxycarbonyl)amino)acrylate)<smiles>C=C([Nb]C(=O)OC)C(=O)OC</smiles>

To a solution of L-serine methyl ester hydrochloride $(20 \mathrm{~g}, 129 \mathrm{mmol})$ in $\mathrm{CH}_{2} \mathrm{Cl}_{2}(130 \mathrm{~mL})$ was added triethylamine $(40 \mathrm{~mL}, 287 \mathrm{mmol})$ dropwise at $0{ }^{\circ} \mathrm{C}$. Following this addition di-tert-butyl dicarbonate $(31 \mathrm{~g}$, $142 \mathrm{mmol}$ ) portionwise at $0{ }^{\circ} \mathrm{C}$. The reaction mixture was allowed to warm to room temperature and stir for $18 \mathrm{~h}$. After this time, the reaction mixture was concentrated in vacuo, diluted with EtOAc $(300 \mathrm{~mL})$, and washed successively with $1 \mathrm{~N} \mathrm{HCl}(300 \mathrm{~mL})$, sat. $\mathrm{NaHCO}_{3}$ solution $(300 \mathrm{~mL})$, and brine $(300 \mathrm{~mL})$. The organic phase was then dried over $\mathrm{MgSO}_{4}$ and concentrated in vacuo to give a yellow oil. This oil was then suspended in $\mathrm{MeCN}(250 \mathrm{~mL})$ and cooled to $0{ }^{\circ} \mathrm{C}$. To the reaction mixture was added di-tert-butyl dicarbonate (62 g, $284 \mathrm{mmol})$, and 4-dimethylaminopyridine $(3.44 \mathrm{~g}, 28 \mathrm{mmol})$ at $0{ }^{\circ} \mathrm{C}$, and the reaction mixture was allowed to return to room temperature and stir for 5 hours. After this time 1,8diazabicyclo[5.4.0]undec-7-ene $(4.0 \mathrm{~mL}, 26.7 \mathrm{mmol})$ was added dropwise at room temperature. Following this the reaction mixture was allowed to stir at that temperature for $18 \mathrm{~h}$. Following this a further portion of diazabicyclo[5.4.0] undec-7-ene $(4.0 \mathrm{~mL}, 26.7 \mathrm{mmol})$ was added and the mixture allowed to stir for a further 6 hours. After this time the reaction was concentrated in vacuo, diluted in EtOAc $(300 \mathrm{~mL})$, and washed successively with $1 \mathrm{~N} \mathrm{HCl}(300 \mathrm{~mL})$, sat. $\mathrm{NaHCO}_{3}$ solution $(300 \mathrm{~mL})$, and brine $(300 \mathrm{~mL})$. The organic phase was dried over $\mathrm{MgSO}_{4}$ and concentrated in vacuo. To the crude mixture was added heptane $(500 \mathrm{~mL})$, and the flask cooled to $0{ }^{\circ} \mathrm{C}$ for 3 hours, permitting precipitation of a white powder. The sold was then filtered, washing with cold heptane to give the title compound as a fluffy white solid, $38 \%$ over three steps (14.7 g, no chromatography). Higher yields can be achieved through isolating each intermediate via silica gel column chromatography. ${ }^{1} \mathbf{H}$ NMR $\left(400 \mathrm{MHz}, \mathrm{CDCl}_{3}\right) \delta 6.33$ (s, 1H), $5.64(\mathrm{~s}, 1 \mathrm{H}), 3.79$ (s, $3 \mathrm{H}), 1.46(\mathrm{~s}, 18 \mathrm{H}) .{ }^{13} \mathbf{C} \mathbf{N M R}\left(101 \mathrm{MHz}, \mathrm{CDCl}_{3}\right): \delta=164.2,150.7,136.2,124.8,83.5,52.5,28.1$. Data is in line with literature precedent. ${ }^{7}$ 


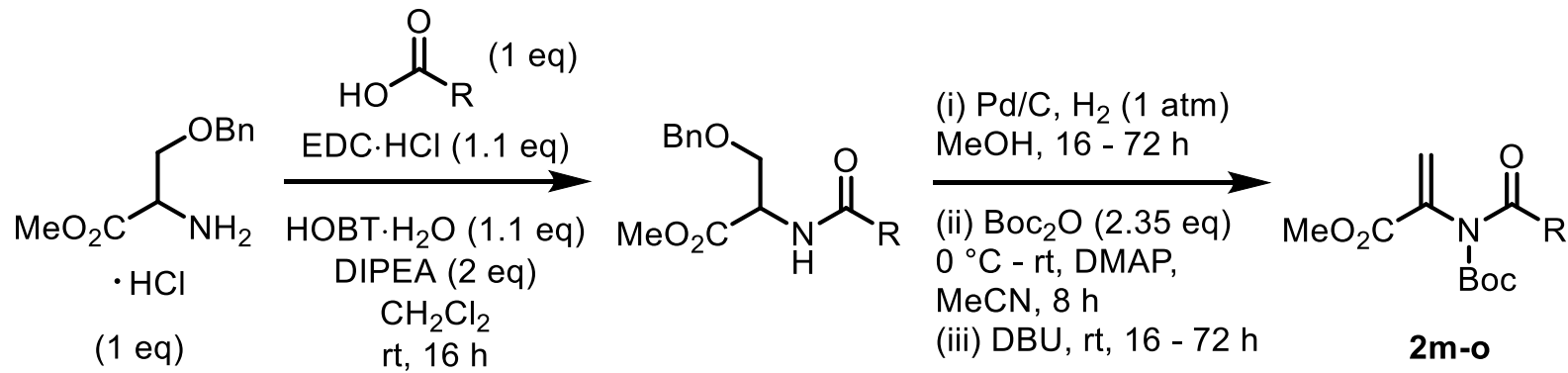

Synthesis of $\mathbf{2 m}$<smiles>C=C(C(C)=O)N(C(=O)OC(C)(C)C)C(=O)C1CCCN1C(=O)OC(C)(C)C</smiles>

To a $250 \mathrm{ml}$ rbf was charged O-benyl-L-serine hydrochloride (3 g, $12.2 \mathrm{mmol})$, Boc-Pro-H (2.62 g, 12.2 mmol), (3-dimethylaminopropyl)- $N$ '-ethylcarbodiimide hydrochloride (EDCI $\cdot \mathrm{HCl}, 2.57 \mathrm{~g}, 13.4 \mathrm{mmol}$ ), and hydroxybenzotriazole hydrate $\left(\mathrm{HOBT} \cdot \mathrm{H}_{2} \mathrm{O}, 1.81 \mathrm{~g}, 13.4 \mathrm{mmol}\right)$. The flask was sealed with a rubber septum and under a stream on nitrogen was added anhydrous $\mathrm{CH}_{2} \mathrm{Cl}_{2}(50 \mathrm{~mL})$ and $N, N$-diisopropylethylamine $(4.24 \mathrm{~mL}, 24.4 \mathrm{mmol})$. The mixture was allowed to stir at room temperature overnight. After this time the reaction was quenched with $1 \mathrm{~N} \mathrm{HCl}(50 \mathrm{~mL})$, and the organic phase then separated. The organic phase was then successively washed with $1 \mathrm{~N} \mathrm{HCl}(50 \mathrm{~mL})$ and brine $(50 \mathrm{~mL})$, dried over $\mathrm{MgSO}_{4}$ and concentrated in vacuo. The resulting crude residue was purified via silica gel column chromatography (EtOAc:Pentane 50:50 v:v) to give the dipeptide as a white colourless solid. This solid was dispersed in $\mathrm{MeOH}(40 \mathrm{~mL})$, and was added palladium on carbon ( $10 \%$ wt., $99 \mathrm{mg}, 0.93 \mathrm{mmol}$ ) and the solvent sparged with $\mathrm{H}_{2}$ for 5 minutes. The reaction mixture was then stirred under an atmosphere of hydrogen for $16 \mathrm{~h}$. After this time the reaction mixture was filtered through a pad of celite, eluting with EtOAc, and the resulting filtrate was concentrated in vacuo. The crude residue was dispersed in $\mathrm{MeCN}(20 \mathrm{~mL})$, cooled to $0{ }^{\circ} \mathrm{C}$, and then was added di-tert-butyl dicarbonate $(4.76 \mathrm{~g}, 21.8 \mathrm{mmol})$ and 4-dimethylaminopyridine $(227 \mathrm{mg}, 1.86 \mathrm{mmol})$. The reaction mixture was allowed to return to room temperature and stir for $8 \mathrm{~h}$. After TLC confirmed the disappearance of the starting material, diazabicyclo[5.4.0] undec-7-ene $(0.28 \mathrm{~mL}, 1.86 \mathrm{mmol})$ was added dropwise. The reaction mixture was then stirred for $96 \mathrm{~h}$, where a further portion of diazabicyclo[5.4.0] undec-7-ene $(1.3 \mathrm{~mL}, 8.7 \mathrm{mmol})$ was added and the reaction allowed to stir for 16 hours. After this time, the reaction mixture was concentrated in vacuo. The resulting residue was dispersed in EtOAc $(200 \mathrm{~mL})$ and washed successively with $1 \mathrm{~N} \mathrm{HCl}(100 \mathrm{~mL})$, sat. $\mathrm{NaHCO}_{3}$ solution $(100 \mathrm{~mL})$, and brine $(100 \mathrm{~mL})$, dried over $\mathrm{MgSO}_{4}$ and concentrated in vacuo. The crude residue was purified via silica gel column chromatography (EtOAc:Pentane $-5: 95-15: 85 \mathrm{v}: \mathrm{v}$ ) to give the alkene structure $2 \mathrm{~m}$ as a thick gel, $61 \%$ over four steps $\left(2.96 \mathrm{~g}\right.$ ). The compound was stored as a $1 \mathrm{M}$ solution in $\mathrm{CH}_{2} \mathrm{Cl}_{2}$ in the freezer for ease of handling. FT-IR (thin film): $v_{\max }\left(\mathrm{cm}^{-1}\right)=2978,1739,1695,1646,1479 .{ }^{1} \mathbf{H}$ NMR $\left(400 \mathrm{MHz}, \mathrm{CDCl}_{3}\right.$, rotameric, both rotamers disclosed) $\delta 6.46(\mathrm{~s}, 1 \mathrm{H}), 6.43(\mathrm{~s}, 1 \mathrm{H}), 5.81(\mathrm{~s}, 1 \mathrm{H}), 5.63(\mathrm{~s}, 1 \mathrm{H}), 5.40(\mathrm{dd}, J=9.0$, $3.0 \mathrm{~Hz}, 1 \mathrm{H}), 5.28(\mathrm{dd}, J=8.8,3.1 \mathrm{~Hz}, 1 \mathrm{H}), 3.78(\mathrm{~s}, 3 \mathrm{H}), 3.77(\mathrm{~s}, 3 \mathrm{H}), 3.63-3.48(\mathrm{~m}, 2 \mathrm{H}), 3.48-3.32(\mathrm{~m}$, $2 \mathrm{H}), 2.33(\mathrm{tdd}, J=13.2,6.4,2.7 \mathrm{~Hz}, 2 \mathrm{H}), 2.13-1.99(\mathrm{~m}, 2 \mathrm{H}), 1.88(\mathrm{ddddd}, J=17.1,9.3,7.6,4.8,2.9 \mathrm{~Hz}$, 4H), $1.46(\mathrm{~s}, 9 \mathrm{H}), 1.44(\operatorname{app} d, J=1.0 \mathrm{~Hz}, 18 \mathrm{H}), 1.41(\mathrm{~s}, 9 \mathrm{H}) .{ }^{13} \mathbf{C} \mathbf{~ N M R}\left(101 \mathrm{MHz}, \mathrm{CDCl}_{3}\right.$ rotameric, both rotamers disclosed) $\delta 175.7,175.3,163.6,154.6,153.9,135.2,135.0,126.6,125.8,84.2,83.9,79.6,61.1$, 60.8, 52.6, 52.5, 47.1, 46.7, 31.0, 30.2, 28.6, 28.5, 28.0, 27.9, 23.9, 23.0, 21.2. HRMS (ESI): $\mathrm{m} / \mathrm{z}$ calculated for $\mathrm{C}_{19} \mathrm{H}_{30} \mathrm{~N}_{2} \mathrm{O}_{7}$ requires 421.1945 for $[\mathrm{M}+\mathrm{Na}]^{+}$, found 421.1944 . 
<smiles>C=C(C(C)=O)N(C(=O)c1ccccc1)C(=O)C1CCN(C(=O)OC(C)(C)C)C1</smiles>

To a $250 \mathrm{ml}$ rbf was charged O-benyl-L-serine hydrochloride (2 g, $8.1 \mathrm{mmol})$, 1-(tertbutoxycarbonyl)pyrrolidine-3-carboxylic acid (1.72 g, $8.1 \mathrm{mmol})$, (3-dimethylaminopropyl)- $N^{\prime}$ ethylcarbodiimide hydrochloride (EDCI $\cdot \mathrm{HCl}, 1.72 \mathrm{~g}, 9 \mathrm{mmol}$ ), and hydroxybenzotriazole hydrate $\left(\mathrm{HOBT}^{\prime} \mathrm{H}_{2} \mathrm{O}, 1.21 \mathrm{~g}, 9 \mathrm{mmol}\right)$. The flask was sealed with a rubber septum and under a stream on nitrogen was added anhydrous $\mathrm{CH}_{2} \mathrm{Cl}_{2}(35 \mathrm{~mL})$ and $\mathrm{N}, \mathrm{N}$-diisopropylethylamine $(3.13 \mathrm{~mL}, 18 \mathrm{mmol})$. The mixture was allowed to stir at room temperature overnight. After this time the reaction was quenched with $1 \mathrm{~N} \mathrm{HCl}$ $(40 \mathrm{~mL})$, and the organic phase then separated. The organic phase was then successively washed with $1 \mathrm{~N}$ $\mathrm{HCl}(40 \mathrm{~mL})$ and brine $(40 \mathrm{~mL})$, dried over $\mathrm{MgSO}_{4}$ and concentrated in vacuo. The resulting crude residue was purified via silica gel column chromatography (EtOAc:Pentane - 50:50 v:v) to give the dipeptide as a white colourless solid. This solid was dispersed in $\mathrm{MeOH}(30 \mathrm{~mL})$, and was added palladium on carbon (10\% wt., $99 \mathrm{mg}, 0.93 \mathrm{mmol}$ ) and the solvent sparged with $\mathrm{H}_{2}$ for 5 minutes. The reaction mixture was then stirred under an atmosphere of hydrogen for $72 \mathrm{~h}$. After this time the reaction mixture was filtered through a pad of celite, eluting with EtOAc, and the resulting filtrate was concentrated in vacuo. The crude residue was dispersed in $\mathrm{MeCN}(20 \mathrm{~mL})$, cooled to $0{ }^{\circ} \mathrm{C}$, and then was added di-tert-butyl dicarbonate (3.34 g, 15.3 $\mathrm{mmol}$ ) and 4-dimethylaminopyridine $(150 \mathrm{mg}, 1.23 \mathrm{mmol})$. The reaction mixture was allowed to return to room temperature and stir for $8 \mathrm{~h}$. After TLC confirmed the disappearance of the starting material, diazabicyclo[5.4.0]undec-7-ene $(1.6 \mathrm{~mL}, 10.04 \mathrm{mmol})$ was added dropwise, and the reaction mixture was allowed to stir for $16 \mathrm{~h}$. After this time, the reaction mixture was concentrated in vacuo. The resulting residue was dispersed in EtOAc $(100 \mathrm{~mL})$ and washed successively with $1 \mathrm{~N} \mathrm{HCl}(50 \mathrm{~mL})$, sat. $\mathrm{NaHCO}_{3}$ solution $(50 \mathrm{~mL})$, and brine $(50 \mathrm{~mL})$, dried over $\mathrm{MgSO}_{4}$ and concentrated in vacuo. The crude residue was purified via silica gel column chromatography (EtOAc:Pentane - 5:95 - 15:85 v:v) to give the alkene structure $2 \mathrm{n}$ as a viscous oil, $54 \%$ over four steps $(1.76 \mathrm{~g})$. FT-IR (thin film): $v_{\max }\left(\mathrm{cm}^{-1}\right)=2977,1737,1691,1646 .{ }^{1} \mathbf{H}$ NMR (400 MHz, $\left.\mathrm{CDCl}_{3}\right) \delta 6.45(\mathrm{~s}, 1 \mathrm{H}), 5.64(\mathrm{~s}, 1 \mathrm{H}), 4.13(\mathrm{dq}, J=11.4,7.1 \mathrm{~Hz}, 1 \mathrm{H}), 3.77(\mathrm{~s}, 3 \mathrm{H}), 3.60(\mathrm{dt}$, $J=12.9,6.1 \mathrm{~Hz}, 2 \mathrm{H}), 3.53-3.27(\mathrm{~m}, 1 \mathrm{H}), 2.33-2.06(\mathrm{~m}, 2 \mathrm{H}), 1.45(\mathrm{~d}, J=2.8 \mathrm{~Hz}, 18 \mathrm{H}) .{ }^{13} \mathbf{C} \mathbf{N M R}(101$ $\left.\mathrm{MHz}, \mathrm{CDCl}_{3}\right) \delta 176.6,163.7,154.8,151.3,135.7,126.0,84.1,79.7,52.6,46.2,42.9$, 28.6, 28.3, 28.0, 24.5. HRMS (ESI): m/z calculated for $\mathrm{C}_{19} \mathrm{H}_{30} \mathrm{~N}_{2} \mathrm{O}_{7}$ requires 421.1945 for $[\mathrm{M}+\mathrm{Na}]^{+}$, found 421.1944 . 
Synthesis of 20<smiles>C=C(C(C)=O)N(C(=O)OCc1ccccc1)C(=O)C1CCCN(C(=O)OC(C)(C)C)C1</smiles>

To a $250 \mathrm{ml}$ rbf was charged O-benyl-L-serine hydrochloride $(2 \mathrm{~g}, 8.1 \mathrm{mmol})$, (S)-1-Boc-Nipecotic acid (1.72 g, $8.1 \mathrm{mmol})$, (3-dimethylaminopropyl)- $\mathrm{N}^{\prime}$-ethylcarbodiimide hydrochloride (EDCI $\cdot \mathrm{HCl}, 1.72 \mathrm{~g}, 9$ $\mathrm{mmol}$ ), and hydroxybenzotriazole hydrate $\left(\mathrm{HOBT} \cdot \mathrm{H}_{2} \mathrm{O}, 1.21 \mathrm{~g}, 9 \mathrm{mmol}\right)$. The flask was sealed with a rubber septum and under a stream on nitrogen was added anhydrous $\mathrm{CH}_{2} \mathrm{Cl}_{2}(35 \mathrm{~mL})$ and $\mathrm{N}, \mathrm{N}$ diisopropylethylamine $(3.13 \mathrm{~mL}, 18 \mathrm{mmol})$. The mixture was allowed to stir at room temperature overnight. After this time the reaction was quenched with $1 \mathrm{~N} \mathrm{HCl}(40 \mathrm{~mL})$, and the organic phase then separated. The organic phase was then successively washed with $1 \mathrm{~N} \mathrm{HCl}(40 \mathrm{~mL})$ and brine $(40 \mathrm{~mL})$, dried over $\mathrm{MgSO}_{4}$ and concentrated in vacuo. The resulting crude residue was purified via silica gel column chromatography (EtOAc:Pentane - 50:50 v:v) to give the dipeptide as a white colourless solid. This solid was dispersed in $\mathrm{MeOH}(30 \mathrm{~mL})$, and was added palladium on carbon $(10 \% \mathrm{wt} ., 99 \mathrm{mg}, 0.93 \mathrm{mmol})$ and the solvent sparged with $\mathrm{H}_{2}$ for 5 minutes. The reaction mixture was then stirred under an atmosphere of hydrogen for $72 \mathrm{~h}$. After this time the reaction mixture was filtered through a pad of celite, eluting with EtOAc, and the resulting filtrate was concentrated in vacuo. The crude residue was dispersed in $\mathrm{MeCN}(18 \mathrm{~mL})$, cooled to 0 ${ }^{\circ} \mathrm{C}$, and then was added di-tert-butyl dicarbonate $(2.84 \mathrm{~g}, 13.0 \mathrm{mmol})$ and 4-dimethylaminopyridine $(127 \mathrm{mg}$, $1.04 \mathrm{mmol})$. The reaction mixture was allowed to return to room temperature and stir for $8 \mathrm{~h}$. After TLC confirmed the disappearance of the starting material, diazabicyclo[5.4.0]undec-7-ene (1.6 mL, $10.04 \mathrm{mmol})$ was added dropwise, and the reaction mixture was allowed to stir for $16 \mathrm{~h}$. After this time, the reaction mixture was concentrated in vacuo. The resulting residue was dispersed in EtOAc $(100 \mathrm{~mL})$ and washed successively with $1 \mathrm{~N} \mathrm{HCl}(50 \mathrm{~mL})$, sat. $\mathrm{NaHCO}_{3}$ solution $(50 \mathrm{~mL})$, and brine $(50 \mathrm{~mL})$, dried over $\mathrm{MgSO}_{4}$ and concentrated in vacuo. The crude residue was purified via silica gel column chromatography (EtOAc:Pentane $-5: 95-15: 85 \mathrm{v}: \mathrm{v}$ ) to give the alkene structure $\mathbf{2} \mathbf{n}$ as a viscous oil, $53 \%$ over four steps $\left(1.79\right.$ g). FT-IR (thin film): $u_{\max }\left(\mathrm{cm}^{-1}\right)=3978,1738,1695,1647,1479 .{ }^{1} \mathbf{H} \mathbf{N M R}\left(400 \mathrm{MHz}, \mathrm{CDCl}_{3}\right) \delta 6.42$ $(\mathrm{s}, 1 \mathrm{H}), 5.62(\mathrm{~s}, 1 \mathrm{H}), 4.19-4.13(\mathrm{~m}, 1 \mathrm{H}), 4.06-3.88(\mathrm{~m}, 1 \mathrm{H}), 3.76(\mathrm{~s}, 3 \mathrm{H}), 3.57(\mathrm{ddt}, J=10.4,7.6,3.7 \mathrm{~Hz}$, $1 \mathrm{H}), 3.01(\mathrm{dd}, J=13.2,10.3 \mathrm{~Hz}, 1 \mathrm{H}), 2.78(\mathrm{~s}, 1 \mathrm{H}), 1.72(\mathrm{dt}, J=12.9,3.4 \mathrm{~Hz}, 1 \mathrm{H}), 2.20-2.08(\mathrm{~m}, 1 \mathrm{H}), 1.66$ $-1.47(\mathrm{~m}, 2 \mathrm{H}), 1.45(\mathrm{~d}, J=2.4 \mathrm{~Hz}, 19 \mathrm{H}) .{ }^{13} \mathbf{C} \mathbf{N M R}\left(101 \mathrm{MHz}, \mathrm{CDCl}_{3}\right) \delta 175.6,163.6,154.5,151.4,135.5$, 126.1, 84.3, 79.4, 52.6, 48.8, 48.6, 45.6, 45.2, 44.9, 44.1, 28.9, 28.6, 27.9. HRMS (ESI): $\mathrm{m} / \mathrm{z}$ calculated for $\mathrm{C}_{19} \mathrm{H}_{30} \mathrm{~N}_{2} \mathrm{O}_{7}$ requires 435.2102 for $[\mathrm{M}+\mathrm{Na}]^{+}$, found 435.2100 . 
Synthesis of $2 p$

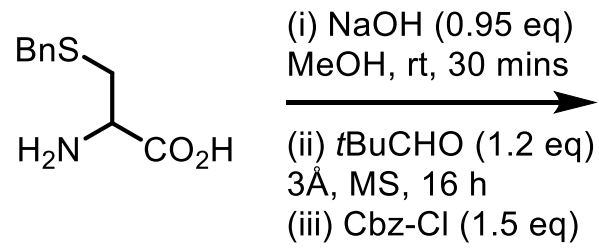

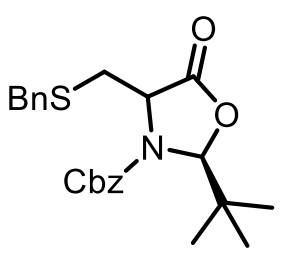

S2p-1

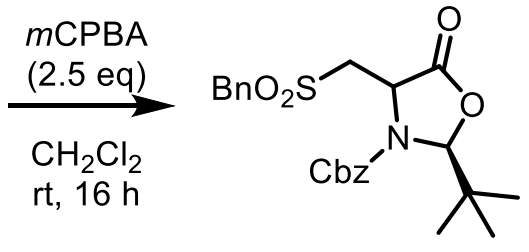

S2p-2
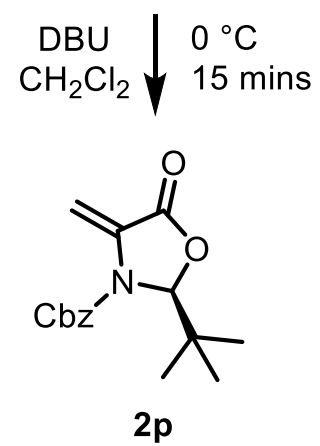

To a suspension of $S$-benzyl cysteine $(21.12 \mathrm{~g}, 100 \mathrm{mmol})$ in $\mathrm{MeOH}(1 \mathrm{~L})$, was added sodium hydroxide $(3.8 \mathrm{~g}, 95 \mathrm{mmol})$ and the reaction mixture allowed to stir for 30 minutes at room temperature. Following this, trimethylacetaldehyde $(13.0 \mathrm{~mL}, 120 \mathrm{mmol})$ and $3 \AA$ molecular sieves $(75 \mathrm{~g})$ in one portion. The reaction mixture was then stirred for 16 hours (until ${ }^{1} \mathrm{H}$ NMR analysis showed complete conversion from aldehyde starting material. The reaction mixture was filtered through a pad of celite and concentrated in vacuo. The crude residue was then placed on a high vacuum for 2 hours to remove residual $\mathrm{MeOH}$. The crude imine structure was dispersed in anhydrous $\mathrm{CH}_{2} \mathrm{Cl}_{2}(1 \mathrm{~L})$, and then cooled to $0{ }^{\circ} \mathrm{C}$. To the flask was then added benzyl chloroformate $(21.1 \mathrm{~mL}, 150 \mathrm{mmol})$ dropwise, and the flask allowed to stir at $0{ }^{\circ} \mathrm{C}$ for 8 hours then allowed to warm to room temperature and stir overnight. The reaction solution was poured into a separating funnel and was added $\mathrm{NaOH}(1 \mathrm{M}, 500 \mathrm{~mL})$. The organic layer was separated, dried over $\mathrm{MgSO}_{4}$ and concentrated in vacuo. The crude residue was then purified via silica gel column chromatography (EtOAc: Pentane - 10:90 v:v) to give S2p-1 as a yellow oil, $14 \%(5.69 \mathrm{~g}) .{ }^{1} \mathbf{H} \mathbf{~ N M R}\left(400 \mathrm{MHz}, \mathrm{CDCl}_{3}\right) \delta$ $7.39(\mathrm{~d}, J=3.0 \mathrm{~Hz}, 4 \mathrm{H}), 7.31(\mathrm{~d}, J=5.4 \mathrm{~Hz}, 1 \mathrm{H}), 5.56(\mathrm{~s}, 1 \mathrm{H}), 5.29-5.07(\mathrm{~m}, 2 \mathrm{H}), 4.55(\mathrm{dd}, J=7.8,6.2$ $\mathrm{Hz}, 1 \mathrm{H}), 3.79$ (q, $J=13.4 \mathrm{~Hz}, 2 \mathrm{H}), 2.94(\mathrm{dd}, J=13.9,7.9 \mathrm{~Hz}, 1 \mathrm{H}), 2.80(\mathrm{dd}, J=13.9,6.1 \mathrm{~Hz}, 1 \mathrm{H}), 0.94$ (s, $9 \mathrm{H})$. This oil was suspended in $\mathrm{CH}_{2} \mathrm{Cl}_{2}(300 \mathrm{~mL})$ and was added meta-chloroperbenzoic acid $(5.95 \mathrm{~g}, 34.5$ $\mathrm{mmol}$ ), and the reaction mixture stirred at room temperature for $16 \mathrm{~h}$. The reaction mixture was washed with $\mathrm{NaOH}(1 \mathrm{M}, 3 \times 200 \mathrm{~mL})$, dried over $\mathrm{Na}_{2} \mathrm{SO}_{4}$ and concentrated in vacuo. The resulting solid was dispersed in $\mathrm{CH}_{2} \mathrm{Cl}_{2}(200 \mathrm{~mL})$ and the reaction flask cooled to $0{ }^{\circ} \mathrm{C}$ and was added $1,8-$ diazabicyclo[5.4.0] undec-7-ene $(2.09 \mathrm{~mL}, 14 \mathrm{mmol})$. The reaction mixture was allowed to stir at $0{ }^{\circ} \mathrm{C}$ for 15 minutes. After this time the reaction was quenched with sat. $\mathrm{NH}_{4} \mathrm{Cl}$ solution $(100 \mathrm{~mL})$. The organic phase was extracted and then washed with sat. $\mathrm{NH}_{4} \mathrm{Cl}$ solution $(3 \times 100 \mathrm{~mL})$, dried over $\mathrm{MgSO}_{4}$ and concentrated in vacuo. The crude residue was then purified via silica gel column chromatography (EtOAc : Pentane $10: 90 \mathrm{v}: \mathrm{v})$ to $2 \mathrm{p}$ as a yellow powder, $68 \%$ two steps $(2.76 \mathrm{~g}) .{ }^{1} \mathbf{H} \mathbf{~ N M R}\left(400 \mathrm{MHz}, \mathrm{CDCl}_{3}\right) \delta 7.38(\mathrm{~s}, 5 \mathrm{H})$, $5.72(\mathrm{~d}, J=1.0 \mathrm{~Hz}, 1 \mathrm{H}), 5.68(\mathrm{~s}, 1 \mathrm{H}), 5.30-5.22(\mathrm{~m}, 2 \mathrm{H}), 0.93(\mathrm{~s}, 9 \mathrm{H}) .{ }^{13} \mathbf{C} \mathbf{N M R}\left(101 \mathrm{MHz}, \mathrm{CDCl}_{3}\right) \delta$ $164.7,134.8,130.3,129.0,128.9,128.8,104.5,94.1,68.9,38.8,24.5$. Data is in with literature precedent. ${ }^{8}$ 


\section{Synthesis of Tertiary Ether Products}

General Procedure $\mathbf{C}$ for the photocatalytic $\alpha$-functionalization of alkyl enol ethers (Conditions A)

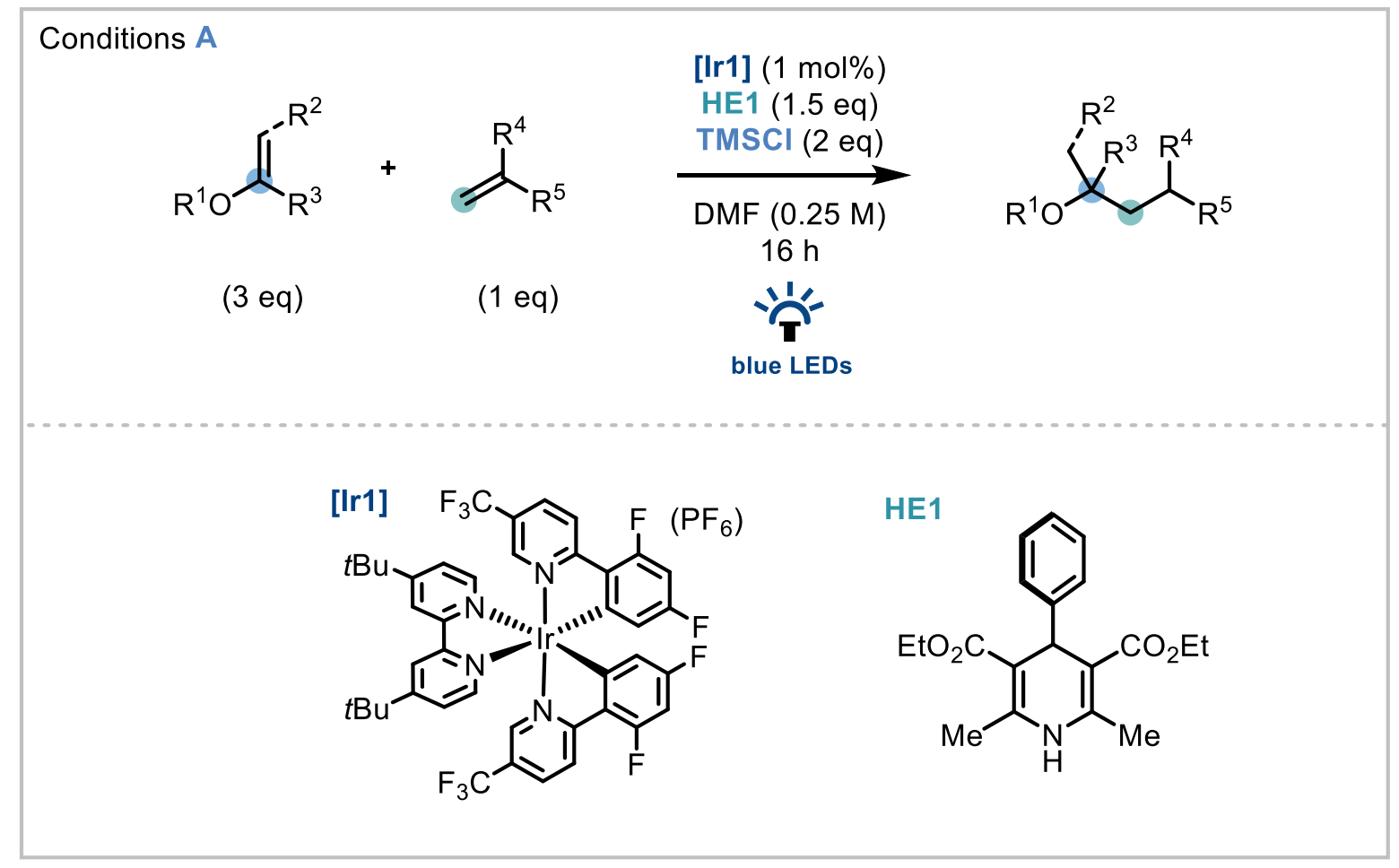

To an oven dried $1.7 \mathrm{~mL}$ glass vial was charged relevant enol ether if solid/density unknown (0.3 mmol), diethyl 4-(4- phenyl)-2,6-dimethyl-1,4-dihydropyridine-3,5-dicarboxylate (HE1/HE-Ph, 49 mg, 0.15 mmol, $1.5 \mathrm{eq})$, and $\left[\mathrm{Ir}\left(\left[\mathrm{dFCF}_{3}\right] \mathrm{ppy}\right)_{2}(\mathrm{dtbbpy})\right] \mathrm{PF}_{6}(1.1 \mathrm{mg}, 0.001 \mathrm{mmol}, 1 \mathrm{~mol} \%)$ and relevant alkene $(0.1 \mathrm{mmol})$ if solid/density unknown). To the vial was added anhydrous DMF $(0.4 \mathrm{~mL})$, and under stirring, the reaction mixture was sparged with a $\mathrm{N}_{2}$ stream. During sparging was added chlorotrimethylsilane $(25.4 \mu \mathrm{L}, 0.2$ $\mathrm{mmol}$ ) and enol ether (if liquid, $0.3 \mathrm{mmol}$ ) and/or alkene (if liquid, $0.1 \mathrm{mmol}$ ). The vial was sealed with a screw cap, and irradiated with blue light for 16 hours. After this time the reaction mixture diluted in EtOAc $(10 \mathrm{~mL})$, and was added water $(5 \mathrm{~mL})$ and brine $(5 \mathrm{~mL})$. The organic phase was extracted and the aqueous phased re-extracted with EtOAc $(2 \times 10 \mathrm{~mL})$. The combined organics were dried over $\mathrm{MgSO}_{4}$ and concentrated in vacuo. The crude residue was purified via silica gel column chromatography (EtOAc:Pentane 1:99 - 5:95 if not stated otherwise) to give $\alpha$-tertiary ether product.

Note: the product often co-elutes with any remaining alkene, or the proposed Michael by-product described previously. For these reasons the reaction conditions have been rigorously designed to remove these possible compounds from the mixture. 
General Procedure $\mathbf{D}$ for the photocatalytic $\alpha$-functionalization of alkyl enol ethers (Conditions B)

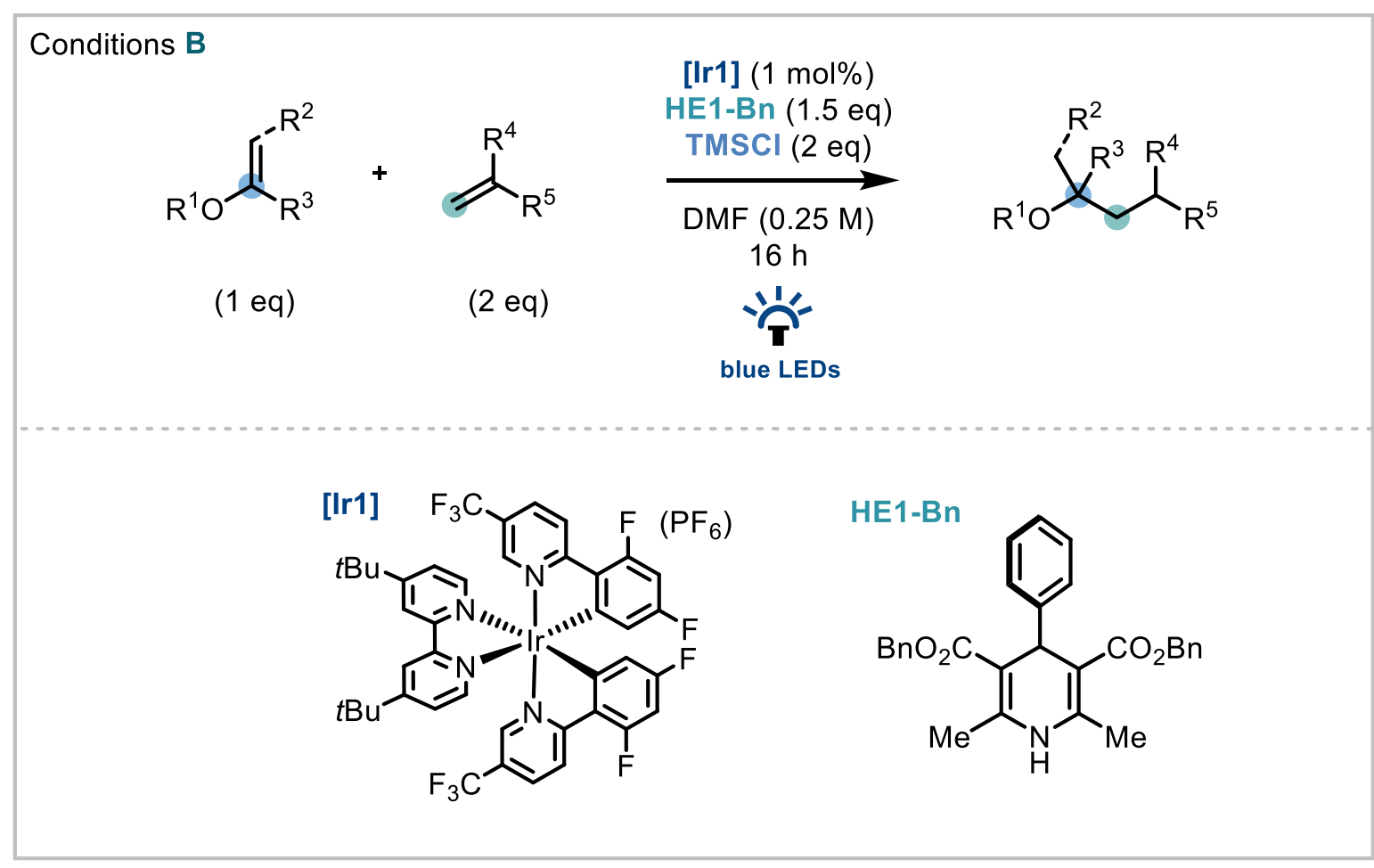

To an oven dried $1.7 \mathrm{~mL}$ glass vial was charged relevant enol ether if solid/density unknown $(0.1 \mathrm{mmol})$, dibenzyl 4-(4- phenyl)-2,6-dimethyl-1,4-dihydropyridine-3,5-dicarboxylate (HE1-Bn, 68 mg, 0.15 mmol, 1.5 eq), and $\left[\mathrm{rr}\left(\left[\mathrm{dFCF}_{3}\right] \mathrm{ppy}\right)_{2}(\mathrm{dtbbpy})\right] \mathrm{PF}_{6}(1.1 \mathrm{mg}, 0.001 \mathrm{mmol}, 1 \mathrm{~mol} \%)$ and relevant alkene $(0.2 \mathrm{mmol})$ if solid/density unknown). To the vial was added anhydrous DMF $(0.4 \mathrm{~mL})$, and under stirring, the reaction mixture was sparged with a $\mathrm{N}_{2}$ stream. During sparging was added chlorotrimethylsilane $(25.4 \mu \mathrm{L}, 0.2$ $\mathrm{mmol}$ ) and enol ether (if liquid, $0.1 \mathrm{mmol}$ ) and/or alkene (if liquid, $0.2 \mathrm{mmol}$ ). The vial was sealed with a screw cap, and irradiated with blue light for 16 hours. After this time the reaction mixture diluted in EtOAc $(10 \mathrm{~mL})$, and was added water $(5 \mathrm{~mL})$ and brine $(5 \mathrm{~mL})$. The organic phase was extracted and the aqueous phased re-extracted with EtOAc $(2 \times 10 \mathrm{~mL})$. The combined organics were dried over $\mathrm{MgSO}_{4}$ and concentrated in vacuo. The crude residue was purified via silica gel column chromatography (EtOAc:Pentane 1:99 - 3:97 if not stated otherwise) to give $\alpha$-tertiary ether product.

For both procedures: for the enol ether reagent the mass balance is often: (a) unreacted enol ether, (b) oxocarbenium hydrolysis products (alcohol and ketone), (c) over-reduced ethers (for example iso-propyl ethers in the case of the gem-dimethyl examples), and (d) occasionally in small quantities subsequent reductive radical reactivity of the ketone creating analogous primary alcohol products. For the alkene moiety, mass balance is most often unreacted alkene. However, on rare occasions we have also isolated small quantities of an alanine derivative, derived from proposed conjugate hydride reduction of the DHA structure. 
<smiles>COC(=O)C(CC(C)(C)OC)C(=O)OC</smiles>

The above compound was synthesized according to General Procedure $\mathbf{C}$ using 2-methoxypropene (28.7 $\mu \mathrm{L}, 0.3 \mathrm{mmol}$ ) and methyl 2-(bis(tert-butoxycarbonyl)amino)acrylate (30.3 mg, $0.1 \mathrm{mmol})$. Silica gel column chromatography gave a colourless oil, 95\% (35.5 mg).

The above compound was also synthesized according to General Procedure $\mathbf{D}$ at double scale, using 2methoxypropene $(19.1 \mu \mathrm{L}, 0.2 \mathrm{mmol}$ ) and methyl 2-(bis(tert-butoxycarbonyl)amino)acrylate (121.2 mg, 0.4 $\mathrm{mmol})$. Before work-up, to the crude reaction mixture was added cysteamine $(46.3 \mathrm{mg}, 0.6 \mathrm{mmol})$ and $\mathrm{NEt}_{3}$ $(0.11 \mathrm{~mL}, 0.8 \mathrm{mmol})$. The solution was stirred at room temperature for 3 hours (TLC showed disappearance of alkene). Regular work-up as per the general procedure, and silica gel column chromatography gave a colourless oil, $65 \%$ (48.8 mg).

FT-IR (thin film): $\nu_{\max }\left(\mathrm{cm}^{-1}\right)=2981,2889,1746,1699 .{ }^{1} \mathbf{H}$ NMR $\left(400 \mathrm{MHz}, \mathrm{CDCl}_{3}\right) \delta 5.10(\mathrm{dd}, J=7.8$, $2.9 \mathrm{~Hz}, 1 \mathrm{H}), 3.70$ (s, 3H), 3.14 (s, 3H), 2.44 (dd, $J=15.4,2.9 \mathrm{~Hz}, 1 \mathrm{H}), 2.07-1.96(\mathrm{~m}, 1 \mathrm{H}), 1.49$ (s, 18H), 1.18 (s, 3H), 1.17 (s, 3H). ${ }^{13} \mathbf{C}$ NMR $\left(101 \mathrm{MHz}, \mathrm{CDCl}_{3}\right) \delta 172.2,152.3,82.9,73.9,55.0,52.5,49.4,39.9$, 28.2, 25.4, 25.3. HRMS (ESI): $\mathrm{m} / \mathrm{z}$ calculated for $\mathrm{C}_{18} \mathrm{H}_{33} \mathrm{O}_{7} \mathrm{~N}_{1}$ requires 398.2149 for $[\mathrm{M}+\mathrm{Na}]^{+}$, found 398.2149 .

Synthesis of $\mathbf{3 b}$

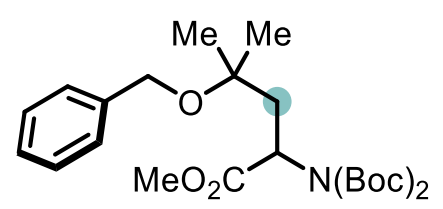

The above compound was synthesized according to General Procedure $\mathbf{C}$ using 2-benzyloxypropene 1aa (44.4 mg, $0.3 \mathrm{mmol}$ ) and methyl 2-(bis(tert-butoxycarbonyl)amino)acrylate (30.3 mg, $0.1 \mathrm{mmol})$. Silica gel column chromatography gave a colourless oil, $51 \%(27.5 \mathrm{mg})$.

The above compound was also synthesized according to General Procedure $\mathbf{D}$ at double scale, using 2benzyloxypropene (29.6 mg, $0.2 \mathrm{mmol}$ ) and methyl 2-(bis(tert-butoxycarbonyl)amino)acrylate (121.2 mg, 0.4 $\mathrm{mmol})$. Before work-up, to the crude reaction mixture was added cysteamine $(46.3 \mathrm{mg}, 0.6 \mathrm{mmol})$ and NEt 3 $(0.11 \mathrm{~mL}, 0.8 \mathrm{mmol})$. The solution was stirred at room temperature for 3 hours (TLC showed disappearance of alkene). Regular work-up as per the general procedure, and silica gel column chromatography gave a colourless oil, 61\% (46.1 mg).

FT-IR (thin film): $\nu_{\max }\left(\mathrm{cm}^{-1}\right)=2981,2889,1745,1698 .{ }^{1} \mathbf{H}$ NMR $\left(400 \mathrm{MHz}, \mathrm{CDCl}_{3}\right) \delta 7.36-7.27(\mathrm{~m}$, $4 \mathrm{H}), 7.25-7.18(\mathrm{~m}, 1 \mathrm{H}), 5.23(\mathrm{dd}, J=7.7,3.1 \mathrm{~Hz}, 1 \mathrm{H}), 4.45(\mathrm{~d}, J=11.6 \mathrm{~Hz}, 1 \mathrm{H}), 4.41(\mathrm{~d}, J=11.5 \mathrm{~Hz}$, $1 \mathrm{H}), 3.70(\mathrm{~s}, 3 \mathrm{H}), 2.60(\mathrm{dd}, J=15.4,3.1 \mathrm{~Hz}, 1 \mathrm{H}), 2.09(\mathrm{dd}, J=15.4,7.7 \mathrm{~Hz}, 1 \mathrm{H}), 1.46(\mathrm{~s}, 18 \mathrm{H}), 1.30$ (s, $3 \mathrm{H}), 1.28(\mathrm{~s}, 3 \mathrm{H}) .{ }^{13} \mathbf{C} \mathbf{N M R}\left(101 \mathrm{MHz}, \mathrm{CDCl}_{3}\right) \delta 172.3,152.4,139.9,128.2,127.2,127.0,83.0,74.5,63.8$, 55.0, 52.5, 41.0, 28.1, 25.9, 25.9. HRMS (ESI): $\mathrm{m} / \mathrm{z}$ calculated for $\mathrm{C}_{24} \mathrm{H}_{37} \mathrm{O}_{7} \mathrm{~N}_{1}$ requires 474.2462 for $[\mathrm{M}+\mathrm{Na}]^{+}$, found 474.2462 . 
Synthesis of $\mathbf{3 c}$<smiles>COC(C)(C)CC(C)C(=O)Oc1ccccc1</smiles>

The above compound was synthesized according to General Procedure $\mathbf{C}$ using 2-methoxypropene (28.7 $\mu \mathrm{L}, 0.3 \mathrm{mmol})$ and phenyl methacrylate $(15.4 \mu \mathrm{L}, 0.1 \mathrm{mmol})$. Silica gel column chromatography gave a colourless oil, 60\% (14.1 mg). FT-IR (thin film): $\nu_{\max }\left(\mathrm{cm}^{-1}\right)=2981,2889,1758 .{ }^{1} \mathbf{H}$ NMR $(400 \mathrm{MHz}$, $\left.\mathrm{CDCl}_{3}\right) \delta 7.42-7.32(\mathrm{~m}, 2 \mathrm{H}), 7.26-7.16(\mathrm{~m}, 1 \mathrm{H}), 7.12-7.04(\mathrm{~m}, 2 \mathrm{H}), 3.17(\mathrm{~s}, 3 \mathrm{H}), 2.86$ (ddq, J = 14.0, 7.1, $3.5 \mathrm{~Hz}, 1 \mathrm{H}), 2.23(\mathrm{dd}, J=14.5,9.8 \mathrm{~Hz}, 1 \mathrm{H}), 1.52(\mathrm{dd}, J=14.4,3.2 \mathrm{~Hz}, 1 \mathrm{H}), 1.33(\mathrm{~d}, J=7.1 \mathrm{~Hz}, 3 \mathrm{H})$, $1.25(\mathrm{~s}, 3 \mathrm{H}), 1.21$ (s, 3H). ${ }^{13} \mathrm{C}$ NMR $\left(101 \mathrm{MHz}, \mathrm{CDCl}_{3}\right) \delta 175.8,151.0,129.3,125.5,121.5,74.2,49.3,44.2$, 35.5, 25.2, 24.8, 19.5. HRMS (ESI): $\mathrm{m} / \mathrm{z}$ calculated for $\mathrm{C}_{14} \mathrm{H}_{20} \mathrm{O}_{3}$ requires 259.1305 for $[\mathrm{M}+\mathrm{Na}]^{+}$, found 259.1306 .

Synthesis of $\mathbf{3 d}$

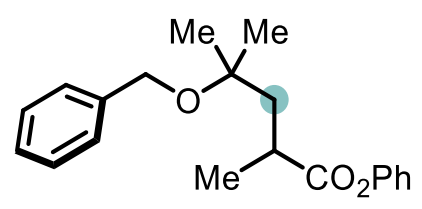

The above compound was synthesized according to General Procedure $\mathbf{C}$ using 2-benzyloxypropene (44.4 $\mathrm{mg}, 0.3 \mathrm{mmol})$ and phenyl methacrylate $(15.4 \mu \mathrm{L}, 0.1 \mathrm{mmol})$. Silica gel column chromatography gave a colourless oil, $61 \%(19.0 \mathrm{mg})$. FT-IR (thin film): $\nu_{\max }\left(\mathrm{cm}^{-1}\right)=2981,2888,1758,1594 .{ }^{1} \mathbf{H}$ NMR $(400 \mathrm{MHz}$, $\left.\mathrm{CDCl}_{3}\right) \delta 7.31-7.14(\mathrm{~m}, 7 \mathrm{H}), 7.12-7.03(\mathrm{~m}, 1 \mathrm{H}), 6.85-6.79(\mathrm{~m}, 2 \mathrm{H}), 4.39(\mathrm{~d}, J=11.3 \mathrm{~Hz}, 1 \mathrm{H}), 4.34(\mathrm{~d}$, $J=11.3 \mathrm{~Hz}, 1 \mathrm{H}), 2.95-2.80(\mathrm{~m}, 1 \mathrm{H}), 2.27(\mathrm{dd}, J=14.5,9.3 \mathrm{~Hz}, 1 \mathrm{H}), 1.55(\mathrm{dd}, J=14.5,3.2 \mathrm{~Hz}, 1 \mathrm{H}), 1.28$ $(\mathrm{d}, J=7.1 \mathrm{~Hz}, 6 \mathrm{H}), 1.24(\mathrm{~s}, 3 \mathrm{H}) .{ }^{13} \mathbf{C} \mathbf{N M R}\left(101 \mathrm{MHz}, \mathrm{CDCl}_{3}\right) \delta 175.9,151.0,139.8,129.3,128.4,127.6$, 127.2, 125.6, 121.6, 75.0, 64.1, 45.0, 35.8, 25.9, 25.6, 20.0. HRMS (ESI): $\mathrm{m} / \mathrm{z}$ calculated for $\mathrm{C}_{20} \mathrm{H}_{24} \mathrm{O}_{3}$ requires 335.1618 for $[\mathrm{M}+\mathrm{Na}]^{+}$, found 335.1618 . 
Synthesis of $\mathbf{3 e}$<smiles>COC(C)CC(C)(C)OCc1ccccc1</smiles>

The above compound was synthesized according to General Procedure $\mathbf{C}$ using 2-benzyloxypropene (44.4 $\mathrm{mg}, 0.3 \mathrm{mmol})$ and methyl methacrylate $(10.7 \mu \mathrm{L}, 0.1 \mathrm{mmol})$. Silica gel column chromatography gave a colourless oil, 38\% (9.5 mg). FT-IR (thin film): $\nu_{\max }\left(\mathrm{cm}^{-1}\right)=2981,2888,1737 .{ }^{1} \mathbf{H}$ NMR $(400 \mathrm{MHz}$, $\left.\mathrm{CDCl}_{3}\right) \delta 7.35-7.29(\mathrm{~m}, 3 \mathrm{H}), 7.25-7.20(\mathrm{~m}, 1 \mathrm{H}), 4.40(\mathrm{~d}, J=11.3 \mathrm{~Hz}, 1 \mathrm{H}), 4.36(\mathrm{~d}, J=11.2 \mathrm{~Hz}, 1 \mathrm{H})$, 3.49 (s, $3 \mathrm{H}), 2.71(\mathrm{dtd}, J=12.7,7.1,3.5 \mathrm{~Hz}, 1 \mathrm{H}), 2.20(\mathrm{dd}, J=14.4,9.4 \mathrm{~Hz}, 1 \mathrm{H}), 1.52(\mathrm{dd}, J=14.4,3.4 \mathrm{~Hz}$, $1 \mathrm{H}), 1.27(\mathrm{~s}, 3 \mathrm{H}), 1.23(\mathrm{~s}, 3 \mathrm{H}), 1.18(\mathrm{~d}, J=7.1 \mathrm{~Hz}, 3 \mathrm{H}) .{ }^{13} \mathbf{C} \mathbf{N M R}\left(101 \mathrm{MHz}, \mathrm{CDCl}_{3}\right) \delta 178.0,139.9,128.3$, 127.4, 127.1, 74.9, 63.9, 51.6, 45.2, 35.5, 25.8, 25.5, 19.8. HRMS (ESI): $\mathrm{m} / \mathrm{z}$ calculated for $\mathrm{C}_{15} \mathrm{H}_{22} \mathrm{O}_{3}$ requires 273.1461 for $[\mathrm{M}+\mathrm{Na}]^{+}$, found 273.1463 .

Synthesis of $\mathbf{3 f}$<smiles>COC(C)(C)CC(C)C(=O)Oc1ccccc1</smiles>

The above compound was synthesized according to General Procedure $\mathbf{C}$ using 2-methoxypropene (28.7 $\mu \mathrm{L}, 0.3 \mathrm{mmol}$ ) and benzyl methacrylate $(16.9 \mu \mathrm{L}, 0.1 \mathrm{mmol})$. Silica gel column chromatography gave a colourless oil, 65\% (16.2 mg). FT-IR (thin film): $\nu_{\max }\left(\mathrm{cm}^{-1}\right)=3034,2972,1736,1498 .{ }^{1} \mathbf{H}$ NMR $(400 \mathrm{MHz}$, $\left.\mathrm{CDCl}_{3}\right) \delta 7.39-7.35(\mathrm{~m}, 4 \mathrm{H}), 7.35-7.28(\mathrm{~m}, 1 \mathrm{H}), 5.10(\mathrm{~s}, 2 \mathrm{H}), 3.09(\mathrm{~s}, 3 \mathrm{H}), 2.76-2.62(\mathrm{~m}, 1 \mathrm{H}), 2.11(\mathrm{dd}$, $J=14.4,9.3 \mathrm{~Hz}, 1 \mathrm{H}), 1.44(\mathrm{dd}, J=14.4,3.4 \mathrm{~Hz}, 1 \mathrm{H}), 1.19(\mathrm{~d}, J=7.1 \mathrm{~Hz}, 3 \mathrm{H}), 1.15$ (s, 3H), 1.10 (s, 3H). ${ }^{13} \mathbf{C}$ NMR $\left(101 \mathrm{MHz}, \mathrm{CDCl}_{3}\right) \delta$ 177.4, 136.4, 128.6, 128.3, 128.2, 74.3, 66.3, 49.4, 44.1, 35.5, 29.8, 25.2, 25.0, 19.7. HRMS (ESI): $\mathrm{m} / \mathrm{z}$ calculated for $\mathrm{C}_{15} \mathrm{H}_{22} \mathrm{O}_{3}$ requires 273.1461 for $[\mathrm{M}+\mathrm{Na}]^{+}$, found 273.1462 . 


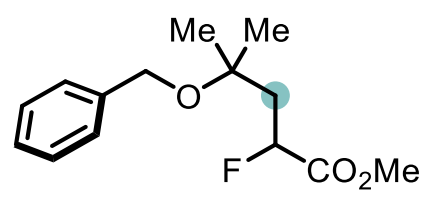

The above compound was synthesized according to General Procedure $\mathbf{C}$ using 2-benzyloxypropene 1aa (44.4 mg, $0.3 \mathrm{mmol}$ ) and methyl 2-fluoroacrylate $(9.3 \mu \mathrm{L}, 0.1 \mathrm{mmol})$. Silica gel column chromatography gave a yellow oil, $52 \%(13.0 \mathrm{mg})$. FT-IR (thin film): $\nu_{\max }\left(\mathrm{cm}^{-1}\right)=2981,2889,1763,1745,1498 .{ }^{1} \mathbf{H}$ NMR $\left(400 \mathrm{MHz}, \mathrm{CDCl}_{3}\right): \delta=7.35-7.31(\mathrm{~m}, 4 \mathrm{H}), 7.29-7.23(\mathrm{~m}, 1 \mathrm{H}), 5.23(\mathrm{ddd}, J=49.3,8.4,2.6 \mathrm{~Hz}, 1 \mathrm{H}), 4.46$ $(\mathrm{d}, J=11.0 \mathrm{~Hz}, 1 \mathrm{H}), 4.43(\mathrm{~d}, J=11.0 \mathrm{~Hz}, 1 \mathrm{H}), 3.70(\mathrm{~s}, 3 \mathrm{H}), 2.25(\mathrm{ddd}, J=34.2,15.3,2.6 \mathrm{~Hz}, 1 \mathrm{H}), 2.08$ $(\mathrm{ddd}, J=23.5,15.2,8.5 \mathrm{~Hz}, 1 \mathrm{H}), 1.36(\mathrm{~s}, 3 \mathrm{H}), 1.35 \mathrm{ppm}(\mathrm{s}, 3 \mathrm{H}) ;{ }^{19} \mathbf{F} \mathbf{N M R}\left(377 \mathrm{MHz}, \mathrm{CDCl}_{3}\right): \delta=-187.76$ $\operatorname{ppm}(\mathrm{ddd}, J=49.7,35.0,23.3 \mathrm{~Hz}) ;{ }^{13} \mathbf{C} \mathbf{N M R}\left(101 \mathrm{MHz}, \mathrm{CDCl}_{3}\right): \delta=171.0(\mathrm{~d}, J=24.1 \mathrm{~Hz}), 139.3,128.8$, 127.6, 127.4, $86.71(\mathrm{~d}, J=183.4 \mathrm{~Hz}), 73.9,64.0,52.4,43.45(\mathrm{~d}, J=20.0 \mathrm{~Hz}), 26.4(\mathrm{~d}, J=1.6 \mathrm{~Hz}), 25.7 \mathrm{ppm}$ (d, $J=2.4 \mathrm{~Hz}$ ).; HRMS (ESI): $\mathrm{m} / \mathrm{z}$ calculated for $\mathrm{C}_{14} \mathrm{H}_{19} \mathrm{O}_{3} \mathrm{~F}_{1}$ requires 277.1211 for $[\mathrm{M}+\mathrm{Na}]^{+}$, found 277.1210 .

Synthesis of $3 h$<smiles>COC(C)(C)CCS(=O)(=O)c1ccccc1</smiles>

The above compound was synthesized according to General Procedure $\mathbf{C}$ using 2-methoxypropene $(29 \mu \mathrm{L}$, $0.3 \mathrm{mmol})$ and phenyl vinyl sulfone $(16.8 \mathrm{mg}, 0.1 \mathrm{mmol})$. Silica gel column chromatography gave an amorphous solid, 50\% (12.1 mg). FT-IR (thin film): $\nu_{\max }\left(\mathrm{cm}^{-1}\right)=2981,2889,1383 .{ }^{1} \mathbf{H}$ NMR $(400 \mathrm{MHz}$, $\left.\mathrm{CDCl}_{3}\right) \delta 7.97-7.88(\mathrm{~m}, 2 \mathrm{H}), 7.72-7.63(\mathrm{~m}, 1 \mathrm{H}), 7.61-7.49(\mathrm{~m}, 2 \mathrm{H}), 3.23-3.12(\mathrm{~m}, 2 \mathrm{H}), 3.07(\mathrm{~s}, 3 \mathrm{H})$, $2.00-1.82(\mathrm{~m}, 2 \mathrm{H}), 1.12(\mathrm{~s}, 6 \mathrm{H}) .{ }^{13} \mathbf{C} \mathbf{~ N M R}\left(101 \mathrm{MHz}, \mathrm{CDCl}_{3}\right) \delta$ 139.5, 133.8, 129.4, 128.2, 73.3, 52.0, 49.3, 32.2, 25.0. HRMS (ESI): $\mathrm{m} / \mathrm{z}$ calculated for $\mathrm{C}_{12} \mathrm{H}_{18} \mathrm{O}_{3} \mathrm{~S}_{1}$ requires 265.0869 for $[\mathrm{M}+\mathrm{Na}]^{+}$, found 265.0870 . 
Synthesis of $\mathbf{3 i}$<smiles>COC(C)(C)CC(c1ccccc1)c1ccccc1</smiles>

The above compound was synthesized according to General Procedure $\mathbf{C}$ using 2-methoxypropene $(29 \mu \mathrm{L}$, $0.3 \mathrm{mmol})$ and 1,1-diphenylethylene $(18.0 \mu \mathrm{L}, 0.1 \mathrm{mmol})$. Silica gel column chromatography gave a colourless oil, $50 \%(12.1 \mathrm{mg})$. FT-IR (thin film): $\nu_{\max }\left(\mathrm{cm}^{-1}\right)=2981,2889,1734 .{ }^{1} \mathbf{H}$ NMR $(400 \mathrm{MHz}$, $\left.\mathrm{CDCl}_{3}\right) \delta 7.27-7.21(\mathrm{~m}, 4 \mathrm{H}), 7.20-7.14(\mathrm{~m}, 4 \mathrm{H}), 7.11-6.92(\mathrm{~m}, 2 \mathrm{H}), 4.08(\mathrm{t}, J=6.3 \mathrm{~Hz}, 1 \mathrm{H}), 3.03(\mathrm{~s}$, $3 \mathrm{H}), 2.28(\mathrm{~d}, J=6.3 \mathrm{~Hz}, 2 \mathrm{H}), 0.96(\mathrm{~s}, 6 \mathrm{H}) .{ }^{13} \mathbf{C} \mathbf{~ N M R}\left(101 \mathrm{MHz}, \mathrm{CDCl}_{3}\right) \delta$ 146.7, 128.6, 128.0, 126.0, 75.2, 49.3, 47.2, 45.3, 26.1. HRMS (ESI): $\mathrm{m} / \mathrm{z}$ calculated for $\mathrm{C}_{18} \mathrm{H}_{22} \mathrm{O}_{1}$ requires 277.153 for $[\mathrm{M}+\mathrm{Na}]^{+}$, found 277.1563.

Synthesis of $\mathbf{3} \mathbf{j}$

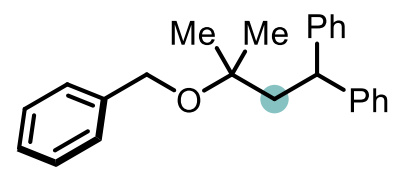

The above compound was synthesized according to General Procedure $\mathbf{C}$ using 2-benzyloxypropene (44.4 $\mathrm{mg}, 0.3 \mathrm{mmol})$ and 1,1-diphenylethylene $(18.0 \mu \mathrm{L}, 0.1 \mathrm{mmol})$. Silica gel column chromatography gave a colourless oil, $59 \%(19.5 \mathrm{mg})$. FT-IR (thin film): $\nu_{\max }\left(\mathrm{cm}^{-1}\right)=2981,2888 .{ }^{1} \mathbf{H} \mathbf{~ N M R}\left(400 \mathrm{MHz}, \mathrm{CDCl}_{3}\right) \delta$ $7.27-7.19(\mathrm{~m}, 6 \mathrm{H}), 7.21-7.12(\mathrm{~m}, 7 \mathrm{H}), 7.10-7.01(\mathrm{~m}, 2 \mathrm{H}), 4.29(\mathrm{~s}, 2 \mathrm{H}), 4.20(\mathrm{t}, J=6.4 \mathrm{~Hz}, 1 \mathrm{H}), 2.39$ (d, $J=6.4 \mathrm{~Hz}, 2 \mathrm{H}), 1.07(\mathrm{~s}, 6 \mathrm{H}) .{ }^{13} \mathbf{C ~ N M R}\left(101 \mathrm{MHz}, \mathrm{CDCl}_{3}\right) \delta$ 146.6, 139.9, 128.6, 128.3, 128.0, 127.3, 127.1, 126.1, 75.7, 63.8, 47.3, 46.5, 26.6. HRMS (ESI): $\mathrm{m} / \mathrm{z}$ calculated for $\mathrm{C}_{24} \mathrm{H}_{26} \mathrm{O}_{1}$ requires 353.1876 for $[\mathrm{M}+\mathrm{Na}]^{+}$, found 353.1877 . 
Synthesis of $\mathbf{3 k}$<smiles>COC(C)(C)CCB1OC(C)(C)C(C)(C)O1</smiles>

The above compound was synthesized according to General Procedure $\mathbf{C}$ using 2-methoxypropene ( $29 \mu \mathrm{L}$, $0.3 \mathrm{mmol})$ and vinylboronic acid pinacol ester $(17.0 \mu \mathrm{L}, 0.1 \mathrm{mmol})$. Silica gel column chromatography gave a yellow oil, $26 \%(6.0 \mathrm{mg})$. FT-IR (thin film): $\nu_{\max }\left(\mathrm{cm}^{-1}\right)=2981,2889,1728,1559,1462 .{ }^{1} \mathbf{H}$ NMR (400 $\left.\mathrm{MHz}, \mathrm{CDCl}_{3}\right): \delta=3.16(\mathrm{~s}, 3 \mathrm{H}), 1.56(\mathrm{dd}, J=5.0,3.5 \mathrm{~Hz}, 2 \mathrm{H}), 1.24(\mathrm{~s}, 12 \mathrm{H}) 1.12(\mathrm{~s}, 6 \mathrm{H}), 0.81-0.73(\mathrm{~m}$, 2H). ${ }^{13} \mathbf{C}$ NMR (101 MHz, $\mathrm{CDCl}_{3}$, C-B carbon not observed): $\delta=83.1,75.0,49.3$, 33.6, 24.9, 24.7. HRMS (ESI): $\mathrm{m} / \mathrm{z}$ calculated for $\mathrm{C}_{12} \mathrm{H}_{25} \mathrm{O}_{3}{ }^{10} \mathrm{~B}_{1}$ requires 250.1825 for $[\mathrm{M}+\mathrm{Na}]^{+}$, found 250.1829 .

Synthesis of $\mathbf{3 1}$<smiles>COC(=O)C(CC(C)(C)OCc1ccccc1)NC(C)=O</smiles>

The above compound was synthesized according to General Procedure $\mathbf{C}$ using 2-benzyloxypropene (44.4 $\mathrm{mg}, 0.3 \mathrm{mmol}$ ) and methyl 2-acetamidoacrylate $(14.0 \mathrm{mg}, 0.1 \mathrm{mmol})$. Silica gel column chromatography (EtOAc:Pentane - 95:5 - 30:70 v:v) gave a yellow oil, 58\% (17.0 mg). FT-IR (thin film): $\nu_{\max }\left(\mathrm{cm}^{-1}\right)=3292$, 2981, 2889, 1743, 1657, 1522. ${ }^{1} \mathbf{H}$ NMR $\left(400 \mathrm{MHz}, \mathrm{CDCl}_{3}\right): \delta=7.43-7.27(\mathrm{~m}, 5 \mathrm{H}), 6.96(\mathrm{~d}, J=5.1 \mathrm{~Hz}$, 1H), $4.47(\mathrm{dd}, J=9.4,4.7 \mathrm{~Hz}, 1 \mathrm{H}), 4.43(\mathrm{~d}, J=10.7 \mathrm{~Hz}, 1 \mathrm{H}), 4.39(\mathrm{~d}, J=10.4 \mathrm{~Hz}, 1 \mathrm{H}), 3.66(\mathrm{~s}, 3 \mathrm{H}), 2.11$ - 1.93 (m, $2 \mathrm{H}), 1.69$ (s, 3H), 1.35 (s, 3H), 1.34 (s, 3H). ${ }^{13} \mathbf{C}$ NMR (101 MHz, CDCl $)$ : $\delta=173.1,170.1$, 138.7, 128.7, 128.0, 127.9, 76.1, 64.3, 52.3, 51.2, 42.1, 25.9, 24.1, 22.7. HRMS (ESI): $\mathrm{m} / \mathrm{z}$ calculated for $\mathrm{C}_{16} \mathrm{H}_{23} \mathrm{O}_{4} \mathrm{~N}_{1}$ requires 316.1519 for $[\mathrm{M}+\mathrm{Na}]^{+}$, found 316.1520 . 
Synthesis of $3 \mathrm{~m}$<smiles>COC(=O)C(CC(C)(C)OC)N(C(=O)OC(C)(C)C)C(=O)C1CCCN1C(=O)OCc1ccccc1</smiles>

The above compound was synthesized according to General Procedure $\mathbf{C}$ using 2-methoxypropene ( $29 \mu \mathrm{L}$, $0.3 \mathrm{mmol})$ and $3 \mathrm{~m}(39.8 \mathrm{mg}, 0.1 \mathrm{mmol}) .1: 1 \mathrm{dr}$. Silica gel column chromatography gave a colourless oil, $56 \%$ (26.5 mg). FT-IR (thin film): $\nu_{\max }\left(\mathrm{cm}^{-1}\right)=2980,2889,1739,1702$. Warm up, carbon also missing. ${ }^{1} \mathbf{H}$ NMR (400 MHz, $\mathrm{CDCl}_{3}$, rotameric) $\delta 5.50-5.36\left(\mathrm{~m}, 3 \mathrm{H}, 2\right.$ x $\left.3 \mathrm{~m} \& 3 \mathrm{~m}^{\prime}\right), 5.33-5.15\left(\mathrm{~m}, 1 \mathrm{H}, 3 \mathrm{~m}^{\prime}\right), 3.72$ - 3.63 (m, 6H, 3m \& 3m'), $3.65-3.50$ (m, 2H, 3m \& 3m'), $3.50-3.33$ (m, 2H, 3m \& 3m'), $3.20-3.05$ (m, 6H, 3m \& 3 m'), $2.59-2.43$ (m, 2H, 3m \& 3 m'), $2.39-2.15$ (m, 2H, 3m \& 3m'), $2.02-1.91$ (m, 2H, $\left.3 \mathrm{~m} \& 3 \mathrm{~m}^{\prime}\right), 1.90-1.77$ (m, 2H, 3m \& 3m'), $1.55-1.46$ (m, 18H, 3m \& 3m'), $1.45-1.39$ (m, 18H, 3m \&

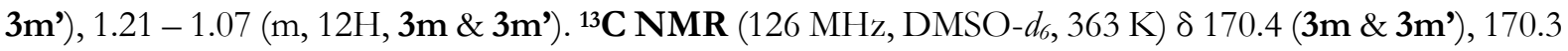
(3m \& 3m'), 151.3 (3m \& 3 3'), 83.6 (2C, 3m \& 3m'), 78.0 (3m \& 3m'), 72.9 (3m), 72.8 (3m'), 60.4 (3m), 60.2 (3m'), 51.6 (3m), 51.5 (3m'), 48.21 (3m), 48.16 (3m'), 45.7 (3m \& 3m'), 39.8 (3m), 39.6 (3m'), 29.2 (3m), 28.5 (3m'), 27.6 (2C, 3m \& 3 3'), 27.1 (3m \& 3m') 27.0 (3m \& 3 3'), 24.2 (3m \& 3m'), 24.0 (3m \& 3m'). HRMS (ESI): $\mathrm{m} / \mathrm{z}$ calculated for $\mathrm{C}_{23} \mathrm{H}_{40} \mathrm{O}_{8} \mathrm{~N}_{2}$ requires 495.2677 for $[\mathrm{M}+\mathrm{Na}]^{+}$, found 495.2671 .

Synthesis of $3 n$<smiles>COC(=O)N1CCC(C(=O)N(CC(C)(C)OC(C)(C)C)C(=O)OC(C)(C)C)C1</smiles>

The above compound was synthesized according to General Procedure $\mathbf{C}$ using 2-methoxypropene ( $29 \mu \mathrm{L}$, $0.3 \mathrm{mmol}$ ) and $\mathbf{3 n}(39.8 \mathrm{mg}, 0.1 \mathrm{mmol}) .1: 1 \mathrm{dr}$. Silica gel column chromatography gave a colourless oil, $67 \%$ (31.5 mg). FT-IR (thin film): $\nu_{\max }\left(\mathrm{cm}^{-1}\right)=2981,2889,1739,1693 .{ }^{1} \mathbf{H}$ NMR (400 MHz, DMSO- $d_{6}$, all diastereomeric peaks overlap) $\delta 5.26(\mathrm{td}, J=8.4,2.9 \mathrm{~Hz}, 1 \mathrm{H}), 4.11-3.97(\mathrm{~m}, 1 \mathrm{H}), 3.87(\mathrm{~d}, J=13.1 \mathrm{~Hz}$, $1 \mathrm{H}), 3.61(\mathrm{~s}, 3 \mathrm{H}), 3.37-3.23(\mathrm{~m}, 1 \mathrm{H}), 3.01(\mathrm{app} \mathrm{d}, 3 \mathrm{H}), 2.86-2.62(\mathrm{~m}, 2 \mathrm{H}), 2.28$ (ddd, $J=15.1,11.8,2.9$ $\mathrm{Hz}, 1 \mathrm{H}), 1.93$ (ddd, $J=23.4,15.5,8.8 \mathrm{~Hz}, 2 \mathrm{H}), 1.78-1.62(\mathrm{~m}, 1 \mathrm{H}), 1.46(\mathrm{~d}, J=1.5 \mathrm{~Hz}, 9 \mathrm{H}), 1.39$ (d, $J=$ $1.3 \mathrm{~Hz}, 9 \mathrm{H}), 1.09$ (s, 3H), 1.06 (app d, 3H). ${ }^{13} \mathbf{C}$ NMR (126 MHz, DMSO-d N $\delta 175.24$ (3n), 175.18 (3n'), 170.40 (3n), 170.37 (3n'), 153.5 (3n \& 3n'), 151.4 (3n \& 3n'), 83.5 (3n \& 3n'), 78.3 (3n \& 3n'), 72.9 (3n \& 3n'), 52.41 (3n), 52.36 (3n'), 51.6 (3n \& 3n'), 48.2 (3n \& 3n'), 45.8 (3n \& 3n'), 43.4 (3n \& 3n'), 42.5 (3n), 42.4 (3n'), 27.6 (3n \& 3n'), 27.2 (3n \& 3n'), 27.0 (3n \& 3n'), 24.5 (3n), 24.4 (3n'), 24.03 (3n), 23.98 (3n'), 23.45 (3n), 23.42 (3n'). HRMS (ESI): $\mathrm{m} / \mathrm{z}$ calculated for $\mathrm{C}_{23} \mathrm{H}_{40} \mathrm{O}_{8} \mathrm{~N}_{2}$ requires 495.2677 for $[\mathrm{M}+\mathrm{H}]^{+}$, found 495.2675 . 
Synthesis of 3o<smiles>COC(C)(C)OC(=O)N1CCCC(C(=O)N(C(=O)c2ccccc2)C(CC(C)(C)OC(C)(C)C)C(=O)OC(C)(C)C)C1</smiles>

The above compound was synthesized according to General Procedure $\mathbf{C}$ using 2-methoxypropene $(29 \mu \mathrm{L}$, $0.3 \mathrm{mmol})$ and $3 \mathbf{o}(41.2 \mathrm{mg}, 0.1 \mathrm{mmol})$, and chlorotrimethylsilane $(37 \mu \mathrm{L}, 0.3 \mathrm{mmol}) .1: 1 \mathrm{dr}$. Silica gel column chromatography gave a colourless oil, $67 \%(32.6 \mathrm{mg})$. FT-IR (thin film): $\nu_{\max }\left(\mathrm{cm}^{-1}\right)=2981,2889$, 1739, 1697. ${ }^{1} \mathbf{H}$ NMR (400 MHz, DMSO- $d_{6}$, all diastereomeric peaks overlap) $\delta 5.29$ (ddd, $J=11.2,8.3$, $2.9 \mathrm{~Hz}, 1 \mathrm{H}), 3.92(\mathrm{~d}, J=6.5 \mathrm{~Hz}, 1 \mathrm{H}), 3.61(\operatorname{app~d}, 3 \mathrm{H}), 3.47(\mathrm{dd}, J=11.9,7.5 \mathrm{~Hz}, 1 \mathrm{H}), 3.40(\mathrm{dd}, J=10.9$, $5.0 \mathrm{~Hz}, 1 \mathrm{H}), 3.26(\mathrm{q}, J=7.4,6.8 \mathrm{~Hz}, 2 \mathrm{H}), 3.00(\operatorname{app~d}, 3 \mathrm{H}), 2.29(\mathrm{dd}, J=15.4,3.0 \mathrm{~Hz}, 1 \mathrm{H}), 2.13-1.99(\mathrm{~m}$, 3H), $1.99-1.83$ (m, 2H), 1.46 (app d, 9H), 1.39 (app d, 9H), 1.09 (app d, 3H), 1.06 (app d, 3H). ${ }^{13}$ C NMR (126 MHz, DMSO- $d_{6}-363$ K) $\delta 174.8$ (3o \& 3o'), 170.4 (3o \& 3o'), 153.0 (3o \& 3o'), 151.41 (3o), 151.38

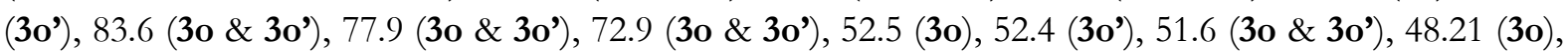

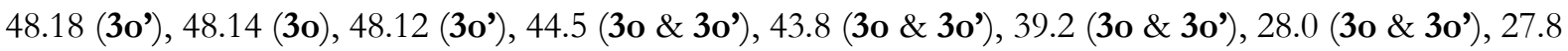
(3o \& 3o'), 27.04 (3o \& 3o'), 26.97 (3o \& 3o'), 24.4 (3o \& 3o'), 23.9 (3o \& 3o'), 23.8 (3o \& 30'). HRMS (ESI): $\mathrm{m} / \mathrm{z}$ calculated for $\mathrm{C}_{24} \mathrm{H}_{42} \mathrm{O}_{8} \mathrm{~N}_{2}$ requires 509.2833 for $[\mathrm{M}+\mathrm{Na}]^{+}$, found 509.2842 .

Synthesis of $3 p$

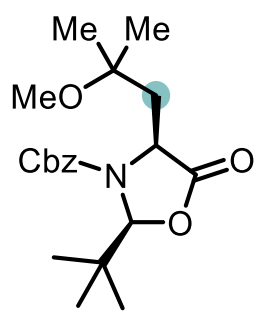

The above compound was synthesized according to General Procedure $\mathbf{C}$ using 2-methoxypropene $(29 \mu \mathrm{L}$, $0.3 \mathrm{mmol})$ and $\mathbf{2 p}(28.9 \mathrm{mg}, 0.1 \mathrm{mmol}) .>20: 1 \mathrm{dr}$. Silica gel column chromatography gave a colourless oil, $56 \%(26.5 \mathrm{mg})$. FT-IR (thin film): $\nu_{\max }\left(\mathrm{cm}^{-1}\right)=2980,2889,1794,1718 .{ }^{1} \mathbf{H} \mathbf{~ N M R}\left(400 \mathrm{MHz}, \mathrm{CDCl}_{3}\right) \delta$ $7.43-7.31(\mathrm{~m}, 5 \mathrm{H}), 5.56(\mathrm{~s}, 1 \mathrm{H}), 5.22(\mathrm{~d}, J=12.0 \mathrm{~Hz}, 1 \mathrm{H}), 5.15(\mathrm{~d}, J=12.0 \mathrm{~Hz}, 1 \mathrm{H}), 4.55(\mathrm{dd}, J=7.9,3.4$ $\mathrm{Hz}, 1 \mathrm{H}), 3.16$ (s, 3H), 2.11 (dd, $J=14.4,7.8 \mathrm{~Hz}, 1 \mathrm{H}), 1.97$ (dd, $J=14.4,3.4 \mathrm{~Hz}, 1 \mathrm{H}), 1.25$ (s, 3H), 1.24 (s, 3H), 0.96 (s, 9H). ${ }^{13} \mathbf{C}$ NMR (101 MHz, $\left.\mathrm{CDCl}_{3}\right) \delta$ 173.2, 156.0, 135.5, 128.8, 128.8, 96.3, 74.0, 68.4, 53.7, 49.5, 45.0, 37.0, 25.3, 25.1. HRMS (ESI): $\mathrm{m} / \mathrm{z}$ calculated for $\mathrm{C}_{20} \mathrm{H}_{29} \mathrm{O}_{5} \mathrm{~N}_{1}$ requires 386.1938 for $[\mathrm{M}+\mathrm{Na}]^{+}$, found 386.1946 . 
Synthesis of $\mathbf{4 b}$

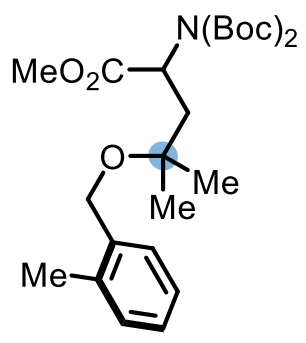

The above compound was synthesized according to General Procedure $\mathbf{C}$ using 1-methyl-2-((prop-1-en-2yloxy)methyl)benzene (48.6 mg, $0.3 \mathrm{mmol}$ ) and methyl 2-(bis(tert-butoxycarbonyl)amino)acrylate $(30.3 \mathrm{mg}$, $0.1 \mathrm{mmol})$. Silica gel column chromatography gave a colourless oil, $55 \%(25.6 \mathrm{mg})$. FT-IR (thin film): $\nu_{\max }$ $\left(\mathrm{cm}^{-1}\right)=2978,1745,1698 .{ }^{1} \mathbf{H}$ NMR $\left(400 \mathrm{MHz}, \mathrm{CDCl}_{3}\right) \delta 7.40(\mathrm{dd}, J=6.0,2.8 \mathrm{~Hz}, 1 \mathrm{H}), 7.18-7.12(\mathrm{~m}$, 2H), $7.12-7.08(\mathrm{~m}, 1 \mathrm{H}), 5.20(\mathrm{dd}, J=7.6,3.0 \mathrm{~Hz}, 1 \mathrm{H}), 4.42(\mathrm{~d}, J=11.7 \mathrm{~Hz}, 1 \mathrm{H}), 4.39$ (d, $J=11.7 \mathrm{~Hz}$, $1 \mathrm{H}), 3.70(\mathrm{~s}, 3 \mathrm{H}), 2.63(\mathrm{dd}, J=15.3,3.0 \mathrm{~Hz}, 1 \mathrm{H}), 2.28(\mathrm{~s}, 3 \mathrm{H}), 2.09(\mathrm{dd}, J=15.4,7.8 \mathrm{~Hz}, 1 \mathrm{H}), 1.45(\mathrm{~s}, 18 \mathrm{H})$, $1.32(\mathrm{~s}, 3 \mathrm{H}), 1.29(\mathrm{~s}, 3 \mathrm{H}) .{ }^{13} \mathbf{C} \mathbf{N M R}\left(101 \mathrm{MHz}, \mathrm{CDCl}_{3}\right) \delta$ 172.2, 152.4, 137.8, 135.7, 129.8, 127.9, 127.0, 125.9, 83.0, 74.5, 61.8, 55.0, 52.5, 41.1, 28.1, 25.7, 18.9. HRMS (ESI): $\mathrm{m} / \mathrm{z}$ calculated for $\mathrm{C}_{25} \mathrm{H}_{39} \mathrm{O}_{7} \mathrm{~N}_{1}$ requires 488.2619 for $[\mathrm{M}+\mathrm{Na}]^{+}$, found 488.2617 .

Synthesis of $\mathbf{4 c}$

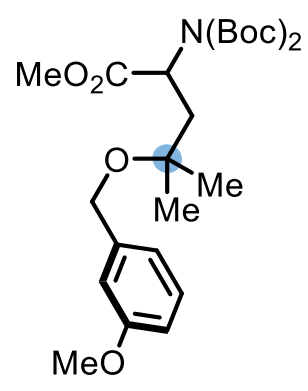

The above compound was synthesized according to General Procedure $\mathbf{C}$ using 1-methoxy-3-((prop-1-en2-yloxy)methyl)benzene $(53.5 \mathrm{mg}, 0.3 \mathrm{mmol}$ ) and methyl 2-(bis(tert-butoxycarbonyl)amino)acrylate (30.3 $\mathrm{mg}, 0.1 \mathrm{mmol})$. Silica gel column chromatography gave a colourless oil, $62 \%(29.7 \mathrm{mg})$. FT-IR (thin film): $\nu_{\max }\left(\mathrm{cm}^{-1}\right)=2981,2889,1745,1698,1602 .{ }^{1} \mathbf{H}$ NMR $\left(400 \mathrm{MHz}, \mathrm{CDCl}_{3}\right) \delta 7.20(\mathrm{t}, J=7.8 \mathrm{~Hz}, 1 \mathrm{H}), 6.96-$ $6.87(\mathrm{~m}, 2 \mathrm{H}), 6.76(\mathrm{ddd}, J=8.3,2.6,1.0 \mathrm{~Hz}, 1 \mathrm{H}), 5.23(\mathrm{dd}, J=7.7,3.0 \mathrm{~Hz}, 1 \mathrm{H}), \delta 4.43(\mathrm{~d}, J=11.7 \mathrm{~Hz}$, $1 \mathrm{H}), 4.39(\mathrm{~d}, J=11.7 \mathrm{~Hz}, 1 \mathrm{H}), 3.80(\mathrm{~s}, 3 \mathrm{H}), 3.70(\mathrm{~s}, 3 \mathrm{H}), 2.71-2.50(\mathrm{~m}, 1 \mathrm{H}), 2.07(\mathrm{dd}, J=15.3,7.6 \mathrm{~Hz}$, 1H), $1.46(\mathrm{~s}, 18 \mathrm{H}), 1.30(\mathrm{~s}, 3 \mathrm{H}), 1.27(\mathrm{~s}, 3 \mathrm{H}) .{ }^{13} \mathbf{C} \mathbf{~ N M R}\left(101 \mathrm{MHz}, \mathrm{CDCl}_{3}\right) \delta$ 172.3, 159.8, 152.4, 141.7, 129.2, 119.5, 112.8, 112.6, 83.0, 74.5, 63.8, 55.3, 55.0, 52.5, 41.0, 28.1, 26.0, 25.8. HRMS (ESI): $\mathrm{m} / \mathrm{z}$ calculated for $\mathrm{C}_{25} \mathrm{H}_{39} \mathrm{O}_{8} \mathrm{~N}_{1}$ requires 504.2568 for $[\mathrm{M}+\mathrm{Na}]^{+}$, found 504.2565 . 
Synthesis of $\mathbf{4 d}$<smiles>CC(=O)OC(CC(C)(C)OCc1cccc(OC(F)(F)F)c1)C(=O)OCc1ccccc1</smiles>

The above compound was synthesized according to General Procedure C using 1-((prop-1-en-2yloxy)methyl)-3-(trifluoromethoxy)benzene $(69.6 \mathrm{mg}, \quad 0.3 \mathrm{mmol}$ ) and methyl 2-(bis(tertbutoxycarbonyl)amino)acrylate $(30.3 \mathrm{mg}, 0.1 \mathrm{mmol})$. Silica gel column chromatography gave a colourless oil, 55\% (28.9 mg). FT-IR (thin film): $\nu_{\max }\left(\mathrm{cm}^{-1}\right)=2981,2889,1746,1698 .{ }^{1} \mathbf{H}$ NMR $\left(400 \mathrm{MHz}, \mathrm{CDCl}_{3}\right)$ $\delta 7.37-7.25(\mathrm{~m}, 2 \mathrm{H}), 7.20(\mathrm{~d}, J=2.2 \mathrm{~Hz}, 1 \mathrm{H}), 7.07(\mathrm{ddt}, J=7.9,2.5,1.2 \mathrm{~Hz}, 1 \mathrm{H}), 5.21(\mathrm{dd}, J=7.5,3.1$ $\mathrm{Hz}, 1 \mathrm{H}), 4.47(\mathrm{~d}, J=12.1 \mathrm{~Hz}, 1 \mathrm{H}), 4.42(\mathrm{~d}, J=12.1 \mathrm{~Hz}, 1 \mathrm{H}), 3.70(\mathrm{~s}, 3 \mathrm{H}), 2.61(\mathrm{dd}, J=15.4,3.1 \mathrm{~Hz}, 1 \mathrm{H})$, $2.08(\mathrm{dd}, J=15.4,7.6 \mathrm{~Hz}, 1 \mathrm{H}), 1.45(\mathrm{~s}, 18 \mathrm{H}), 1.30(\mathrm{~s}, 3 \mathrm{H}), 1.27(\mathrm{~s}, 3 \mathrm{H}) .{ }^{19} \mathbf{F} \mathbf{N M R}\left(377 \mathrm{MHz}, \mathrm{CDCl}_{3}\right) \delta$ 57.69. ${ }^{13} \mathrm{C}$ NMR $\left(126 \mathrm{MHz}, \mathrm{CDCl}_{3}\right) \delta$ 172.2, 152.4, 149.4, 149.4, 142.4, 138.0, 129.5, 128.4, 125.4, 119.6, 119.3, 83.1, 77.4, 77.4, 77.2, 76.9, 74.8, 63.1, 54.9, 52.5, 41.0, 28.1, 25.9, 25.8. HRMS (ESI): $\mathrm{m} / \mathrm{z}$ calculated for $\mathrm{C}_{25} \mathrm{H}_{36} \mathrm{O}_{8} \mathrm{~N}_{1} \mathrm{~F}_{3}$ requires 558.2285 for $[\mathrm{M}+\mathrm{Na}]^{+}$, found 558.2285 .

Synthesis of $4 \mathrm{e}$<smiles>CC(=O)CC(CC(C)(C)OCc1ccc(F)cc1)C(=O)O[Na]</smiles>

The above compound was synthesized according to General Procedure $\mathbf{C}$ using 1-fluoro-4-((prop-1-en-2yloxy)methyl)benzene $(49.8 \mathrm{mg}, 0.3 \mathrm{mmol}$ ) and methyl 2-(bis(tert-butoxycarbonyl)amino)acrylate $(30.3 \mathrm{mg}$, $0.1 \mathrm{mmol})$. Silica gel column chromatography gave a colourless oil, $62 \%(29.3 \mathrm{mg})$. FT-IR (thin film): $\nu_{\max }$ $\left(\mathrm{cm}^{-1}\right)=2981,2889,1745,1698,1605,1511 .{ }^{1} \mathbf{H} \mathbf{~ N M R}\left(400 \mathrm{MHz}, \mathrm{CDCl}_{3}\right) \delta 7.33-7.27(\mathrm{~m}, 2 \mathrm{H}), 7.02-$ $6.93(\mathrm{~m}, 2 \mathrm{H}), 5.21(\mathrm{dd}, J=7.6,3.1 \mathrm{~Hz}, 1 \mathrm{H}), 4.41(\mathrm{~d}, J=11.4 \mathrm{~Hz}, 1 \mathrm{H}), 4.36(\mathrm{~d}, J=11.4 \mathrm{~Hz}, 1 \mathrm{H}), 3.70(\mathrm{~s}$, $3 \mathrm{H}), 2.63-2.54(\mathrm{~m}, 1 \mathrm{H}), 2.08(\mathrm{dd}, J=15.4,7.7 \mathrm{~Hz}, 1 \mathrm{H}), 1.45(\mathrm{~s}, 18 \mathrm{H}), 1.29(\mathrm{~s}, 3 \mathrm{H}), 1.27(\mathrm{~s}, 3 \mathrm{H}) .{ }^{19} \mathbf{F}$ NMR $\left(377 \mathrm{MHz}, \mathrm{CDCl}_{3}\right) \delta-116.30(\mathrm{ddd}, J=14.1,9.2,5.6 \mathrm{~Hz}) .{ }^{13} \mathbf{C} \mathbf{~ N M R}\left(101 \mathrm{MHz}, \mathrm{CDCl}_{3}\right) \delta 172.2,162.1(\mathrm{~d}, J$ $=243.9 \mathrm{~Hz}), 152.4,135.6(\mathrm{~d}, J=3.2 \mathrm{~Hz}), 128.9(\mathrm{~d}, J=7.9 \mathrm{~Hz}), 115.0(\mathrm{~d}, J=21.4 \mathrm{~Hz}), 83.1,74.6,63.2,54.9$, 52.5, 41.0, 28.1, 25.9, 25.8. HRMS (ESI): $\mathrm{m} / \mathrm{z}$ calculated for $\mathrm{C}_{24} \mathrm{H}_{36} \mathrm{O}_{7} \mathrm{~N}_{1} \mathrm{~F}_{1}$ requires 492.2368 for $[\mathrm{M}+\mathrm{Na}]^{+}$, found 492.2365 . 
Synthesis of $\mathbf{4 f}$<smiles>CC(=O)CC(CC(C)(OCc1ccc(Br)cc1)OC(C)(C)C)C(=O)O</smiles>

The above compound was synthesized according to General Procedure $\mathbf{C}$ using 1-bromo-4-((prop-1-en-2yloxy)methyl)benzene (68.1 mg, $0.3 \mathrm{mmol}$ ) and methyl 2-(bis(tert-butoxycarbonyl)amino)acrylate (30.3 mg, $0.1 \mathrm{mmol})$. Silica gel column chromatography gave a colourless oil, $55 \%(29.0 \mathrm{mg})$. FT-IR (thin film): $\nu_{\max }$ $\left(\mathrm{cm}^{-1}\right)=2981,2888,1745,1698 .{ }^{1} \mathbf{H}$ NMR $\left(400 \mathrm{MHz}, \mathrm{CDCl}_{3}\right) \delta 7.44-7.38(\mathrm{~m}, 2 \mathrm{H}), 7.24-7.17(\mathrm{~m}, 2 \mathrm{H})$, $5.20(\mathrm{dd}, J=7.6,3.1 \mathrm{~Hz}, 1 \mathrm{H}), 4.39(\mathrm{~d}, J=11.8 \mathrm{~Hz}, 1 \mathrm{H}), 4.35(\mathrm{~d}, J=11.7 \mathrm{~Hz}, 1 \mathrm{H}), 3.70(\mathrm{~s}, 3 \mathrm{H}), 2.64-2.54$ $(\mathrm{m}, 1 \mathrm{H}), 2.07(\mathrm{dd}, J=15.4,7.7 \mathrm{~Hz}, 1 \mathrm{H}), 1.45(\mathrm{~s}, 18 \mathrm{H}), 1.29(\mathrm{~s}, 3 \mathrm{H}), 1.26(\mathrm{~s}, 3 \mathrm{H}) .{ }^{13} \mathbf{C}$ NMR $(101 \mathrm{MHz}$, $\left.\mathrm{CDCl}_{3}\right) \delta 172.2,152.4,139.0,131.3,128.9,120.8,83.1,74.7,63.2,54.9,52.5,41.1,28.1,25.9,25.8$. HRMS (ESI): $\mathrm{m} / \mathrm{z}$ calculated for $\mathrm{C}_{24} \mathrm{H}_{36} \mathrm{O}_{7} \mathrm{~N}_{1} \mathrm{Br}_{1}$ requires 552.1567 for $[\mathrm{M}+\mathrm{Na}]^{+}$, found 552.1570 .

Synthesis of $4 \mathrm{~g}$

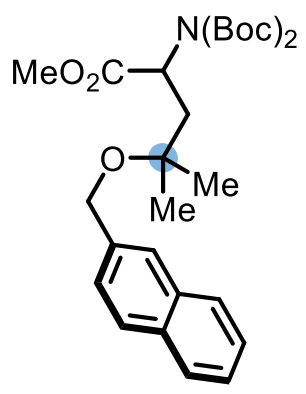

The above compound was synthesized according to General Procedure C using 2-((prop-1-en-2yloxy)methyl)naphthalene $(59.4 \mathrm{mg}, 0.3 \mathrm{mmol}$ ) and methyl 2-(bis(tert-butoxycarbonyl)amino)acrylate (30.3 mg, $0.1 \mathrm{mmol})$. Silica gel column chromatography gave a colourless oil, 62\% (31.1 mg).

The above compound was also synthesized according to General Procedure $\mathbf{D}$ at double scale, using $\mathbf{1} \mathbf{p}$ (39.6 mg, $0.2 \mathrm{mmol}$ ) and methyl 2-(bis(tert-butoxycarbonyl)amino)acrylate (121.2 mg, $0.4 \mathrm{mmol})$. After work-up the crude reaction mixture was diluted in $\mathrm{CH}_{2} \mathrm{Cl}_{2}(2 \mathrm{~mL}$ ), and was added cysteamine (46.3 $\mathrm{mg}, 0.6$ mmol) and $\mathrm{NEt}_{3}(0.11 \mathrm{~mL}, 0.8 \mathrm{mmol})$. The solution was stirred at room temperature for 3 hours (TLC showed disappearance of alkene). Silica gel column chromatography gave a colourless oil, $46 \%$ (46.1 mg).

FT-IR (thin film): $\nu_{\max }\left(\mathrm{cm}^{-1}\right)=2981,2888,1745,1699 .{ }^{1} \mathbf{H}$ NMR $\left(400 \mathrm{MHz}, \mathrm{CDCl}_{3}\right) \delta 7.85-7.75(\mathrm{~m}$, 4H), $7.49-7.39(\mathrm{~m}, 3 \mathrm{H}), 5.28(\mathrm{dd}, J=7.6,3.0 \mathrm{~Hz}, 1 \mathrm{H}), 4.62(\mathrm{~d}, J=11.9 \mathrm{~Hz}, 1 \mathrm{H}), 4.58(\mathrm{~d}, J=11.7 \mathrm{~Hz}$, 1H), 3.71 (s, 3H), 2.65 (dd, $J=15.4,3.2 \mathrm{~Hz}, 1 \mathrm{H}), 2.13$ (dd, $J=15.4,7.6 \mathrm{~Hz}, 1 \mathrm{H}), 1.45$ (s, 18H), 1.35 (s, 3H), 1.32 (s, 3H). ${ }^{13} \mathbf{C}$ NMR (101 MHz, $\left.\mathrm{CDCl}_{3}\right) \delta$ 172.3, 152.4, 137.5, 133.5, 132.9, 128.0, 127.8, 127.7, 125.9, 125.7, 125.6, 125.5, 83.0, 74.7, 64.0, 55.0, 52.5, 41.1, 28.1, 26.0, 25.9. HRMS (ESI): $\mathrm{m} / \mathrm{z}$ calculated for $\mathrm{C}_{28} \mathrm{H}_{39} \mathrm{O}_{7} \mathrm{~N}_{1}$ requires 524.2619 for $[\mathrm{M}+\mathrm{Na}]^{+}$, found 524.2620 . 
Synthesis of $\mathbf{4 h}$

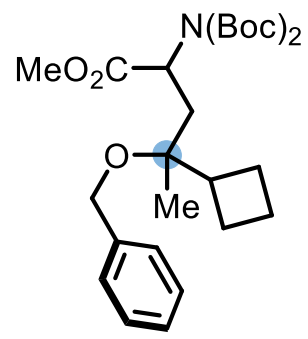

The above compound was synthesized according to General Procedure $\mathbf{C}$ using $\mathbf{1 p}$ ( $56.0 \mathrm{mg}, 0.3 \mathrm{mmol})$ and methyl 2-(bis(tert-butoxycarbonyl)amino)acrylate $(30.3 \mathrm{mg}, 0.1 \mathrm{mmol})$. 1.6:1 dr. Silica gel column chromatography gave a thick yellow oil, 63\% (31.2 mg).

The above compound was also synthesized according to General Procedure $\mathbf{D}$ at double scale, using $\mathbf{1 p}$ (37.6 mg, $0.2 \mathrm{mmol}$ ) and methyl 2-(bis(tert-butoxycarbonyl)amino)acrylate (121.2 mg, $0.4 \mathrm{mmol}) .1 .5: 1 \mathrm{dr}$. Silica gel column chromatography gave a thick yellow oil, 63\% (48.2 mg).

FT-IR (thin film): $\nu_{\max }\left(\mathrm{cm}^{-1}\right)=2981,2889,1745,1699 .{ }^{1} \mathbf{H}$ NMR $\left(400 \mathrm{MHz}, \mathrm{CDCl}_{3}\right) \delta 7.29-7.20(\mathrm{~m}$, $8 \mathrm{H}, 41$ \& 41'), 7.14 (app ddd, $J=7.1,4.3,1.8 \mathrm{~Hz}, 2 \mathrm{H}, 41$ \& 41'), 5.11 (dd, $J=7.7,3.0 \mathrm{~Hz}, 1 \mathrm{H}, 4 \mathrm{l}$ ), 5.06 (dd, $\left.J=7.5,2.8 \mathrm{~Hz}, 1 \mathrm{H}, 4 \mathbf{l}^{\prime}\right), 4.42-4.27(\mathrm{~m}, 4 \mathrm{H}, 41$ \& 4l'), $3.62(\mathrm{~d}, J=0.9 \mathrm{~Hz}, 6 \mathrm{H}, 41$ \& 4l'), $2.68-2.56(\mathrm{~m}, 2 \mathrm{H}$, $\left.4 \mathbf{l} \& 4 \mathbf{l}^{\prime}\right), 2.54$ (dd, $\left.J=15.5,2.9 \mathrm{~Hz}, 1 \mathrm{H}, 4 \mathbf{l}\right), 2.41$ (dd, $\left.J=15.5,3.0 \mathrm{~Hz}, 1 \mathrm{H}, 4 \mathbf{l}^{\prime}\right), 2.08-1.96$ (m, 2H, 41 \& 4l'), $1.94-1.85$ (m, 2H, 41 \& 4l'), $1.85-1.70\left(\mathrm{~m}, 8 \mathrm{H}, 4 \mathbf{1} \& 4 \mathbf{l}^{\prime}\right), 1.62(\mathrm{dtd}, J=10.6,6.4,5.7,2.0 \mathrm{~Hz}, 2 \mathrm{H}, 41$ \& 4l'), 1.39 (s, 18H, 4l), 1.38 (s, 18H, 41'), 1.16 (s, 3H, 41), 1.10 (s, 3H, 4l'). ${ }^{13} \mathrm{C}$ NMR $\left(101 \mathrm{MHz}, \mathrm{CDCl}_{3}\right) \delta$ 172.34, 172.27, 152.4, 152.3, 140.3, 140.2, 128.2, 128.2, 127.1, 127.0 (41 \& 41'), 126.9, 83.0, 83.0, 77.0, 76.6, 63.9, 63.8, 54.7, 54.6, 52.5 (41 \& 41'), 44.0, 43.5, 36.5, 36.4, 28.2, 28.1 (41 \& 41'), 24.2, 23.9, 23.7, 23.6, 19.7, 19.5, 17.4, 17.66. HRMS (ESI): $\mathrm{m} / \mathrm{z}$ calculated for $\mathrm{C}_{27} \mathrm{H}_{41} \mathrm{O}_{7} \mathrm{~N}_{1}$ requires 514.2775 for $[\mathrm{M}+\mathrm{Na}]^{+}$, found 514.2773.

Synthesis of $4 \mathbf{i}$

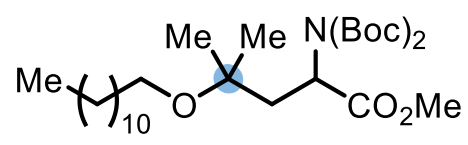

The above compound was synthesized according to General Procedure C using 1-(prop-1-en-2yloxy)dodecane (52.0 mg, $0.25 \mathrm{mmol}$ ) and methyl 2-(bis(tert-butoxycarbonyl)amino)acrylate (30.3 mg, 0.1 $\mathrm{mmol})$. Silica gel column chromatography gave a colourless oil, $78 \%$ (41.3 mg).

The above compound was also synthesized according to General Procedure D, using 1-(prop-1-en-2yloxy)dodecane (22.6 mg, $0.1 \mathrm{mmol}$ ) and methyl 2-(bis(tert-butoxycarbonyl)amino)acrylate (60.6 mg, 0.2 $\mathrm{mmol})$. Silica gel column chromatography gave a thick yellow oil, $49 \%$ (25.9 mg).

FT-IR (thin film): $\nu_{\max }\left(\mathrm{cm}^{-1}\right)=2981,2930,2889,1747,1700 .{ }^{1} \mathbf{H}$ NMR $\left(400 \mathrm{MHz}, \mathrm{CDCl}_{3}\right) \delta 5.13(\mathrm{dd}, J$ $=7.8,3.0 \mathrm{~Hz}, 1 \mathrm{H}), 3.69(\mathrm{~s}, 3 \mathrm{H}), 3.40-3.16(\mathrm{~m}, 2 \mathrm{H}), 2.46(\mathrm{dd}, J=15.4,3.0 \mathrm{~Hz}, 1 \mathrm{H}), 1.97(\mathrm{dd}, J=15.3,7.8$ $\mathrm{Hz}, 1 \mathrm{H}), 1.49$ (s, 18H), 1.23 (s, 18H), 1.18 (s, 3H), 1.16 (s, 3H), 0.87 (t, $J=6.7 \mathrm{~Hz}, 3 \mathrm{H}) .{ }^{13} \mathbf{C}$ NMR $(101$ $\left.\mathrm{MHz}_{2} \mathrm{CDCl}_{3}\right) \delta 172.3,152.3,82.9,73.4,61.6,55.0,52.4,40.6,32.1,30.7,29.8$ (3C), 29.7, 29.5, 28.2, 26.4, 25.9, 22.8, 14.2. HRMS (ESI): $\mathrm{m} / \mathrm{z}$ calculated for $\mathrm{C}_{28} \mathrm{H}_{52} \mathrm{O}_{7} \mathrm{~N}_{1}$ requires 514.3738 for $[\mathrm{M}+\mathrm{Na}]^{+}$, found 514.3757. 
Synthesis of $\mathbf{4} \mathbf{j}$<smiles>CCOC(CC(C)(C)OCC)CC(C)(C)OCCCOCc1ccccc1</smiles>

The above compound was synthesized according to General Procedure $\mathbf{C}$ using $\mathbf{1 k}$ ( $62.0 \mathrm{mg}, 0.25 \mathrm{mmol}$ ) and methyl 2-(bis(tert-butoxycarbonyl)amino)acrylate $(30.3 \mathrm{mg}, 0.1 \mathrm{mmol})$. Silica gel column chromatography gave a colourless oil, 55\% (27.8 mg). FT-IR (thin film): $\nu_{\max }\left(\mathrm{cm}^{-1}\right)=2978,2932,2868$, 1746, 1699. ${ }^{1} \mathbf{H}$ NMR $\left(400 \mathrm{MHz}, \mathrm{CDCl}_{3}\right) \delta 7.27(\mathrm{~d}, J=4.4 \mathrm{~Hz}, 4 \mathrm{H}), 7.24-7.16(\mathrm{~m}, 1 \mathrm{H}), 5.08(\mathrm{dd}, J=7.9$, $3.1 \mathrm{~Hz}, 1 \mathrm{H}), 4.43(\mathrm{~s}, 2 \mathrm{H}), 3.62(\mathrm{~s}, 3 \mathrm{H}), 3.49(\mathrm{t}, J=6.3 \mathrm{~Hz}, 2 \mathrm{H}), 3.42-3.22(\mathrm{~m}, 2 \mathrm{H}), 2.40(\mathrm{dd}, J=15.3,3.1$ $\mathrm{Hz}, 1 \mathrm{H}), 1.92(\mathrm{dd}, J=15.3,7.8 \mathrm{~Hz}, 1 \mathrm{H}), 1.74(\mathrm{t}, J=6.3 \mathrm{~Hz}, 2 \mathrm{H}), 1.43(\mathrm{~s}, 18 \mathrm{H}), 1.12(\mathrm{~s}, 3 \mathrm{H}), 1.10(\mathrm{~s}, 3 \mathrm{H})$. ${ }^{13} \mathbf{C}$ NMR $\left(101 \mathrm{MHz}, \mathrm{CDCl}_{3}\right) \delta 172.3,152.3,138.9,128.4,127.8,127.6,82.9,73.5,73.0,67.7,58.3,54.9$, 52.5, 40.9, 30.9, 28.2, 25.7, 25.7. HRMS (ESI): $\mathrm{m} / \mathrm{z}$ calculated for $\mathrm{C}_{27} \mathrm{H}_{43} \mathrm{O}_{8} \mathrm{~N}_{1}$ requires 532.2881 for $[\mathrm{M}+\mathrm{Na}]^{+}$, found 532.2876 .

Synthesis of $4 \mathbf{k}$<smiles>CCCCN(CC(C)C)C(C)(C)CC(C)(C)OCC1CCCN1C(=O)OCc1ccccc1</smiles>

The above compound was synthesized according to General Procedure $\mathbf{C}$ using 11 (72.0 mg, $0.25 \mathrm{mmol}$ ) and methyl 2-(bis(tert-butoxycarbonyl)amino)acrylate $(30.3 \mathrm{mg}, 0.1 \mathrm{mmol}) .1: 1 \mathrm{dr}$. Silica gel column chromatography gave a colourless oil, 63\% (34.1 mg). FT-IR (thin film): $\nu_{\max }\left(\mathrm{cm}^{-1}\right)=2978,2927,2855$, 1748, 1697. ${ }^{1} \mathbf{H}$ NMR $\left(500 \mathrm{MHz}\right.$, DMSO- $\left.d_{6}, 373 \mathrm{~K}\right) \delta 5.00(\mathrm{dd}, J=8.1,3.1 \mathrm{~Hz}, 1 \mathrm{H}), 3.72(\mathrm{tt}, J=6.8,3.6$ $\mathrm{Hz}, 1 \mathrm{H}), 3.65$ (s, $3 \mathrm{H}), 3.44(\mathrm{dt}, J=8.8,3.7 \mathrm{~Hz}, 1 \mathrm{H}), 3.32-3.19(\mathrm{~m}, 3 \mathrm{H}), 2.37$ (ddd, $J=15.2,9.9,3.1 \mathrm{~Hz}$, $1 \mathrm{H}), 1.92(\mathrm{td}, J=14.8,8.1 \mathrm{~Hz}, 1 \mathrm{H}), 1.89-1.74(\mathrm{~m}, 4 \mathrm{H}), 1.46(\mathrm{~s}, 18 \mathrm{H}), 1.42(\mathrm{~s}, 9 \mathrm{H}), 1.19-1.10(\mathrm{~m}, 6 \mathrm{H})$. Carbon needs work. ${ }^{13} \mathbf{C}$ NMR (126 MHz, DMSO- $\left.d_{6}\right) \delta 170.61$ (41), 170.58 (4l'), 153.1 (41 \& 41'), 151.3 (41 \& 41'), 81.9 (41 \& 41'), 77.7 (41 \& 41'), 72.9 (41), 72.8 (41'), 56.5 (41), 56.4 (41'), 54.1 (41), 54.0 (41'), 51.5 (41 \& 41'), 45.9 (41), 45.8 (41'), 40.4 (41), 40.3 (41'), 30.6 (41 \& 41'), 27.8 (41), 27.7 (41'), 27.2 (2C, 41 \& 41'), 24.7 (41 \& 41'), 24.5 (41), $24.3\left(\mathbf{4 1} \mathbf{l}^{\prime}\right), 22.2$ (41 \& 41'). HRMS (ESI): $\mathrm{m} / \mathrm{z}$ calculated for $\mathrm{C}_{27} \mathrm{H}_{48} \mathrm{O}_{9} \mathrm{~N}_{2}$ requires 567.3252 for $[\mathrm{M}+\mathrm{Na}]^{+}$, found 567.3249 . 
Synthesis of $\mathbf{4 1}$<smiles>COC(=O)CC(C)(CC(C)(C)OCC1CCCO1)OC(=O)O</smiles>

The above compound was synthesized according to General Procedure $\mathbf{C}$ using $1 \mathrm{~m}(42.7 \mathrm{mg}, 0.25 \mathrm{mmol})$ and methyl 2-(bis(tert-butoxycarbonyl)amino)acrylate (30.3 mg, $0.1 \mathrm{mmol})$. Crude dr 1.1:1. Silica gel column (DCM:Pentane 90:10 - 100:0 v:v, then EtOAc:Pentane 3:97 - 10:90 v:v) chromatography gave a colourless oil, $40 \%$ (17.6 mg). FT-IR (thin film): $\nu_{\max }\left(\mathrm{cm}^{-1}\right)=2978,2873,1745,1699 .{ }^{1} \mathbf{H} \mathbf{~ N M R}\left(400 \mathrm{MHz}, \mathrm{CDCl}_{3}\right.$, mixture of diastereomers) $\delta 5.13(\mathrm{ddd}, J=15.4,7.7,3.1 \mathrm{~Hz}, 1 \mathrm{H}), 4.06-3.89(\mathrm{~m}, 1 \mathrm{H}), 3.82(\mathrm{tt}, J=8.1,6.3$ $\mathrm{Hz}, 1 \mathrm{H}), 3.76-3.65(\mathrm{~m}, 4 \mathrm{H}), 3.37(\mathrm{ddd}, J=9.0,5.6,2.5 \mathrm{~Hz}, 1 \mathrm{H}), 3.24(\mathrm{ddd}, J=14.3,9.1,5.6 \mathrm{~Hz}, 1 \mathrm{H}), 2.50$ $(\mathrm{td}, J=14.9,3.1 \mathrm{~Hz}, 1 \mathrm{H}), 2.04-1.88(\mathrm{~m}, 2 \mathrm{H}), 1.88-1.77(\mathrm{~m}, 2 \mathrm{H}), 1.73-1.55(\mathrm{~m}, 1 \mathrm{H}), 1.49(\mathrm{~s}, 18 \mathrm{H}), 1.28$ - $1.10(\mathrm{~m}, 6 \mathrm{H}) .{ }^{13} \mathrm{C} \mathbf{N M R}\left(101 \mathrm{MHz}, \mathrm{CDCl}_{3}\right) \delta 172.3,172.2,152.3,152.3,83.0,78.3,78.3,73.9,73.9$, 68.4, 68.4, 64.6, 64.6, 54.9, 54.9, 52.5, 40.9, 40.6, 28.8, 28.7, 28.2, 25.8, 25.7, 25.7, 25.6, 25.6. ${ }^{13} \mathbf{C} \mathbf{N M R}(101 \mathrm{MHz}$, $\left.\mathrm{CDCl}_{3}\right) \delta 172.3,172.2,152.32,152.27,83.0$ (4n \& $\left.4 \mathbf{n}^{\prime}\right), 78.3,78.3,73.9,73.9,68.4,68.4,64.6$, 64.6, 54.9, 54.9, 52.5 (4n \& 4n'), 40.9, 40.6, 28.8, 28.7, 28.2 (4n \& 4n'), 25.8, 25.70, 25.68 (4n \& 4n'), 25.65, 25.58. HRMS (ESI): $\mathrm{m} / \mathrm{z}$ calculated for $\mathrm{C}_{22} \mathrm{H}_{39} \mathrm{O}_{8} \mathrm{~N}_{1}$ requires 468.2568 for $[\mathrm{M}+\mathrm{Na}]^{+}$, found 468.2565 .

Synthesis of $4 \mathrm{~m}$

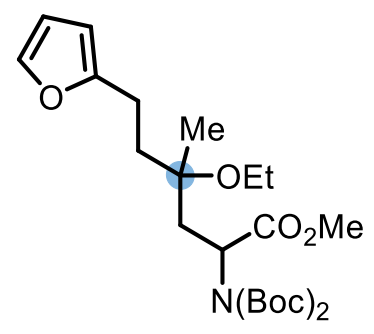

The above compound was synthesized according to General Procedure $\mathbf{C}$ using $\mathbf{1 n}$ (49.9 $\mathrm{mg}, 0.3 \mathrm{mmol})$ and methyl 2-(bis(tert-butoxycarbonyl)amino)acrylate $(30.3 \mathrm{mg}, 0.1 \mathrm{mmol}) .1 .2: 1 \mathrm{dr}$. Silica gel column chromatography gave a yellow oil, 69\% (32.5 mg). FT-IR (thin film): $\nu_{\max }\left(\mathrm{cm}^{-1}\right)=2980,2931,1744,1699$. ${ }^{1} \mathbf{H}$ NMR $\left(400 \mathrm{MHz}, \mathrm{CDCl}_{3}\right) \delta 7.27$ (d, $\left.J=1.5 \mathrm{~Hz}, 2 \mathrm{H}, \mathbf{4 o} \& \mathbf{4} \mathbf{o}^{\prime}\right), 6.25\left(\mathrm{dt}, J=3.2,1.6 \mathrm{~Hz}, 2 \mathrm{H}, \mathbf{4 o} \& \mathbf{4} \mathbf{o}^{\prime}\right)$, 5.97 (d, $\left.J=3.2 \mathrm{~Hz}, 2 \mathrm{H}, \mathbf{4 o} \& \mathbf{4} \mathbf{o}^{\prime}\right), 5.15$ (td, $\left.J=7.9,2.9 \mathrm{~Hz}, 2 \mathrm{H}, \mathbf{4 o} \& \mathbf{4} \mathbf{o}^{\prime}\right), 3.70$ (s, 6H, 4o \& 4o'), 3.51 3.22 (m, 4H, 4o \& 4o'), 2.67 - 2.53 (m, 3H 4o \& 2H 4o'), 2.42 (dd, J = 15.6, $\left.3.1 \mathrm{~Hz}, 1 \mathrm{H}, 4 \mathbf{o}^{\prime}\right), 2.10$ (dd, $J$ $=15.5,7.7 \mathrm{~Hz}, 1 \mathrm{H}, \mathbf{4 o}), 1.99\left(\mathrm{dd}, J=15.6,8.2 \mathrm{~Hz}, 1 \mathrm{H}, \mathbf{4 \mathbf { o } ^ { \prime }}\right), 1.94-1.71$ (m, 4H, 4o \& 4o'), 1.49 (d, $J=1.7$ $\mathrm{Hz}, 36 \mathrm{H}$, , 4o \& 4o'), 1.21 (s, 3H, 4o), 1.18 (s, 3H, 4o'), 1.13 (td, $J=7.0,3.4 \mathrm{~Hz}, 6 \mathrm{H}, 4 \mathbf{o} \&$ 4o'). ${ }^{13} \mathbf{C}$ NMR $\left(101 \mathrm{MHz}, \mathrm{CDCl}_{3}\right) \delta$ 172.3, 172.2, 156.4 (4o \& 4o'), 152.31, 152.29, 140.8 (4o \& 4o'), 110.2 (4o \& 4o'),

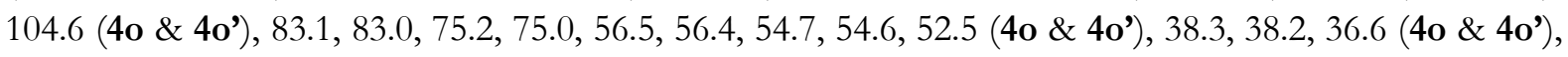
29.8 (4o \& 40'), 28.15, 28.10, 23.2, 23.1, 22.5 (4o \& 4o'), 16.00, 15.97. HRMS (ESI): m/z calculated for $\mathrm{C}_{24} \mathrm{H}_{39} \mathrm{O}_{8} \mathrm{~N}_{1}$ requires 492.2566 for $[\mathrm{M}+\mathrm{Na}]^{+}$, found 492.2566 . 
Synthesis of $4 n$<smiles>CCOC1(CC(NC(C)C)C(C)(O)O)CCCC1</smiles>

The above compound was synthesized according to General Procedure $\mathbf{C}$ using 1-ethoxycyclopent-1-ene $(33.7 \mu \mathrm{L}, 0.3 \mathrm{mmol}$ ) and methyl 2-(bis(tert-butoxycarbonyl)amino)acrylate $(30.3 \mathrm{mg}, 0.1 \mathrm{mmol})$. Silica gel column chromatography gave a gummy solid, $66 \%$ (27.6 mg).

The above compound was also synthesized according to General Procedure $\mathbf{D}$, using 1-ethoxycyclopent1-ene (22.4 mg, $0.2 \mathrm{mmol}$ ) and methyl 2-(bis(tert-butoxycarbonyl)amino)acrylate (121.2 mg, $0.4 \mathrm{mmol})$. Before work-up, to the crude reaction mixture was added cysteamine $(46.3 \mathrm{mg}, 0.6 \mathrm{mmol})$ and $\mathrm{NEt}_{3}(0.11$ $\mathrm{mL}, 0.8 \mathrm{mmol}$ ). The solution was stirred at room temperature for 3 hours (TLC showed disappearance of alkene). After normal work-up, silica gel column chromatography gave a thick yellow oil, 48\% (39.6 mg).

FT-IR (thin film): $\nu_{\max }\left(\mathrm{cm}^{-1}\right)=2980,2889,1745,1699 .{ }^{1} \mathbf{H}$ NMR $\left(400 \mathrm{MHz}, \mathrm{CDCl}_{3}\right) \delta 5.13$ (dd, $J=8.3$, $2.9 \mathrm{~Hz}, 1 \mathrm{H}), 3.70(\mathrm{~s}, 3 \mathrm{H}), 3.27$ (qd, $J=7.0,5.5 \mathrm{~Hz}, 2 \mathrm{H}), 2.55(\mathrm{dd}, J=15.6,2.9 \mathrm{~Hz}, 1 \mathrm{H}), 2.10$ (dd, $J=15.6$, $8.3 \mathrm{~Hz}, 1 \mathrm{H}), 1.93-1.74(\mathrm{~m}, 2 \mathrm{H}), 1.75-1.60(\mathrm{~m}, 2 \mathrm{H}), 1.61-1.51(\mathrm{~m}, 2 \mathrm{H}), 1.49(\mathrm{~s}, 18 \mathrm{H}), 1.46-1.31(\mathrm{~m}$, $2 \mathrm{H}), 1.10(\mathrm{t}, J=7.0 \mathrm{~Hz}, 3 \mathrm{H}) .{ }^{13} \mathbf{C} \mathbf{~ N M R}\left(101 \mathrm{MHz}, \mathrm{CDCl}_{3}\right) \delta 172.4,152.3,85.3,82.9,56.9,55.6,52.4,36.5$, 36.2, 36.1, 28.2, 24.0, 23.4, 16.1. HRMS (ESI): $\mathrm{m} / \mathrm{z}$ calculated for $\mathrm{C}_{21} \mathrm{H}_{37} \mathrm{O}_{7} \mathrm{~N}_{1}$ requires 438.2462 for $[\mathrm{M}+\mathrm{Na}]^{+}$, found 438.2460 .

Synthesis of $4 p$<smiles>CCOC1(CC(C(C)=O)[N+](=O)OC)CCCCCC1</smiles>

The above compound was synthesized according to General Procedure $\mathbf{C}$ using $\mathbf{1 q}$ (42.1 $\mathrm{mg}, 0.3 \mathbf{m m o l})$ and methyl 2-(bis(tert-butoxycarbonyl)amino)acrylate (30.3 $\mathrm{mg}, 0.1 \mathrm{mmol}$ ). Silica gel column chromatography gave a yellow oil, $82 \%(36.2 \mathrm{mg})$.

The above compound was also synthesized according to General Procedure $\mathbf{D}$, using $\mathbf{1 q}(14.0 \mathrm{mg}, 0.1$ $\mathrm{mmol}$ ) and methyl 2-(bis(tert-butoxycarbonyl)amino)acrylate $(60.6 \mathrm{mg}, 0.2 \mathrm{mmol})$. Silica gel column chromatography gave a thick yellow oil, $48 \%$ (21.3 mg).

FT-IR (thin film): $\nu_{\max }\left(\mathrm{cm}^{-1}\right)=2980,2931,1744,1700 .{ }^{1} \mathbf{H}$ NMR $\left(400 \mathrm{MHz}, \mathrm{CDCl}_{3}\right) \delta 5.12(\mathrm{dd}, J=7.4$, $2.7 \mathrm{~Hz}, 1 \mathrm{H}), 3.69(\mathrm{~s}, 3 \mathrm{H}), 3.45-3.18(\mathrm{~m}, 2 \mathrm{H}), 2.47(\mathrm{dd}, J=15.8,2.8 \mathrm{~Hz}, 1 \mathrm{H}), 1.97(\mathrm{dd}, J=15.8,7.4 \mathrm{~Hz}$, $1 \mathrm{H}), 1.87-1.72(\mathrm{~m}, 2 \mathrm{H}), 1.67-1.53(\mathrm{~m}, 5 \mathrm{H}), 1.49(\mathrm{~s}, 22 \mathrm{H}), 1.44-1.27(\mathrm{~m}, 3 \mathrm{H}), 1.09(\mathrm{t}, J=6.9 \mathrm{~Hz}, 3 \mathrm{H})$. ${ }^{13} \mathbf{C}$ NMR $\left(101 \mathrm{MHz}, \mathrm{CDCl}_{3}\right) \delta 172.5,152.3,82.9,78.5,56.0,54.6,52.5,38.5,37.9,37.8,29.8,28.2,28.1$, 22.3, 22.2, 16.0. HRMS (ESI): $\mathrm{m} / \mathrm{z}$ calculated for $\mathrm{C}_{23} \mathrm{H}_{41} \mathrm{O}_{7} \mathrm{~N}_{1}$ requires 466.2775 for $[\mathrm{M}+\mathrm{Na}]^{+}$, found 466.2773 . 
Synthesis of $\mathbf{4 q}$<smiles>COC(=O)C(CC1(C)CCCCO1)C(=O)OC</smiles>

The above compound was synthesized according to General Procedure $\mathbf{C}$ using $\mathbf{1 r}(49.0 \mathrm{mg}, 0.5 \mathrm{mmol})$ and methyl 2-(bis(tert-butoxycarbonyl)amino)acrylate $(30.3 \mathrm{mg}, 0.1 \mathrm{mmol}) .1 .3: 1 \mathrm{dr}$. Silica gel column chromatography gave a colourless oil, $37 \%(14.7 \mathrm{mg})$. FT-IR (thin film): $\nu_{\max }\left(\mathrm{cm}^{-1}\right)=2981,2888,1745$, 1700. ${ }^{1} \mathbf{H}$ NMR $\left(400 \mathrm{MHz}, \mathrm{CDCl}_{3}\right.$, diastereomers overlap) $\delta 5.14(\mathrm{dd}, J=7.7,2.8 \mathrm{~Hz}, 1 \mathrm{H}), 3.71(\mathrm{~d}, J=1.0$ $\mathrm{Hz}, 3 \mathrm{H}), 3.67-3.60(\mathrm{~m}, 2 \mathrm{H}), 2.70(\mathrm{dd}, J=15.4,2.7 \mathrm{~Hz}, 1 \mathrm{H}), 1.86(\mathrm{dd}, J=15.5,7.8 \mathrm{~Hz}, 1 \mathrm{H}), 1.63$ (tdd, $J$ $=10.2,7.9,5.6 \mathrm{~Hz}, 2 \mathrm{H}), 1.49(\mathrm{~s}, 22 \mathrm{H}), 1.17(\mathrm{~s}, 3 \mathrm{H}) \cdot{ }^{13} \mathbf{C} \mathbf{~ N M R}\left(101 \mathrm{MHz}, \mathrm{CDCl}_{3}\right.$, major diastereomer) $\delta$ 172.3, 152.1, 82.8, 71.9, 61.6, 54.5, 52.4, 39.8, 35.3, 28.0, 25.7, 23.7, 19.3. HRMS (ESI): $\mathrm{m} / \mathrm{z}$ calculated for $\mathrm{C}_{20} \mathrm{H}_{35} \mathrm{O}_{7} \mathrm{~N}_{1}$ requires 424.2306 for $[\mathrm{M}+\mathrm{Na}]^{+}$, found 424.2306 .

Synthesis of $4 \mathbf{r}$<smiles>CC(=O)NC(COC(C)(C)CC1COC(C)(C)O1)CC(C)(C)C</smiles>

The above compound was synthesized according to General Procedure $\mathbf{C}$ using 1 s (51.6 $\mathrm{mg}, 0.3 \mathrm{mmol}$ ) and methyl 2-(bis(tert-butoxycarbonyl)amino)acrylate $(30.3 \mathrm{mg}, 0.1 \mathrm{mmol}) .1: 1 \mathrm{dr}$. Silica gel column chromatography gave a colourless oil, 43\% (20.6 mg). FT-IR (thin film): $\nu_{\max }\left(\mathrm{cm}^{-1}\right)=2981,1795,1746$, 1699. ${ }^{1} \mathbf{H}$ NMR $\left(400 \mathrm{MHz}, \mathrm{CDCl}_{3}\right) \delta 5.12\left(\mathrm{td}, J=7.5,3.1 \mathrm{~Hz}, 2 \mathrm{H}, 4 \mathrm{~s} \& 4 \mathbf{s}^{\prime}\right), 4.23(\mathrm{ddt}, J=6.5,5.0,1.9 \mathrm{~Hz}$, 1H, 4s), $4.19-4.09$ (m, 2H, 4s \& 4s'), 4.05 (dtd, $J=7.9,5.4,1.3 \mathrm{~Hz}, 3 \mathrm{H}$, , 4s \& 2 x 4s'), $3.83-3.72$ (m, $\left.2 \mathrm{H}, \mathbf{4 s} \& \mathbf{4} \mathbf{s}^{\prime}\right), 3.70$ (s, 6H, 4s \& 4s'), $3.54-3.40$ (m, 2H, 4s \& 4s'), 3.25 (ddd, $J=12.3,8.7,7.4 \mathrm{~Hz}, 2 \mathrm{H}, 4 \mathbf{s}$ \& 4s'), 2.46 (ddd, $\left.J=15.4,3.1,1.4 \mathrm{~Hz}, 2 \mathrm{H}, 4 \mathbf{s} \& 4 \mathbf{s}^{\prime}\right), 1.97$ (ddd, $\left.J=15.4,7.8,1.8 \mathrm{~Hz}, 2 \mathrm{H}, 4 \mathbf{s} \& 4 \mathbf{s}^{\prime}\right), 1.49$ (s, 36H, 4s \& 4s'), 1.39 (d, $\left.J=2.3 \mathrm{~Hz}, 6 \mathrm{H}, 4 \mathrm{~s} \& 4 \mathrm{~s}^{\prime}\right), 1.33$ (d, $J=1.6 \mathrm{~Hz}, 6 \mathrm{H}, 4 \mathrm{~s} \&$ 4s'), $1.21-1.14$ (m, 12H, 4s \& 4s'). ${ }^{13} \mathbf{C}$ NMR (101 MHz, $\left.\mathrm{CDCl}_{3}\right) \delta 172.2(2 \mathrm{C}), 152.3$ (2C), 109.1 (2C), 83.08, 83.05, $76.2(2 \mathrm{C})$, 75.09, 75.06, 74.2 (2C), 67.9, 67.8, 65.8 (2C), 63.2, 63.1, 54.81, 54.75, 52.5 (2C), 40.94, 40.87, 29.8 (2C), 28.2, 28.1, 26.9, 26.9, 25.7, 25.65, 25.67, 25.44 (2C), 25.38. HRMS (ESI): $\mathrm{m} / \mathrm{z}$ calculated for $\mathrm{C}_{23} \mathrm{H}_{41} \mathrm{O}_{9} \mathrm{~N}_{1}$ requires 498.2674 for $[\mathrm{M}+\mathrm{Na}]^{+}$, found 498.2674 . 
Synthesis of $4 \mathrm{~s}$

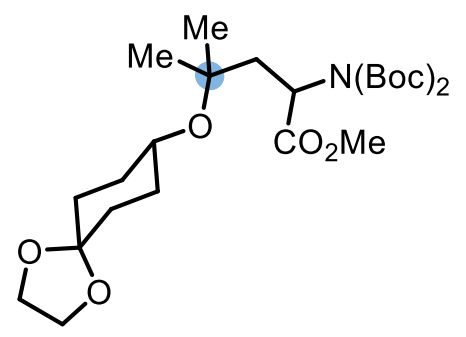

The above compound was synthesized according to General Procedure $\mathbf{C}$ using $1 \mathbf{t}$ (59.4 mg, $0.3 \mathrm{mmol}$ ) and methyl 2-(bis(tert-butoxycarbonyl)amino)acrylate $(30.3 \mathrm{mg}, 0.1 \mathrm{mmol})$ and chlorotrimethylsilane $(50.8 \mu \mathrm{L}$, $0.4 \mathrm{mmol})$. Silica gel column chromatography gave a colourless oil, $45 \%(22.5 \mathrm{mg})$. FT-IR (thin film): $\nu_{\max }$ $\left(\mathrm{cm}^{-1}\right)=3034,2972,2917,1789,1736 .{ }^{1} \mathbf{H}$ NMR $\left(400 \mathrm{MHz}, \mathrm{CDCl}_{3}\right) \delta 5.14(\mathrm{dd}, J=7.7,3.1 \mathrm{~Hz}, 1 \mathrm{H}), 3.93$ $-3.87(\mathrm{~m}, 4 \mathrm{H}), 3.70(\mathrm{~s}, 3 \mathrm{H}), 3.55(\mathrm{dt}, J=7.4,3.6 \mathrm{~Hz}, 1 \mathrm{H}), 2.48(\mathrm{dd}, J=15.1,3.1 \mathrm{~Hz}, 1 \mathrm{H}), 1.89(\mathrm{dd}, J=$ 15.2, 7.6 Hz, 1H), 1.80 (ddd, $J=11.1,6.5,3.4 \mathrm{~Hz}, 2 \mathrm{H}), 1.72-1.58$ (m, 4H), $1.49(\mathrm{~s}, 20 \mathrm{H}), 1.19$ (s, 3H), 1.16 (s, 3H). ${ }^{13} \mathrm{C}$ NMR $\left(101 \mathrm{MHz}, \mathrm{CDCl}_{3}\right) \delta 172.4,152.3,108.7,82.9,74.2,67.1,64.3,64.3,55.0,52.5,42.6$, 32.0, 31.9, 31.7, 31.7, 28.2, 28.2, 26.2, 26.0. HRMS (ESI): $\mathrm{m} / \mathrm{z}$ calculated for $\mathrm{C}_{25} \mathrm{H}_{43} \mathrm{O}_{9} \mathrm{~N}_{1}$ requires 524.2830 for $[\mathrm{M}+\mathrm{Na}]^{+}$, found 524.2829 .

Synthesis of $4 t$<smiles>C=CCCCC(C)(CC(COC)[N+](=O)[O-])OCC</smiles>

The above compound was synthesized according to General Procedure $\mathbf{C}$ using $\mathbf{1 t}(59.4 \mathrm{mg}, 0.3 \mathrm{mmol}$ ) and methyl 2-(bis(tert-butoxycarbonyl)amino)acrylate $(30.3 \mathrm{mg}, 0.1 \mathrm{mmol})$ and chlorotrimethylsilane $(50.8 \mu \mathrm{L}$, $0.4 \mathrm{mmol})$. Crude dr could not be determined. Silica gel column chromatography gave a colourless oil, $38 \%$ $(16.9 \mathrm{mg}, 1.3: 1 \mathrm{dr})$. FT-IR (thin film): $\nu_{\max }\left(\mathrm{cm}^{-1}\right)=2932,2868,1789,1747,1701,1641 .{ }^{1} \mathbf{H}$ NMR (400 $\left.\mathrm{MHz}, \mathrm{CDCl}_{3}\right) \delta 5.88-5.71\left(\mathrm{~m}, 2 \mathrm{H}, \mathbf{1 t} \& \mathbf{1} \mathbf{t}^{\prime}\right), 5.13\left(\mathrm{td}, J=8.0,2.8 \mathrm{~Hz}, 2 \mathrm{H}, \mathbf{1} \mathbf{t} \& \mathbf{1} \mathbf{t}^{\prime}\right), 5.07-4.83(\mathrm{~m}, 4 \mathrm{H}, \mathbf{1 t}$ \& $\left.\mathbf{1} \mathbf{t}^{\prime}\right), 3.70\left(\mathrm{~s}, \mathbf{6 H}, \mathbf{1 t} \& \mathbf{1} \mathbf{t}^{\prime}\right), 3.44-3.17\left(\mathrm{~m}, 4 \mathrm{H}, \mathbf{1 t} \& \mathbf{1} \mathbf{t}^{\prime}\right), 2.49(\mathrm{dd}, J=15.6,2.6 \mathrm{~Hz}, 1 \mathrm{H}, \mathbf{1 t}), 2.37(\mathrm{dd}, J=$

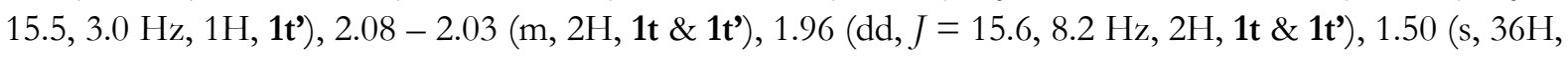
$\left.\mathbf{1 t} \& \mathbf{1} \mathbf{t}^{\mathbf{\prime}}\right), 1.47-1.31\left(\mathrm{~m}, 6 \mathrm{H}, \mathbf{1 t} \& \mathbf{1} \mathbf{t}^{\prime}\right), 1.21-1.06\left(\mathrm{~m}, 12 \mathrm{H}, \mathbf{1 t} \& \mathbf{1} \mathbf{t}^{\mathbf{\prime}}\right) .{ }^{13} \mathbf{C} \mathbf{N M R}\left(101 \mathrm{MHz}, \mathrm{CDCl}_{3}\right) \delta 172.3$ $\left(\mathbf{1} \mathbf{t} \& \mathbf{1} \mathbf{t}^{\prime}\right), 152.3\left(\mathbf{1} \mathbf{t} \& \mathbf{1} \mathbf{t}^{\prime}\right), 139.0\left(\mathbf{1} \mathbf{t} \& \mathbf{1} \mathbf{t}^{\prime}\right), 114.7\left(\mathbf{1 t} \& \mathbf{1} \mathbf{t}^{\prime}\right), 83.0(\mathbf{1 t}), 82.9\left(\mathbf{1} \mathbf{t}^{\prime}\right), 75.6(\mathbf{1 t}), 75.4\left(\mathbf{1} \mathbf{t}^{\prime}\right), 56.3(\mathbf{1 t})$,

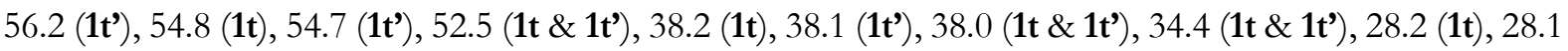

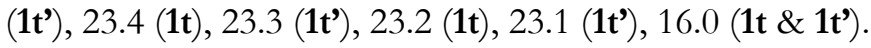


Unsuccessful/low yielding substrates

enol ether<smiles>C=C(C)OC(=C)C(C)=O</smiles>

$0 \%$<smiles>[SeH3-]C1=CCCC1</smiles>

$0 \%$<smiles>COC1=CCCCC1</smiles>

$11 \% N M R$<smiles>C=C(C)OCc1cc(C(F)(F)F)cc(C(F)(F)F)c1</smiles>

$\sim 20 \%$ NMR<smiles>C=C(C)SCc1ccccc1</smiles>

Trace<smiles>C=C(C)OCc1ccc(OC)cc1</smiles>

trace<smiles>C=C(C)Oc1ccccc1</smiles>

$\sim 20 \%$ NMR multiple products<smiles>C=C(Cc1ccccc1)OCC</smiles>

only ketone products isolated<smiles>C=C(C)OC(C)c1ccccc1</smiles>

low conversion<smiles>C=C(OC)c1ccccc1</smiles><smiles>C=C(C)OCc1ccc(NC=CC)cc1</smiles>

$\sim 40 \%$ but low efficiency compared to previous report<smiles>C=C(NC(=C)[PH2+]COCC)OCC</smiles>

only alkene hydrogenation products observed 


\section{Mechanistic Studies}

\section{1: Synthesis of Deuterated Materials}

Synthesis of $\mathbf{H E}-\mathbf{P h}-\boldsymbol{D}_{\boldsymbol{1}}$<smiles>[2H]N1C(C)=C(C(=O)OCC)C(c2ccccc2)C(C(=O)OCC)=C1[N+](=O)[O-]</smiles>

To an oven-dried $1.7 \mathrm{~mL}$ vial was charged $\mathrm{HE}-\mathrm{Ph}$ (HE1, $329 \mathrm{mg}, 1 \mathrm{mmol})$ and $\mathrm{CD}_{3} \mathrm{OD}(1 \mathrm{~mL})$. The reaction mixture was allowed to stir at room temperature for 48 hours. After this time the solvent was removed under a stream of nitrogen and dried on the high vacuum to give $\mathrm{HE}-\mathrm{Ph}-d_{1}$ in quantitative yield (328 mg), 93\% D incorporation. ${ }^{1} \mathbf{H}$ NMR (400 MHz, $\left.\mathrm{CD}_{3} \mathrm{CN}\right) \delta 7.33-7.22(\mathrm{~m}, 4 \mathrm{H}), 7.20-7.08(\mathrm{~m}, 1 \mathrm{H})$, $4.95(\mathrm{~s}, 1 \mathrm{H}), 4.06(\mathrm{qd}, J=7.1,1.9 \mathrm{~Hz}, 4 \mathrm{H}), 2.29(\mathrm{~s}, 6 \mathrm{H}), 1.21(\mathrm{t}, J=7.1 \mathrm{~Hz}, 6 \mathrm{H})$.

Synthesis of HE-Ph- $\boldsymbol{D}_{\boldsymbol{1}}$,

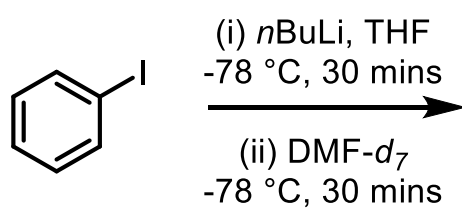

(ii) DMF- $-d_{7}$
$-78^{\circ} \mathrm{C}, 30 \mathrm{~min}$<smiles>[2H]C(=O)c1ccccc1</smiles>

PhCDO

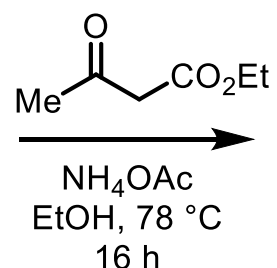

$16 \mathrm{~h}$<smiles>[2H]C1(c2ccccc2)C(C(=O)OCC)=C(C)NC(C)=C1C(=O)OCC</smiles>

$\mathrm{HE}-\mathrm{Ph}-D_{1}$

To a stirred solution of iodobenzene $(0.98 \mathrm{~mL}, 8.8 \mathrm{mmol})$ in anhydrous THF $(46 \mathrm{~mL})$, was added $n$ BuLi (1.6 $\mathrm{M}$ in hexanes, $6 \mathrm{~mL}, 9.6 \mathrm{mmol}$ ) dropwise at $-78^{\circ} \mathrm{C}$. The reaction mixture was allowed to stir for 30 mins at that temperature before adding DMF- $d_{7}$ dropwise, and stirring for a further 30 mins. The reaction mixture was quenched with sat $\mathrm{NH}_{4} \mathrm{Cl}$ solution $(30 \mathrm{~mL})$ and $\mathrm{H}_{2} \mathrm{SO}_{4}(1 \mathrm{drop})$. The reaction mixture allowed to warm to room temperature and concentrated in vacuo. The crude residue was re-dispersed in $\mathrm{H}_{2} \mathrm{O}(150$ $\mathrm{mL})$ and $\mathrm{Et}_{2} \mathrm{O}(150 \mathrm{~mL})$. The organic phase was extracted and the aqueous phase re-extracted with $\mathrm{Et}_{2} \mathrm{O}$ $(2 \times 150 \mathrm{~mL})$. The combined organics were washed with brine $(150 \mathrm{~mL})$, dried over $\mathrm{MgSO}_{4}$ and concentrated in vacuo. The resulting crude residue was purified via silica gel column chromatography (EtOAc:Pentane - 0:100 - 10:90 v:v) to give benzaldehyde- $d_{1}$ as an amber oil, 68\% (640 mg). ${ }^{1} \mathbf{H}$ NMR $\left(400 \mathrm{MHz}, \mathrm{CDCl}_{3}\right) \delta 7.98-7.77(\mathrm{~m}, 2 \mathrm{H}), 7.71-7.58(\mathrm{~m}, 1 \mathrm{H}), 7.60-7.47(\mathrm{~m}, 2 \mathrm{H}) .{ }^{13} \mathbf{C} \mathbf{N M R}(101 \mathrm{MHz}$, $\left.\mathrm{CDCl}_{3}\right) \delta$ 134.6, 129.9, 129.1. To the flask was added ethyl acetoacetate $(1.51 \mathrm{~mL}, 11.95 \mathrm{mmol})$, ammonium acetate $(460 \mathrm{mg}, 5.97 \mathrm{mmol})$, and $\mathrm{EtOH}(8 \mathrm{~mL})$ and the flask heated to reflux overnight. The flask was allowed to return to room temperature and was concentrated in vacuo. The crude residue was dispersed in $\mathrm{CH}_{2} \mathrm{Cl}_{2}(50 \mathrm{~mL})$ and brine $(50 \mathrm{~mL})$. The organic phase was extracted and the aqueous phase re-extracted with $\mathrm{CH}_{2} \mathrm{Cl}_{2}(2 \times 50 \mathrm{~mL})$. The combined organics were dried over $\mathrm{MgSO}_{4}$ and concentrated in vacuo. The crude residue was purified via silica gel column chromatography (EtOAc:Pentane - 10:90 v:v) to give HEPh- $d_{1}$ ' as a white solid, $17 \%(330 \mathrm{mg})>95 \%$ D incorporation. ${ }^{1} \mathbf{H}$ NMR $\left(400 \mathrm{MHz}, \mathrm{CD}_{3} \mathrm{CN}\right) \delta 7.31-7.18$ $(\mathrm{m}, 4 \mathrm{H}), 7.16-7.08(\mathrm{~m}, 1 \mathrm{H}), 6.98(\mathrm{~s}, 1 \mathrm{H}), 4.03(\mathrm{qd}, J=7.1,1.8 \mathrm{~Hz}, 4 \mathrm{H}), 2.27(\mathrm{~s}, 6 \mathrm{H}), 1.18(\mathrm{t}, J=7.1 \mathrm{~Hz}$, 6H). ${ }^{13} \mathrm{C}$ NMR $\left(101 \mathrm{MHz}, \mathrm{CD}_{3} \mathrm{CN}\right) \delta$ 168.4, 149.3, 146.0, 128.9, 128.7, 127.1, 103.7, 60.3, 18.8, 14.6. HE$\mathbf{P h}-\boldsymbol{D}_{1}$ ' was converted into $\mathbf{H E}-\mathbf{P h}-\boldsymbol{D}_{2}$ using the method described above. 


\section{2: Deuterium Incorporation Studies}

Regular Spectrum of $3 a$
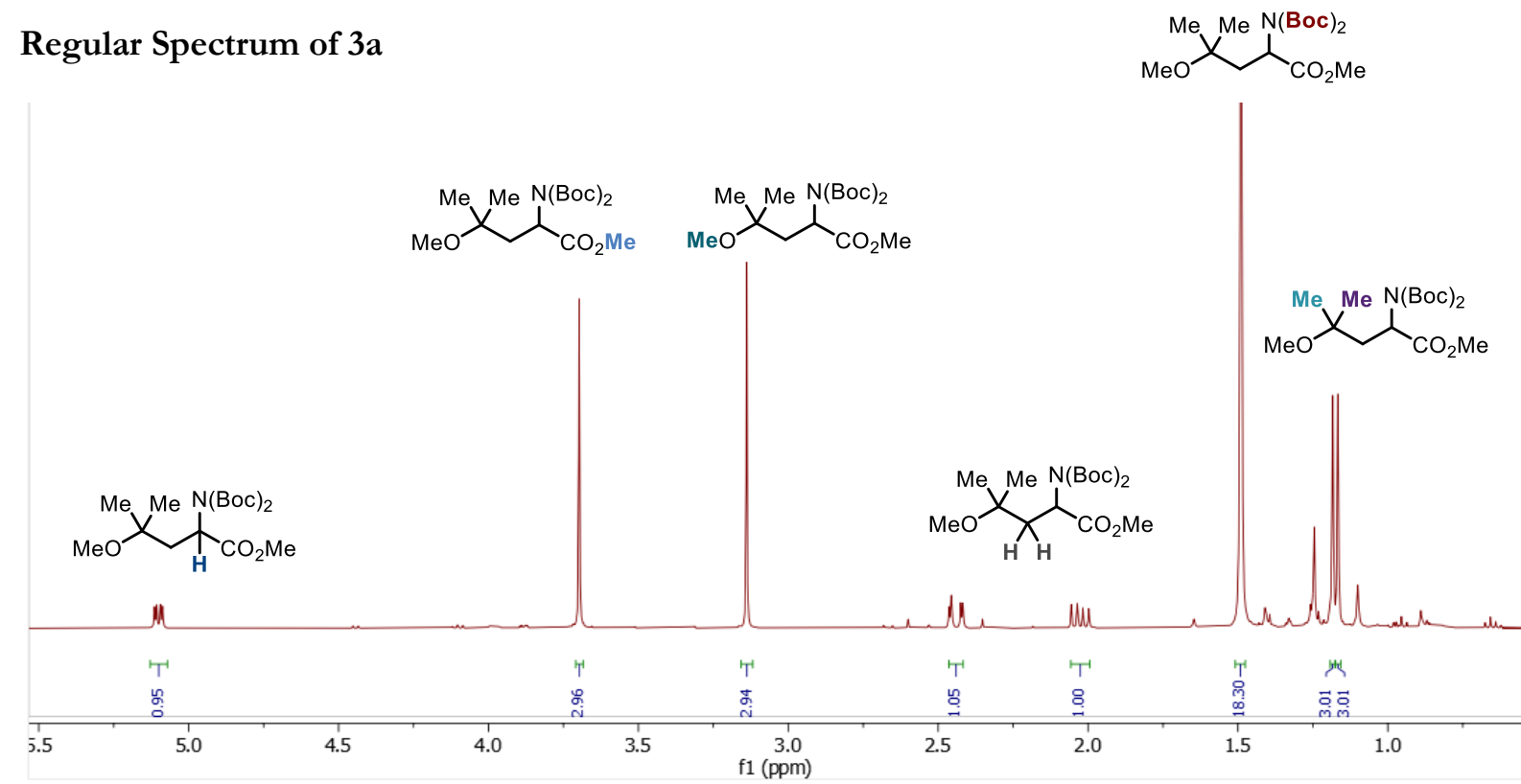

Experiment using HE-Ph- $d_{1}$
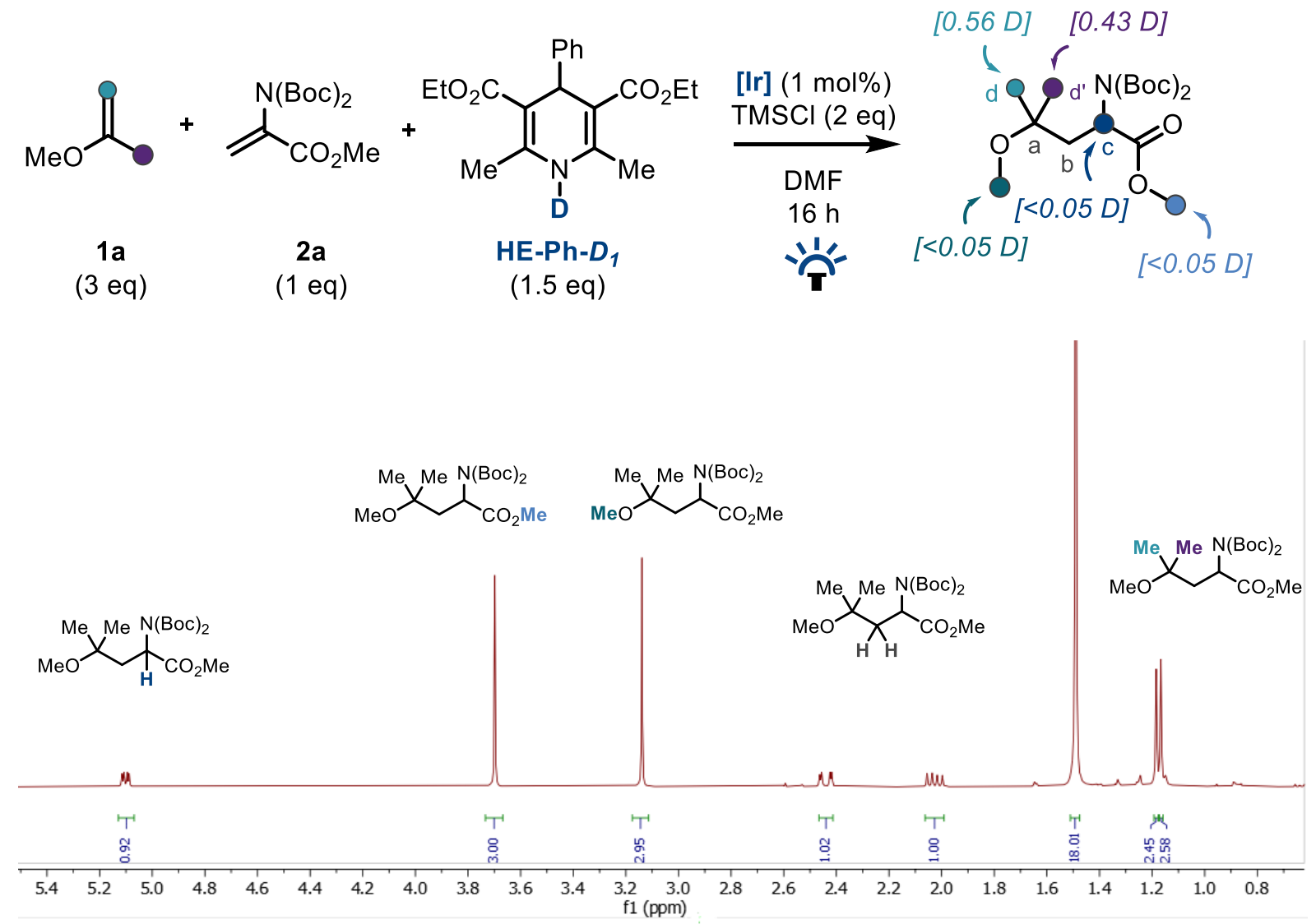
Experiment using HE-Ph- $\boldsymbol{d}_{1}$

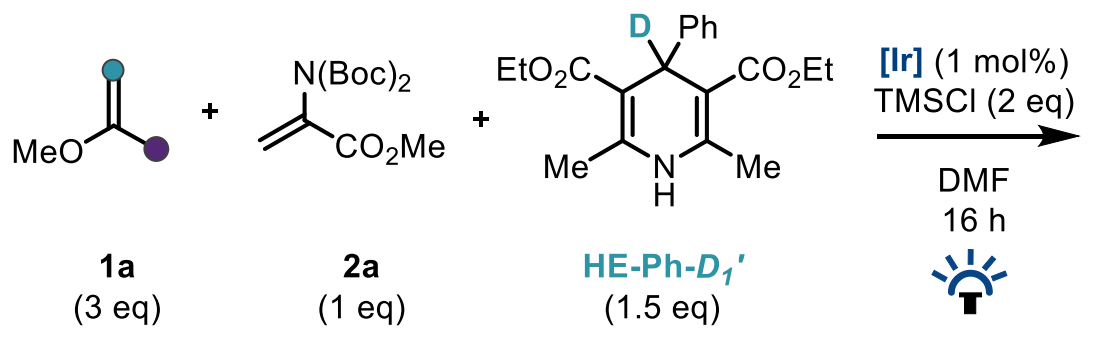
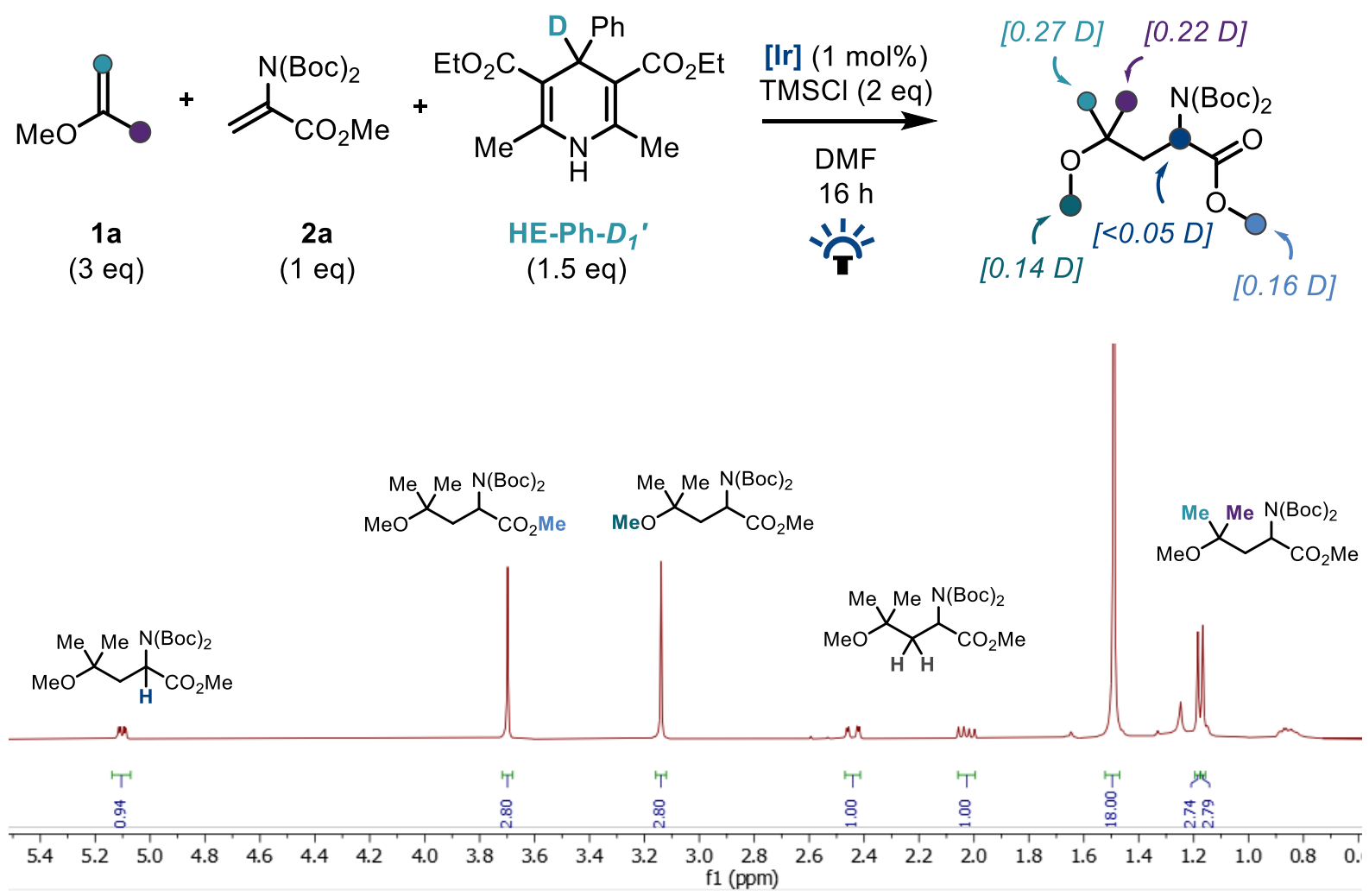

Experiment using HE-Ph- $d_{2}$

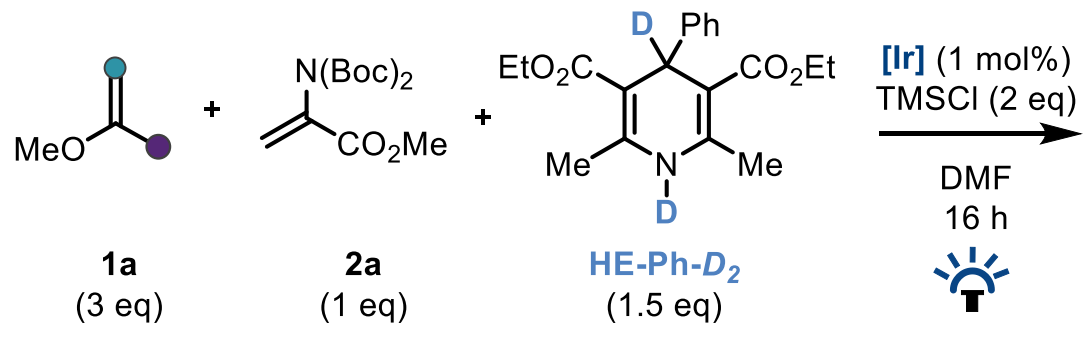

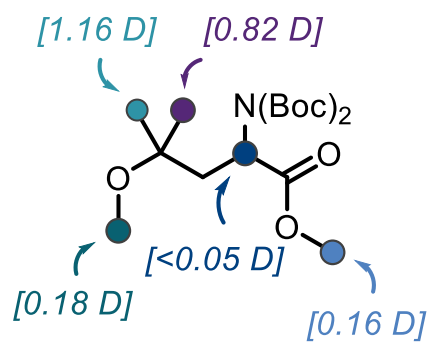

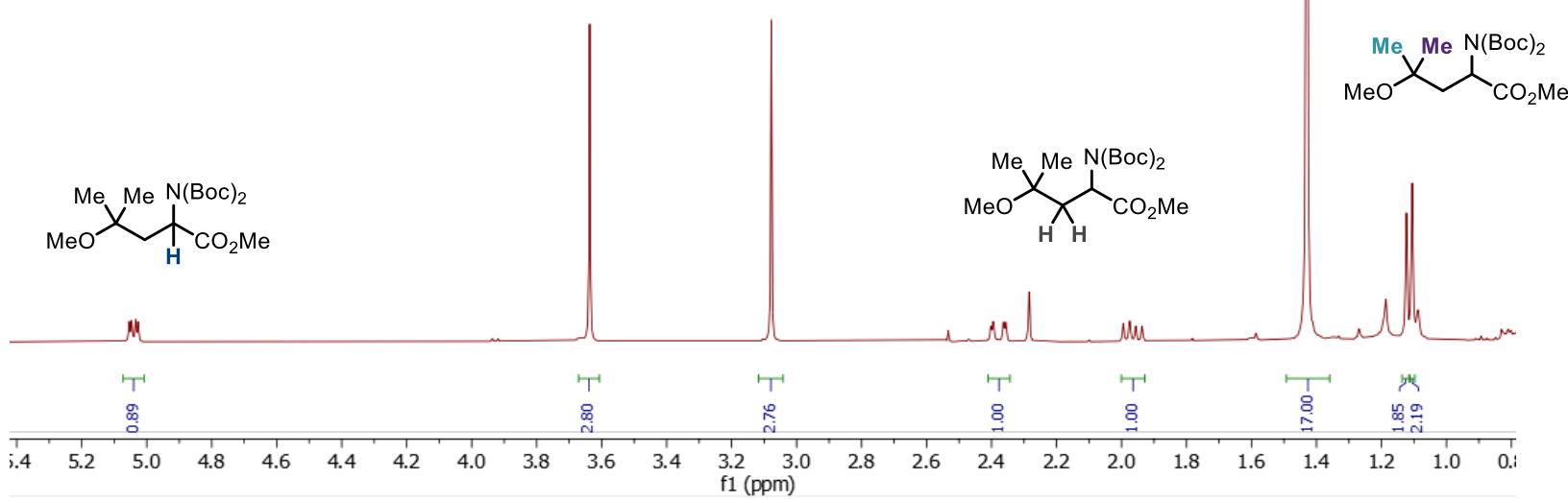

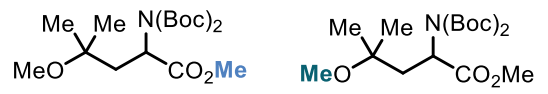


Experiment using DMF- $d_{7}$ as solvent
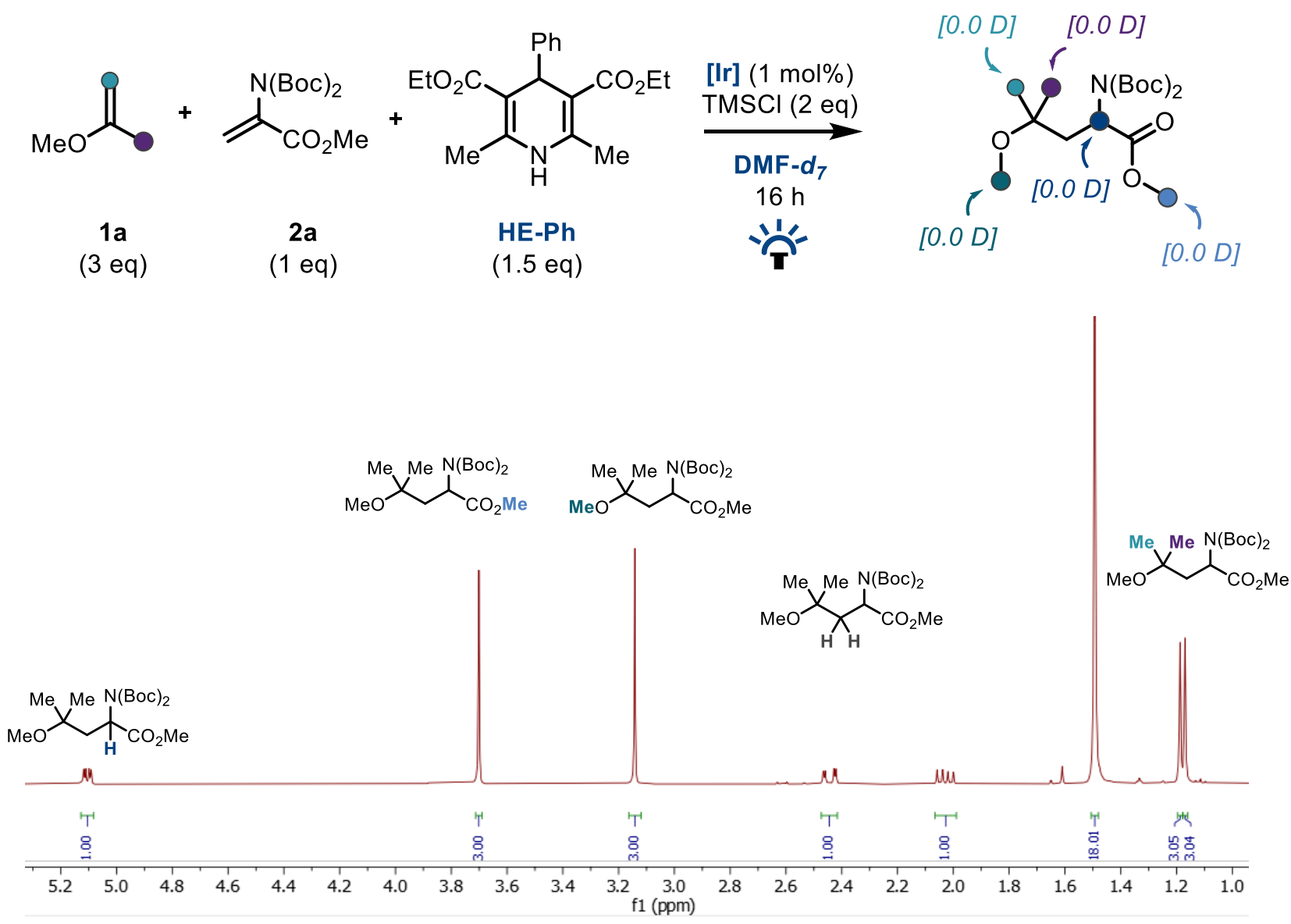
Regular Spectrum of af

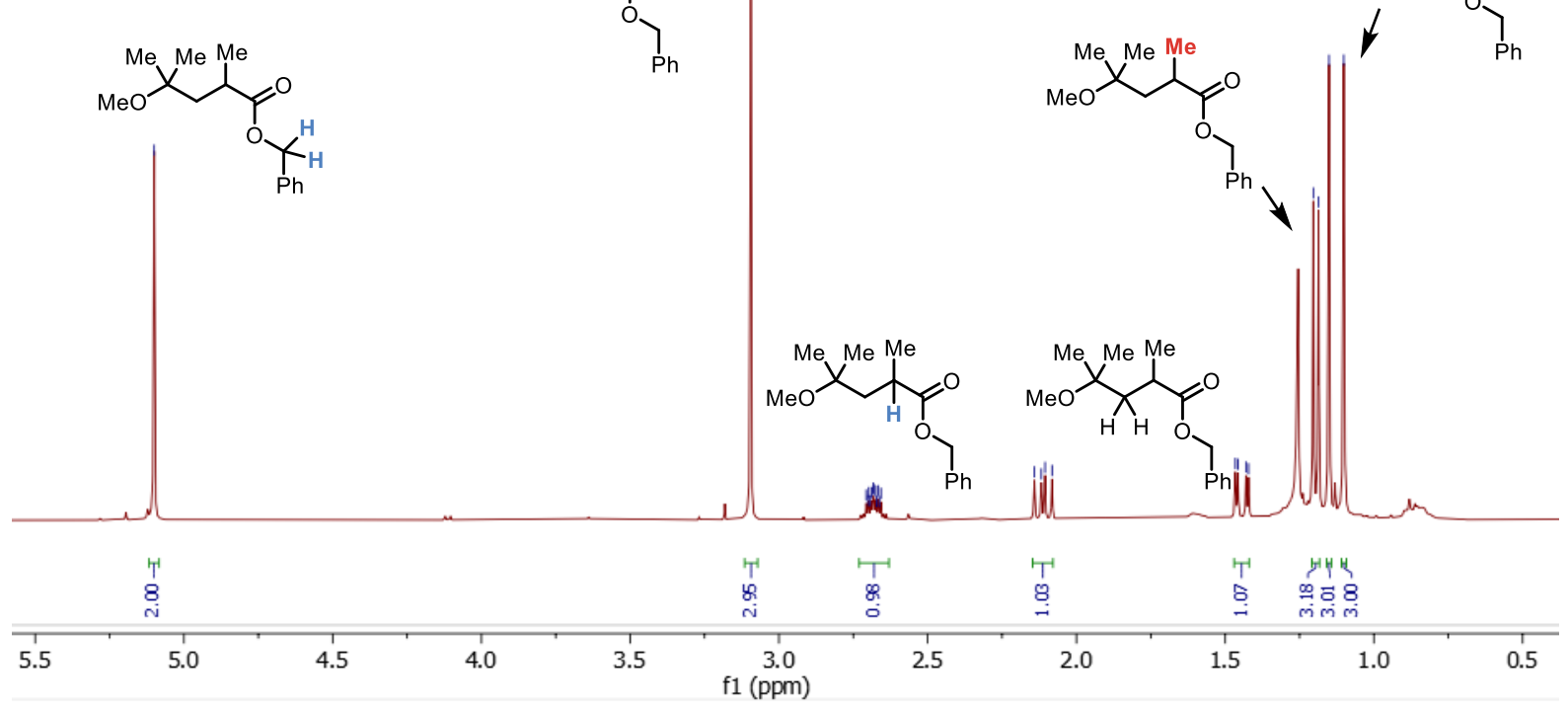

Experiment using HE-Ph- $d_{1}$
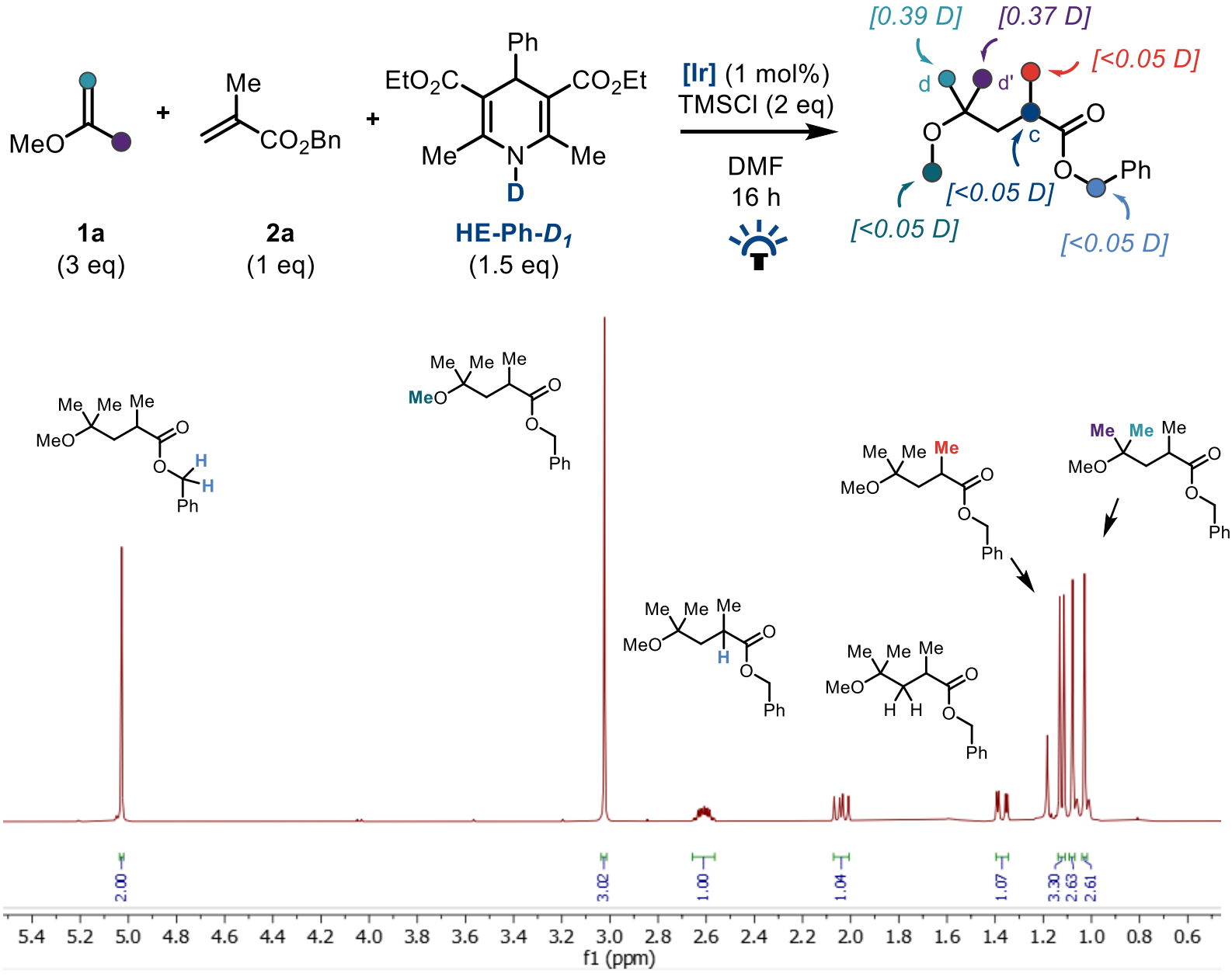

S52 
<smiles>C=C(C[CH+]C(=O)OC)C(=O)OCc1ccccc1</smiles>

$1 \mathrm{a}$

(3 eq) 2a

(1 eq)<smiles>[R]C1=C(C(=O)OCC)C([2H])(c2ccccc2)C(C(=O)OCC)=C(C)N1</smiles>

HE-Ph- $D_{1}{ }^{\prime}$

(1.5 eq)

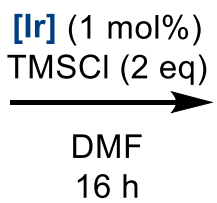

$16 \mathrm{~h}$
[0.29 D] [0.31 D]

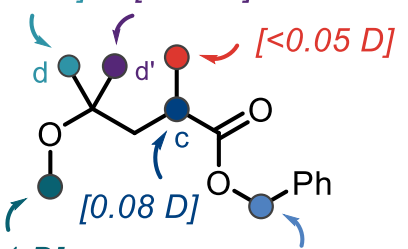

$[0.21 D]$
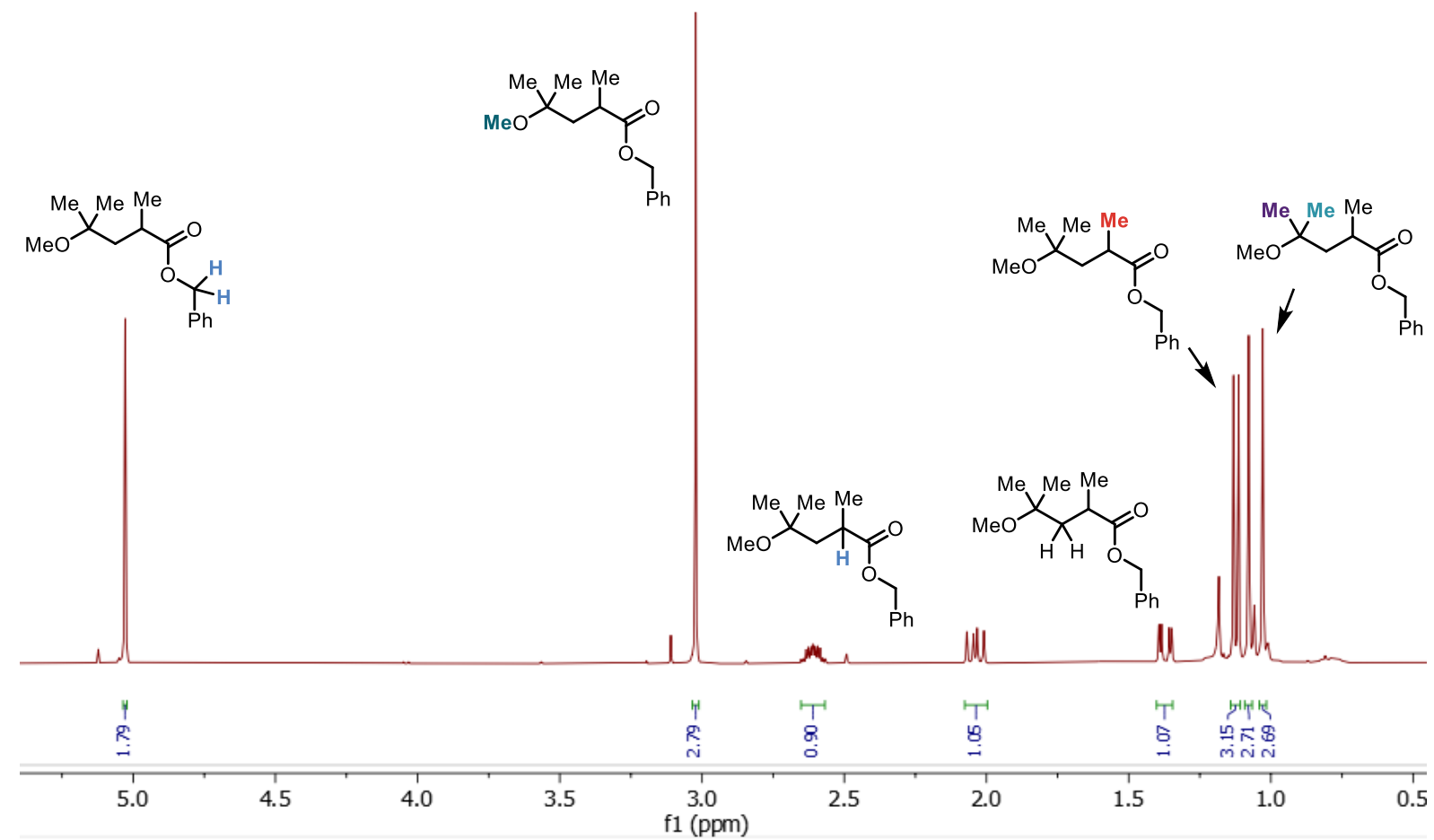

These results demonstrate that when benzyl methacrylate is used as coupling partner, we still observe scrambling at the other positions across the molecule. Despite this, there is $0.08 \mathrm{D}$-incorporation at the cposition suggesting that some direct HAT at this position is viable. Taken together with the results with the DHA derivative, this indirect termination is a feature of this transformation, and is not coupling-partnerdependent. Despite this, it is worth noting that this phenomenon is most pronounced with DHA. 
Ground state NMR investigations ( ${ }^{1} \mathrm{H}$ NMR, $\left.400 \mathrm{MHz}, \mathrm{DMF}-d_{7}\right) \mathrm{Ar}=4-\mathrm{FC}_{6} \mathrm{H}_{5}$

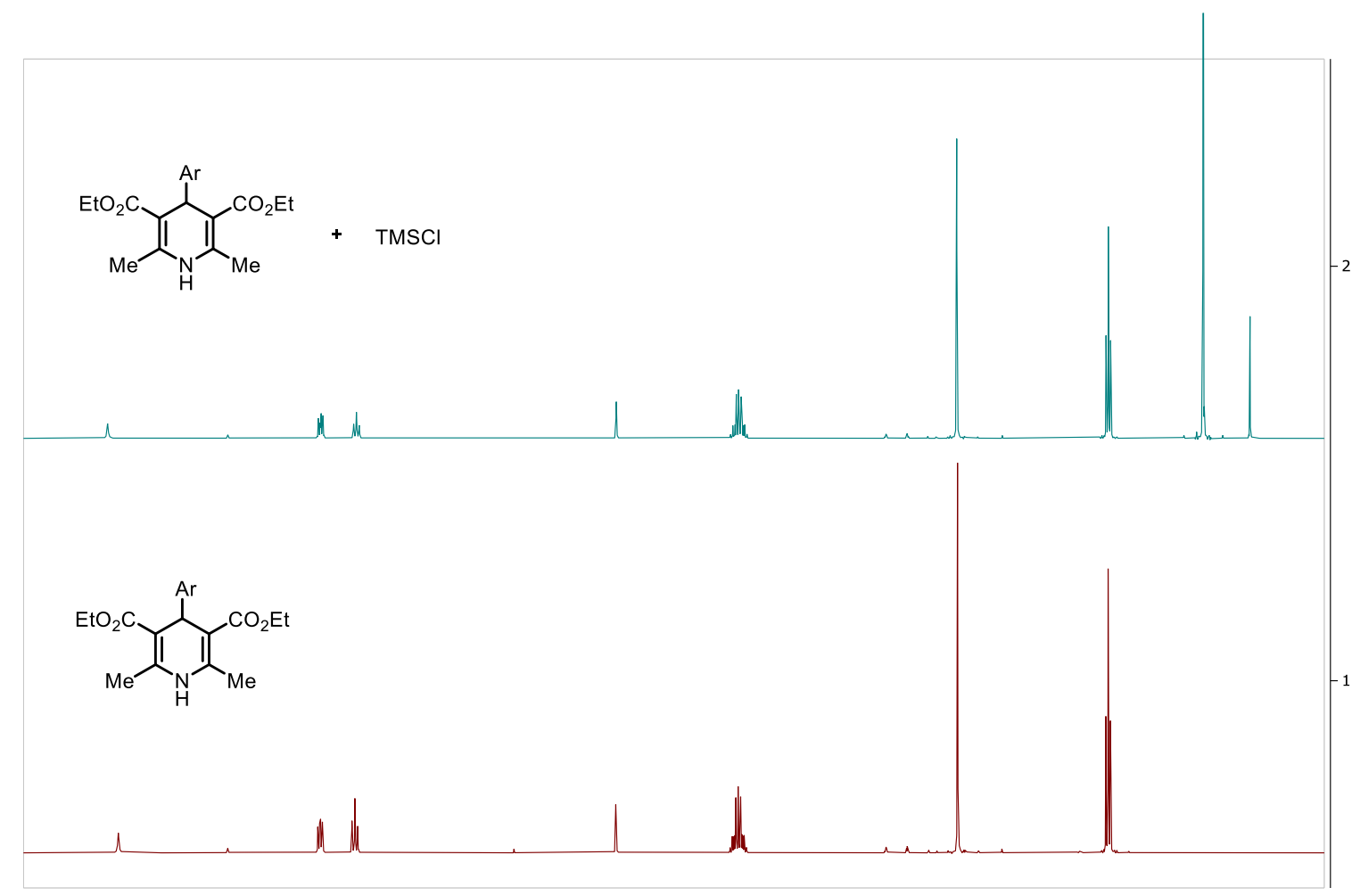

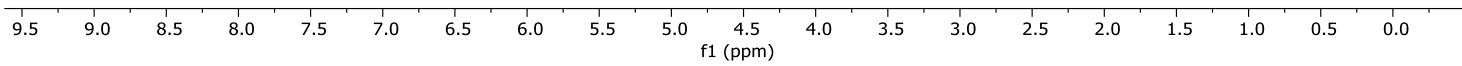

Ground state NMR investigations ( ${ }^{19} \mathrm{~F}$ NMR, $\left.397 \mathrm{MHz}, \mathrm{DMF}-d_{7}\right) \mathrm{Ar}=4-\mathrm{FC}_{6} \mathrm{H}_{5}$

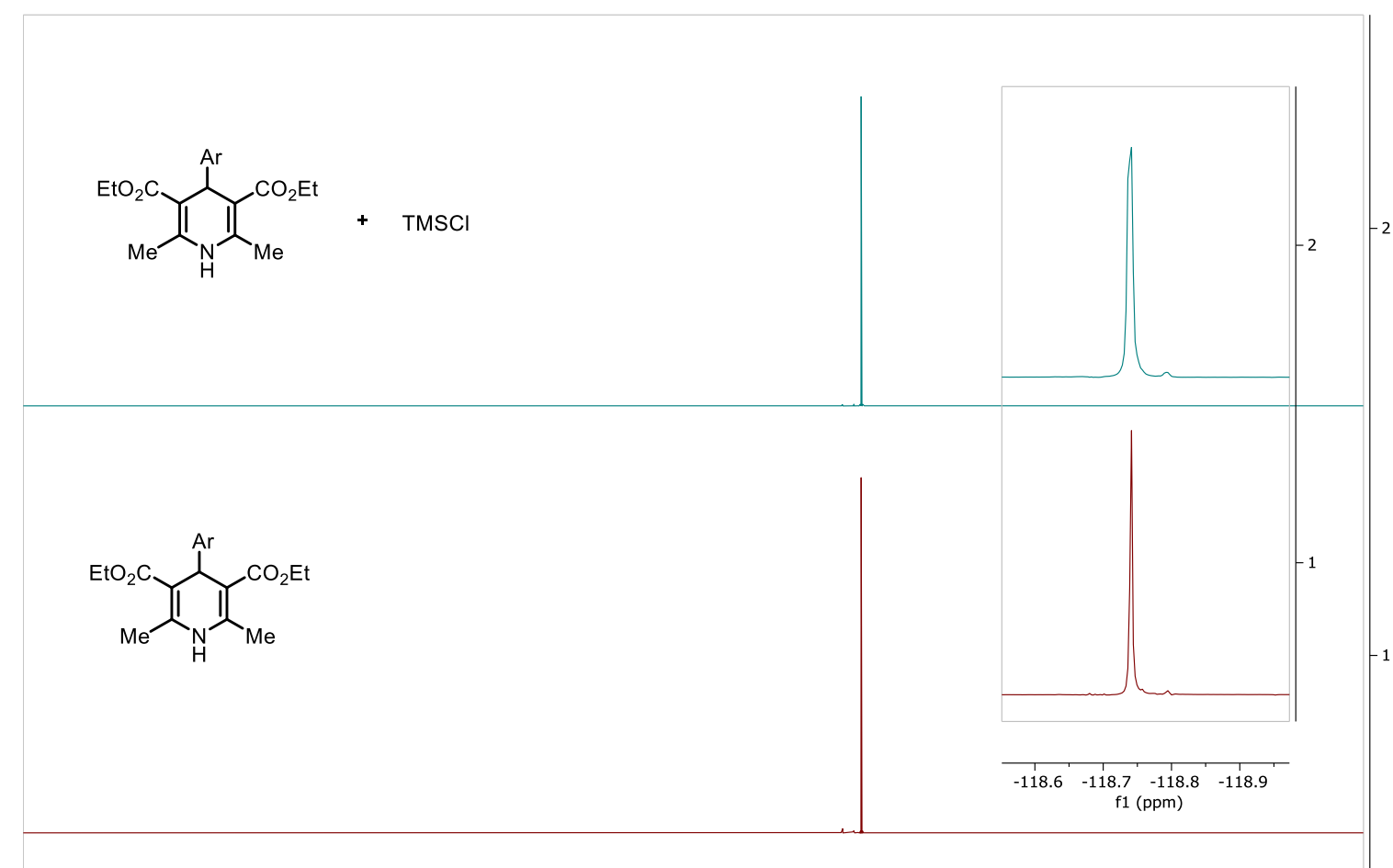

\begin{tabular}{llllllllllllllllll}
\hline & 60 & 40 & 20 & 0 & -20 & -40 & -60 & -80 & -100 & -120 & -140 & -160 & -180 & -200 & -220 & -240
\end{tabular} 


\subsection{Studies into presence of an $\alpha$-oxy radical}

\subsubsection{TEMPO studies}

Suppression of reactivity was observed on addition of TEMPO, with complete suppression observed using 3 equivalents. With 1 eq of TEMPO, 27\% of the $\mathrm{C}-\mathrm{C}$ coupled product was still observed. This can be reasoned through the super-stoichiometric quantity of the 2-methoxypropene, and points to the radical sourced from the enol ether rather than the alkene acceptor.

Scheme S1. TEMPO Studies

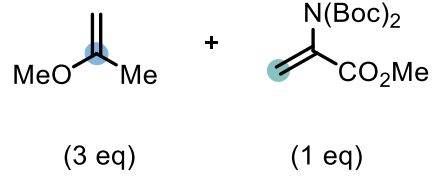

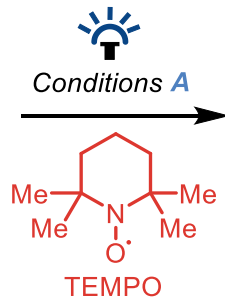

TEMPO

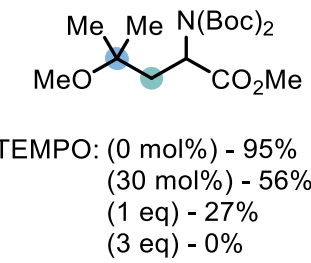

\subsubsection{Enol ether dimerization studies}

In order to further probe the intermediacy of an $\alpha$-oxy radical in the mechanistic pathway, the reaction was conducted without the alkene acceptor. When using S1a, pinacol-type homodimerization product S1aa was observed in significant quantity. This is in line with previous reports on $\alpha$-oxy radical formation from analogous acetals. ${ }^{9}, 10$ Furthermore when this reaction was conducted with the alkene acceptor both $\mathrm{C}-\mathrm{C}$ coupled product (S3a) and pinacol dimer (S1aa). These results support the intermediacy of an $\alpha$-oxy radical in the reaction mixture arising from an enol ether starting material.

Scheme S2. Dimerization studies

A
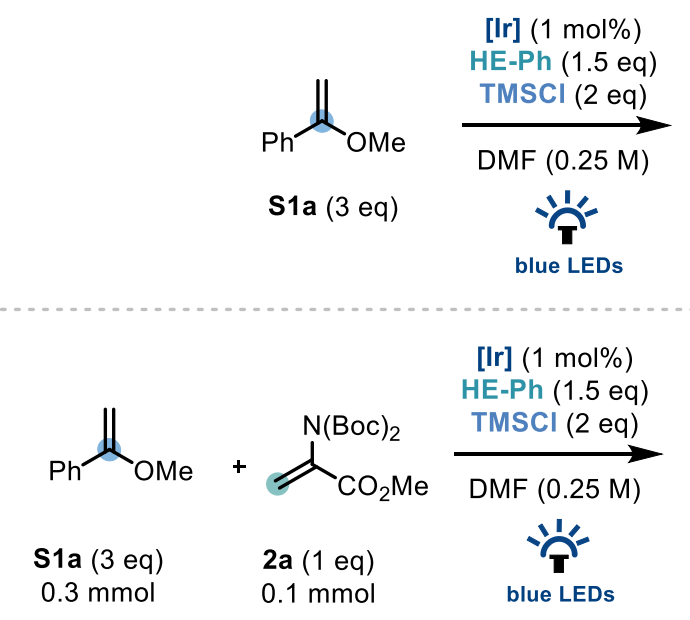

[Ir] $(1 \mathrm{~mol} \%)$ HE-Ph (1.5 eq) $\underset{\operatorname{DMSCl}(2 \mathrm{eq})}{\stackrel{\operatorname{TMS}}{\longrightarrow}}$

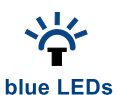

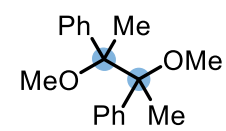

S1aa-42\%, 1:1 dr based on enol ether

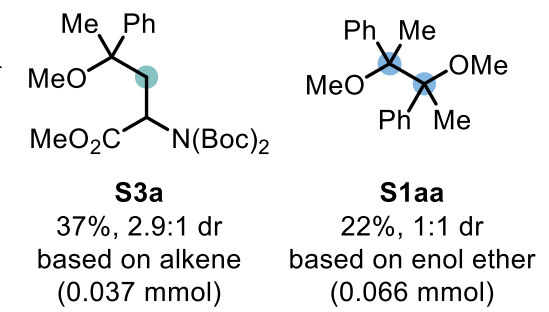

Further to this, when the dimerization reaction was conducted using the naphthyl substituted enol ether (19), interestingly the methylnaphthyl dimer S1g was formed in modest yields. This structure most likely arises from homodimerization of a methylnaphtyl radical, formed via $\beta$-scission of an $\alpha$-oxy radical intermediate, similar to a process detailed recently by Doyle and co-workers. ${ }^{11}$ 
Scheme S3. Further dimerization studies

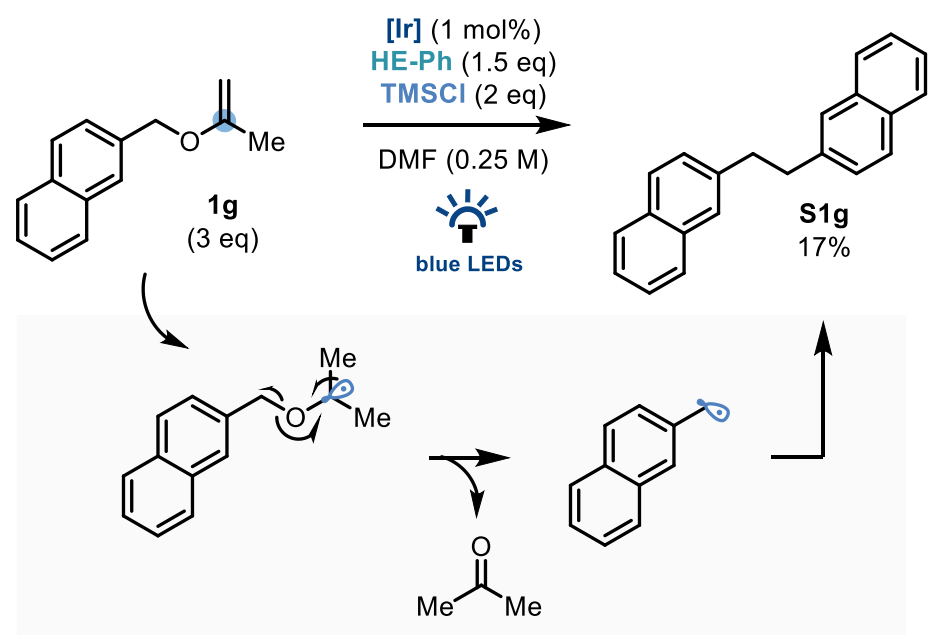

6.3.3. Data for compounds synthesized in this section

Data for S1aa<smiles>COC(C)(c1ccccc1)C(C)(c1ccccc1)C(C)(C)c1ccccc1</smiles>

1:1 dr. Colourless solid, 42\% (17.1 mg) ${ }^{1} \mathbf{H}$ NMR (400 MHz, $\left.\mathrm{CDCl}_{3}\right) \delta 7.33-7.20$ (m, 5H, S1aa \& S1aa'), 7.19 - 7.02 (m, 3H, S1aa \& S1aa'), 6.90 - 6.78 (m, 2H, S1aa \& S1aa'), 3.10 (s, 3H, S1aa), 3.03 (s, 3H, S1aa'), 1.65 (s, 3H, S1aa), 1.44 (s, 3H, S1aa'). ${ }^{13} \mathbf{C} \mathbf{~ N M R}\left(101 \mathrm{MHz}, \mathrm{CDCl}_{3}\right) \delta$ 142.0, 141.4, 129.3, 129.1, $126.9,126.6,126.5,84.3,83.6,77.5,77.2,76.8,50.8,50.8,19.3,18.7$. Data is in line with literature precedent. ${ }^{?}$

Data for S3a<smiles>CO[R6](=O)NC(CC(C)(OC)c1ccccc1)C(=O)OC</smiles>

2.9:1 dr. Colourless oil, 37\% (16.2 mg). ${ }^{1} \mathbf{H}$ NMR (400 MHz, $\left.\mathrm{CDCl}_{3}\right) \delta 7.43-7.36$ (m, 4H, S3a \& S3a'), 7.32 (ddd, $\left.J=7.8,6.8,2.3 \mathrm{~Hz}, 4 \mathrm{H}, \mathbf{S 3 a} \& \mathbf{S 3} \mathbf{a}^{\prime}\right), 7.26-7.20$ (m, 2H, S3a \& S3a'), 5.07 (ddd, J = 20.0, 8.2, $\left.2.7 \mathrm{~Hz}, 2 \mathrm{H}, \mathbf{S 3 a} \& \mathbf{S} \mathbf{a}^{\prime}\right), 3.66$ (s, 3H, S3a'), 3.64 (s, 3H, S3a), 3.09 (s, 3H, S3a), 3.05 (s, 3H, S3a'), 2.79 (dd, $J=15.4,2.4 \mathrm{~Hz}, 1 \mathrm{H}, \mathbf{S 3 a}), 2.72(\mathrm{dd}, J=15.3,3.1 \mathrm{~Hz}, 1 \mathrm{H}, \mathbf{S 3 a}), 2.35$ (dd, $\left.J=15.4,8.3 \mathrm{~Hz}, 2 \mathrm{H}, \mathbf{S} 3 \mathbf{a} \& \mathbf{S} 3 \mathbf{a}^{\prime}\right)$, 1.57 (s, 3H, S3a'), 1.55 (s, 3H, S3a), 1.47 (d, $J=1.5 \mathrm{~Hz}, 36 \mathrm{H}, \mathbf{S 3 a} \& \mathbf{S 3 a}) .{ }^{13} \mathbf{C} \mathbf{N M R}\left(101 \mathrm{MHz}, \mathrm{CDCl}_{3}\right)$

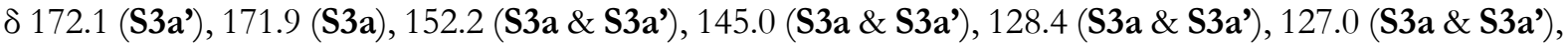
126.3 (S3a), 126.2 (S3a'), 82.9 (S3a), 82.8 (S3a'), 78.3 (S3a \& S3a'), 55.1 (S3a), 54.9 (S3a'), 52.5 (S3a \& S3a'), 50.4 ('S3a'), 50.3 (S3a), 42.4 ('S3a'), 42.1 (S3a), 28.2 ('S3a \& S3a'), 23.7 (S3a), 23.3 ('S3a'). Data is in line with literature precedent. ${ }^{10}$ 


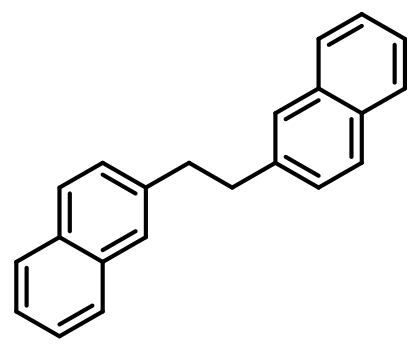

Colourless solid, $17 \%(7.1 \mathrm{mg}) .{ }^{1} \mathbf{H}$ NMR $\left(500 \mathrm{MHz}, \mathrm{CDCl}_{3}\right) \delta 7.84-7.74(\mathrm{~m}, 6 \mathrm{H}), 7.68-7.64(\mathrm{~m}, 2 \mathrm{H})$, $7.49-7.40(\mathrm{~m}, 4 \mathrm{H}), 7.37$ (dd, $J=8.4,1.8 \mathrm{~Hz}, 2 \mathrm{H}), 3.19$ (s, 4H). ${ }^{13} \mathbf{C}$ NMR $\left(126 \mathrm{MHz}, \mathrm{CDCl}_{3}\right) \delta$ 139.4, $133.8,132.2,128.0,127.8,127.6,127.5,126.7,126.1,125.3,38.2$. Data is in line with literature precedent. ${ }^{12}$ 


\subsection{Further Mechanistic Discussion}

\section{Figure S1. Hantzsch ester oxidation pathway}

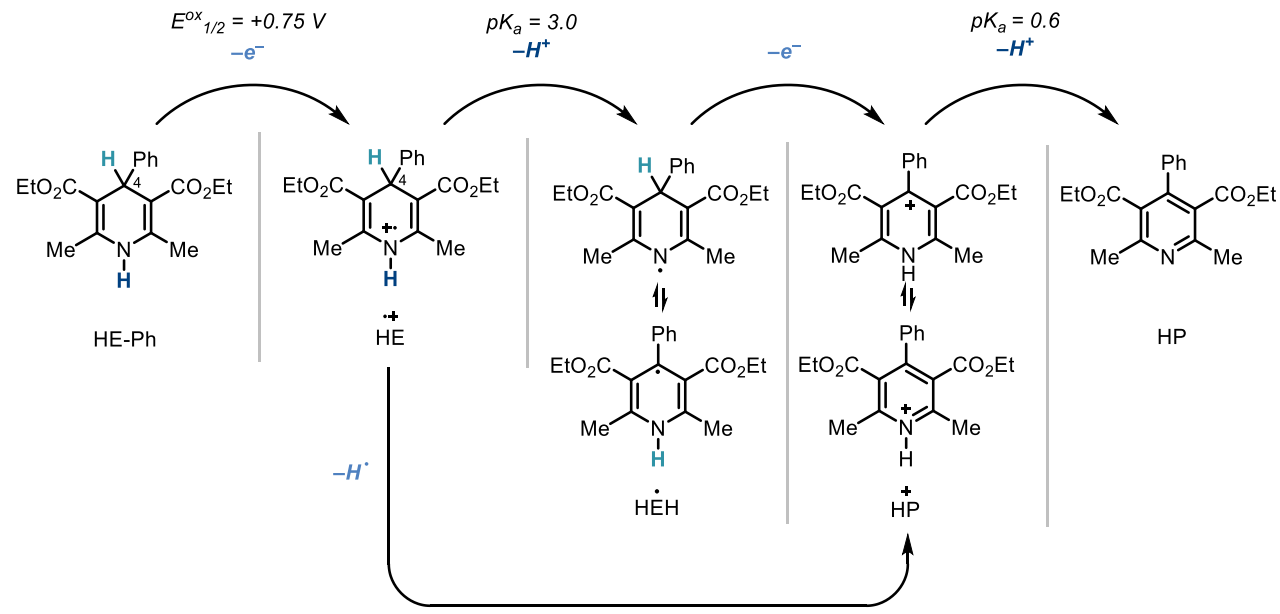

Previous work in the field has deduced that Hantzsch esters can terminate reductive Giese-type reactions with ester derivatives in two ways: ${ }^{13}$ (1) Sequential single electron reduction from $\mathrm{HEH} \bullet$ to the enolate anion and then subsequent protonation from HP+. (2) Direct hydrogen atom transfer between the radical and the HE(radical cation) intermediate.

Both of these methods suggest that we should observe transfer from the C-D bond to the c-position. This contrasts with our own experimental observations, where $<0.05$ incorporation is shown.

\section{Figure S2. Reaction termination studies}
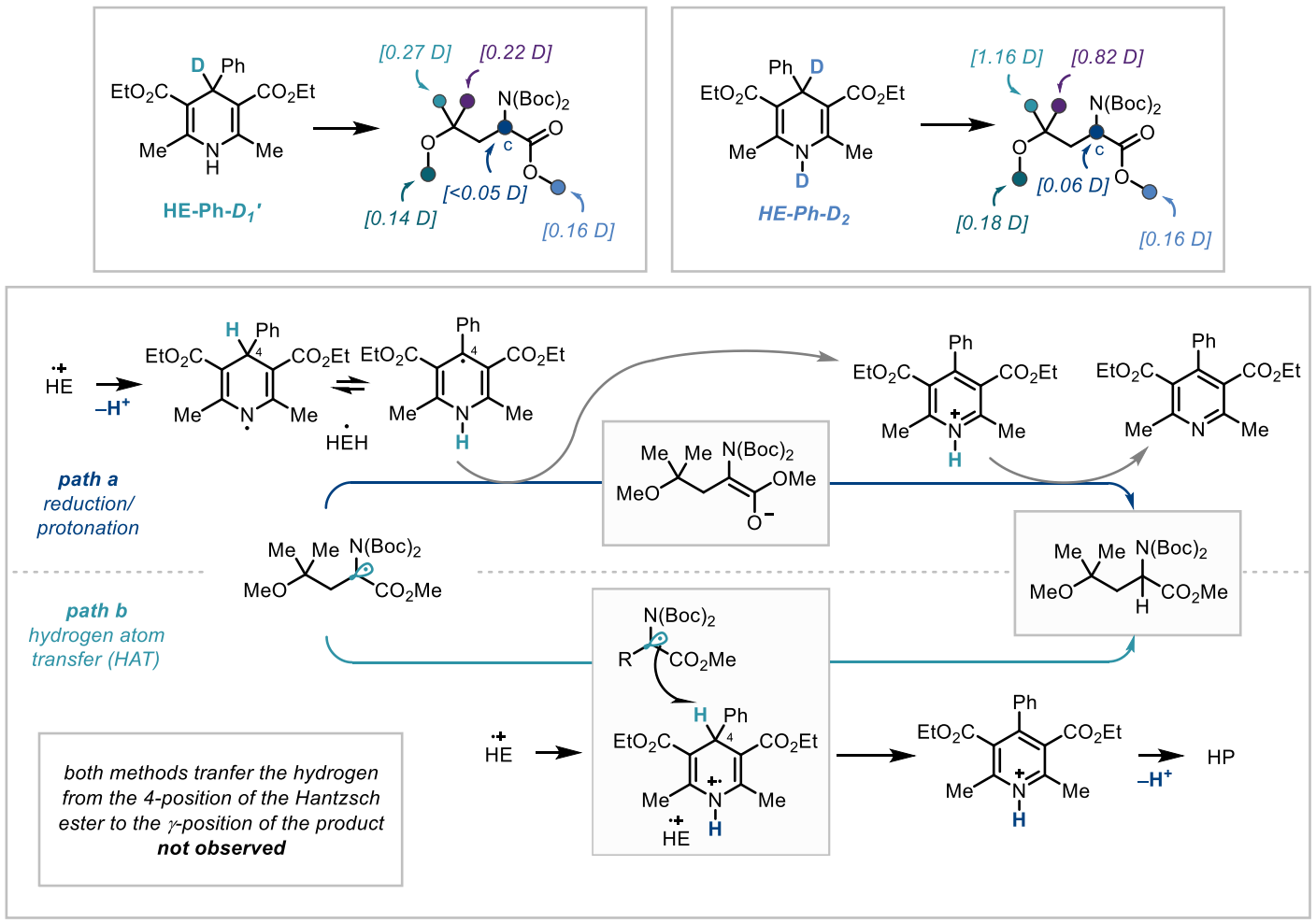

This is further reinforced by the experiment with HE-Ph- $D_{2}$-again showing no incorporation at the cposition - which rules out substantial cross-protonation. Following this, conducting the reaction in DMF- 
$d_{7}$ demonstrated no deuterium incorporation at any position, ruling out a termination via interaction with the solvent via HAT or some solvent induced protonation event. We suggest that this experiment along with the above analysis rules out path $b$ as a constructive method for radical termination. In the experiment using DMF- $d_{7}$ a fresh ampoule was used immediately and freshly distilled TMSCl was also used. For these reasons we also rule out solvent/reagent moisture as responsible for the lack of deuterium incorporation. For this reason, we also rule out path $a$.

Interestingly we did detect deuterium incorporation at multiple other positions across the molecule. For these reasons, and those outlined above with regards to traditional termination mechanisms, we suggest that path $c$ is in operation in this transformation. In this pathway, we suggest intramolecular HAT takes place due to the $\mathrm{sp}^{3}$-rich architecture to form any of the four alkyl radicals below. These intermediates could then undergo HAT with the HE(radical cation) intermediate to form the product and the Hantzsch pyridinium. We believe that this Hantzsch pyridinium then can donate a proton to start the cycle in the Lewis acid-assisted protic activation of the enol ether. This pathway is consistent with the deuterium incorporation experiments. We suggest that intermolecular HAT with another substrate is also less plausible. This is as we expect an intermolecular HAT to be more selective than the pseudo-random nature of the HAT observed in the experimental investigations.

\section{Figure S3. Alternative termination pathway}

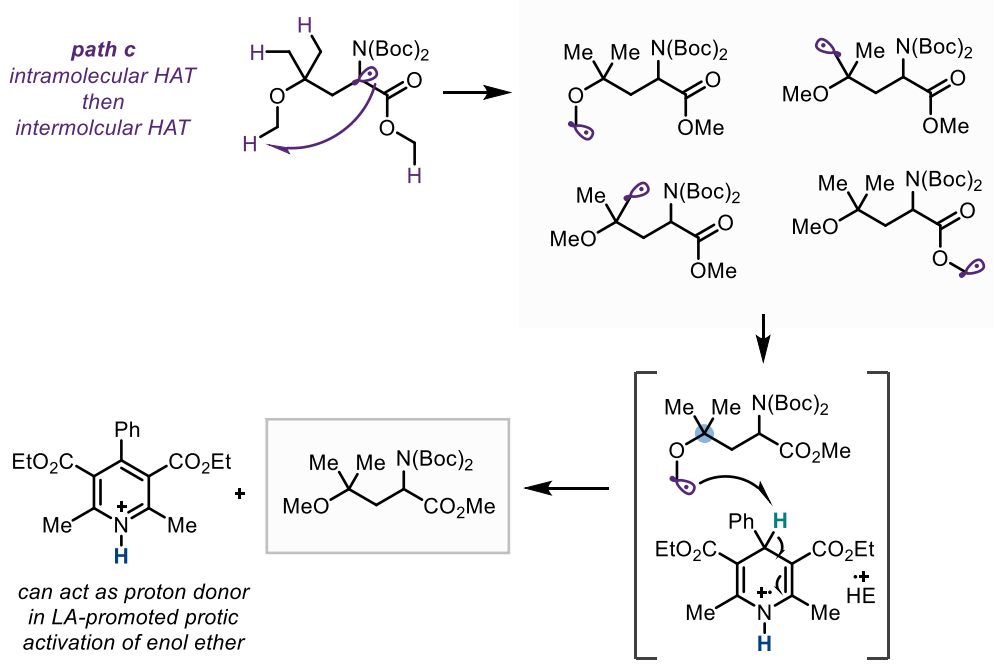




\section{Investigation into the source of the glutamate adduct $3 a a$}

\subsection{Further experiments}

During the optimization studies, we observed an unexepected protected glutamic acid by-product $\mathbf{3 a a}$ in the reaction mixture in modest yields. This was highlighted when using para-toluenesulfonic acid as an additive, as we observed no formation of $\mathbf{3 a}$ but a reasonable quantity of this gluatamate derivative $\mathbf{3 a a}$ (Scheme S4). The yields that follow in this section, are ${ }^{1} \mathrm{H}$ NMR yields with respect to 1,3,5trimethoxybenzene as an internal standard.

Scheme S4: Initial observations

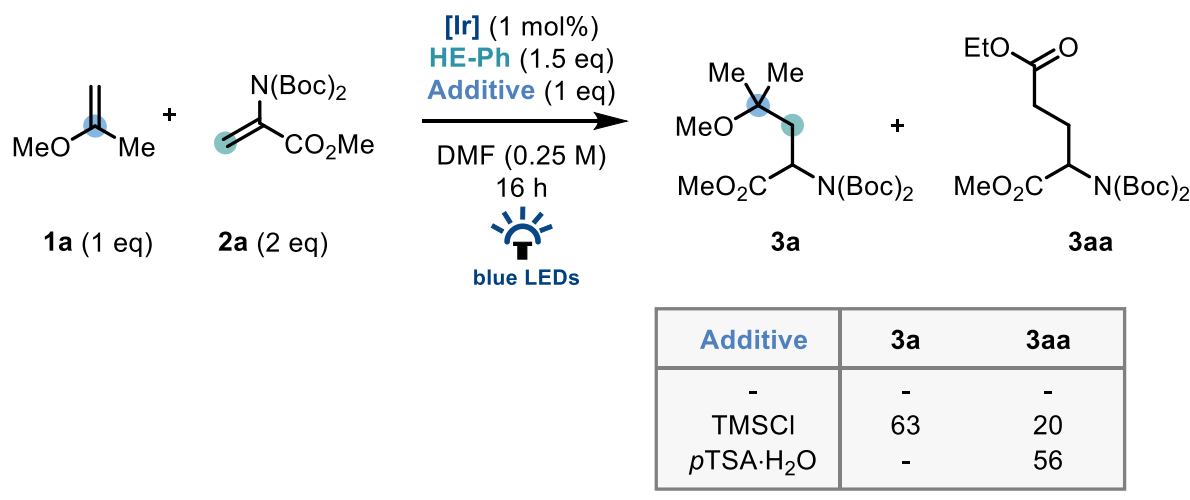

In order to investigate the source of this ethyl ester moiety in the by-product, we looked to the Hantzsch ester, and indeed when the methyl ester variant was employed as the reductant in the reaction methodology, the ester observed in this by-product was the methyl ester (3ab, Scheme S5). This result suggests that the ester moiety is most likely derived from the Hantzsch ester (or at the very least the methoxide section).

Scheme S5: Use of modified Hantzsch ester:

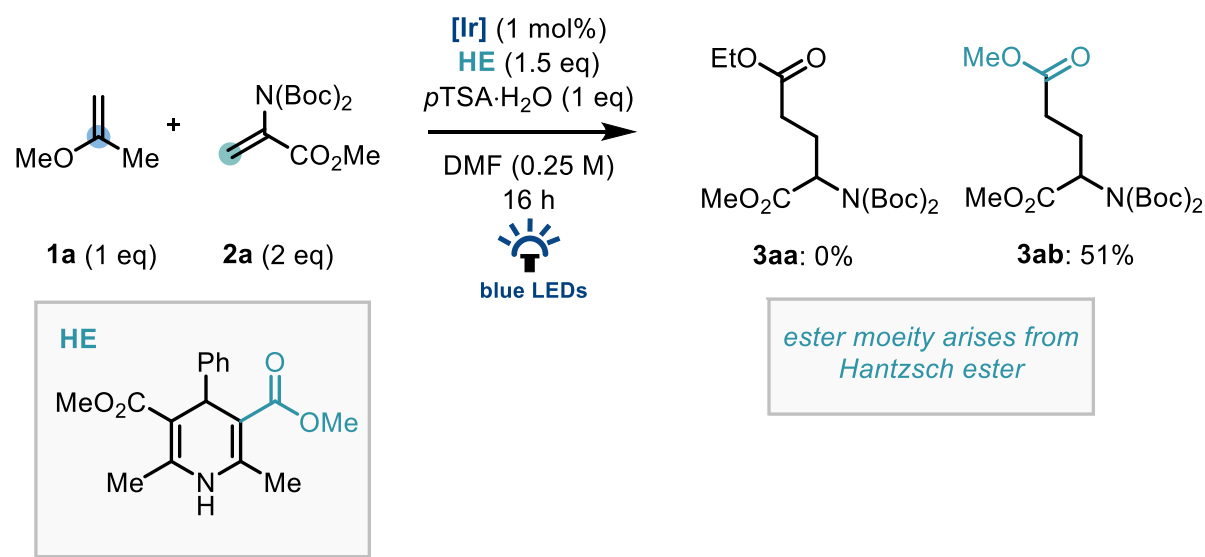

Following this we conducted control/deletion experiments in the hope of uncovering the pathway to this product. We observed that when using an alternative enol ether (benzyloxypropene $\mathbf{1 b}$, Scheme $\mathrm{S} 6$ ), the glutamate by-product was still formed. This result rules out the introduction of the extra $\mathrm{CH}_{2}$ unit by any participation of a methyl radical species, derived from a $\beta$-scission of a $\alpha$-oxy radical, in a mechanism similar to that discussed in a recent report by Doyle and co-workers. ${ }^{11}$ 
Scheme S6: Control experiment using benzyloxypropene

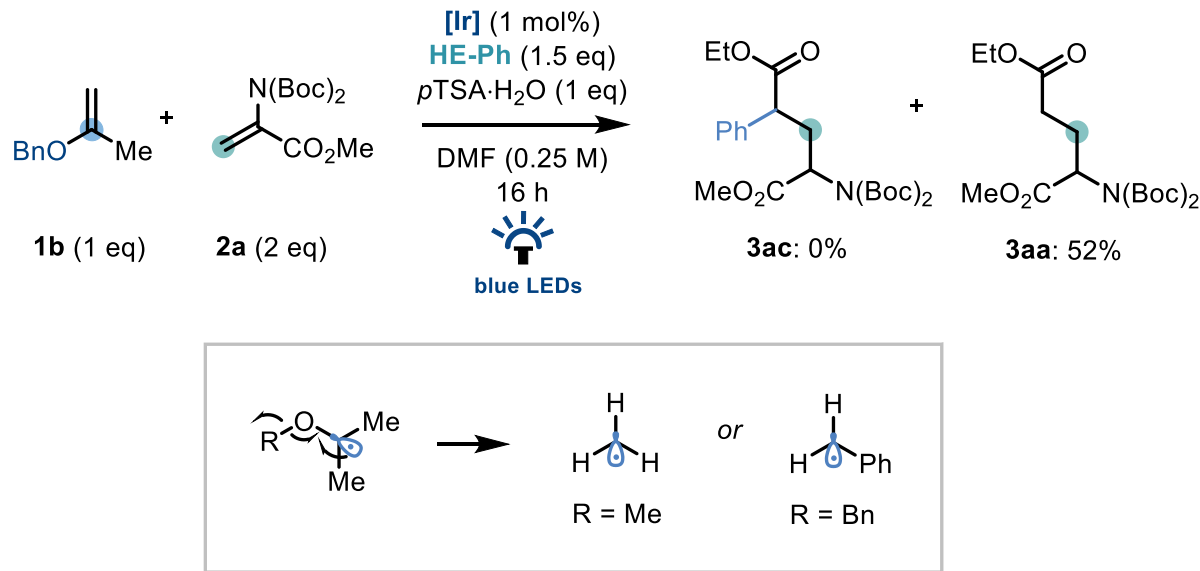

Furthermore, when we omitted the enol ether from the reaction mixture, the glutamate was still observed in good yields. Subsequent studies excluding the Hantzsch ester or light resulted in no formation of $\mathbf{3 a a}$. These investigations demonstrated that the glutamate is derived from a background reaction between the Hantzsch ester and DHA, facilitated by an acidic species and light (Scheme S7).

Scheme S7. Further control experiments

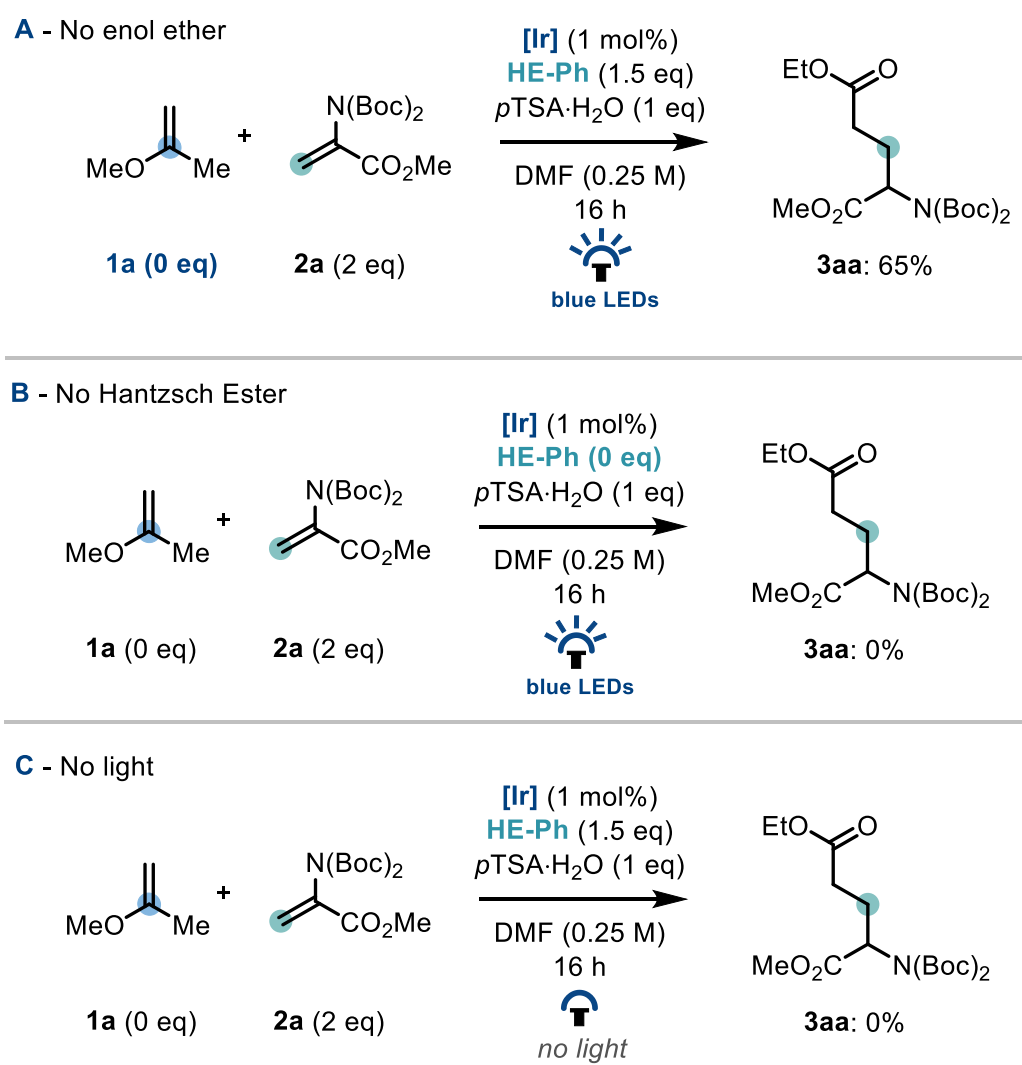

Next we looked to see whether Hantzsch ester degradation products could form under the reaction conditions (Scheme S8). As the glutamate product could be seen as a Michael addition between ethyl acetate and DHA, we explored employing both ethyl acetate and ethyl acetoacetate to the reaction conditions, in both a catalyzed and uncatalyzed system. In fact, we observed no conversion to $\mathbf{3 a a}$ using either EtOAc or ethyl acetoacetate. 
Scheme S8: Investigation into ethyl (aceto)acetate as a potential degradation product, and subsequent Michael addition
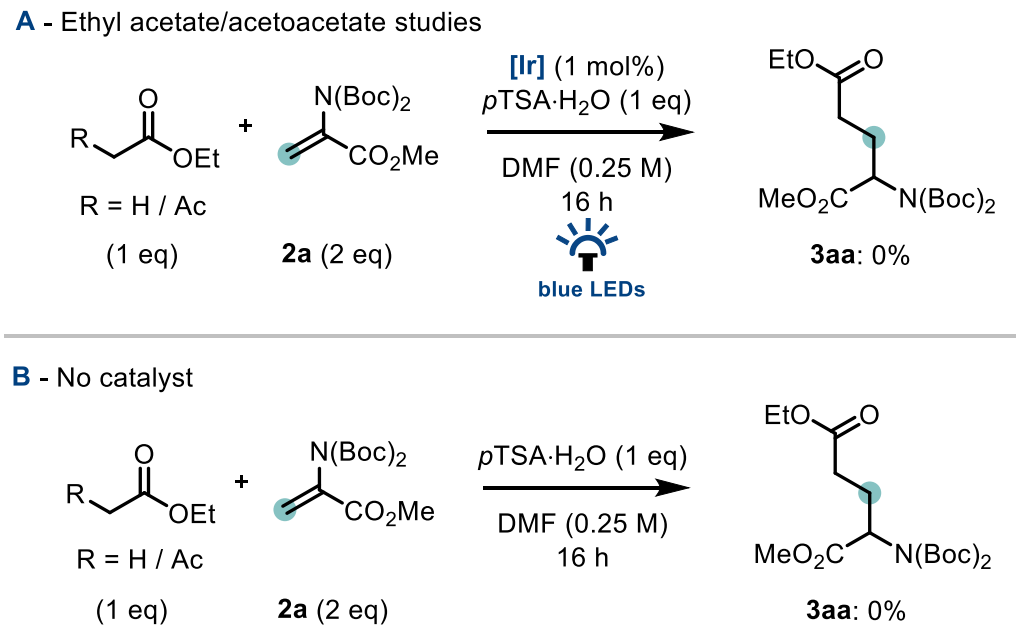

One other potential source of the methylene unit between the ester and the DHA substituents was from solvent. As this by-product was primarily formed in DMF screening studies, and due to its previous use as a $\mathrm{C} 1$ building block, we conducted deuterium incorporation studies using DMF- $d$. Product formation was indeed still observed, but interestingly no incorporation of deuterium was observed in any position.

Scheme S9: Studies into the origin of the one-carbon unit

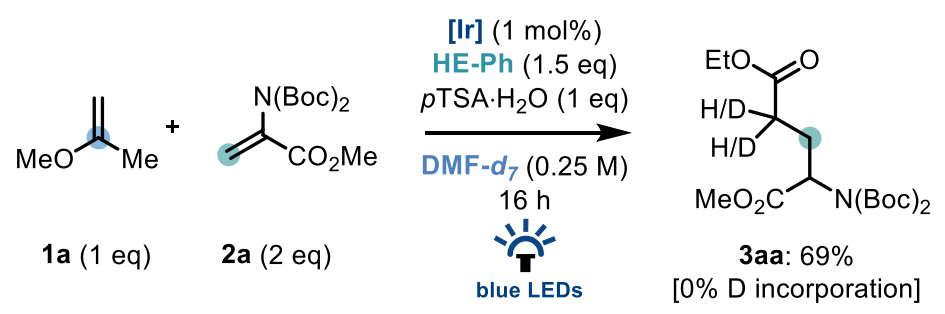

Drawing on these mechanistic investigations we have been able to rule out certain sources of this byproduct, however the exact pathway of the reaction between the Hantzsch ester and the DHA remains unclear. 


\subsection{Data and relevant spectra for glutamate adducts}

Data for 3aa<smiles>CCOC(=O)CCC(C(C)=O)N(CC)OC(=O)O</smiles>

Colourless oil. ${ }^{1} \mathbf{H}$ NMR (500 MHz, $\left.\mathrm{CDCl}_{3}\right) \delta 4.94(\mathrm{dd}, J=9.6,5.1 \mathrm{~Hz}, 1 \mathrm{H}), 4.13(\mathrm{q}, J=7.2 \mathrm{~Hz}, 2 \mathrm{H}), 3.72$ (s, 3H), $2.54-2.42(\mathrm{~m}, 1 \mathrm{H}), 2.42-2.32(\mathrm{~m}, 2 \mathrm{H}), 2.17$ (dddd, $J=13.7,9.4,7.7,5.9 \mathrm{~Hz}, 1 \mathrm{H}), 1.49(\mathrm{~s}, 17 \mathrm{H})$, $1.25(\mathrm{t}, J=7.1 \mathrm{~Hz}, 3 \mathrm{H}) .{ }^{13} \mathrm{C}$ NMR $\left(126 \mathrm{MHz}, \mathrm{CDCl}_{3}\right) \delta 172.8,171.0,152.1,83.4,60.6,57.5,52.4,31.0$, 28.1, 25.3, 14.3. HRMS (ESI): $\mathrm{m} / \mathrm{z}$ calculated for $\mathrm{C}_{18} \mathrm{H}_{31} \mathrm{O}_{8} \mathrm{~N}_{1}$ requires 412.1942 for $[\mathrm{M}+\mathrm{Na}]^{+}$, found 412.1942. Spectra on following page.

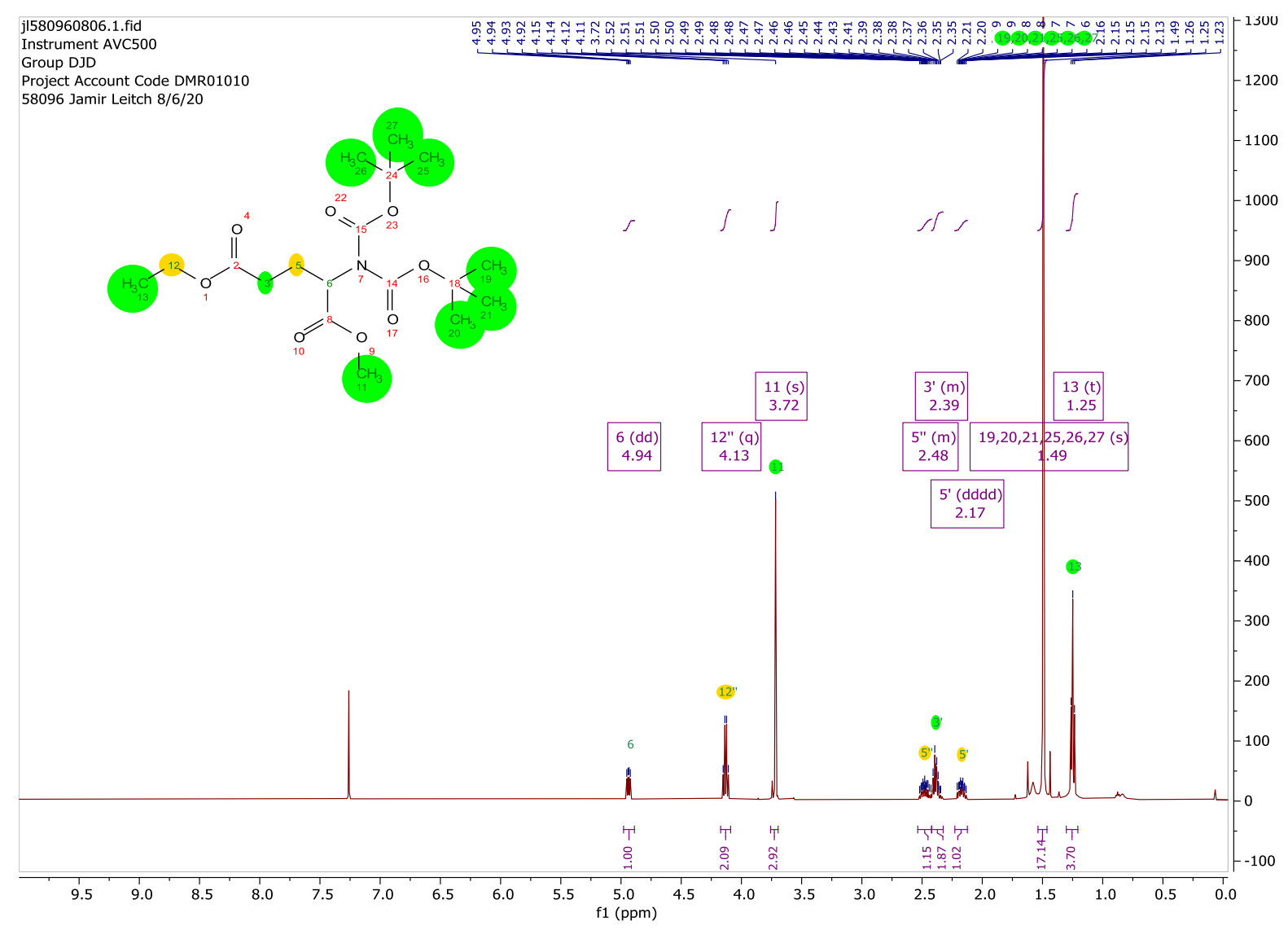




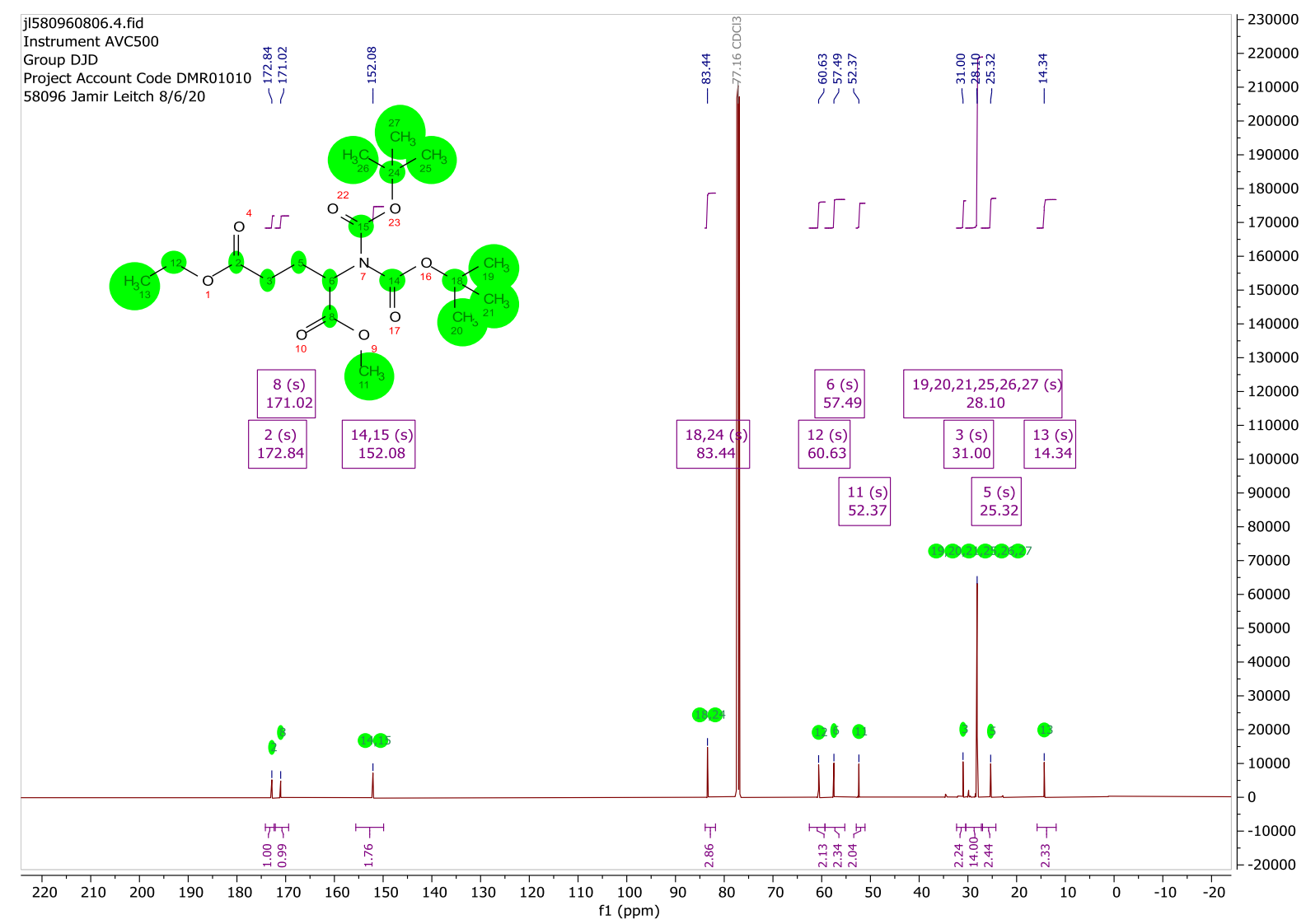

Data for 3ab

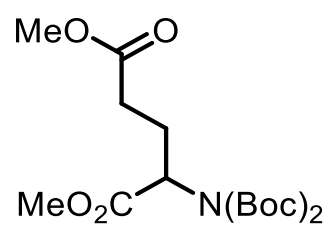

Colourless oil. ${ }^{1} \mathbf{H}$ NMR $\left(400 \mathrm{MHz}, \mathrm{CDCl}_{3}\right) \delta 4.94(\mathrm{dd}, J=9.6,4.8 \mathrm{~Hz}, 1 \mathrm{H}), 3.72(\mathrm{~s}, 3 \mathrm{H}), 3.67(\mathrm{~s}, 3 \mathrm{H}), 2.51$ $-2.45(\mathrm{~m}, 1 \mathrm{H}), 2.41(\mathrm{td}, J=8.3,7.6,4.5 \mathrm{~Hz}, 2 \mathrm{H}), 2.22-2.13(\mathrm{~m}, 1 \mathrm{H}), 1.49(\mathrm{~s}, 18 \mathrm{H}) .{ }^{13} \mathbf{C} \mathbf{~ N M R}(101 \mathrm{MHz}$, $\left.\mathrm{CDCl}_{3}\right) \delta 173.3,171.0,152.1,83.5,57.5,52.4,51.8,30.8,28.1,25.3$. Data is in line with literature precedent. ${ }^{14}$ 


\section{Computational Data}

\subsection{Calculating $\mathrm{p} K_{a}$ values}

\subsubsection{Computational methods}

Calculations were performed using Gaussian 16 A.03.15 Geometry optimisations on structures were performed using the hybrid-meta-generalised gradient (GGA) $\omega$ B97X-D functional in combination with the $6-31+\mathrm{G}(\mathrm{d}, \mathrm{p})$ basis set. ${ }^{16}$ The effect of dimethyl sulfoxide (DMSO) solvation was evaluated using the SMD implicit solvent model. ${ }^{17}$ Harmonic vibrational frequencies at the same level of theory were calculated to characterize stationary points as minima or transition state (TS) structures and to calculate the zero-point vibrational energy and thermal corrections. Free energies were evaluated at $25{ }^{\circ} \mathrm{C}$ and have been corrected to a standard liquid state of $1 \mathrm{~mol} / \mathrm{L}$. In all cases, vibrational entropies were obtained using a quasi-harmonic approximation, treating vibrational modes below $100 \mathrm{~cm}^{-1}$ as free rotors and as rigid rotors above this cutoff, as first proposed by Grimme ${ }^{18}$ and implemented in Python. ${ }^{19}$ Single point energies were evaluated with at the SMD(DMSO)- $\omega$ B97X-D/6-311++G(d,p) level of theory. Molecular graphics were generated with PyMol 4.50 .5

Ho and Schlegel have previously reported the use of the M06-2X and PBE functional respectively for calculations of $\mathrm{p} K_{\mathrm{a}}$ values for small organic molecules in DMSO, acetonitrile and water. ${ }^{20,21}$ Through our own benchmarking studies outlined below, we have found that the $\omega$ B97X-D functional gave values that were within 1.2 units of error for experimental measurements of comparable of molecules.

\subsubsection{Methodology}

The $\mathrm{p} K_{\mathrm{a}}$ was calculated following the protocol reported by Ho and Schlegel using eq. 1 - 3. . $^{21}$ However, based in our own benchmarking studies, we modified the methodology to use the SMD(DMSO)- $\omega$ B97X$\mathrm{D} / 6-311++\mathrm{G}(\mathrm{d}, \mathrm{p}) / / \mathrm{SMD}$ (DMSO)- $\omega \mathrm{B} 97 \mathrm{X}-\mathrm{D} / 6-31+\mathrm{G}(\mathrm{d}, \mathrm{p})$ level of theory, which gave values that were within 1.2 units of experimental measurements of comparable of molecules.

$$
\begin{gathered}
\mathbf{H A}_{\text {(solv) }} \underset{\text { dissociation }}{\stackrel{\Delta \mathrm{G}_{\text {solv }}}{\longrightarrow} \mathbf{A}_{\text {(solv) }}+\mathbf{H}_{(\text {(solv) }}} \\
p K a=\frac{\Delta G_{\text {solv }}}{R T \ln (10)}+X_{\text {corr }} \\
\Delta G_{\text {solv }}=G_{\text {solv }}\left(A^{-}\right)-G_{\text {solv }}(H A)+G_{\text {solv }}\left(H^{+}\right)+G_{g a s}\left(H^{+}\right)
\end{gathered}
$$

$\mathrm{R}$ is the gas constant $\left(1.987 \times 10^{-3} \mathrm{kcal} \mathrm{mol}^{-1} \mathrm{~K}^{-1}\right.$ and $\mathrm{T}$ is the temperature, taken as $\left.298 \mathrm{~K}\right) \cdot{ }^{17} \mathbf{G}_{\text {solv }}\left(\mathbf{A}^{-}\right)$and $\mathbf{G}_{\text {solv }}(\mathbf{H A})$ are obtained of computationally from the thermodynamic data of the conjugate base and acid in solution. From literature, $\mathbf{G}_{\text {solv }}\left(\mathbf{H}^{+}\right)=-273.3 \mathrm{kcal} \mathrm{mol}{ }^{-1}$ in DMSO. and $\mathbf{G}_{\text {gas }}\left(\mathbf{H}^{+}\right)=-6.3 \mathrm{kcal} \mathrm{mol}^{-1} \cdot{ }^{20} \mathrm{~A}$ correction of $\mathbf{X}_{\text {corr }}=1.4 \mathrm{kcal} \mathrm{mol}^{-1}$ is included as a standard state correction for the model. ${ }^{20}$ 


\subsubsection{Benchmarking $\mathrm{p} K_{a}$ values: Pyridinium and Hantzsch Ester}

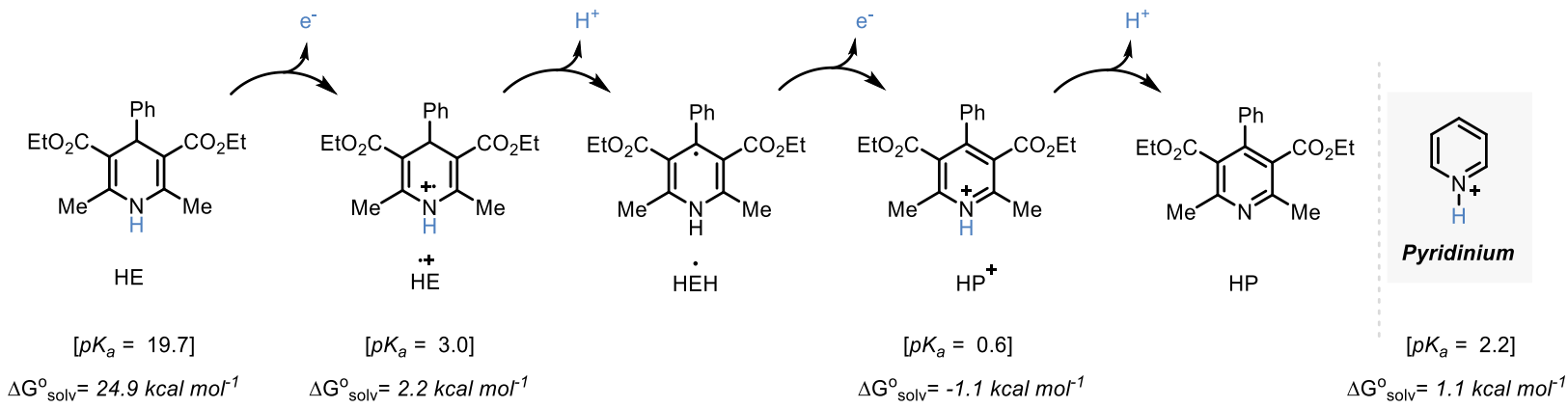

Scheme S10: $\mathbf{p} \boldsymbol{K}_{\mathbf{a}}$ 's Hantzsch ester (HE) and its intermediates and structure of pyridinium (from PPTS) for comparison. Absolute energies are presented in Table S2. Values were obtained at the SMD(DMSO)$\omega B 97 X-D / 6-311++G(d, p) / / S M D(D M S O)-\omega B 97 X-D / 6-31+G(d, p)$ level of theory.

Table S1. Benchmarking study of Hantzsch ester intermediates and pyridinium. Values in every column were obtained using the functional indicated and the $6-31+\mathrm{G}(\mathrm{d}, \mathrm{p})$ basis in conjunction with the SMD implicit solvation model to describe DMSO. Single point energies were obtained using each functional listed in the table alongside the $6-311++\mathrm{G}(\mathrm{d}, \mathrm{p})$ basis set and the SMD solvation model. Absolute energies are presented in Tables S3-S5.

\begin{tabular}{c|cccc}
\multicolumn{5}{c}{$\boldsymbol{p} \mathbf{K}_{\mathbf{a}}$ value } \\
\hline Species & $\boldsymbol{P B E}$ & $\mathbf{M 0 6 - 2 x}$ & $\boldsymbol{\omega B} 97 \boldsymbol{X}-\boldsymbol{D}$ & literature \\
Pyridinium & 0.2 & -1.5 & 2.2 & $3.4^{22}$ \\
HE & 15.8 & 15.7 & 19.7 & - \\
$H E \cdot+$ & 0.0 & -2.2 & 3.0 & - \\
$H P+$ & -1.0 & -3.8 & 0.6 & -
\end{tabular}

\subsection{Calculating redox potentials}

\subsubsection{Computational details}

Calculations were performed using Gaussian 16 A.03.15 Geometry optimisations on structures were performed using the PBE functional ${ }^{23}$ in conjunction with Grimme's dispersion correction with BeckeJohnson damping (D3BJ). ${ }^{24}$ This functional was used in combination with the split-valence $6-31+\mathrm{G}(\mathrm{d}, \mathrm{p})$ basis set. The effect of acetonitrile $(\mathrm{MeCN})$ solvation was evaluated using the SMD implicit solvent model. ${ }^{15}$ Single point energies were evaluated with at the SMD(MeCN)-PBE-D3BJ/6-311++G(d,p) level of theory. Entropy corrections were incorporated as described above.

This functional was chosen based on benchmark studies carried out within the group which demonstrated that the PBE functional leads to values within $0.05 \mathrm{~V}$ of those obtained using M06-2X functional (previously suggested by Neese and Pantazis) ${ }^{25}$ at a much lower computational cost. Furthermore, Hansen and co-workers have also recently reported the good performance of the PBE functional for reduction potential calculations of small molecules and organometallic species. ${ }^{26}$ 


\subsubsection{Methodology}

The reduction and oxidation potentials (Equations 4 and $\mathbf{5}$, respectively) were calculated using the Nernst equation (eq. 6), following the protocol reported by Nicewicz and coworkers. ${ }^{27}$ The values for the Faraday's constant $(\mathbf{F})$ and the reference electrode $\left(\mathbf{E}_{1 / 2}, \mathbf{S C E}\right)$ in $\mathrm{MeCN}$ are given as $23.061 \mathrm{kcal} / \mathrm{V}$ and $4.140 \mathrm{~V}$ respectively.

$$
\begin{gathered}
\mathbf{A}_{\text {(solv) }}+\mathbf{e}^{-} \underset{\text { reduction }}{\stackrel{\Delta \mathrm{G}^{\mathrm{o}}{ }_{1 / 2}}{\longrightarrow}} \mathbf{A}_{\text {(solv) }}^{-\cdot} \\
\mathbf{A}_{\text {(solv) }}^{-\cdot} \frac{\Delta \mathrm{G}^{\mathrm{o}}{ }_{1 / 2}}{\text { oxidation }} \mathbf{A}_{\text {(solv) }}+\mathbf{e}^{-} \\
E_{1 / 2}^{0}=-\frac{\left(\Delta G_{\text {reduced }}-\Delta G_{\text {oxidised }}\right)}{n_{e} F}-E_{1 / 2}^{0, S C E(M e C N)}=-\frac{\Delta G_{1 / 2}^{0}}{n_{e} F}
\end{gathered}
$$

\section{Oxidation Potentials of the Hantzsch Ester Intermediates}

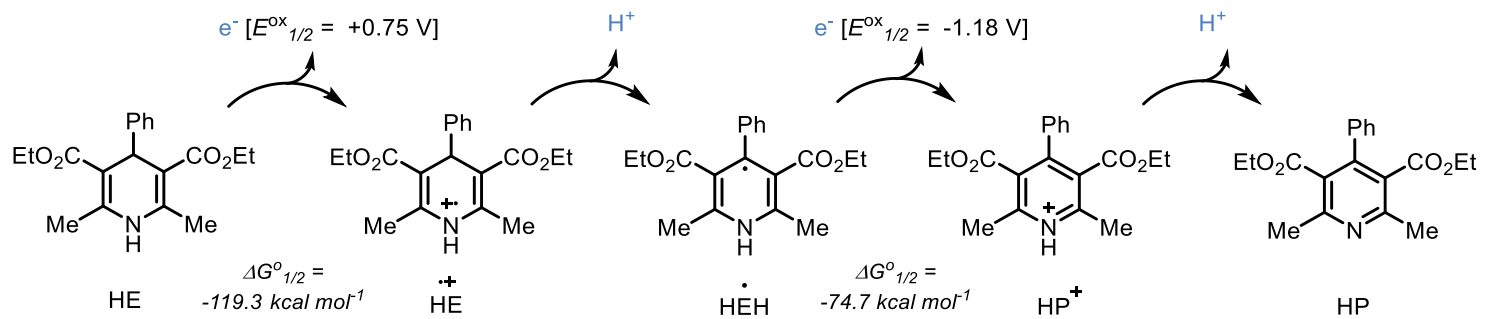

Scheme S11. Oxidation potentials of Hantzsch ester intermediates $H E$ and $H E H$. Free energies of reduction $\left(\Delta \mathbf{G}^{0}{ }_{1 / 2}\right)$, reported in kcal mol ${ }^{-1}$ and reduction potentials $\left(\Delta \mathbf{E}^{0}{ }_{1 / 2}\right)$, reported in volts $(\mathrm{V}) \cdot \Delta \mathbf{E}^{0_{1 / 2}}$ values were derived from corresponding $\Delta \mathbf{G}^{0_{1 / 2}}$ using Equations $\mathbf{5} \& \mathbf{6}$. Absolute energies are presented in Table S6. Values were obtained at the SMD(MeCN)/PBE-D3BJ/6-311++G(d,p)//SMD(MeCN)/PBE$\mathrm{D} 3 \mathrm{BJ} / 6-31+\mathrm{G}(\mathrm{d}, \mathrm{p})$ level of theory. 
Reduction Potential of DHA (2a)<smiles>C=C(N)C(=O)OC</smiles>

2a

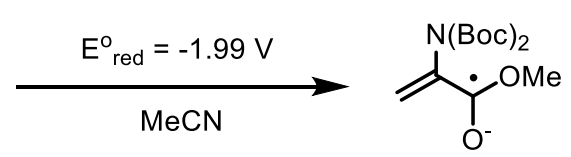

$\Delta G^{\circ}{ }_{1 / 2}=-56.0 \mathrm{kcal} \mathrm{mol}^{-1} \quad 2 \mathrm{a}-\boldsymbol{r}$

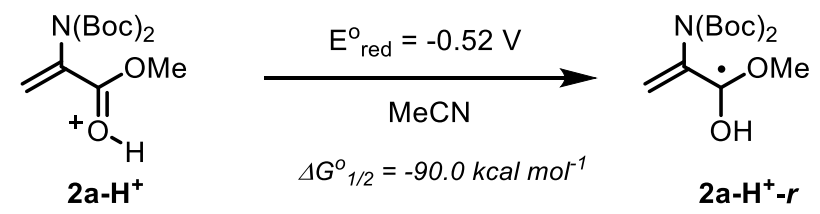

Scheme S12. Reduction potential of DHA (2a) in both its neutral and protonated forms. Free energies of reduction $\left(\Delta \mathbf{G}^{0}{ }_{1 / 2}\right)$, reported in kcal mol ${ }^{-1}$ and reduction potentials $\left(\Delta \mathbf{E}_{1 / 2}^{0}\right)$, reported in volts $(\mathrm{V}) \boldsymbol{\Delta} \mathbf{E}^{0_{1 / 2}}$ values were derived from corresponding $\Delta \mathbf{G}^{0_{1 / 2}}$ using Equations $4 \& \mathbf{6}$ described previously. Absolute energies are presented in Table S6. Values were obtained at the $\operatorname{SMD}(\mathrm{MeCN}) / \mathrm{PBE}-\mathrm{D} 3 \mathrm{BJ} / 6-$ $311++\mathrm{G}(\mathrm{d}, \mathrm{p}) / / \mathrm{SMD}(\mathrm{MeCN}) / \mathrm{PBE}-\mathrm{D} 3 \mathrm{BJ} / 6-31+\mathrm{G}(\mathrm{d}, \mathrm{p})$ level of theory.

\section{Reduction Potential of the Oxocarbenium Ion}<smiles>COC(C)=C(C)C</smiles>

S1

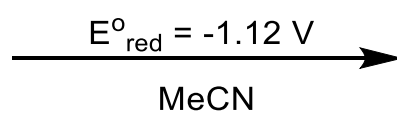

$\Delta G^{\circ}{ }_{1 / 2}=$ $-76.2 \mathrm{kcal} \mathrm{mol}^{-1}$<smiles>COC(C)C</smiles>

S1-r

Scheme S13. Reduction potential of the oxocarbenium species S1. Free energies of reduction $\left(\Delta \mathbf{G}^{0}{ }_{1 / 2}\right)$, reported in kcal mol-1 and reduction potentials $\left(\Delta \mathbf{E}_{1 / 2}^{0}\right)$, reported in volts $(\mathrm{V}) \Delta \mathbf{E}^{0_{1 / 2}}$ values were derived from corresponding $\Delta \mathbf{G}^{\mathbf{0}_{1 / 2}}$ using Equations $\mathbf{4} \& \mathbf{6}$ described previously. Absolute energies are presented in Table S6. Values were obtained at the SMD $(\mathrm{MeCN}) / \mathrm{PBE}-\mathrm{D} 3 \mathrm{BJ} / 6-311++\mathrm{G}(\mathrm{d}, \mathrm{p}) / / \mathrm{SMD}(\mathrm{MeCN}) / \mathrm{PBE}-$ $\mathrm{D} 3 \mathrm{BJ} / 6-31+\mathrm{G}(\mathrm{d}, \mathrm{p})$ level of theory.

\section{Oxidation Potential of the Enol Ether}<smiles>C=C(C)OC</smiles>

$1 \mathrm{a}$

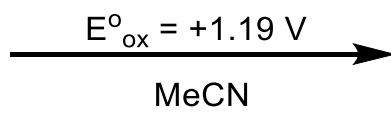

$\Delta G^{\circ}{ }_{1 / 2}=$ $-129.5 \mathrm{kcal} \mathrm{mol}^{-1}$<smiles>C=C(C)OC</smiles>

$1 a-r$

Scheme S14. Oxidation potential of enol ether 1a. Free energies of reduction $\left(\Delta \mathbf{G}^{0}{ }_{1 / 2}\right)$, reported in kcal mol-1 $^{-1}$ and reduction potentials $\left(\Delta \mathbf{E}_{1 / 2}^{0}\right)$, reported in volts (V) $\Delta \mathbf{E}^{0}{ }_{1 / 2}$ values were derived from corresponding $\Delta \mathbf{G}^{\mathbf{0}_{1 / 2}}$ using Equations $\mathbf{5} \& \mathbf{6}$ described previously. Absolute energies are presented in Table S6. Values were obtained at the SMD $(\mathrm{MeCN}) / \mathrm{PBE}-\mathrm{D} 3 \mathrm{BJ} / 6-311++\mathrm{G}(\mathrm{d}, \mathrm{p}) / / \mathrm{SMD}(\mathrm{MeCN}) / \mathrm{PBE}-$ $\mathrm{D} 3 \mathrm{BJ} / 6-31+\mathrm{G}(\mathrm{d}, \mathrm{p})$ level of theory. 


\subsection{Calculating the Electrophilicity Index ( $\omega)$}

\subsubsection{Methodology}

Calculations were performed using Gaussian 16 A.03.15 Geometry optimisations of all structures were calculated using the B3LYP functional in combination with the split-valence 6-311+G(d,p) basis set.28-30 The computational method was adapted from a previously reported approach by De Proft and coworkers, who found that Becke's functional gave efficient and accurate geometries of the radical intermediates. ${ }^{31}$

\subsubsection{Calculating the $\omega$-index}

The global electrophilicity index $(\boldsymbol{\omega})$ is defined as the "measure of energy of stabilisation when an electronic charge transfer occurs from the environment to the system". ${ }^{31,32}$ It can also be expressed in terms of the inherent electronic chemical potential $(\boldsymbol{\mu})$ and chemical hardness $(\boldsymbol{\eta})$ of the system, as shown in equation 7 .

$$
\omega=\frac{\mu^{2}}{2 \eta}
$$

Both chemical potential $(\boldsymbol{\mu})$ and chemical hardness $(\boldsymbol{\eta})$ are formally defined in terms of the partial derivative of the total energy to the number of electrons at a constant external potential. ${ }^{31}$ However, they can be approximated using vertical ionization energy (I) and electron affinity (A) parameters (equations $\mathbf{8}$ and $\mathbf{9}$ ).

$$
\begin{gathered}
\mu \approx-\frac{I+A}{2} \\
\eta \approx I-A
\end{gathered}
$$

These two terms can be feasibly calculated from the free energy of the radical species, as well as its corresponding anionic and cationic structures. Ionization energy $(\mathbf{I})$ is taken as the free energy difference between the cation and free radical species. Similarly, the electron affinity is calculated as the difference between the anion and radical structures. These values, as well as their applications in equations $\mathbf{8}$ and $\mathbf{9}$ are summarized in Table $\mathbf{S} 2$.

The electrophilicity index $(\omega)$ is placed on a scale with a range from 0 to 4.0, with a lower value indicating, a greater nucleophilic character of the free radical species. For example, De Proft and coworkers define a strong nucleophile with an index of 0 to 1.0 and a moderate nucleophile would typically have an index in the range from 1.0 to $1.5 .{ }^{31}$ Conversely, strong electrophiles have a $\omega$ value between 2.5 to 4.0 and anything between 1.5 to 2.5 is has weakly nucleophilic to electrophilic properties. ${ }^{32}$

Following the Giese-type addition of the $\alpha$-oxy radical into the electrophilic acceptor, the resulting captodative $\boldsymbol{\gamma}$-radical intermediate $(\boldsymbol{S} 2-\boldsymbol{r})$ had a measured $\omega$ index of 1.50 (Scheme S16). As a result, this free-radical species could be classified as either moderately or weakly nucleophilic that can plausibly abstract a hydrogen atom off the Hantzsch Ester intermediate (HE•+). However, this $\omega$-index was the highest when it was compared against values obtained for free radical intermediates, generated from proposed intramolecular 1,4 and 1,5 HAT events (S3-S5-r). Radical intermediate S5-r was the most nucleophilic species, with a $\omega$ index of 0.68 and would subsequently have an enhanced polarity match with the electrophilic HE intermediate. Hence, it was not possible to rule out an intramolecular 1,5 HAT event by S2-r to yield S5-r, followed by an intermolecular HAT with $\mathrm{HE} \bullet+$ as the termination step. This alternative mechanistic pathway is currently being investigated. 
<smiles>COC(=O)[C@H](CC(C)(C)OC)[Nb](=O)OC</smiles>

S2-r

$\omega=1.50$<smiles>CO[N+](=O)C(CC(C)(C)OC)C(=O)O[Tl]</smiles>

S3-r

$\omega=1.34$<smiles>COC(=O)C(CC(C)(C)OC)NC(C)(C)OC</smiles>

S4-r

$\omega=1.20$<smiles>COC(=O)C(CC(C)(C)O[Co])[N+](=O)[O-]</smiles>

S5-r

$\omega=0.68$

most electrophilic

most nucleophilic

Scheme S15. $\omega$ indices of potential free radical species that were obtained following the addition of the $\alpha$ oxy radical S1-r into $\mathbf{2 a}$.

Table S2. Free energies of the radical species $\left(\mathbf{E}_{\mathrm{rad}}\right)$, as well as their corresponding anionic $\left(\mathbf{E}_{\text {an }}\right)$ and cationic $\left(\mathbf{E}_{\text {cat }}\right)$ forms, calculated at the B3LYP/6-311++G(d,p) level of theory. The vertical ionization energy $(\mathbf{I})$, electron affinity $(\mathbf{A})$, chemical potential $(\boldsymbol{\mu})$ and hardness $(\boldsymbol{\eta})$, with the electrophilicity index $(\boldsymbol{\omega})$ were all derived from the former parameters using equations 7-9 described above.

\begin{tabular}{cccccccc||c}
\hline & $\mathbf{E}_{\text {rad }}$ & $\mathbf{E}_{\text {an }}$ & $\mathbf{E}_{\text {cat }}$ & $\mathbf{I}$ & $\mathbf{A}$ & $\boldsymbol{\mu}$ & $\boldsymbol{\eta}$ & $\boldsymbol{\omega}$ \\
\hline $\boldsymbol{S 2 - \boldsymbol { r }}$ & -1286.87751 & -1286.92403 & -1286.61379 & 7.1763 & 1.26566 & -4.22099 & 5.910660 & $\mathbf{1 . 5 0}$ \\
$\boldsymbol{S 3 - \boldsymbol { r }}$ & -1286.85271 & -1286.87998 & -1286.55148 & 8.1967 & 0.742312 & -4.46950 & 7.454378 & $\mathbf{1 . 3 4}$ \\
$\boldsymbol{S 4 - \boldsymbol { r }}$ & -1286.84713 & -1286.8611 & -1286.53876 & 8.3912 & 0.379982 & -4.38558 & 8.011208 & $\mathbf{1 . 2 0}$ \\
$\boldsymbol{S 5 - r}$ & -1286.86065 & -1286.83887 & -1286.5996 & 7.1041 & -0.592793 & -3.25566 & 7.696903 & $\mathbf{0 . 6 8}$
\end{tabular}

\subsection{Absolute Energies}

Table S3. Absolute energies for the Hantzsch Ester intermediates and pyridinium species. Units are given in Hartrees. $\mathbf{E}_{\mathrm{el}}$ : absolute electronic energies, $\mathbf{Z P E}$ : zero-point energy correction, $\mathbf{H}$ : enthalpy and $\mathbf{q h}$ $\mathbf{G}(\mathbf{T})$ : quasi-harmonic Gibbs energy (calculated at the SMD(DMSO)/ $\mathbf{\omega B} 97 \mathbf{X}-\mathbf{D} / \mathbf{6}-\mathbf{3 1 G +} \mathbf{( d , p )}$ level of theory). $\mathbf{E}_{\text {el }}{ }^{\text {high }}$ corresponds to the single point energies, which were calculated at the SMD(DMSO)/ $\mathbf{\omega B 9 7 X - D / 6 - 3 1 1 + G ( d , p ) ~ l e v e l ~ o f ~ t h e o r y . ~ T h e r m o c h e m i s t r y ~ w a s ~ e v a l u a t e d ~ a t ~} 298.15 \mathrm{~K}$ and $1 \mathrm{M}$.

\begin{tabular}{|c|c|c|c|c|c|c|}
\hline & Species & $E$ & $Z P E$ & $\boldsymbol{H}$ & $q h-G(T)$ & $E_{e l}{ }^{h i g h}$ \\
\hline \multirow{7}{*}{ 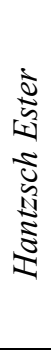 } & $H E$ & -1093.302755 & 0.394183 & -1092.88356 & -1092.955784 & -1093.521843 \\
\hline & HE-neg & -1092.803465 & 0.379683 & -1092.399145 & -1092.470551 & -1093.022516 \\
\hline & $H E \bullet+$ & -1093.107609 & 0.392866 & -1092.690189 & -1092.762248 & -1093.32573 \\
\hline & $H E H \bullet$ & -1092.666616 & 0.379743 & -1092.261355 & -1092.335379 & -1092.886241 \\
\hline & $H E H \bullet-n e g$ & -1092.648432 & 0.378091 & -1092.244711 & -1092.319906 & -1092.859819 \\
\hline & $H P+$ & -1092.556434 & 0.383537 & -1092.147762 & -1092.220566 & -1092.774831 \\
\hline & $H P$ & -1092.098513 & 0.369309 & -1091.704213 & -1091.776695 & -1092.316956 \\
\hline & Pyridine & -248.219586 & 0.089761 & -248.124633 & -248.1542 & -248.264529 \\
\hline & Pyridinium & -248.681417 & 0.103793 & -248.572323 & -248.602092 & -248.725755 \\
\hline
\end{tabular}


Table S4. Absolute energies for the Hantzsch Ester intermediates and pyridinium species. Units are given in Hartrees. E: absolute electronic energies, ZPE: zero-point energy correction, $\mathbf{H}$ : enthalpy and $\mathbf{q h}-\mathbf{G}(\mathbf{T})$ : quasi-harmonic Gibbs energy (calculated at the SMD(DMSO)/PBE-D3BJ/6-31G+(d,p) level of theory). $\mathbf{E}_{\text {el }}{ }^{\text {high }}$ corresponds to the single point energies, which were calculated at the SMD(DMSO)/PBE-D3BJ/6$\mathbf{3 1 1 + G ( d , p ) ~ l e v e l ~ o f ~ t h e o r y . ~ T h e r m o c h e m i s t r y ~ w a s ~ e v a l u a t e d ~ a t ~} 298.15 \mathrm{~K}$ and $1 \mathrm{M}$.

\begin{tabular}{|c|c|c|c|c|c|c|}
\hline & Species & $E$ & $Z P E$ & $H$ & $q h-G(T)$ & $\mathbf{E}_{\text {el }}^{\text {high }}$ \\
\hline \multirow{7}{*}{ 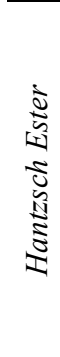 } & $\overline{H E}$ & -1092.370934 & 0.37836 & -1091.966234 & -1092.041499 & -1092.593399 \\
\hline & HE-neg & -1091.880334 & 0.364354 & -1091.489978 & -1091.564502 & -1092.102922 \\
\hline & $H E^{+}$ & -1092.182895 & 0.378393 & -1091.778250 & -1091.85400 & -1092.40394 \\
\hline & $H E H \bullet$ & -1091.745787 & 0.365029 & -1091.355178 & -1091.429139 & -1091.968385 \\
\hline & $H E H \bullet-n e g$ & -1091.725901 & 0.364224 & -1091.33543 & -1091.411262 & -1091.947074 \\
\hline & $H P^{+}$ & -1091.634218 & 0.36917 & -1091.239169 & -1091.313248 & -1091.855292 \\
\hline & $H P$ & -1091.179547 & 0.35519 & -1090.798537 & -1090.872563 & -1091.400844 \\
\hline & Pyridine & -248.00369 & 0.086386 & -247.91194 & -247.941782 & -248.049404 \\
\hline & Pyridinium & -248.460914 & 0.100124 & -248.355321 & -248.385352 & -248.506103 \\
\hline
\end{tabular}

Table S5. Absolute energies for the Hantzsch Ester intermediates and pyridinium species. Units are given in Hartrees. E: absolute electronic energies, ZPE: zero-point energy correction, $\mathbf{H}$ : enthalpy and $\mathbf{q h}-\mathbf{G}(\mathbf{T})$ : quasi-harmonic Gibbs energy (calculated at the SMD(DMSO)/M06-2X/6-31G+(d,p) level of theory). $\mathbf{E}_{\mathrm{e}}$ high corresponds to the single point energies, which were calculated at the SMD(DMSO)/ M06-2X/6$311+\mathbf{G}(\mathbf{d}, \mathbf{p})$ level of theory. Thermochemistry was evaluated at $298.15 \mathrm{~K}$ and $1 \mathrm{M}$.

\begin{tabular}{|c|c|c|c|c|c|c|}
\hline & Structure & $E$ & $Z P E$ & $\boldsymbol{H}$ & $q h-G(T)$ & $E_{e l} l^{h i g h}$ \\
\hline \multirow{7}{*}{ 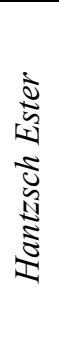 } & $H E$ & -1093.173717 & 0.393279 & -1092.755217 & -1092.827963 & -1093.424985 \\
\hline & HE-neg & -1092.682507 & 0.378857 & -1092.278708 & -1092 & -1092.934102 \\
\hline & $H E \bullet+$ & -1092.9706 & 0.391609 & -1092.553335 & -1092.628333 & -1093.220521 \\
\hline & $H E H_{\bullet}$ & -1092.541423 & 0.379372 & -1092.13656 & -1092. & -1092.785958 \\
\hline & $H E H \bullet-n e g$ & -1092.519436 & 0.377917 & -1092.116207 & -1092.190099 & -1092.769861 \\
\hline & $H P+$ & -1092.427596 & 0.383046 & -1092.019511 & -1092.092031 & -1092.676949 \\
\hline & $H P$ & -1091.978446 & 0.368834 & -1091.584584 & -1091.657161 & -1092.22833 \\
\hline & & -248.19 & 0.089568 & 48.100069 & -248.129667 & -248.246573 \\
\hline & Pyridinium & -248.649026 & 0.103438 & -248.540266 & -248.570067 & -248.699555 \\
\hline
\end{tabular}


Table S6. Absolute energies for the S1, 1a, the Hantzsch Ester intermediates (HE and $H E H \cdot)$ as well as their corresponding radical species. In the following table, E correspond to the absolute electronic energies, ZPE to the zero point energy correction, $\mathbf{H}$ to enthalpy and $\mathbf{q h}-\mathbf{G}(\mathbf{T})$ to the quasi-harmonic Gibbs energy (calculated at the SMD $(\mathrm{MeCN}) / \mathbf{P B E}-\mathbf{D 3} / \mathbf{6 - 3 1 + G ( d , p ) ~ l e v e l ~ o f ~ t h e o r y ) . ~} \mathbf{E}_{\mathrm{el}}{ }^{\text {high }}$ corresponds to the single point energies, which were calculated at the $\operatorname{SMD}(\mathrm{MeCN}) / \mathbf{P B E}-\mathbf{D} 3 / \mathbf{6}-\mathbf{3 1 1 + + G}(\mathbf{d}, \mathbf{p})$ level of theory. Thermochemistry was evaluated at $298.15 \mathrm{~K}$ and $1 \mathrm{M}$.

\begin{tabular}{|c|c|c|c|c|c|c|}
\hline & Species & $E$ & $Z P E$ & $\boldsymbol{H}$ & $q h-G(T)$ & $\mathbf{E}_{\text {el }}$ high \\
\hline & $2 a$ & -1052.35366 & 0.353308 & -1051.974124 & -1052.048548 & -1052.586531 \\
\hline & $2 a-r$ & -1052.437753 & 0.349161 & -1052.061963 & -1052.137073 & -1052.671376 \\
\hline & $2 a-H+$ & -1052.758768 & 0.365913 & -1052.366749 & -1052.440268 & -1052.990714 \\
\hline & $2 a-H^{+}-r$ & -1052.895277 & 0.361757 & -1052.506401 & -1052.582845 & -1052.128127 \\
\hline & S1 & -232.612037 & 0.120771 & -232.483278 & -232.518198 & -232.658769 \\
\hline & $S 1-r$ & -232.729923 & 0.119043 & -232.602925 & -232.638314 & -232.777959 \\
\hline & $1 a$ & -232.160485 & 0.109354 & -232.043794 & -232.077196 & -232.209072 \\
\hline & $1 a-r$ & -231.954528 & 0.108624 & -231.838121 & -231.873102 & -232.000786 \\
\hline \multirow{4}{*}{ 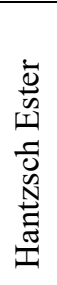 } & $H E$ & -1092.316916 & 0.377869 & -1091.91273 & -1091.987917 & -1092.597958 \\
\hline & $H E^{+}$. & -1092.127517 & 0.377756 & -1091.723504 & -1091.798963 & -1092.407397 \\
\hline & $H E H \cdot$ & -1091.691643 & 0.364595 & -1091.300581 & -1091.376553 & -1091.972206 \\
\hline & $H P^{+}$ & -1091.579661 & 0.368935 & -1091.184783 & -1091.259169 & -1091.858522 \\
\hline
\end{tabular}




\section{5. xyz coordinates}

2a

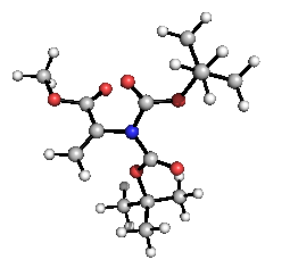

\begin{tabular}{|c|c|c|c|}
\hline & -1.389878 & 1.695566 & \\
\hline & -1.870952 & 2.667791 & 1.977974 \\
\hline & -1.612591 & 0.907143 & 2.579385 \\
\hline & -0.572689 & 1.458959 & 0.812329 \\
\hline & -0.247851 & 2.47172 & -0.244501 \\
\hline & -0.542055 & 3.729907 & 0.150066 \\
\hline & 0.220581 & 2.18184 & -1.344041 \\
\hline & -0.311678 & 4.763147 & -0.84405 \\
\hline & 0.751449 & 4.789066 & -1.128253 \\
\hline & 33448 & 4.58345 & -1.73 \\
\hline & 1964 & 5.701756 & -0.3 \\
\hline & -0.0 & 0.163769 & 0.58 \\
\hline & 34208 & -0.978328 & 78597 \\
\hline & 1.40 & 0.125818 & 0.519 \\
\hline & -1.990985 & -0.584364 & $4 \quad-0.178827$ \\
\hline & 1.84 & -0.952698 & -0.137221 \\
\hline & 9397 & 1.041858 & 0.994 \\
\hline & -0.504139 & -2.116472 & 20.68643 \\
\hline & 3.308841 & -1.256708 & -0.22926 \\
\hline & 3.31 & -2.591603 & -0.9 \\
\hline & 31 & -2.487739 & -1.9 \\
\hline & 663 & -2.927313 & -1.1 \\
\hline & 242 & -3.361814 & -0.400688 \\
\hline & 3.8 & -1.411229 & 1.17 \\
\hline & 196 & -0.4 & 1.71 \\
\hline & 345 & -2.1 & 1.75 \\
\hline & 744 & -1.778547 & 1.09 \\
\hline & 352 & -0.168451 & -1.0 \\
\hline & 52 & -0.472352 & -1.23 \\
\hline & 72 & -0.044568 & -2.02 \\
\hline & 207 & 0.79588 & -0.521 \\
\hline & -3.1 & -1.537744 & $4-0$ \\
\hline C & 34855 & -0.631791 & -0.8 \\
\hline & -3.92327 & -0.19729 & -1.852103 \\
\hline & -5.150312 & -1.222418 & $8 \quad-1.051794$ \\
\hline $\mathrm{H}$ & -4.467467 & 0.186803 & -0.18758 \\
\hline & -2.767327 & -2.637821 & -1.316508 \\
\hline & -1.980275 & -3.293279 & -0.916986 \\
\hline & -3.661526 & -3.248392 & -1.524759 \\
\hline & -2.423415 & -2.198528 & -2.267509 \\
\hline & -3.534663 & -2.081828 & 1.051094 \\
\hline & 21038 & -1.255539 & 1.756868 \\
\hline & -4.467903 & -2.659437 & 0.947379 \\
\hline & -2.76152 & -2.744635 & 1.465688 \\
\hline
\end{tabular}




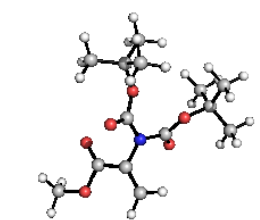

$\begin{array}{llll}\text { C } & 2.171465 & 1.913938 & 1.603176 \\ \text { H } & 3.141859 & 2.391766 & 1.750009 \\ \text { H } & 1.315343 & 2.275668 & 2.180027 \\ \text { C } & 1.984091 & 0.94684 & 0.591669 \\ \mathrm{C} & 2.981317 & 0.366342 & -0.250891 \\ \text { O } & 2.810416 & -0.481388 & -1.171989 \\ \text { O } & 4.272463 & 0.830073 & 0.067592 \\ \mathrm{C} & 5.320696 & 0.29982 & -0.753544 \\ \mathrm{H} & 6.251259 & 0.748881 & -0.374064 \\ \mathrm{H} & 5.383568 & -0.799818 & -0.677538 \\ \mathrm{H} & 5.186134 & 0.572841 & -1.815257 \\ \mathrm{~N} & 0.646204 & 0.459227 & 0.359709 \\ \mathrm{C} & -0.325369 & 1.357375 & -0.136011 \\ \mathrm{O} & -0.057091 & 2.312901 & -0.864196 \\ \mathrm{O} & -1.539999 & 1.073206 & 0.386911 \\ \mathrm{C} & 0.38218 & -0.907557 & 0.59397 \\ \mathrm{O} & 0.993108 & -1.579771 & 1.425381 \\ \mathrm{O} & -0.562348 & -1.36153 & -0.258847 \\ \mathrm{C} & -1.166238 & -2.710495 & -0.082161 \\ \mathrm{C} & -2.767858 & 1.744509 & -0.125915 \\ \mathrm{C} & -2.747296 & 3.22154 & 0.276038 \\ \mathrm{H} & -1.939817 & 3.763273 & -0.237143 \\ \mathrm{H} & -3.711637 & 3.683738 & 0.006197 \\ \mathrm{H} & -2.610976 & 3.321821 & 1.365825 \\ \mathrm{C} & -3.88185 & 0.995785 & 0.608825 \\ \mathrm{H} & -4.857905 & 1.430101 & 0.338511 \\ \mathrm{H} & -3.885469 & -0.071265 & 0.332348 \\ \mathrm{H} & -3.754068 & 1.078728 & 1.700737 \\ \mathrm{C} & -2.890379 & 1.546692 & -1.638893 \\ \mathrm{H} & -3.874685 & 1.919246 & -1.96785 \\ \mathrm{H} & -2.110108 & 2.095611 & -2.18552 \\ \mathrm{H} & -2.825321 & 0.476659 & -1.895682 \\ \mathrm{C} & -0.115431 & -3.786829 & -0.366771 \\ \mathrm{H} & 0.679138 & -3.779776 & 0.392949 \\ \mathrm{H} & -0.601673 & -4.776795 & -0.363671 \\ \mathrm{H} & 0.337142 & -3.628903 & -1.359921 \\ \mathrm{C} & -1.777514 & -2.837919 & 1.315625 \\ \mathrm{H} & -2.476559 & -2.007545 & 1.508797 \\ \mathrm{H} & -2.342932 & -3.782804 & 1.373743 \\ \mathrm{H} & -1.004341 & -2.846078 & 2.09749 \\ \mathrm{C} & -2.259555 & -2.722302 & -1.152911 \\ \mathrm{H} & -1.826557 & -2.56569 & -2.154662 \\ \mathrm{H} & -2.774208 & -3.696675 & -1.144061 \\ \mathrm{H} & -3.00356 & -1.931948 & -0.961292\end{array}$




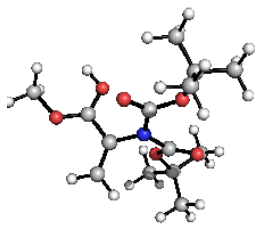

\begin{tabular}{|c|c|c|c|}
\hline & -1.317247 & 1.671743 & 1.867032 \\
\hline & -1.750882 & 2.662837 & 2.016622 \\
\hline & -1.575779 & 0.874982 & 2.569186 \\
\hline & -0.519241 & 1.408793 & 0.810353 \\
\hline & -0.166741 & 2.463784 & -0.143308 \\
\hline & -0.226547 & 3.691109 & 0.260333 \\
\hline & 0.156487 & 2.098666 & -1.353433 \\
\hline & -0.018966 & 4.80205 & -0.685928 \\
\hline & 1.011821 & 4.767417 & -1.070637 \\
\hline & -0.773143 & 4.74435 & -1.4 \\
\hline & -0.167068 & 5.702047 & -0.079382 \\
\hline & -0.010773 & 0.111236 & 0.51 \\
\hline & -0.905094 & -0.99893 & 549 \\
\hline$C$ & 1.403491 & 0.054650 & 0.4112 \\
\hline U & -2.057599 & -0.5276 & -0.1 \\
\hline & 1.83 & -1.124163 & -0.6 \\
\hline 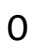 & $2.06083 \quad 1$ & 1.0687070 & 0.666385 \\
\hline 0 & -0.606433 & -2.153063 & $3 \quad 0.586074$ \\
\hline & 3.31269 & -1.394378 & -0.169048 \\
\hline & 3.31 & -2.852205 & -0.624361 \\
\hline & 2.76 & -2.968447 & -1.572296 \\
\hline & 4.355236 & -3.179295 & -0.781893 \\
\hline & 2.85 & -3.502199 & 0.137444 \\
\hline 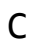 & 4.002707 & -1.234651 & $1.1 \varepsilon$ \\
\hline$H$ & 4.01 & -0.18 & 1.51 \\
\hline$H$ & 3.56 & -1.85 & 1.947791 \\
\hline$H$ & 5.0 & -1.57 & \\
\hline$C$ & 3.8 & -0.474 & \\
\hline & 4.9 & -0.77 & -1 \\
\hline & 3.29 & -0.567241 & -2.1 \\
\hline & 3.88 & 0.577249 & -0.92 \\
\hline & -3.2 & -1.42 & a. 30195 \\
\hline 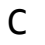 & -4.3 & -0.441197 & -0.795701 \\
\hline & -4.0 & 0.00 & -1.756577 \\
\hline & -5.2 & -0.9 & -0.9 \\
\hline H & -4.491837 & 0.362587 & -0.05972 \\
\hline C & -2.97 & -2.5 & -1.34459 \\
\hline $\mathrm{H}$ & -2.209307 & -3.207369 & -0.99559 \\
\hline $\mathrm{H}$ & -3.904818 & -3.059491 & -1.540734 \\
\hline $\mathrm{H}$ & -2.643629 & -2.044225 & -2.29194 \\
\hline C & -3.630163 & -1.991023 & 1.067878 \\
\hline $\mathrm{H}$ & -3.754106 & -1.180975 & $5 \quad 1.805338$ \\
\hline & -4.591368 & -2.52341 & 0.980354 \\
\hline & -2.874373 & -2.701614 & $4 \quad 1.432386$ \\
\hline & 0.437529 & 2.849128 & -1.93727 \\
\hline
\end{tabular}




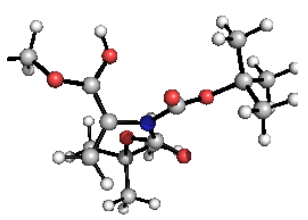

\begin{tabular}{|c|c|c|c|}
\hline & -1.439474 & 1.393452 & \\
\hline & -2.120125 & 2.214594 & \\
\hline & -1.311669 & $0.5861 \quad 2$ & .791169 \\
\hline & -0.763138 & 1.345113 & 0.850672 \\
\hline & -0.803632 & 2.338064 & -0.137563 \\
\hline & -1.355904 & 3.541034 & 0.13891 \\
\hline & 36632 & 2.123008 & -1.356578 \\
\hline & 29195 & 4.104611 & \\
\hline & 55539 & & \\
\hline & -2.9 & 3.36196 & -1.189268 \\
\hline & -2.7 & 4.966666 & -0.407416 \\
\hline & 0.06 & 0.195687 & 0.553797 \\
\hline & -0.5 & -1.074359 & 0.350206 \\
\hline & $971 €$ & $0.403657 \quad 0$ & .513141 \\
\hline & 57814 & -0.895914 & -0.1745 \\
\hline & 2.06 & -0.552223 & -0.20368 \\
\hline & 1.98 & 1.387697 & 1.035166 \\
\hline & -0.008256 & -2.141324 & 0.635881 \\
\hline & 3.560518 & -0.621873 & -0.275586 \\
\hline & $3.7 \varepsilon$ & -1.89709 & -1.089464 \\
\hline & 3.31 & -1.812261 & -2.084707 \\
\hline & 4.86 & -2.061276 & -1.224256 \\
\hline & 3.3 & -2.771797 & -0.571361 \\
\hline & 4.1 & -0.763697 & 1.132134 \\
\hline & 3.9 & 0.1504 & 72604 \\
\hline & 3.6 & -1.613926 & 1.658136 \\
\hline & 5.2 & -0.960448 & 1.051 \\
\hline & 4.0 & 0.6 & $-1 . e$ \\
\hline & & 0.4 & -1 \\
\hline & & 0.7 & $-2 . e$ \\
\hline & $3.9<-r a$ & 1.525254 & -0.442221 \\
\hline & $-2.7>-7$ & -2.035085 & -0.27301 \\
\hline & -3.5 & -1.3 & -0.8044 \\
\hline & -3 & -0.8 & -1.78015 \\
\hline & -4.7 & 7504 & -0.5 \\
\hline & -4.3 & -0.571178 & -0.099603 \\
\hline$C$ & -2.2 & -3.06701 & -1.273623 \\
\hline & -1.3 & -3.56704 & -0.900694 \\
\hline & -2.990581 & -3.828372 & -1.442205 \\
\hline & -1.985688 & -2.586903 & -2.240432 \\
\hline & -2.980266 & -2.62355 & 1.117181 \\
\hline & -3.278517 & -1.831635 & 1.824201 \\
\hline & -3.803671 & -3.35382 & 1.052845 \\
\hline & -2.089804 & -3.138064 & 1.506256 \\
\hline & 0.029283 & 2.981581 & -1.753569 \\
\hline
\end{tabular}




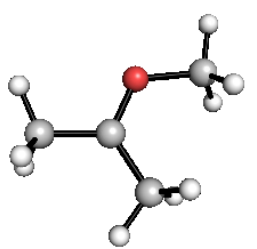
C 0.470664
$\begin{array}{ll}-0.001104 & 0.000115\end{array}$
C 0.360323
1.466738
0.000042
H 1.353006
1.932524
$-0.000096$
H -0.215583
1.79951
$-0.884741$
H -0.215859
1.799689
0.88446
$0 \quad-0.567932$
$-0.767475$
0.000029
C -1.928683
$-0.204238$
$-0.000033$
H -2.585345
$-1.080942$
$-0.000584$
H -2.067957
0.398692
0.908321
H $\quad-2.067499$
0.399528
$-0.907912$
C 1.764802
$-0.696881$
0.000014
H 2.340741
$-0.354147$
H 2.341606
$-0.353247$
$-0.880247$
H 1.657708
$-1.788894$
0.87929
0.000448

S1-r

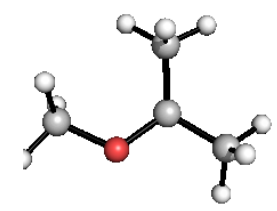
C $\quad 0.46892 \quad 0.008257 \quad-0.222137$
C $0.429196 \quad 1.482966 \quad 0.039303$
H $\quad 0.397401 \quad 1.708356 \quad 1.131643$
H $1.34247 \quad 1.951638-0.36108$
H $\quad-0.437277 \quad 1.986418 \quad-0.420445$
$\begin{array}{llll}0 & -0.628876 & -0.768085 & 0.12448\end{array}$
$\begin{array}{llll}\text { C } & -1.926522 & -0.174154 & -0.036518\end{array}$
$\begin{array}{llll}H & -2.653535 & -0.971924 & 0.175237\end{array}$
$\begin{array}{llll}H & -2.087443 & 0.65852 & 0.670356\end{array}$
$\begin{array}{llll}H & -2.070723 & 0.187164 & -1.071657\end{array}$
C $\quad \begin{array}{llll}.742235 & -0.742544 & -0.000186\end{array}$
H $2.583169 \quad-0.241028 \quad-0.506235$
$\begin{array}{llll}H & 2.002282 & -0.80523 & 1.08228\end{array}$
H $1.671688-1.77639 \quad-0.378711$ 
<smiles>COC(OC(C)O)O[Ge]([O-])(O)O</smiles>
C $\quad 0.507465$
$-1.426386$
$-0.026983$
H $\quad-0.09404$
$-1.819668$
0.810465
H 1.524587
$-1.835177$
0.060308
H 0.057749
$-1.808664$
$-0.960496$
C 0.564446
0.075573
$-0.020982$
C 1.712703
0.787283
0.075953
H 2.673418
0.271888
0.133555
H 1.702008
1.881198
0.077057
$\begin{array}{llll}0 & -0.612204 & 0.778883 & -0.17166\end{array}$
$\begin{array}{llll}\text { C } & -1.852425 & 0.100941 & 0.098719\end{array}$
H $\quad-1.908081 \quad-0.234695 \quad 1.149564$
H $\begin{array}{llll}H & -2.63921 & 0.847483 & -0.082122\end{array}$
H $\quad-2.011932 \quad-0.757886-0.575294$

1a-r

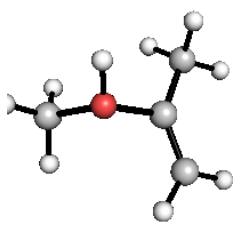
$\begin{array}{llll}C & 1.77256 & -0.659001 & -0.000037\end{array}$
$\begin{array}{llll}\text { H } & 1.636218 & -1.748008 & -0.000094\end{array}$
$\begin{array}{llll}H & 2.358986 & -0.344086 & 0.882901\end{array}$
H $2.359006 \quad-0.343961 \quad-0.882909$
C $0.477993 \quad 0.055032 \quad-0.000003$
C $0.404781 \quad 1.476026 \quad 0.000013$
H $1.342993 \quad 2.035768 \quad-0.000228$
$\begin{array}{llll}H & -0.539631 & 2.023853 & 0.000374\end{array}$
$\begin{array}{llll}0 & -0.581681 & -0.712667 & 0.000131\end{array}$
C $\quad-1.943175 \quad-0.163224 \quad-0.000094$
$\begin{array}{llll}H & -2.092738 & 0.436297 & -0.909295\end{array}$
H $-2.591002 \quad-1.046809 \quad-0.000758$
H $\quad-2.09334 \quad 0.435285 \quad 0.909694$ 


\section{HE (DMSO)}

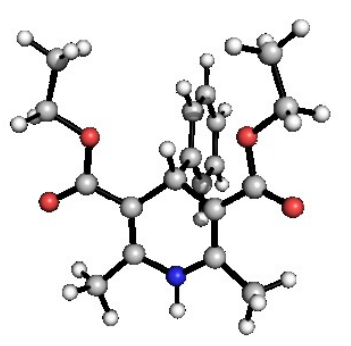

$\begin{array}{llll}0 & 2.33161 & -0.880332 & -1.020351\end{array}$

$\begin{array}{llll}0 & -2.331812 & -0.877052 & -1.022307\end{array}$

$\begin{array}{llll}0 & 3.631658 & 0.989869 & -0.865565\end{array}$

$\begin{array}{llll}0 & -3.629717 & 0.994549 & -0.866051\end{array}$

$\begin{array}{llll}\mathrm{N} & 0.002121 & 3.01811 & 0.228513\end{array}$

C $0.000434 \quad 0.237022 \quad-0.235112$

$\begin{array}{llll}\text { C } & 1.2618 & 1.093351 & -0.360146\end{array}$

$\begin{array}{llll}\text { C } & -1.259753 & 1.095016 & -0.360837\end{array}$

$\begin{array}{llll}\text { C } & 1.227717 & 2.432401 & -0.038471\end{array}$

$\begin{array}{llll}\text { C } & -1.224082 & 2.434047 & -0.039272\end{array}$

C $2.392588 \quad 3.37741 \quad 0.032833$

$\begin{array}{llll}\text { C } & -2.387776 & 3.380576 & 0.031319\end{array}$

$\begin{array}{llll}\text { C } & 2.519686 & 0.451514 & -0.758917\end{array}$

$\begin{array}{llll}C & -2.518356 & 0.454836 & -0.759937\end{array}$

C $3.511912-1.630364-1.416283$

C $\quad-3.513145 \quad-1.625655 \quad-1.417868$

C $3.095998-3.079763-1.574017$

C $\quad-3.099637-3.076005-1.573265$

H $\quad 0.000178 \quad-0.497284-1.053838$

H $0.002697 \quad 4.009304 \quad 0.471602$

H $2.096756 \quad 4.314673 \quad 0.531464$

H $3.23778 \quad 2.927937 \quad 0.571893$

H $2.757031 \quad 3.625556 \quad-0.978308$

$\begin{array}{llll}H & -2.090339 & 4.3185 & 0.527752\end{array}$

$\begin{array}{llll}H & -3.232916 & 2.933206 & 0.572272\end{array}$

$\begin{array}{llll}H & -2.753117 & 3.626987 & -0.979897\end{array}$

H $3.902483-1.209954-2.359187$

H $4.287639-1.508583-0.641326$

H $\quad-3.902348 \quad-1.205957 \quad-2.361671$

H $\quad-4.289184-1.501387-0.643639$

H $3.969669-3.678047-1.882277$

H $2.314824 \quad-3.190649-2.344389$

H $2.715519-3.490481-0.62425$

H $\quad-3.974111-3.673186-1.881373$

H $\quad-2.318055-3.189362-2.342864$

$\mathrm{H} \quad-2.720616 \quad-3.486031 \quad-0.622614$

C $\quad-0.000612 \quad-0.569124 \quad 1.069951$

$\begin{array}{llll}\text { C } & 0.000047 & 0.080796 & 2.320712\end{array}$

$\begin{array}{llll}C & -0.002445 & -1.976299 & 1.042719\end{array}$

C $\quad-0.001148 \quad-0.65766 \quad 3.514535$

H $0.001536 \quad 1.175336 \quad 2.365318$

$\begin{array}{llll}C & -0.003687 & -2.720178 & 2.233576\end{array}$

H $\quad-0.00287 \quad-2.490006 \quad 0.076253$

$\begin{array}{llll}C & -0.003116 & -2.062598 & 3.47518\end{array}$

$\begin{array}{llll}\mathrm{H} & -0.000635 & -0.135002 & 4.476754\end{array}$

$\begin{array}{llll}H & -0.005115 & -3.814517 & 2.191538\end{array}$

H $\quad-0.004106 \quad-2.640041 \quad 4.4052$ 


\section{HE-neg (DMSO)}
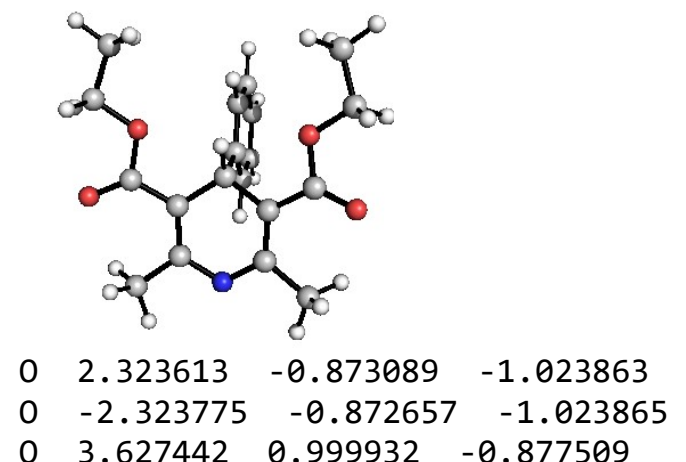

$\begin{array}{llll}0 & 3.627442 & 0.999932 & -0.877509\end{array}$

$\begin{array}{llll}0 & -3.627341 & 1.00051 & -0.877095\end{array}$

$\begin{array}{llll}\mathrm{N} & 0.000291 & 3.118418 & 0.214973\end{array}$

C $0.000034 \quad 0.243986 \quad-0.241107$

$\begin{array}{llll}\text { C } & 1.252765 & 1.110807 & -0.374399\end{array}$

C $\quad-1.252571 \quad 1.111028 \quad-0.374327$

$\begin{array}{llll}\text { C } & 1.17816 & 2.467948 & -0.040504\end{array}$

$\begin{array}{llll}\text { C } & -1.177704 & 2.468164 & -0.040474\end{array}$

$\begin{array}{llll}\text { C } & 2.390065 & 3.367569 & 0.044278\end{array}$

$\begin{array}{llll}\text { C } & -2.389433 & 3.368032 & 0.04423\end{array}$

$\begin{array}{llll}\text { C } & 2.501564 & 0.477459 & -0.763517\end{array}$

$\begin{array}{llll}\text { C } & -2.50151 & 0.477879 & -0.763342\end{array}$

$\begin{array}{llll}\text { C } & 3.506709 & -1.606628 & -1.416804\end{array}$

$\begin{array}{llll}\text { C } & -3.507012 & -1.606005 & -1.416734\end{array}$

C $3.108803-3.062688-1.575533$

C $\quad-3.109291-3.062078-1.575808$

H $\quad-0.000069-0.507586-1.04485$

$\begin{array}{llll}\text { H } & 2.08224 & 4.337444 & 0.466538\end{array}$

$\begin{array}{llll}\text { H } & 3.19158 & 2.927614 & 0.658523\end{array}$

$\begin{array}{llll}\text { H } & 2.833195 & 3.541575 & -0.951537\end{array}$

$\begin{array}{llll}H & -2.081323 & 4.338065 & 0.465914\end{array}$

$\begin{array}{llll}H & -3.190787 & 2.928523 & 0.659024\end{array}$

$\begin{array}{llll}H & -2.832929 & 3.54153 & -0.951499\end{array}$

H $3.900085 \quad-1.188384 \quad-2.360684$

$\begin{array}{llll}\text { H } & 4.286028 & -1.481517 & -0.644724\end{array}$

$\begin{array}{llll}H & -3.900502 & -1.187554 & -2.360474\end{array}$

H $-4.286185-1.480957-0.644497$

$\begin{array}{llll}\text { H } & 3.987712 & -3.653978 & -1.88336\end{array}$

H $2.327959-3.182117-2.345358$

$\begin{array}{llll}H & 2.730548 & -3.477403 & -0.626292\end{array}$

$\begin{array}{llll}H & -3.988306 & -3.653183 & -1.883691\end{array}$

$\begin{array}{llll}\mathrm{H} & -2.328538 & -3.18143 & -2.345738\end{array}$

H $\quad-2.731008-3.47707 \quad-0.626701$

$\begin{array}{llll}\text { C } & -0.000034 & -0.5454 & 1.074183\end{array}$

$\begin{array}{llll}C & 0.000408 & 0.122998 & 2.316315\end{array}$

C $\quad-0.000558 \quad-1.953378 \quad 1.075084$

C $0.000331 \quad-0.594085 \quad 3.523333$

$\begin{array}{llll}H & 0.000833 & 1.218443 & 2.336725\end{array}$

$\begin{array}{llll}C & -0.000634 & -2.678006 & 2.27861\end{array}$

$\begin{array}{llll}\mathrm{H} & -0.000913 & -2.483267 & 0.116946\end{array}$

C $\quad-0.000188-2.000183 \quad 3.509525$

$\begin{array}{llll}H & 0.000684 & -0.054818 & 4.476737\end{array}$

$\begin{array}{llll}H & -0.001036 & -3.773278 & 2.255291\end{array}$

H $\quad-0.000241 \quad-2.561648 \quad 4.449481$ 


\section{$\mathrm{HE}^{+} \cdot(\mathrm{DMSO})$}

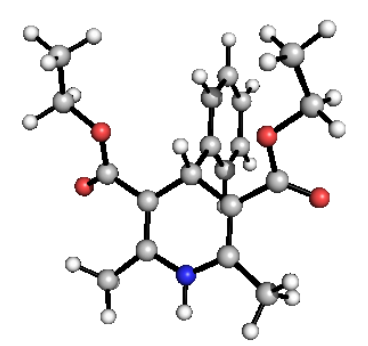

$\begin{array}{llll}0 & 2.463001 & -0.694698 & -1.082057 \\ 0 & -2.515122 & -0.571516 & -1.091341\end{array}$

$\begin{array}{llll}0 & 3.588739 & 0.742422 & 0.293957\end{array}$

$\begin{array}{llll}0 & -3.497802 & 0.792103 & 0.45906\end{array}$

$\begin{array}{llll}\mathrm{N} & 0.054936 & 3.164304 & -0.072204\end{array}$

C $\quad 0.014105 \quad 0.364947 \quad-0.326476$

$\begin{array}{llll}\text { C } & 1.2864 & 1.160516 & -0.281227\end{array}$

$\begin{array}{llll}\text { C } & -1.233587 & 1.195721 & -0.249925\end{array}$

C $\quad 1.277909 \quad 2.540855 \quad-0.143423$

$\begin{array}{llll}\text { C } & -1.185258 & 2.573858 & -0.106742\end{array}$

$\begin{array}{llll}\text { C } & 2.470899 & 3.438268 & -0.073386\end{array}$

$\begin{array}{llll}\text { C } & -2.353635 & 3.498581 & 0.00374\end{array}$

$\begin{array}{llll}\text { C } & 2.574179 & 0.410354 & -0.320114\end{array}$

$\begin{array}{llll}\text { C } & -2.541619 & 0.478736 & -0.250383\end{array}$

$\begin{array}{llll}\text { C } & 3.619652 & -1.597106 & -1.093363\end{array}$

$\begin{array}{llll}\text { C } & -3.691404 & -1.449606 & -1.073568\end{array}$

$\begin{array}{llll}\text { C } & 3.233813 & -2.817699 & -1.899707\end{array}$

C $\quad-3.414764-2.596295 \quad-2.020461$

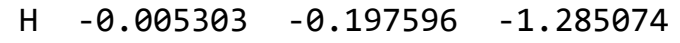

$\begin{array}{llll}H & 0.06941 & 4.189512 & -0.000664\end{array}$

$\begin{array}{llll}H & 2.216017 & 4.446931 & -0.434536\end{array}$

H $\quad 2.818161 \quad 3.522555 \quad 0.970773$

H $\quad 3.302631 \quad 3.0397 \quad-0.668534$

$\begin{array}{llll}H & -2.099727 & 4.490082 & -0.403319\end{array}$

$\begin{array}{llll}H & -2.635057 & 3.623867 & 1.063707\end{array}$

$\begin{array}{llll}H & -3.22663 & 3.101097 & -0.529451\end{array}$

H $4.472792 \quad-1.055967 \quad-1.534633$

$\begin{array}{llll}H & 3.864178 & -1.846647 & -0.047932\end{array}$

$\begin{array}{llll}H & -4.568287 & -0.855757 & -1.379389\end{array}$

H $-3.840681 \quad-1.790572 \quad-0.035932$

$\begin{array}{llll}H & 4.090032 & -3.511783 & -1.926623\end{array}$

$\begin{array}{llll}H & 2.977067 & -2.549221 & -2.937443\end{array}$

$\begin{array}{llll}\text { H } & 2.378977 & -3.342737 & -1.443332\end{array}$

$\begin{array}{llll}\text { H } & -4.285579 & -3.272479 & -2.024215\end{array}$

$\begin{array}{llll}H & -3.255082 & -2.23714 & -3.050194\end{array}$

H $\quad-2.531956 \quad-3.173733 \quad-1.701127$

C $0.001502 \quad-0.710737 \quad 0.78927$

$\begin{array}{llll}\text { C } & 0.073979 & -0.302617 & 2.133546\end{array}$

$\begin{array}{llll}\text { C } & -0.091868 & -2.075366 & 0.471388\end{array}$

$\begin{array}{llll}\text { C } & 0.055748 & -1.261526 & 3.157582\end{array}$

$\begin{array}{llll}\text { H } & 0.144706 & 0.762971 & 2.377332\end{array}$

$\begin{array}{llll}\text { C } & -0.110956 & -3.031211 & 1.498726\end{array}$

$\begin{array}{llll}\text { H } & -0.149415 & -2.389098 & -0.574874\end{array}$

C $\quad-0.036843 \quad-2.626867 \quad 2.84196$

$\begin{array}{llll}\text { H } & 0.113662 & -0.939258 & 4.201822\end{array}$

$\begin{array}{llll}H & -0.183052 & -4.093749 & 1.246417\end{array}$

$\begin{array}{llll}H & -0.051461 & -3.374432 & 3.641071\end{array}$ 


\section{HEH・ (DMSO)}

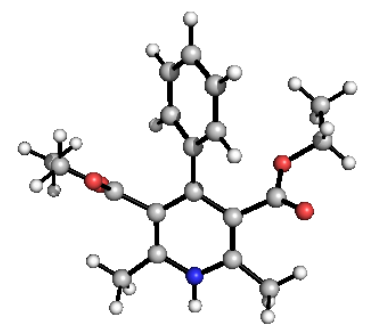

$\begin{array}{llll}0 & -3.185149 & -0.351929 & 0.572298 \\ 0 & 2.690743 & 0.102962 & 0.947129 \\ 0 & -2.635433 & -0.650379 & -1.621992\end{array}$

$\begin{array}{llll}0 & 3.46327 & 1.565454 & -0.624661\end{array}$

N $\quad-0.596271 \quad 3.098312 \quad-0.076732$

$\begin{array}{llll}\text { C } & 0.064442 & 0.386368 & -0.292247\end{array}$

$\begin{array}{llll}\text { C } & -1.306618 & 0.832132 & -0.252397\end{array}$

$\begin{array}{llll}\text { C } & 1.085823 & 1.418483 & -0.16093\end{array}$

$\begin{array}{llll}\text { C } & -1.636529 & 2.17118 & -0.143314\end{array}$

$\begin{array}{llll}\text { C } & 0.742715 & 2.759072 & -0.065497\end{array}$

$\begin{array}{llll}\text { C } & -3.008624 & 2.767981 & -0.16057\end{array}$

$\begin{array}{llll}\text { C } & 1.674101 & 3.921283 & 0.099648\end{array}$

$\begin{array}{llll}C & -2.425004 & -0.134654 & -0.526438\end{array}$

C $2.525878 \quad 1.060996 \quad 0.001193$

$\begin{array}{llll}\text { C } & -4.318575 & -1.26651 & 0.399226\end{array}$

$\begin{array}{llll}\text { C } & 4.025852 & -0.475252 & 1.061669\end{array}$

C $\quad-5.006993 \quad-1.397381 \quad 1.741042$

C $\quad 3.911651 \quad-1.708524 \quad 1.934315$

$\begin{array}{llll}\mathrm{H} & -0.839335 & 4.084124 & 0.031253\end{array}$

$\begin{array}{llll}H & -3.116069 & 3.468474 & -1.009313\end{array}$

$\begin{array}{llll}H & -3.791962 & 2.003329 & -0.243702\end{array}$

$\begin{array}{llll}H & -3.192889 & 3.347053 & 0.76332\end{array}$

H $\quad 1.757259 \quad 4.482395 \quad-0.849044$

$\begin{array}{llll}H & 2.682572 & 3.60444 & 0.390725\end{array}$

H $\quad 1.27972 \quad 4.61779 \quad 0.859864$

$\begin{array}{llll}H & -4.986306 & -0.847508 & -0.371869\end{array}$

$\begin{array}{llll}H & -3.928724 & -2.231776 & 0.035782\end{array}$

H $4.701172 \quad 0.280155 \quad 1.498413$

$\begin{array}{llll}H & 4.387352 & -0.718788 & 0.048691\end{array}$

$\begin{array}{llll}H & -5.864579 & -2.083135 & 1.640146\end{array}$

$\begin{array}{llll}H & -5.385184 & -0.424084 & 2.0945\end{array}$

$\begin{array}{llll}H & -4.324441 & -1.811311 & 2.501386\end{array}$

$\begin{array}{llll}H & 4.907406 & -2.170174 & 2.042125\end{array}$

H $3.540753 \quad-1.454856 \quad 2.941151$

$\begin{array}{llll}\text { H } & 3.232911 & -2.450864 & 1.482471\end{array}$

C $0.414887-1.020198 \quad-0.505417$

$\begin{array}{llll}\text { C } & 1.474587 & -1.390561 & -1.380296\end{array}$

$\begin{array}{llll}\text { C } & -0.273413 & -2.0721 & 0.159574\end{array}$

C $\quad 1.827654 \quad-2.730289-1.572784$

$\begin{array}{llll}\text { H } & 2.009487 & -0.613944 & -1.93705\end{array}$

C $0.078738 \quad-3.412834 \quad-0.038679$

$\begin{array}{llll}\mathrm{H} & -1.06363 & -1.832375 & 0.877856\end{array}$

$\begin{array}{llll}\text { C } & 1.134223 & -3.757244 & -0.903392\end{array}$

H $2.644119 \quad-2.977244 \quad-2.259913$

$\begin{array}{llll}H & -0.464035 & -4.195375 & 0.502447\end{array}$

H $1.412082-4.805068-1.052538$ 


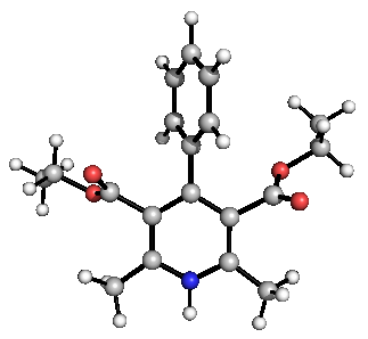
$\begin{array}{llll}0 & 2.759666 & 0.148759 & 0.880678\end{array}$
$\begin{array}{llll}0 & -3.180623 & -0.373559 & 0.495864\end{array}$
$\begin{array}{llll}0 & 3.335925 & 1.528303 & -0.849657\end{array}$
$\begin{array}{llll}0 & -2.546517 & -0.709483 & -1.67613\end{array}$
$\begin{array}{llll}\mathrm{N} & -0.636973 & 3.062752 & 0.023203\end{array}$
$\begin{array}{llll}\text { C } & 0.044745 & 0.425458 & -0.278006\end{array}$
C $1.044623 \quad 1.414189 \quad-0.105769$
$\begin{array}{llll}\text { C } & -1.312674 & 0.826217 & -0.289818\end{array}$
$\begin{array}{llll}\text { C } & 0.688784 & 2.763068 & 0.036716\end{array}$
$\begin{array}{llll}\text { C } & -1.656103 & 2.173492 & -0.126021\end{array}$
$\begin{array}{llll}\text { C } & 1.647391 & 3.892785 & 0.216008\end{array}$
$\begin{array}{llll}\text { C } & -3.050068 & 2.708342 & -0.106509\end{array}$
$\begin{array}{llll}\text { C } & 2.507076 & 1.049196 & -0.080894\end{array}$
$\begin{array}{llll}\text { C } & -2.403454 & -0.176722 & -0.58104\end{array}$
$\begin{array}{llll}\text { C } & 4.110613 & -0.430587 & 0.900646\end{array}$
$\begin{array}{llll}\text { C } & -4.300053 & -1.315976 & 0.327043\end{array}$
$\begin{array}{llll}\text { C } & 4.065499 & -1.644406 & 1.802639\end{array}$
$\begin{array}{llll}\text { C } & -5.01387 & -1.411703 & 1.656847\end{array}$
$\begin{array}{llll}H & 1.12924 & 4.799693 & 0.561353\end{array}$
$\begin{array}{llll}H & 2.428445 & 3.62903 & 0.945607\end{array}$
H $\quad 2.148556 \quad 4.117045 \quad-0.740413$
H $\quad-3.061196 \quad 3.795048 \quad-0.277652$
$\begin{array}{llll}H & -3.51733 & 2.506171 & 0.87262\end{array}$
$\begin{array}{llll}H & -3.667786 & 2.224701 & -0.87881\end{array}$
$\begin{array}{llll}\text { H } & 4.384098 & -0.690222 & -0.134653\end{array}$
$\begin{array}{llll}H & 4.805897 & 0.342141 & 1.267741\end{array}$
H $\quad-3.881309-2.2830240 .004866$
H $\quad-4.951451 \quad-0.926753 \quad-0.472146$
H $5.069379 \quad-2.099126 \quad 1.837986$
$\begin{array}{llll}H & 3.358288 & -2.397346 & 1.417517\end{array}$
$\begin{array}{llll}H & 3.775547 & -1.372435 & 2.830621\end{array}$
$\begin{array}{llll}H & -5.858815 & -2.112867 & 1.556757\end{array}$
$\begin{array}{llll}H & -4.343369 & -1.792639 & 2.444364\end{array}$
$\begin{array}{llll}H & -5.414357 & -0.433488 & 1.969104\end{array}$
$\begin{array}{llll}\text { C } & 0.404697 & -1.004798 & -0.446326\end{array}$
$\begin{array}{llll}\text { C } & -0.121773 & -1.974313 & 0.432723\end{array}$
C $1.28475-1.401189-1.475112$
$\begin{array}{llll}\text { C } & 0.240546 & -3.320508 & 0.290513\end{array}$
H $\quad-0.78144 \quad-1.670203 \quad 1.251019$
$\begin{array}{llll}\text { C } & 1.63124 & -2.75083 & -1.620706\end{array}$
H $1.677126 \quad-0.657532 \quad-2.175662$
$\begin{array}{llll}\text { C } & 1.115156 & -3.712207 & -0.736063\end{array}$
$\begin{array}{llll}H & -0.158292 & -4.063269 & 0.987874\end{array}$
$\begin{array}{llll}H & 2.305062 & -3.051051 & -2.428687\end{array}$
$\begin{array}{llll}H & -0.891528 & 4.0522 & 0.137898\end{array}$
$\begin{array}{llll}H & 1.393677 & -4.764538 & -0.846987\end{array}$ 


\section{HP (DMSO)}

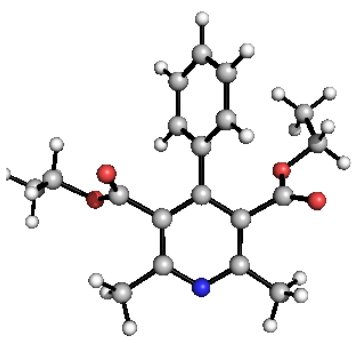

$\begin{array}{llll}0 & 2.755247 & 0.181428 & 0.876236\end{array}$

$\begin{array}{llll}0 & -3.182549 & -0.351366 & 0.511904\end{array}$

$\begin{array}{llll}0 & 3.322339 & 1.54891 & -0.862756\end{array}$

$\begin{array}{llll}0 & -2.567653 & -0.699022 & -1.659845\end{array}$

$\begin{array}{llll}\mathrm{N} & -0.669198 & 3.145123 & 0.027317\end{array}$

C $0.040943 \quad 0.434981 \quad-0.280799$

$\begin{array}{llll}C & 1.026985 & 1.434359 & -0.115832\end{array}$

$\begin{array}{llll}\text { C } & -1.310516 & 0.840894 & -0.288686\end{array}$

$\begin{array}{llll}\text { C } & 0.63172 & 2.784808 & 0.03681\end{array}$

$\begin{array}{llll}\text { C } & -1.629569 & 2.209117 & -0.132988\end{array}$

$\begin{array}{llll}\text { C } & 1.628262 & 3.894162 & 0.239357\end{array}$

$\begin{array}{llll}\text { C } & -3.051281 & 2.703433 & -0.146976\end{array}$

C $2.483872 \quad 1.078096-0.09523$

$\begin{array}{llll}\text { C } & -2.399711 & -0.155643 & -0.570056\end{array}$

$\begin{array}{llll}\text { C } & 4.107671 & -0.381317 & 0.888273\end{array}$

$\begin{array}{llll}\text { C } & -4.31039 & -1.273818 & 0.33583\end{array}$

$\begin{array}{llll}\text { C } & 4.088356 & -1.583326 & 1.808828\end{array}$

$\begin{array}{llll}\text { C } & -5.041024 & -1.356041 & 1.658712\end{array}$

H $\quad 1.109253 \quad 4.788518 \quad 0.613999$

$\begin{array}{llll}H & 2.420575 & 3.611583 & 0.951391\end{array}$

H $\quad 2.123793 \quad 4.152944 \quad-0.712143$

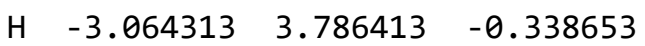

$\begin{array}{llll}H & -3.536505 & 2.521457 & 0.828116\end{array}$

H $\quad-3.659046 \quad 2.197685 \quad-0.914899$

H $4.375915 \quad-0.654996 \quad-0.145206$

H $\quad 4.804087 \quad 0.400266 \quad 1.235465$

$\begin{array}{llll}H & -3.908217 & -2.250645 & 0.02057\end{array}$

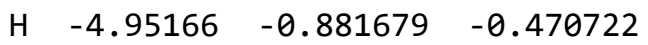

H $\quad 5.096993 \quad-2.02784 \quad 1.841628$

H $3.384562 \quad-2.349358 \quad 1.443236$

H $3.804864-1.299625 \quad 2.835659$

$\begin{array}{llll}H & -5.895633 & -2.04492 & 1.554257\end{array}$

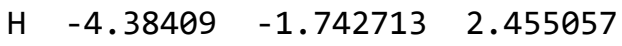

$\begin{array}{llll}H & -5.429414 & -0.370646 & 1.964211\end{array}$

$\begin{array}{llll}\text { C } & 0.407407 & -0.998584 & -0.445291\end{array}$

$\begin{array}{llll}\text { C } & -0.095121 & -1.967631 & 0.44758\end{array}$

$\begin{array}{llll}\text { C } & 1.270907 & -1.403068 & -1.484301\end{array}$

$\begin{array}{llll}\text { C } & 0.269687 & -3.314618 & 0.309832\end{array}$

H $\quad-0.747926 \quad-1.661122 \quad 1.270846$

$\begin{array}{llll}\text { C } & 1.628739 & -2.751578 & -1.623536\end{array}$

H $1.650105 \quad-0.661773 \quad-2.194795$

C $1.132655 \quad-3.710753 \quad-0.725098$

$\begin{array}{llll}\text { H } & -0.116883 & -4.054537 & 1.017597\end{array}$

$\begin{array}{llll}H & 2.294695 & -3.053037 & -2.43804\end{array}$

H $\quad 1.416591 \quad-4.762271 \quad-0.831688$ 


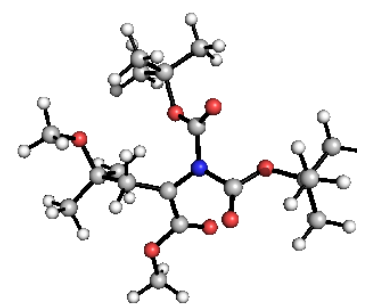

$\begin{array}{llll}\mathrm{C} & -2.815078 & -0.93437 & -1.362632 \\ \mathrm{H} & -3.794109 & -0.835884 & -1.843672 \\ \mathrm{H} & -2.368855 & -1.872886 & -1.704788 \\ \mathrm{H} & -2.182268 & -0.104791 & -1.687129 \\ \mathrm{C} & -3.002593 & -0.929198 & 0.152827 \\ \mathrm{C} & -1.64506 & -0.84345 & 0.943832 \\ \mathrm{H} & -1.60936 & 0.127496 & 1.443117 \\ \mathrm{O} & -3.75496 & 0.267797 & 0.400319 \\ \mathrm{C} & -4.27149 & 0.450862 & 1.701287 \\ \mathrm{H} & -3.506792 & 0.332221 & 2.481752 \\ \mathrm{H} & -4.650734 & 1.475663 & 1.741155 \\ \mathrm{H} & -5.102032 & -0.234603 & 1.914989 \\ \mathrm{C} & -3.79672 & -2.166473 & 0.578253 \\ \mathrm{H} & -3.938553 & -2.211473 & 1.663402 \\ \mathrm{H} & -4.781271 & -2.169612 & 0.096264 \\ \mathrm{H} & -3.257736 & -3.069363 & 0.277601 \\ \mathrm{H} & -1.651018 & -1.597039 & 1.744276 \\ \mathrm{C} & -0.36543 & -1.018853 & 0.189936 \\ \mathrm{~N} & 0.635275 & -0.043795 & 0.229828 \\ \mathrm{C} & -0.009095 & -2.245372 & -0.512414 \\ \mathrm{O} & 0.888318 & -2.336077 & -1.338929 \\ \mathrm{O} & -0.798219 & -3.270941 & -0.160075 \\ \mathrm{C} & -0.625684 & -4.488817 & -0.890573 \\ \mathrm{H} & -0.818551 & -4.327872 & -1.954922 \\ \mathrm{H} & 0.384918 & -4.881404 & -0.752417 \\ \mathrm{H} & -1.357863 & -5.182574 & -0.477034 \\ \mathrm{C} & 0.356246 & 1.343071 & 0.227277 \\ \mathrm{C} & 1.966658 & -0.464714 & 0.529577 \\ \mathrm{O} & -0.682039 & 1.59686 & -0.548478 \\ \mathrm{O} & 2.835407 & 0.272056 & -0.126456 \\ \mathrm{O} & 2.184457 & -1.397624 & 1.269804 \\ \mathrm{O} & 1.009307 & 2.135288 & 0.870113 \\ \mathrm{C} & 4.288927 & 0.163739 & 0.108917 \\ \mathrm{C} & -1.28586 & 2.947638 & -0.608902 \\ \mathrm{C} & -1.774615 & 3.352312 & 0.776892 \\ \mathrm{H} & -2.361938 & 4.27255 & 0.687413 \\ \mathrm{H} & -2.421603 & 2.573217 & 1.19281 \\ \mathrm{H} & -0.947822 & 3.539925 & 1.465746 \\ \mathrm{C} & -2.462497 & 2.749625 & -1.555159 \\ \mathrm{H} & -3.170028 & 2.027402 & -1.137946 \\ \mathrm{H} & -2.973895 & 3.707514 & -1.696911 \\ \mathrm{H} & -2.120354 & 2.394756 & -2.533554 \\ \mathrm{C} & -0.280371 & 3.932185 & -1.195387 \\ \mathrm{H} & 0.105173 & 3.562905 & -2.152195 \\ \mathrm{H} & -0.788926 & 4.885007 & -1.378362\end{array}$




$\begin{array}{llll}\text { H } & 0.557842 & 4.112653 & -0.519396 \\ \mathrm{C} & 4.779134 & -1.19916 & -0.365948 \\ \mathrm{H} & 5.872987 & -1.220831 & -0.31089 \\ \mathrm{H} & 4.385399 & -2.008034 & 0.253613 \\ \mathrm{H} & 4.484957 & -1.372283 & -1.406713 \\ \mathrm{C} & 4.602273 & 0.422246 & 1.578284 \\ \mathrm{H} & 5.688735 & 0.493634 & 1.697017 \\ \mathrm{H} & 4.16 & 1.36889 & 1.906217 \\ \mathrm{H} & 4.240389 & -0.382803 & 2.221757 \\ \mathrm{C} & 4.847512 & 1.278558 & -0.766202 \\ \mathrm{H} & 5.939252 & 1.292839 & -0.68686 \\ \mathrm{H} & 4.57861 & 1.120748 & -1.816038 \\ \mathrm{H} & 4.462819 & 2.252764 & -0.446658\end{array}$




\section{References}

1. Choi, G. B.; Zhu, Q.; Miller, D. C.; Gu, C. J.; Knowles, R. R. Catalytic Alkylation of Remote C-H Bonds Enabled by Proton-Coupled Electron Transfer. Nature, 2016, 539, 268-271.

2. $\quad$ Baraldi, P. T.; Noel, T.; Wang, Q.; Hessel, V. The accelerated preparation of 1,4-dihydropyridines using microflow reactors. Tetrahedron Lett. 2014, 55, 2090-2092.

3. Ghosh, S.; Jana, C. K. Metal free biomimetic deaminative direct $\mathrm{C}-\mathrm{C}$ coupling of unprotected primary amines with active methylene compounds. Org. Biomol. Chem. 2019, 17, 10153-10157.

4. Okimoto, Y.; Sakaguchi, S.; Ishii, Y. Development of a Highly Efficient Catalytic Method for Synthesis of Vinyl Ethers. J. Am. Chem. Soc. 2002, 124, 1590-1591.

5. Clauss, C.; Bestian, H. Über die Einwirkung von Wasserstoff auf einige metallorganische Verbindungen und Komplexe. Justus Liebigs Annal. Chem. 1962, 654, 8-19.

6. Xing, S.; Li, Y.; Liu, C.; Ren, J.; Wang, Z. Lewis Acid Catalyzed Intramolecular [3+2] CrossCycloaddition of Donor-Acceptor Cyclopropanes with Carbonyls: A General Strategy for the Construction of Acetal[n.2.1] Skeletons. Angew. Chem. Int. Ed. 2011, 50, 12605-12609.

7. Rossolini, T.; Leitch, J. A.; Grainger, R.; Dixon, D. J. Photocatalytic Three-Component Umpolung Synthesis of 1,3-Diamines. Org. Lett. 2018, 20, 6794-6798.

8. Hargrave, J. D.; Bish, G.; Kociok-Kohn, G.; Frost, C. G. Rhodium-Catalysed Conjugate Addition of Arylboronic Acids to Enantiopure Dehydroamino Acid Derivatives. Org. Biomol. Chem. 2010, 8, 51205125.

9. Bunpei, H.; Keita, N.; Shigeki, H. Reductive Coupling of Aromatic Dialkyl Acetals Using the Combination of Zinc and Chlorotrimethylsilane in the Presence of Potassium Carbonate. Chem. Lett. 2007, 36, 1418-1419.

10. Rossolini, T.; Ferko, B.; Dixon, D. J. Photocatalytic Reductive Formation of $\alpha$-Tertiary Ethers from Ketals. Org. Lett. 2019, 21, 6668-6673.

11. Cao, Z.-C.; Shi, Z.-J. Deoxygenation of Ethers To Form Carbon-Carbon Bonds via Nickel Catalysis. J. Am. Chem. Soc. 2017, 139, 6546-6549.

12. Kariofillis, S. K.; Shields, B. J.; Tekle-Smith, M. A.; Zacuto, M. J.; Doyle, A. G. Nickel/PhotoredoxCatalyzed Methylation of (Hetero)aryl Chlorides Using Trimethyl Orthoformate as a Methyl Radical Source. J. Am. Chem. Soc. 2020, 142, 7683-7689.

13. (a) Aycock, R. A.; Vogt, D. B.; Jui, N. T. A Practical and Scalable System for Heteroaryl Amino Acid Synthesis. Chem. Sci. 2017, 8, 7998-8003. (b) Aycock, R. A.; Wang, H.; Jui, N. T. A Mild Catalytic System for Radical Conjugate Addition of Nitrogen Heterocycles. Chem. Sci. 2017, 8, 3121-3125. (c) Seath, C. P.; Vogt, D. B.; Xu, Z.; Boyington, A. J.; Jui, N. T. Radical Hydroarylation of Functionalized Olefins and Mechanistic Investigation of Photocatalytic Pyridyl Radical Reactions. J. Am. Chem. Soc. 2018, 140, 15525-15534.

14. Kokotos, G.; Padrón, J. M.; Martin, T.; Gibbons, W. A.; Martin, V. S. A General Approach to the Asymmetric Synthesis of Unsaturated Lipidic $\alpha$-Amino Acids. The First Synthesis of $\alpha$ Aminoarachidonic Acid. J. Org. Chem. 1998, 63, 3741-3744.

15. Gaussian 16, Revision A.03, M. J. Frisch, G. W. Trucks, H. B. Schlegel, G. E. Scuseria, M. A. Robb, J. R. Cheeseman, G. Scalmani, V. Barone, G. A. Petersson, H. Nakatsuji, X. Li, M. Caricato, A. V. Marenich, J. Bloino, B. G. Janesko, R. Gomperts, B. Mennucci, H. P. Hratchian, J. V. Ortiz, A. F. Izmaylov, J. L. Sonnenberg, D. Williams-Young, F. Ding, F. Lipparini, F. Egidi, J. Goings, B. Peng, A. Petrone, T. Henderson, D. Ranasinghe, V. G. Zakrzewski, J. Gao, N. Rega, G. Zheng, W. Liang, M. Hada, M. Ehara, K. Toyota, R. Fukuda, J. Hasegawa, M. Ishida, T. Nakajima, Y. Honda, O. Kitao, H. Nakai, T. Vreven, K. Throssell, J. A. Montgomery, Jr., J. E. Peralta, F. Ogliaro, M. J. Bearpark, J. J. Heyd, E. N. Brothers, K. N. Kudin, V. N. Staroverov, T. A. Keith, R. Kobayashi, J. Normand, K. Raghavachari, A. P. Rendell, J. C. Burant, S. S. Iyengar, J. Tomasi, M. Cossi, J. M. 
Millam, M. Klene, C. Adamo, R. Cammi, J. W. Ochterski, R. L. Martin, K. Morokuma, O. Farkas, J. B. Foresman, and D. J. Fox, Gaussian, Inc., Wallingford CT, 2016.

16. Chai, J.D.; Head-Gordon, M. Long-Range Corrected Hybrid Density Functionals with Damped Atom-Atom Dispersion Corrections. Phys. Chem. Chem. Phys. 2008, 10,6615-6620.

17. Marenich, A. V.; Cramer, C. J.; Truhlar, D. G. Universal Solvation Model Based on Solute Electron Density and on a Continuum Model of the Solvent Defined by the Bulk Dielectric Constant and Atomic Surface Tensions. J. Phys. Chem. B 2009, 113, 6378-6396.

18. Grimme, S. Supramolecular Binding Thermodynamics by Dispersion-Corrected Density Functional Theory. Chem. Eur. J. 2012, 18, 9955-9964.

19. Funes-Ardoiz, I.; Paton, R. S. GoodVibes v2.0.2 DOI: 10.5281/zenodo.595246.

20. Ho, J. Are Thermodynamic Cycles Necessary for Continuum Solvent Calculation of $\mathrm{p} K_{a} \mathrm{~s}$ and Reduction Potentials? Phys. Chem. Chem. Phys. 2015, 17, 2859-2868.

21. Thapa, B.; Schlegel, H. B. Density Functional Theory Calculation of $\mathrm{p} K_{a}$ 's of Thiols in Aqueous Solution Using Explicit Water Molecules and the Polarizable Continuum Model. J. Phys. Chem. A 2016, 120, 5726-5735.

22. Bordwell F. G. Equilibrium acidities in dimethyl sulfoxide solution. Acc. Chem. Res. 1988, 21, 456463.

23. Grimme, S.; Antony, J.; Ehrlich, S.; Krieg, H. A Consistent and Accurate Ab Initio Parametrization of Density Functional Dispersion Correction (DFT-D) for the 94 Elements H-Pu. J. Chem. Phys. 2010, 132, 154104.

24. Perdew, J. P.; Burke, K.; Ernzerhof, M. Generalized Gradient Approximation Made Simple. Phys. Rev. Lett. 1996, 77, 3865-3868.

25. Isegawa, M.; Neese, F.; Pantazis, D. A. Ionization Energies and Aqueous Redox Potentials of Organic Molecules: Comparison of DFT, Correlated ab Initio Theory and Pair Natural Orbital Approaches. J. Chem. Theory Comput. 2016, 12, 2272-2284.

26. Demissie, T. B.; Ruud, K.; Hansen, J. H. DFT as a Powerful Predictive Tool in Photoredox Catalysis: Redox Potentials and Mechanistic Analysis. Organometallics 2015, 34, 4218-4228.

27. Roth, H. G.; Romero, N. A.; Nicewicz, D. A. Experimental and Calculated Electrochemical Potentials of Common Organic Molecules for Applications to Single-Electron Redox Chemistry. Synlett 2016, 27, 714-723.

28. Becke, A. D. Pair correlation functions of uncharged and weakly charged Brownian particles. J. Chem. Phys. 1993, 97, 5648-5652.

29. Hehre, W. J. Ab initio molecular orbital theory. Acc. Chem. Res. 1976, 9, 399-406.

30. Lee, C.; Yang, W.; Parr, R.G. Development of the Colle-Salvetti correlation-energy formula into a functional of the electron density. Phys. Rev. B. 1988, 37, 785-788.

31. Parr, R.G.; v. Szentpaly, L.; Liu, S. Electrophilicity Index. J. Am. Chem. Soc. 1999, 121, 1922-1924.

32. De. Vleeschouwer, F.; Van Speybroeck, V.; Waroquier, M.; Geerlings, P.; De Proft, F. Electrophilicity and Nucleophilicity Index for Radicals. Org. Lett. 2007, 9, 2721-2724. 


\section{NMR Spectra}

$1 \mathrm{aa}-{ }^{1} \mathrm{H}$ NMR $\left(400 \mathrm{MHz}, \mathrm{DMSO}-d_{6}\right)$

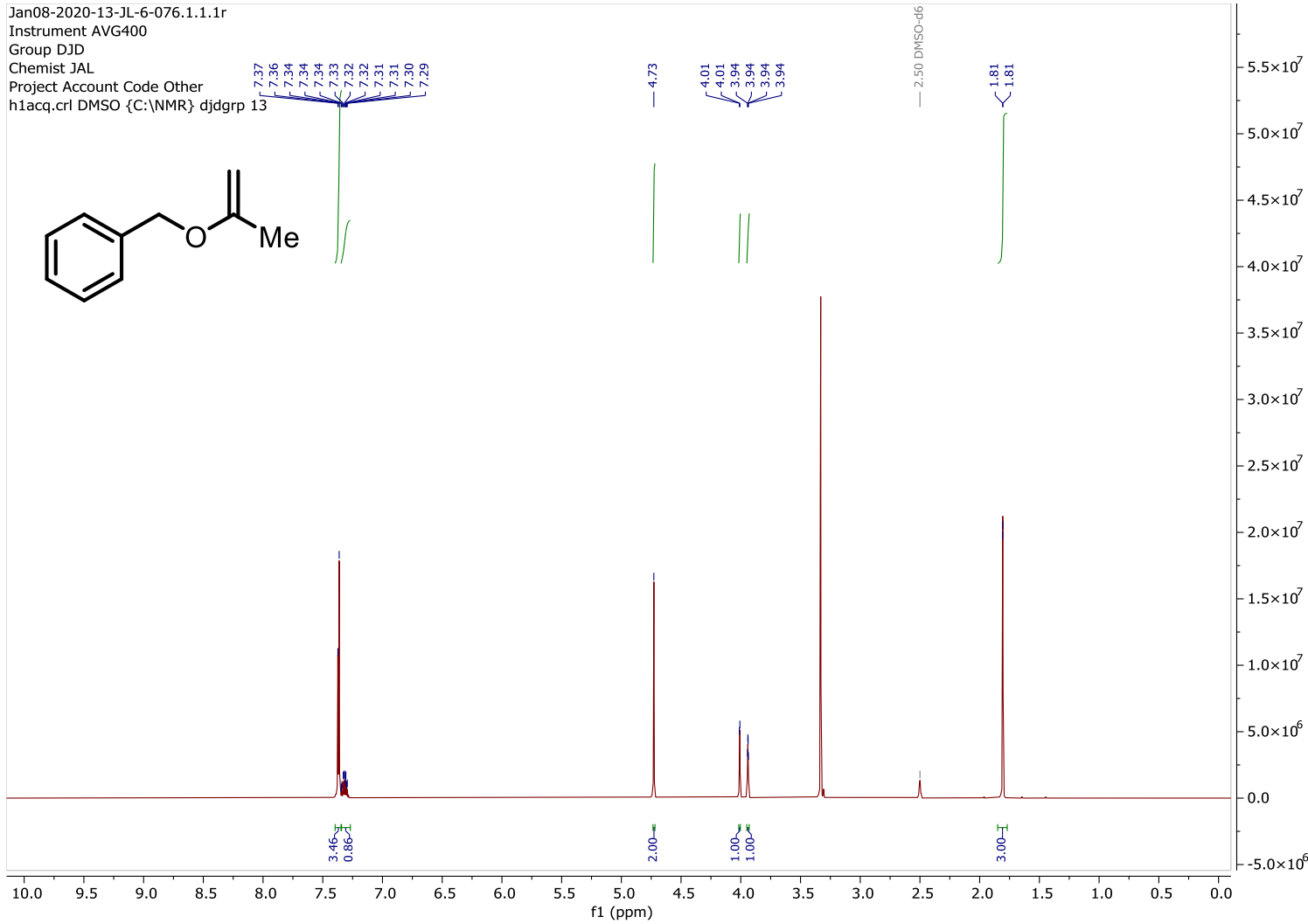

1aa $-{ }^{13} \mathrm{C}$ NMR $\left(101 \mathrm{MHz}, \mathrm{DMSO}-d_{6}\right)$

Jan08-2020-13-JL-6-076.2.1.1r Instrument AVG400

Group DJD

Chemist JAL

c13acq_512.crl DMSO \{C:INMR $\}$ djdgrp 13<smiles>C=C(C)OCc1ccccc1</smiles> 
$1 \mathbf{b}-{ }^{1} \mathrm{H}$ NMR $\left(400 \mathrm{MHz}\right.$, DMSO- $\left.d_{6}\right)$

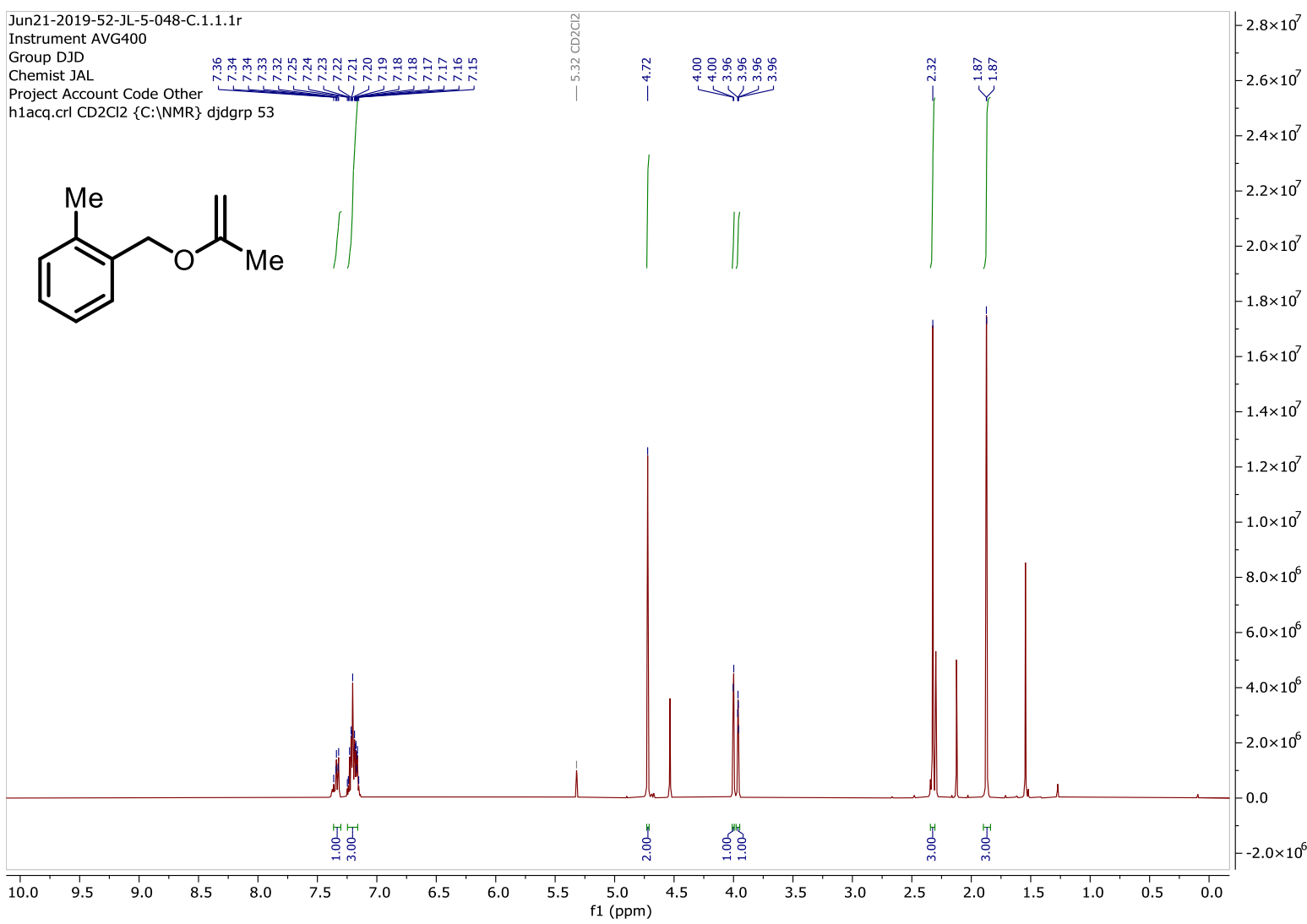

1b $-{ }^{13} \mathrm{C}$ NMR $\left(101 \mathrm{MHz}\right.$, DMSO- $\left.d_{6}\right)$

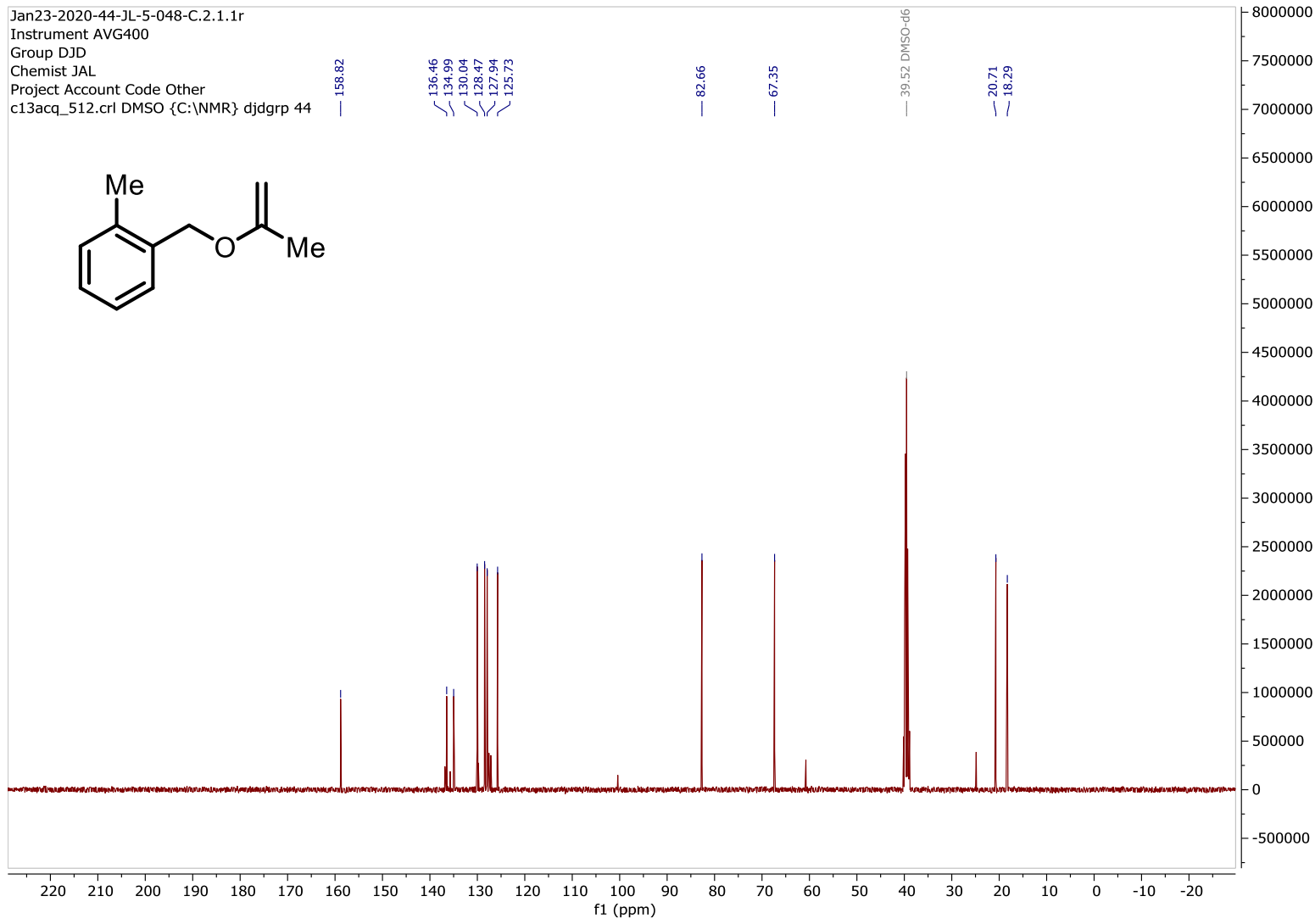


1c $-{ }^{1} \mathrm{H}$ NMR $\left(400 \mathrm{MHz}, \mathrm{DMSO}-d_{6}\right)$

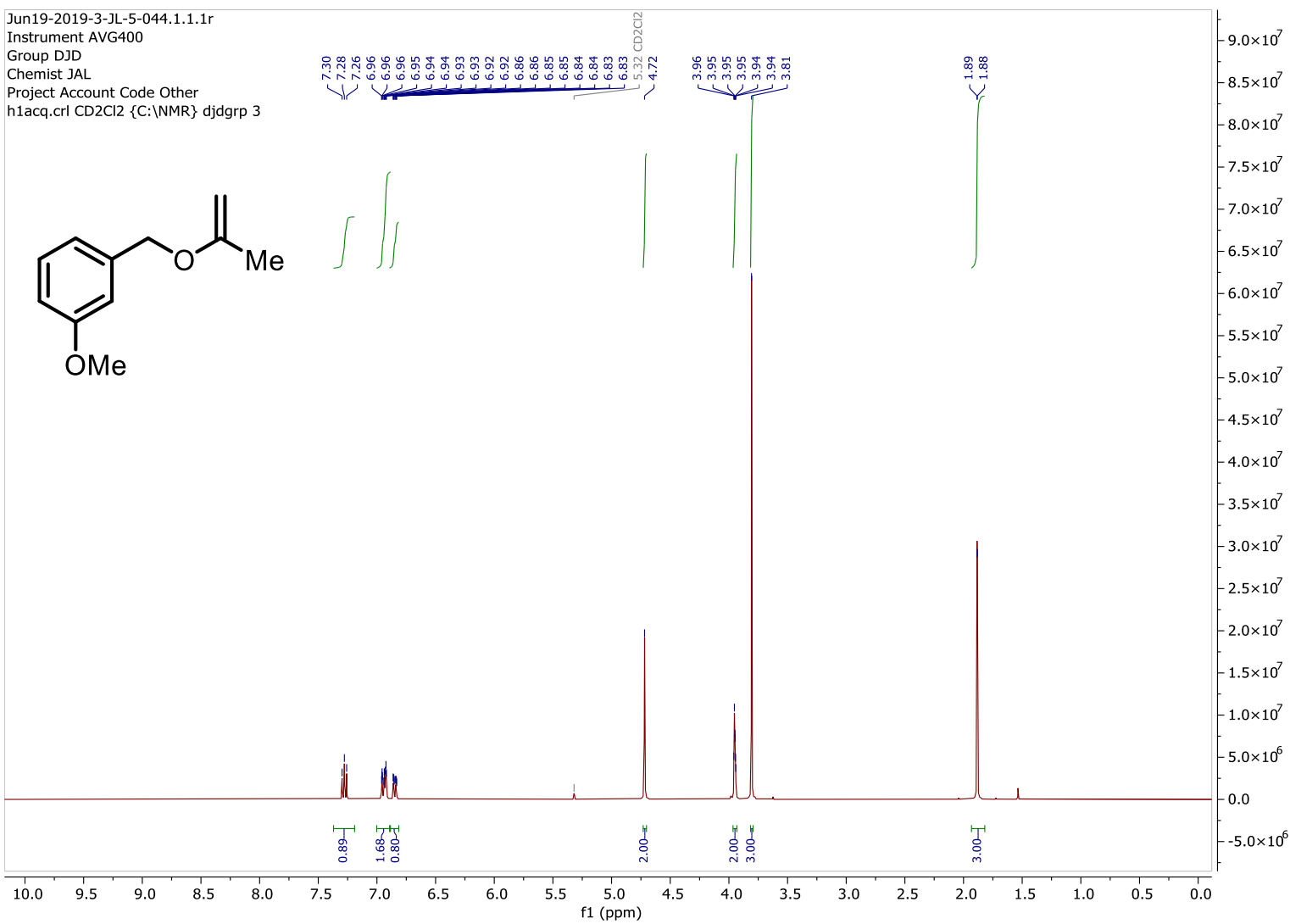

1c $-{ }^{13} \mathrm{C}$ NMR $\left(101 \mathrm{MHz}, \mathrm{DMSO}-d_{6}\right)$

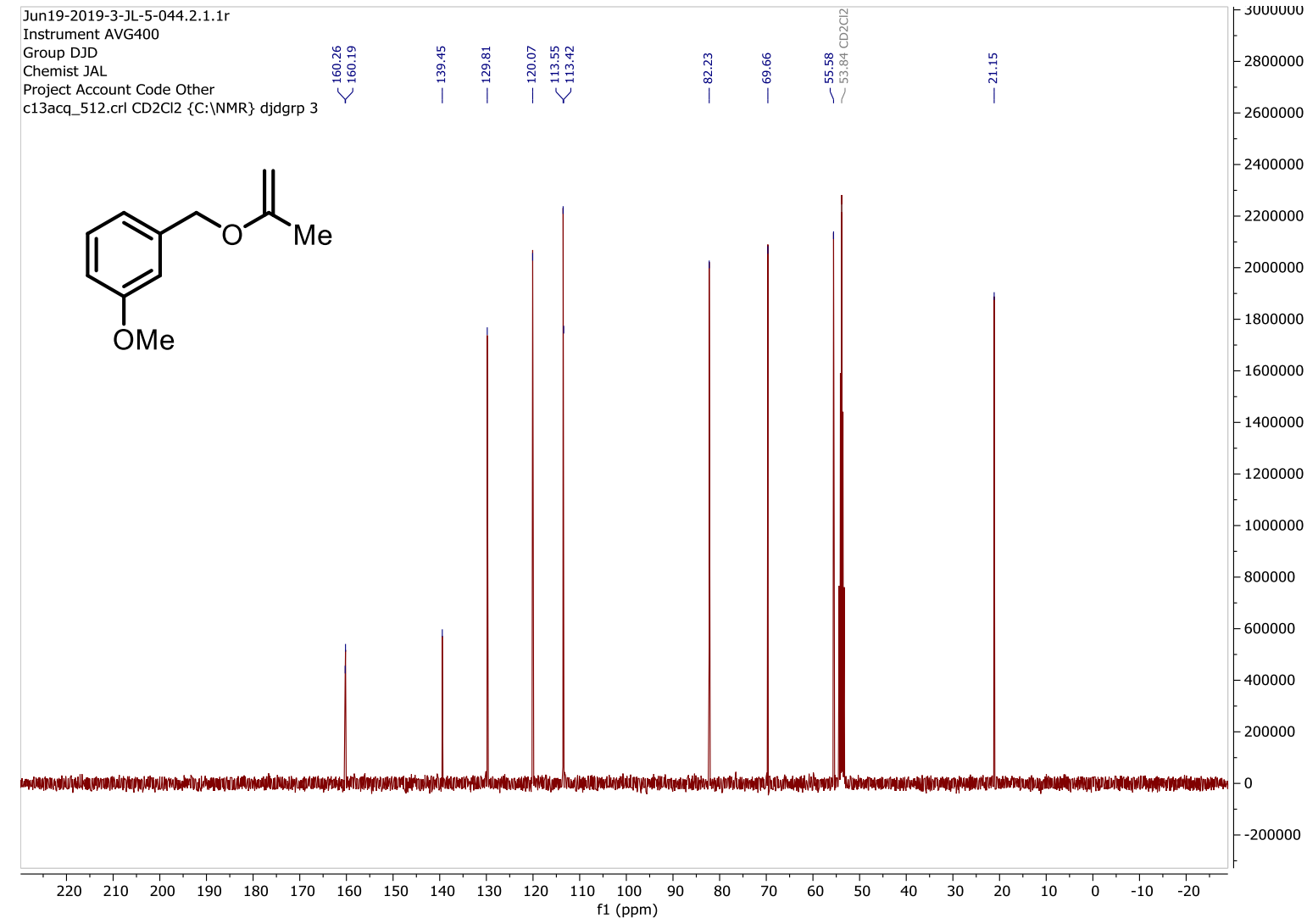


1d $-{ }^{1} \mathrm{H}$ NMR $\left(400 \mathrm{MHz}\right.$, DMSO- $\left.d_{6}\right)$

Aug21-2019-4-JL-5-069-E.1.1.1r

Instrument AVG400

Group DJD

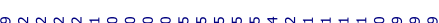

管

M1<smiles>C=C(C)OCc1cccc(OC(F)(F)F)c1</smiles>
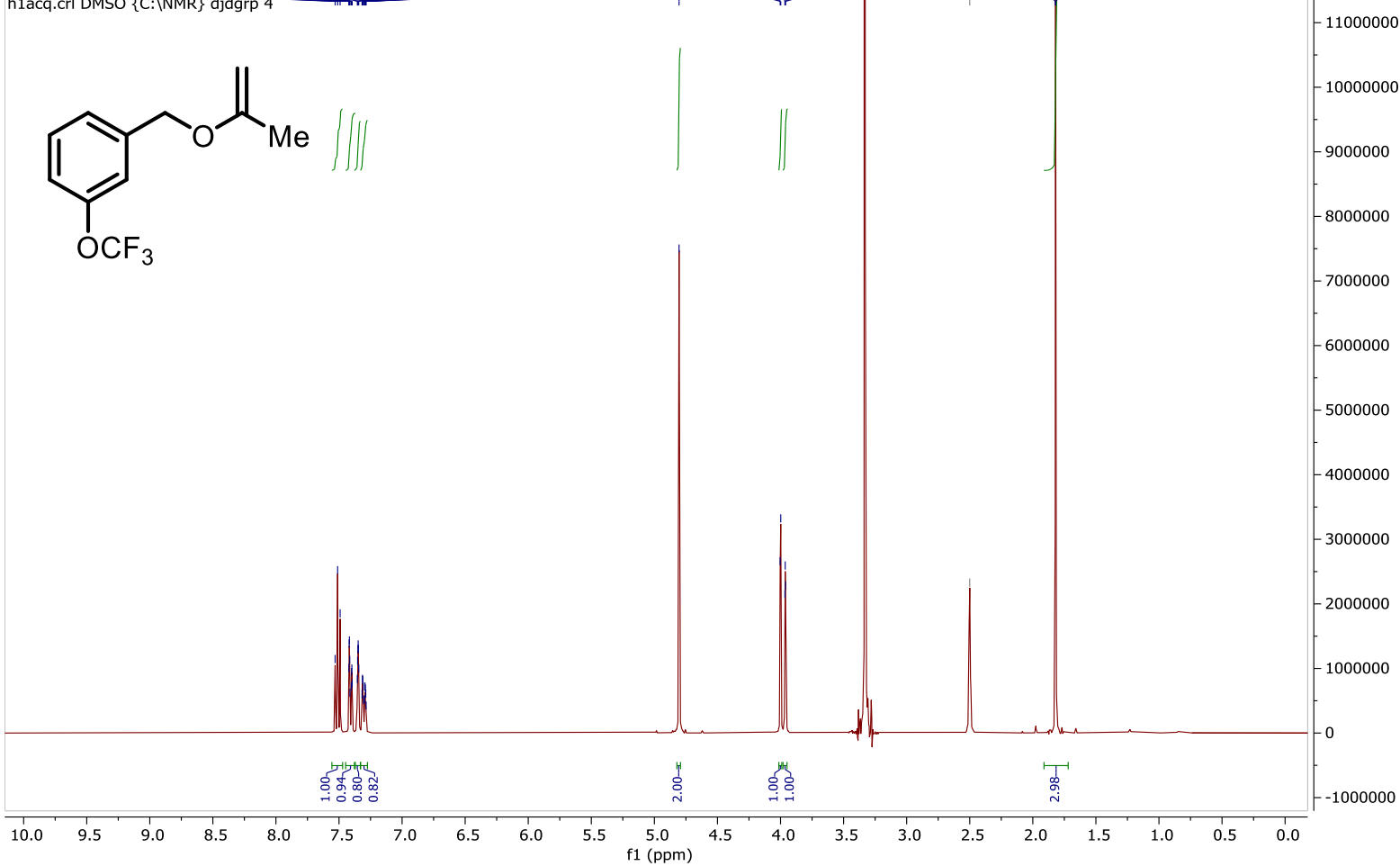

1d $-{ }^{19} \mathrm{~F}$ NMR $\left(377 \mathrm{MHz}, \mathrm{DMSO}-d_{6}\right)$

Aug21-2019-4-JL-5-069-E.2.1.1r

Instrument AVG400

Group DJD

Project Account Code Other

f19acq.crl DMSO $\{C: \mid N M R\}$ djdgrp 4

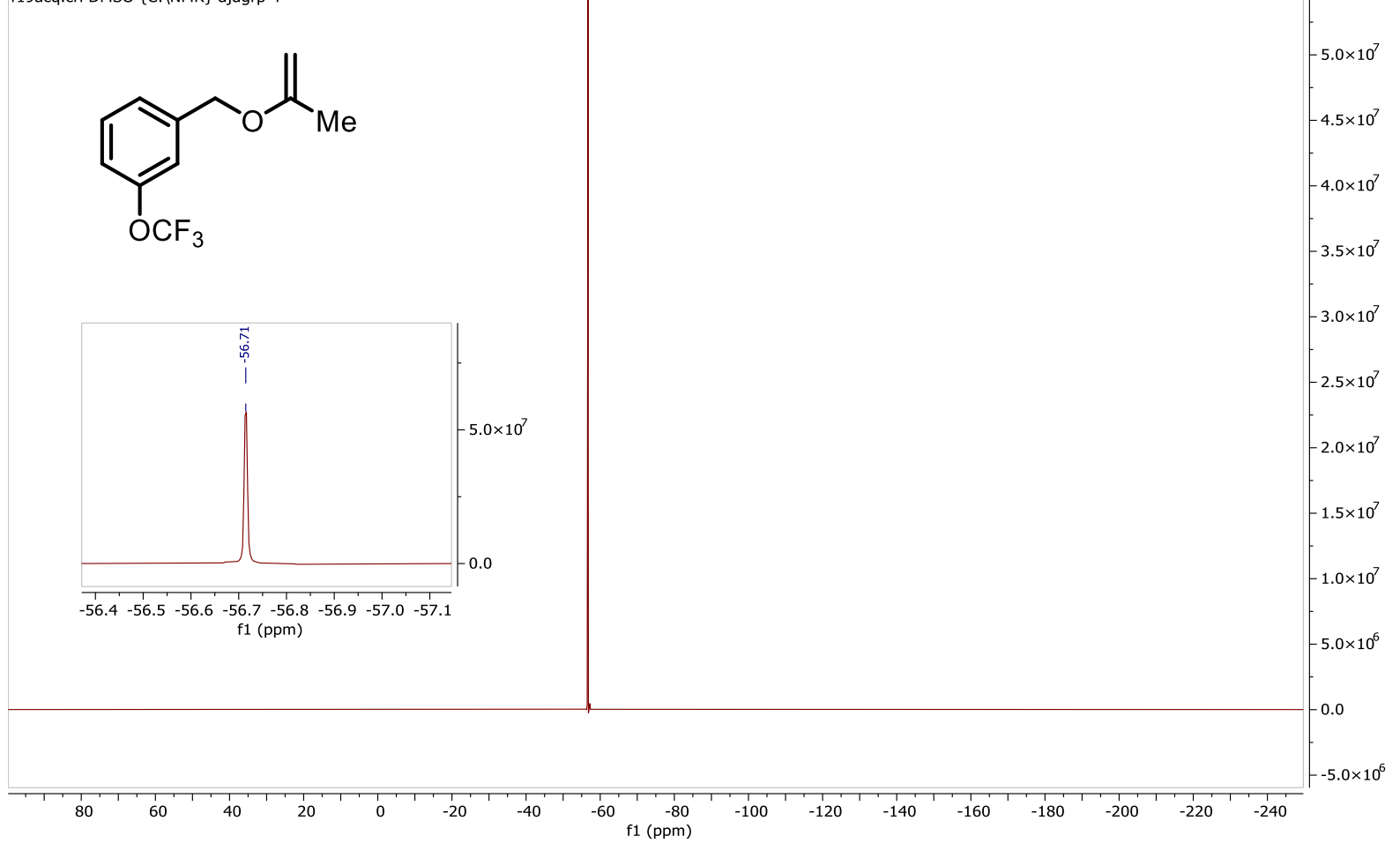


1d $-{ }^{13} \mathrm{C}$ NMR $\left(101 \mathrm{MHz}\right.$, DMSO- $\left.d_{6}\right)$

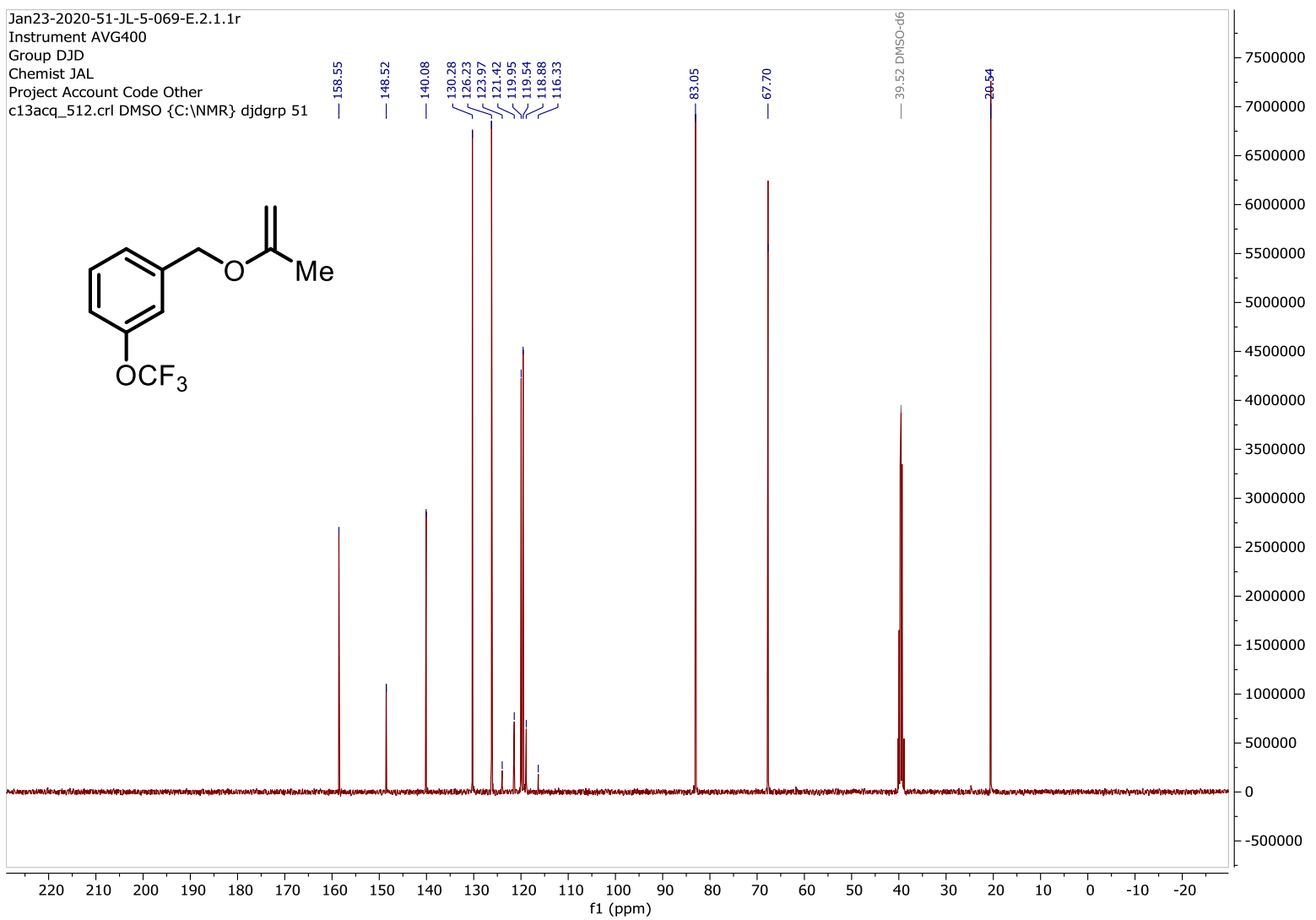


1e $-{ }^{1} \mathrm{H}$ NMR $\left(400 \mathrm{MHz}, \mathrm{DMSO}-d_{6}\right)$

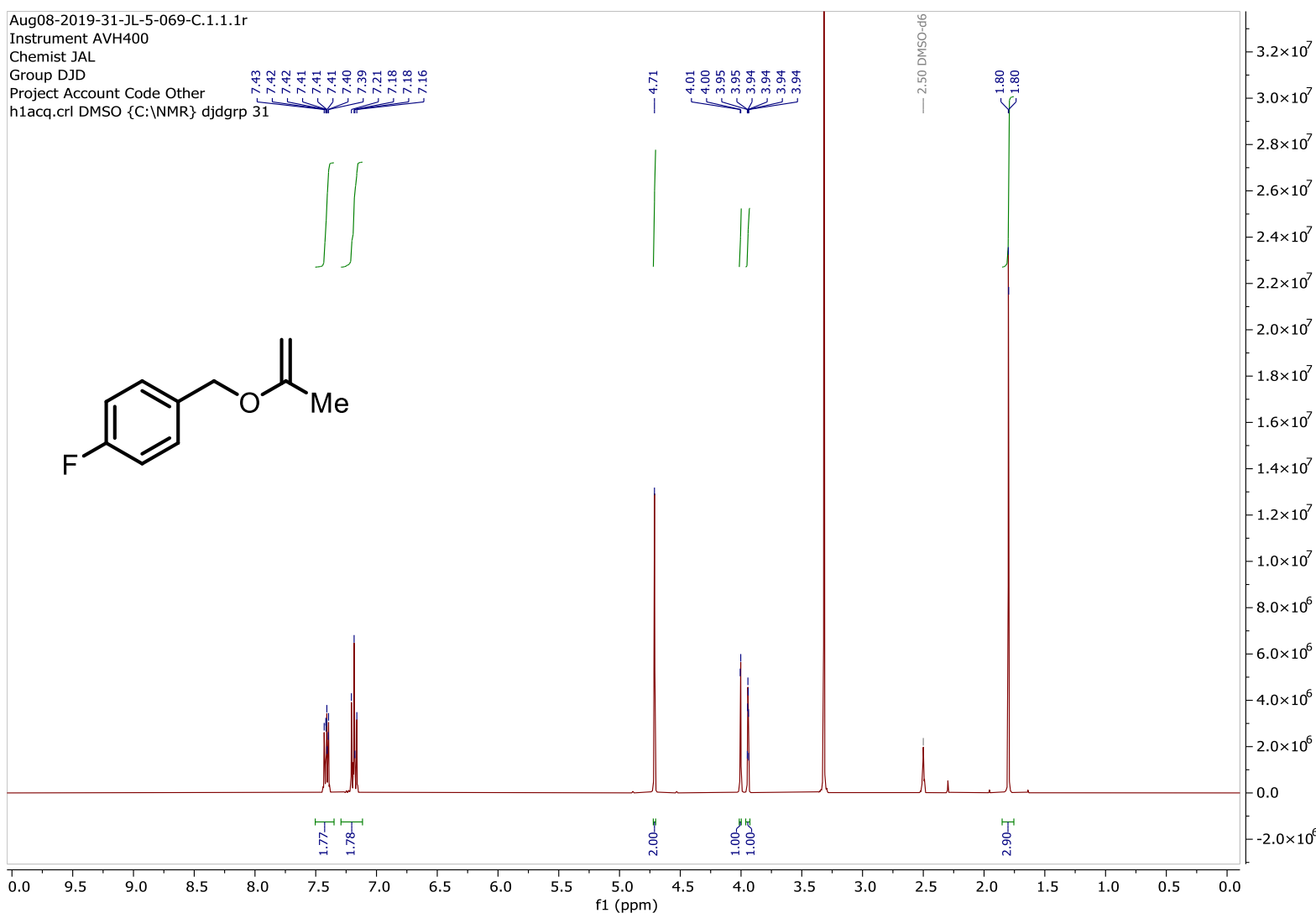

1e $-{ }^{19} \mathrm{~F}$ NMR $(377 \mathrm{MHz}$, DMSO-d $)$

Aug08-2019-31-JL-5-069-C.3.1.1r Instrument AVH400

Chemist JAL

Project Account Code Other

f19acq.crl DMSO \{C:INMR\} djdgrp 31

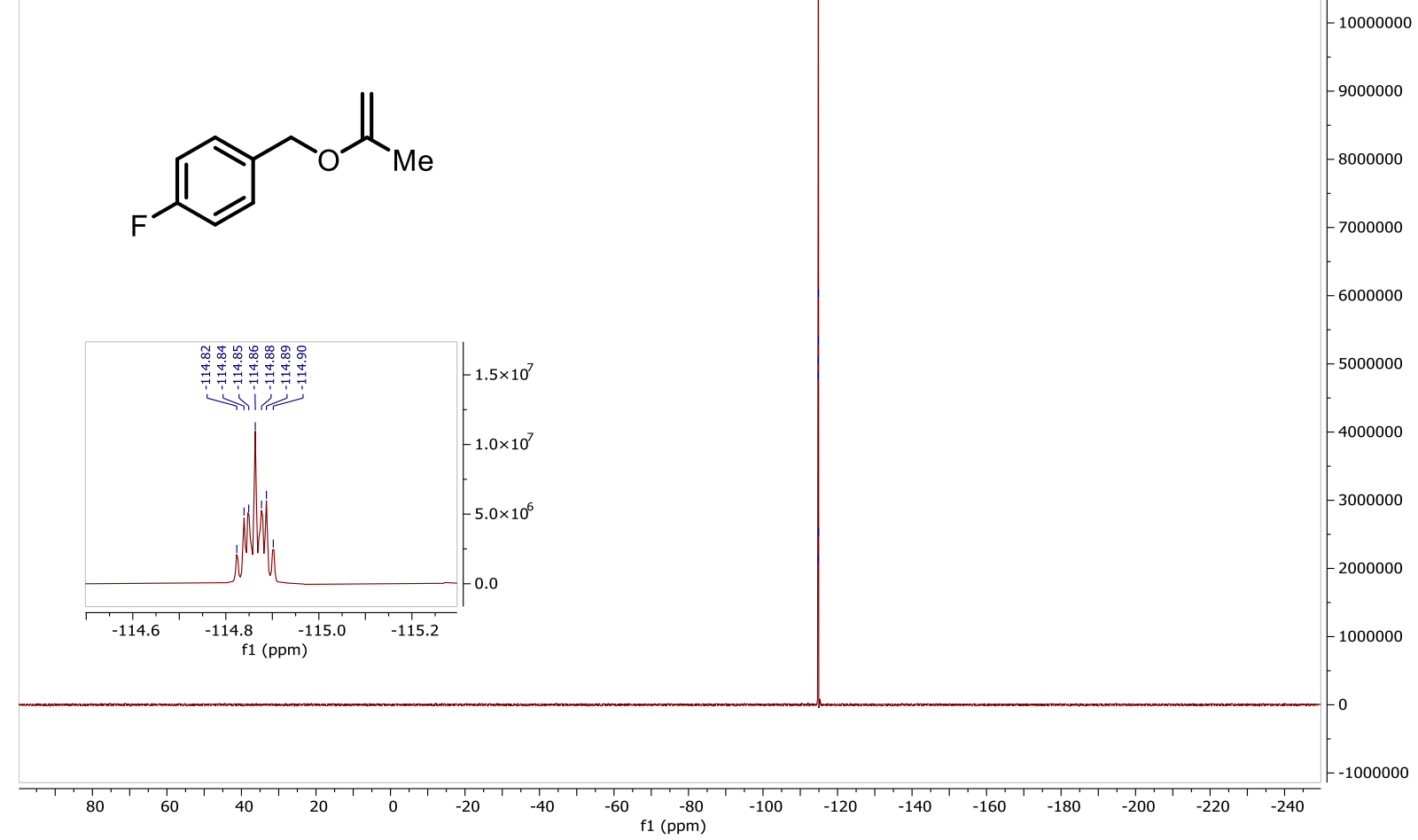


1e $-{ }^{13} \mathrm{C}$ NMR $\left(101 \mathrm{MHz}\right.$, DMSO- $\left.d_{6}\right)$

Aug08-2019-31-JL-5-069-C.2.1.1r

Instrument AVH400

Chemist JAL
Group DJD

unt Code Other

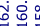

c13acq_512.crl DMSO \{C:|NMR $\}$ djdgrp $31 \backslash$ ।

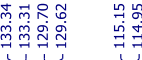

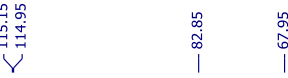

$\overbrace{\mathrm{O}}$

$\checkmark v$ V

3500000

3000000

$-2500000$

2000000

1500000

1000000

500000

$\begin{array}{llllllllllllllllllllllllllllll}220 & 210 & 200 & 190 & 180 & 170 & 160 & 150 & 140 & 130 & 120 & 110 & 100 & 90 & 80 & 70 & 60 & 50 & 40 & 30 & 20 & 10 & 0 & -10 & -20\end{array}$ 
1f $-{ }^{1} \mathrm{H}$ NMR $\left(400 \mathrm{MHz}, \mathrm{DMSO}-d_{6}\right)$

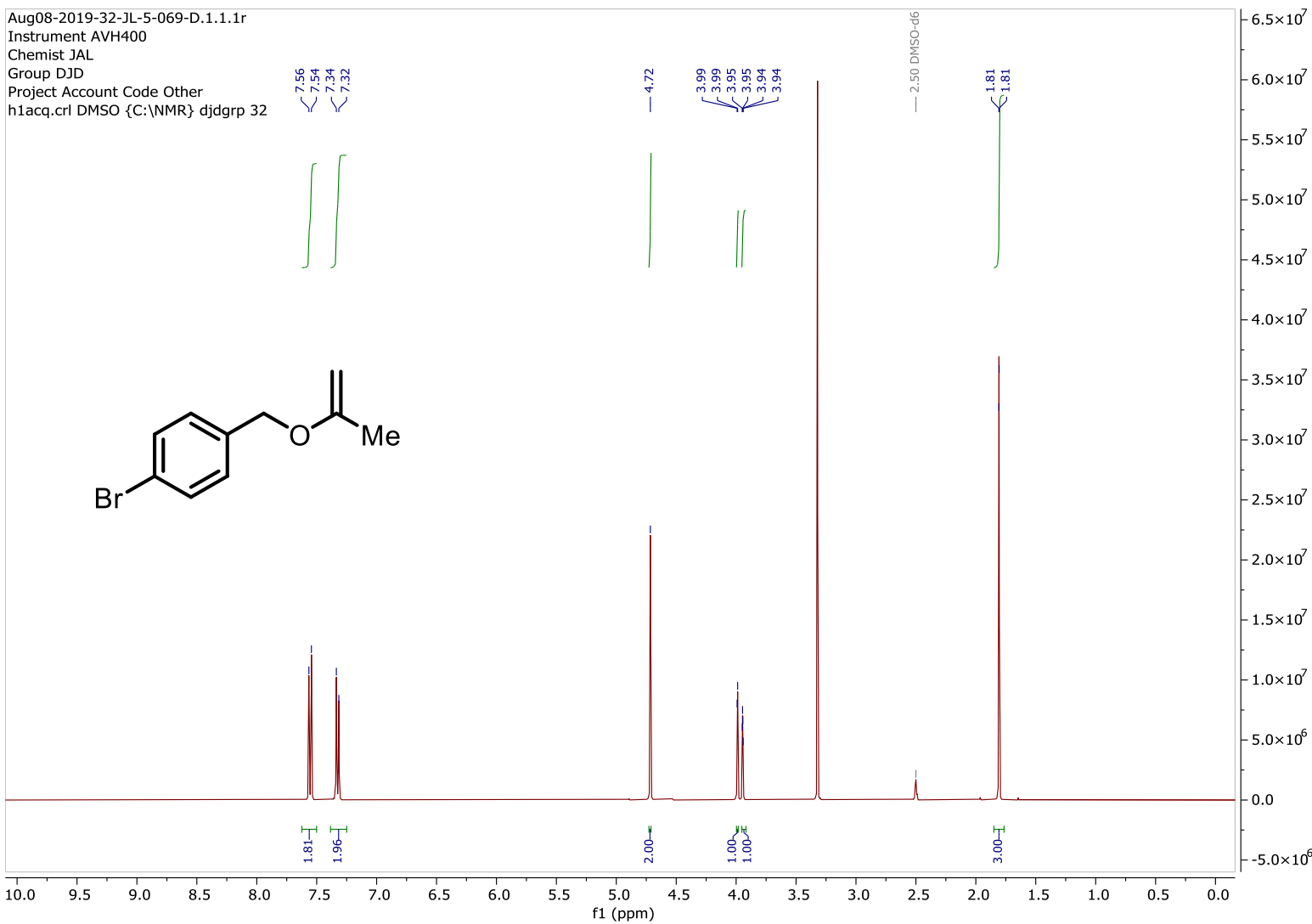

1f $-{ }^{13} \mathrm{C}$ NMR $\left(101 \mathrm{MHz}\right.$, DMSO- $\left.d_{6}\right)$

Aug08-2019-32-JL-5-069-D.2.1.1r

Instrument AVH400

Chemist JAL

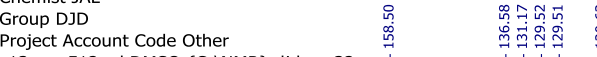

c13acq 512.crl DMSO \{C:INMR djdgrp 32 |

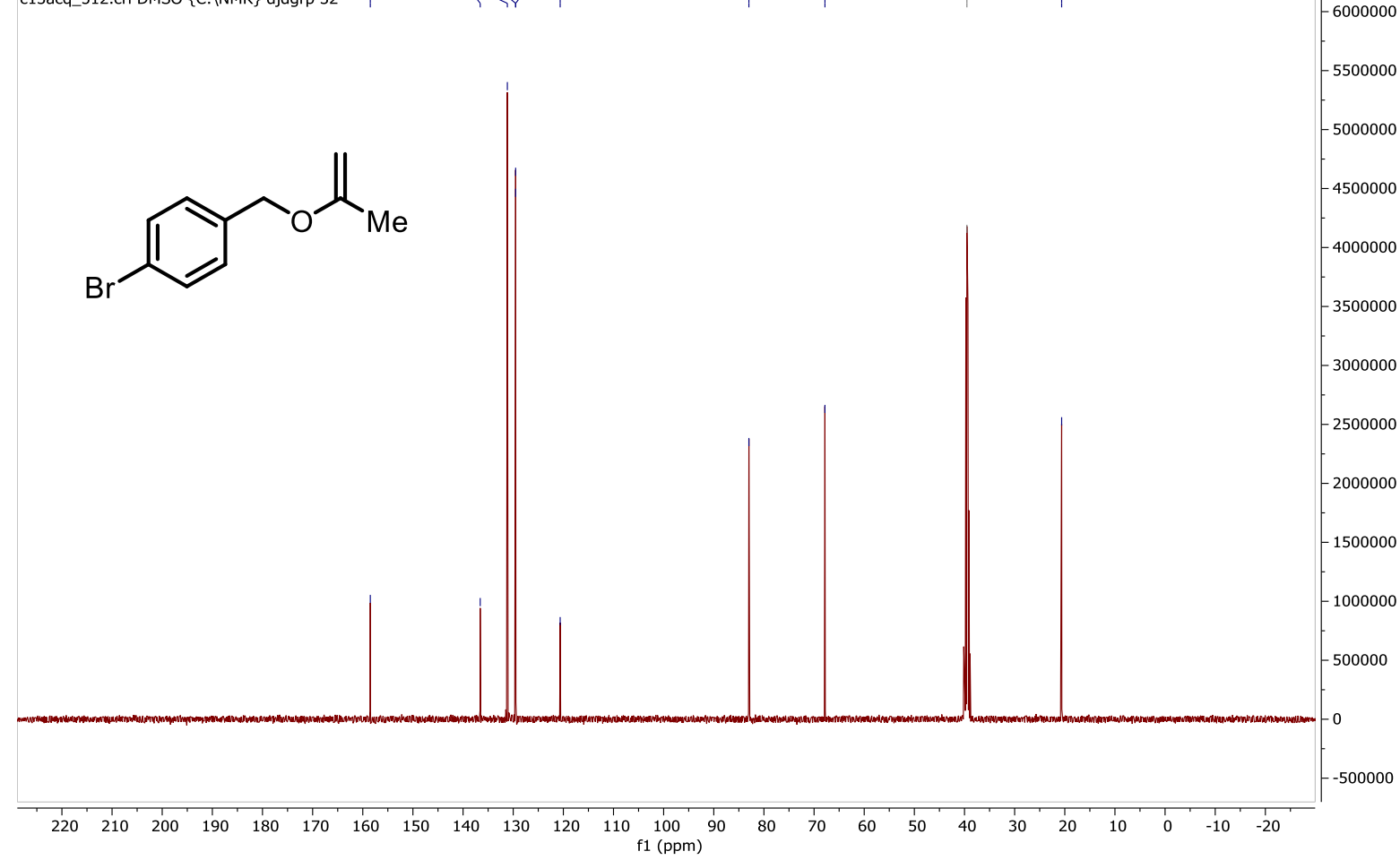


$1 \mathrm{~g}-{ }^{1} \mathrm{H}$ NMR $\left(400 \mathrm{MHz}, \mathrm{DMSO}-d_{6}\right)$

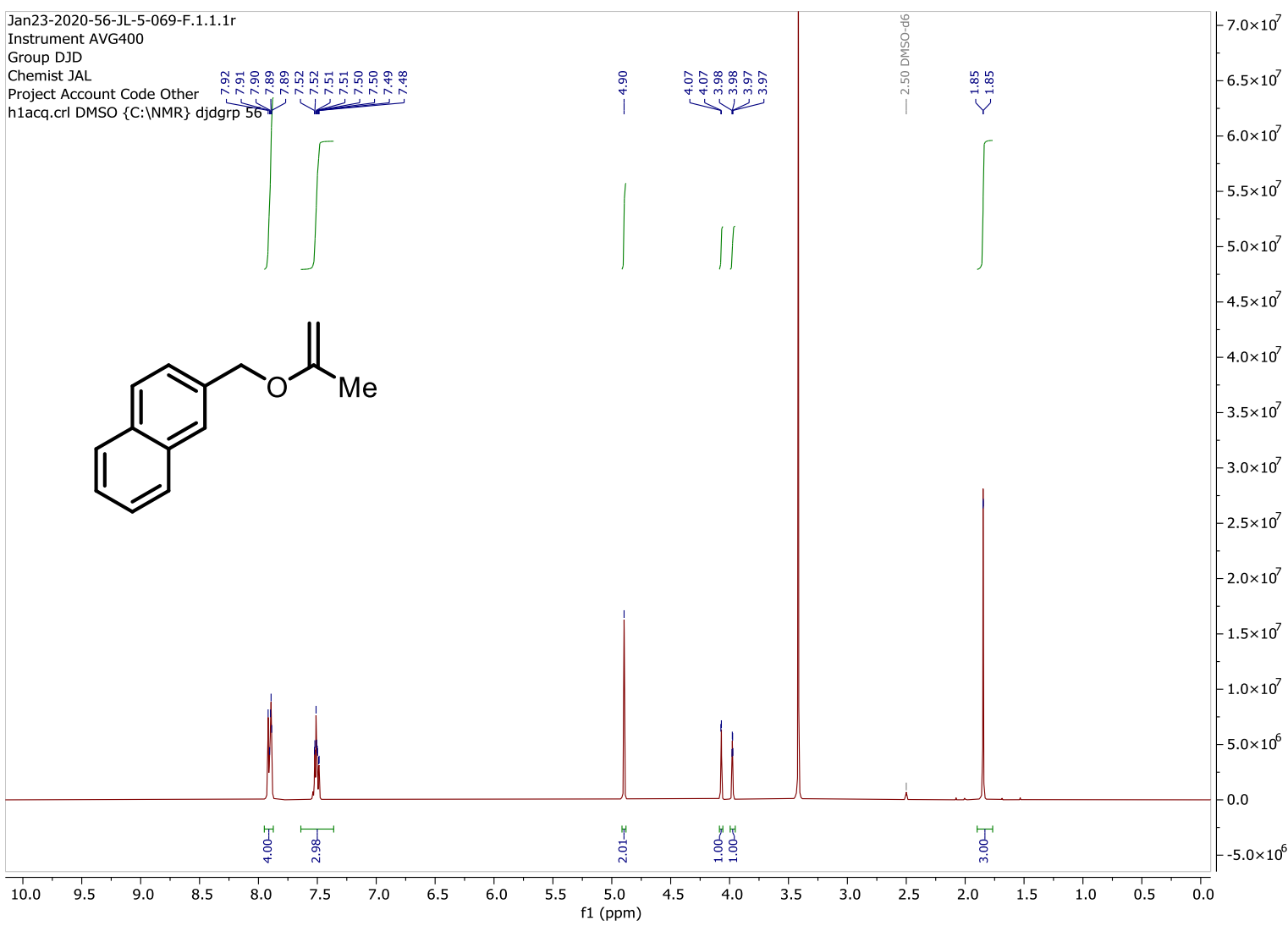

$1 \mathbf{g}-{ }^{13} \mathrm{C}$ NMR $\left(101 \mathrm{MHz}, \mathrm{DMSO}-d_{6}\right)$

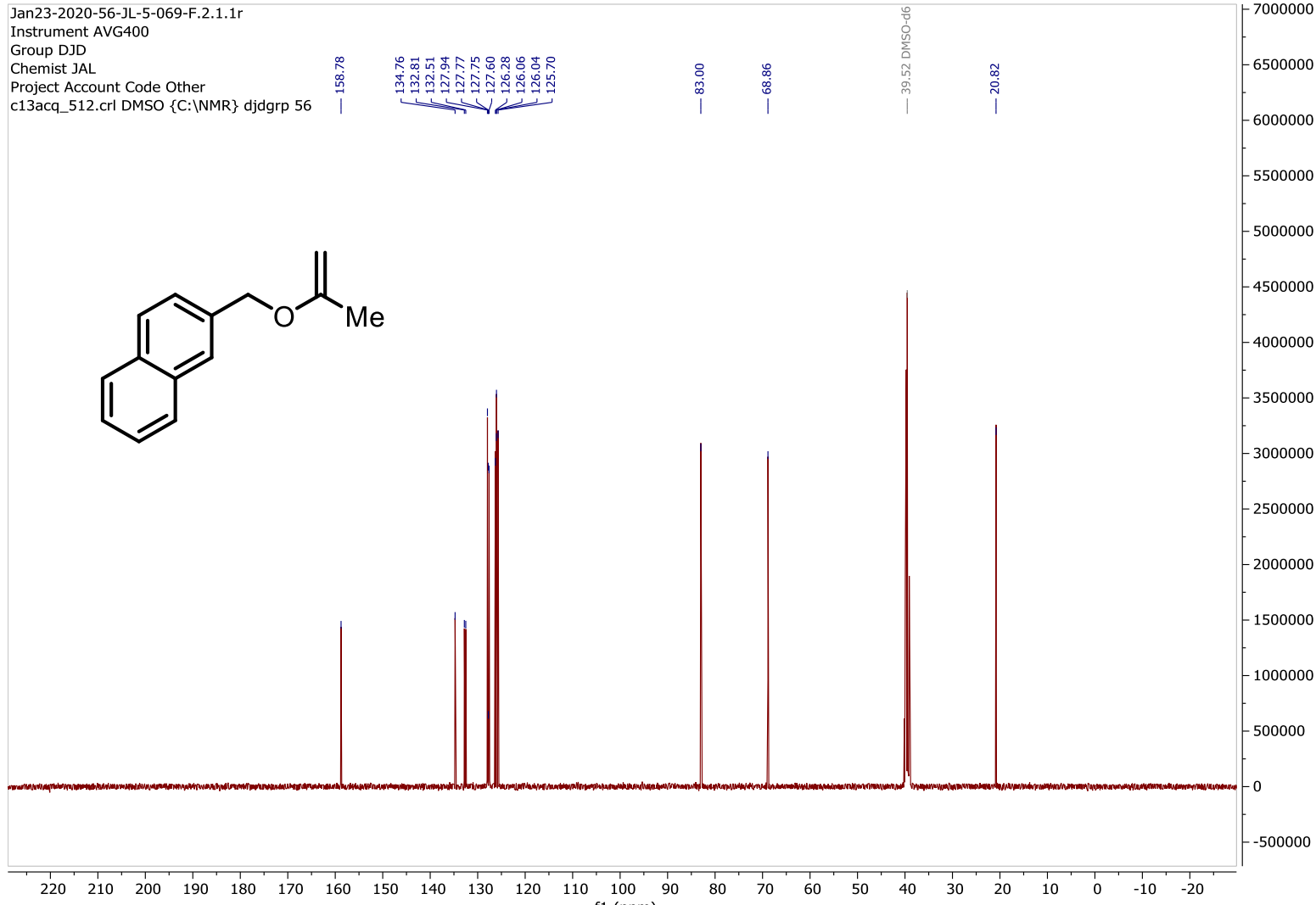

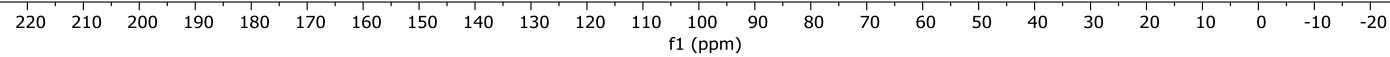


$1 \mathbf{h}-{ }^{1} \mathrm{H}$ NMR $\left(400 \mathrm{MHz}\right.$, DMSO- $\left.d_{6}\right)$

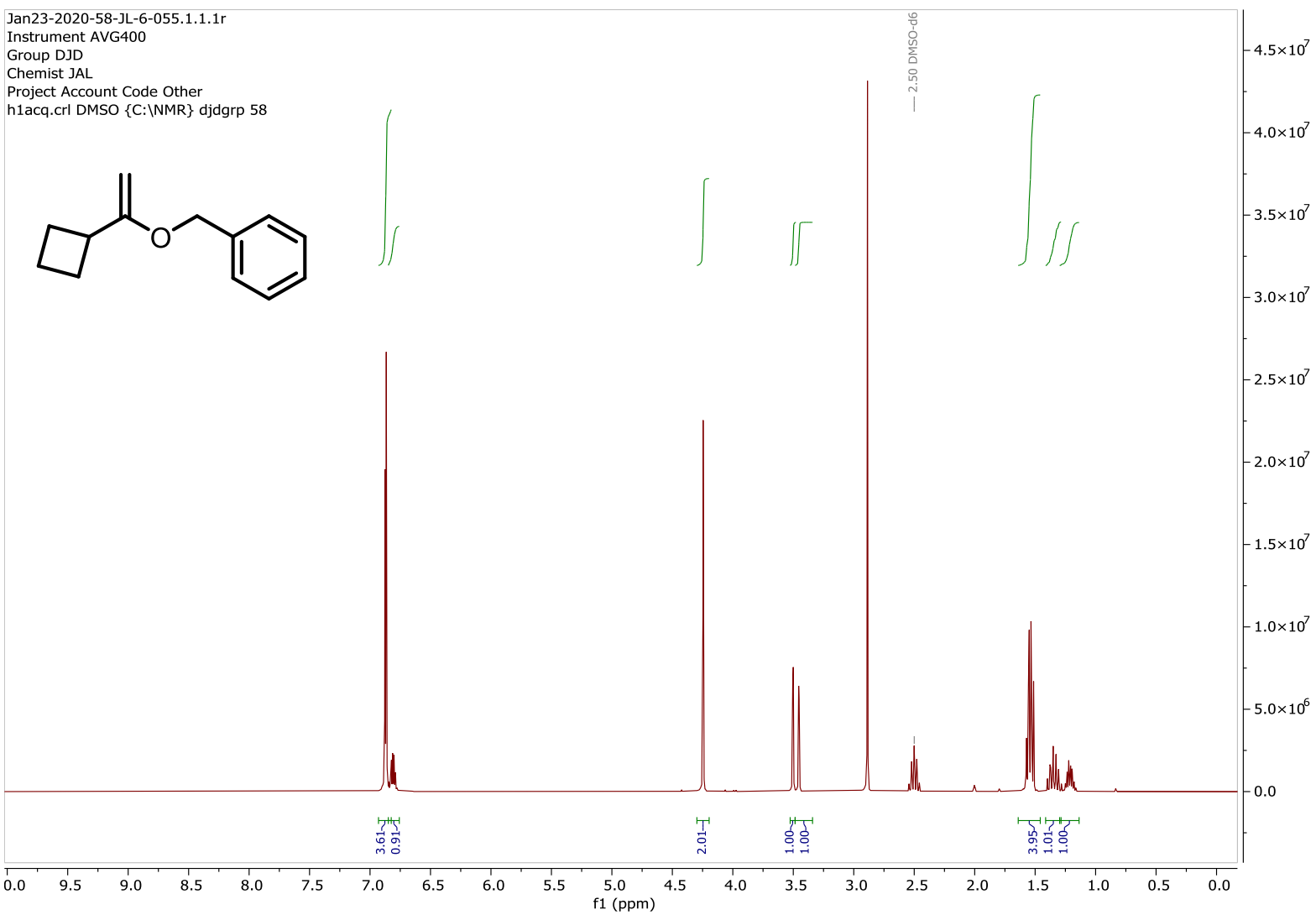

1h $-{ }^{13} \mathrm{C}$ NMR $\left(101 \mathrm{MHz}\right.$, DMSO- $\left.d_{6}\right)$

Jan23-2020-58-JL-6-055.2.1.1r

Instrument AVG400

Chemist JAL

Project Account Code Other

c13acq_512.crl DMSO \{C:|NMR $\}$ djdgrp 58

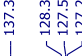

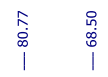

14000000

i

13000000

12000000

11000000<smiles>C=C(OCc1ccccc1)C1CCC1</smiles>

10000000

900000

8000000

7000000

6000000

5000000

4000000

3000000

200000

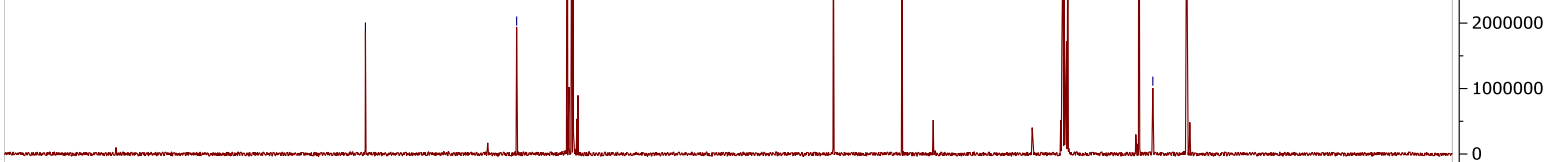

$\begin{array}{llllllllllllllllllllllllllllllllll}220 & 210 & 200 & 190 & 180 & 170 & 160 & 150 & 140 & 130 & 120 & 110 & 100 & 90 & 80 & 70 & 60 & 50 & 40 & 30 & 20 & 10 & 0 & -10 & -20\end{array}$

$-1000000$ 


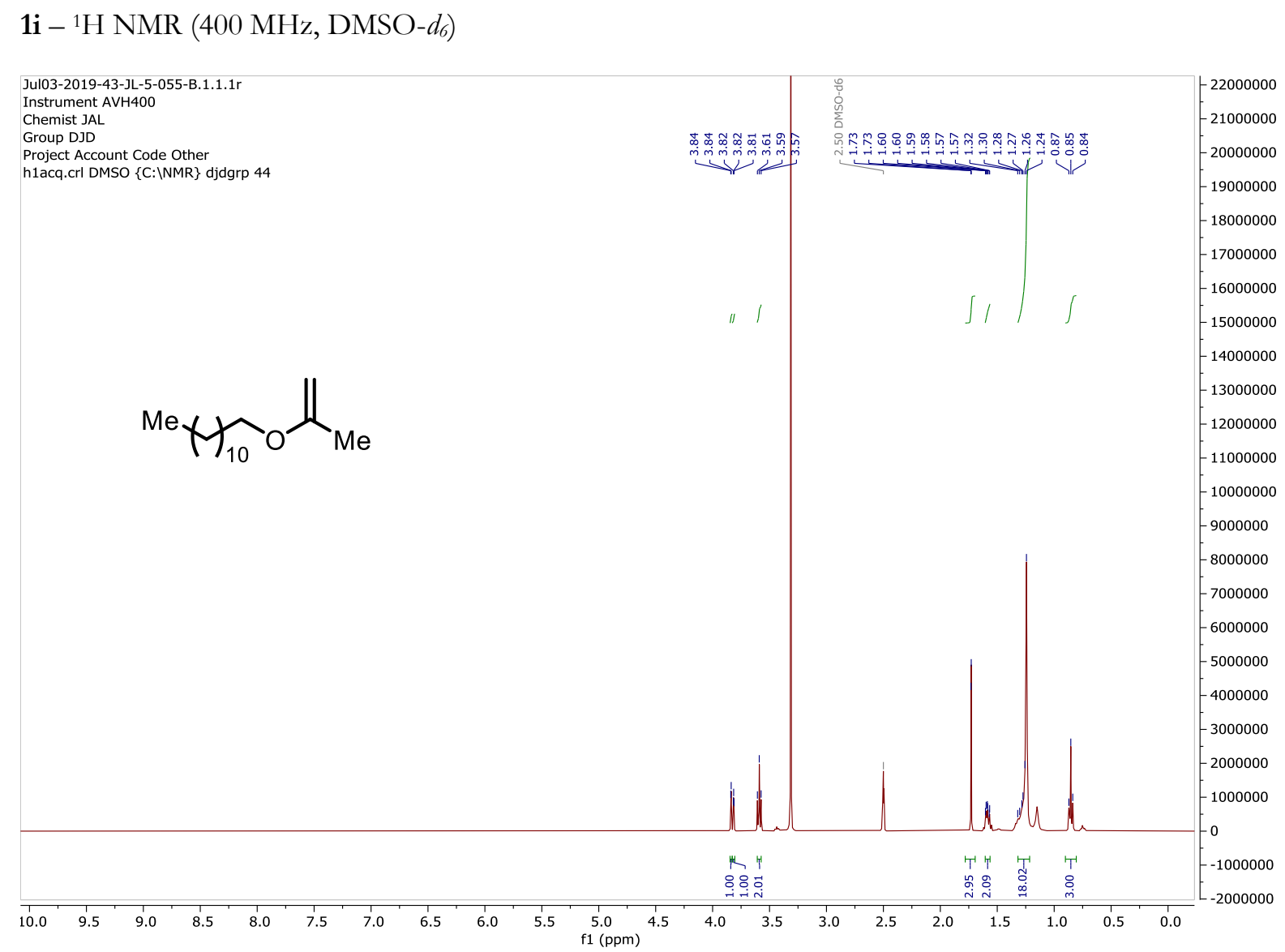

$1 \mathbf{i}-{ }^{13} \mathrm{C}$ NMR $\left(101 \mathrm{MHz}\right.$, DMSO- $\left.d_{6}\right)$

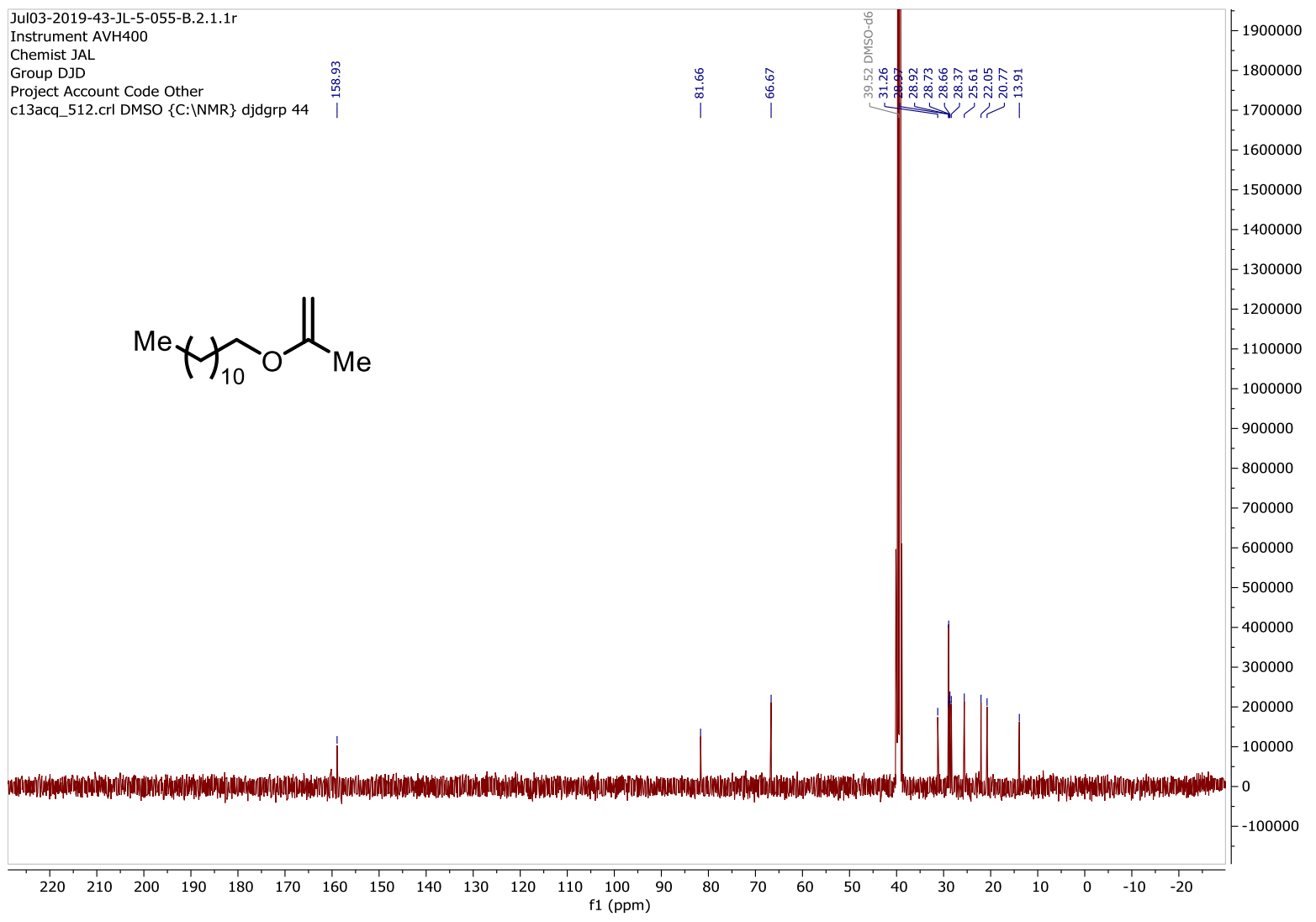




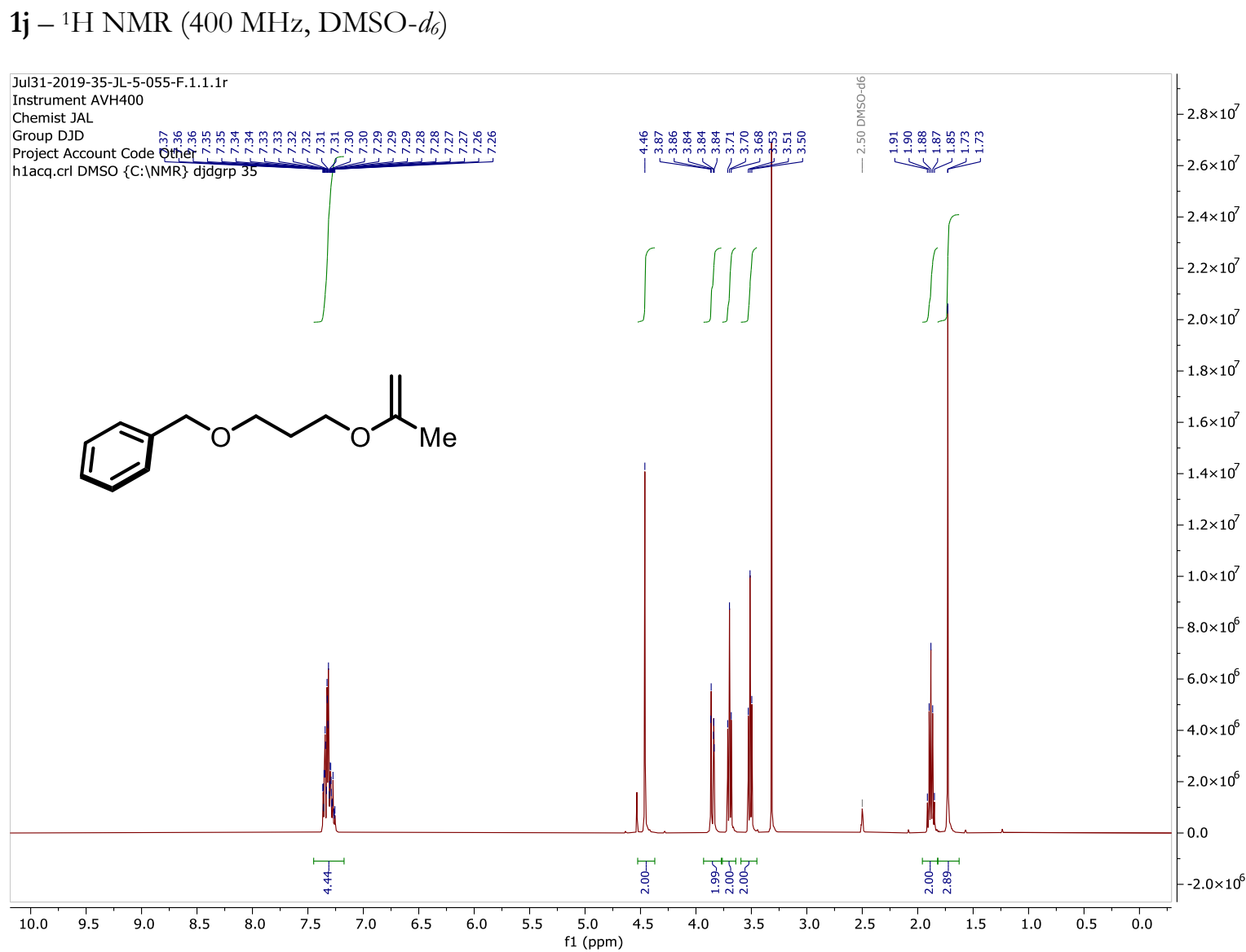

1j $-{ }^{13} \mathrm{C}$ NMR (101 MHz, DMSO- $\left.d_{6}\right)$

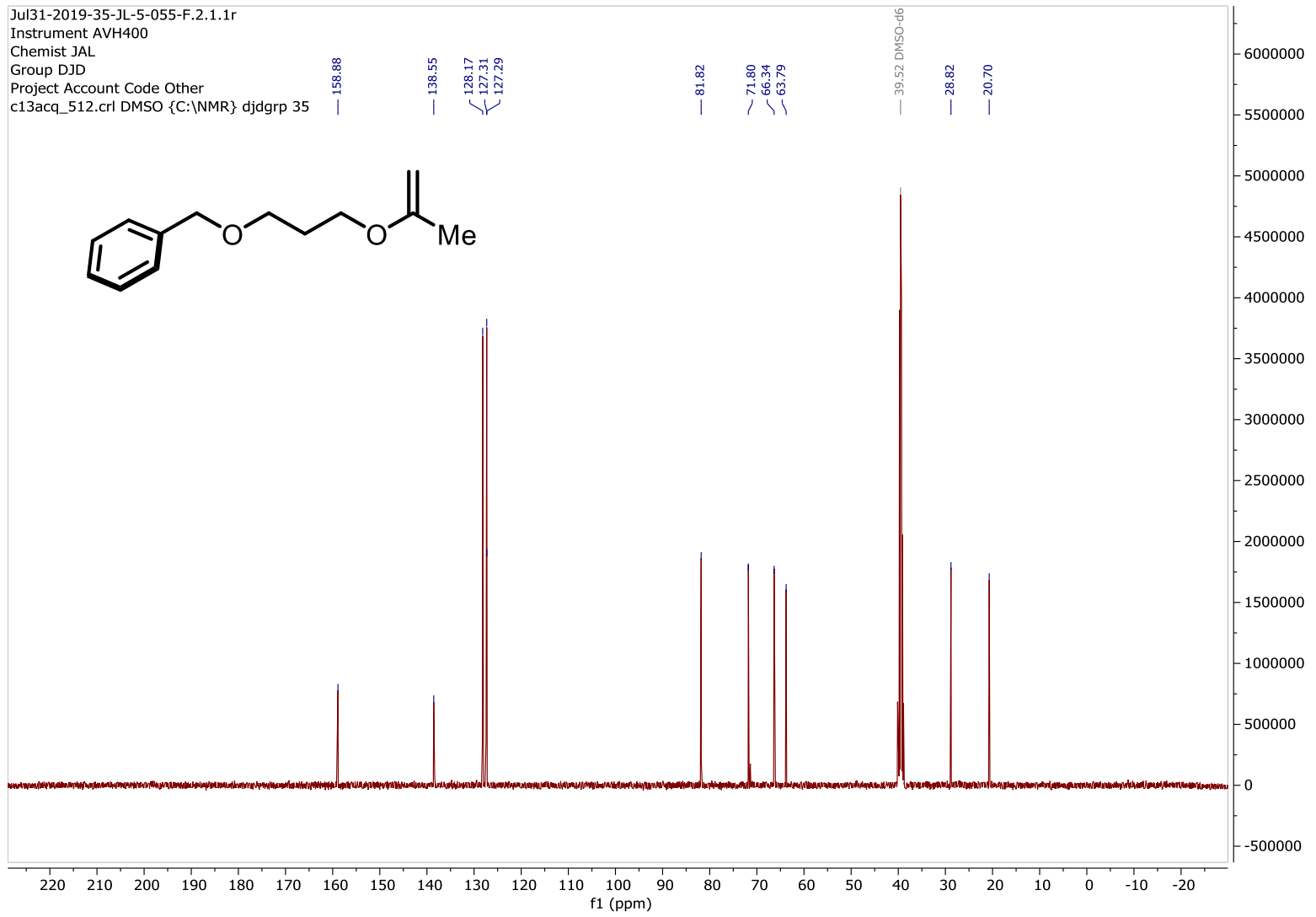


$1 \mathrm{k}-{ }^{1} \mathrm{H}$ NMR $\left(400 \mathrm{MHz}\right.$, DMSO- $\left.d_{6}\right)$

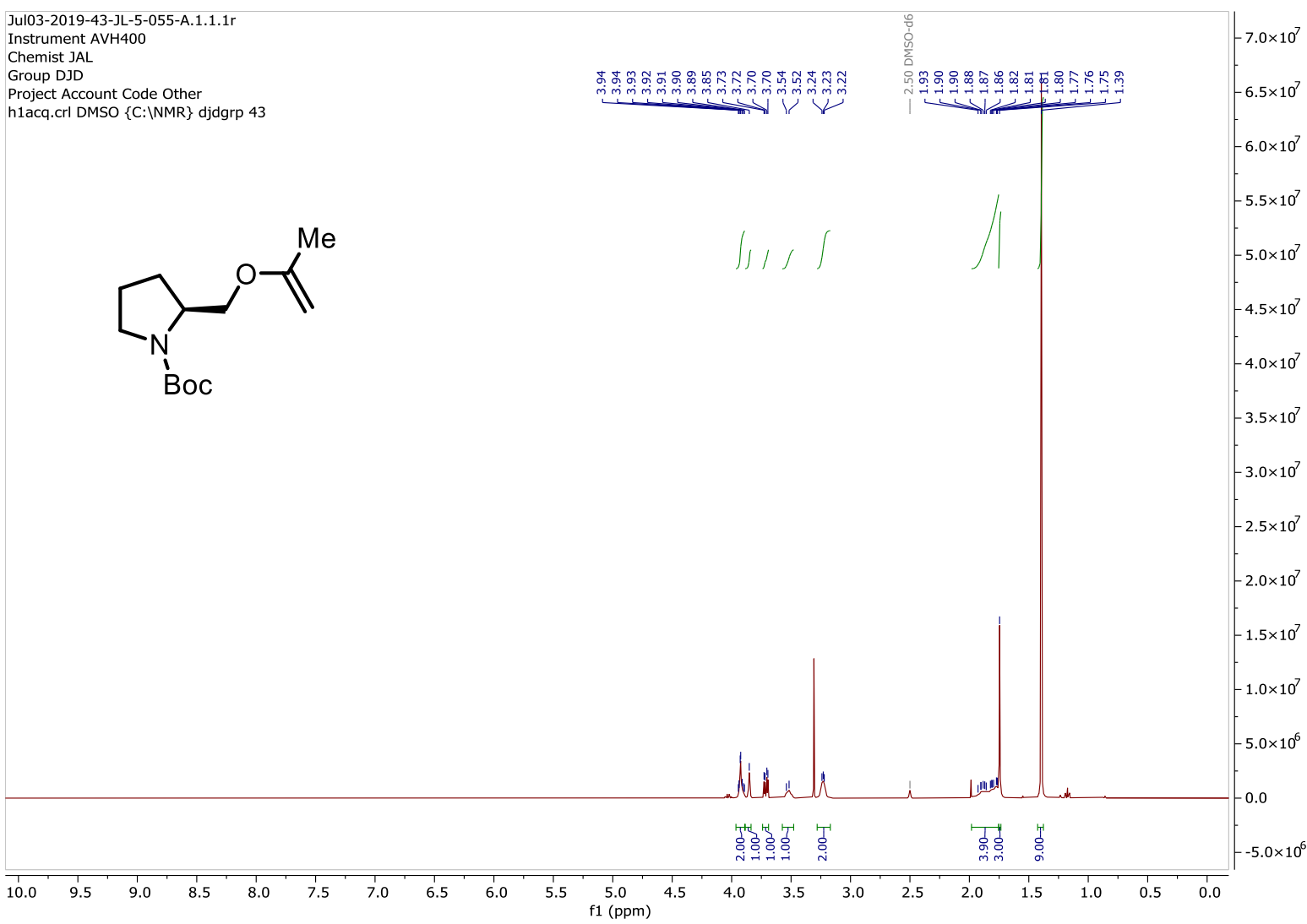

1k $-{ }^{13} \mathrm{C}$ NMR (101 MHz, DMSO-d $)$

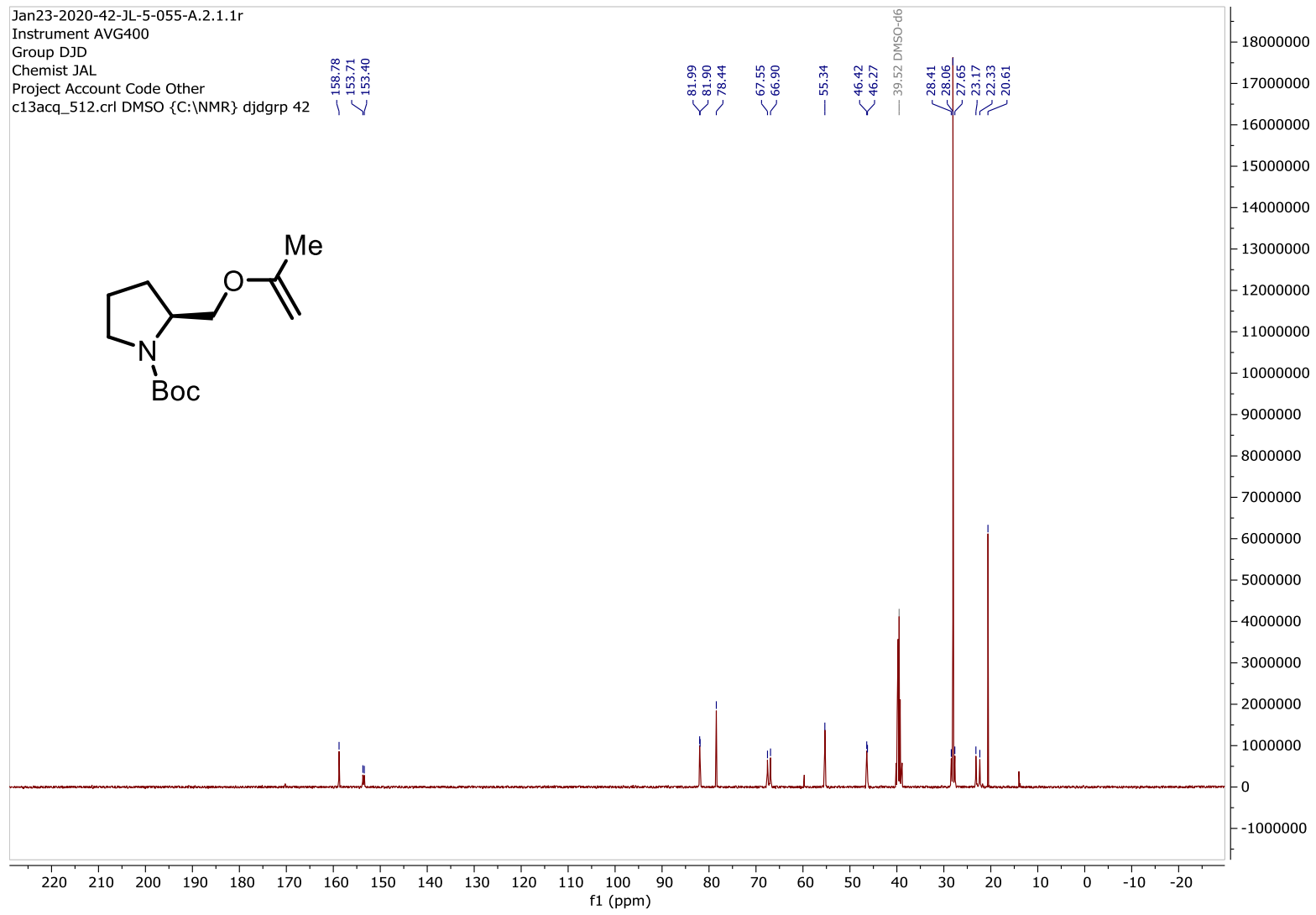




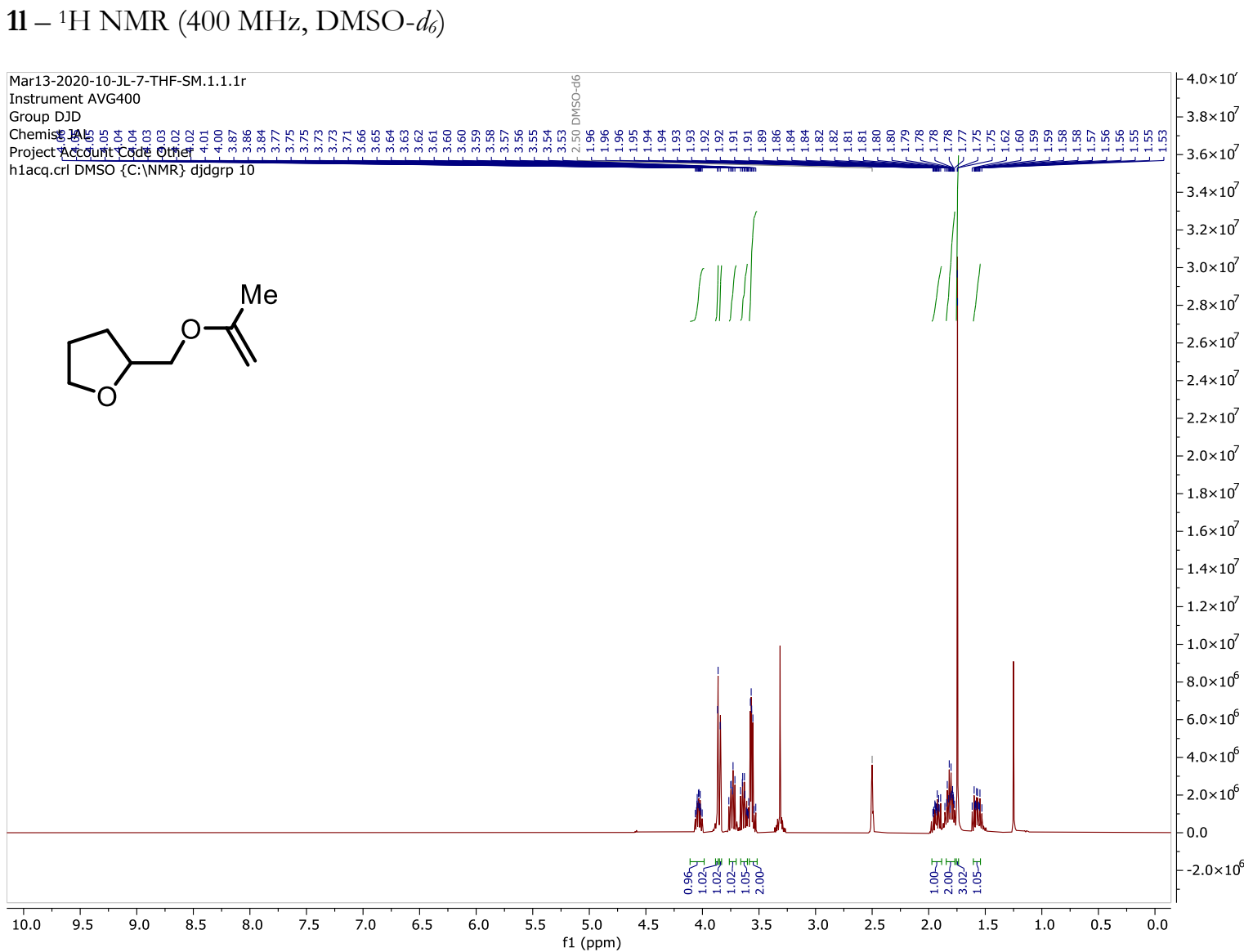

$11-{ }^{13} \mathrm{C}$ NMR (101 MHz, DMSO- $\left.d_{6}\right)$

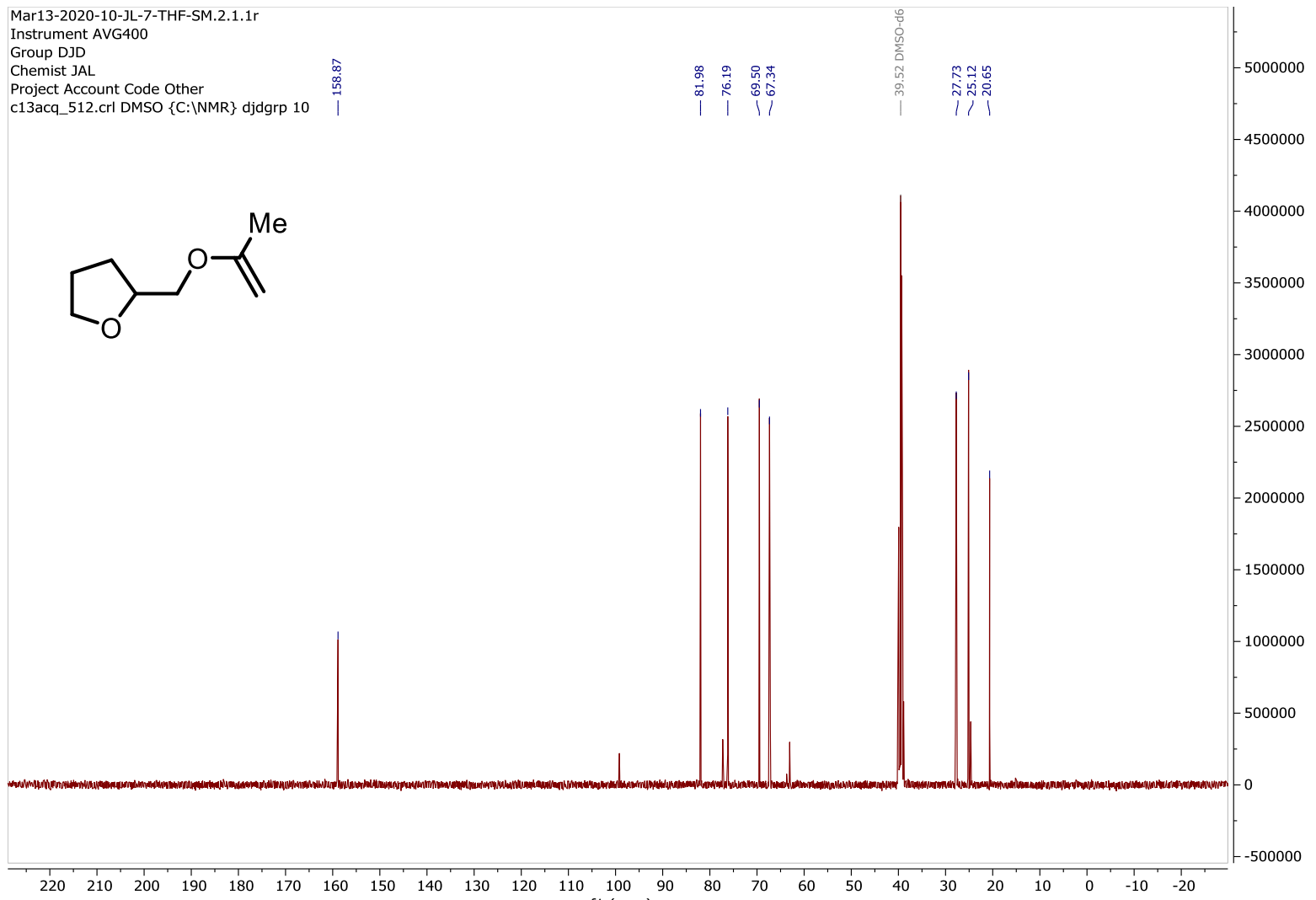


$1 \mathrm{~m}-{ }^{1} \mathrm{H}$ NMR $\left(400 \mathrm{MHz}, \mathrm{DMSO}-d_{6}\right)$

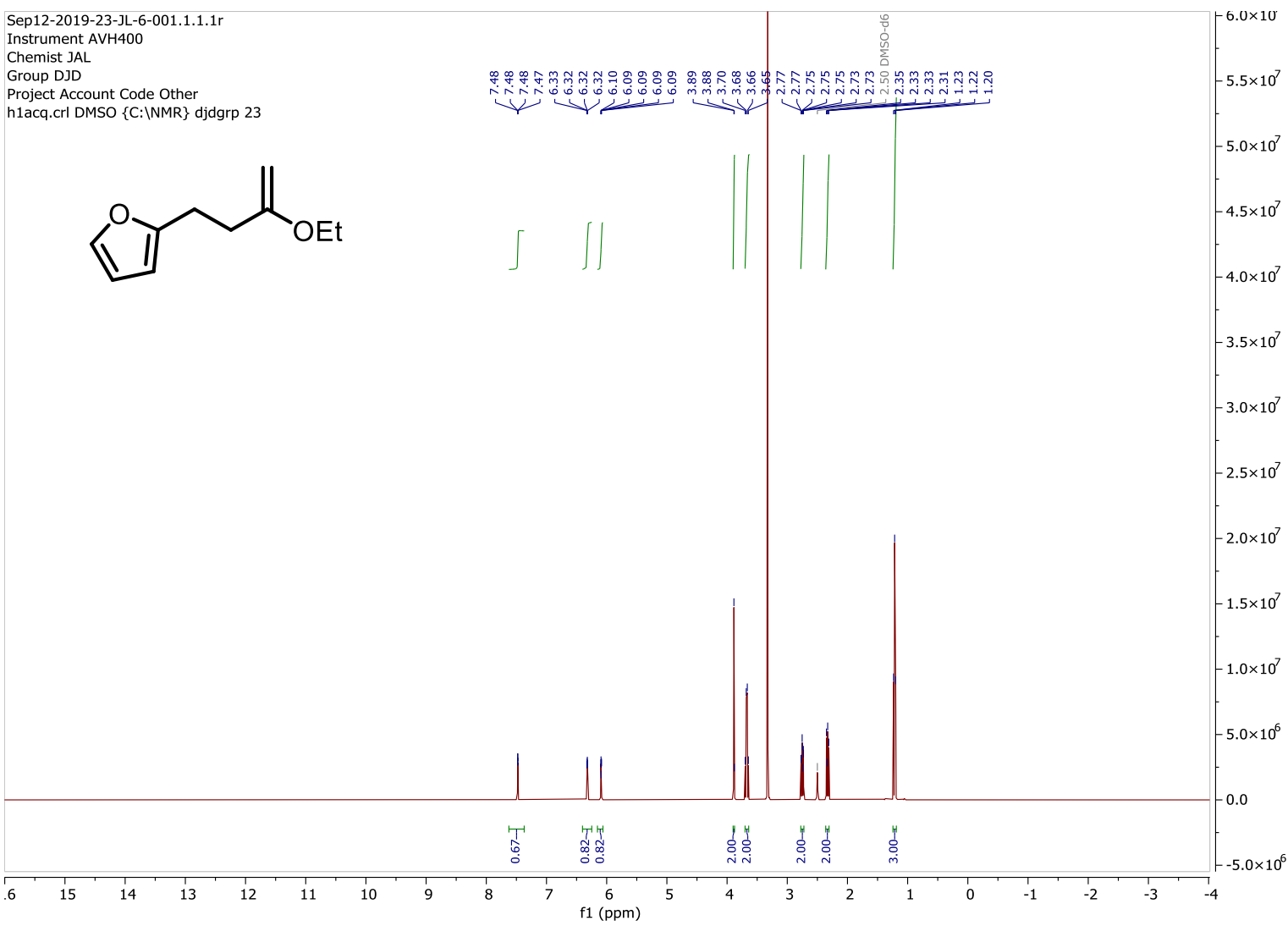

$1 \mathrm{~m}-{ }^{13} \mathrm{C}$ NMR $\left(101 \mathrm{MHz}, \mathrm{DMSO}-d_{6}\right)$

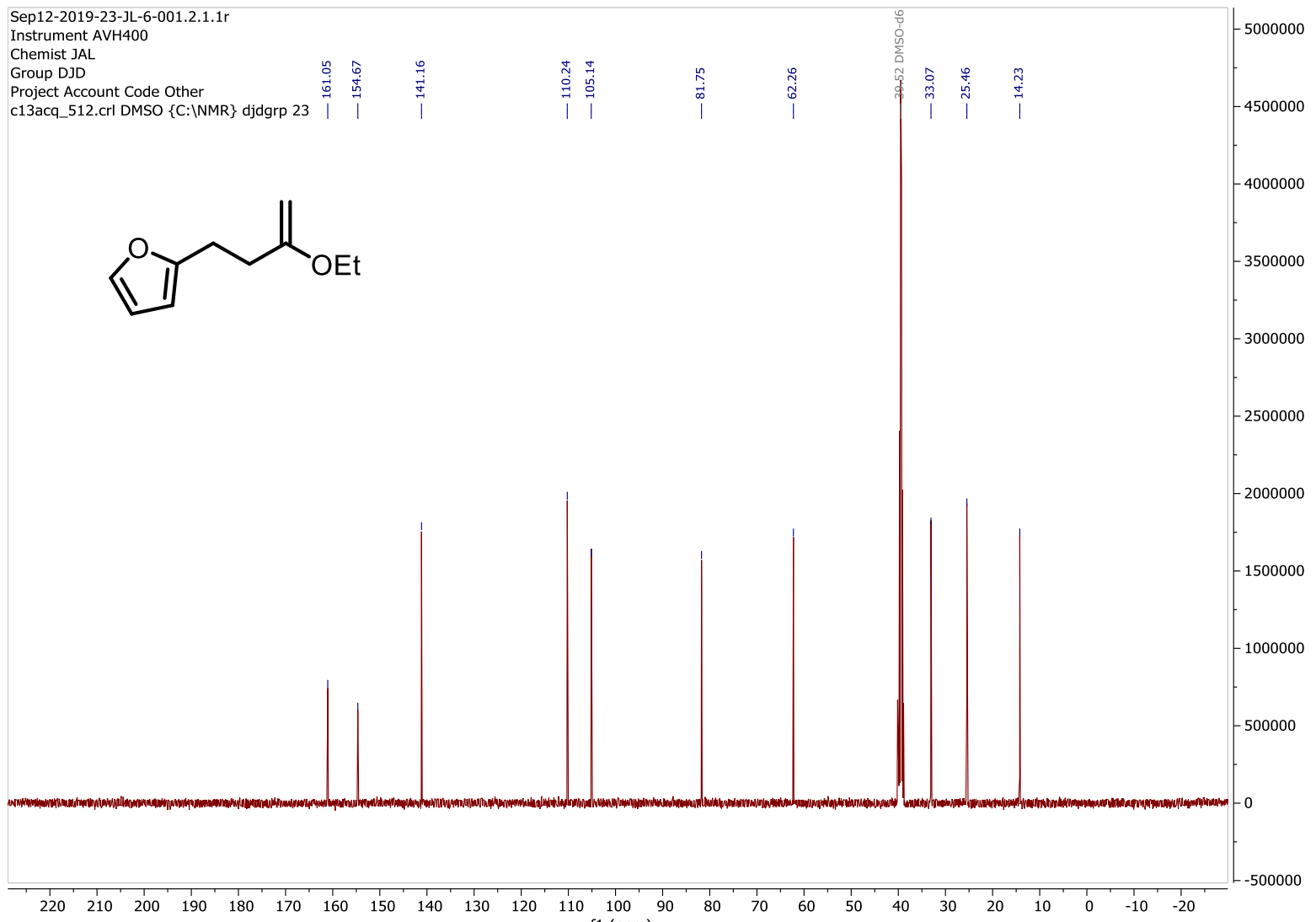


1n $-{ }^{1} \mathrm{H}$ NMR $\left(400 \mathrm{MHz}, \mathrm{CDCl}_{3}\right)$

Apr16-2019-45-JL-4-082-B-post distill.1.1.1r Instrument AVH400

Chemist JAL

Group DJD

Account Code Othe

h1acq.crl CDCl3 \{C:|NMR\} djdgrp 45

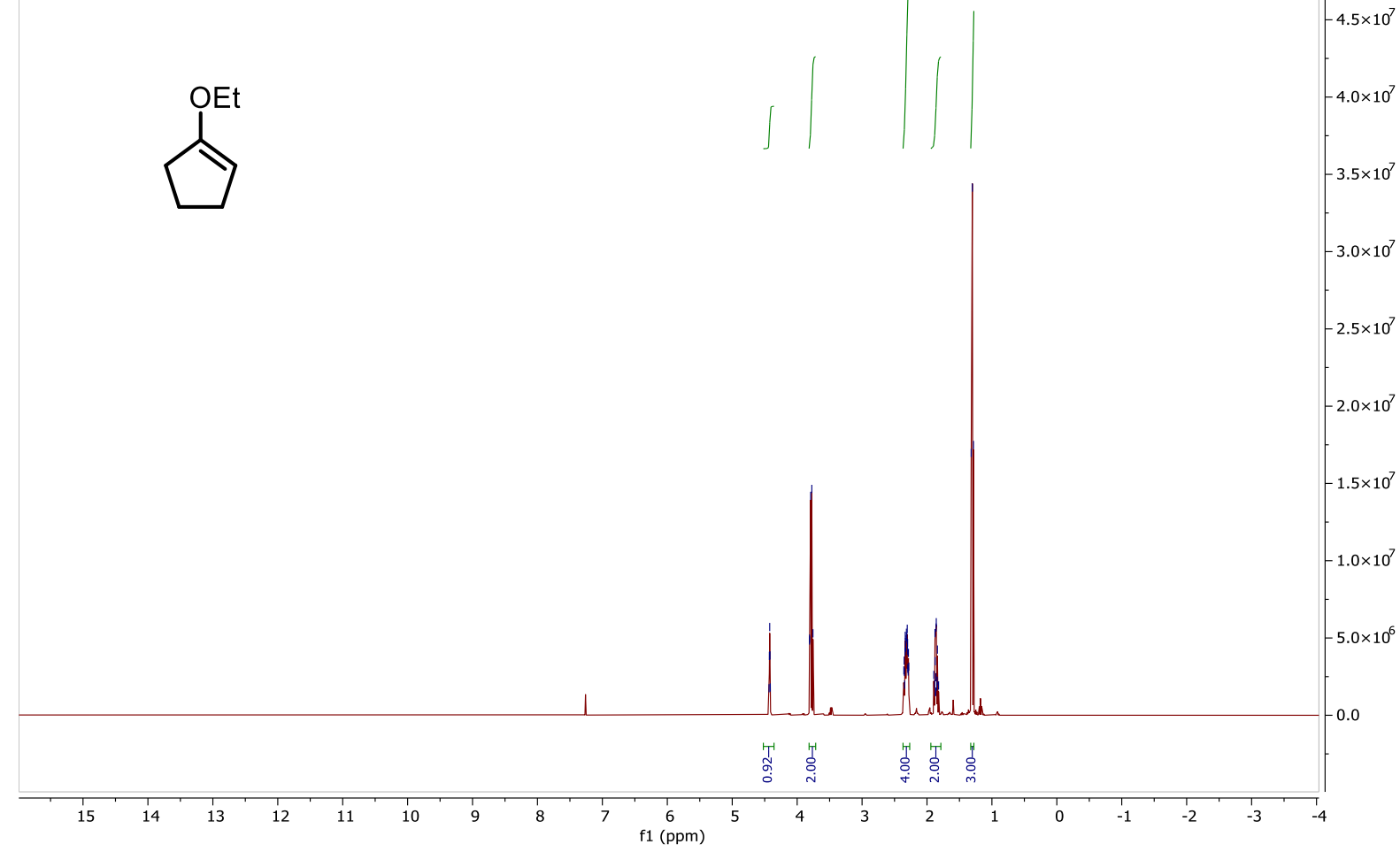

1n $-{ }^{13} \mathrm{C} \mathrm{NMR}\left(101 \mathrm{MHz}, \mathrm{CDCl}_{3}\right)$

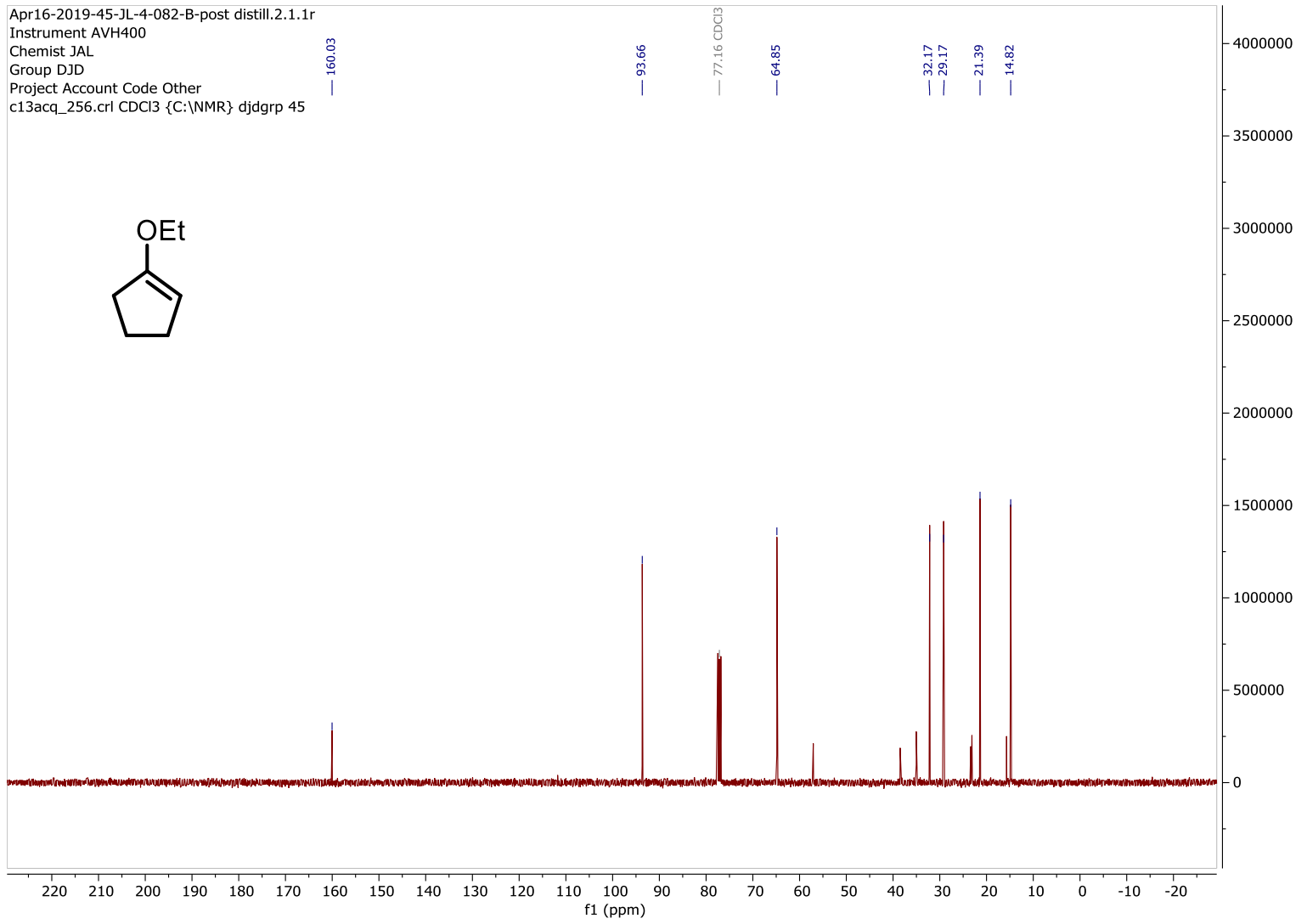


1p $-{ }^{1} \mathrm{H}$ NMR $\left(400 \mathrm{MHz}\right.$, DMSO- $\left.d_{6}\right)$

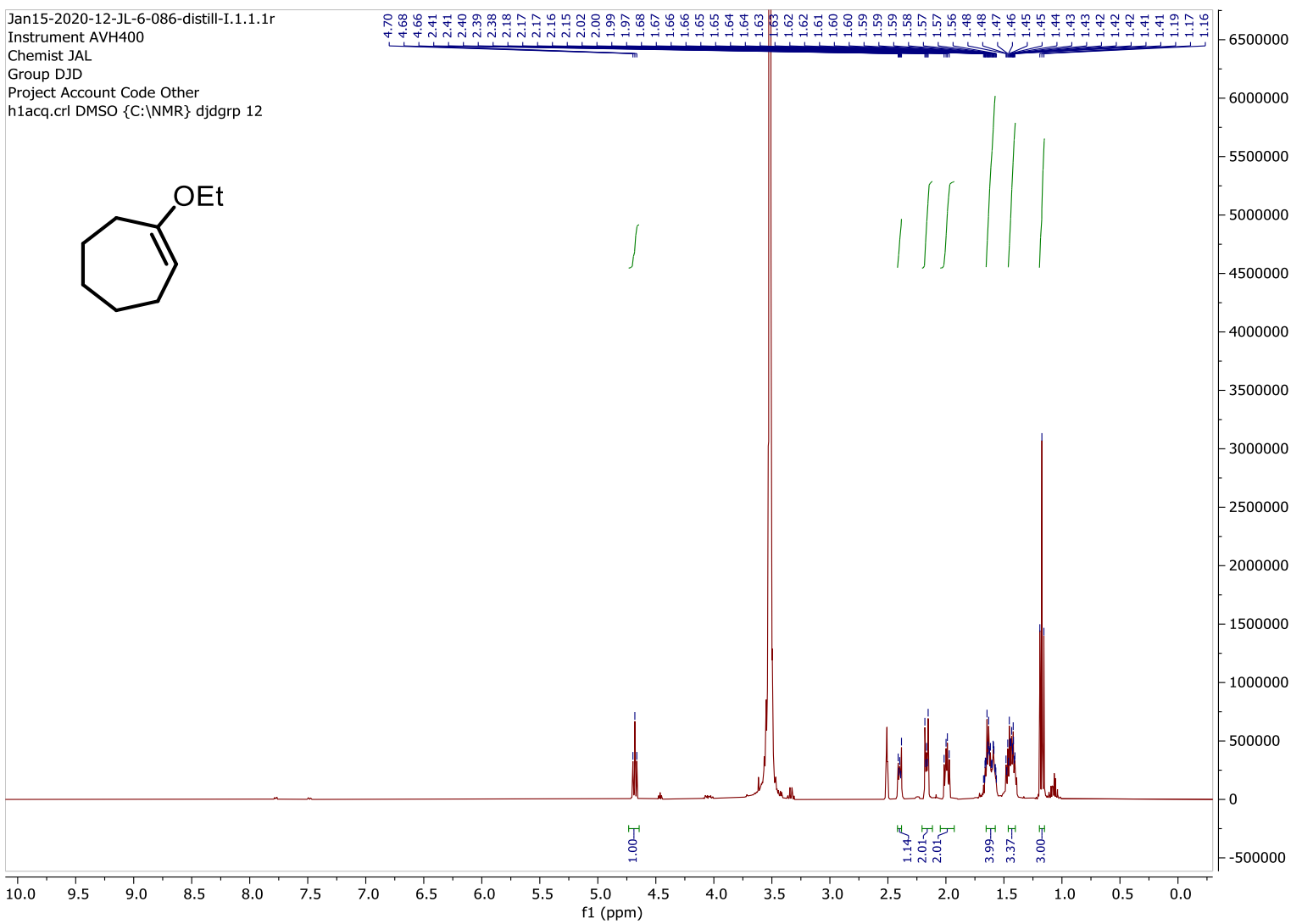

1p $-{ }^{13} \mathrm{C}$ NMR $\left(101 \mathrm{MHz}\right.$, DMSO- $\left.d_{6}\right)$

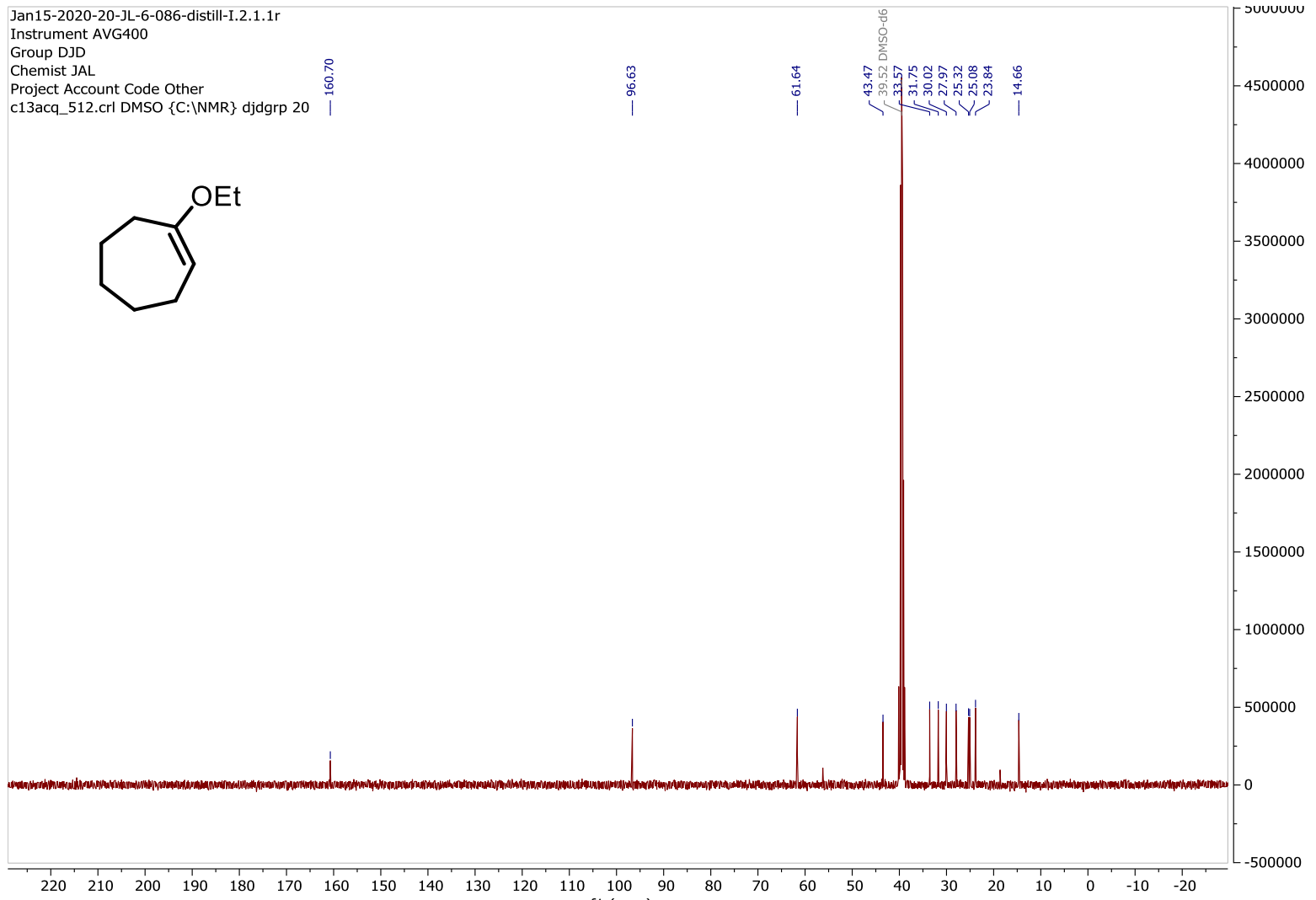

$\begin{array}{lllllllllllllllllllllllll}220 & 210 & 200 & 190 & 180 & 170 & 160 & 150 & 140 & 130 & 120 & 110 & 100 & 90 & 80 & 70 & 60 & 50 & 40 & 30 & 20 & 10 & 0 & -10 & -20\end{array}$ 
1q- ${ }^{1} \mathrm{H}$ NMR $\left(400 \mathrm{MHz}\right.$, DMSO- $\left.d_{6}\right)$

Aug01-2019-55-JL-5-047.1.1.1r

Instrument AVH40O

Chemist JAL

Group DJD

Project Account Code Other
h1acq.crl DMSO $\{C:$ NMR $\}$ djdgrp 55<smiles>C=C1CCCCO1</smiles>

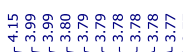

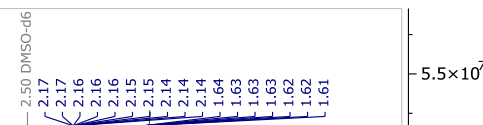

(1)

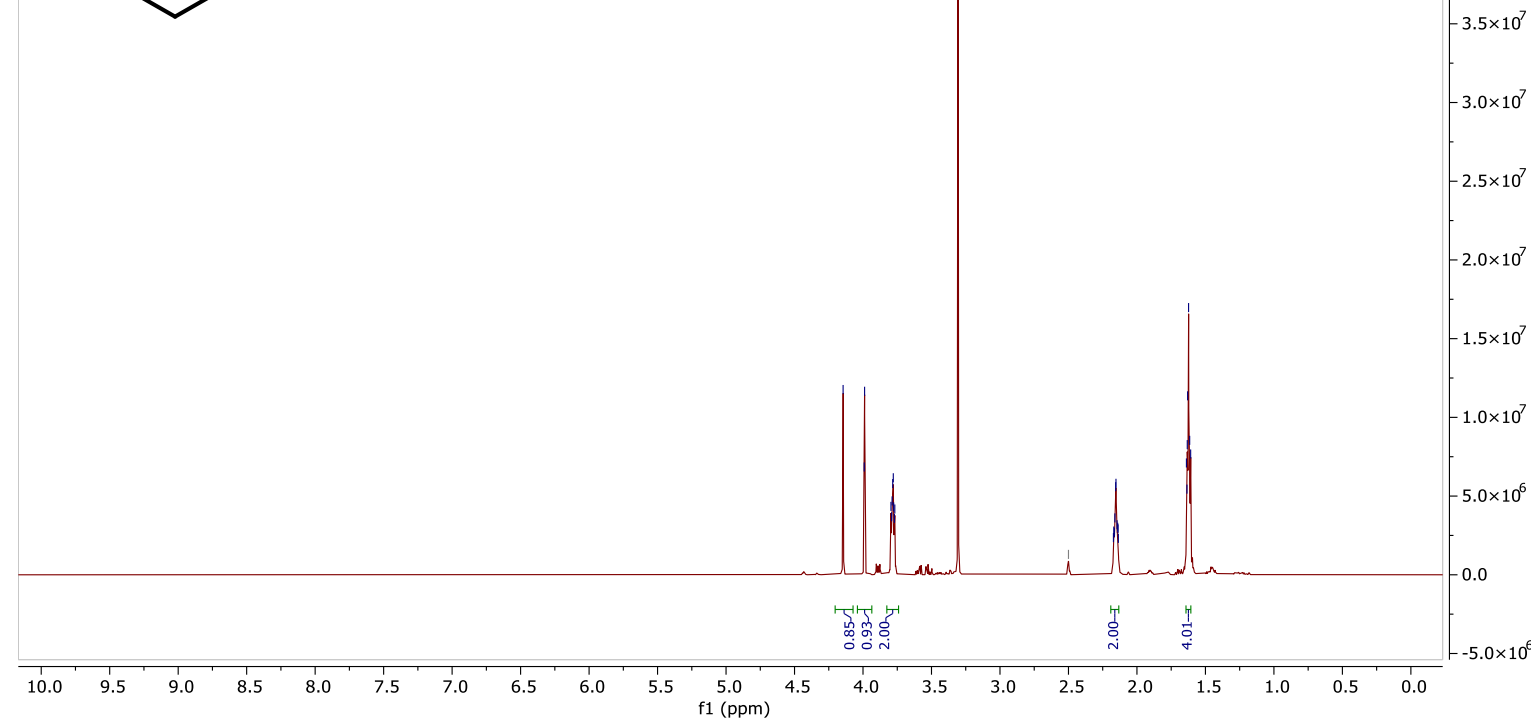

1q - ${ }^{13} \mathrm{C}$ NMR (101 MHz, DMSO-d $)$

Aug01-2019-55-JL-5-047.2.1.1r Instrument AVH400

Chemist JAL

Group DJD

c13acq_512.crl DMSO \{C:|NMR\} djdgrp 55 .

过

$\begin{array}{llllllllllllllllllllllllllllll}220 & 210 & 200 & 190 & 180 & 170 & 160 & 150 & 140 & 130 & 120 & 110 & 100 & 90 & 80 & 70 & 60 & 50 & 40 & 30 & 20 & 10 & 0 & -10 & -20\end{array}$ 
$1 \mathbf{r}-{ }^{1} \mathrm{H}$ NMR $\left(400 \mathrm{MHz}, \mathrm{DMSO}-d_{6}\right)$

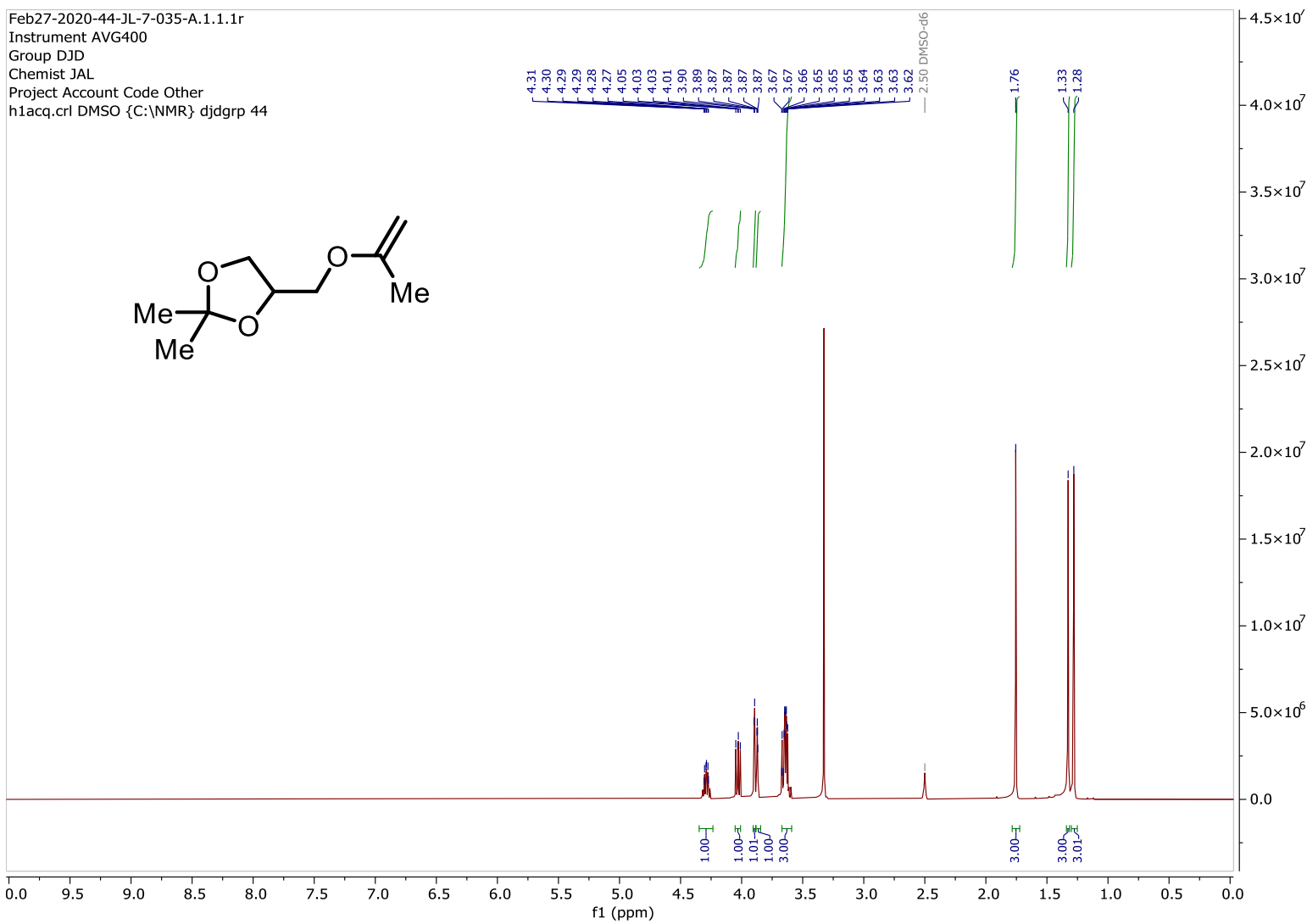

$1 \mathbf{r}-{ }^{13} \mathrm{C}$ NMR $\left(101 \mathrm{MHz}, \mathrm{DMSO}-d_{6}\right)$

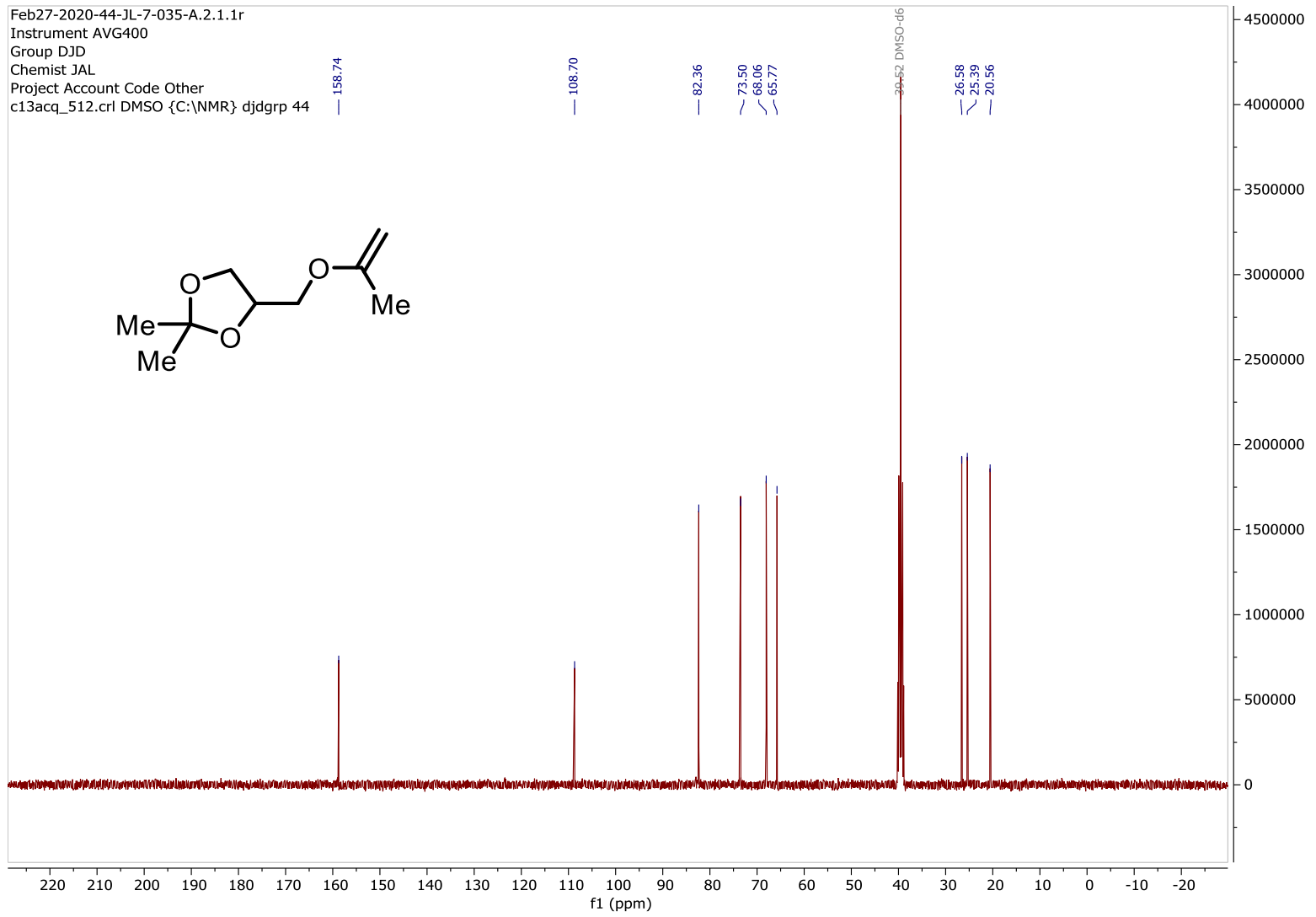


1s $-{ }^{1} \mathrm{H}$ NMR $\left(400 \mathrm{MHz}, \mathrm{DMSO}-d_{6}\right)$

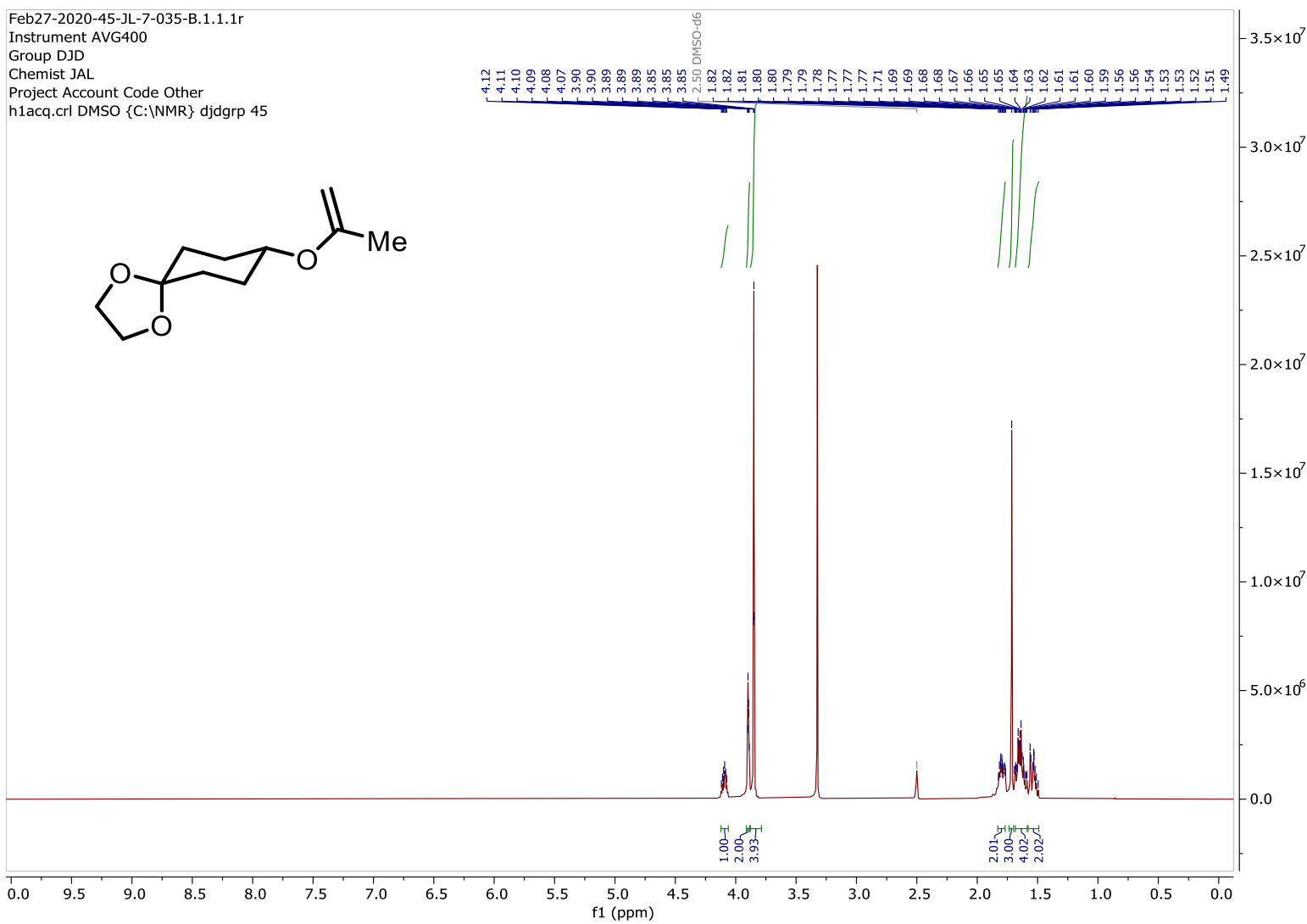

1s $-{ }^{13} \mathrm{C}$ NMR $\left(101 \mathrm{MHz}, \mathrm{DMSO}-d_{6}\right)$

Feb27-2020-45-JL-7-035-B.2.1.1r

Instrument AVG400

Group DJD

Chemist JAL

<smiles>C=C(C)OC1CCC2(CC1)OCCO2</smiles>

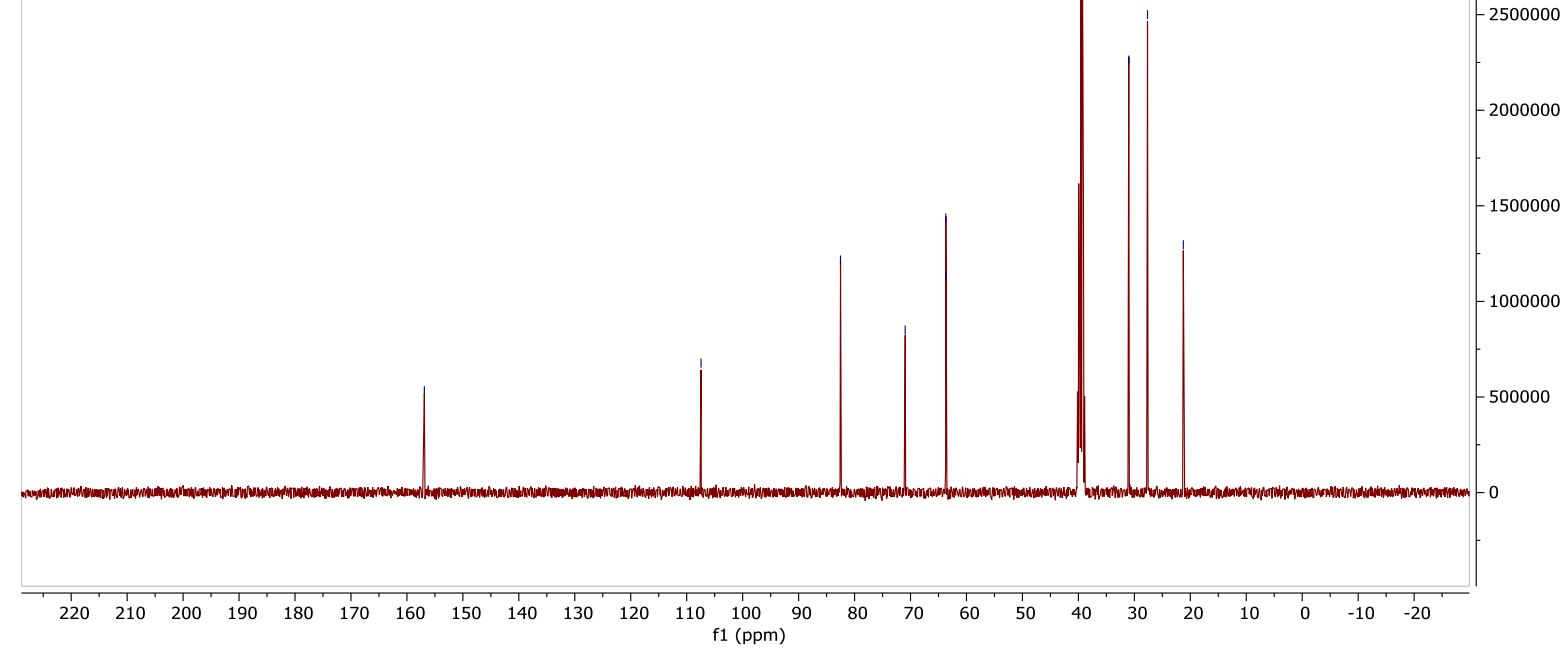


$2 \mathrm{~m}-{ }^{1} \mathrm{H}$ NMR $\left(400 \mathrm{MHz}, \mathrm{CDCl}_{3}\right)$

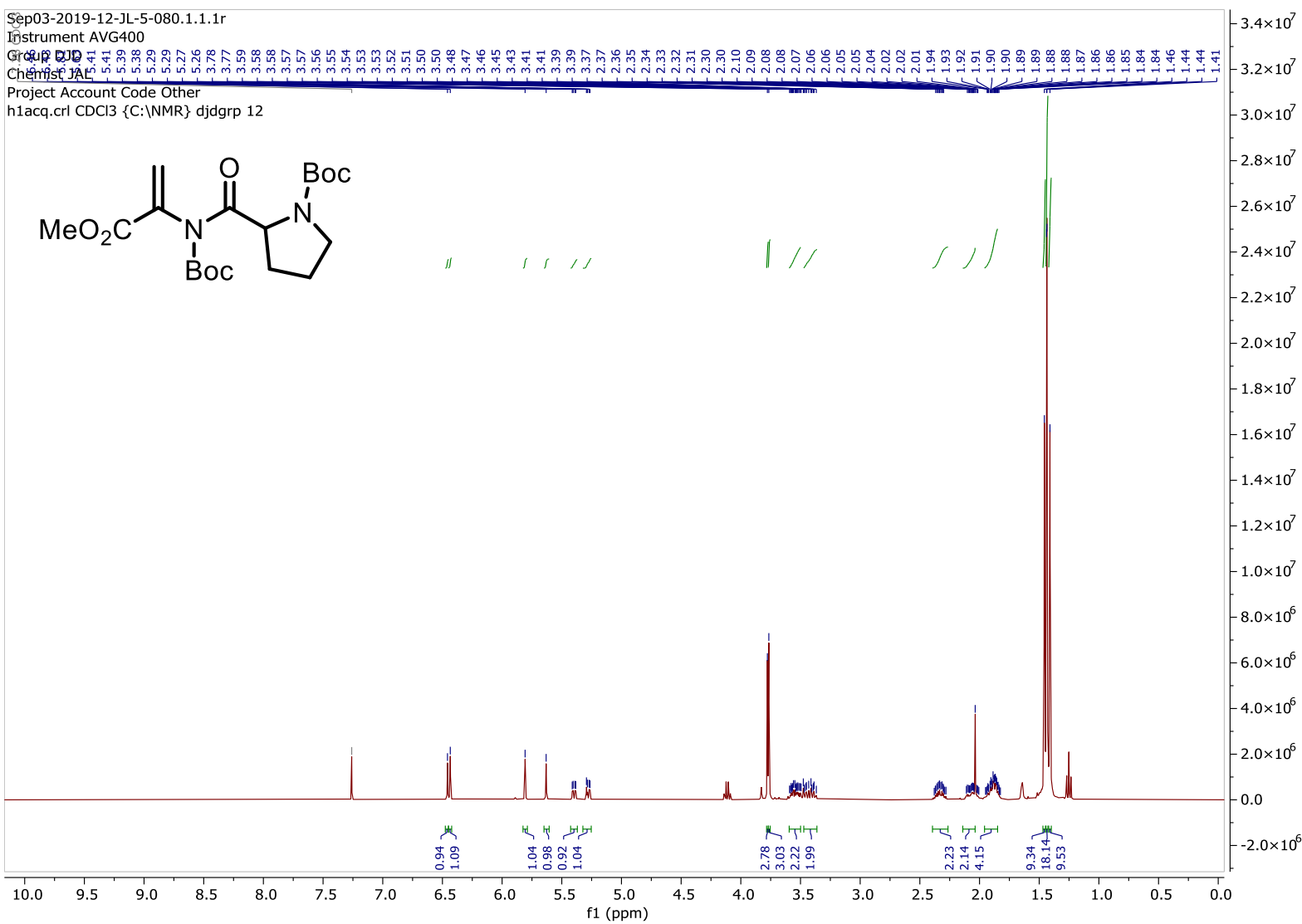

$2 \mathrm{~m}-{ }^{13} \mathrm{C} \mathrm{NMR}\left(101 \mathrm{MHz}, \mathrm{CDCl}_{3}\right)$

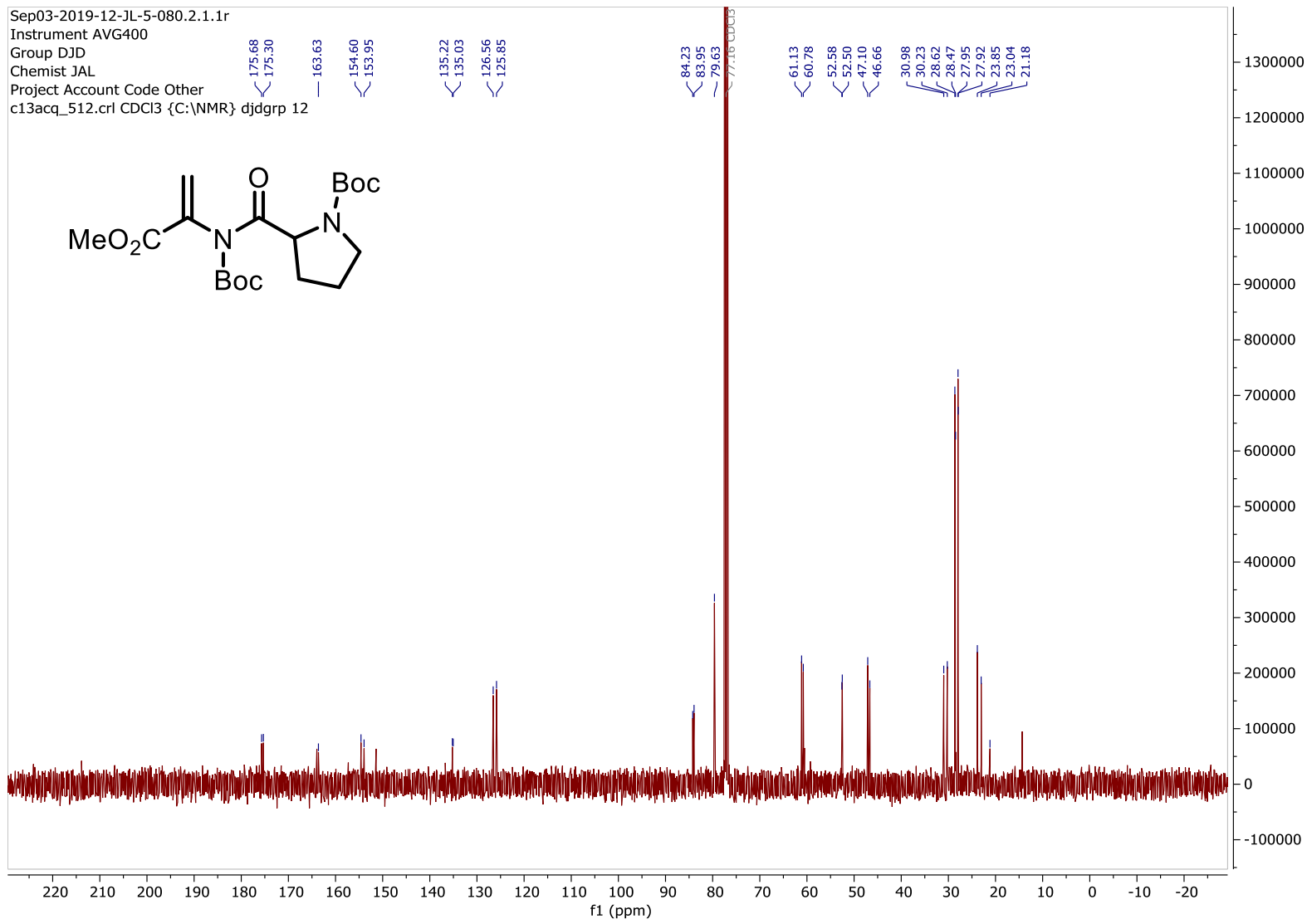


2n $-{ }^{1} \mathrm{H}$ NMR $\left(400 \mathrm{MHz}, \mathrm{CDCl}_{3}\right)$

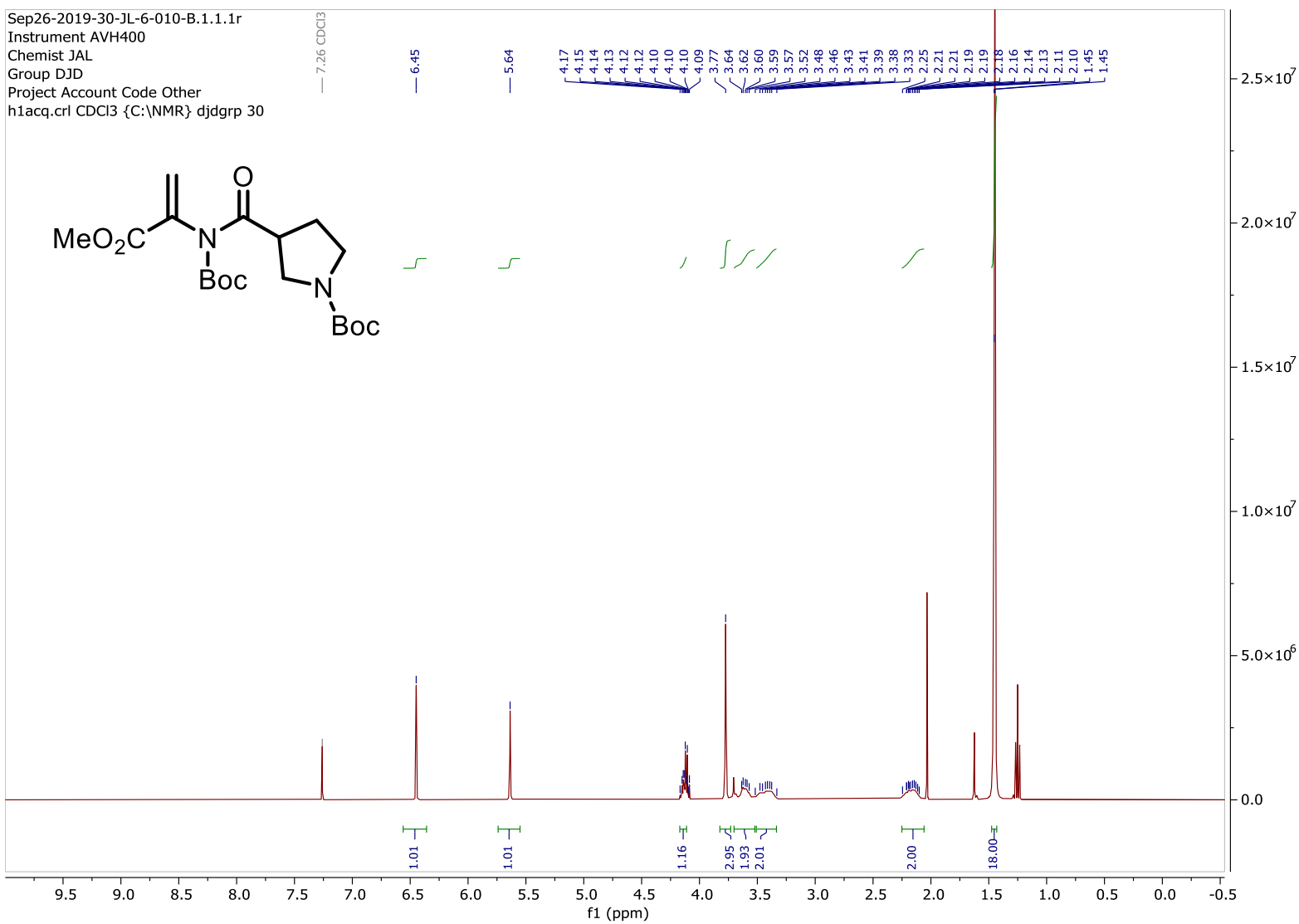

2n $-{ }^{13} \mathrm{C} \mathrm{NMR}\left(101 \mathrm{MHz}, \mathrm{CDCl}_{3}\right)$

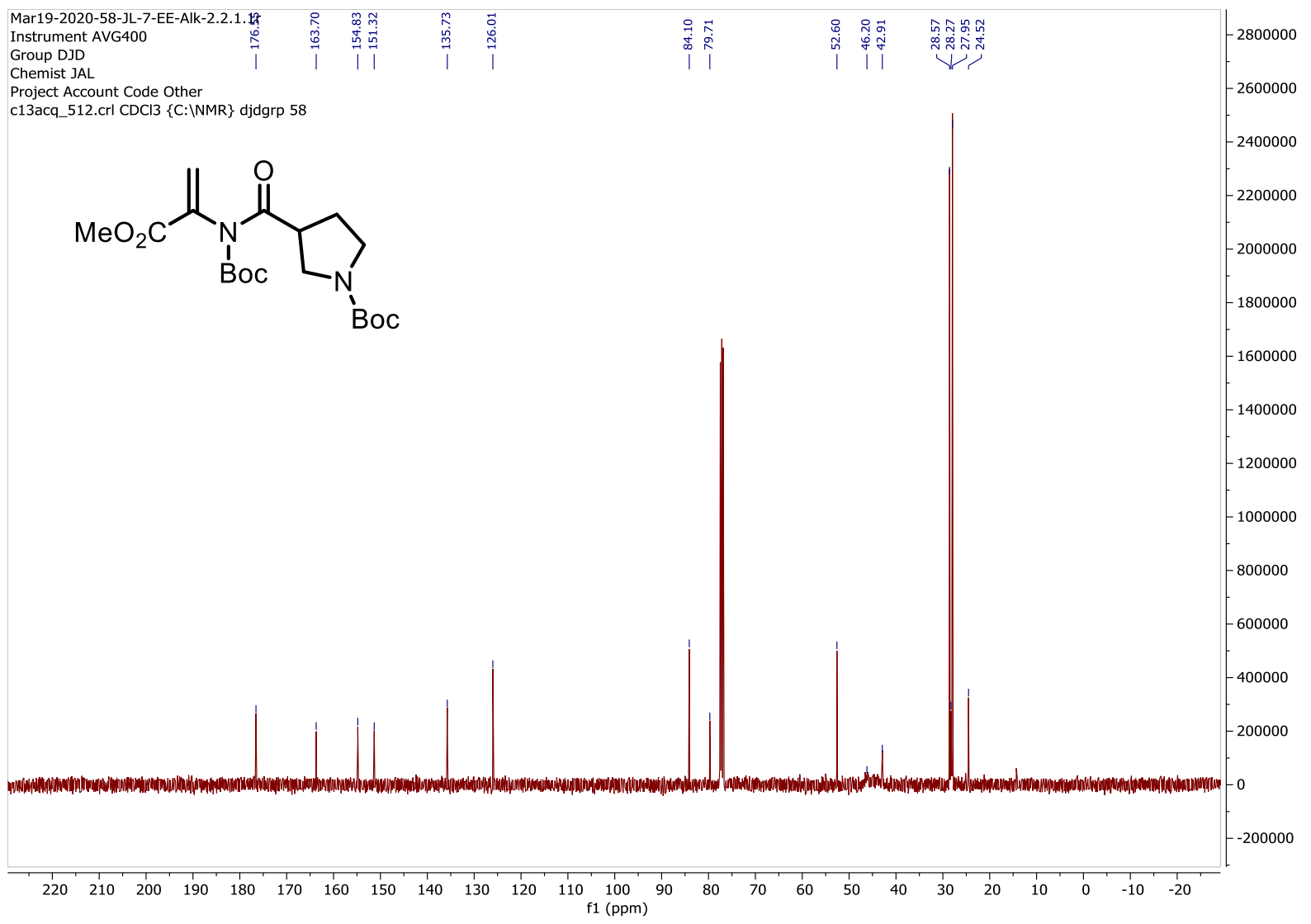


2o $-{ }^{1} \mathrm{H}$ NMR $\left(400 \mathrm{MHz}, \mathrm{CDCl}_{3}\right)$

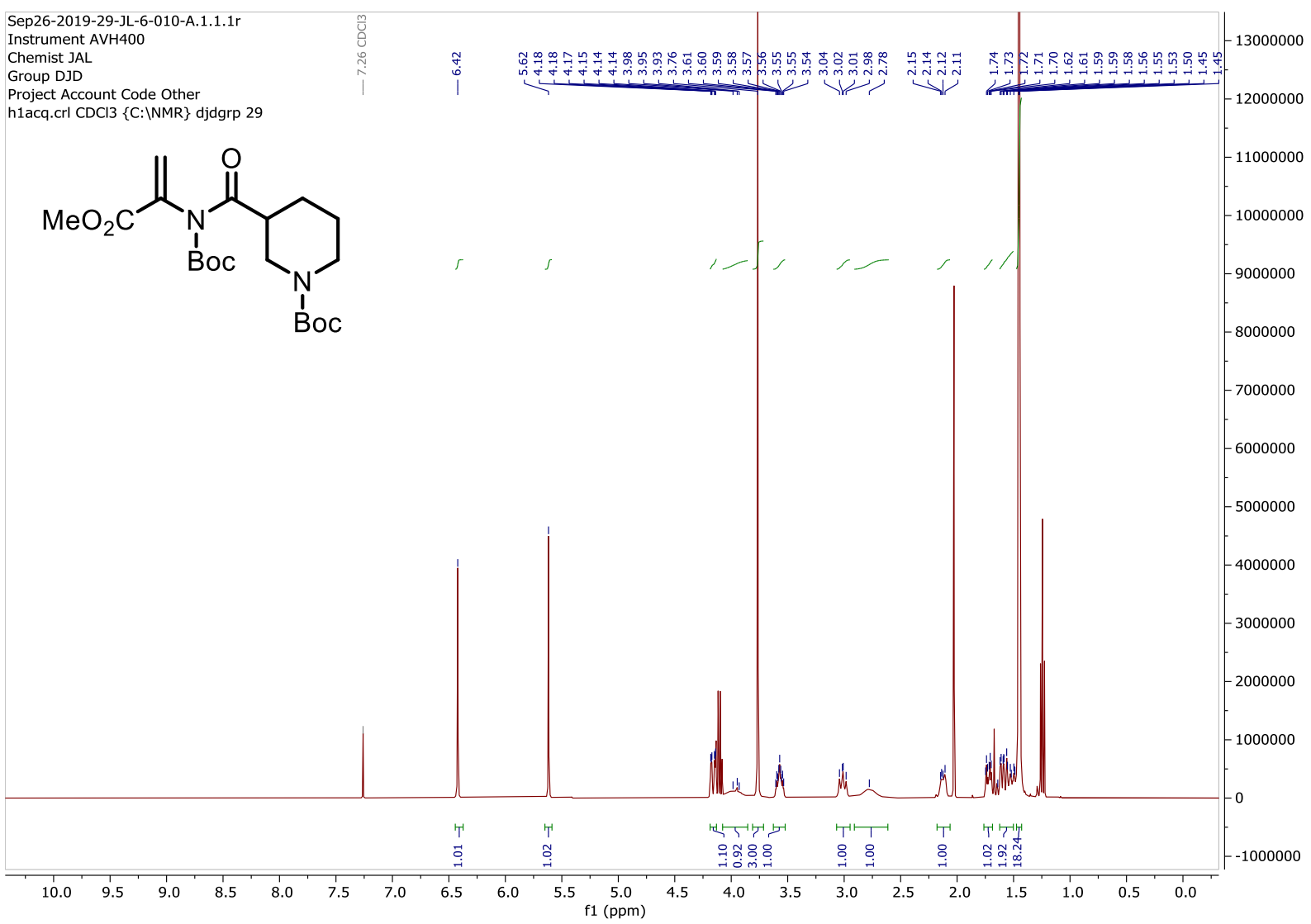

2o- ${ }^{13} \mathrm{C}$ NMR $\left(101 \mathrm{MHz}, \mathrm{CDCl}_{3}\right)$

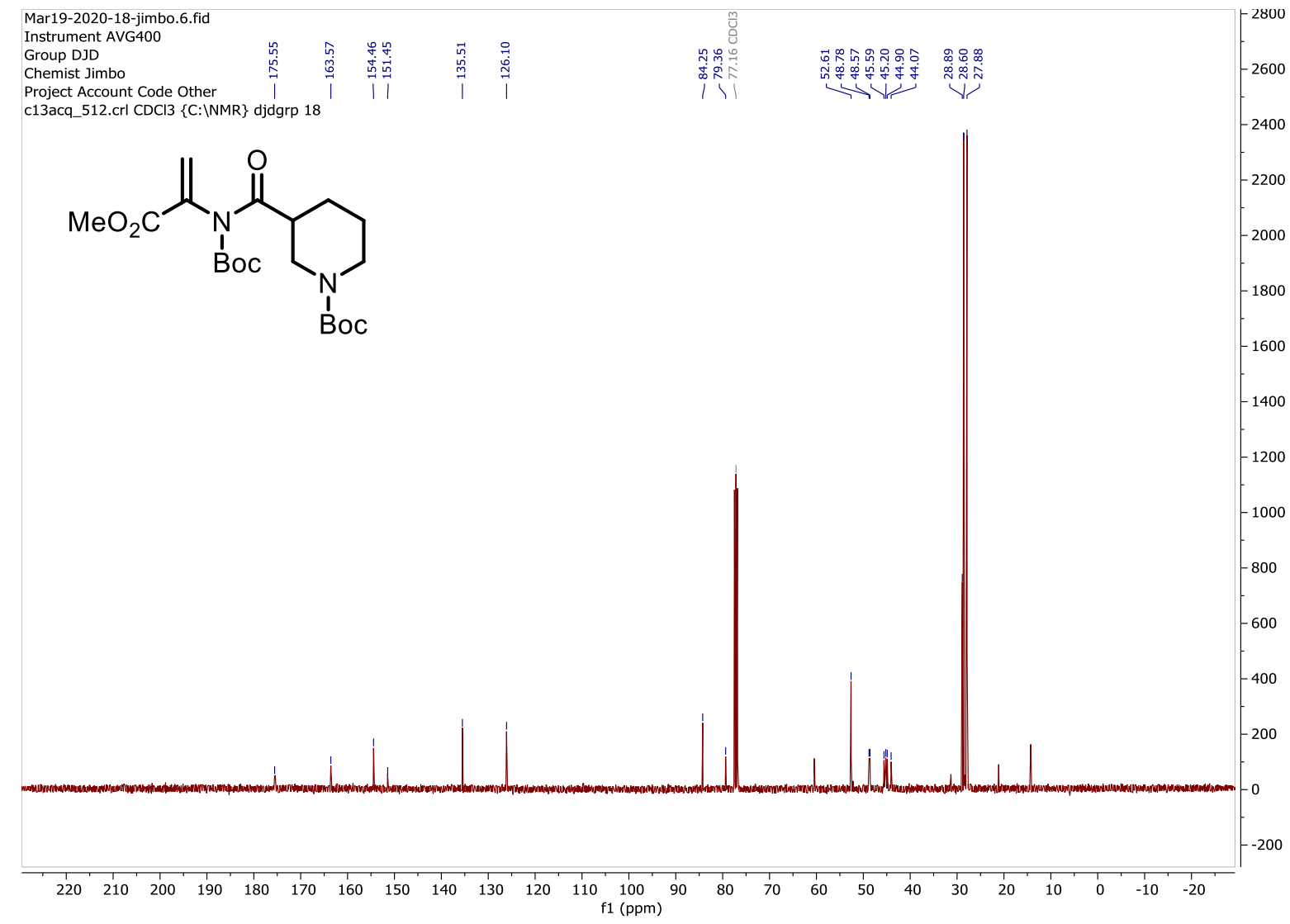


3a $-{ }^{1} \mathrm{H}$ NMR $\left(400 \mathrm{MHz}, \mathrm{CDCl}_{3}\right)$

Feb21-2020-10-JL-7-021-I.2.1.1r

Instrument AVH40O

Chemist JAL
Group DJD

Project Account Code Othe

Project Account Code Other
h1acqQ.crl CDCl3 $\{\mathrm{C}: \mid \mathrm{NMR}\}$ djdgrp 10

hiacqQ.crl CDCl3 \{C: $\mid$ NMR\} djdgrp 10
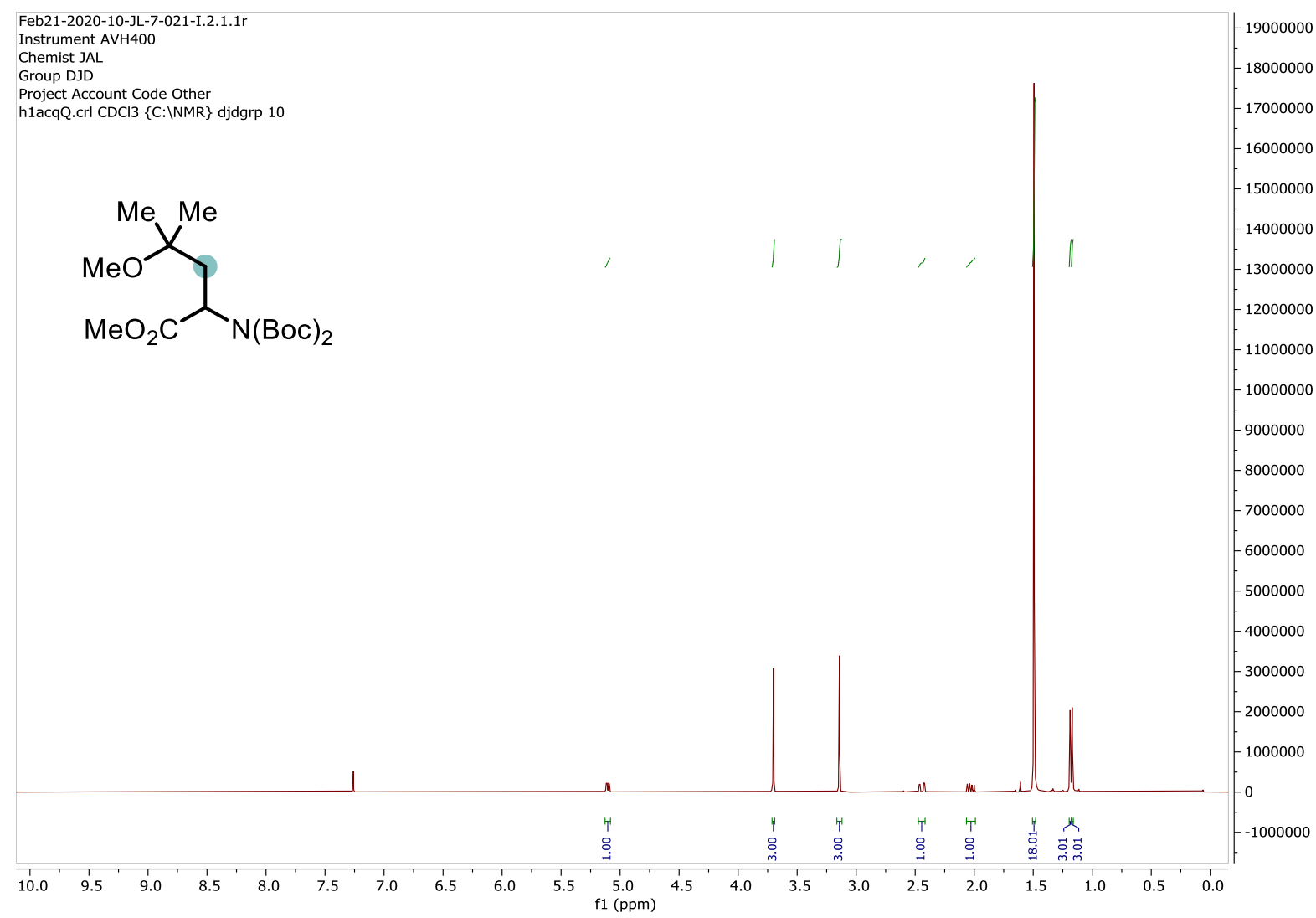

3a $-{ }^{13} \mathrm{C}$ NMR $\left(101 \mathrm{MHz}, \mathrm{CDCl}_{3}\right)$

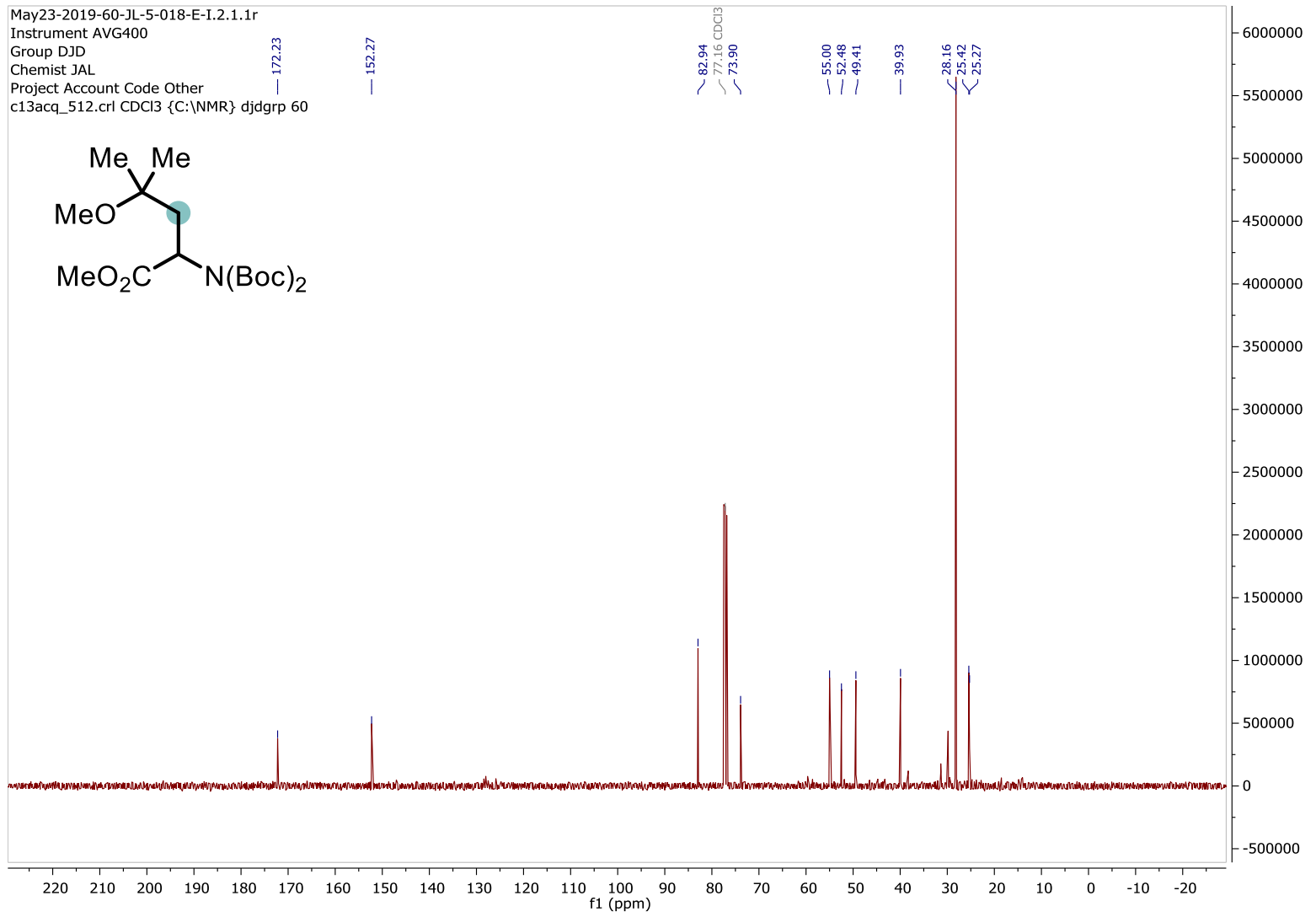


3b $-{ }^{1} \mathrm{H}$ NMR $\left(400 \mathrm{MHz}, \mathrm{CDCl}_{3}\right)$

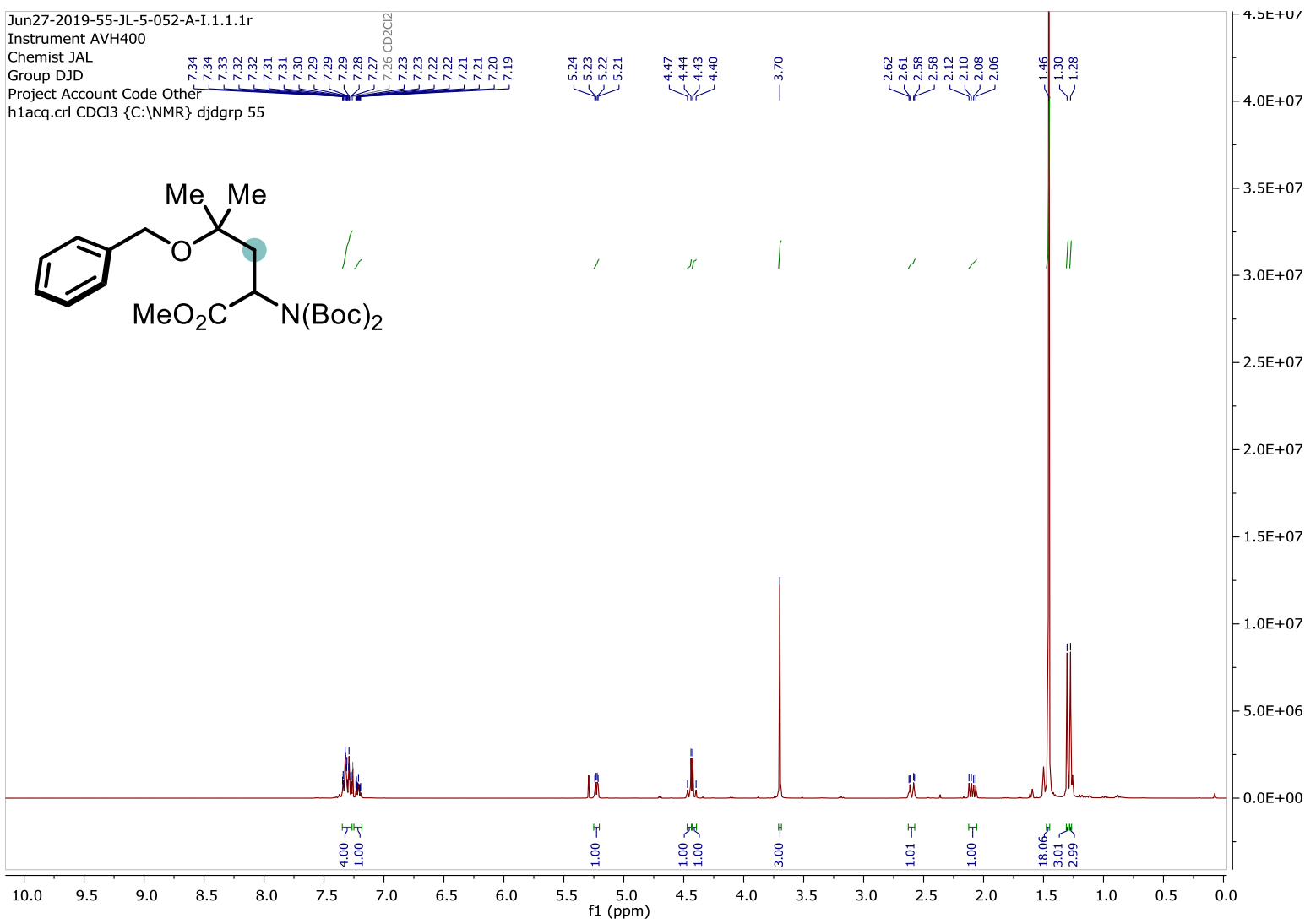

3b $-{ }^{13} \mathrm{C}$ NMR $\left(101 \mathrm{MHz}, \mathrm{CDCl}_{3}\right)$

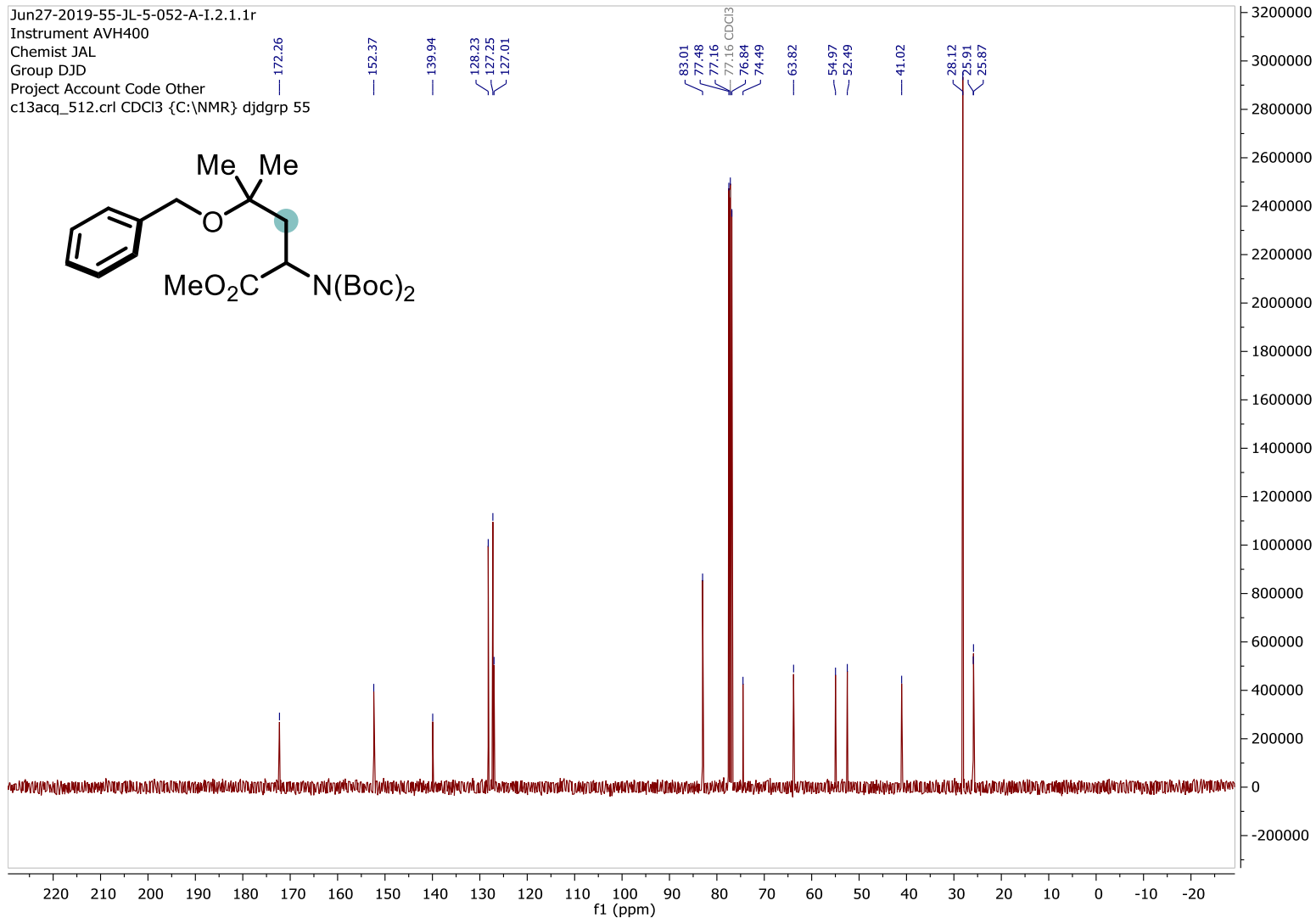


3c $-{ }^{1} \mathrm{H}$ NMR $\left(400 \mathrm{MHz}, \mathrm{CDCl}_{3}\right)$

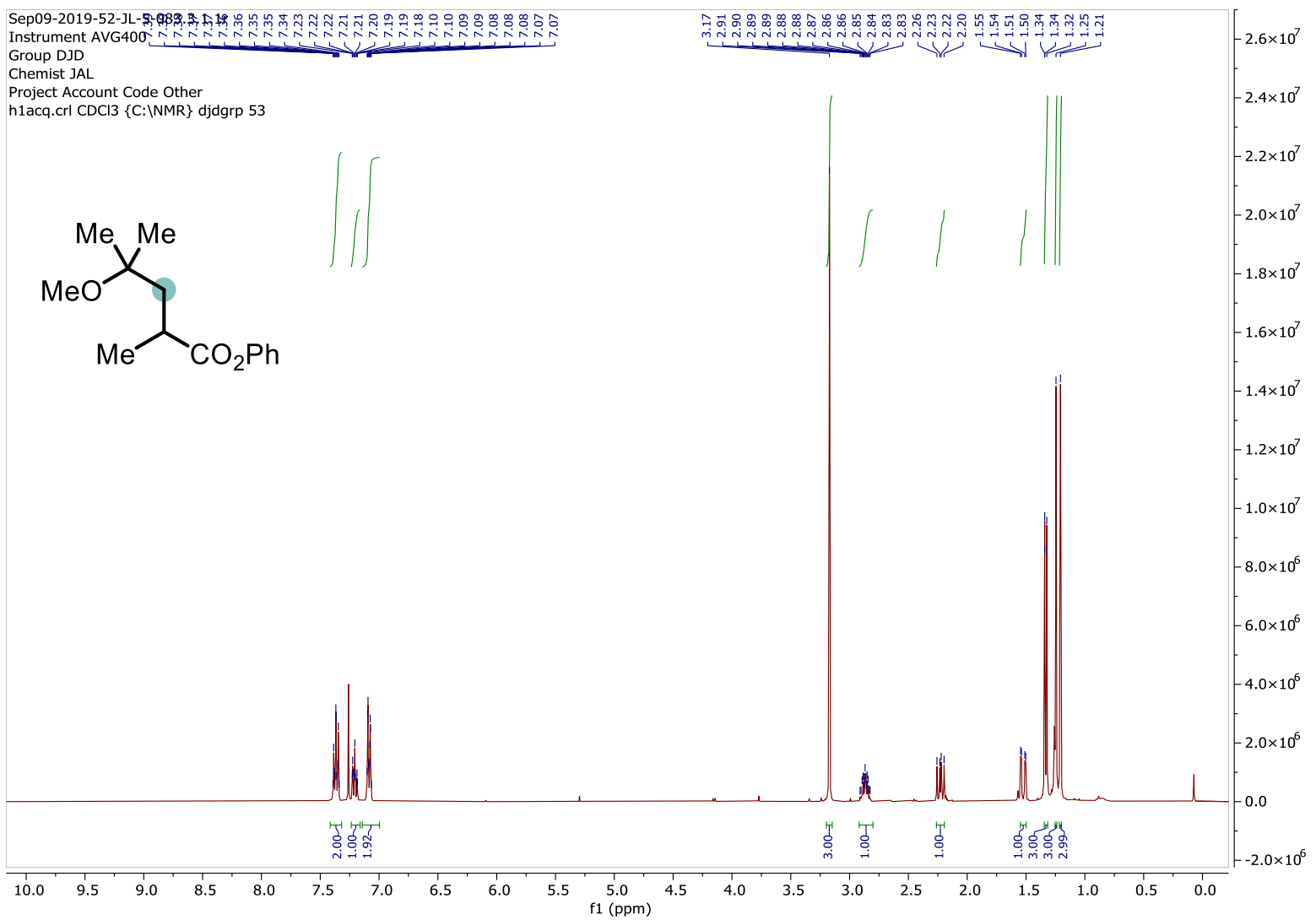

3c $-{ }^{13} \mathrm{C}$ NMR $\left(101 \mathrm{MHz}, \mathrm{CDCl}_{3}\right)$

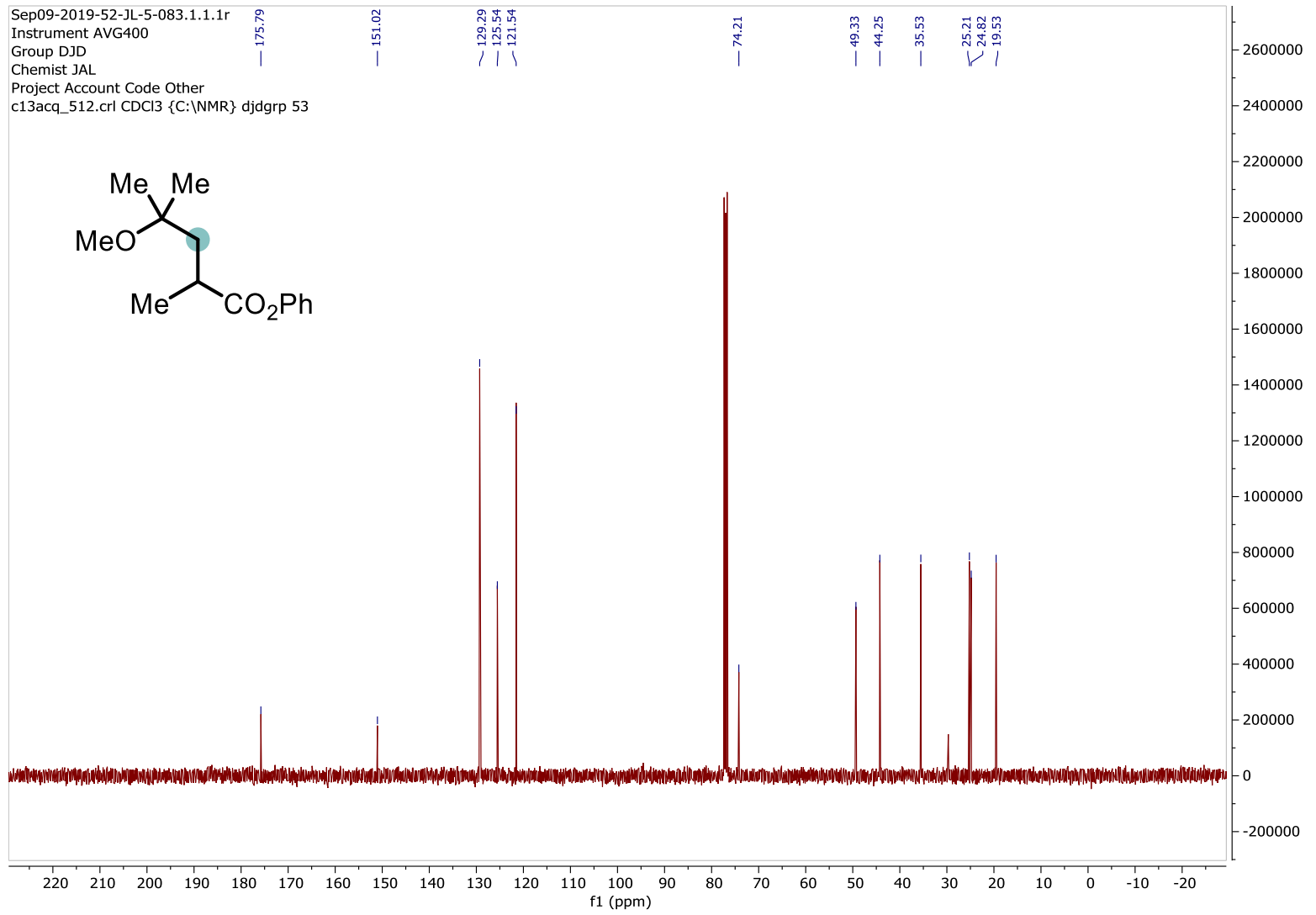


3d $-{ }^{1} \mathrm{H}$ NMR $\left(400 \mathrm{MHz}, \mathrm{CDCl}_{3}\right)$

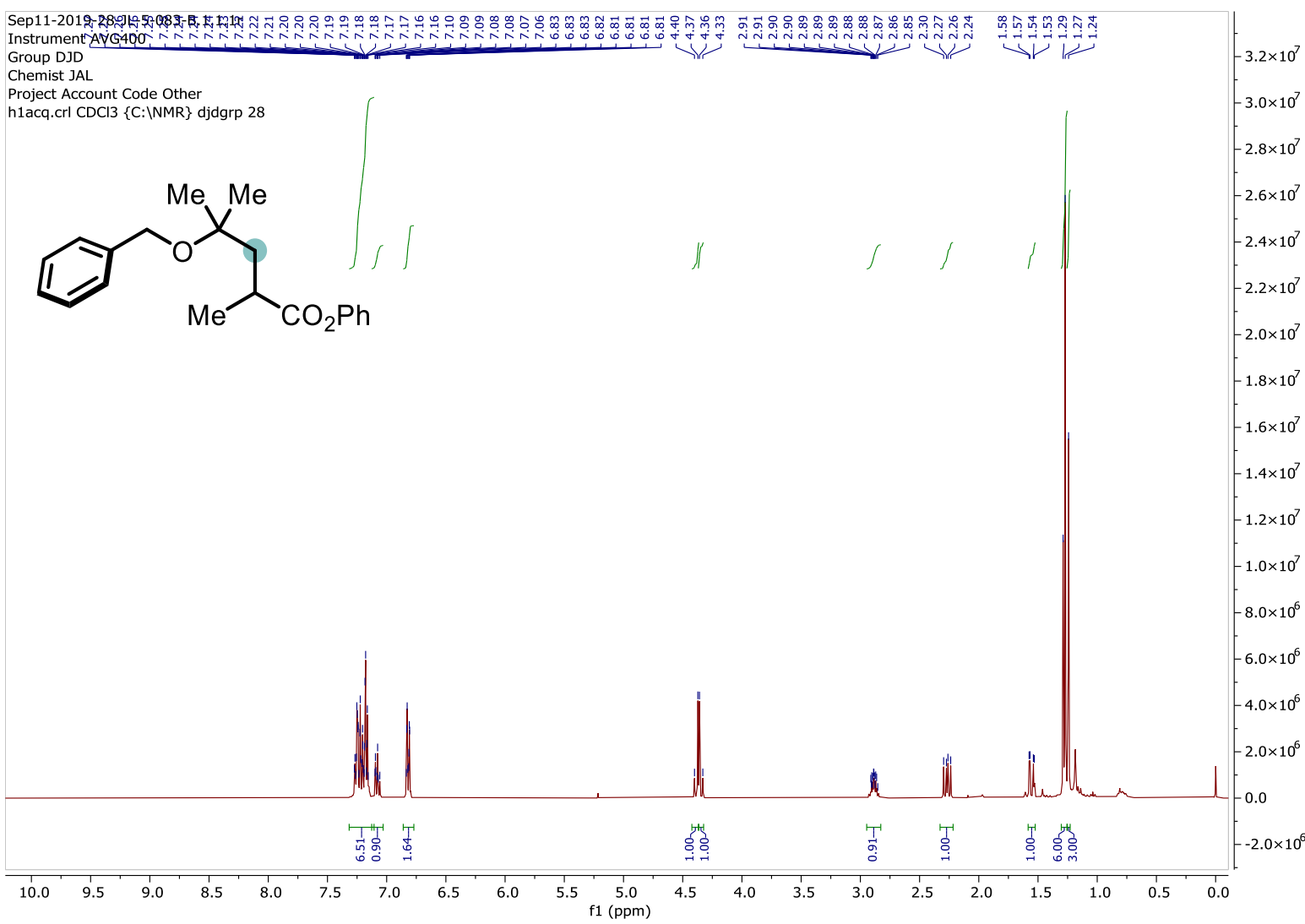

3d $-{ }^{13} \mathrm{C}$ NMR $\left(101 \mathrm{MHz}, \mathrm{CDCl}_{3}\right)$

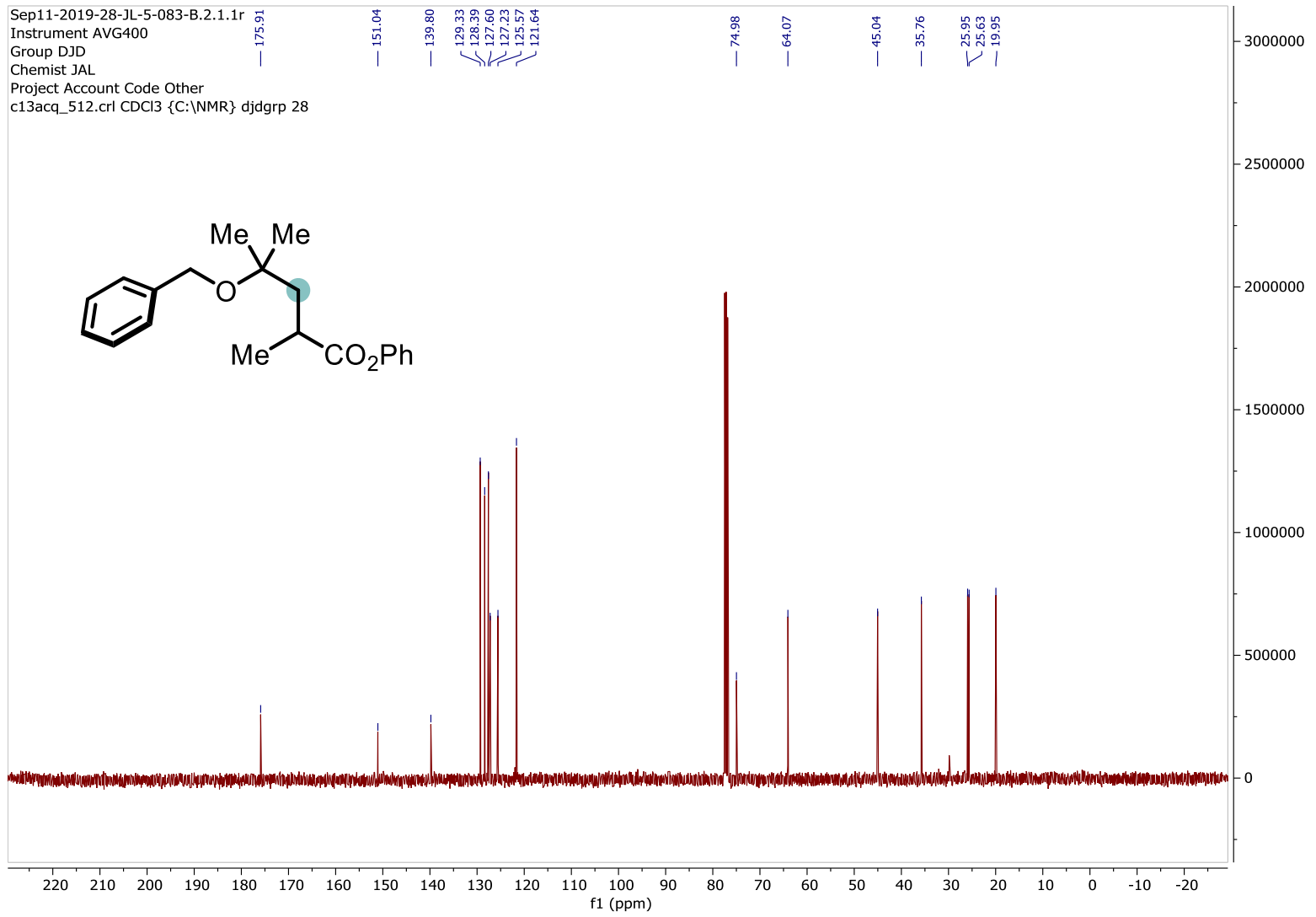


$3 \mathbf{e}-{ }^{1} \mathrm{H}$ NMR $\left(400 \mathrm{MHz}, \mathrm{CDCl}_{3}\right)$

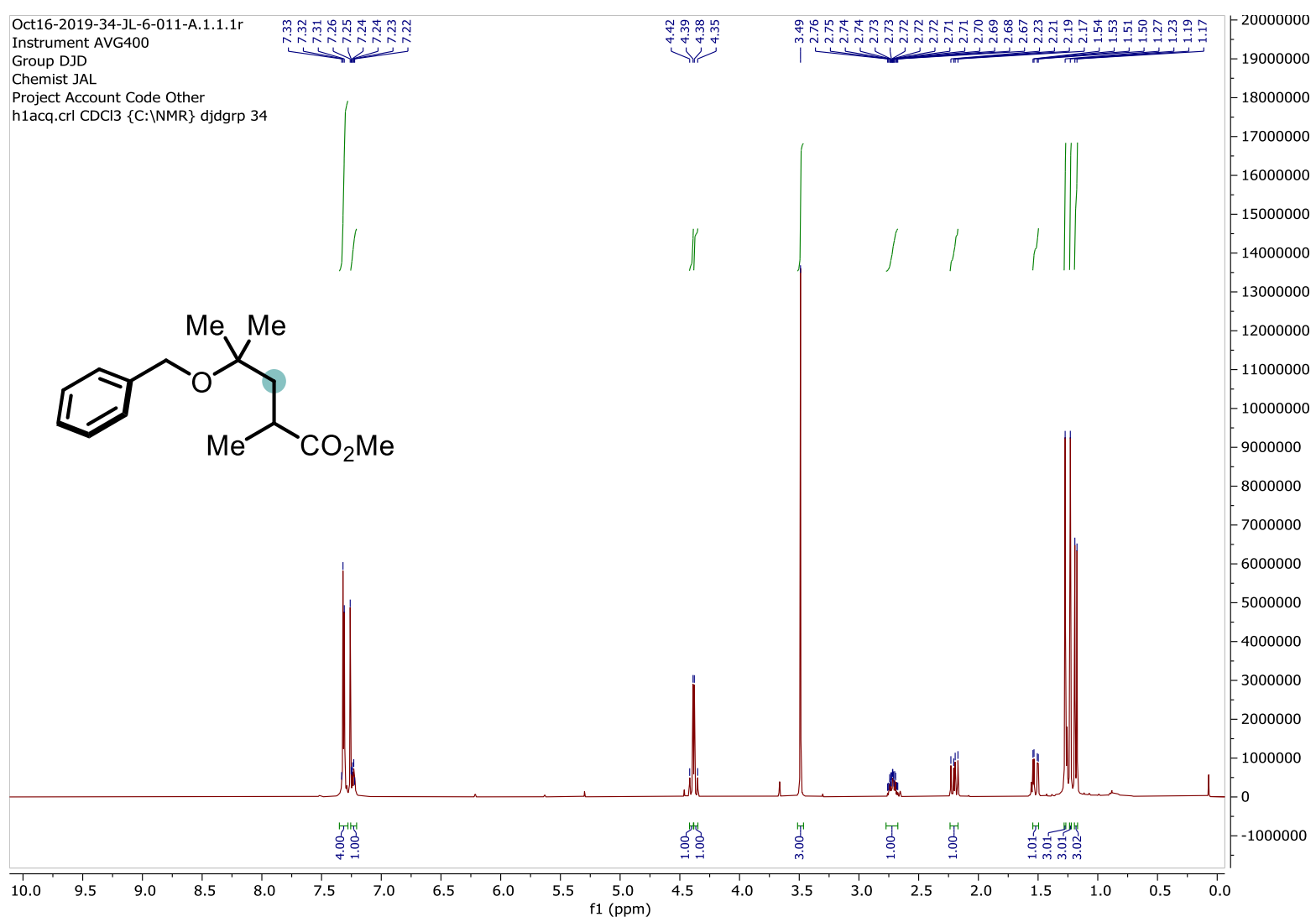

$3 \mathbf{e}-{ }^{13} \mathrm{C}$ NMR $\left(101 \mathrm{MHz}, \mathrm{CDCl}_{3}\right)$

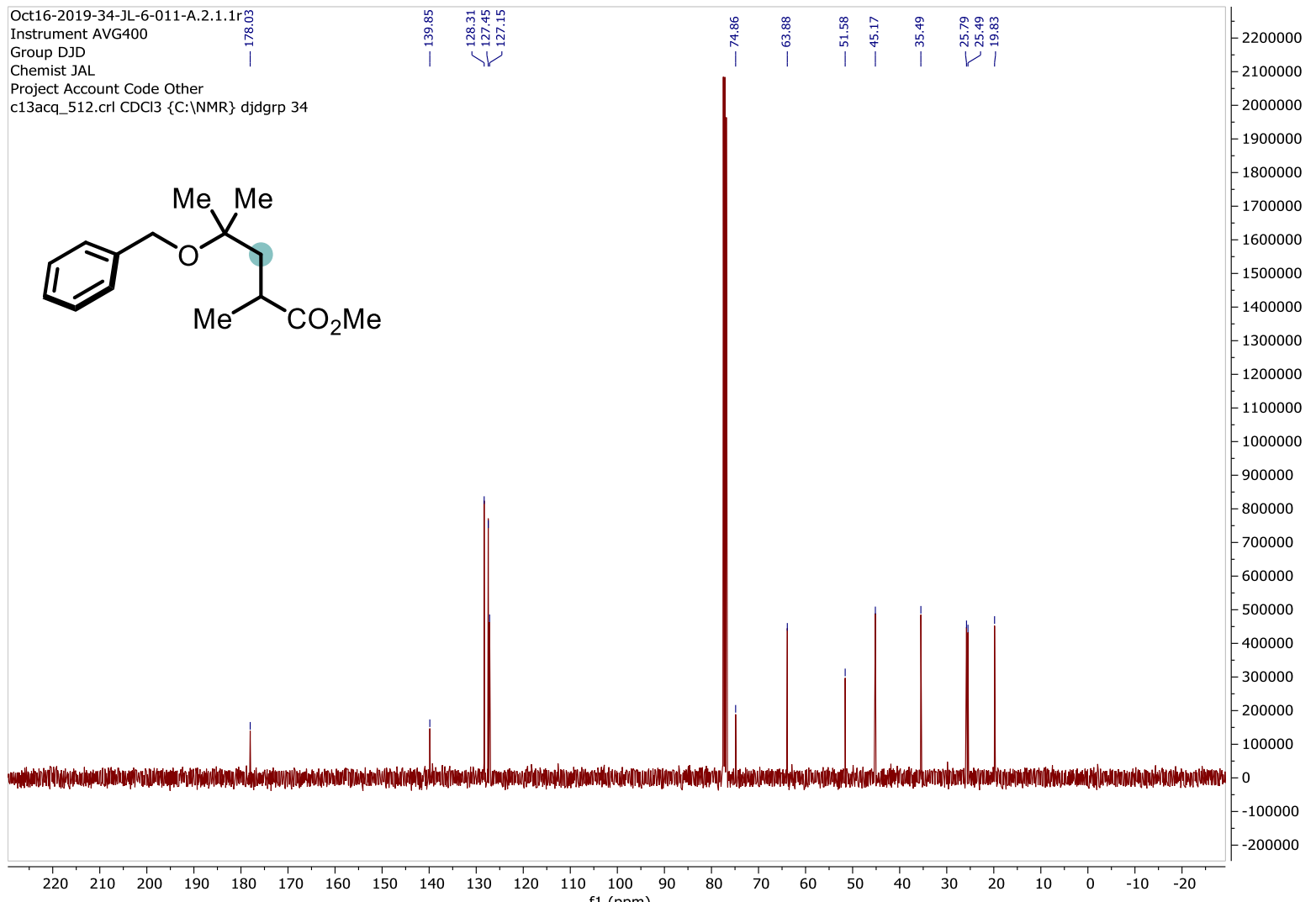


3f $-{ }^{1} \mathrm{H}$ NMR $\left(400 \mathrm{MHz}, \mathrm{CDCl}_{3}\right)$

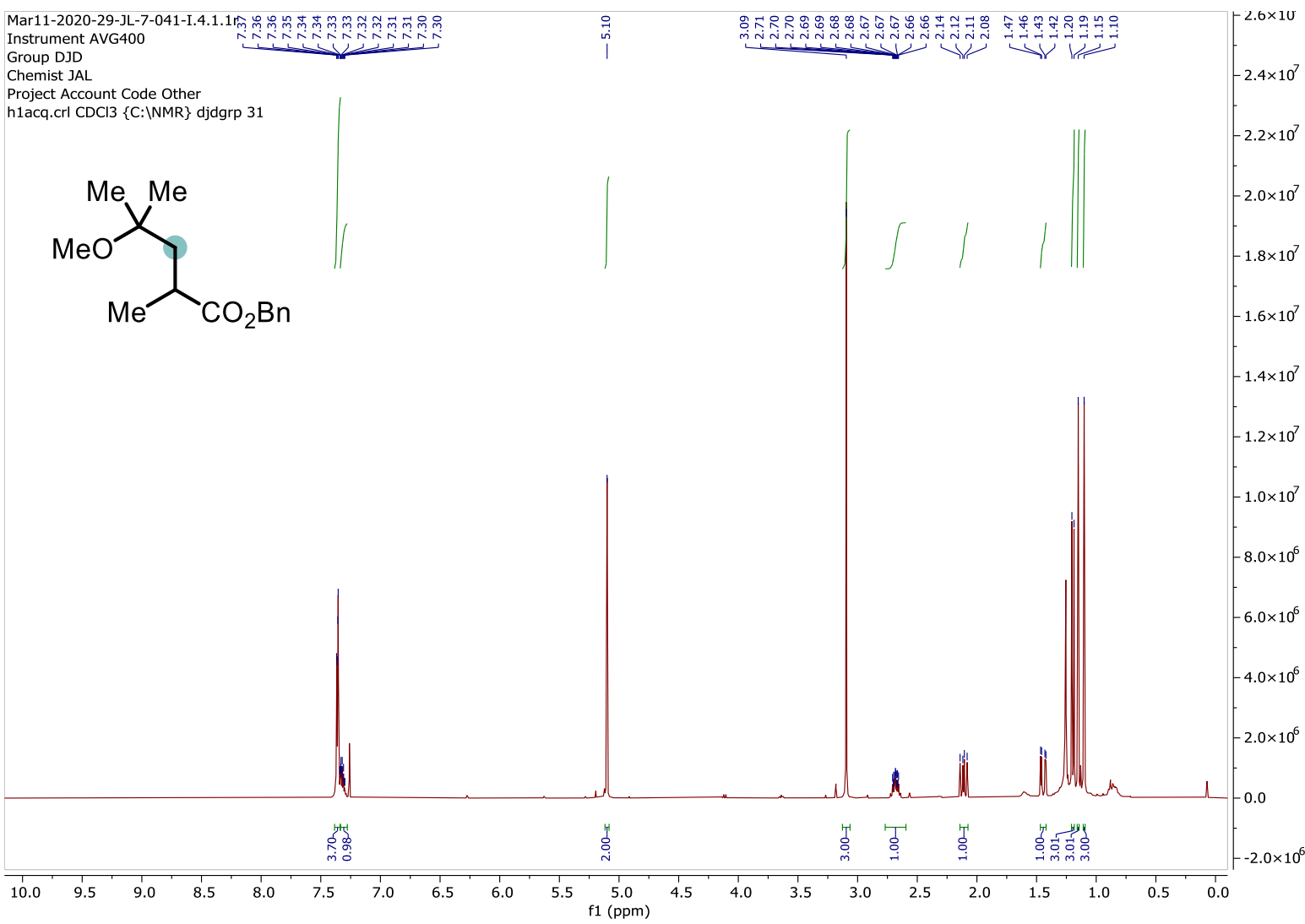

3f $-{ }^{13} \mathrm{C}$ NMR $\left(101 \mathrm{MHz}, \mathrm{CDCl}_{3}\right)$

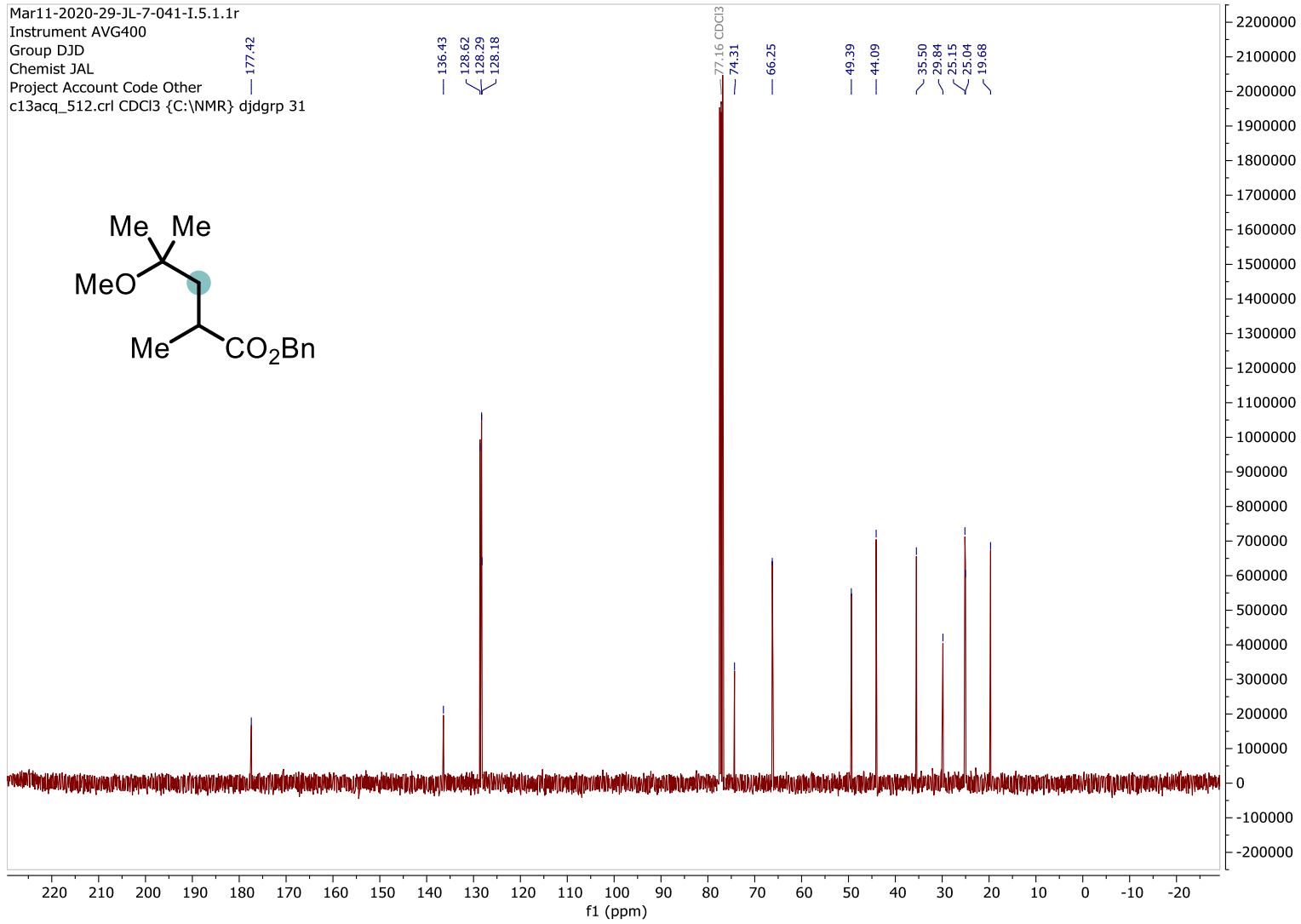


$3 \mathbf{g}-{ }^{1} \mathrm{H}$ NMR $\left(400 \mathrm{MHz}, \mathrm{CDCl}_{3}\right)$

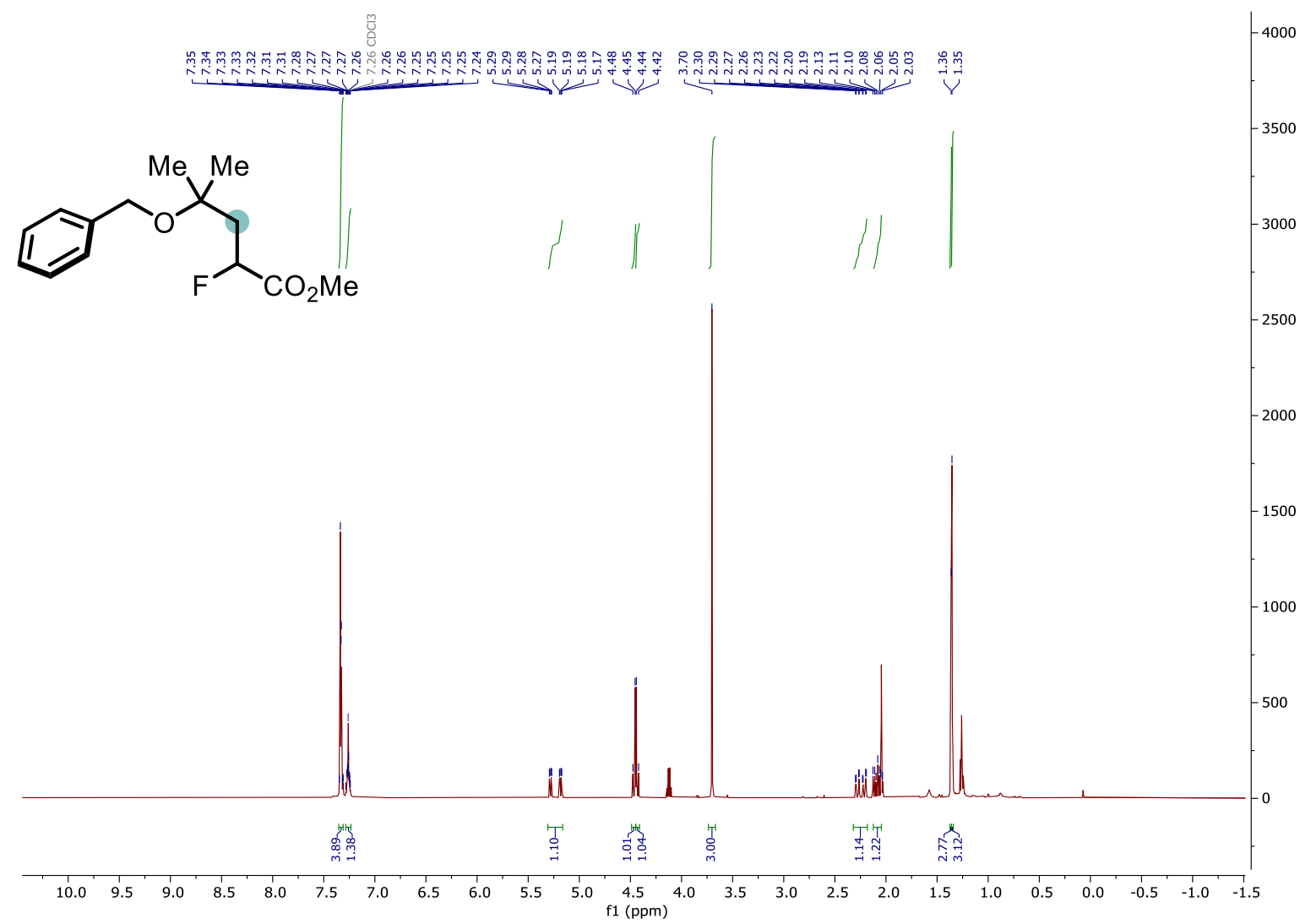

3g $-{ }^{19} \mathrm{~F} \mathrm{NMR}\left(377 \mathrm{MHz}, \mathrm{CDCl}_{3}\right)$

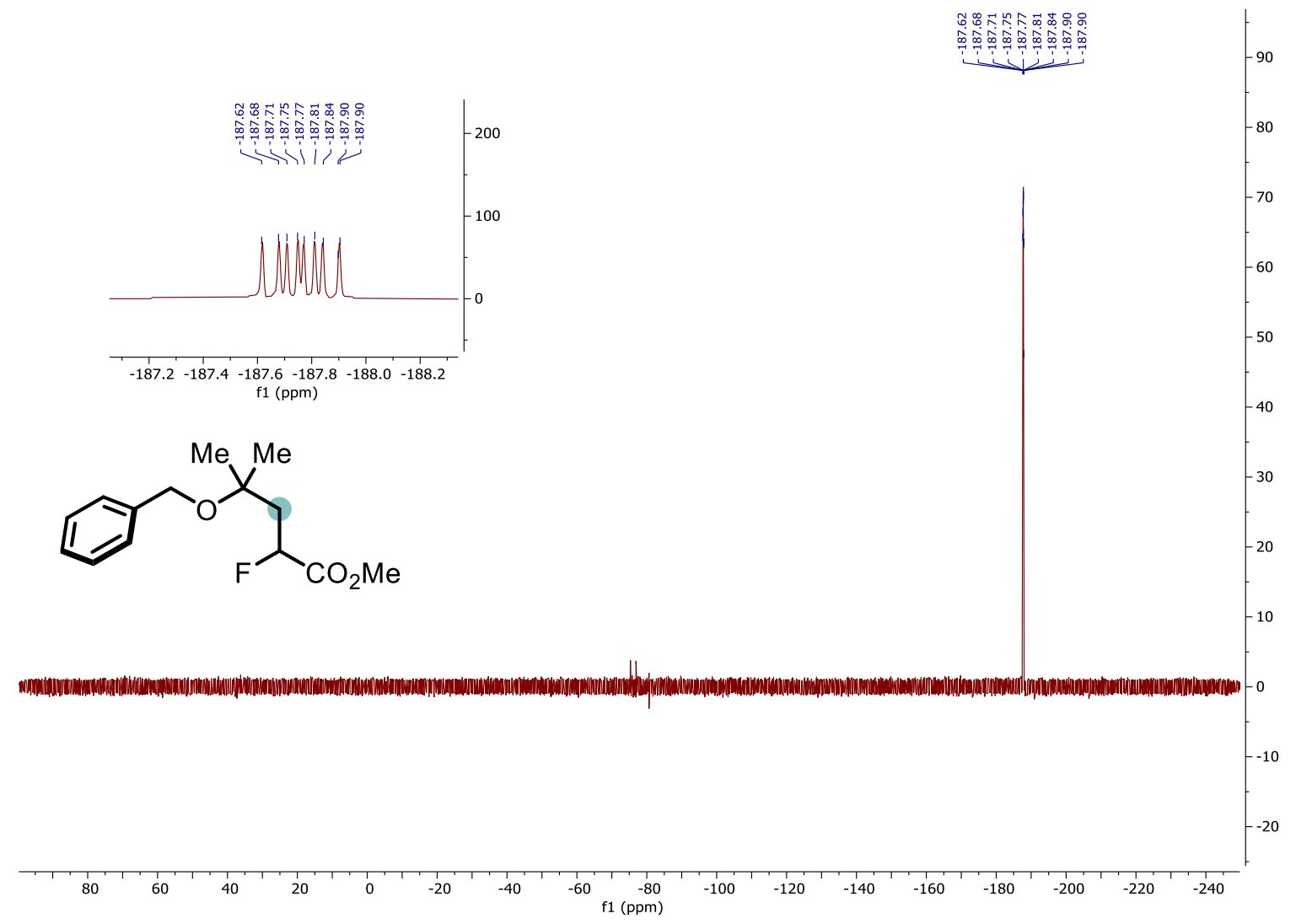


3g $-{ }^{13} \mathrm{C}$ NMR $\left(101 \mathrm{MHz}, \mathrm{CDCl}_{3}\right)$

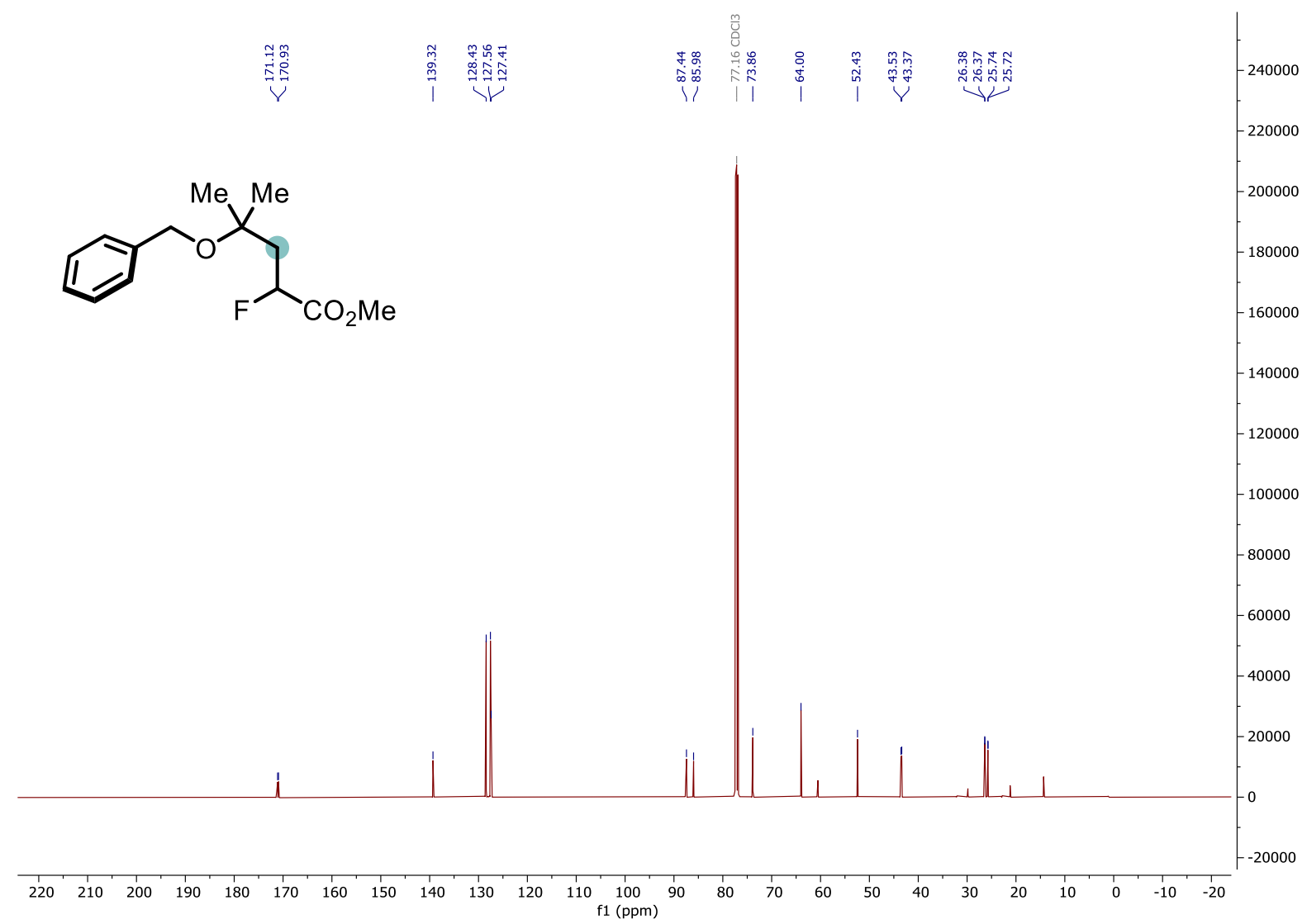


3h- ${ }^{1} \mathrm{H}$ NMR $\left(400 \mathrm{MHz}, \mathrm{CDCl}_{3}\right)$

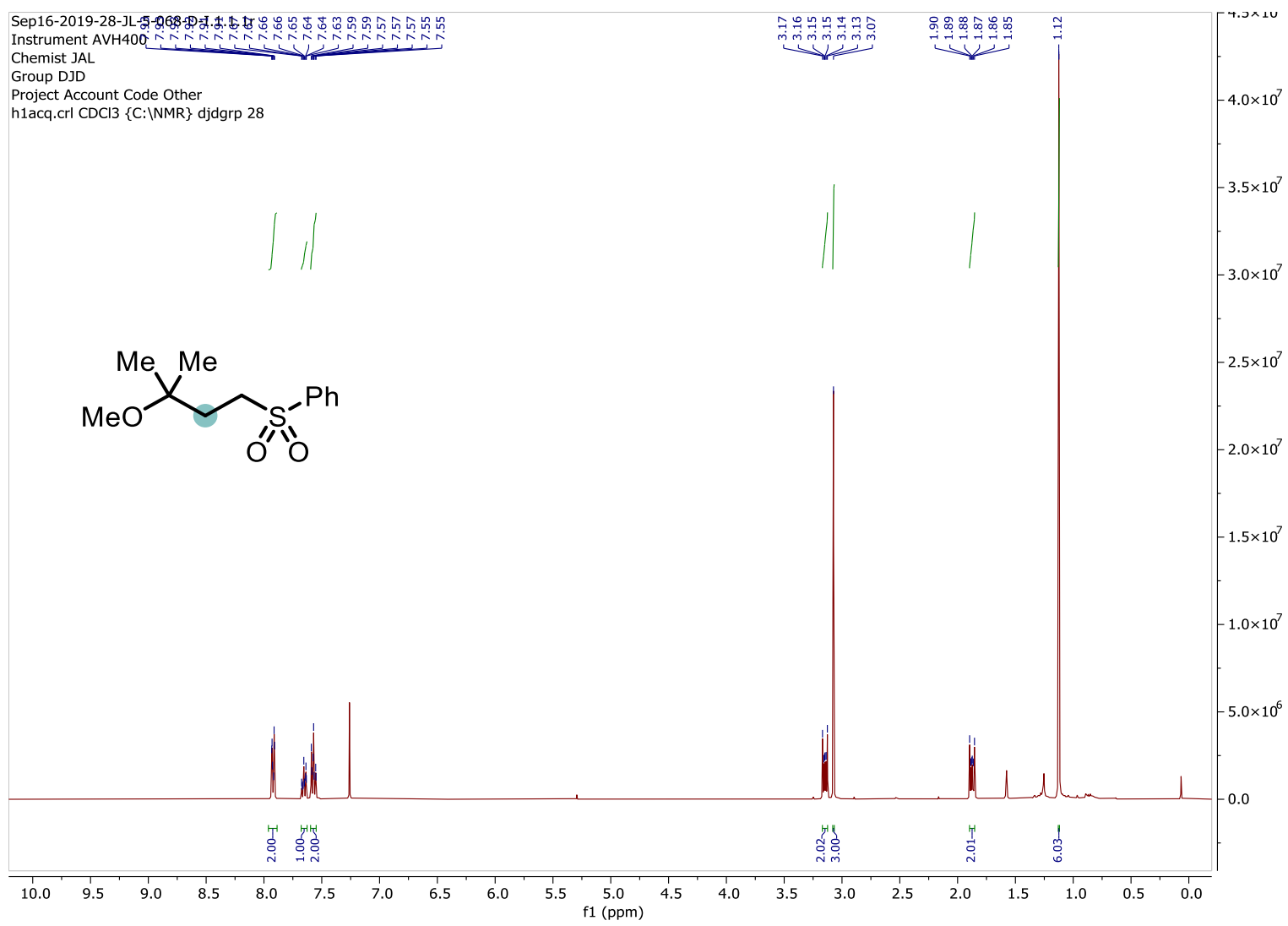

3h $-{ }^{13} \mathrm{C}$ NMR $\left(101 \mathrm{MHz}, \mathrm{CDCl}_{3}\right)$

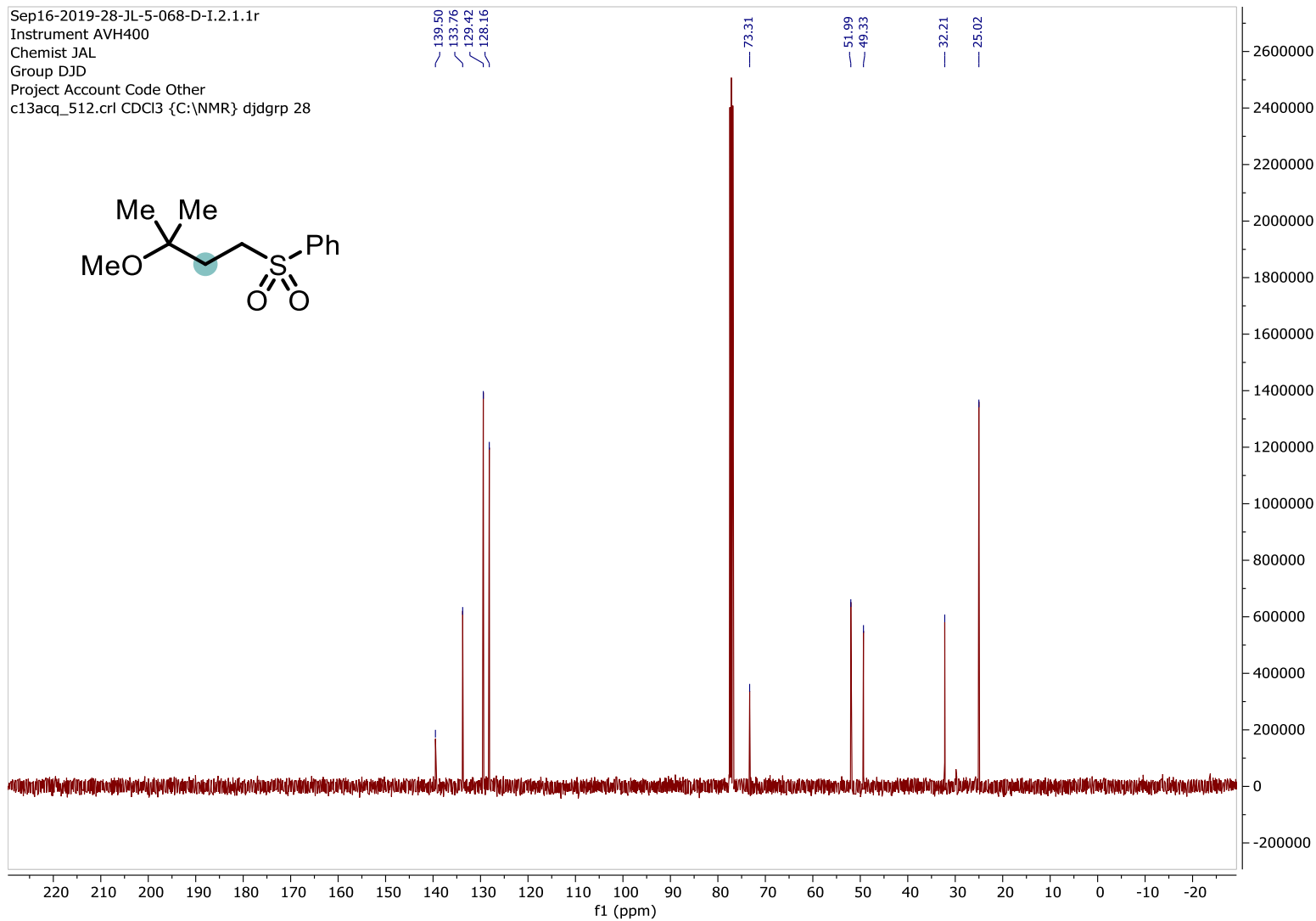


$3 \mathbf{i}-{ }^{1} \mathrm{H}$ NMR $\left(400 \mathrm{MHz}, \mathrm{CDCl}_{3}\right)$

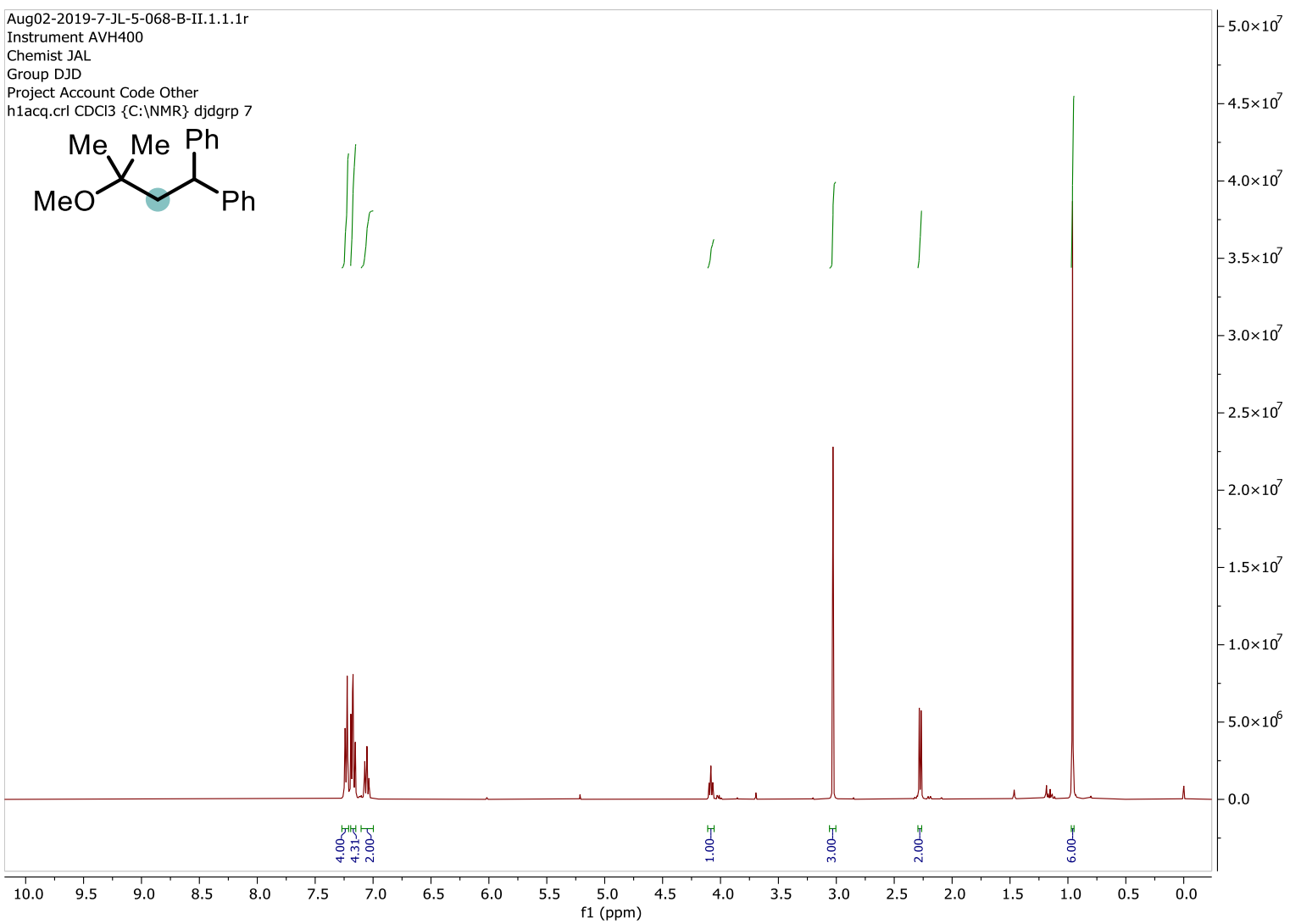

$3 \mathbf{i}-{ }^{13} \mathrm{C}$ NMR (101 MHz, $\left.\mathrm{CDCl}_{3}\right)$

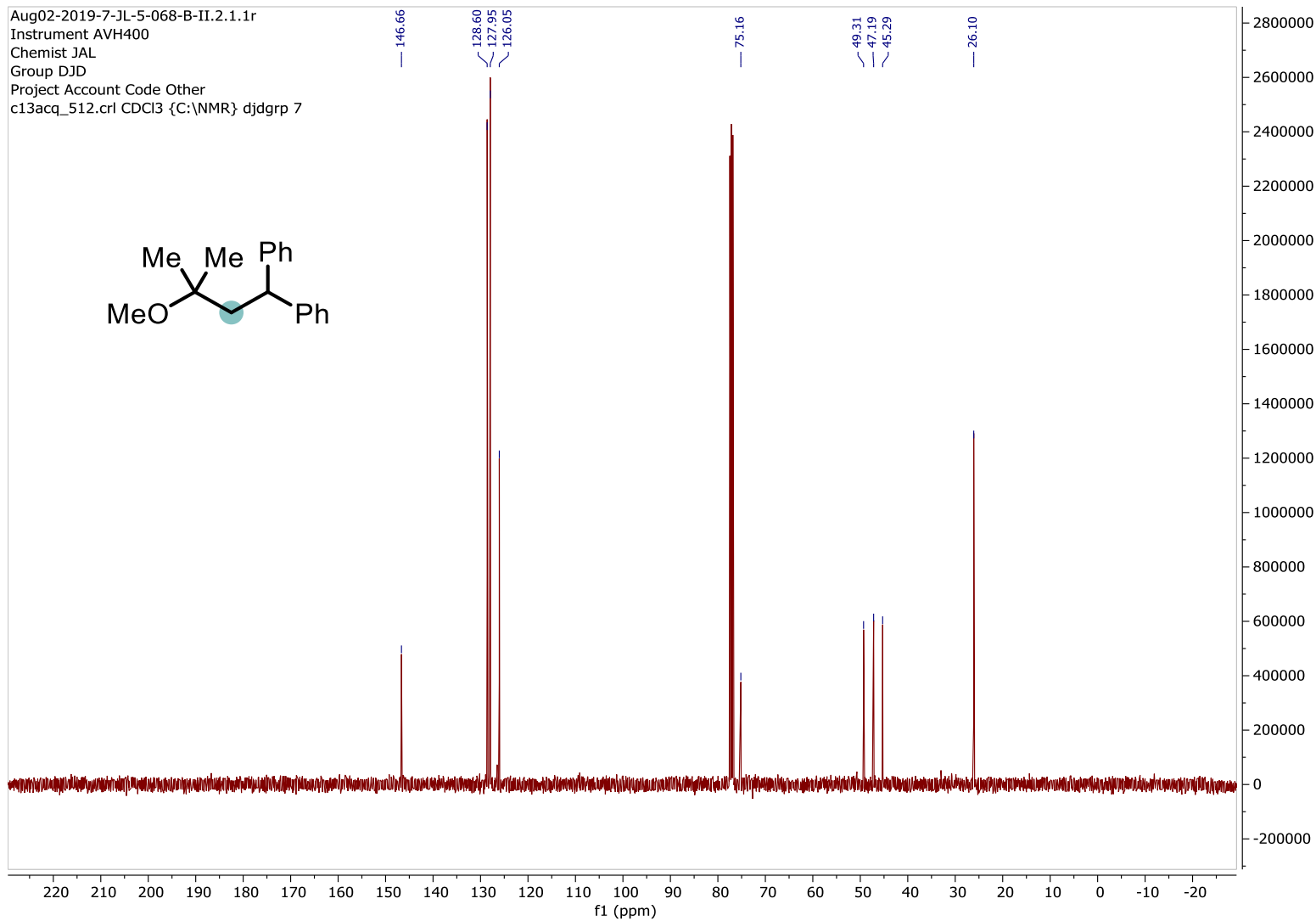


3j- ${ }^{1} \mathrm{H}$ NMR (400 MHz, $\left.\mathrm{CDCl}_{3}\right)$

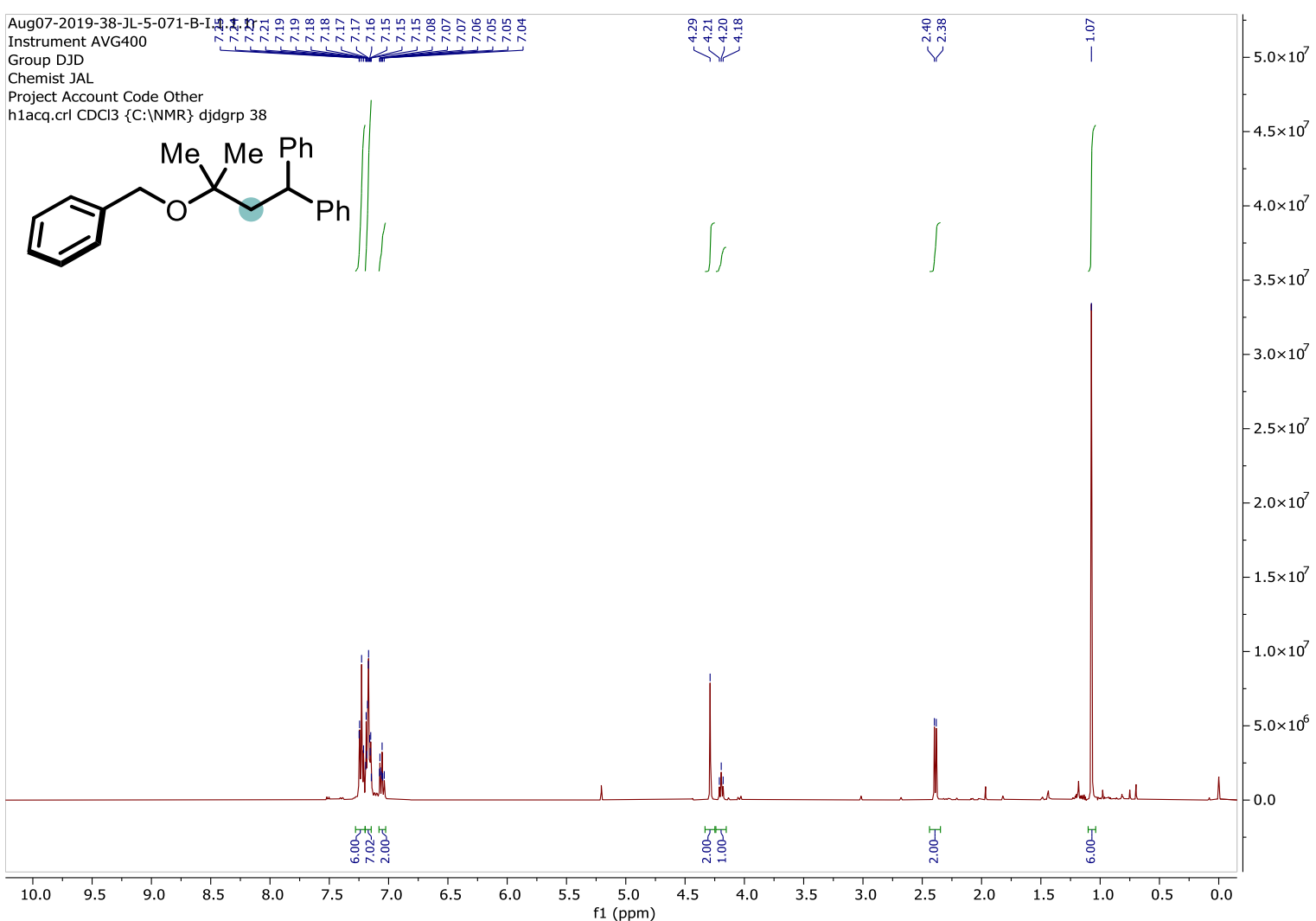

$3 \mathbf{j}-{ }^{13} \mathrm{C}$ NMR $\left(101 \mathrm{MHz}, \mathrm{CDCl}_{3}\right)$

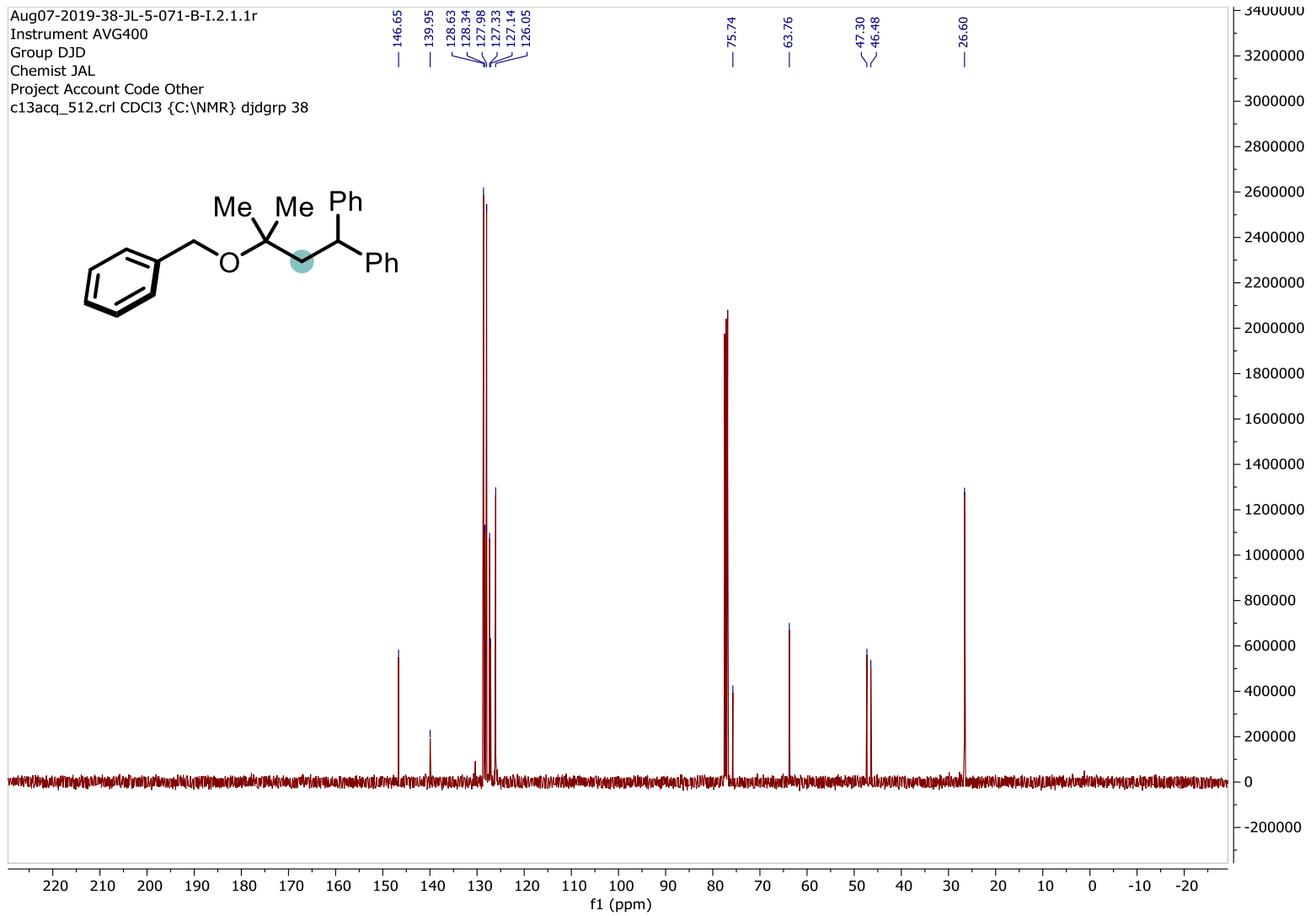


$3 \mathbf{k}-{ }^{1} \mathrm{H}$ NMR $\left(400 \mathrm{MHz}, \mathrm{CDCl}_{3}\right)$

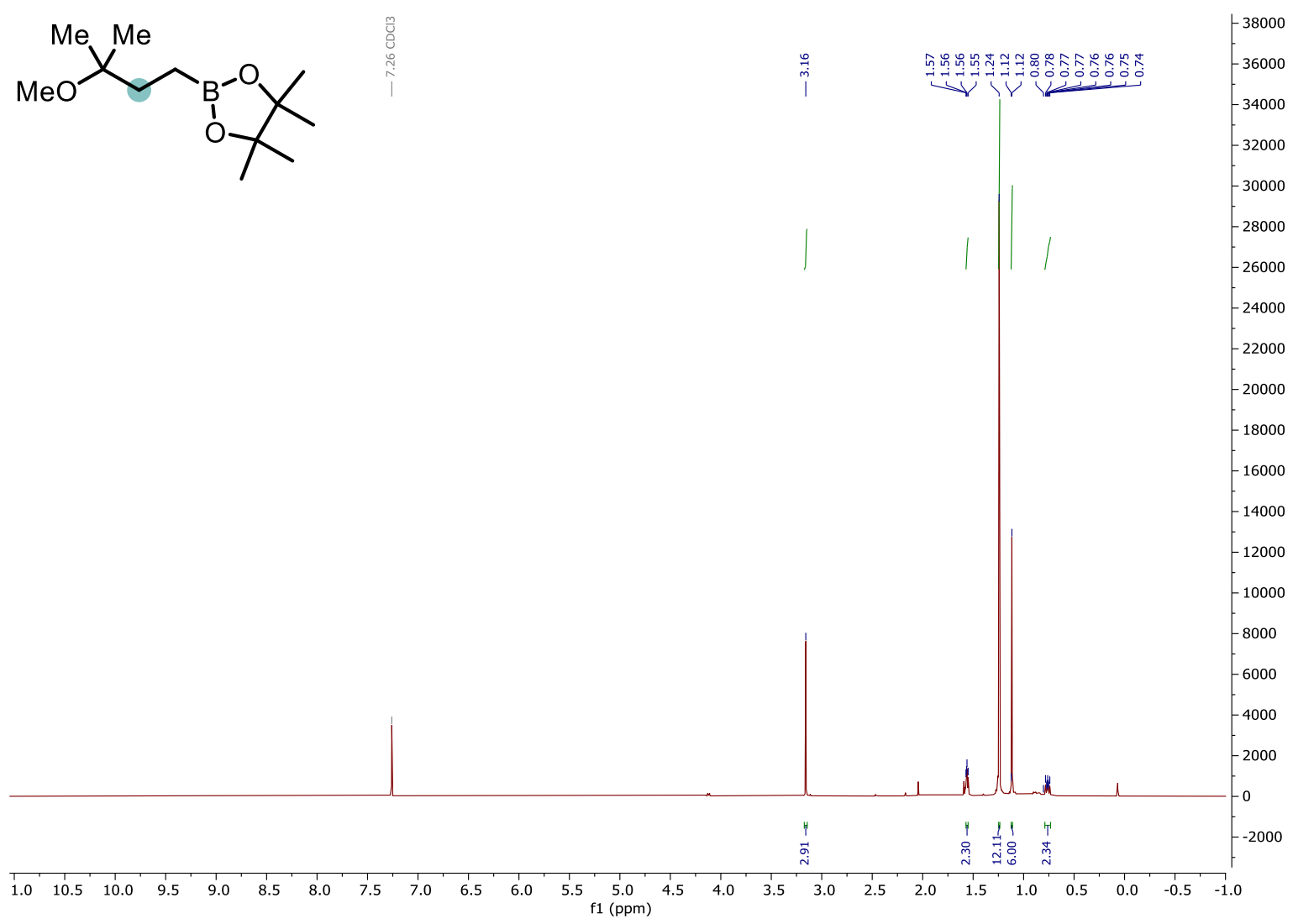

3k $-{ }^{13} \mathrm{C}$ NMR $\left(101 \mathrm{MHz}, \mathrm{CDCl}_{3}\right)$
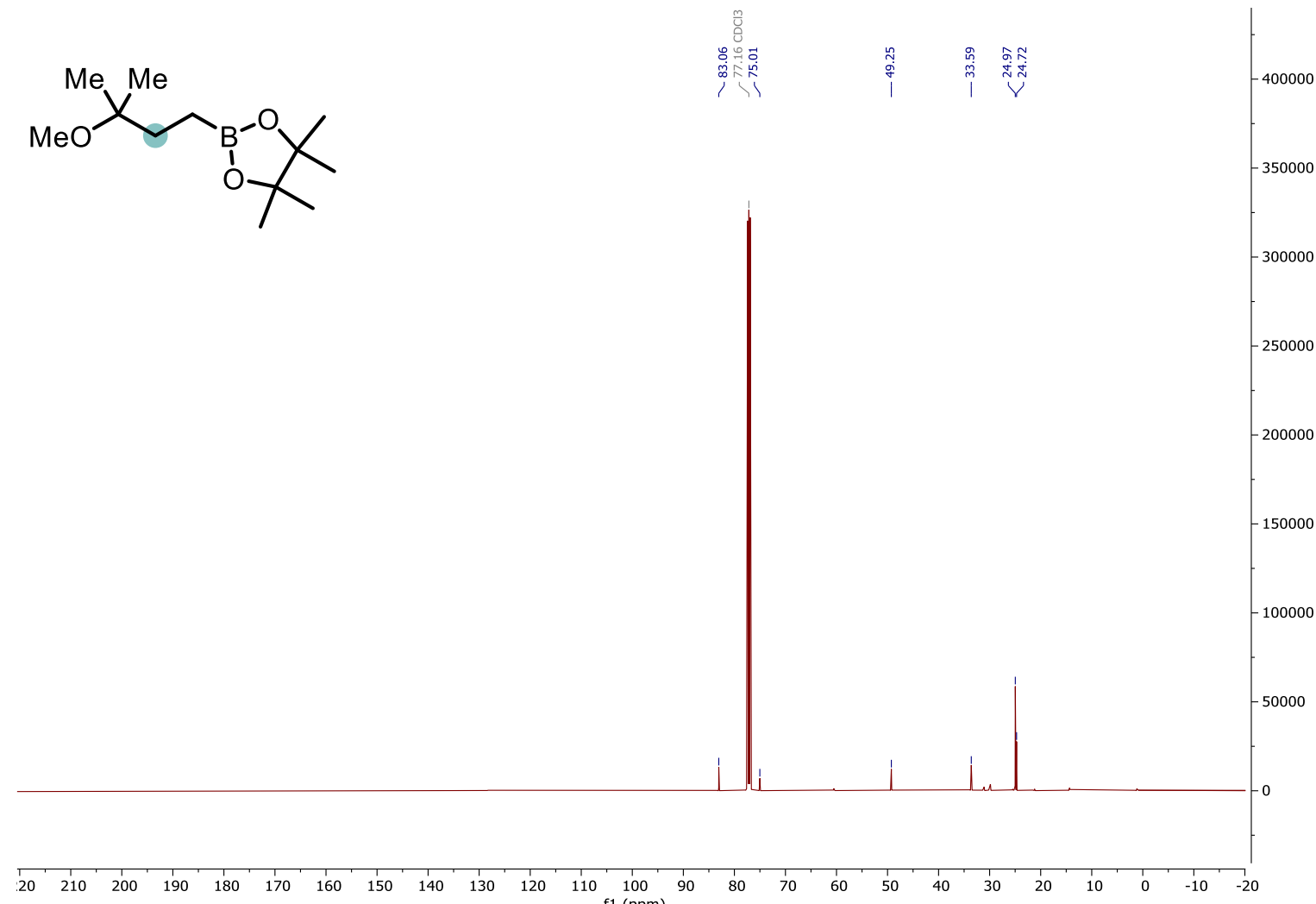
$31-{ }^{1} \mathrm{H}$ NMR $\left(400 \mathrm{MHz}, \mathrm{CDCl}_{3}\right)$

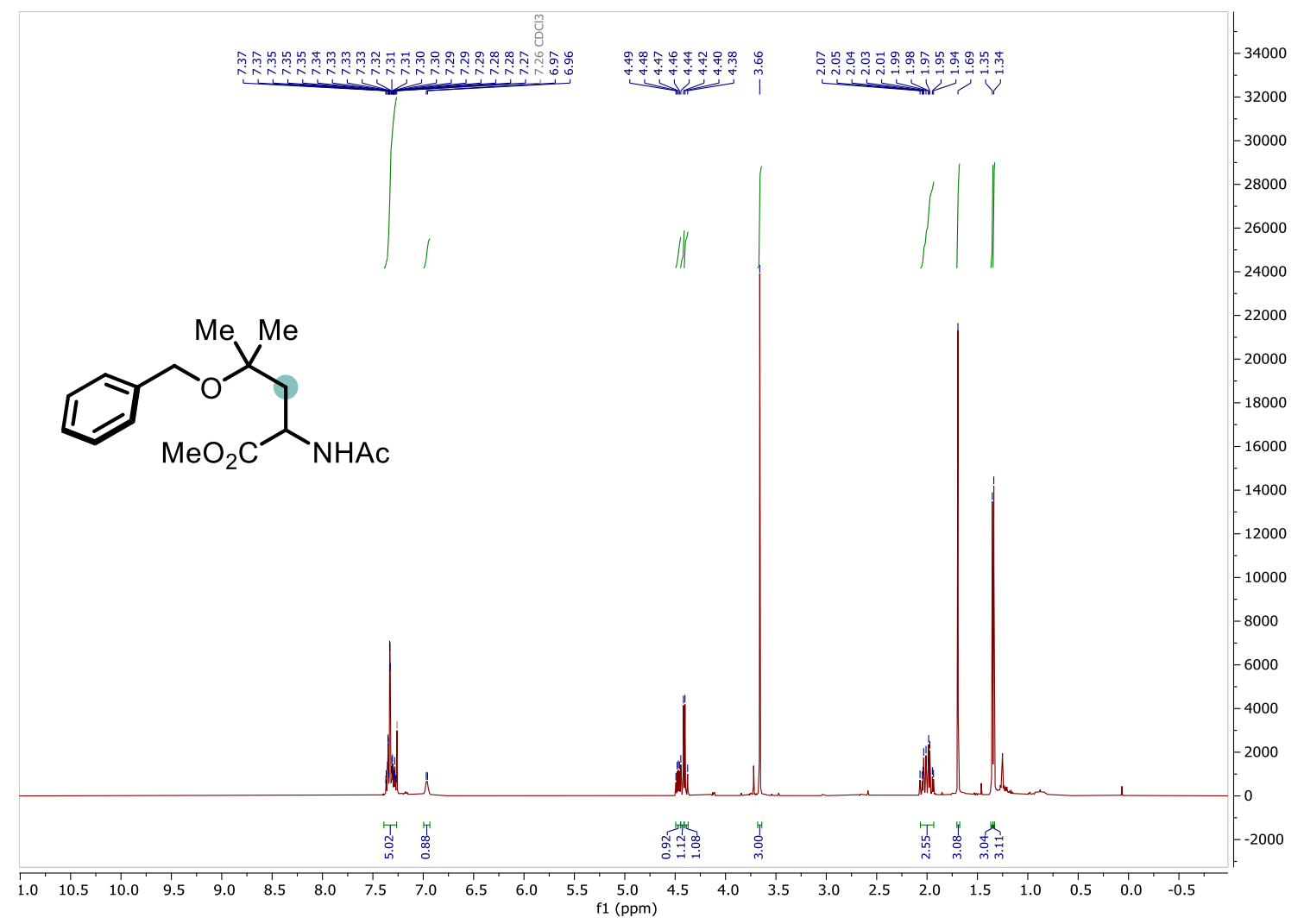

$31-{ }^{13} \mathrm{C}$ NMR $\left(101 \mathrm{MHz}, \mathrm{CDCl}_{3}\right)$

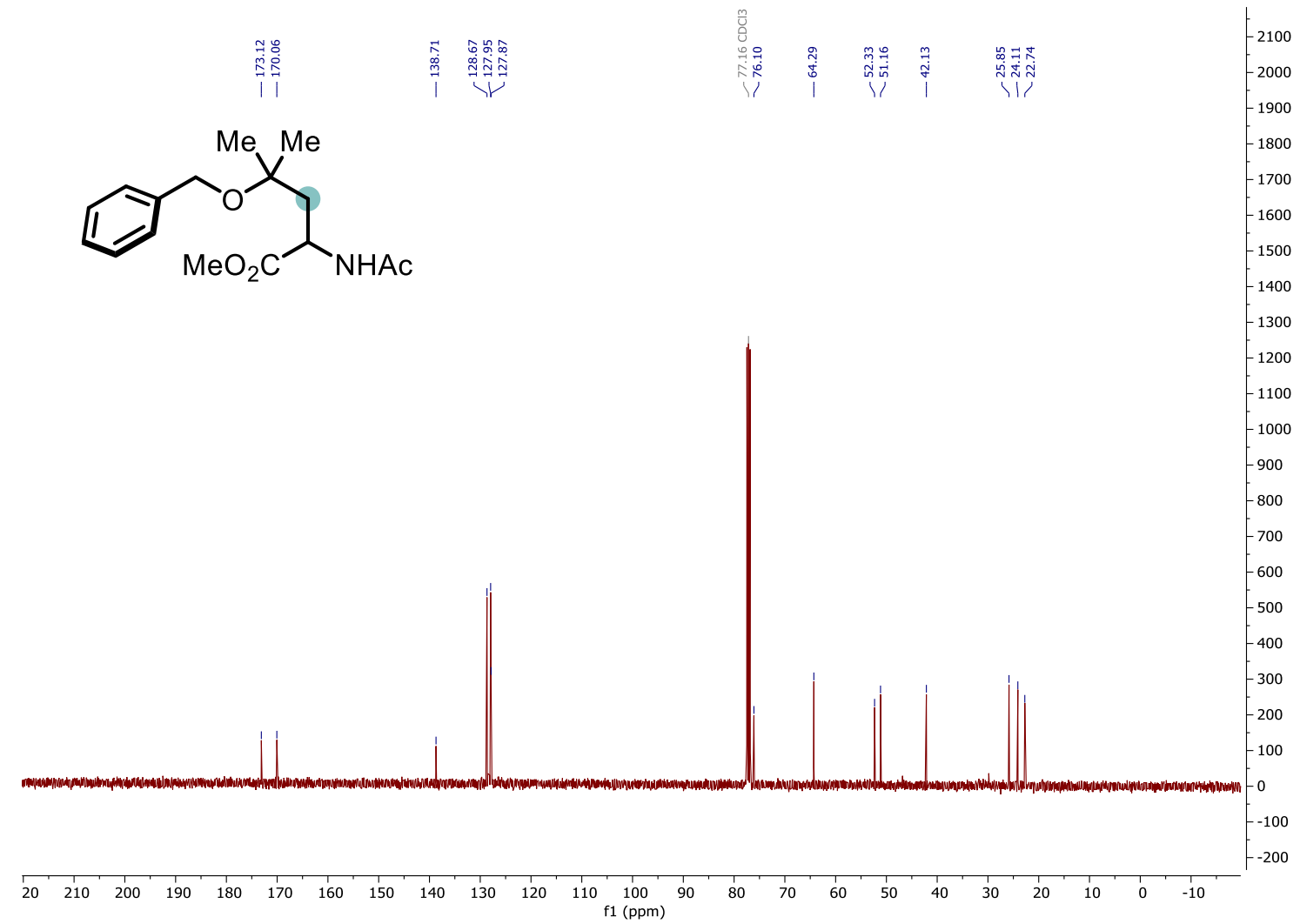


3m- ${ }^{1} \mathrm{H}$ NMR $\left(400 \mathrm{MHz}, \mathrm{CDCl}_{3}\right)$

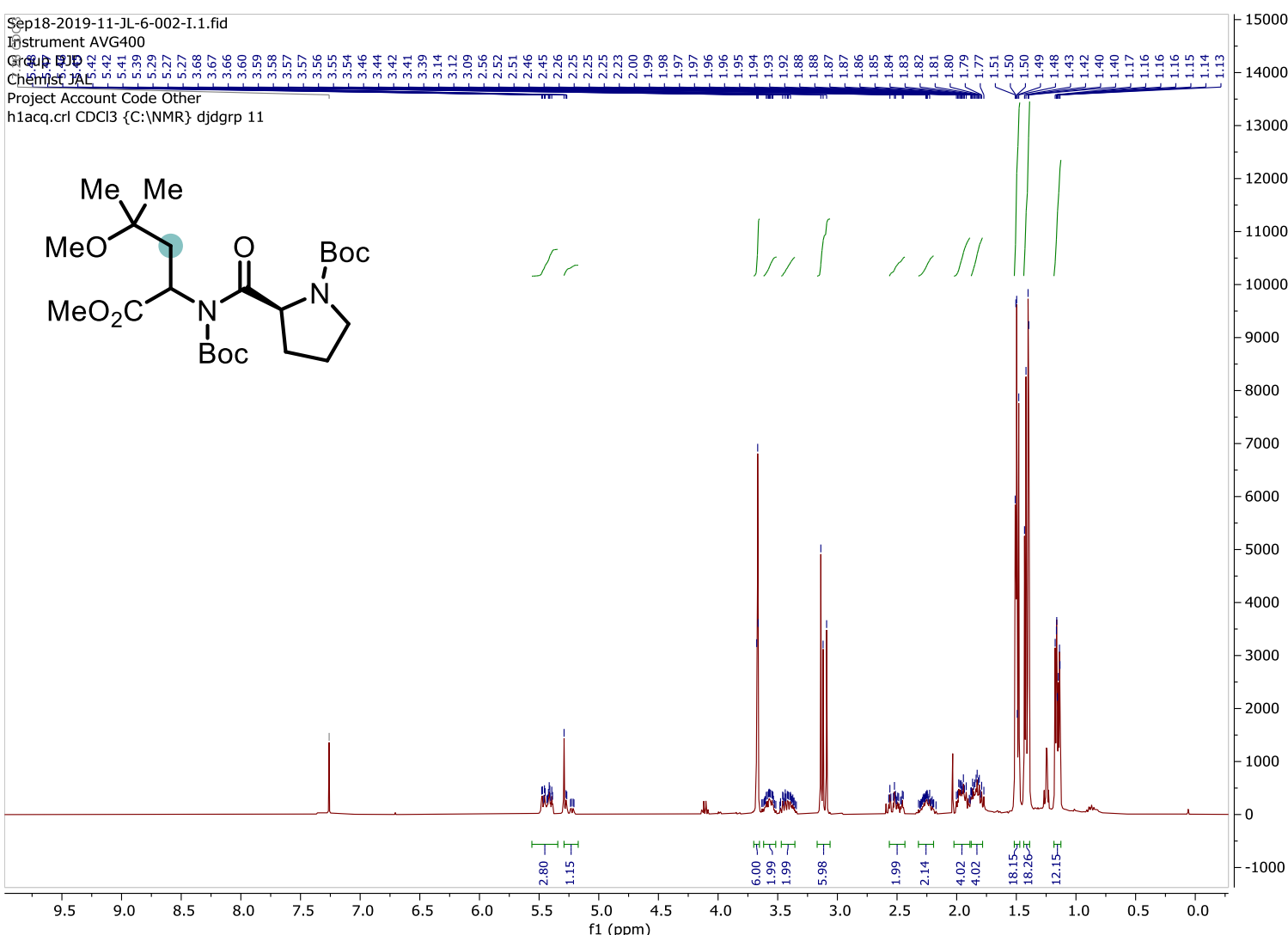

$3 \mathrm{~m}-{ }^{13} \mathrm{C}$ NMR $\left(126 \mathrm{MHz}\right.$, DMSO- $\left.d_{6}, 363 \mathrm{~K}\right)$

j177520303.4.fid

Groject Code DMR01010

Project Code DMR01010
Jamie Leitch 5775203.03 .2020
VT: 363K

$13 \mathrm{C}$

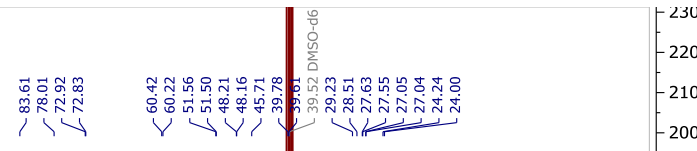<smiles>COC(=O)C(CC(C)(C)OC)N(C(=O)OCc1ccccc1)C(=O)C1CCCN1C(=O)OCc1ccccc1</smiles>

300 
3n- ${ }^{1} \mathrm{H}$ NMR $\left(400 \mathrm{MHz}, \mathrm{DMSO}-d_{6}\right)$

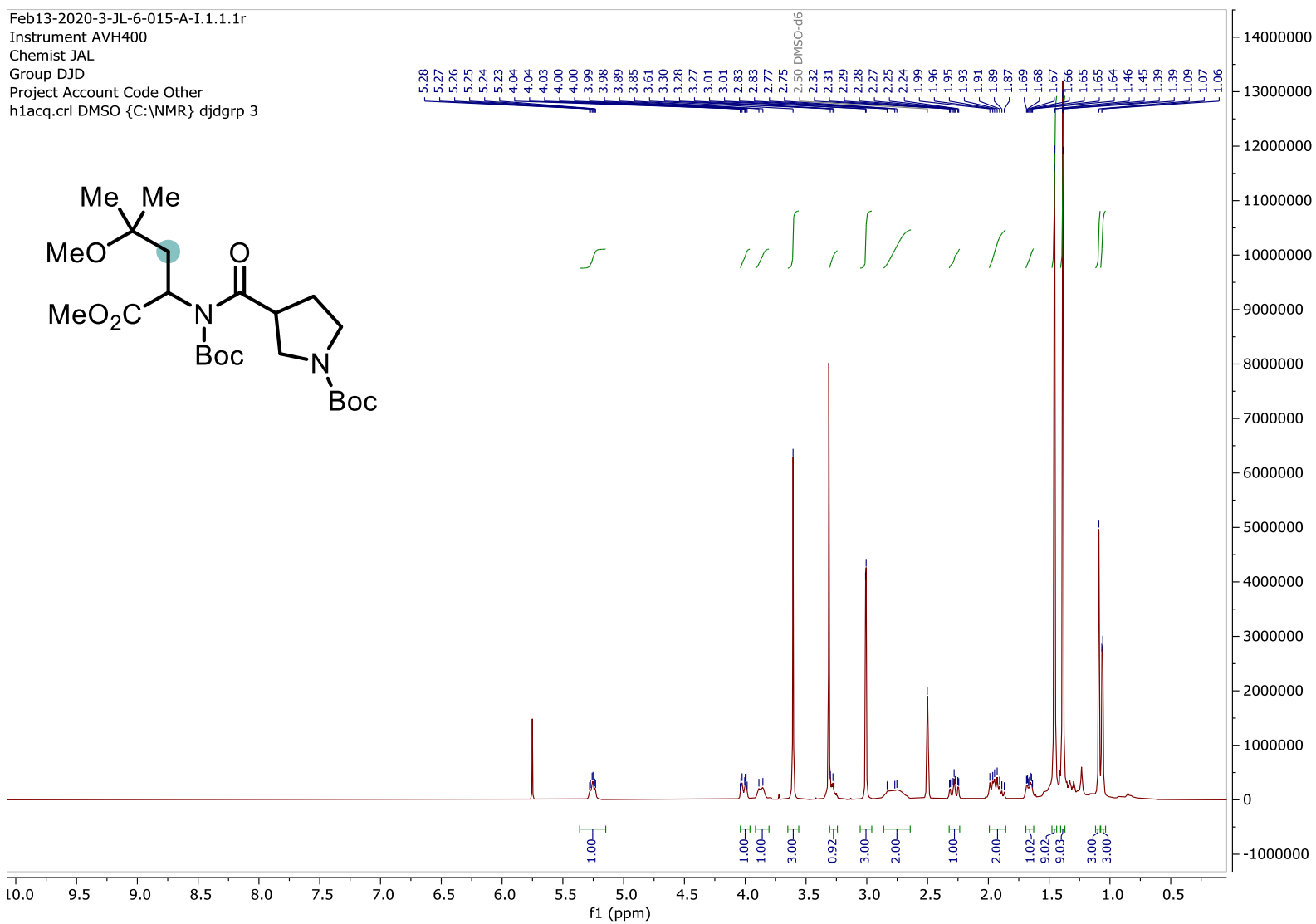

$3 \mathbf{n}-{ }^{13} \mathrm{C}$ NMR $\left(126 \mathrm{MHz}\right.$, DMSO- $\left.d_{6}, 363 \mathrm{~K}\right)$

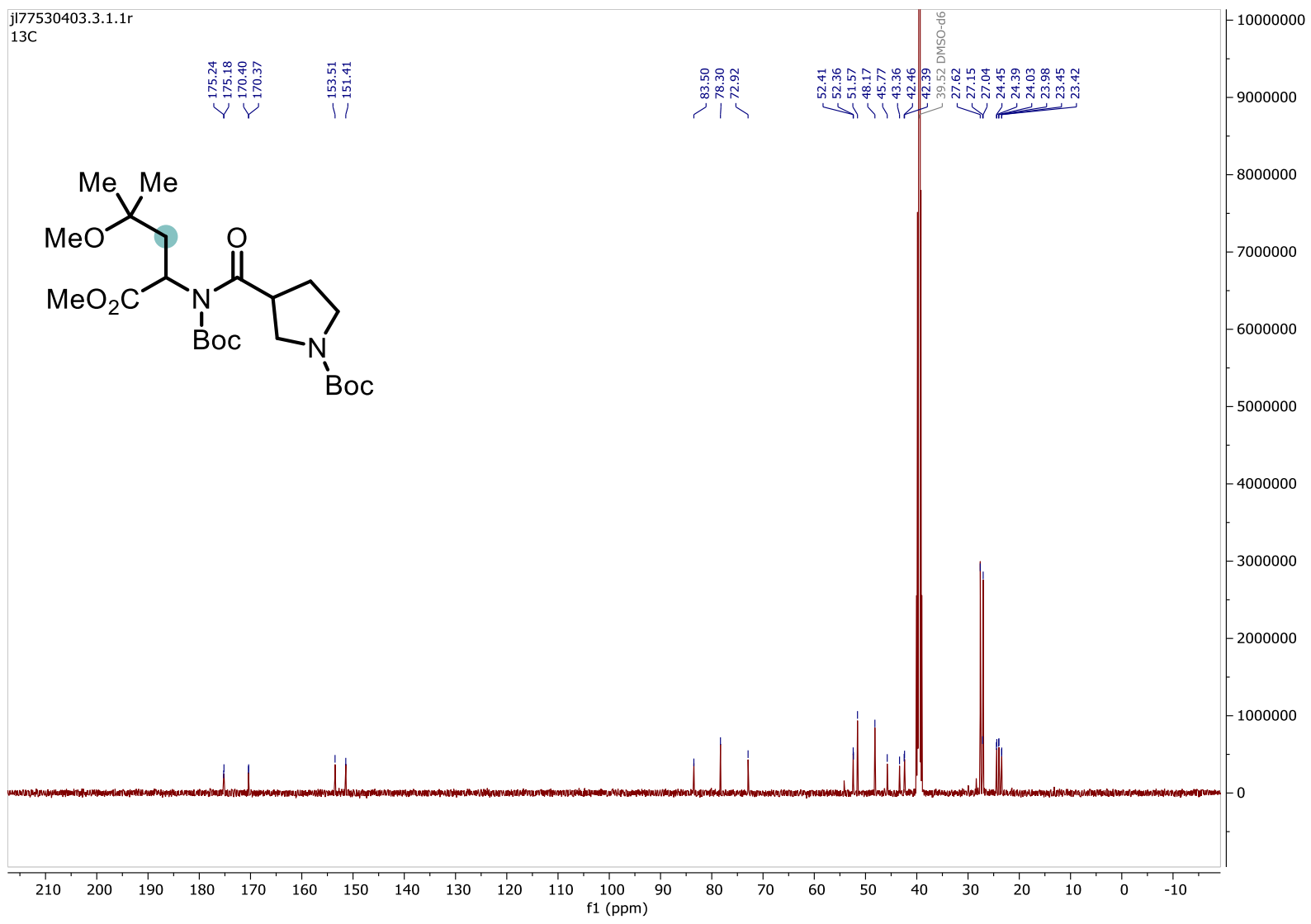


3o- ${ }^{1} \mathrm{H}$ NMR $\left(400 \mathrm{MHz}, \mathrm{CDCl}_{3}\right)$

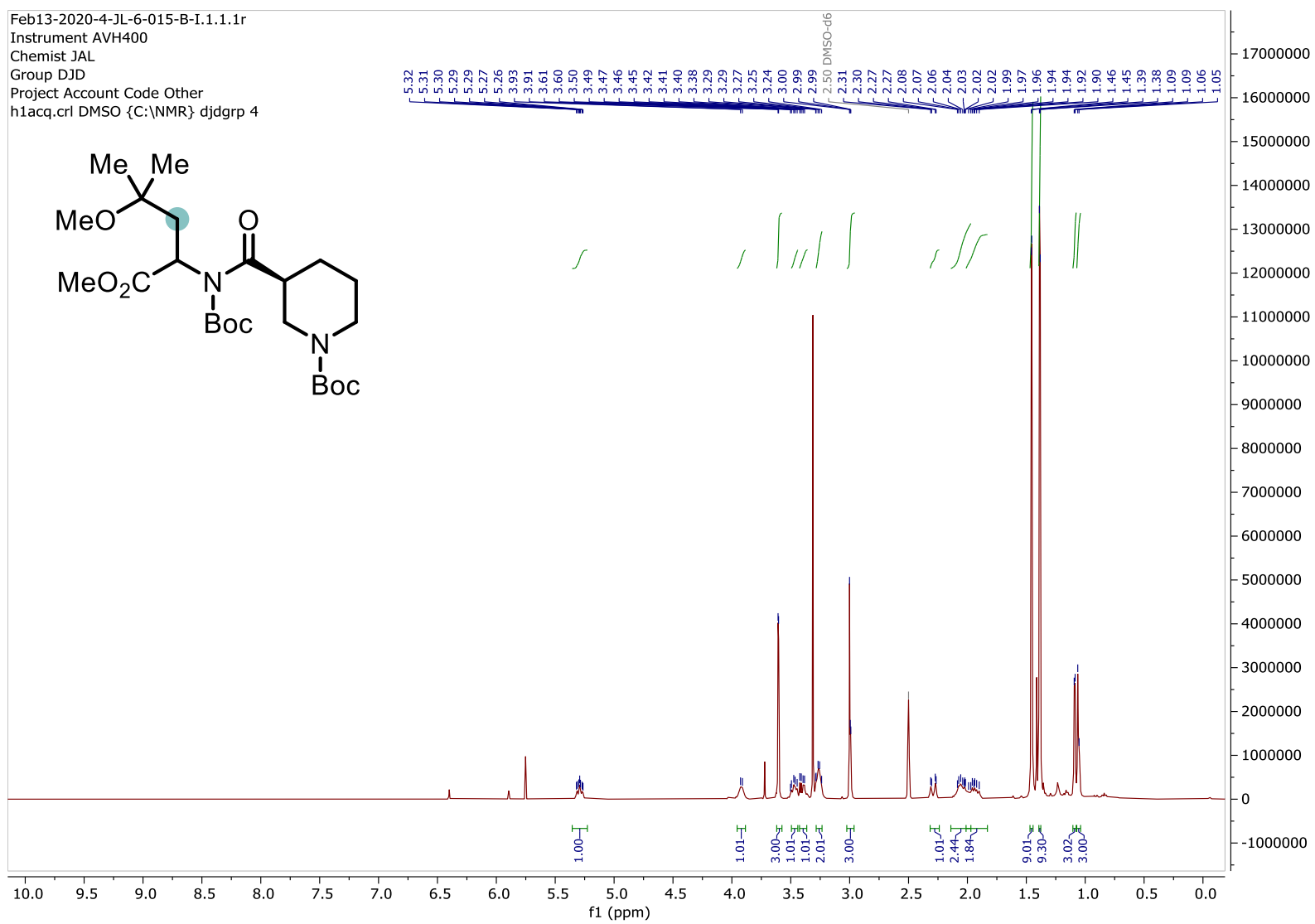

$30-{ }^{13} \mathrm{C}$ NMR $\left(126 \mathrm{MHz}, \mathrm{DMSO}-d_{6}, 363 \mathrm{~K}\right)$

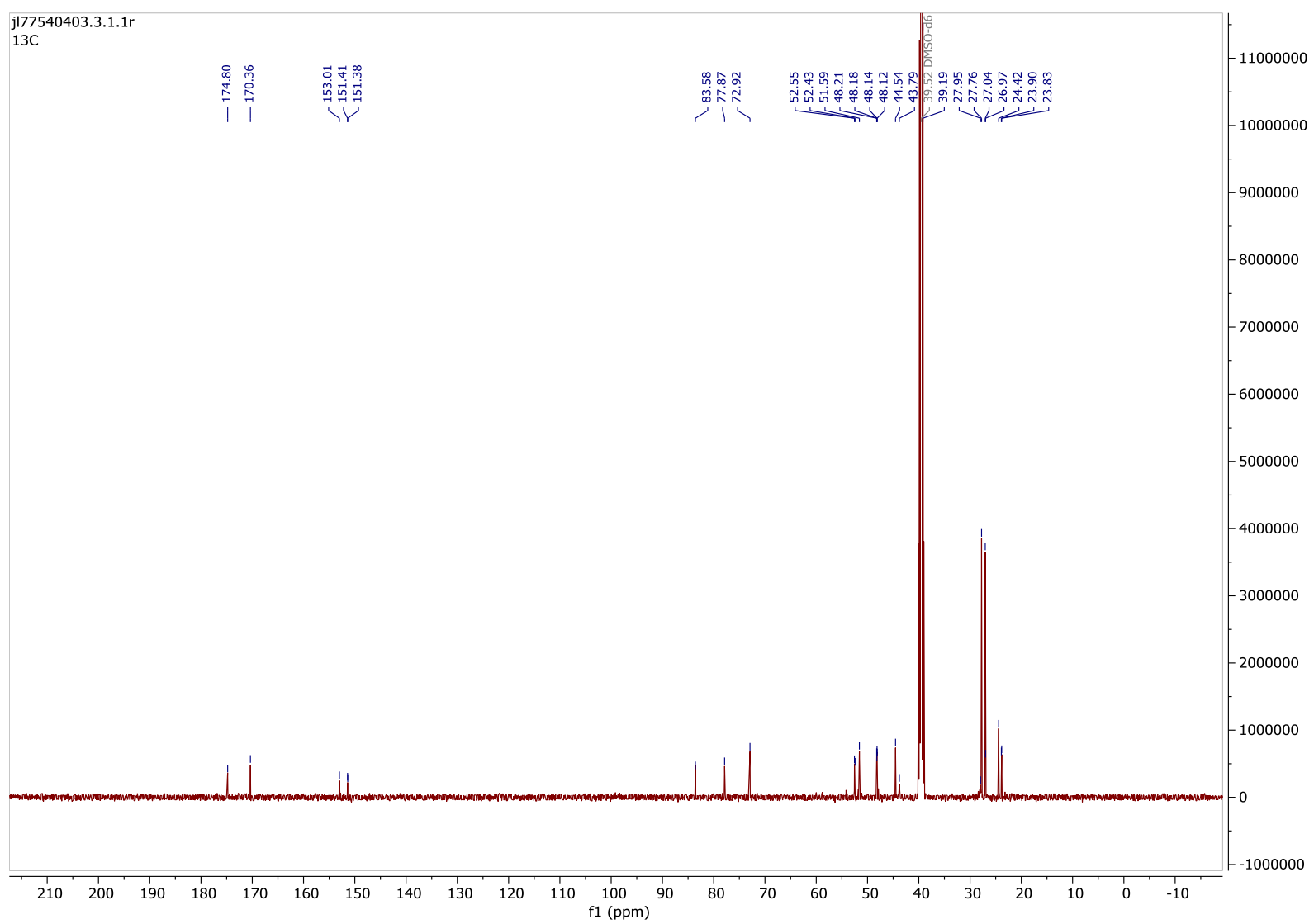


3p- ${ }^{1} \mathrm{H}$ NMR $\left(400 \mathrm{MHz}, \mathrm{CDCl}_{3}\right)$

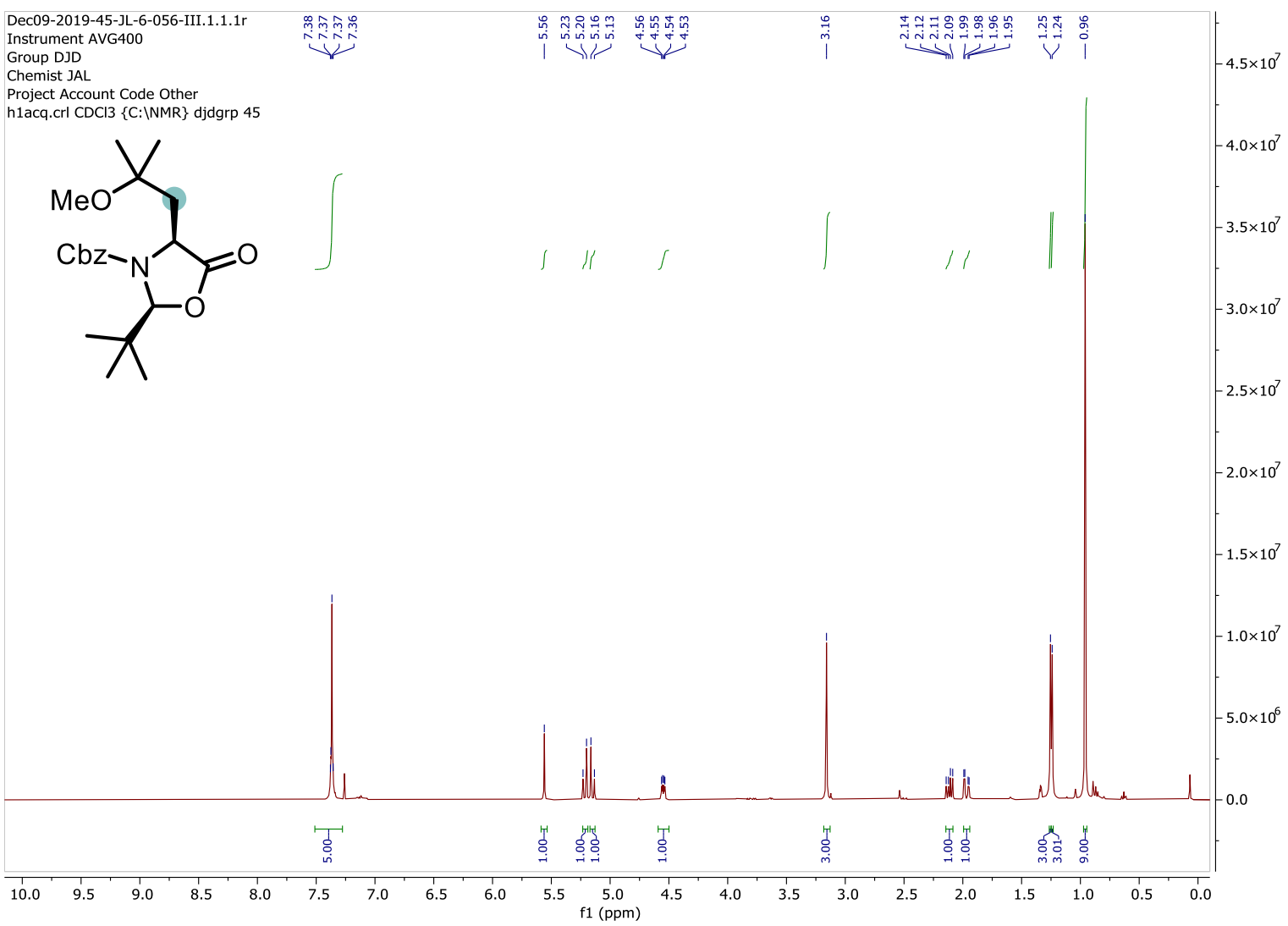

3p $-{ }^{13} \mathrm{C} \mathrm{NMR}\left(101 \mathrm{MHz}, \mathrm{CDCl}_{3}\right)$

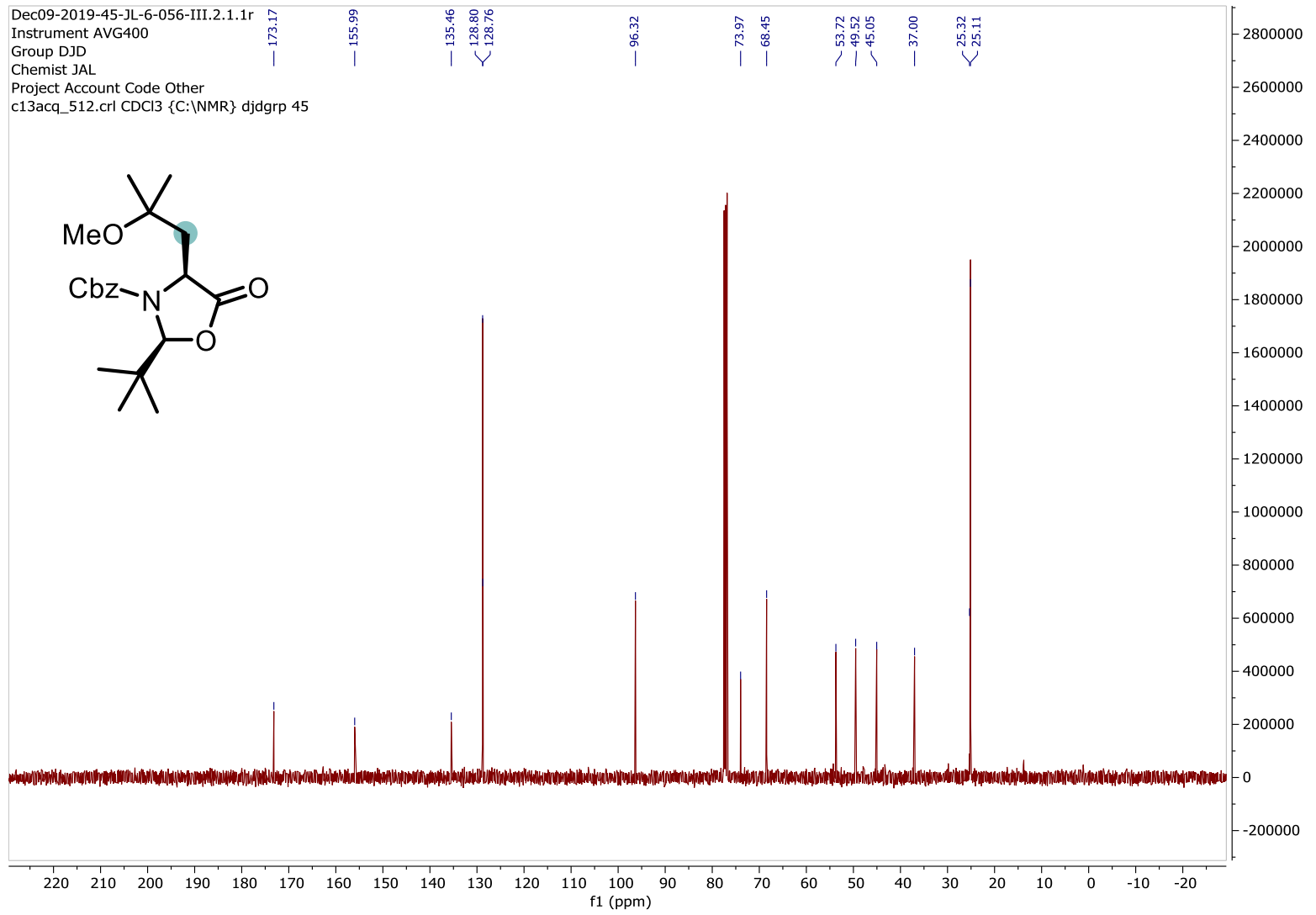


4b- ${ }^{1} \mathrm{H}$ NMR $\left(400 \mathrm{MHz}, \mathrm{CDCl}_{3}\right)$

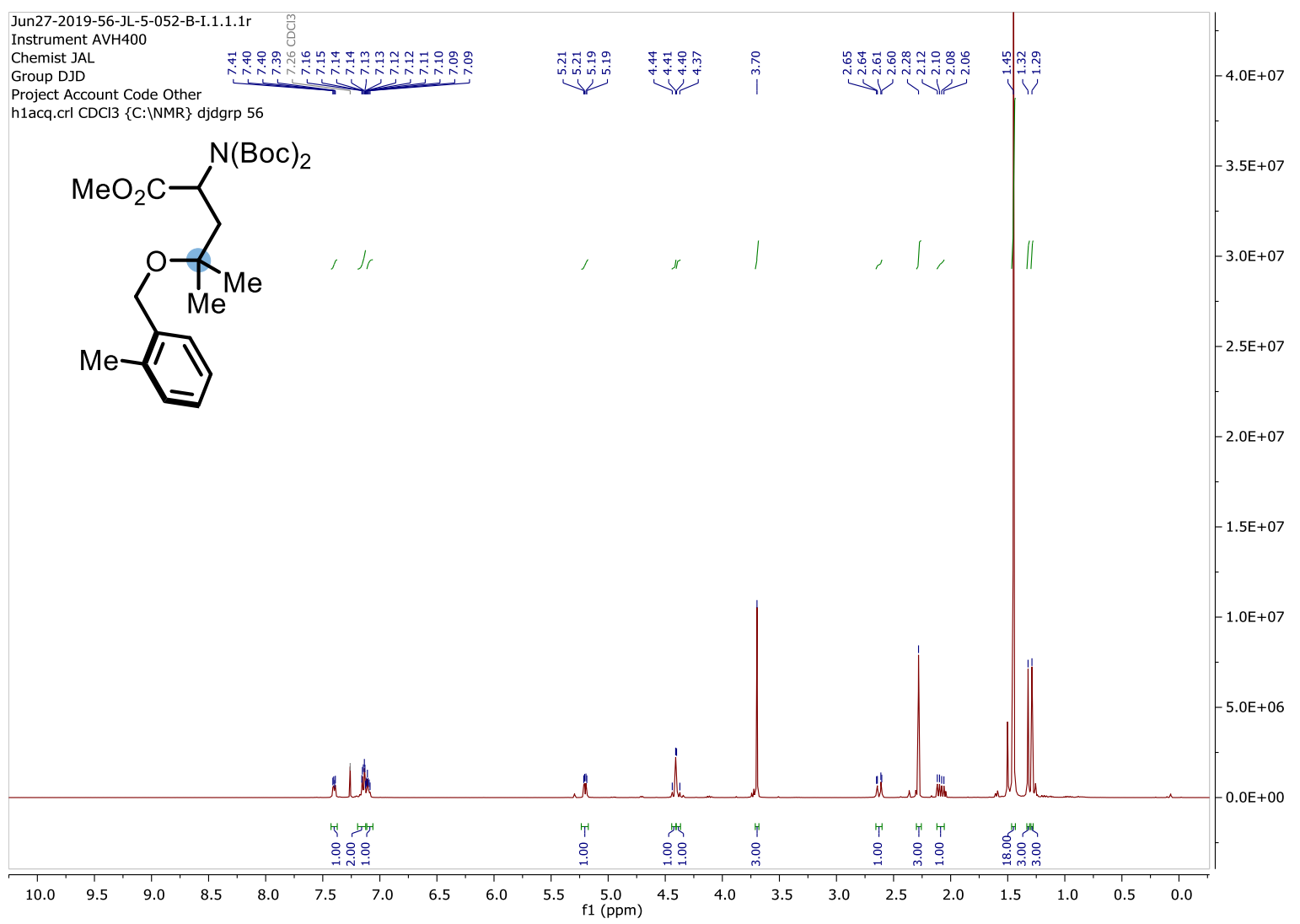

4b $-{ }^{13} \mathrm{C}$ NMR $\left(101 \mathrm{MHz}, \mathrm{CDCl}_{3}\right)$

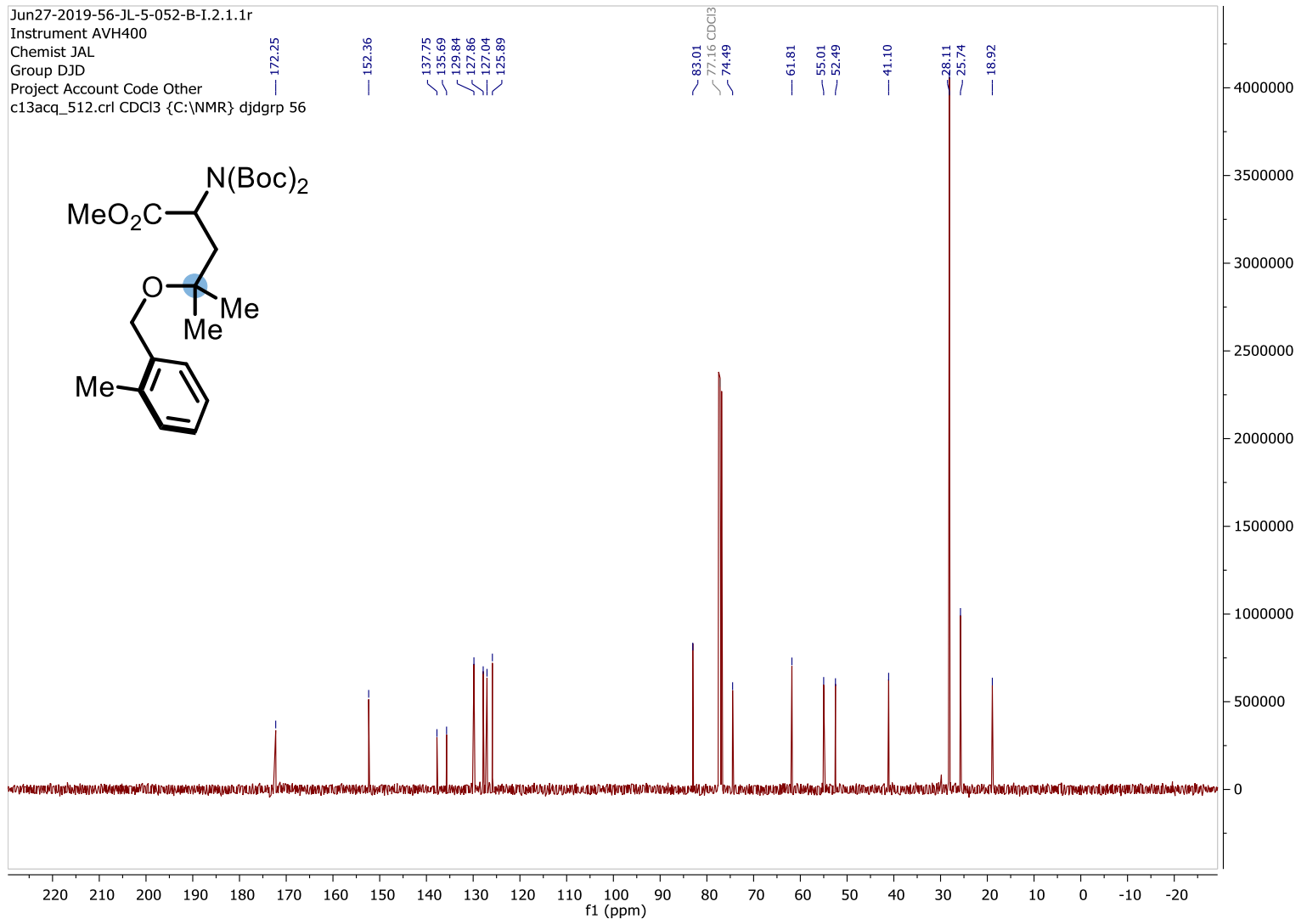


4c- ${ }^{1} \mathrm{H}$ NMR $\left(400 \mathrm{MHz}, \mathrm{CDCl}_{3}\right)$

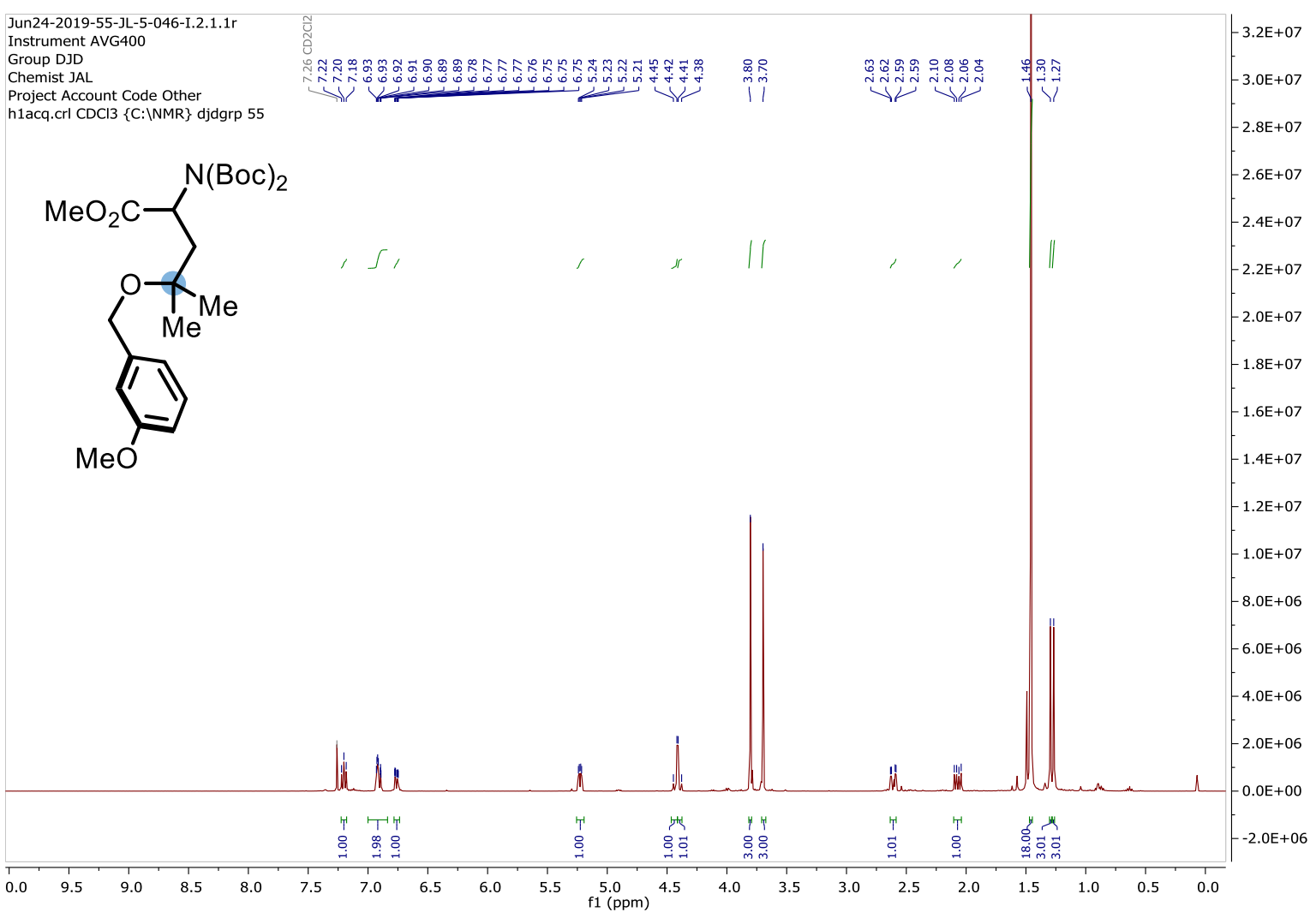

4c $-{ }^{13} \mathrm{C}$ NMR $\left(101 \mathrm{MHz}, \mathrm{CDCl}_{3}\right)$

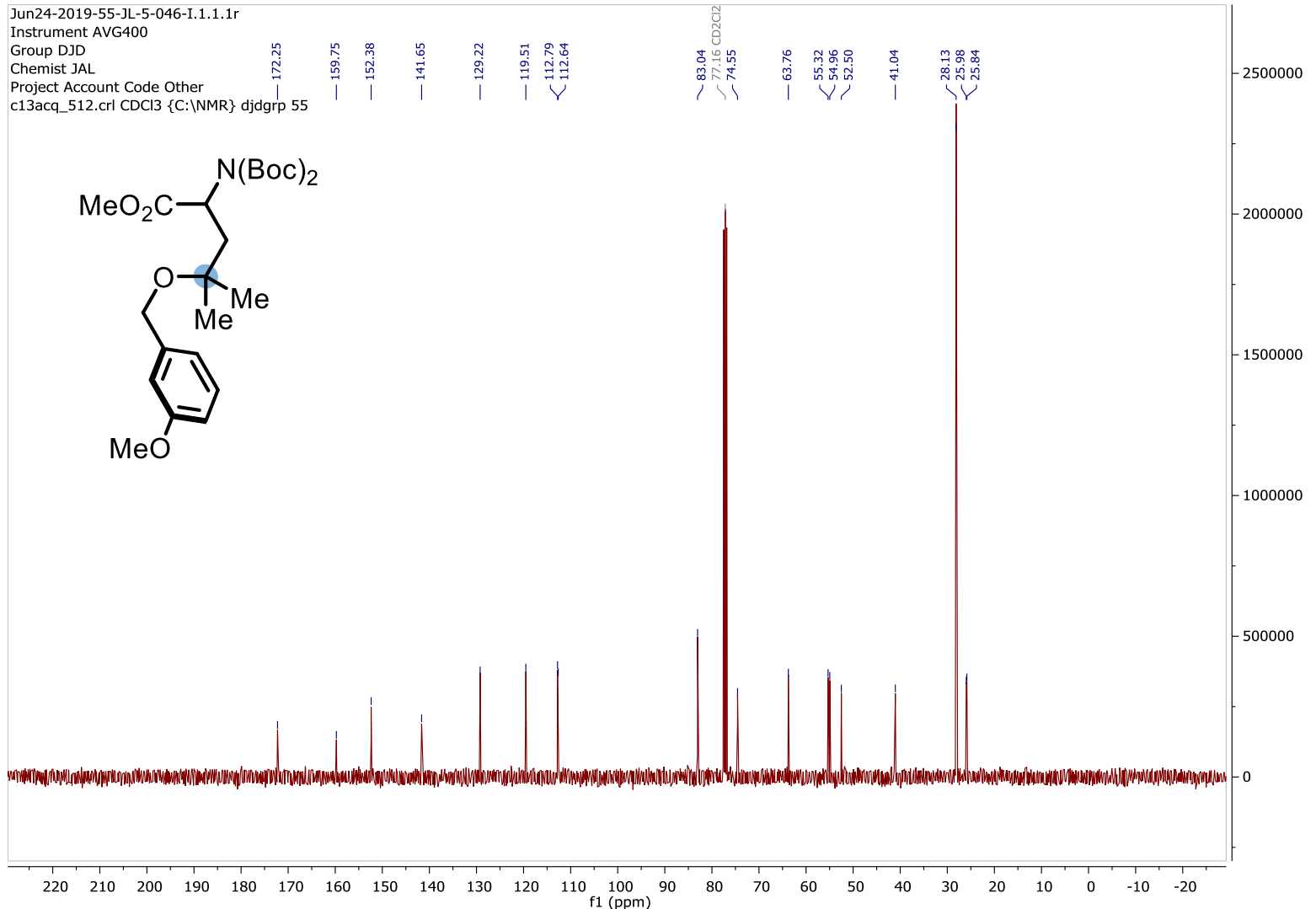


4d $-{ }^{1} \mathrm{H}$ NMR $\left(400 \mathrm{MHz}, \mathrm{CDCl}_{3}\right)$

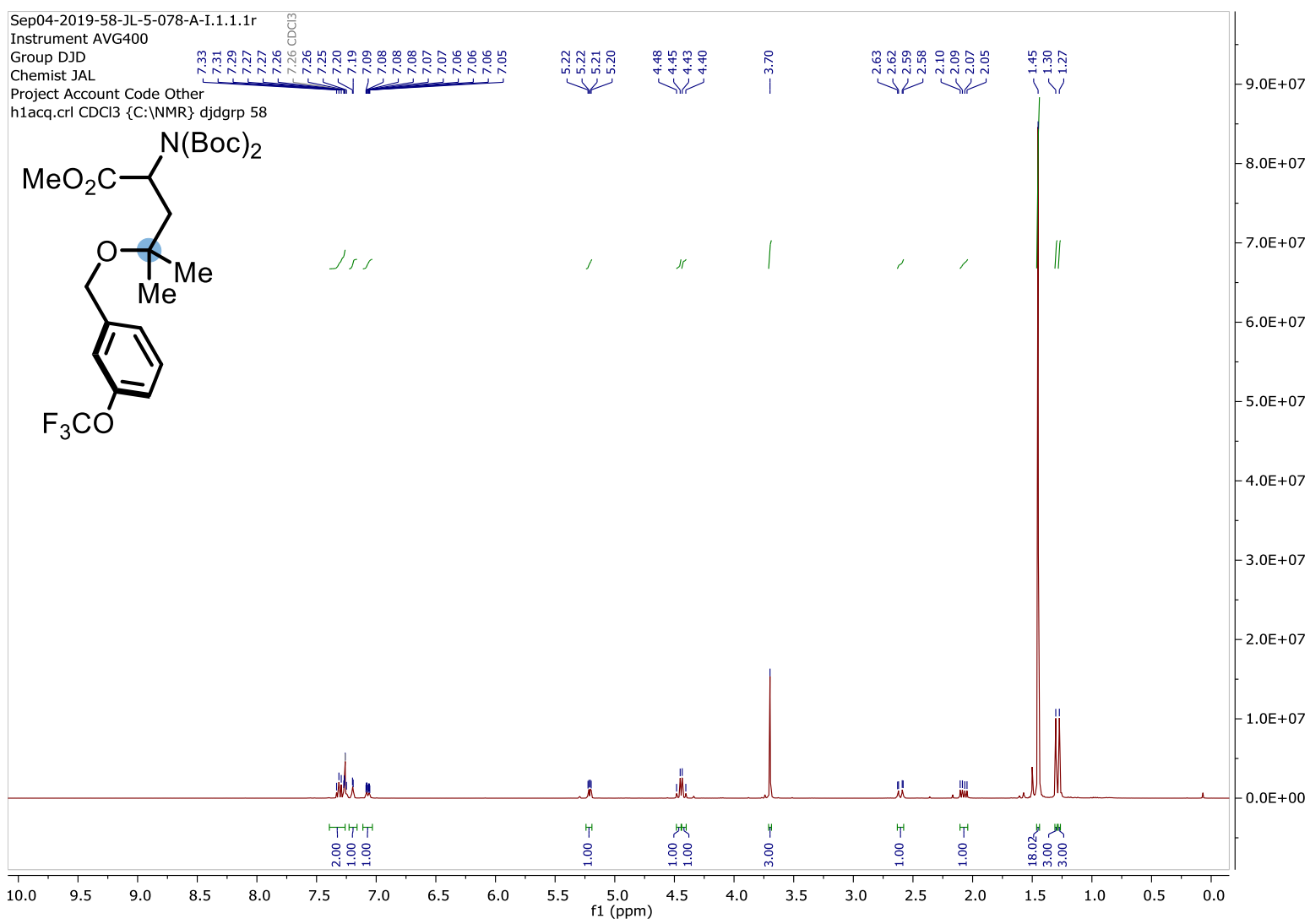

4d $-{ }^{19} \mathrm{~F}$ NMR $\left(377 \mathrm{MHz}, \mathrm{CDCl}_{3}\right.$

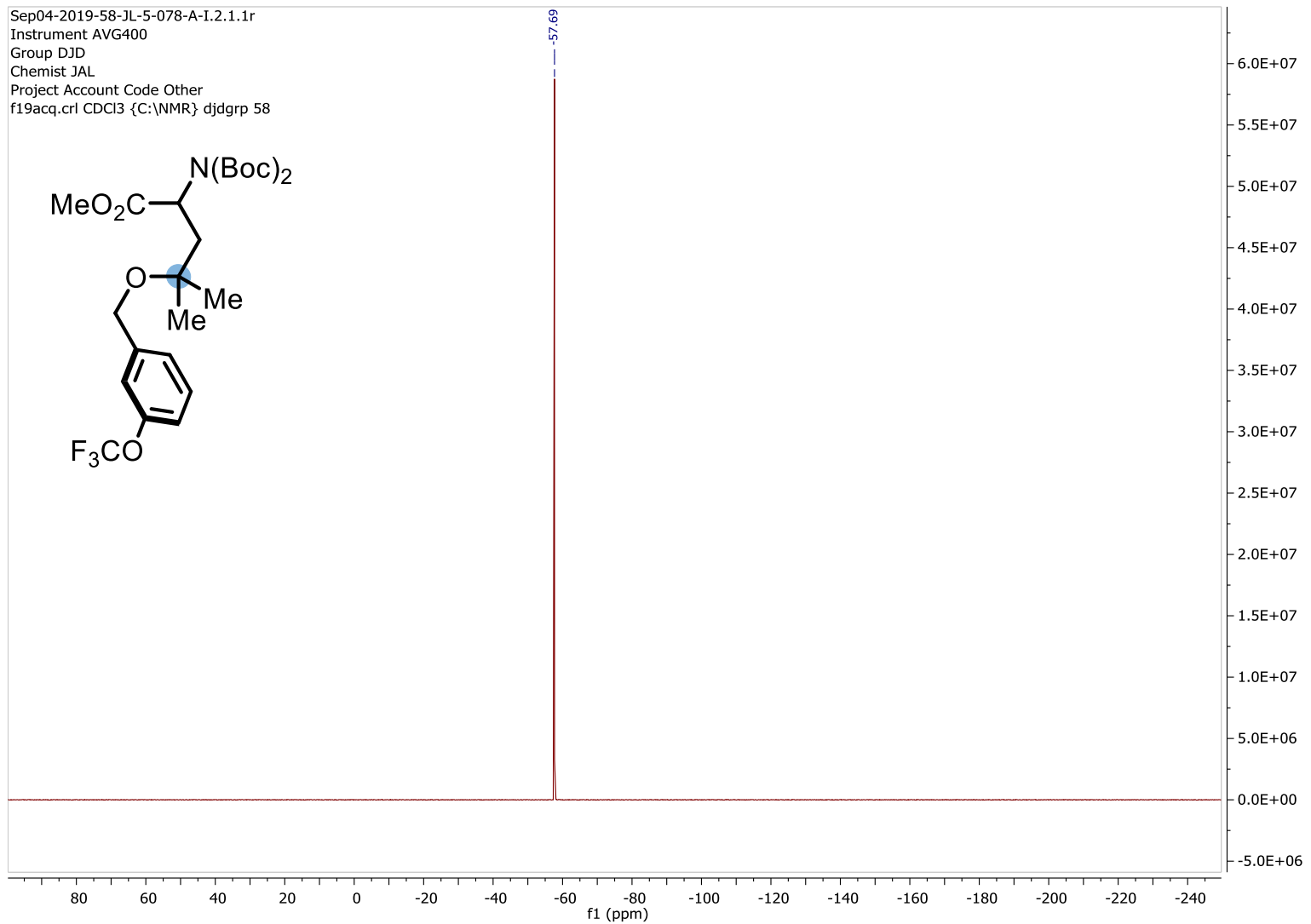


4d $-{ }^{13} \mathrm{C}$ NMR $\left(126 \mathrm{MHz}, \mathrm{CDCl}_{3}\right)$

j178512602.4.fid

Instrument AVC500

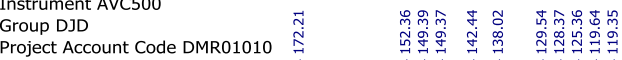

|

$-40000$
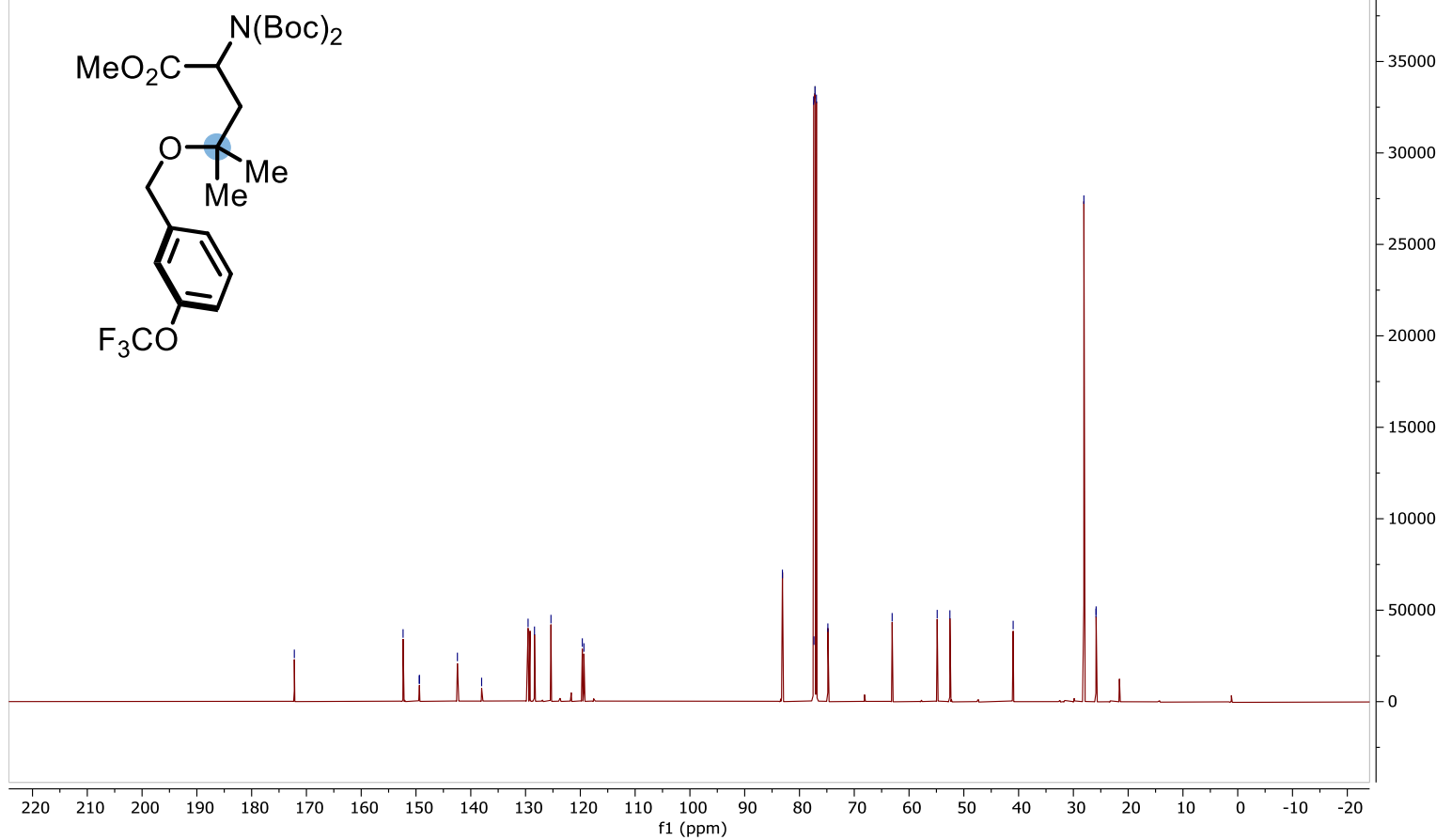
$4 \mathrm{e}-{ }^{1} \mathrm{H}$ NMR $\left(400 \mathrm{MHz}, \mathrm{CDCl}_{3}\right)$

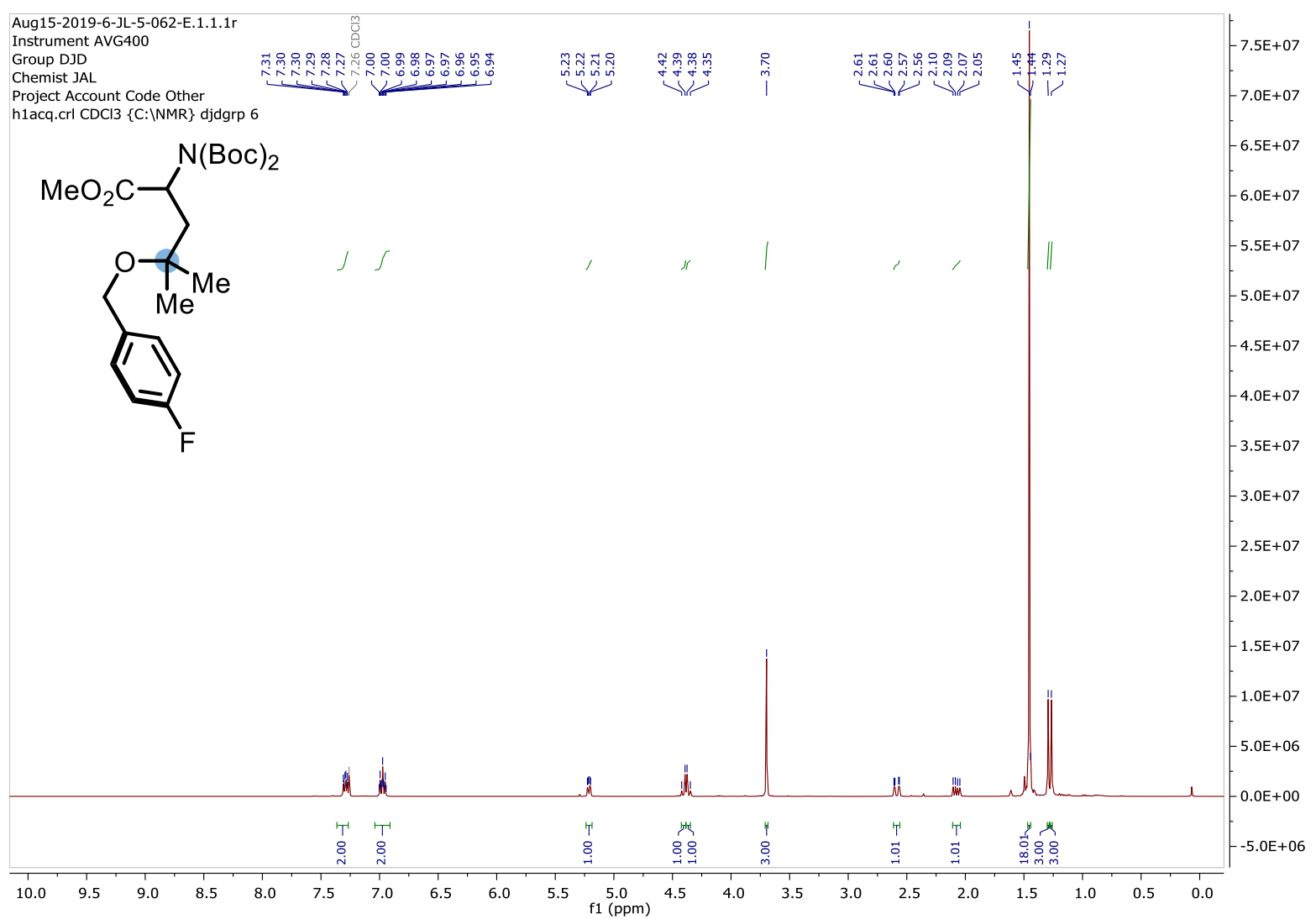

$4 \mathrm{e}-{ }^{19} \mathrm{~F}$ NMR $\left(377 \mathrm{MHz}, \mathrm{CDCl}_{3}\right.$

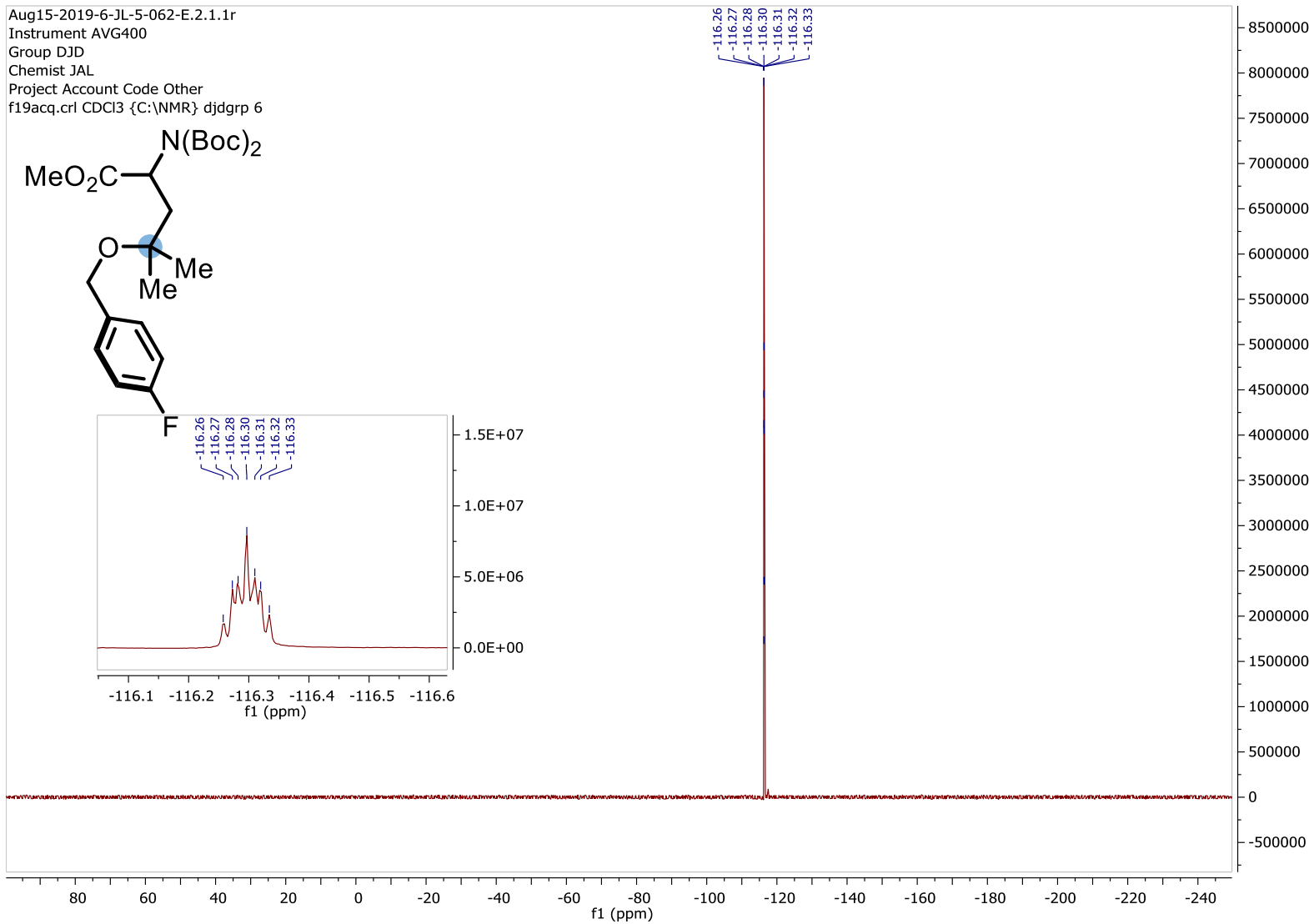


$4 \mathbf{e}-{ }^{13} \mathrm{C}$ NMR $\left(101 \mathrm{MHz}, \mathrm{CDCl}_{3}\right)$

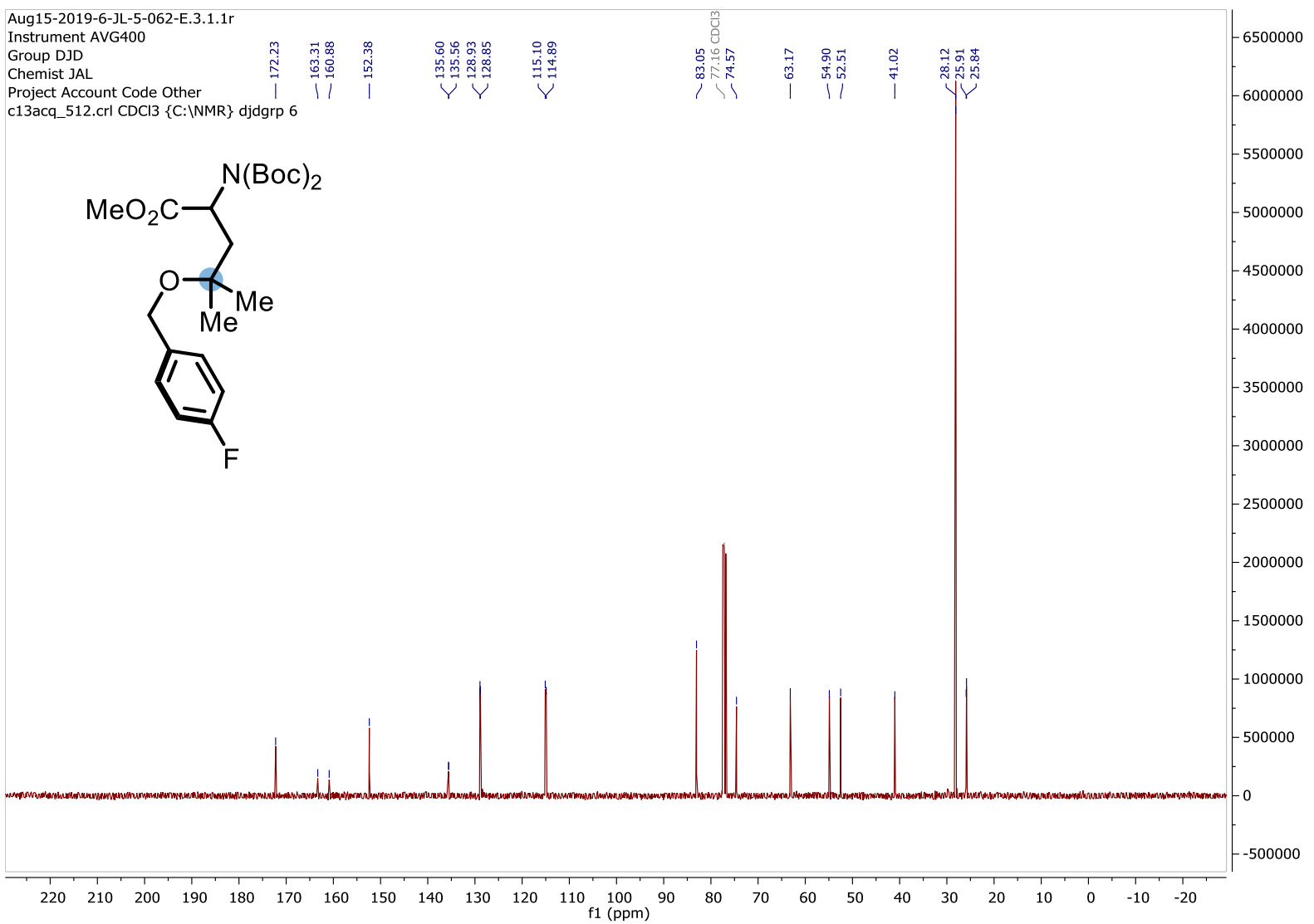


$4 \mathbf{f}-{ }^{1} \mathrm{H}$ NMR $\left(400 \mathrm{MHz}, \mathrm{CDCl}_{3}\right)$

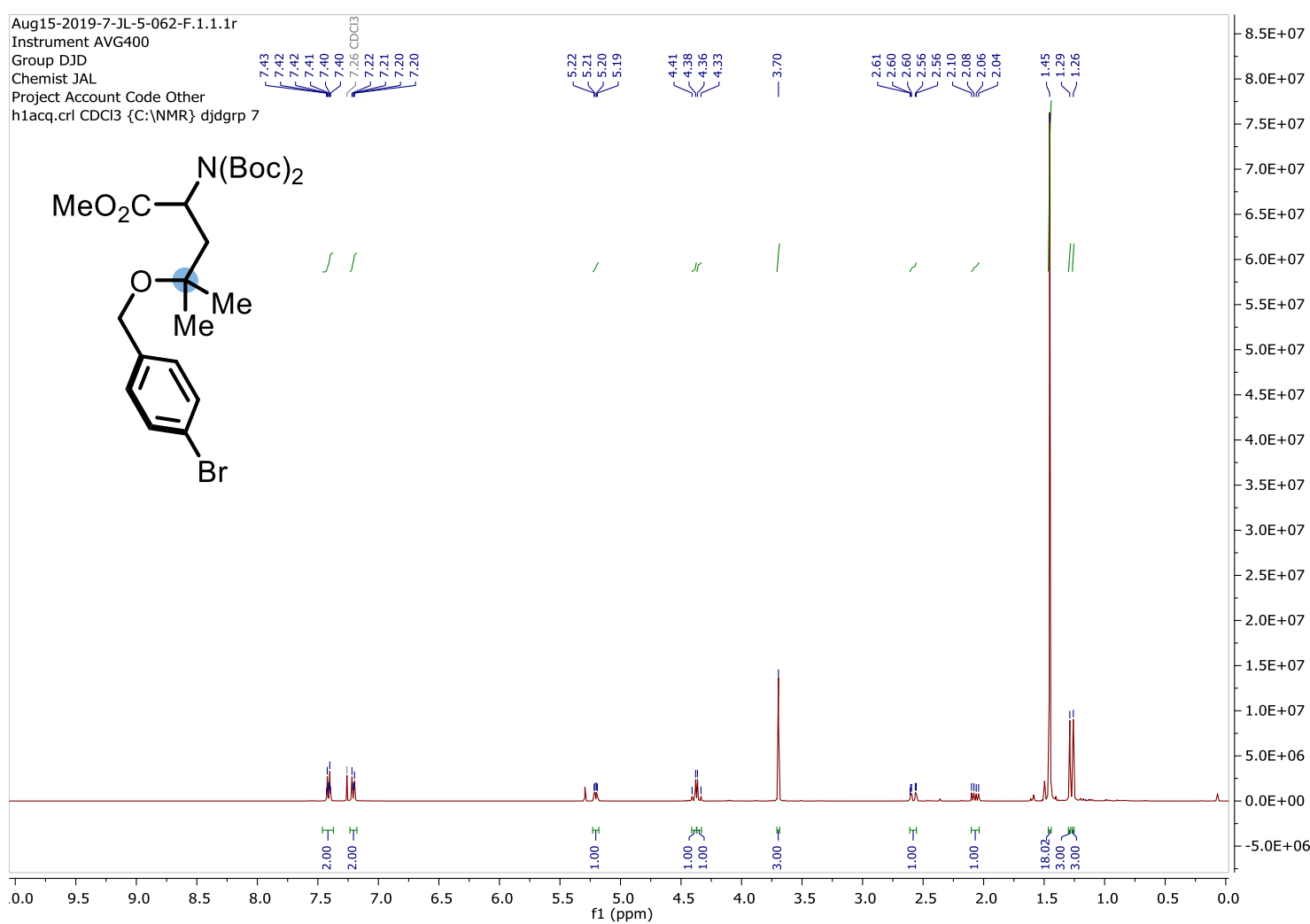

$4 \mathbf{f}-{ }^{13} \mathrm{C}$ NMR $\left(101 \mathrm{MHz}, \mathrm{CDCl}_{3}\right)$

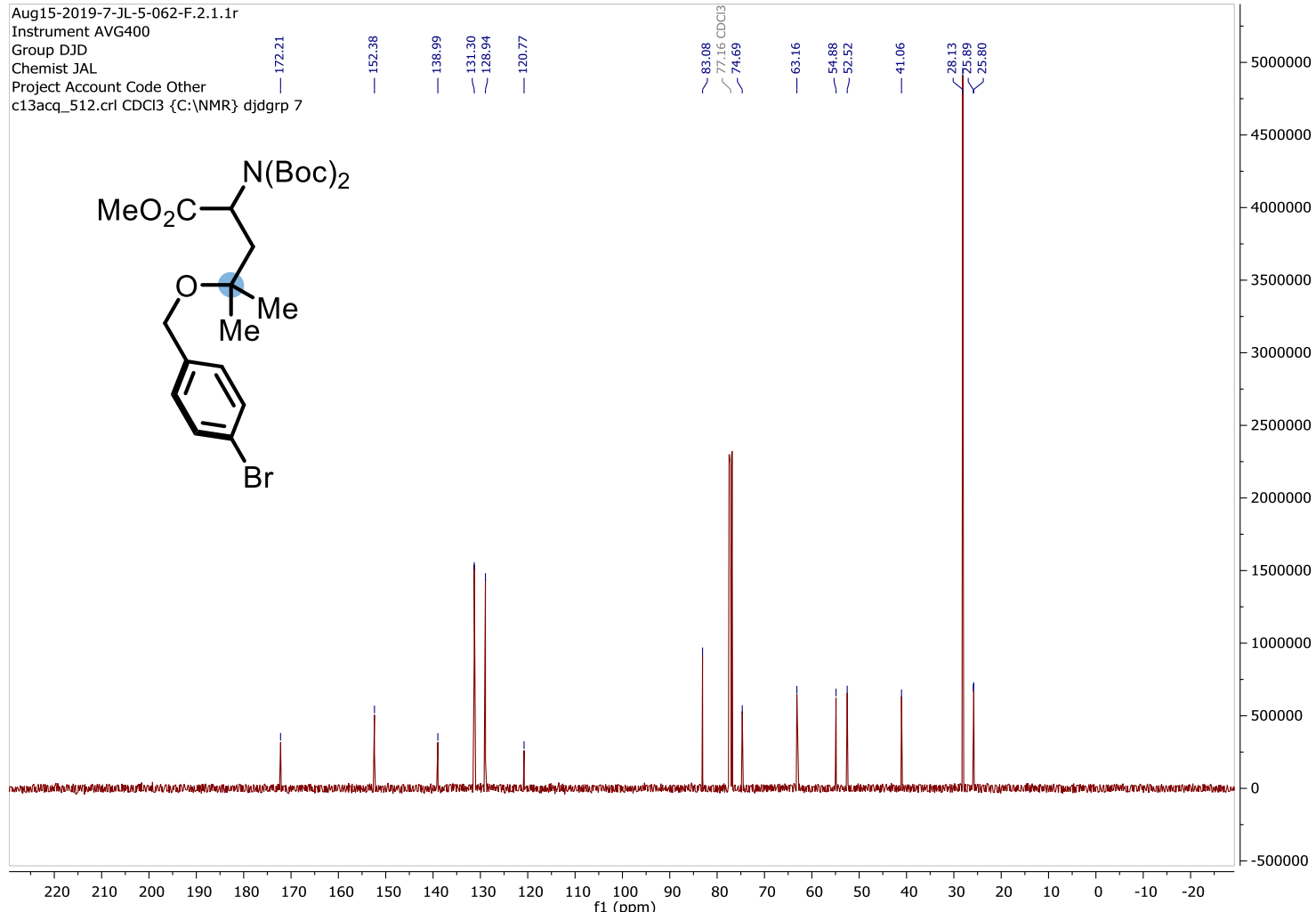


4g $-{ }^{1} \mathrm{H}$ NMR $\left(400 \mathrm{MHz}, \mathrm{CDCl}_{3}\right)$

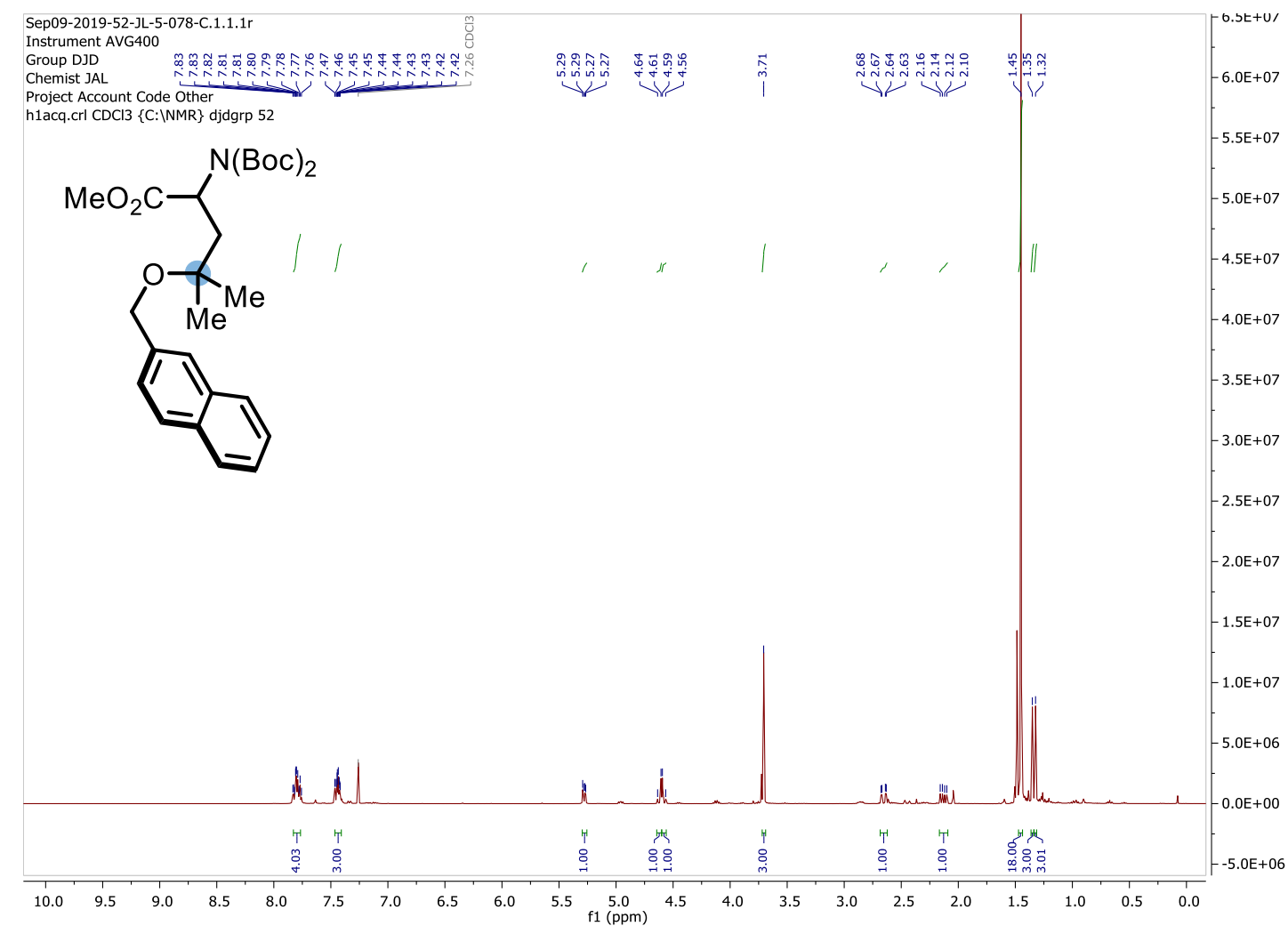

4g $-{ }^{13} \mathrm{C}$ NMR $\left(101 \mathrm{MHz}, \mathrm{CDCl}_{3}\right)$

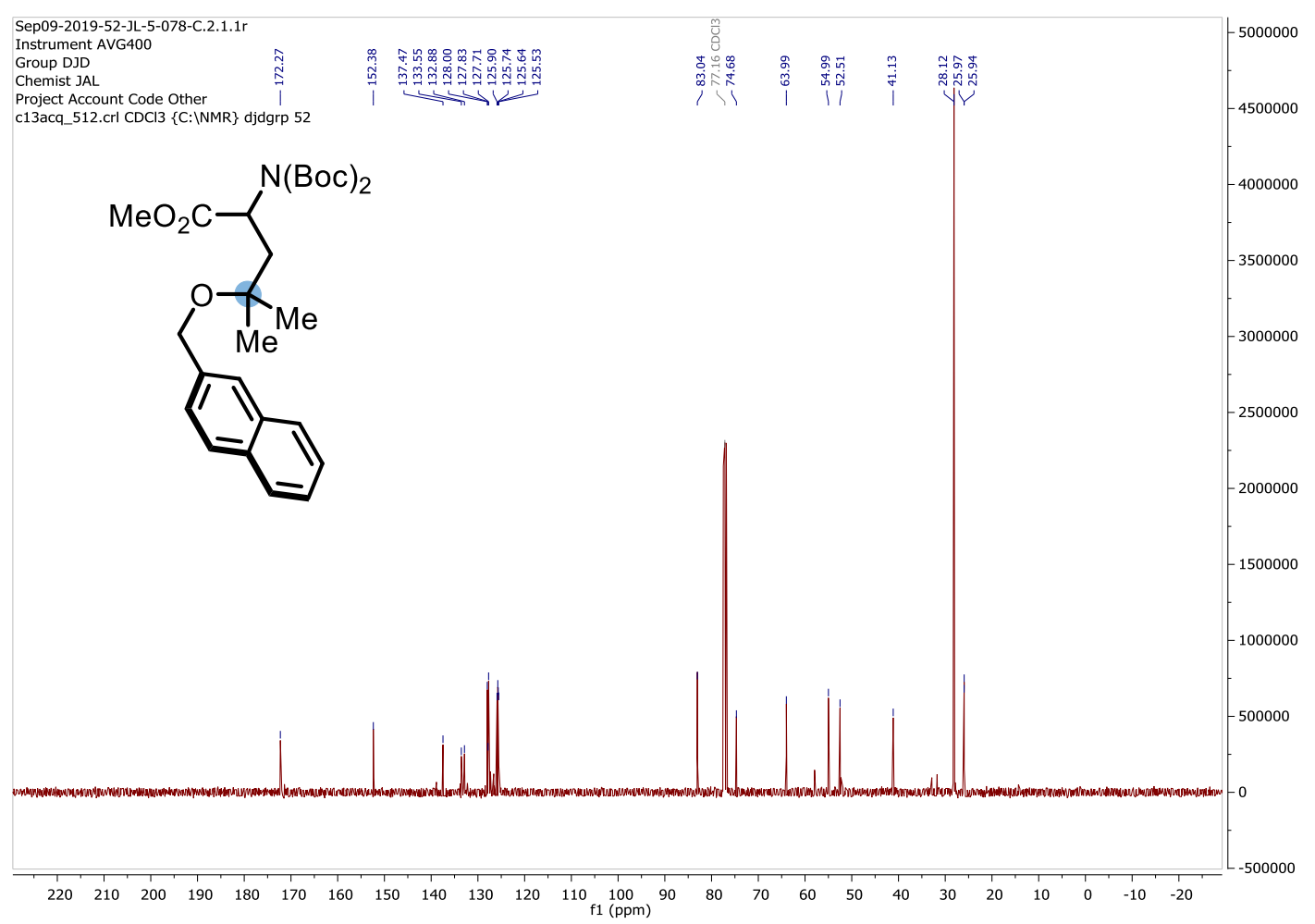


4h $-{ }^{1} \mathrm{H}$ NMR $\left(400 \mathrm{MHz}, \mathrm{CDCl}_{3}\right)$

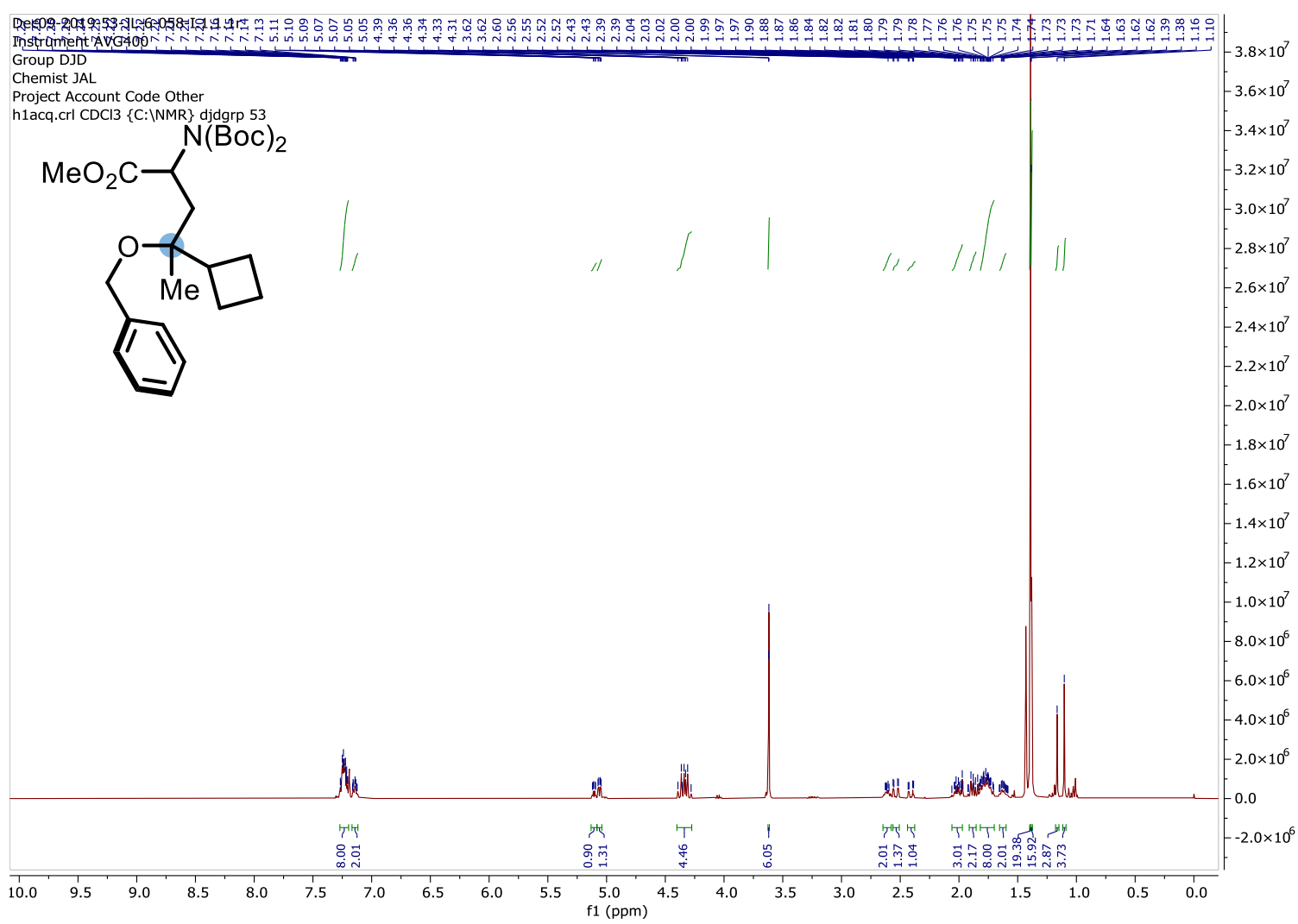

4h $-{ }^{13} \mathrm{C}$ NMR $\left(101 \mathrm{MHz}, \mathrm{CDCl}_{3}\right)$

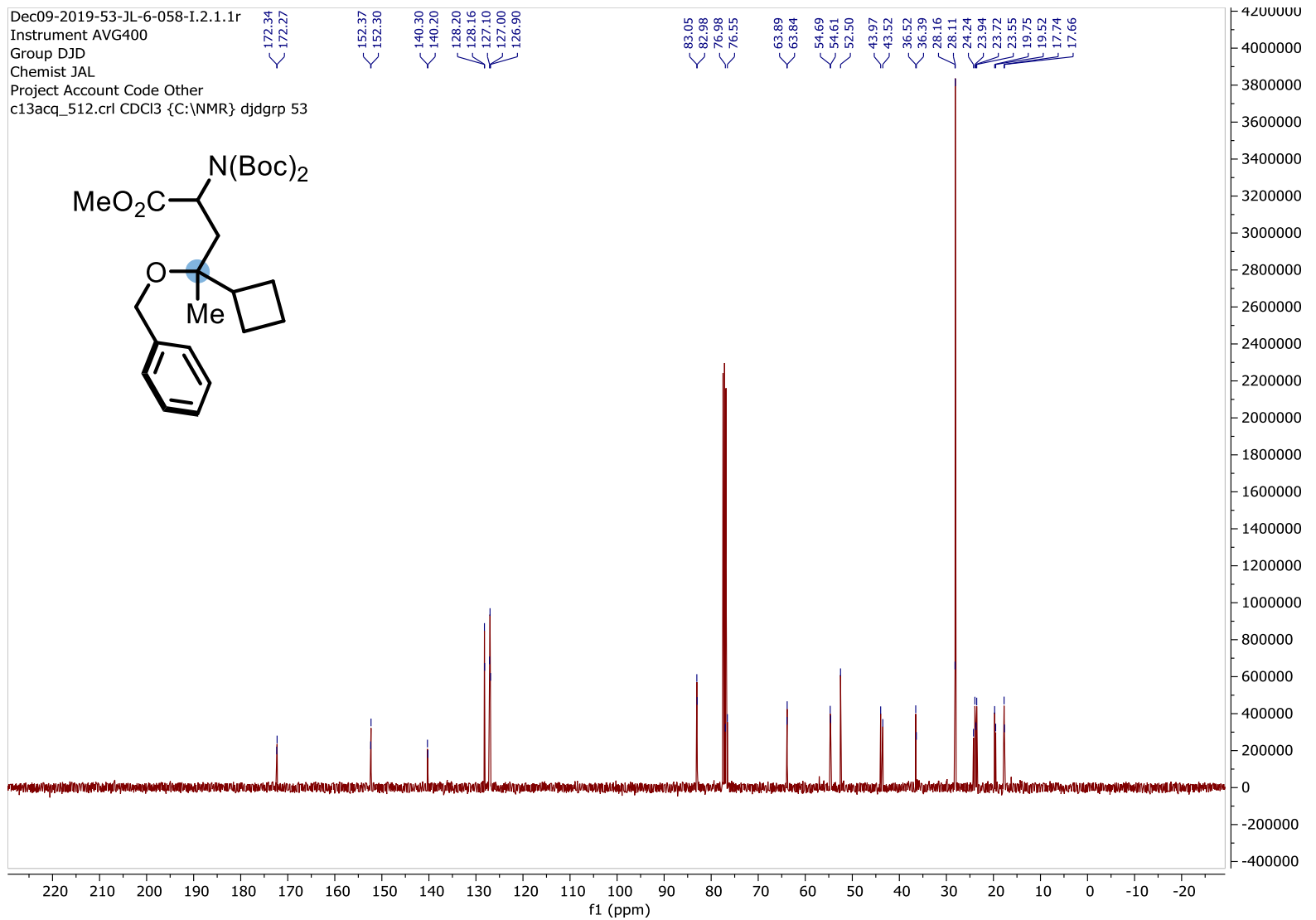


$4 \mathbf{i}-{ }^{1} \mathrm{H}$ NMR $\left(400 \mathrm{MHz}, \mathrm{CDCl}_{3}\right)$

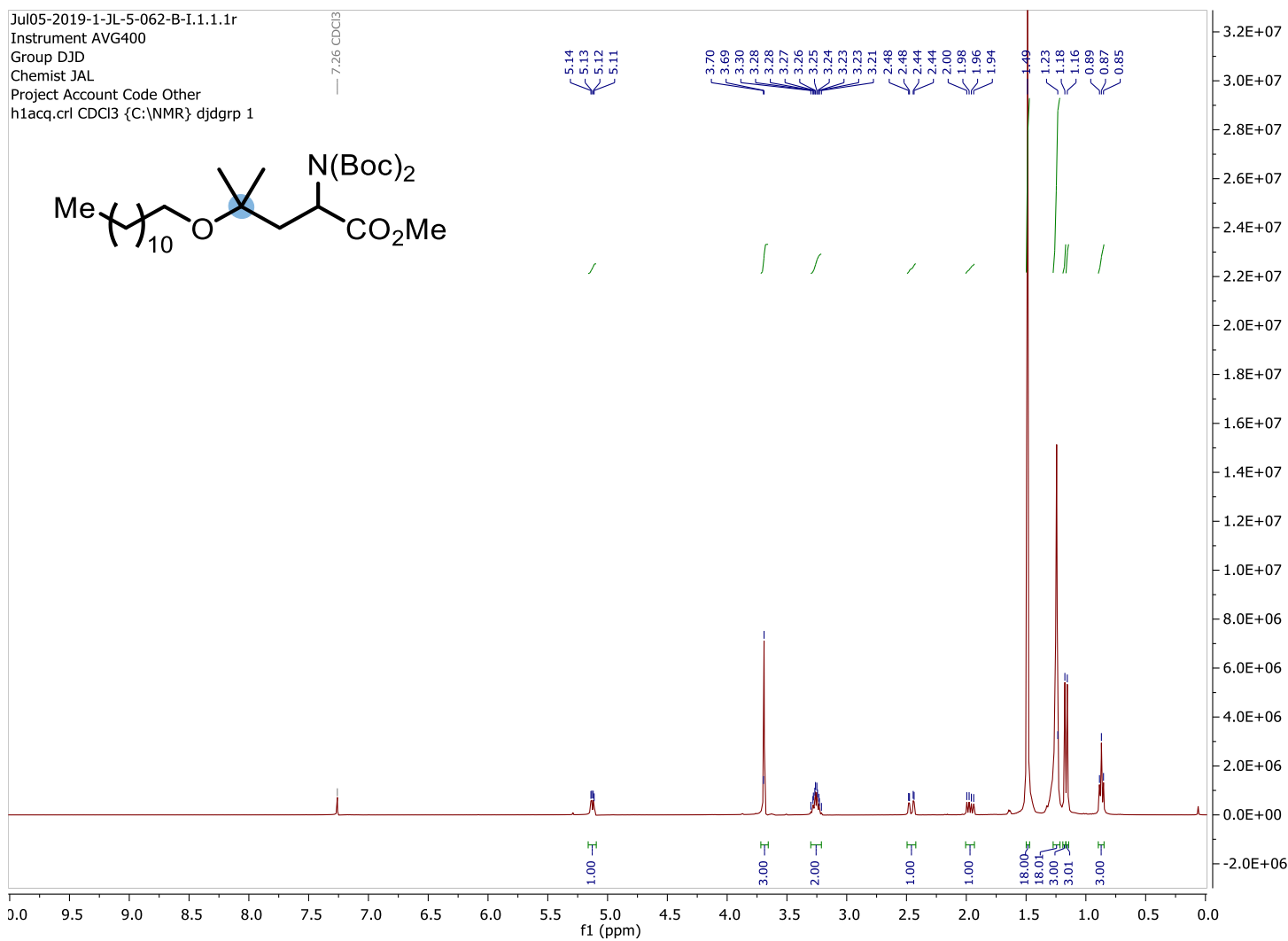

$4 \mathbf{i}-{ }^{13} \mathrm{C}$ NMR $\left(101 \mathrm{MHz}, \mathrm{CDCl}_{3}\right)$

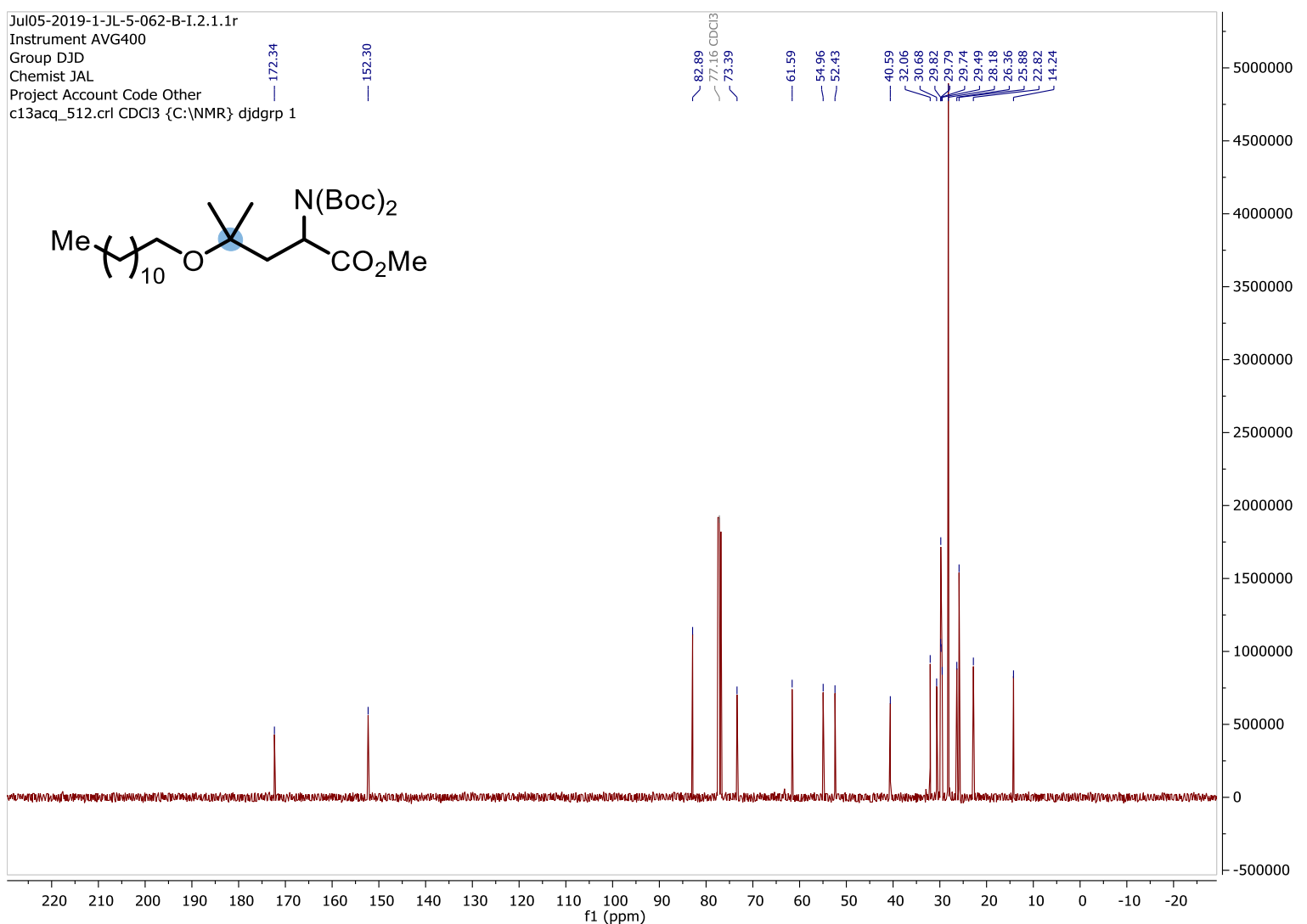


4j- ${ }^{1} \mathrm{H}$ NMR $\left(400 \mathrm{MHz}, \mathrm{CDCl}_{3}\right)$

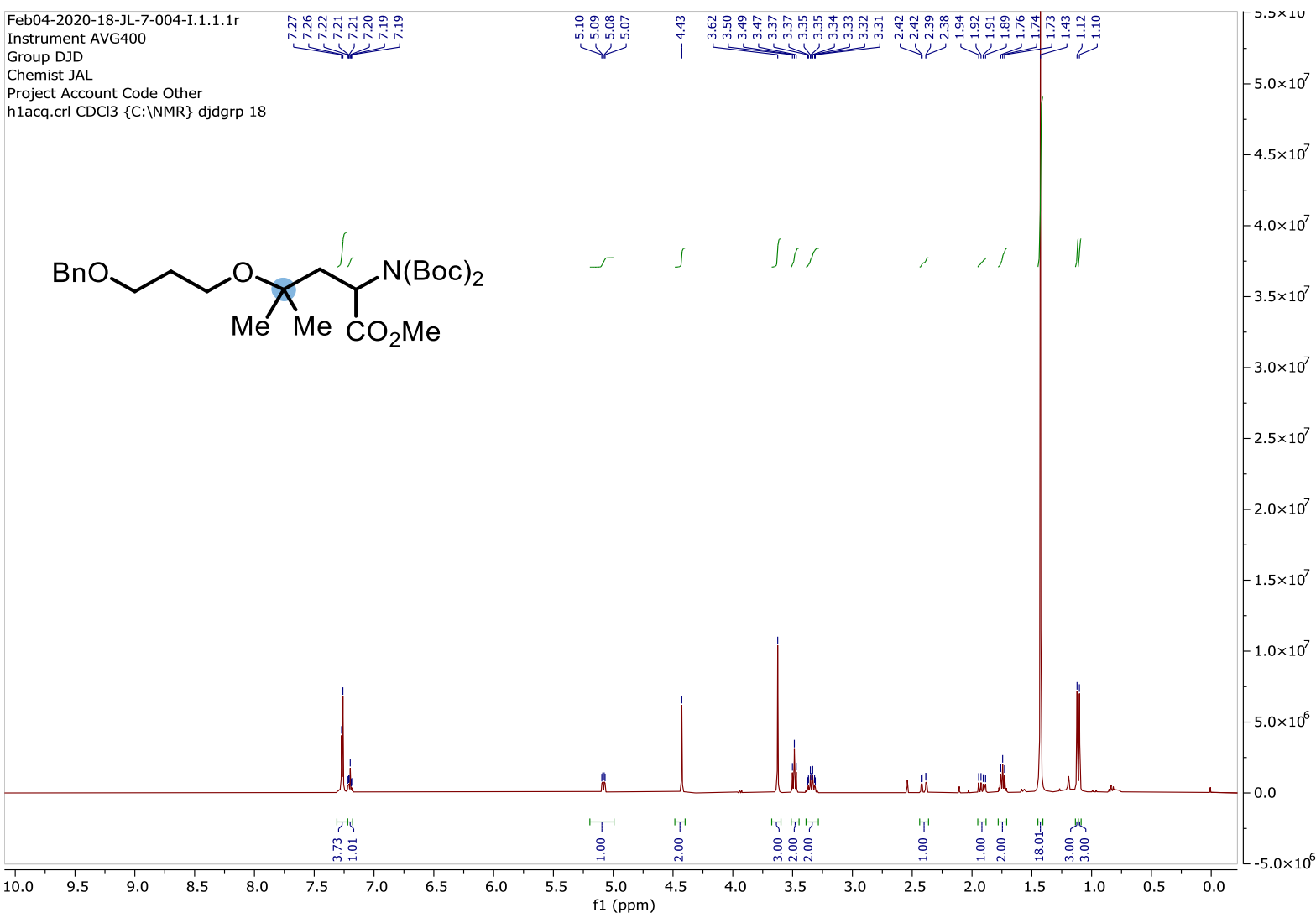

$4 \mathbf{j}-{ }^{13} \mathrm{C}$ NMR $\left(101 \mathrm{MHz}, \mathrm{CDCl}_{3}\right)$

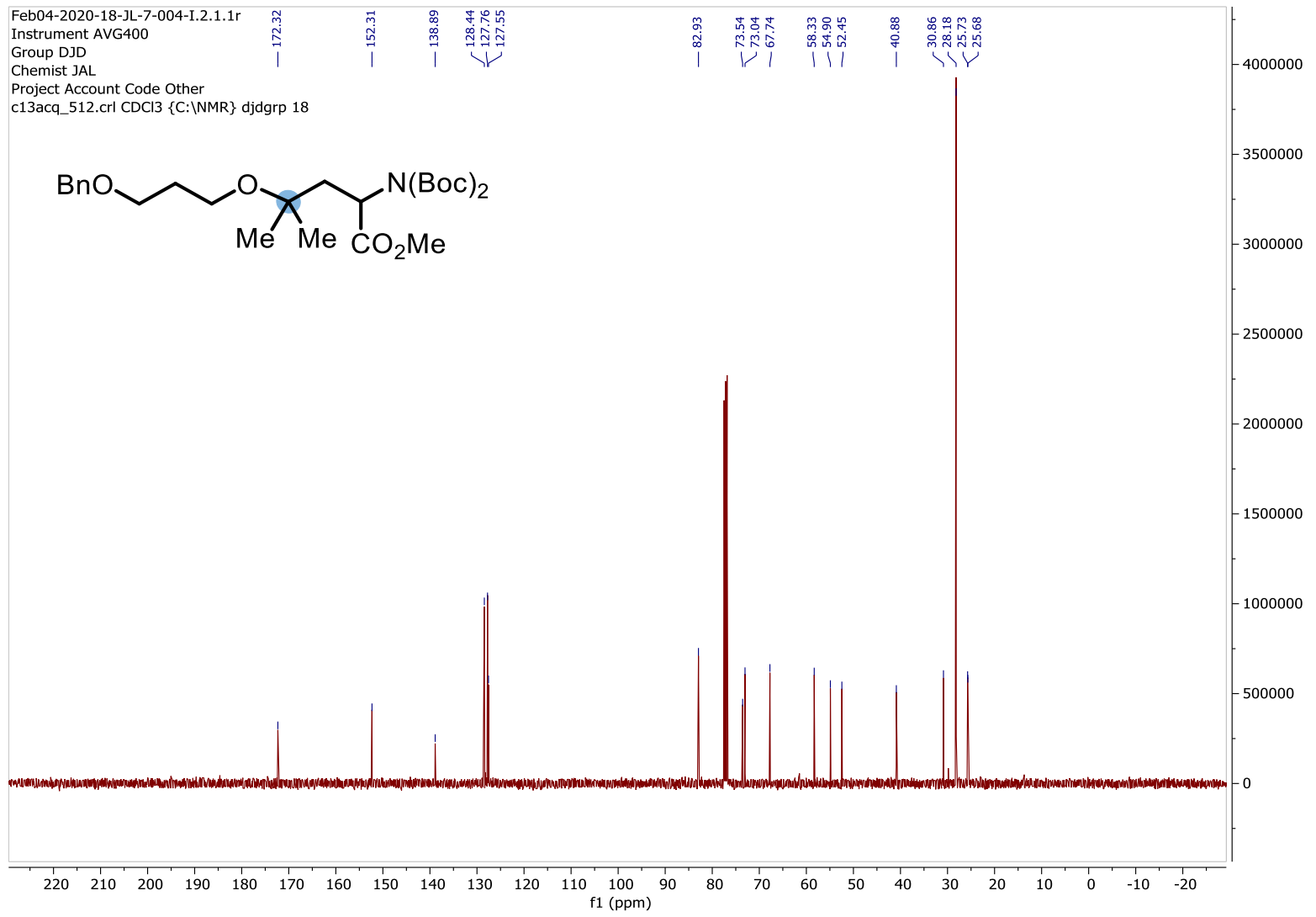


4k $-{ }^{1} \mathrm{H}$ NMR $\left(400 \mathrm{MHz}, \mathrm{CDCl}_{3}, 373 \mathrm{~K}\right)$

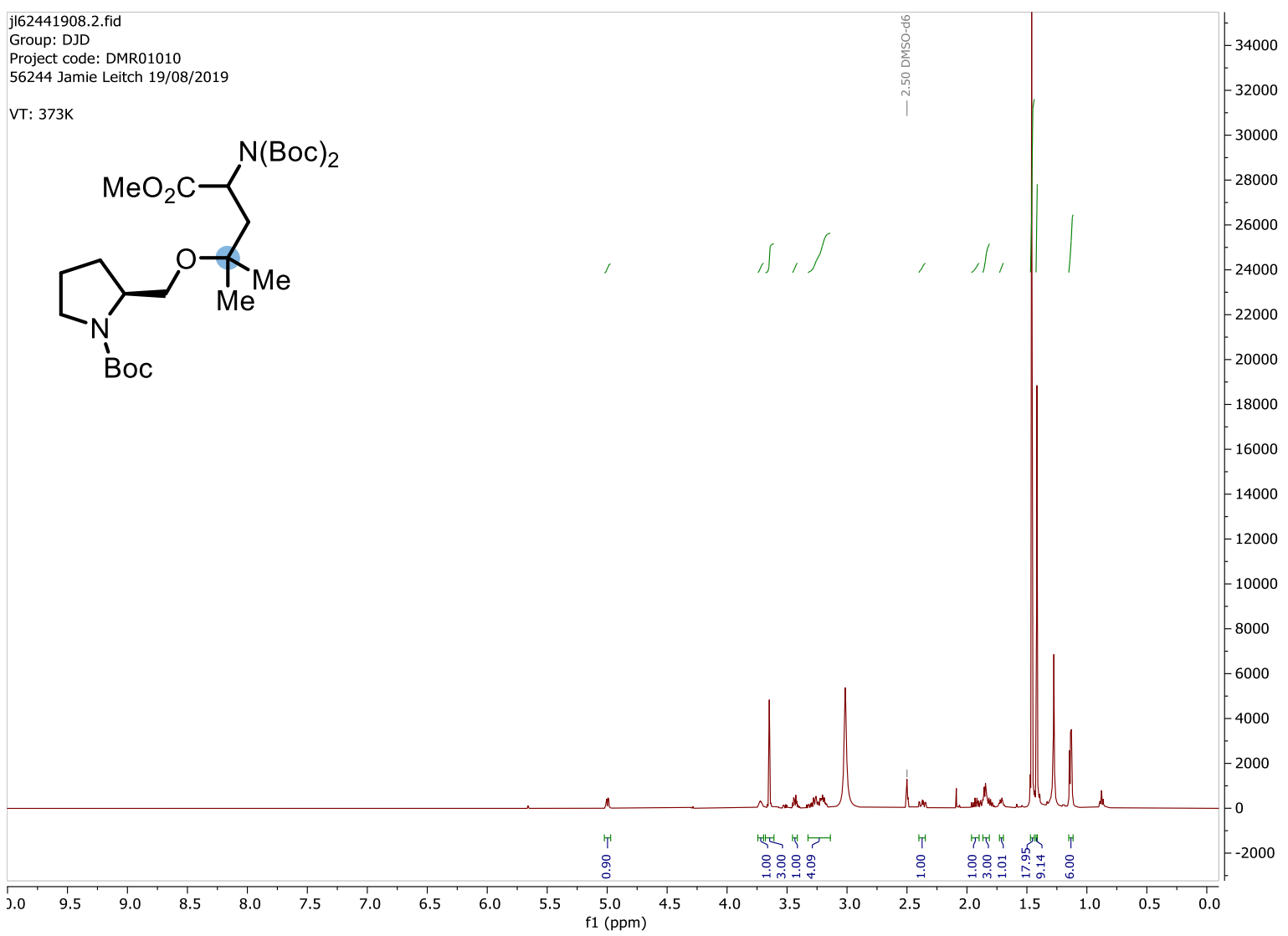

4k $-{ }^{13} \mathrm{C}$ NMR $\left(101 \mathrm{MHz}, \mathrm{CDCl}_{3}, 373 \mathrm{~K}\right)$

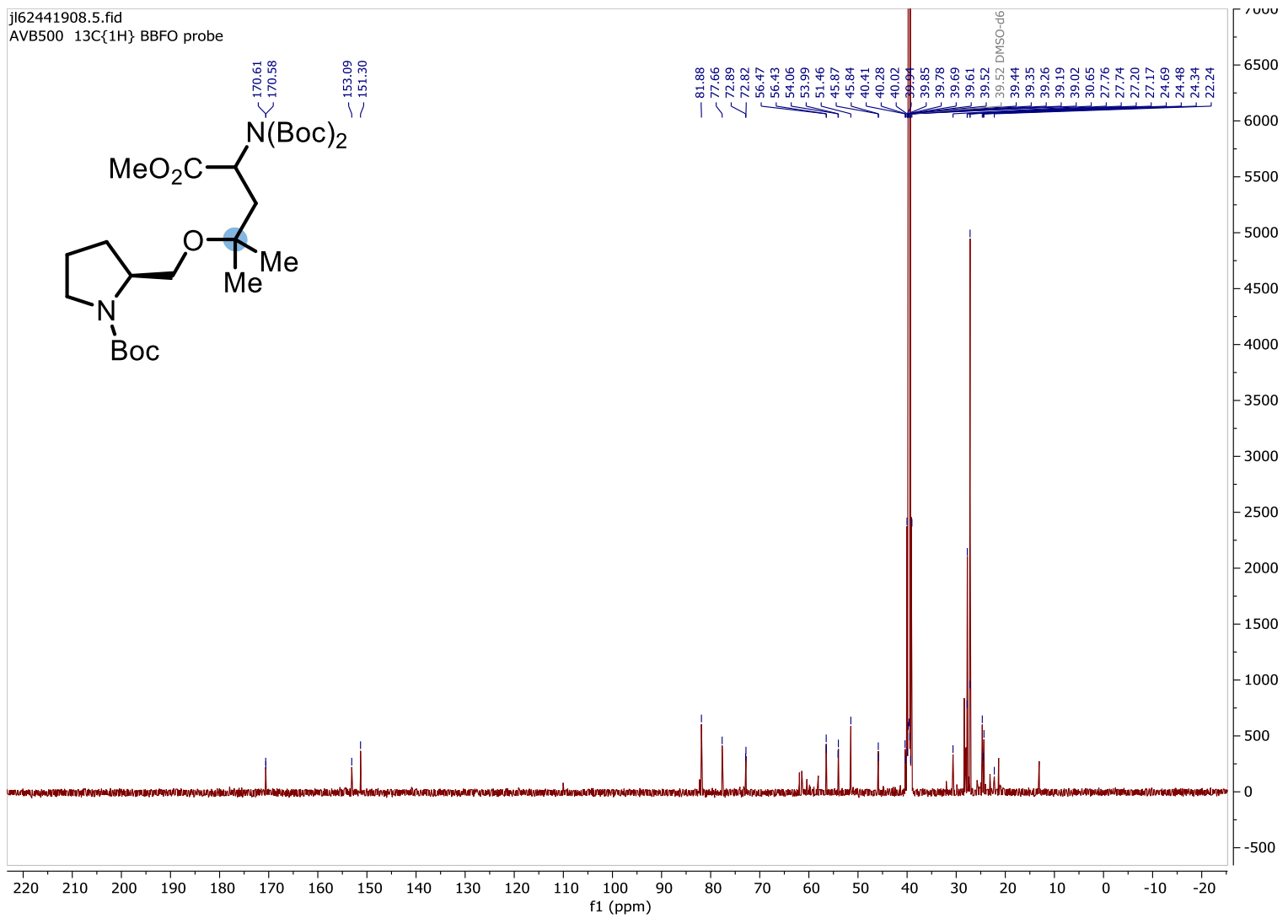


$41-{ }^{1} \mathrm{H}$ NMR $\left(400 \mathrm{MHz}, \mathrm{CDCl}_{3}\right)$

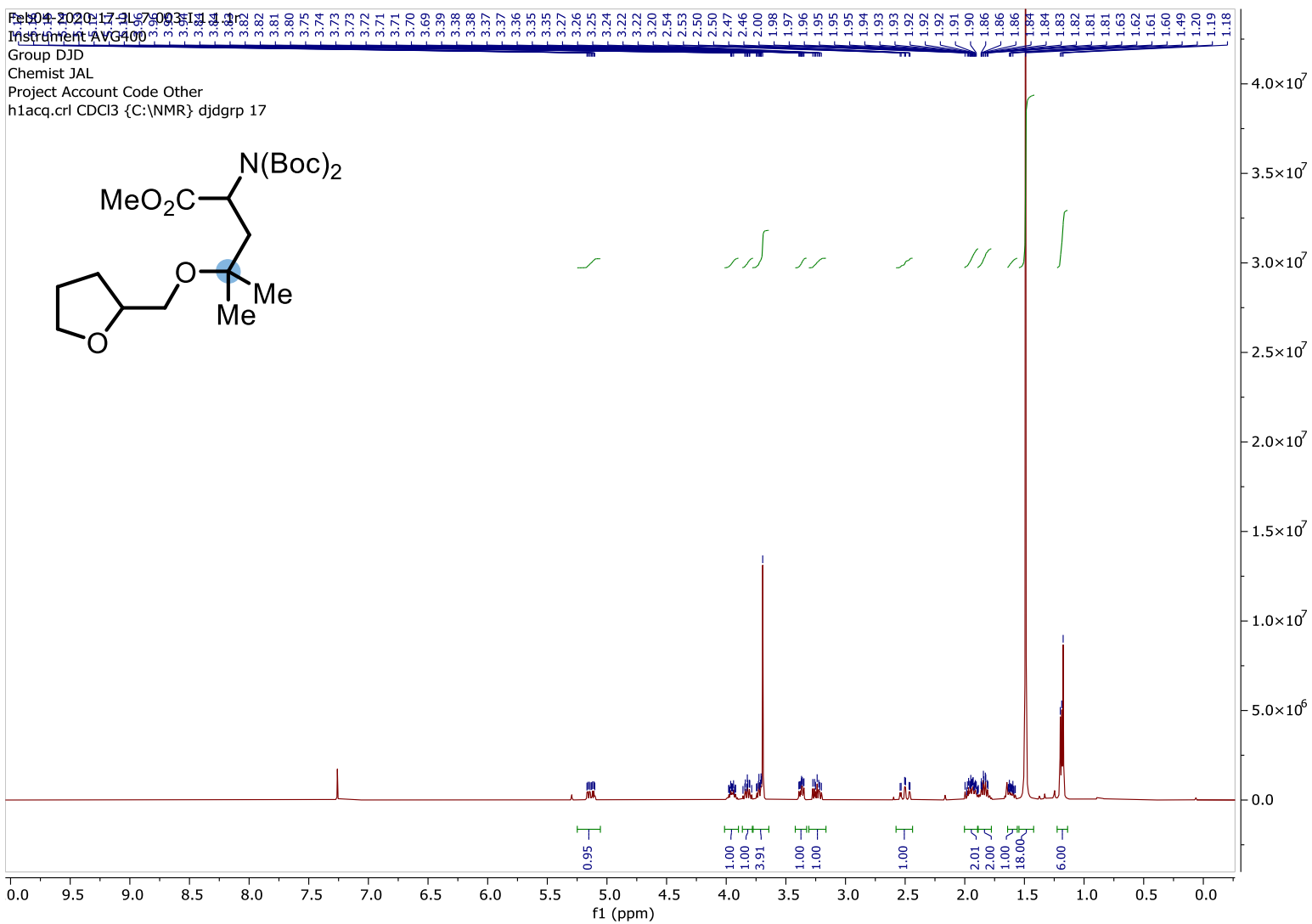

$41-{ }^{13} \mathrm{C}$ NMR (101 MHz, $\left.\mathrm{CDCl}_{3}\right)$

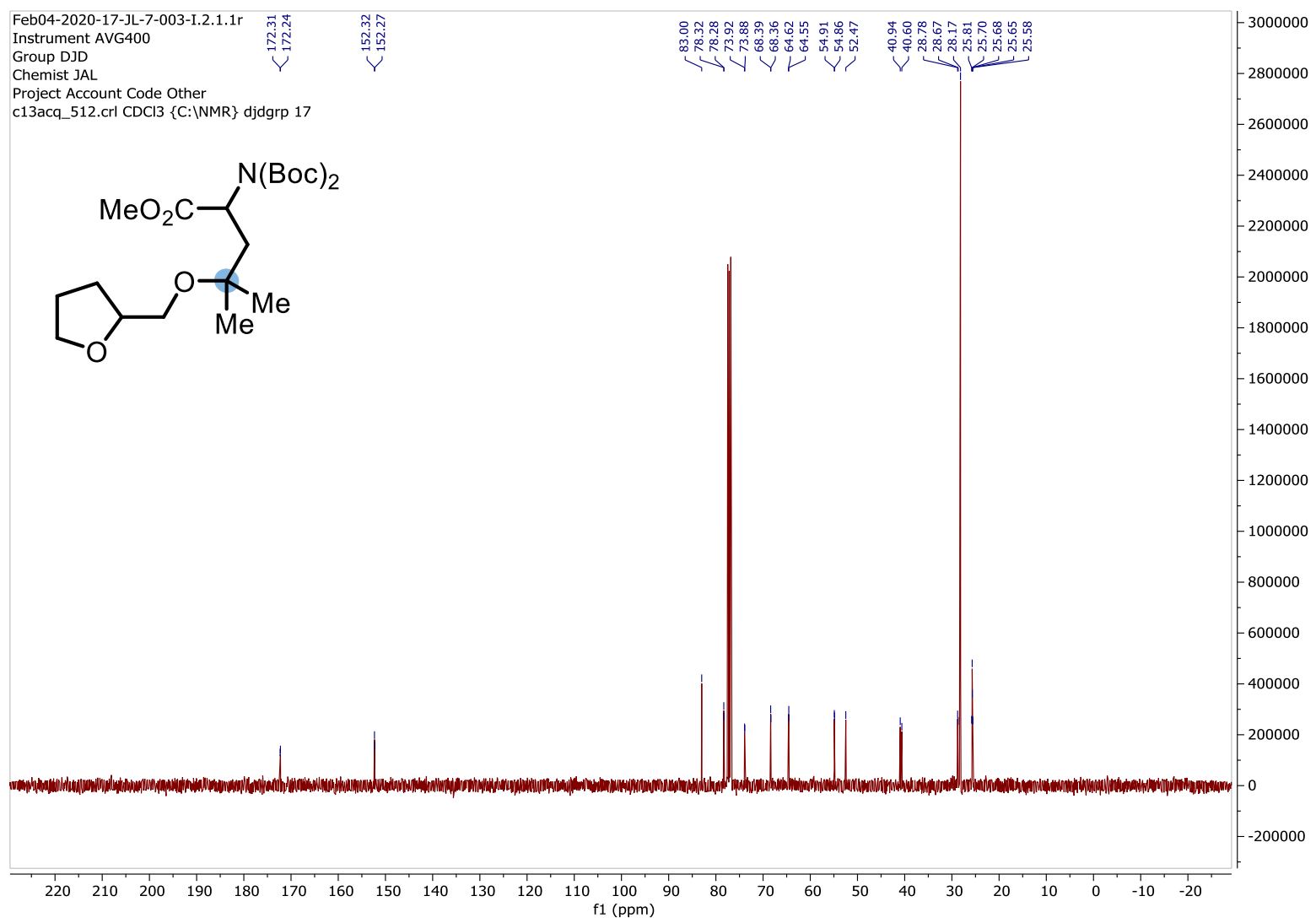


4m $-{ }^{1} \mathrm{H}$ NMR $\left(400 \mathrm{MHz}, \mathrm{CDCl}_{3}\right)$

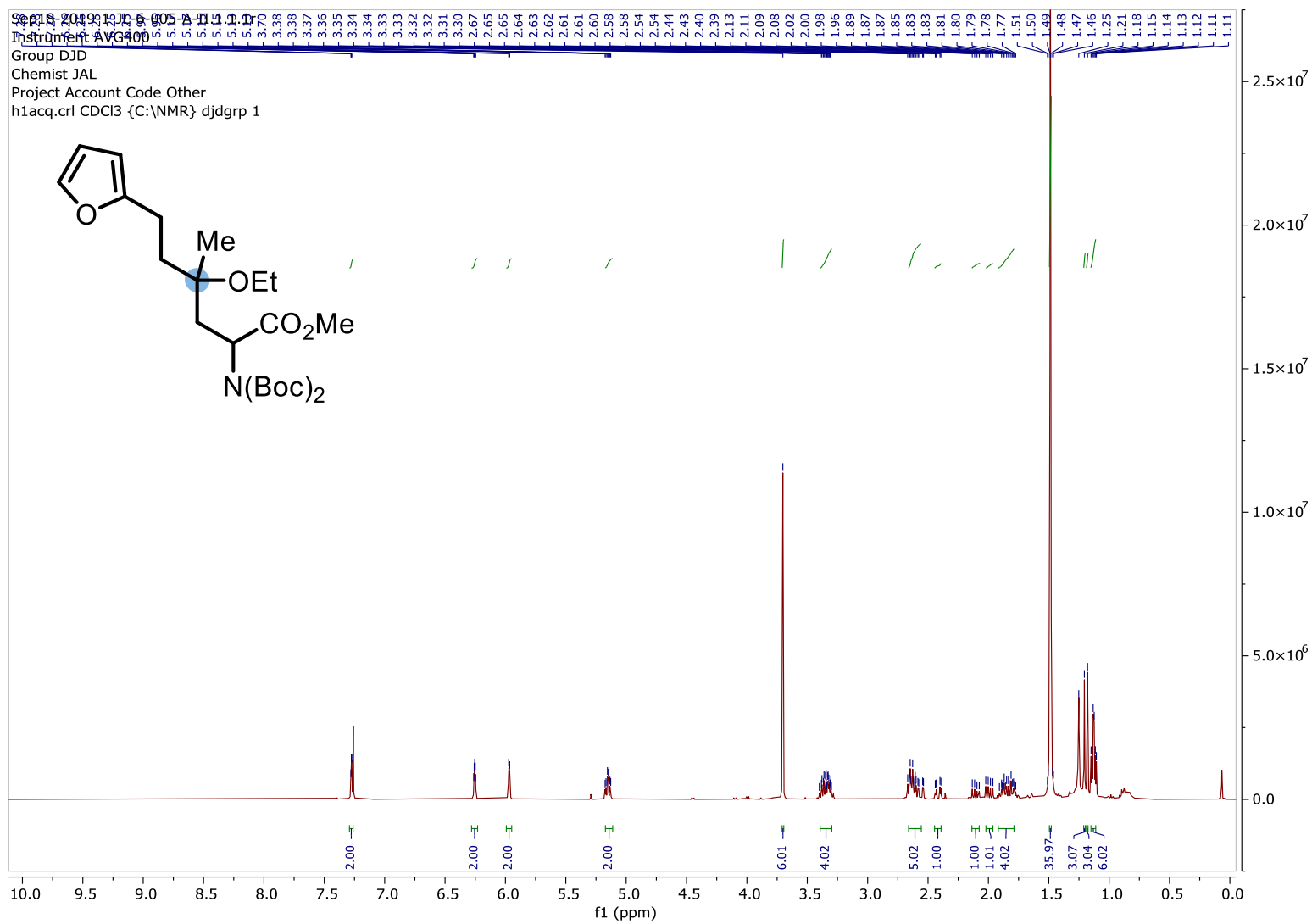

4m $-{ }^{13} \mathrm{C}$ NMR $\left(101 \mathrm{MHz}, \mathrm{CDCl}_{3}\right)$

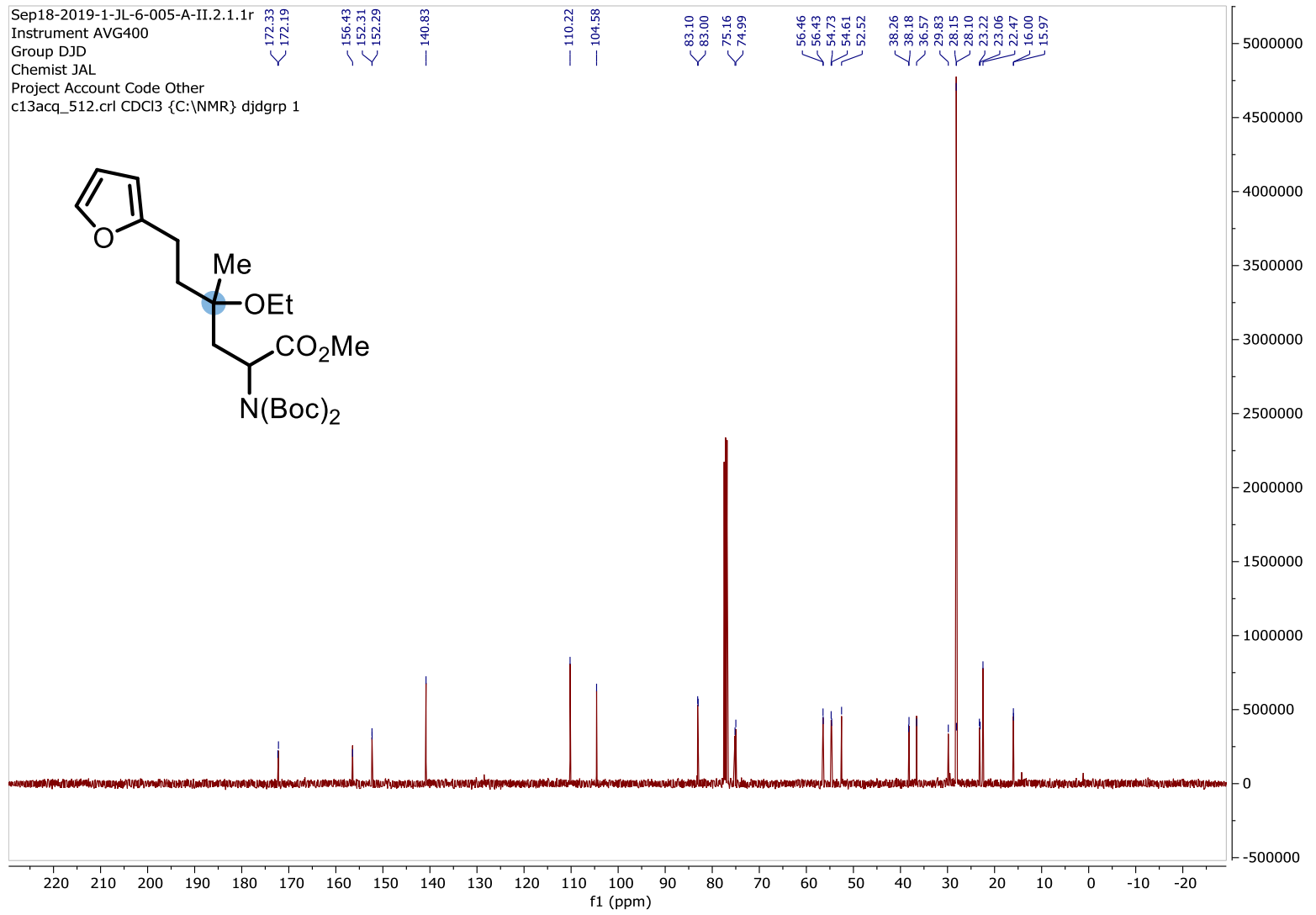


4n $-{ }^{1} \mathrm{H}$ NMR $\left(400 \mathrm{MHz}, \mathrm{CDCl}_{3}\right)$

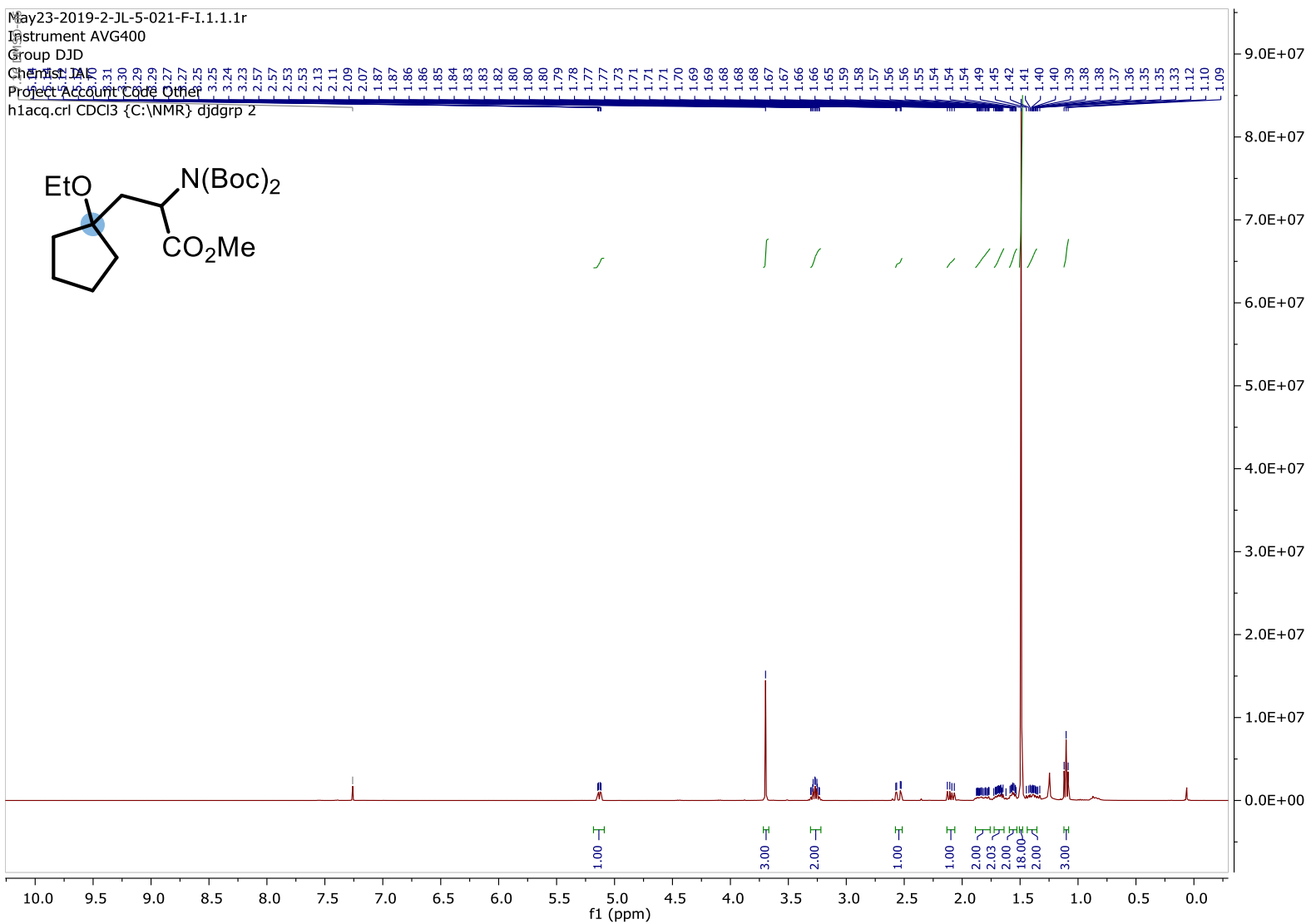

4n $-{ }^{13} \mathrm{C}$ NMR $\left(101 \mathrm{MHz}, \mathrm{CDCl}_{3}\right)$

May23-2019-2-JL-5-021-F-I.2.1.1 Instrument AVG400

Group DJD

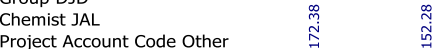

c13acq_512.crl CDCl3 \{C:|NMR\} djdgr|p 2
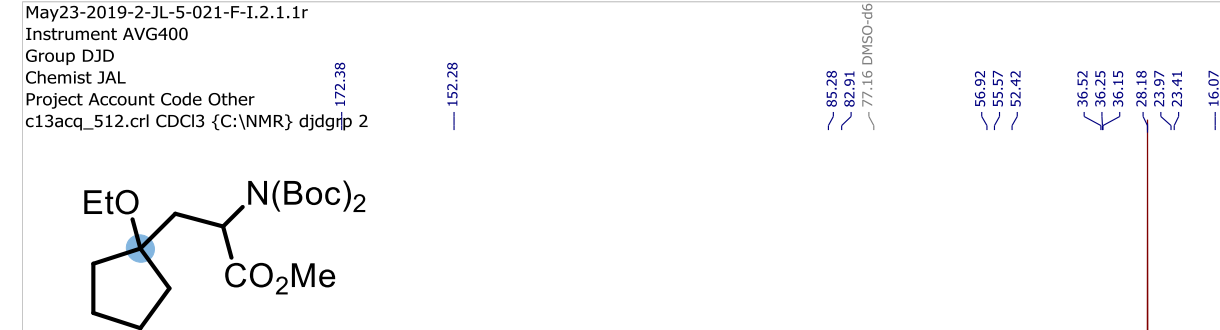

6500000

6000000

5500000

5000000

4500000

4000000

3500000

3000000

2500000

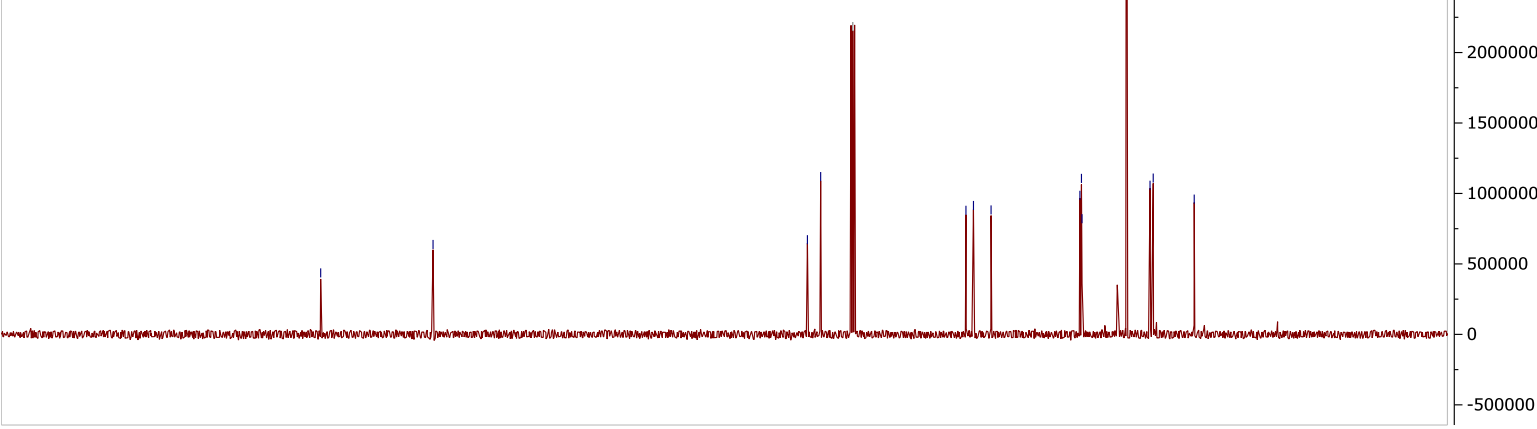

$\begin{array}{lllllllllllllllllllllllllllllllllllllll}220 & 210 & 200 & 190 & 180 & 170 & 160 & 150 & 140 & 130 & 120 & 110 & 100 & 90 & 80 & 70 & 60 & 50 & 40 & 30 & 20 & 10 & 0 & -10 & -20\end{array}$ 
$4 \mathrm{p}-{ }^{1} \mathrm{H}$ NMR $\left(400 \mathrm{MHz}, \mathrm{CDCl}_{3}\right)$

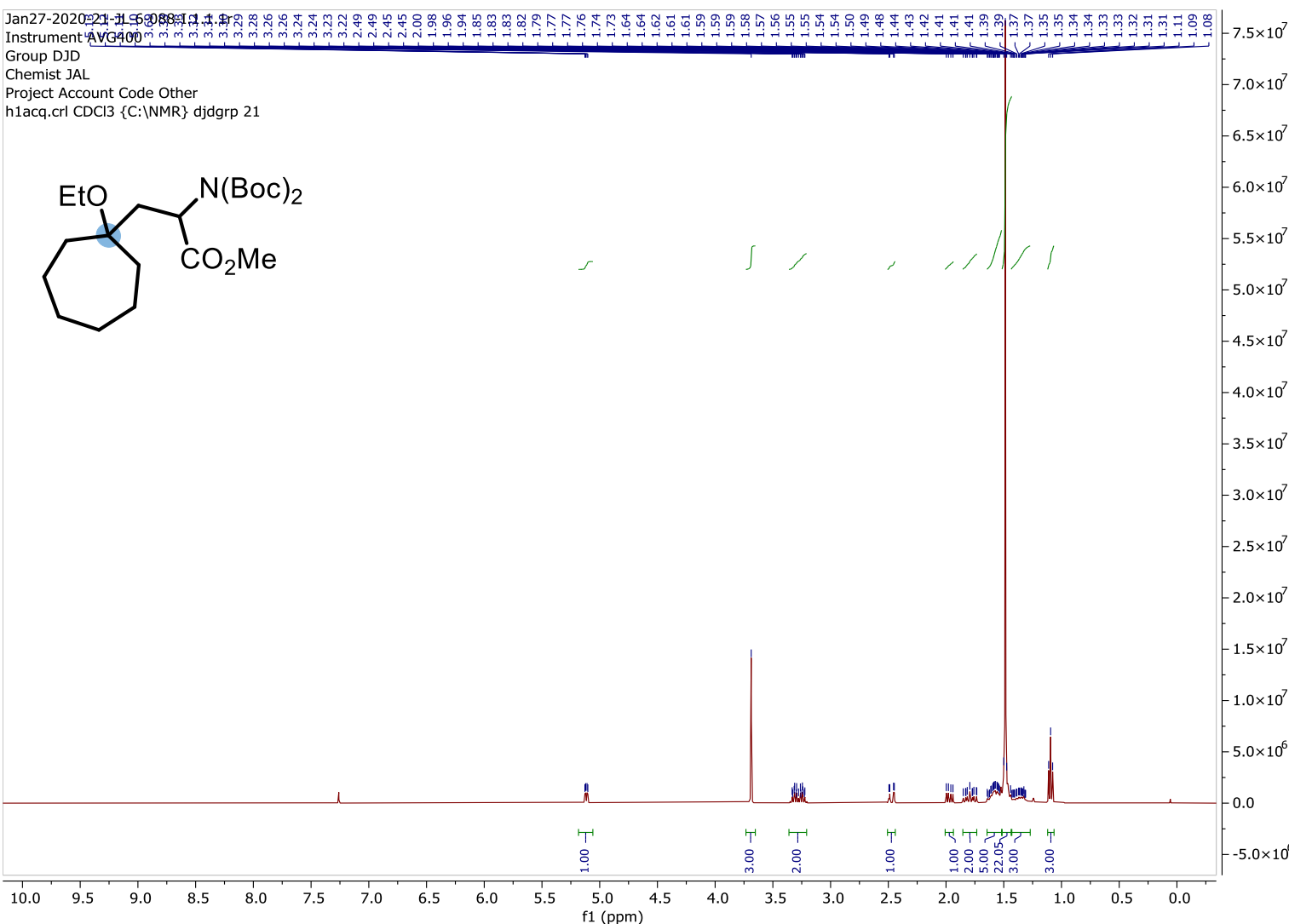

$4 p-{ }^{13} \mathrm{C}$ NMR $\left(101 \mathrm{MHz}, \mathrm{CDCl}_{3}\right)$

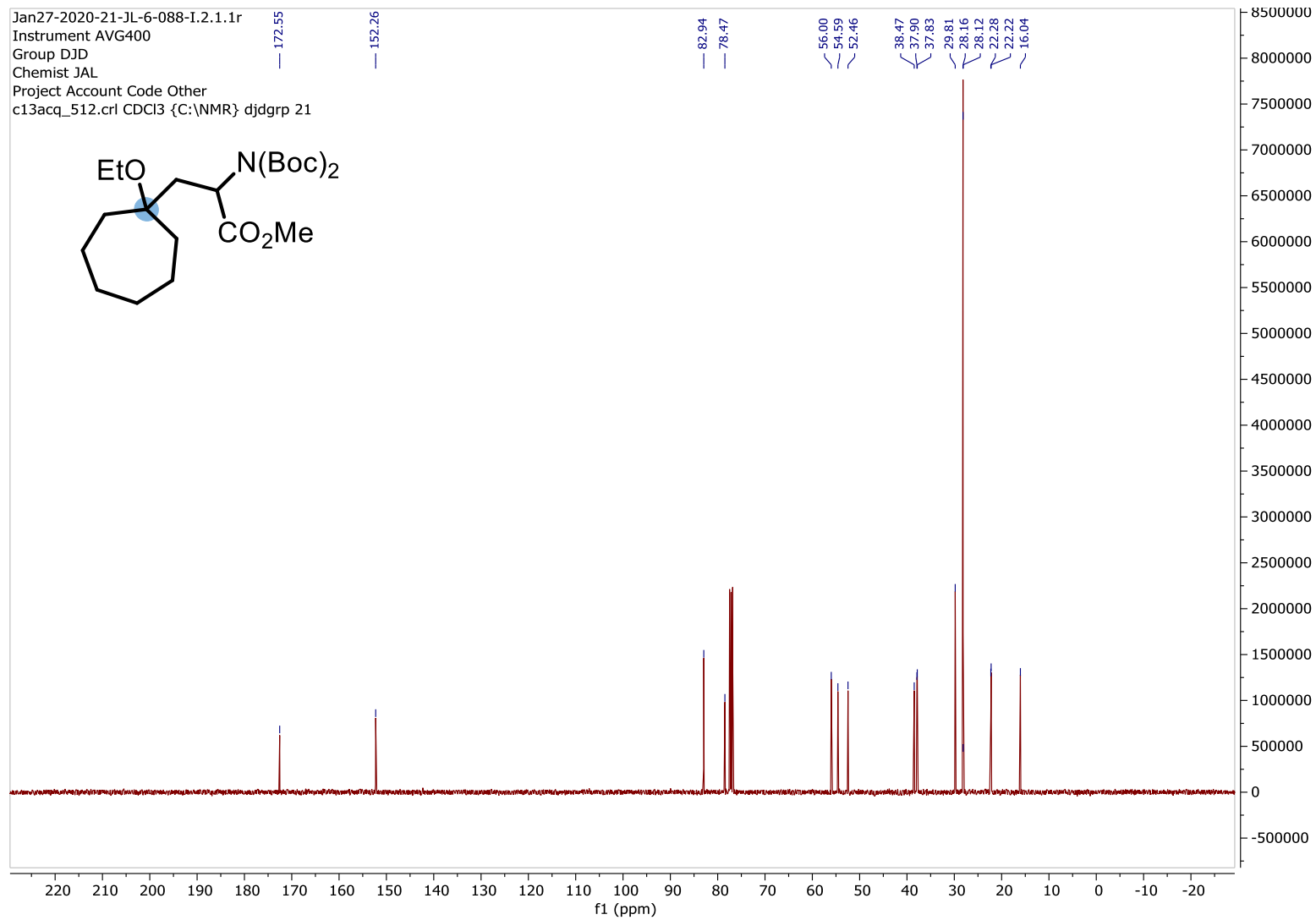


$4 q-{ }^{1} \mathrm{H}$ NMR $\left(400 \mathrm{MHz}, \mathrm{CDCl}_{3}\right)$

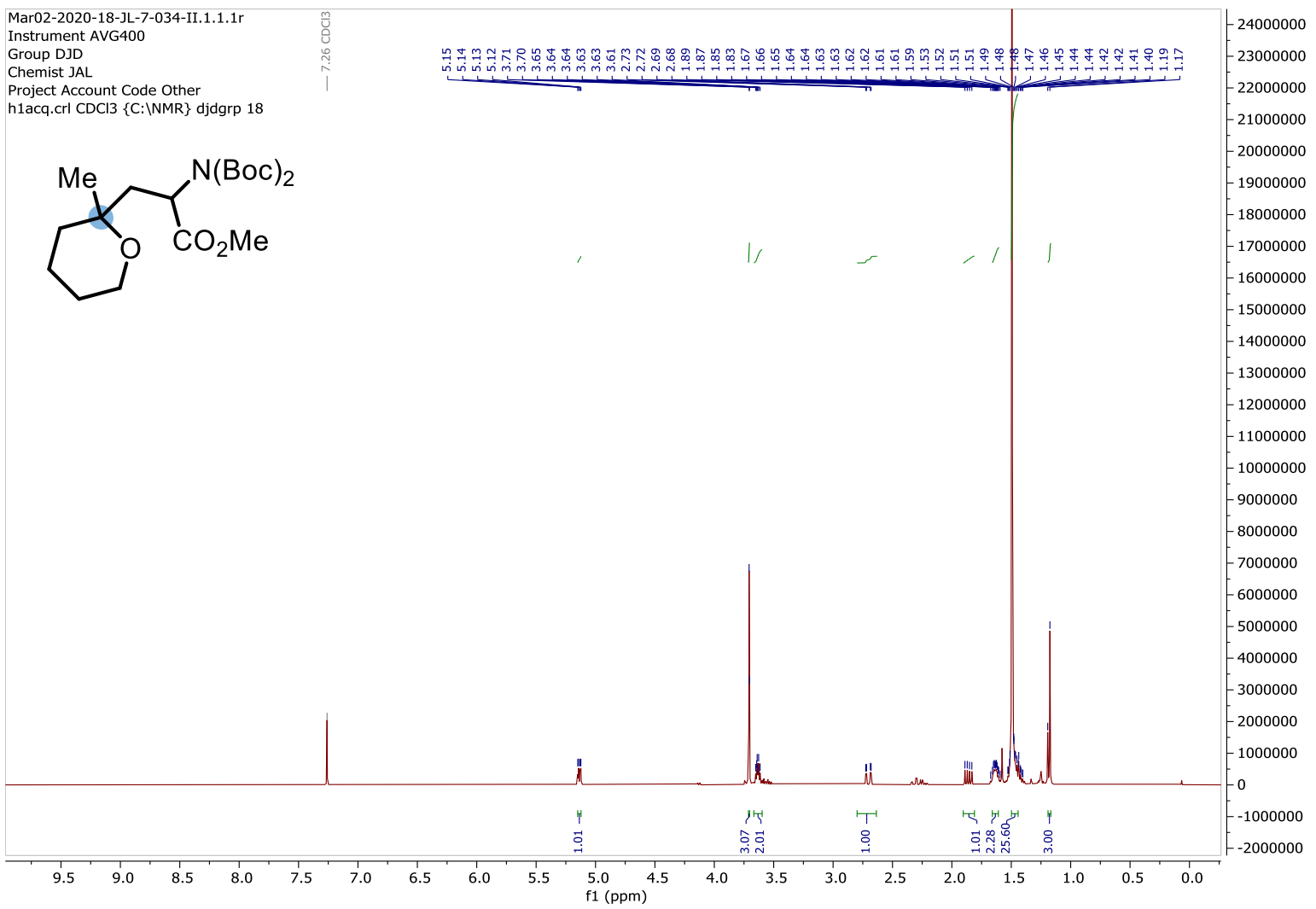

4q $-{ }^{13} \mathrm{C} \mathrm{NMR}\left(101 \mathrm{MHz}, \mathrm{CDCl}_{3}\right)$

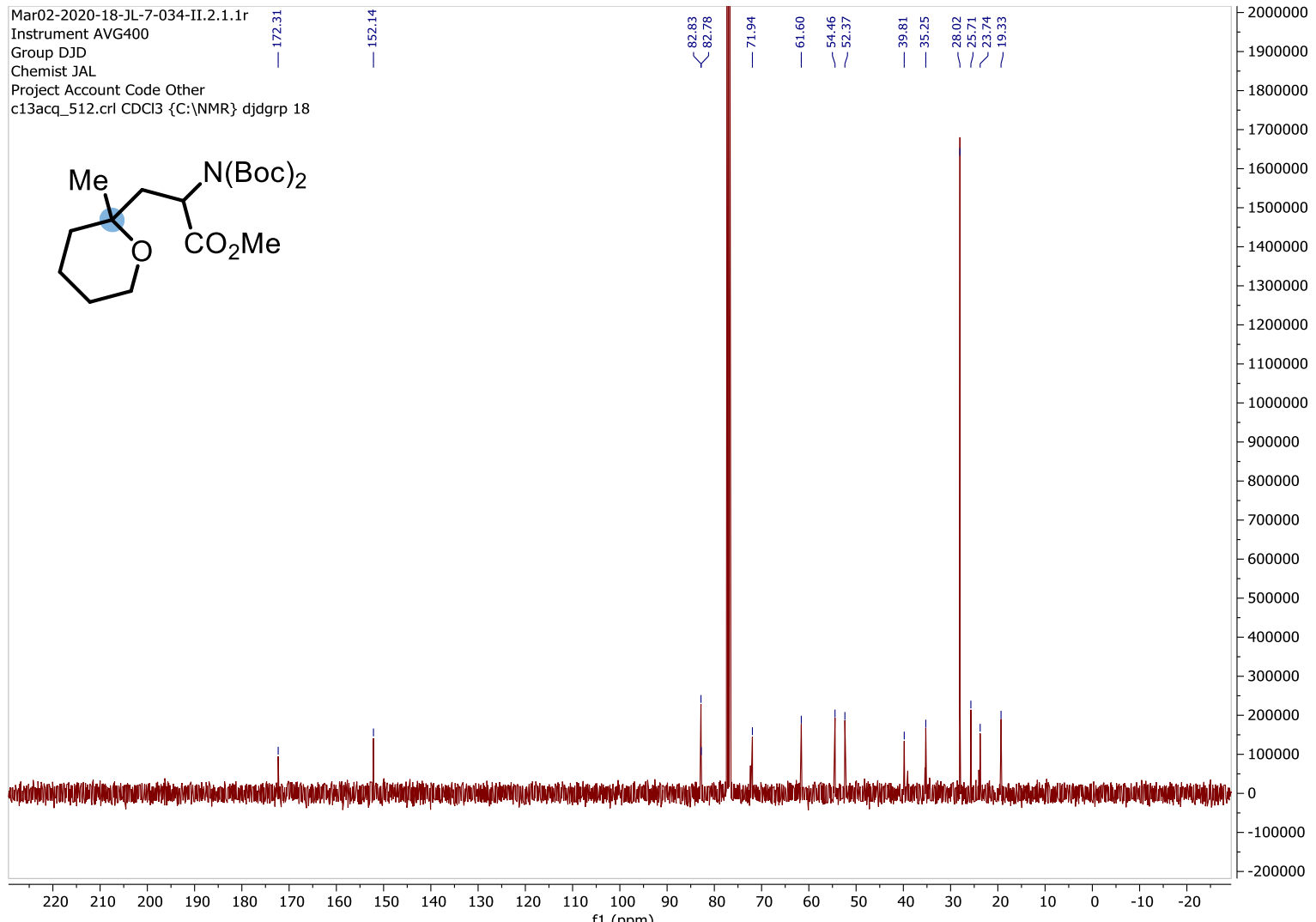


$4 \mathbf{r}-{ }^{1} \mathrm{H}$ NMR $\left(400 \mathrm{MHz}, \mathrm{CDCl}_{3}\right)$

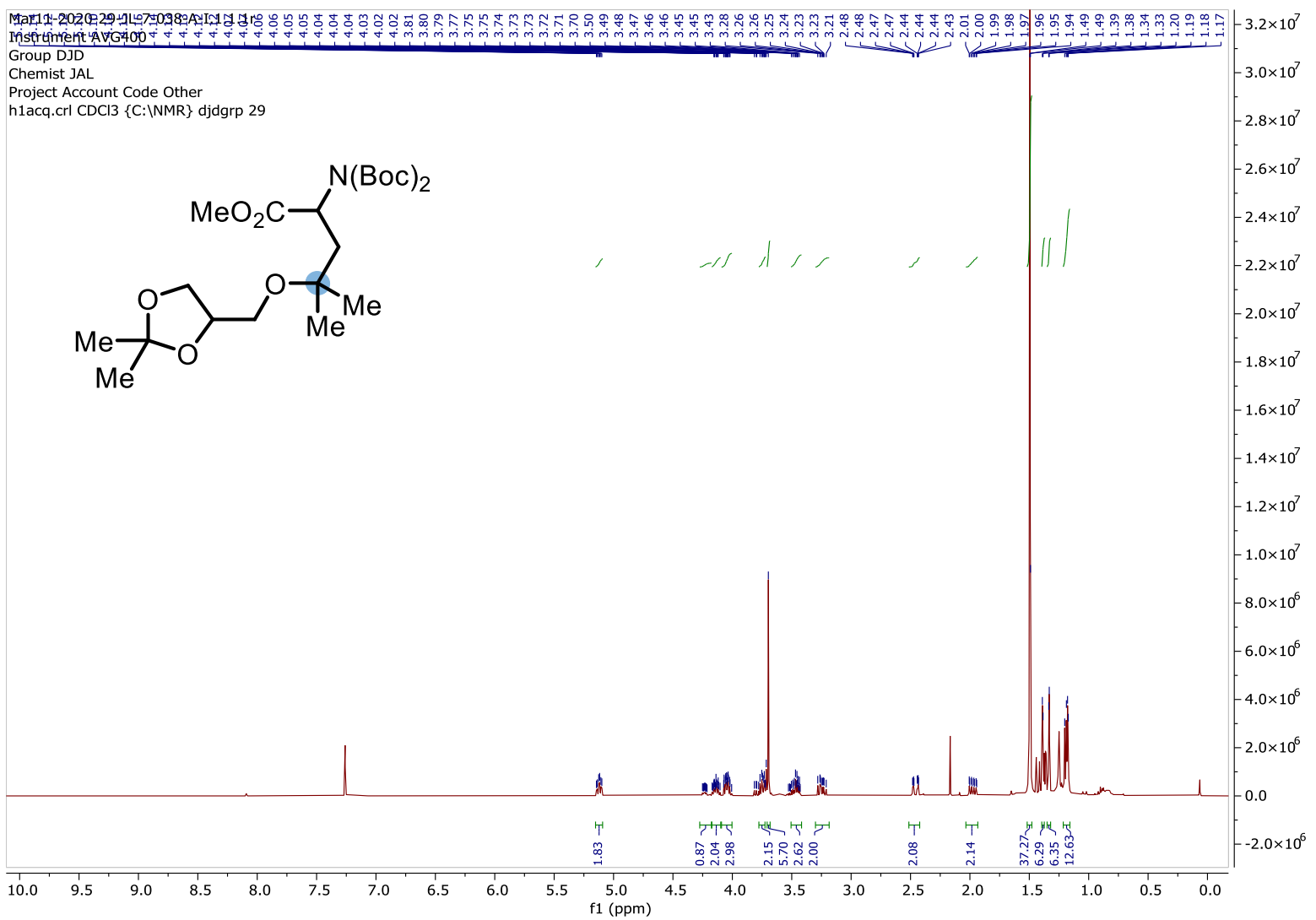

$4 \mathbf{r}-{ }^{13} \mathrm{C} \mathrm{NMR}\left(101 \mathrm{MHz}, \mathrm{CDCl}_{3}\right)$

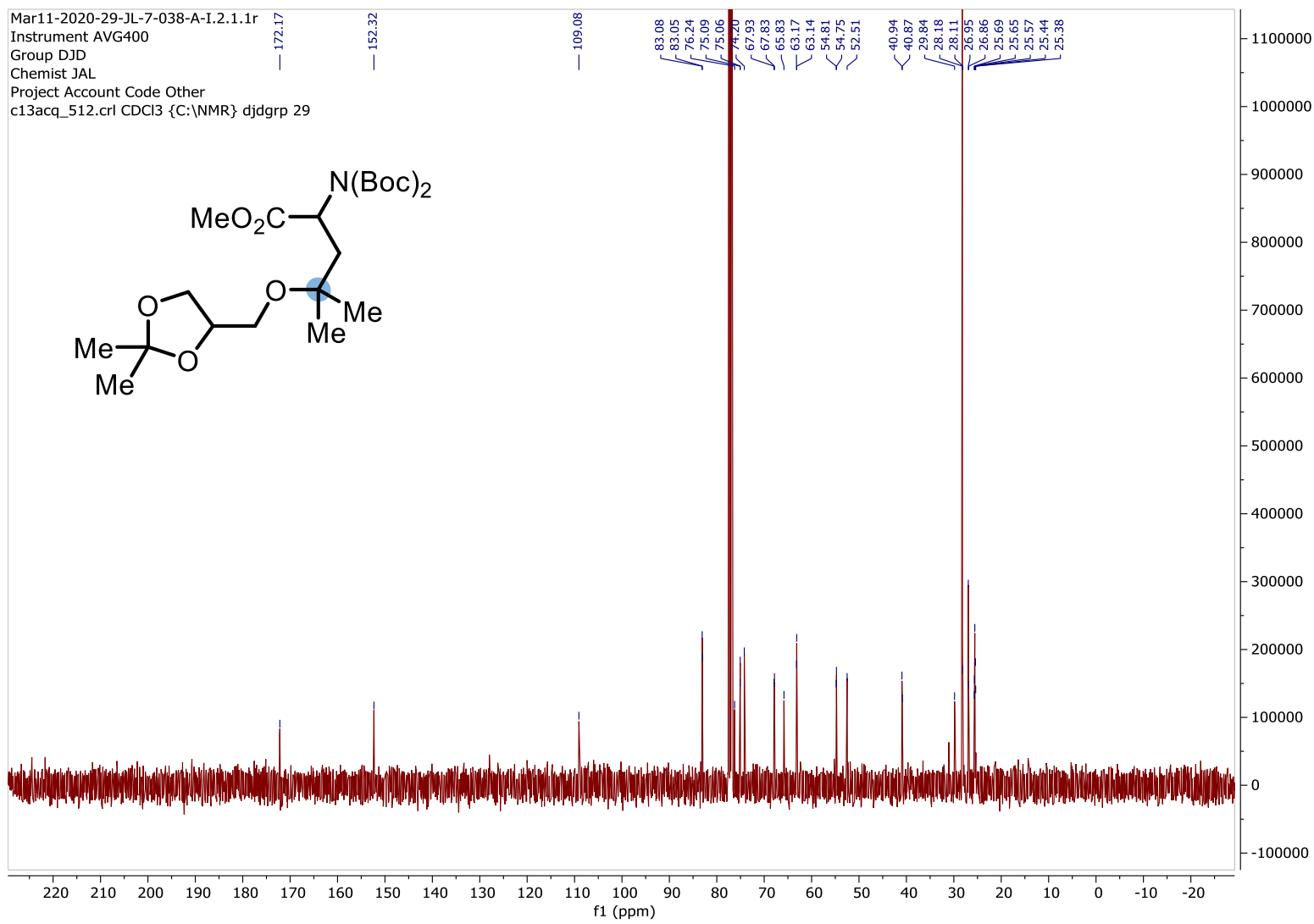


4s $-{ }^{1} \mathrm{H}$ NMR $\left(400 \mathrm{MHz}, \mathrm{CDCl}_{3}\right)$

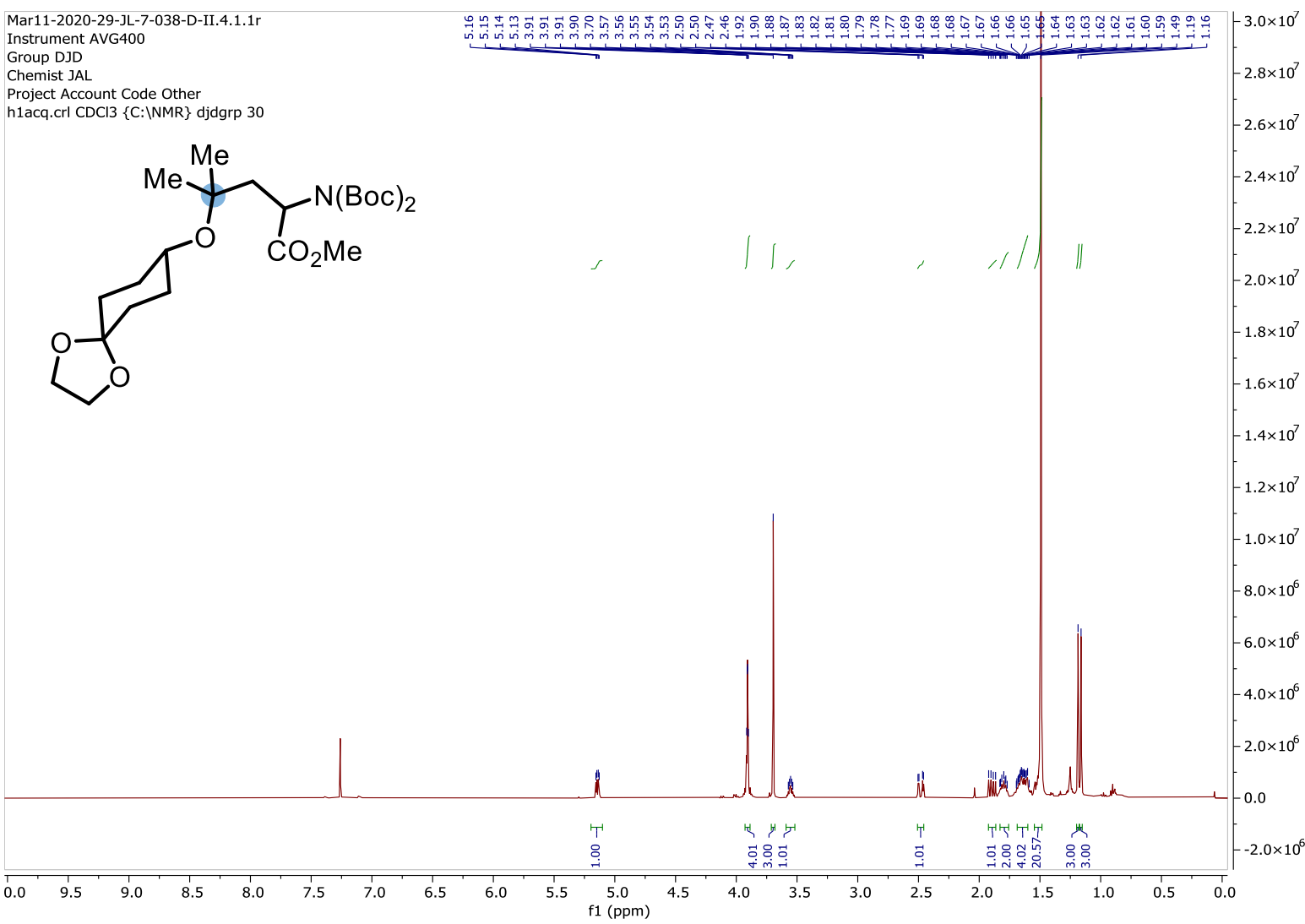

4s $-{ }^{13} \mathrm{C}$ NMR $\left(101 \mathrm{MHz}, \mathrm{CDCl}_{3}\right)$

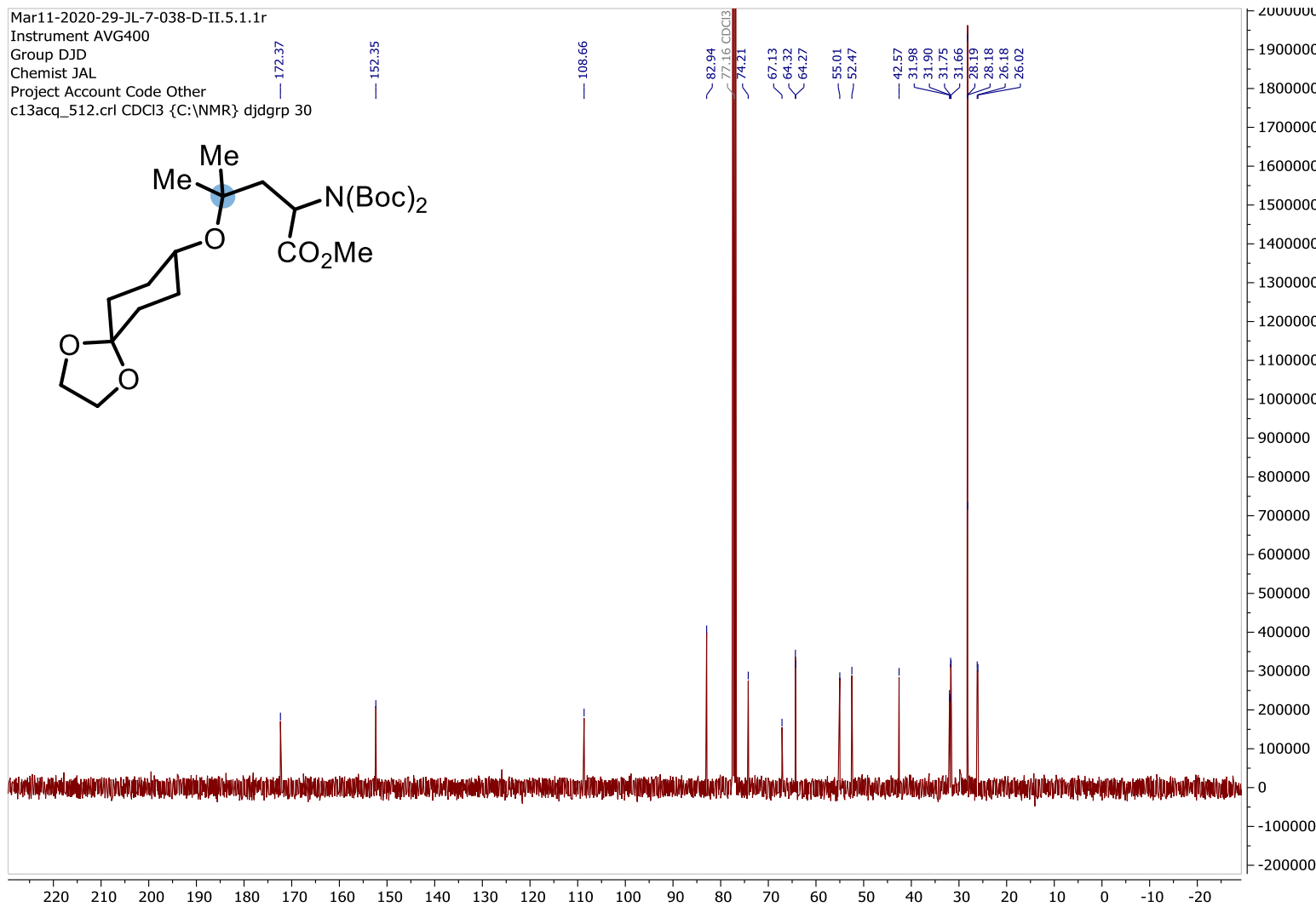


4t $-{ }^{1} \mathrm{H}$ NMR $\left(400 \mathrm{MHz}, \mathrm{CDCl}_{3}\right)$

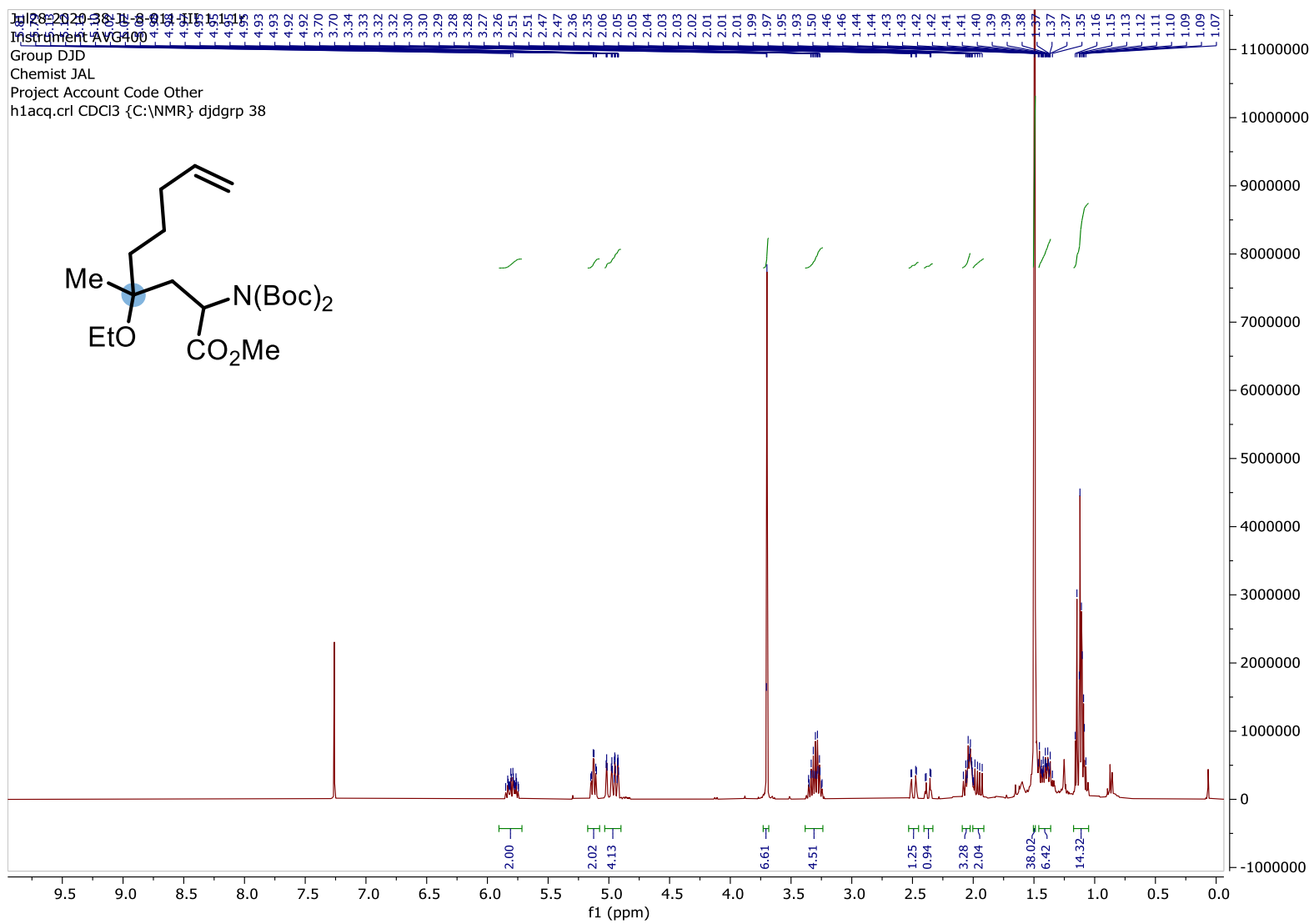

4t $-{ }^{13} \mathrm{C}$ NMR $\left(101 \mathrm{MHz}, \mathrm{CDCl}_{3}\right)$

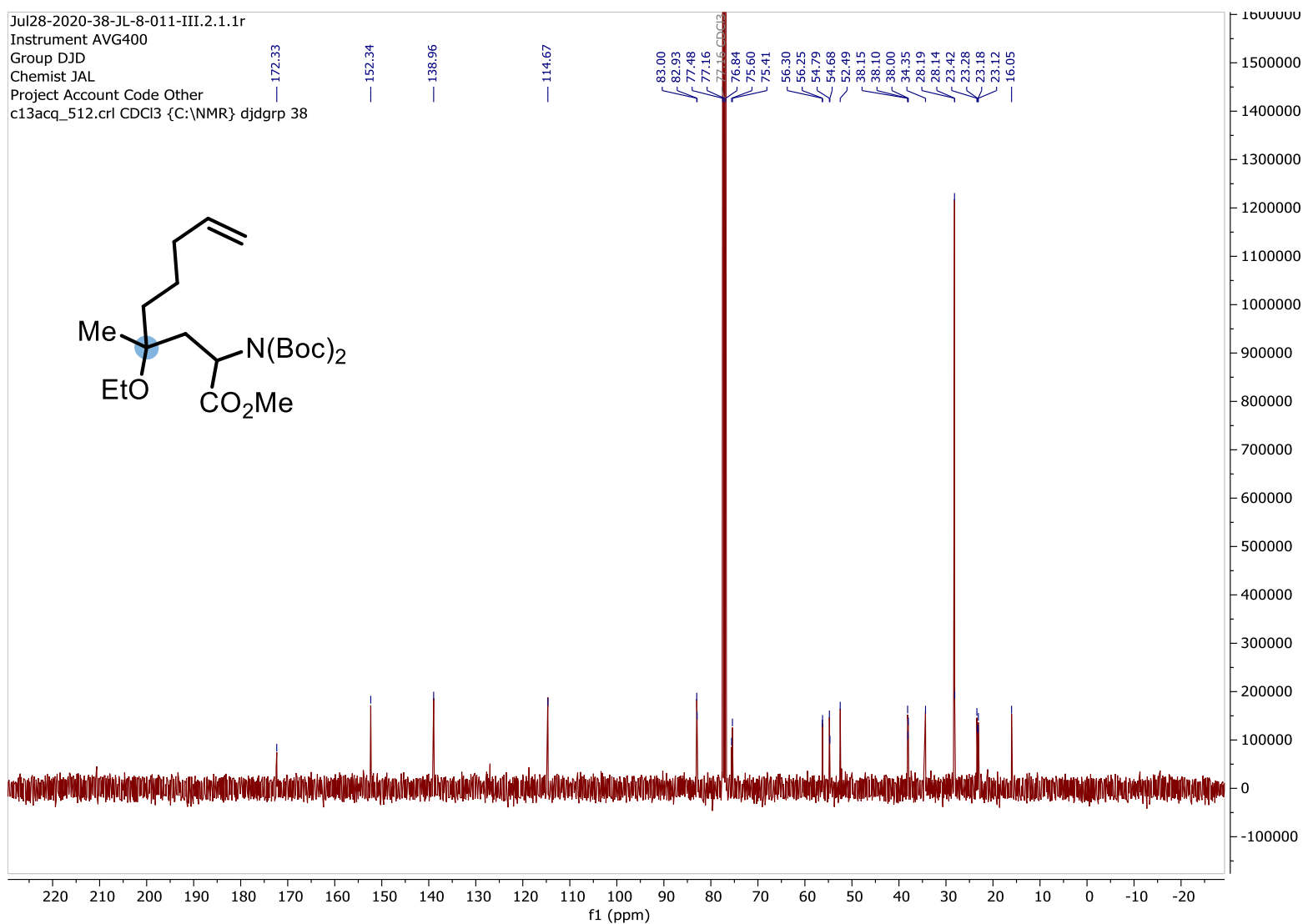

